\title{
NARRACIÓN Y MATERIA Supervivencias de la imagen cinematográfica
}

\author{
Tesis Doctoral \\ Universidad de Salamanca \\ Departamento de Historia del Arte - Bellas Artes \\ Noviembre de 2015

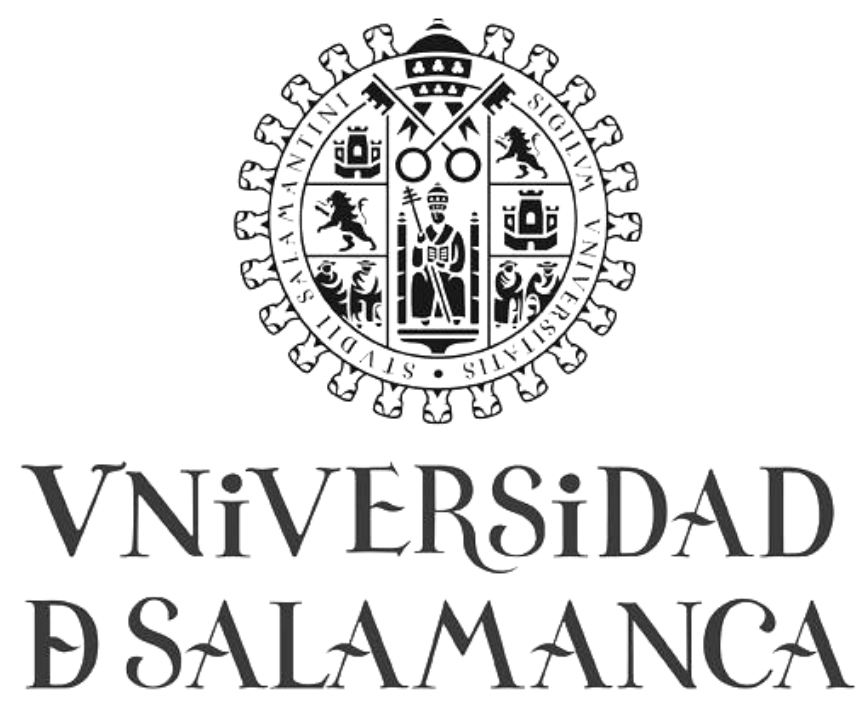

Alumno:

Director:

Roberto Amador Ballesteros

Fernando González García

[robertoamaba@telefonica.net]

[fergogar@usal.es] 

"En sus edificaciones, en sus imágenes y en sus historias, la humanidad se prepara a sobrevivir, si es preciso, a la cultura.

$Y$ lo que resulta primordial, lo hace riéndose. Tal vez esta risa suene a algo bárbaro. Bien está.» Experiencia y pobreza (Walter Benjamin, 1933)

"Voy a tratar ahora de la existencia de lo que llamamos simulacros de las cosas; los cuales, como películas desprendidas de la corteza exterior de los cuerpos, vuelan por los aires de acá para allá; ellos son los que nos aterrorizan apareciendo en nuestras mentes, en la vigilia o también en sueños.» De rerum natura (Lucrecio, s. I a. C.)

«Es una cuestión muy oscura la de cómo se desarrolló por vez primera en la mente del hombre (...) el sentimiento de belleza en su forma más sencilla, esto es, en recibir un placer especial por ciertos colores, formas y sonidos. Parece que la costumbre, en todos estos casos, ha jugado cierto papel; pero debe de haber alguna causa fundamental en la constitución del sistema nervioso de cada especie.»

El origen de las especies (Charles Darwin, 1859)

"Lleno de desesperación, y todavía inflamado por el recuerdo de su profundo cariño, el enamorado viaja de la capital a la remota provincia donde se encuentra la aldea, con el propósito romántico de desenterrar su cuerpo y apoderarse de sus exuberantes trenzas. Llega a la tumba. A medianoche desentierra el ataúd, lo destapa y, en el momento de desprender el cabello, lo detienen los ojos de la amada, que se abren. La mujer había sido enterrada viva. La vitalidad no había desaparecido del todo, y las caricias del enamorado la despertaron del letargo que fuera equivocadamente tomado por la muerte.»

El entierro prematuro (Edgar Allan Poe, 1844) 



\section{ÍNDICE}




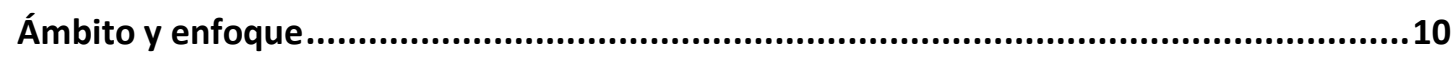

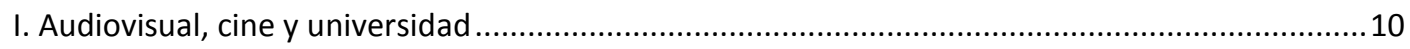

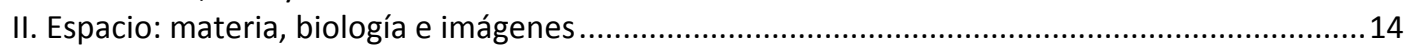

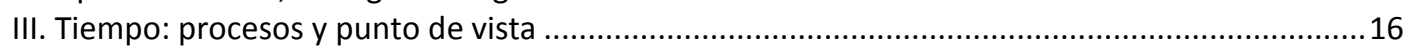

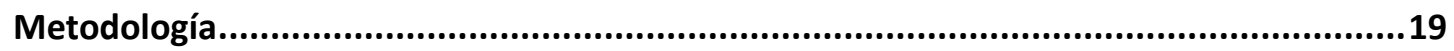



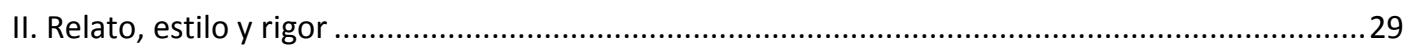

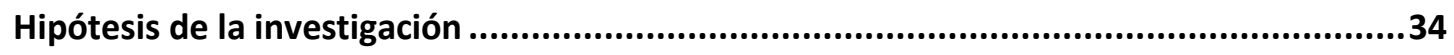





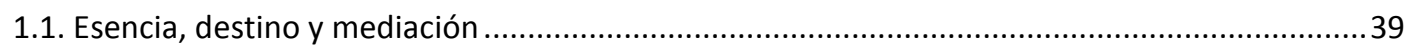

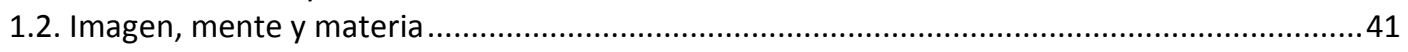

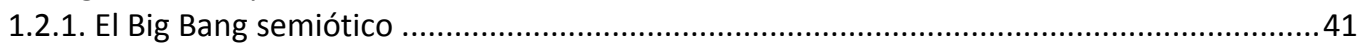

1.2.2. Imágenes mentales. Posmodernidad frente a verdad fisiológica ....................................43

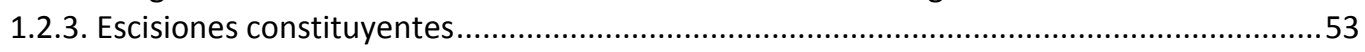

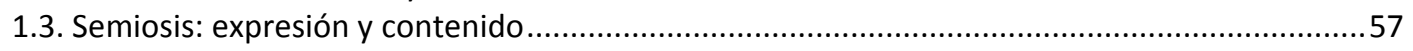





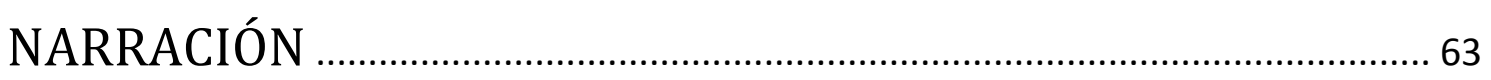

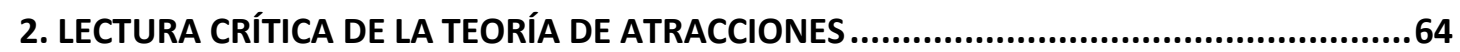



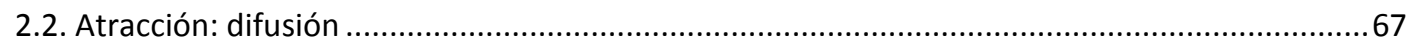

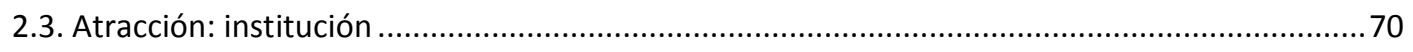

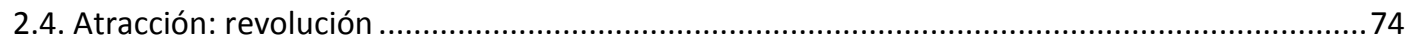

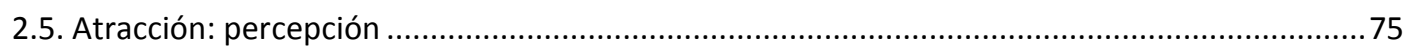

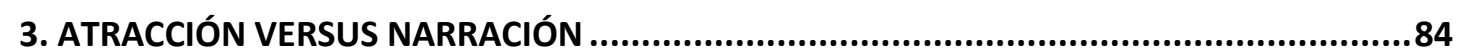

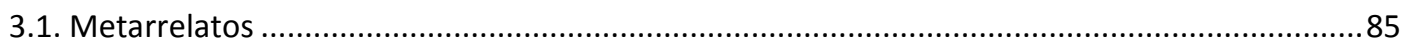

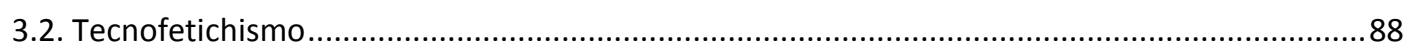

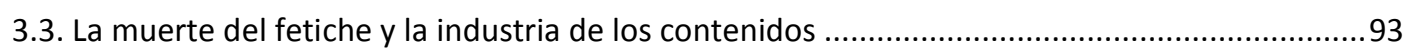

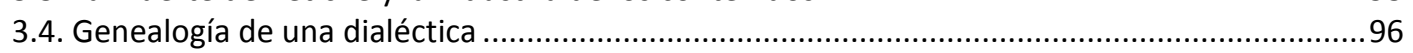

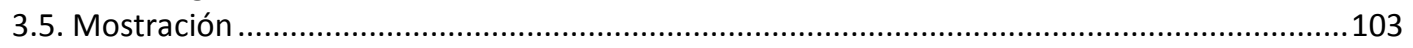

4. NARRATIVA ESPECTACULAR .................................................................. 107





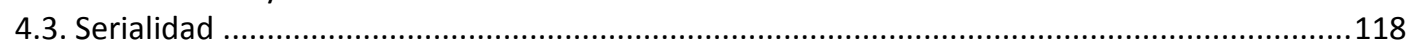

5. SUPERVIVENCIA. INTENSIFICACIÓN Y RAZÓN BIOLÓGICA ........................................125

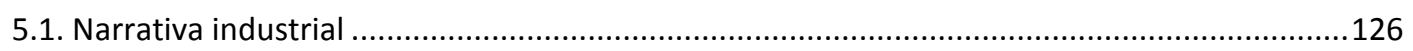

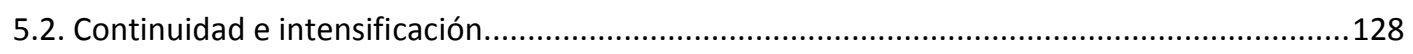

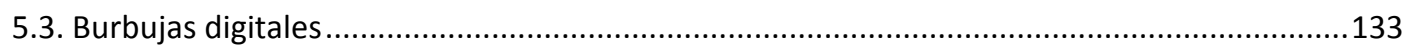

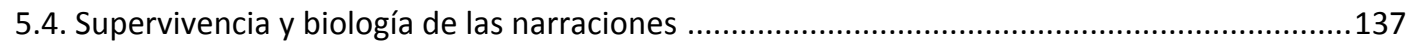

5.5. Corolario y metáfora. El intersticio del fotograma ............................................................ 151

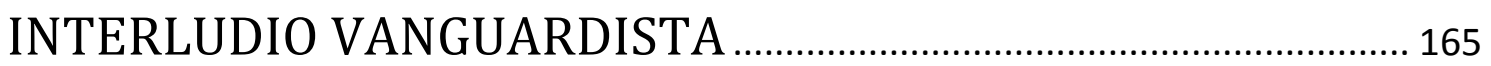

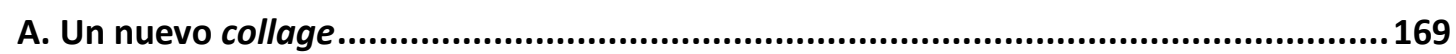

B. Narración y atracción trascendidas. El cine como meditación.................................174

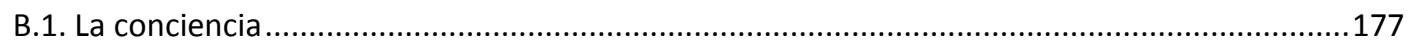

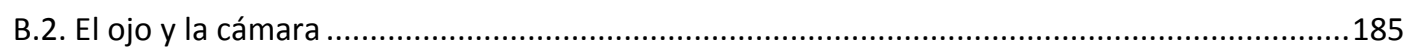










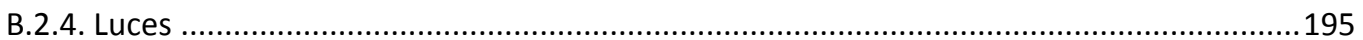

C. El fin de la ficción. Prefiguraciones expandidas ........................................................199

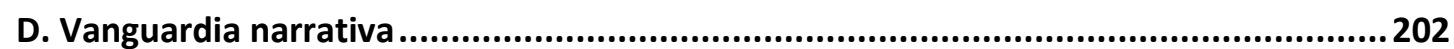

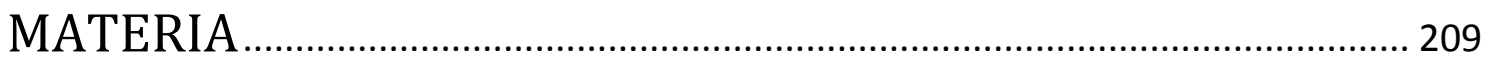

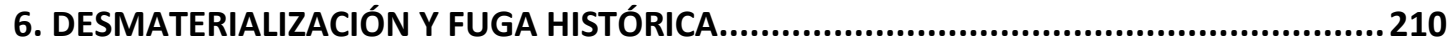

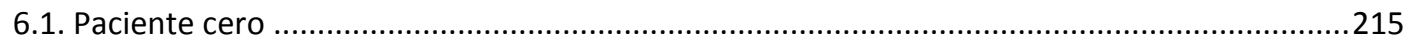

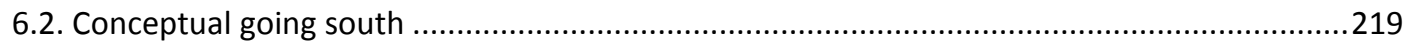

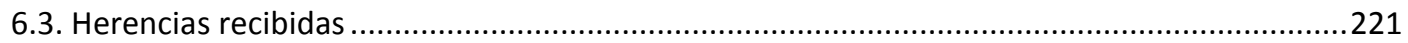

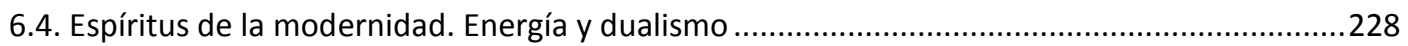

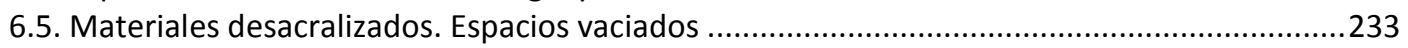

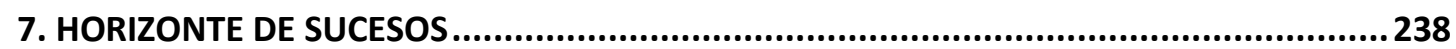

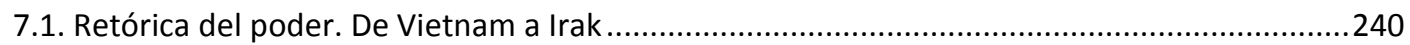

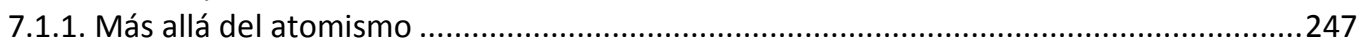

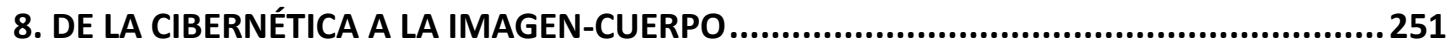

8.1. [Des]corporeización. Símbolo, información, tecnología y distancias ....................................254

8.2. El cuerpo y la máquina. Licuefacción de mercado ..........................................................257

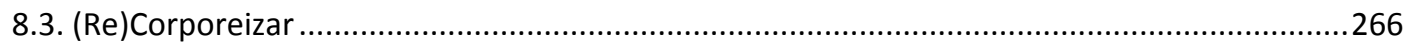



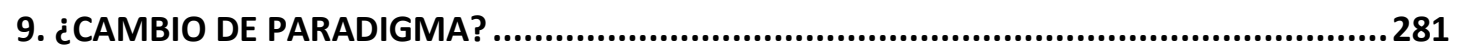

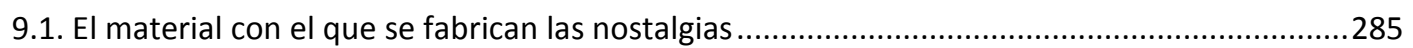

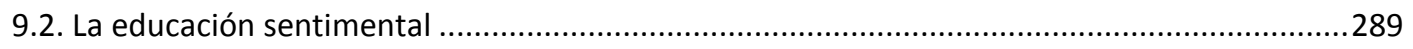

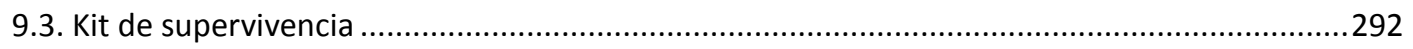

9.4. Donde viven los monstruos. Donde viven las imágenes ....................................................301

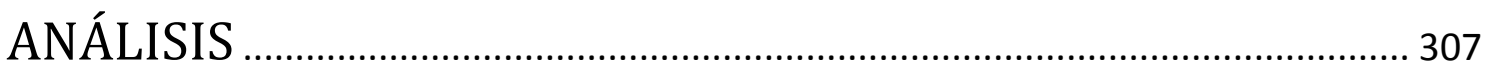

10. PIXAR. NARRACIÓN Y MATERIA EN EL CINE DE ATRACCIONES ................................308



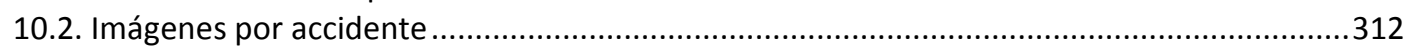

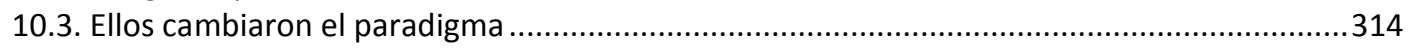



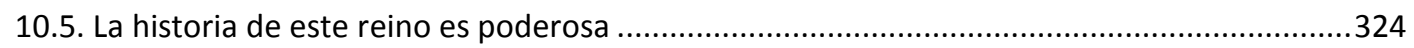



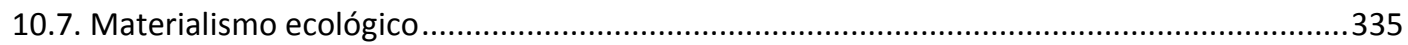

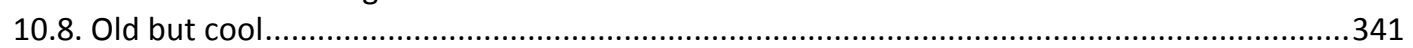

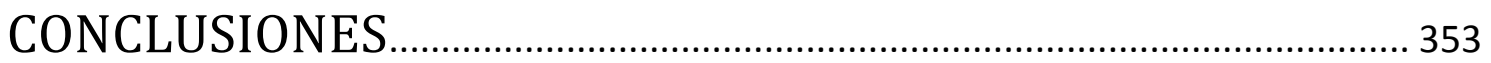

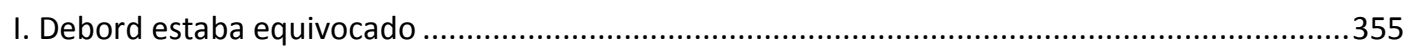



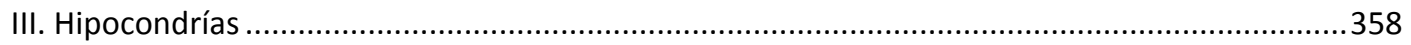

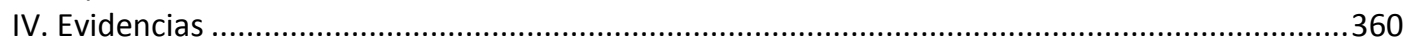

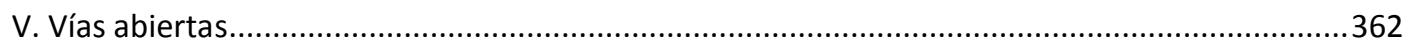

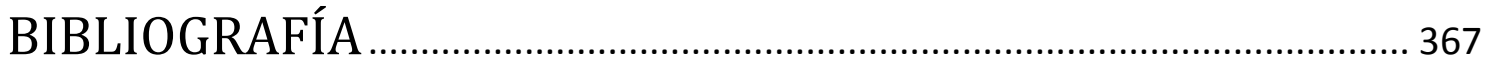

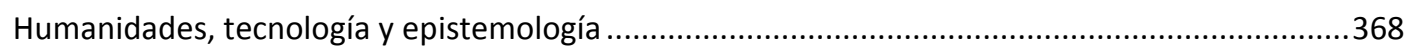

Teoría y práctica del audiovisual. Cine, comunicación, fotografía..................................................376

Naturaleza humana. Estética evolucionista, consiliencia y ciencias del cuerpo ..............................389

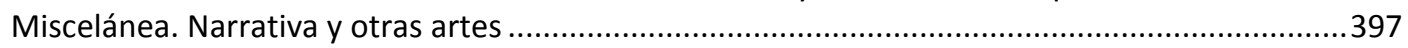





\section{INTRODUCCIÓN}




\section{Ámbito y enfoque}

\section{Audiovisual, cine y universidad}

«Cuando empiezo a hablar de cine, me desvío por otros caminos» Jean Cocteau ${ }^{1}$

Siempre hay que trazar unas coordenadas que permitan la orientación del sujeto. Así de torpes somos los humanos. Una tesis doctoral no iba a ser la excepción. Atendiendo al grado de concreción que se le supone a este tipo de trabajo académico, es indispensable localizar ámbito y objeto de la investigación. Porque, al ir acompañada por la etiqueta cine, se puede llegar a creer que voy a hablar de cine y solamente de cine. ¿Se puede hablar de cine y de nada más? Sin duda, pero se estaría hablando poco y mal. Hay que trazar, entonces, unas referencias de partida. Hay que redactar, también, un manual de usuario. Es esta una investigación dinámica y de trayecto, repleta de puntos de encuentro pero también de desvíos. Es ahora, concluyendo el primer párrafo, cuando solicitaré por primera y única vez paciencia al lector.

Todo sería más sencillo y funcional si ese objeto al que llamamos cine fuera un contenedor único. Para infortunio de las metodologías, no lo es. De ahí que recurra al envoltorio del audiovisual contemporáneo. El audiovisual como fenómeno genérico y como nodriza. El audiovisual convertido en un gran plano general tan vital y accidentado como un encuadre de Playtime (Jacques Tati, 1967). Conviene tener presente este supraconjunto para comprender los movimientos, las entradas en campo y los mutis, los regresos y las novedades que acontecen en el cine.

Investigar el cine en el siglo XXI no es solo escudriñar un gran plano general, es también un rodaje con multicámara proyectado en una colosal split screen. "La historia del cine ya no tiene centro y el objeto-cine ya no es homogéneo". ${ }^{2}$ Un hecho que, por un lado, procede de la imparable diversificación en la creación audiovisual y, por el otro, del devenir de la Historia como disciplina. El relato de la Historia -incluido el del cine- a lo largo del último medio siglo es el de una progresiva atomización que arrancó con la historia total de Annales, y que no dejó de

\footnotetext{
${ }^{1}$ LIANDRAT-GUIGUES, Suzanne; LEUTRAT, Jean-Louis, Cómo pensar el cine, Madrid: Cátedra, 2003, p. 10.

${ }^{2}$ LAGNY, Michele, Cine e Historia. Problemas y métodos en la investigación cinematográfica, Barcelona: Bosch, 1997, p. 81.
} 
fragmentarse en múltiples y discontinuos relatos hasta concluir en una Historia de migajas arqueológicas. $^{3}$

Hablaré del cine como medio, como objeto tecnológico y artístico inscrito en un entramado de relaciones biológicas, sociales, económicas, históricas e industriales. Hablaré del cine, a su vez, en su doble vertiente teórica y práctica. Enemigas íntimas. Resulta paradójico que en la época de la presunta superación de la división de saberes, el cine mantenga tan rígidas sus fronteras internas. El cine todavía arrastra su condición de aparato moderno. Su fuerte compartimentación a lo largo de la historia, contradice su sincretismo técnico y estético. Esto ha contribuido a historiar el cine de un modo sindical, repartiendo funciones y carnés de oficio. Si el futuro académico del cine quiere seguir siendo próspero, debe favorecer el intrusismo del resto de humanidades y de las ciencias. Reconociendo desde este mismo momento una de las principales influencias que inspiran este trabajo, hago mías las palabras con las que Steven Pinker titulaba un reciente texto dirigido a los profesionales de las humanidades: la ciencia no es vuestra enemiga. ${ }^{4}$

Decía que el cine arrastraba ese peso muerto-moderno, porque su estratificación -la fosilización- del saber y de la práctica encajaría mejor en un periodo decisivo pero lejano y superado, al menos desde un punto de vista terminológico. ¿En cuál? En aquella modernidad de la razón basada en las escisiones. ${ }^{5}$ Thomas Kuhn avisó de una de las consecuencias más dolorosas del efecto de especialización: "una resistencia considerable al cambio de paradigma". ${ }^{6}$ Kuhn se refería a un paradigma que, una vez demostrada su caducidad, era necesario reemplazar. Kuhn se refería al terreno de las ciencias, Gianni Vattimo lo extendía al de las letras "en la medida en que la especialización de los lenguajes y de las esferas de interés y la fragmentación de la existencia pertenecen a la modernidad". ${ }^{7}$ Leo a Kuhn y recuerdo al

\footnotetext{
${ }^{3}$ Me valgo del sintagma para unir la discontinuidad operativa de Foucault durante los setenta, con la diversificación temática y la pluralidad de los tiempos de las migajas metahistóricas de Dosse en los ochenta. Respectivamente:

FOUCAULT, Michel, La arqueología del saber, México: Siglo XXI, 1970.

DOSSE, François, La historia en migajas. De Annales a la "nueva historia", Valencia: Edicions Alfons el Magnánim, 1988.

${ }^{4}$ PINKER, Steven, "Science is not your enemy" en The New Republic, 6 de agosto de 2013. <http://www.newrepublic.com/article/114127/science-not-enemy-humanities> [consulta: 28-01-2015].

5 "La modernidad del sentimiento intenta suturarlas". MOLINUEVO, José Luis, La vida en tiempo real. La crisis de las utopías digitales, Madrid: Biblioteca Nueva, 2006, p. 140.

${ }^{6}$ KUHN, Thomas, La estructura de las revoluciones científicas, México: Fondo de Cultura Económica, 2004, p. 110.

${ }^{7}$ VATTIMO, Gianni, Nihilismo y emancipación, Barcelona: Paidós, 2004, p. 26.
} 
Ortega de La rebelión de las masas ${ }^{8}$ clamar contra la barbarie que suponía dicha especialización. Productora de monstruos y de teratologías del conocimiento como el sabioignorante.

El cine siempre se ha resistido a abandonar la modernidad. El cine es y será un moderno recalcitrante. El cine es el hijo biológico de la modernidad empírica que, abandonado al nacer, fue recogido y criado por una manada de románticos salvajes. El cine continúa siendo un complejo dispositivo de fracción. Pero que lo sea, no implica que deba estudiarse levantando fronteras. Es un error metodológico irreparable si tenemos en cuenta que su primera ubicación dentro el panorama contemporáneo es la de subconjunto. Además, no se puede obviar una palabra como dispositivo, que incomoda seriamente la individualidad del objetocine.

La estrategia de atomizar para hacer manejable el cine, en última instancia y deseando su inminente superación, no será del todo nociva si no se pierde de vista la relación entre las partes. Aun así, lo más urgente es devolver -quizá instaurar- la porosidad a un dispositivo cinematográfico del que se escindió a la fuerza su componente intelectual. El paisaje sigue siendo el de una guerra de trincheras donde la universidad, los creadores, la industria y la crítica cavan sus zanjas. En lo único que parecen coincidir es en despreciar las sugerencias y las aportaciones de otros niveles de conocimiento. Estos suelen ser vistos como invasores, como reduccionistas, como bárbaros insensibles a la estética. Admitido y asimilado el lejano "imperialismo legítimo de la semiótica" ${ }^{9}$, ahora parece que toca combatir el imperialismo científico.

Historiadores, escritores, artistas, filósofos, filólogos, no ahuyenten a los hombres de la bata blanca. En el año de gracia 2015, es hora de abandonar la caza de brujas, el victimismo y el voluntarismo ${ }^{10}$, la ingenuidad y el modo verbal condicional para ofrecer algo más que sospechas y buenos deseos. Podría glosar a René Girard cuando afirmaba que la ciencia no suponía una "posición de repliegue" o "una sabia resignación" en cuanto a las múltiples y profundas ambiciones de las humanidades. Esa posición de repliegue o de resignación no se correspondería con el reduccionismo científico tantas veces denunciado, sino con "otra

\footnotetext{
${ }^{8}$ ORTEGA y GASSET, José, La rebelión de las masas, Madrid: Espasa Calpe, 1972, pp. 171-174.

${ }^{9} \mathrm{ECO}$, Umberto, La estructura ausente. Introducción a la semiótica, Barcelona: Lumen, 1989, p. 38.

${ }^{10}$ MARTIN, Adrian; NAREMORE, James, "El futuro del estudio académico del cine" en Mutaciones del cine contemporáneo, Madrid: Errata Naturae, 2010, pp. 218-239.
} 
manera de satisfacer esas ambiciones" ${ }^{11}$ Otra manera que no es una nueva manera, sino un afán -como veremos en el apartado metodológico- trágicamente postergado.

Este marco global exime, en parte, de cuestionar la pertenencia del audiovisual a la esfera del arte. Es un criterio aceptado, institucionalizado y certificado por su valor académico y burocrático. A él se ha llegado desde un nacimiento alejado de cualquier prurito intelectual. El cine fue uno de los corolarios del positivismo científico, sí, pero sus producciones no tardaron en arrinconar la ambición intelectual. Tampoco hay que olvidar que la integración del audiovisual en los estudios universitarios, puede llevar a la confusión entre los motores de la creación y los puntos de vista aplicados. La conversión del historiador en un criptógrafo que ve “códigos por todas partes"12, siempre preocupó a Gombrich. Algo relacionado con lo que JeanMichel Frodon explicó a través de un símil científico con batracios de por medio:

De manera lógica, pero peligrosamente, una vez que entró en la universidad el cine cayó en las redes de los procedimientos analíticos y discursivos elaborados para otros terrenos (a empezar por la semiología y la sociología, seguidas por el psicoanálisis, la historia, la estética según las categorías de la historia del arte clásico, la economía). Todas ellas tienen en común que tratan las películas como ranas muertas despedazadas con la ayuda de escalpelos forjados para otros usos. $^{13}$

No deja de ser curioso que las humanidades se levanten en armas frente a los científicos, cuando su propia metodología se ha nutrido con los botines y los saqueos de mil batallas. Esos escalpelos forjados para otros usos a los que aludía Frodon, nos visitarán más adelante bajo nuevos sintagmas como el de apropiación conceptual o imposturas intelectuales. La legitimidad del cine no ya como arte, sino como disciplina digna de formar parte de la institución universitaria -y quien dice universidad, dice museo-, es una etapa superada a raíz del triunfo del estructuralismo a finales de los años sesenta. No obstante, el acontecimiento ha dejado agrias discusiones y hasta cadáveres en el camino.

\footnotetext{
${ }^{11}$ GIRARD, René, La violencia y lo sagrado, Barcelona: Anagrama, 2012, p. 99.

12 GOMBRICH, Ernst, "Objetivos y límites de la iconología" en WOODFIELD, Richard (ed.), Gombrich esencial, Madrid: Debate, 1997, p. 480.

${ }^{13}$ FRODON, Jean-Michel, “Voyager le cinéma” en Trafic, no 37, marzo de 2001, p. 240.
} 
Cuando el cine llamaba a la puerta de la universidad, algunos se ofuscaban porque, según ellos, terminaría entre las manos del último mono. Hoy, una vez que penetró en el sancta sanctórum, las protestas cambian de naturaleza, pero permanecen. ${ }^{14}$

Caer en las manos del último mono me parece una sentencia maravillosa y casi profética para el devenir de este escrito. Elimino su tono peyorativo y se la entrego a cualquier sapiens dispuesto a sentarse conmigo delante de una pantalla.

\section{Espacio: materia, biología e imágenes}

Sin salir de ese master shot de Playtime donde he localizado de manera imaginaria esta investigación, corto a una escala de plano más cercana para centrar el objetivo: imagen e imágenes, en singular y en plural. El singular toca un problema no superado: el recurso a la imagen-extracto, a la imagen fija sustraída del discurso y a los problemas e insuficiencias metodológicas que el acto acarrea A pesar de ello, no desecharé la imagen o el fotograma aislado -ni siquiera sus periferias y sus engarces- como unidad analítica. Lógicamente, también atenderé a la entidad espacio-temporal nacida de su unión. Me interesan las imágenes en tanto textos y documentos históricos y estéticos productores de sentido. Así como la íntima relación que establecen con algunos de sus factores y materiales constituyentes. A saber, los soportes físicos y los elementos escalares (dimensión, el formato, la escala y la proporción). Dentro de los soportes físicos incluyo la mente, al tiempo que invisto a la biología como invitada de honor y tutora de esta investigación.

También busco ver parte de la tramoya. Asomarme -siempre que sea posible y necesario- a ese fuera de cuadro no del espacio cinematográfico ${ }^{15}$, sino del espacio creativo y material tantas veces enmascarado por la enunciación. Comprobar de qué manera pueden llegar a

\footnotetext{
${ }^{14}$ LIANDRAT-GUIGUES, Suzanne; LEUTRAT, Jean-Louis, op. cit., p. 92. La problemática también es tratada en los apartados: “¿Ha bastado un siglo para legitimar el cine?”, pp. 40-43; “¿Para qué sirven las teorías?”, pp. 108-110; “¿Por qué resulta delicado asegurar la transmisión?”, pp. 110-114. Para un breve apunte sobre la problemática en España: VILLAFAÑE, Justo, Introducción a la teoría de la imagen, Madrid: Pirámide, 1985, pp. 19-27.

${ }^{15}$ El fuera de campo, el campo off, es parte consustancial del espacio cinematográfico. No entro ahora en las diferencias conceptuales y terminológicas entre fuera de campo (Bonitzer) y fuera de cuadro (Aumont). En este sentido, mi concepción de espacio cinematográfico es heredera, entre otros, de la del Rohmer teórico. ROHMER, Éric, El gusto por la belleza, Barcelona: Paidós, 2000. ROHMER, Éric, L'organisation de l'espace dans le Faust de Murnau, París: Petite bibliothèque des Cahiers du cinéma, 2000.

Véase también: AUMONT, Jacques; BERGALA, Alain; MARIE, Michel; VERNET, Marc, Estética del cine. Espacio fílmico, montaje, narración, lenguaje, Barcelona: Paidós, 1985, p. 25.
} 
influir esos factores en una representación que tan pronto trata de esconderlos, como de mostrarlos en todo su esplendor mediante una suerte de enunciación enunciada. ${ }^{16}$ Recuerdo las palabras de José Enrique Monterde, al notar que el monumental despliegue de los dispositivos cinematográficos puede estar destinado a la invisibilidad desde el momento que ciertos usos borran "su conciencia tecnológica". ${ }^{17}$ Remarco ese modo de uso para añadirle un modo de consumo.

Es este un punto importante. El enmascaramiento vía enunciación es solo una parte a la que hay que añadirle otra, la de unos procesos cognitivos siempre dispuestos a (re)elaborar narraciones, a buscar significados, a resolver patrones y a omitir errores. La tutela biológica a la que queda sometida esta investigación, se integrará dentro de un ejercicio de trazabilidad histórica que querrá comprobar de qué forma una imagen o un concepto pueden revelar una genealogía. Hasta qué punto las imágenes poseen y desvelan su relación con la materia. Imágenes en superficie y en profundidad. La posible supervenencia ${ }^{18}$ de la primera respecto de la segunda. La emergencia de la segunda en la primera, lo que Jacques Aumont ${ }^{19}$ conoce como modulaciones subterráneas y superficiales. Guerras y pactos, nacimientos y defunciones que fulminan el mito eborario de la creación para instalarse en un campo de batalla fulleriano. ${ }^{20}$ La materia irrumpirá en la estética (im)poniendo unas condiciones para la firma del armisticio.

Todo ello sin abrazar el determinismo material y tecnológico, el cual no comparto ni en su vertiente estética ni social. Otra cosa muy distinta será el determinismo biológico, este sí acreditado aun en porcentajes volubles y aun en permanente conflicto con el ambiente. También preguntaré si el tamaño importa o si, definitivamente, es otro de los mitos occidentales levantados sobre el miedo y el yo. Lejos de parecer un motivo epidérmico, esta relación de la imagen con su materia deviene síntoma factual y gozne temporal. El síntoma siempre puede ayudar a conocer aquello que lo causa, así como toda una cadena de sucesos posteriores. Si bien, mirar hacia el futuro no será labor de este trabajo, más allá de vislumbrar tendencias y posibles vías abiertas.

\footnotetext{
${ }^{16}$ ZUNZUNEGUI, Santos, Pensar la imagen, Madrid: Cátedra, 2003, p. 161.

${ }^{17}$ MONTERDE, José Enrique, La representación cinematográfica de la Historia, Madrid: Akal, 2001, p. 16.

${ }^{18}$ Mario Bunge establece diferencias entre supervenencia y emergencia en: Emergencia y convergencia. Novedad cualitativa y unidad del conocimiento, Barcelona: Gedisa, 2004, pp. 29-32.

${ }^{19}$ AUMONT, Jacques, Materia de imágenes, redux, Santander: Shangrila Textos Aparte, 2014, p. 16.

${ }^{20}$ En alusión al célebre aforismo empleado por Samuel Fuller en Pierrot el loco (Pierrot le fou, Jean-Luc Godard, 1965). "A film is like a battleground. It's love, hate, action, violence, death. In one word: emotion".
} 


\section{Tiempo: procesos y punto de vista}

Esbozado el objeto de análisis dentro un campo determinado, debo señalar cuándo y dónde se asienta: el contexto de la investigación. El tiempo queda fijado por lo que denominaremos momento actual, en buena medida como extensión natural del epígrafe del curso de doctorado ${ }^{21}$ realizado como paso previo a esta investigación. Momento actual también como convención, como título descriptivo y punto de apoyo a partir del cual volver la vista para relacionar diferentes momentos que, aun separados por el tiempo, sueñan con la repetición y con el ciclo. La movilidad temporal tendrá el hoy como faro, pero será irremediable ver la luz desde diferentes distancias. Algo inevitable al estudiar acontecimientos cuyos límites quedan fijados por pura conformidad. De todas maneras -y quiero ser rotundo en este aspecto-, estos juegos temporales se alejarán de una concepción teleológica del presente.

La geografía donde aparecerán los objetos y los procesos sometidos al análisis, será del todo diversa. No es esta una investigación sujeta al lugar. La entiendo como un fenómeno global susceptible de precisiones atendiendo a las características propias de cada ejemplo. Bien de una industria nacional, bien de cariz internacional como la estadounidense, de la individualidad de ciertos creadores, de grupos y cooperativas o de versos libres que, a pesar de luchar por desligarse de la industrias y de las normas establecidas, no pueden escapar del momento histórico al que pertenecen.

No es este un estudio que promueve el territorio como protagonista. Se sitúa al margen de localismos y regionalismos tan devotos de investigaciones que encuentran fomento, justificación y recompensa en instituciones interesadas -también endogámicas y catetas- en una focalización identitaria. Tomar el ambiente por los hechos, tomar el lugar como objeto y no como contexto, distorsiona el diagnóstico. Alterar lo que aquí considero una justa relación entre ambos pertenece a otro tipo de investigación igual de legítima e interesante.

Uno de los objetivos fundamentales de la investigación es poner en cuestión la idea de generación espontánea. Su fuerte relación con un contexto histórico donde los resultados, desde su innegable valor y protagonismo que no pretendo negar, sepultan el trayecto. No

\footnotetext{
${ }^{21}$ Situación del Arte en el momento actual. Cursos de doctorado impartidos en la Universidad de Salamanca, coordinados por José Vicente Luengo Ugidos y Fernando González García.
} 
ignoraré los posibles errores de Beethoven ${ }^{22}$ encontrados en el camino. Atenderé a la maduración de los frutos, y a los costos del viaje.

Toda gran obra de arte trata, como ocurre cuando se asciende hasta la cima de una montaña, del proceso específico de experimentarla. ${ }^{23}$

Tomada como aforismo, esta última cita corre el riesgo de caer en la pura intencionalidad, en la afectación y, de paso, presentarme como un escritor de libros de autoayuda o como un catequista. Lo que quiero resaltar de la relación entre las imágenes y sus procesos al introducir esta cita, debo apostillarlo con algo menos novelesco, con la Shoah:

Los hechos terribles eran revelados por imágenes (...) pero estas solo mostraban sus resultados, no su proceso, de lo que se desprende el carácter metonímico y no realista de unas imágenes (...) nutridas por un mito: la reproducción. ${ }^{24}$

Mito de la reproducción que viene precedido por el de la creación. Mito que para Heidegger ${ }^{25}$ se extendía a todo el conjunto de los entes mediante el eterno -al menos desde Aristóteles hasta nuestros días- entramado materia-forma. Siguiendo con la terminología heideggeriana, para comprender la imagen tengo que tener presente no solo aquello que él denominaba la materia conformada, también los procesos previos y últimos. Esto es, la materia in-formada y la materia sobre-informada. El primero vendría a coincidir con las diferentes fases de la creación y fabricación, mientras que el segundo lo haría con la fase de lectura e interpretación. En este sentido, la investigación en curso será transversal.

Otro de los preliminares que conviene aclarar es el punto de vista de la tesis. Ejerceré como un historiador que, al mismo tiempo y de manera irremediable también es ciudadano, espectador, creador, cliente y usuario. Es un punto de vista donde el poder ejecutivo de quien escribe no es unívoco. Busco lazos y roces entre los perfiles sin propósito conciliador. Creo que existe -permítanme la cursilería- cierta sinergia en el choque y en la aplicación crítica de estos puntos de vista. De esta forma, se obtiene la capacidad analítica del historiador, la percepción

\footnotetext{
${ }^{22}$ La equivocada idea de que proceso y producto deben parecerse. La expresión proviene de la falta de correspondencia entre la exquisitez de las composiciones del músico y las deplorables y hasta reprochables condiciones ambientales en las que fueron realizadas.

${ }^{23}$ DUTTON, Denis, El instinto del arte. Belleza, placer y evolución, Barcelona: Paidós, 2010, p. 147.

${ }^{24}$ SÁNCHEZ-BIOSCA, Vicente, Cine de historia, cine de memoria, Madrid: Cátedra, 2006, p. 149.

${ }^{25}$ HEIDEGGER, Martin, Caminos de bosque, Madrid: Alianza, 2010, pp. 16-20.
} 
intelectual y emocional del espectador, la conciencia del creador, los intereses de un usuario y los derechos de un consumidor. Es esta una sopa de subjetividades contenidas en una subjetividad superior o, como apostillaba Ricoeur ${ }^{26}$, implicada. Es decir, una subjetividad -o una serie de subjetividades- adecuada a la objetividad y a la verdad que le conviene y que se le supone a la Historia.

Historiar, sin disociar todas esas personalidades, resulta complejo, está sujeto a fuertes influencias del entorno y a imperativos culturales, pero resulta fascinante. A la hora de constatar los hechos que conforman el relato, las ideas opuestas siempre serán válidas como contrapeso a las propias, aunque en ocasiones será inevitable y necesario desautorizarlas. Llegada la oportunidad, optaré por formalizar en lugar de ideologizar. Descarto el uso de la ideología como actividad supraestructural. Es la siguiente una cuestión de orden, diría que hasta de higiene: obtener la idea, la información y el mensaje a partir de las formas y su contexto. Nunca aplicar la idea para predeterminarlos. Los recetarios ideológicos y los juegos tendenciosos no me interesan.

\footnotetext{
${ }^{26}$ RICOEUR, Paul, Historia y verdad, Madrid: Ediciones Encuentro, 1990, p. 24.
} 


\section{Metodología}

$$
\begin{array}{r}
\text { «Filch. - Siempre he sido partidario del método y no de hablar al buen tuntún. } \\
\text { Señora Peachum. - iQuiere un método! } \\
\text { Peachum. - Que haga de idiota. }
\end{array}
$$

Vuelve esta tarde a las seis y te enseñaremos todo lo necesario. iLárgate!»

La ópera de cuatro cuartos (Bertolt Brecht, 1928)

« ¡Ciencia de la historia! ¡Monstruosa esquematicidad que prevé, de cuanto fue, todas las formas internas, la norma, la irregularidad, y esa infinidad de conceptos que dan nombre, en los modos más diversos e infinitos, a sus aspectos, a sus inefabilidades, y finalmente, a su potente curso! ¡Ayúdame, ciencia de la historia! Si sé toda la infinidad que hay tras de mí, fatal por existente, seré el que gane» Poema para un verso de Shakespeare (Pier Paolo Pasolini, 1961-1964)

«Ningún historiador puede estar totalmente libre de prejuicios, pero creo que es erróneo sacar la conclusión de que los valores artísticos son completamente relativos» ${ }^{27}$

Ernst Gombrich

Gabi Teichert asesta dos golpes de hoz sobre el lomo de un libro que se niega a abrirse en canal. El libro es un grueso tomo de Historia, y es rojo. A continuación, cambia la hoz por un martillo y aporrea sus páginas. El libro vomita polvo acumulado. Entre la apatía y el enfado, Gabi lo sacude para redoblar su ataque sobre otro volumen, uno más delgado y negro que se muestra igual de testarudo. Sin darse por vencida, Gabi recurre a un taladro que perfora un boquete perfecto y minúsculo. Por último, tras una pausa, la esforzada mujer vierte el turbio contenido de un matraz en un vaso de precipitados y le añade unas hojas recién arrancadas. Lo espesa, lo remueve y lo huele. Cata el brebaje.

\footnotetext{
${ }^{27}$ Respectivamente: BRECHT, Bertolt, La ópera de cuatro cuartos, Madrid: Alianza Editorial, 2000, p. 18. PASOLINI, Pier Paolo, Poesía en forma de rosa, Madrid: Visor, 2002, p. 112.

GOMBRICH, Ernst, La Historia del Arte, Madrid: Debate, 1997, p. 626.
} 
En esta escena de La patriota (Die patriotin, Alexander Kluge, 1979), su protagonista -una simple profesora- no consigue averiguar qué demonios le pasa a la Historia. Disciplina que no deja de defraudar, que ha perdido su influencia sobre un público que la considera demodé. Inútil y arcaica, sin respuestas para los nuevos tiempos, sin soluciones para los viejos problemas. Gabi, en este simulacro de alquimia, no ha logrado transmutar el plomo -el polvoen oro. No ha dado con el método y menos con los ingredientes. Ni siquiera se ha visto impregnada tras ingerir el bebedizo. Es magistral cómo Kluge construye la escena, cómo deja flotando los significados a la espera de ser recogidos. Cuando hago mención a la alquimia y al bebedizo, quiero imaginar que la vasta cultura del cineasta alemán le sirvió para darle a la escena el tono medievalista ${ }^{28}$ que necesitaba.

La Historia, ambigua y terca como una biblia, sigue fracasando en la extraña mezcla de ciencia y sortilegio. Gabi se desespera, igual que hacen sus decepcionados y cada vez más escasos alumnos. Le recriminan su vaivén constante, su indefinición. Gabi les responde y es justo en ese momento cuando, sin saberlo, se reencarna en Clío. La musa griega que aquí cambia sus tradicionales atributos iconográficos sólo en parte: mantiene el globo terráqueo y los libros, pero prefiere la hoz, el martillo y el taladro a la trompeta. Cuando todo parece perdido, cuando lo único que queda es un caput mortuum, emerge la nueva forma. Gabi-Clío verbaliza ante el alumno que hace las veces de inquisidor: "No me atormente. Estoy enferma del estómago. Estoy agotada". Kluge termina así de ilustrar, con agudeza, los problemas epistemológicos que afligen a la Historia y, por extensión, a las humanidades.

Igual que le sucedía a Gabi, trabajar en la historia del cine provoca un sentimiento de malestar a partir del cual "no es posible librarse de la interrogación de quienes desearían un «buen método»". ${ }^{29}$ Historiar las imágenes nos hace mendigar metodologías, igual que le sucedía al atribulado Filch. Uno no puede resignarse a hacer el tonto de cualquier manera.

\section{Consiliencia}

En Otázky pro dve zeny (1985), maravilloso cortometraje documental de la cineasta checa Drahomíra Vihanová, una tierna bisabuela de 71 años daba la respuesta que muchos hombres y mujeres del nuevo siglo continúan ignorando. "Por supuesto que el arte y la ciencia están

\footnotetext{
${ }^{28}$ Uno de los remedios más comunes durante la peste negra del siglo XIV, era realizar brebajes con la pulpa extraída de las páginas de una biblia.

${ }^{29}$ SORLIN, Pierre, Sociología del cine. La apertura para la historia de mañana, México D.F.: Fondo de Cultura Económica, 1985, p. 129.
} 
conectados, seguro". Anežka Zlatníková era bisabuela, modista, ama de casa y taquillera de la estación de ferrocarril de Srbsko. Todo a tiempo parcial, porque parecía poeta a tiempo completo. Su compañera de reparto, la Doctora Alena Koneèná, tenía 40 años, era química macromolecular y no necesitaba respuestas, solo pedía que se le formulara la pregunta correcta: "Alguien debería preguntarme sobre las relaciones entre la ciencia y las artes".

En este texto convivirán ambas, la pregunta y la respuesta. Habrá una relación decisiva entre tesis-métodos y ciencia-arte. Nótese el uso nada inocente que hago y haré del plural de método. Diferentes metodologías han sido aplicadas a la historia del cine con un parecido acercamiento al objeto vía reproductibilidad. ${ }^{30}$ Una situación que, en buena medida, ha igualado lo que de diverso tiene el paisaje en cuanto a corrientes analíticas. No me corresponderá discutir si el análisis se ve afectado o es deudor del tipo de acercamiento a la obra. Asumo la imposibilidad de abrazar una metodología única, definitiva y cerrada para el estudio y la historia de las imágenes.

La imposibilidad la hago extensible al campo de una innecesaria teoría indígena ${ }^{31}$ del cine y a sus correspondientes mitologías. La teoría del cine siempre se ha hecho desde fuera ${ }^{32}$, desde la literatura, la pintura, la fotografía, la filosofía, la lingüística y la psicología... hasta desde la teología. El único inconveniente reside en que ese desde fuera, ha sido digerido hasta convertirse en un desde dentro encargado de redactar una nueva y estricta ley de extranjería. No son las humanidades, sino sus practicantes los que se han convertido en los celosos guardianes de la esencia cinematográfica. El callejón sin salida de una ontología incapaz de explorar las mediaciones entre el ontos y el logos, entre el ser y su estudio.

Que tanto el uso del plural, como el aviso de ausencia de cierre metodológico y de la apuesta por la confluencia de saberes no lleve a equívocos: mi postura se aleja de la inestabilidad y de la indeterminación extrema de la deconstrucción y de los juegos agonísticos posmodernos. Hay que sacudirse la pereza intelectual del relativismo y reclamar el esfuerzo necesario para seguir suministrando verdad al discurso, para seguir desentrañando hechos y valores objetivos.

\footnotetext{
${ }^{30}$ El análisis terminó deslizándose hacia la reproducción más o menos miniaturizada del original. Ya fuera una moviola (Rohmer, para escribir su tesis sobre el Fausto de Murnau, se valió de una), una copia en formato subestándar o, más recientemente, en vídeo magnético y digital.

${ }^{31}$ AUMONT, Jacques; BERGALA, Alain; MARIE, Michel; VERNET, Marc, op. cit., p. 14.

${ }^{32}$ MOLINUEVO, José Luis, Retorno a la imagen. Estética del cine en la modernidad melancólica, Salamanca: Archipiélagos, 2010, p. 11.
} 
Es un problema que hay que afrontar, un acto nada sencillo que cualquier tesis doctoral aunque sea de humanidades- no puede eludir.

Reconozco cierta herencia semiótica. Aprecio su valor y funcionalidad a nivel global y puntual para cualquier análisis textual. Me interesa, además, ver cómo impacta esa armonía entre forma, estructura y análisis en las relaciones sociales. No puedo esconder mi admiración por algunos escritos de Jacques Aumont, Edgar Morin, Didi-Huberman, Rudolf Arnheim o Jacques Rancière, así como por otros heréticos de las humanidades. Tampoco puedo olvidar la figura de Jean Mitry como punto de inflexión en la apertura, ampliación y diversificación de la teoría cinematográfica. Pero si de deudas se trata, la principal es la de una consiliencia práctica y no retórica. Vocablo de origen inglés -consilience- popularizado por Edward Osborne Wilson. ${ }^{33} \mathrm{El}$ sociobiólogo americano recogió y sintetizó toda una tradición secular orientada a suprimir los guetos establecidos por las dos culturas. Aquellas dos culturas que protagonizaron la célebre charla de Charles Percy Snow ${ }^{34}$ en 1959 y que, en su revisión de 1963, anunciaba el surgimiento de una tercera llamada a ocupar el vacío existente.

La idea de consiliencia ya estaba implícita, contra todo pronóstico y en versión poética, en uno de los padres del romanticismo alemán: Friedrich Schlegel. En Conversación sobre la poesía, Schlegel otorgaba a la poesía el valor de metarrelato histórico, hasta el punto de considerar que "en un estado ideal de la humanidad solo habría poesía, es decir, las artes y las ciencias serían uno y lo mismo". ${ }^{35}$ Más cercanos en el tiempo y sujetos a diferentes matices, encontramos a Erwin Schrödinger ${ }^{36}$ y a Howard Gardner. ${ }^{37}$ Este último, además, estudió ${ }^{38}$ la contribución de tres pioneros en la aplicación de la operatividad científica y de los principios fisiológicos de la mente a las ciencias sociales y a los fenómenos estéticos: Jean Piaget (aprendizaje), Claude Lévi-Strauss (antropología) y Noam Chomsky (lenguaje). Para Gardner, uno de los objetivos irrenunciables de la revolución cognitiva, debía ser la construcción de un relato sobre cómo el ser humano ha sido capaz de alcanzar semejantes logros en la producción simbólica artística y filosófica.

\footnotetext{
${ }^{33}$ WILSON, Edward Osborne, Consilience. La unidad del conocimiento, Barcelona: Galaxia Guntenberg, 1999. [Primera edición de 1998]

${ }^{34}$ SNOW, Charles Percy, Las dos culturas, México D.F.: UNAM, 2006.

${ }^{35}$ SCHLEGEL, Friedrich, Conversación sobre la poesía, Buenos Aires: Biblios, 2005, p. 71.

${ }^{36}$ MORA, Francisco, Neurocultura. Una cultura basada en el cerebro, Madrid: Alianza, 2007, p. 43.

${ }^{37}$ GARDNER, Howard, The mind's new science. A history of the cognitive revolution, Nueva York: Basic Books, 1985.

${ }^{38}$ GARDNER, Howard, Arte, mente y cerebro. Una aproximación cognitiva a la creatividad, Barcelona: Paidós, 1997.
} 
Como nexo cinematográfico entre el ímpetu idealista romántico del XIX y el avance de las ciencias de la cognición del siglo XX, surge la presencia -más intuitiva que propiamente científica- de Jean Epstein. El cineasta y teórico francés quiso hacer de la lirosofía ${ }^{39}$ una doctrina, una "ciencia evolucionada", un "nuevo modo de conocimiento" que conciliara razón y sentimiento, ciencia y afecto. En el ámbito de la Historia, cruzando el ecuador del siglo veinte, Ricoeur también avisaba de la necesidad de lo Uno en tanto conocimiento verdadero y en tanto cultura integrada. Pero lo hacía casi con la angustia de un fracaso por adelantado:

Es ella [la cultura integrada] la que nos impulsa a coser juntos los hilos de la ciencia, de la ética, de las bellas artes y de la fe en un gran tapiz de una sola cara. La intención es recta, pero vacía, ya que no tenemos ningún medio para compensar los desniveles metodológicos con un súper-saber que lo englobe todo. No conocemos la unidad, sino que sólo la exigimos. ${ }^{40}$

Mi acercamiento a esta consiliencia tiene muy presente la cautela del filósofo citado. No busco una fusión espesa, difusa y mucho menos idealista entre ciencia y humanidades. Solo pretendo matizar las segundas a través de nociones biológicas y naturalistas -bioculturares y evolucionistas, si se prefiere-, que considero imprescindibles para comprender las manifestaciones artísticas del ser humano. Acudo a ellas porque las considero la mejor manera de huir "del intercambio incesante de los roles y las identidades, de lo real y lo virtual". ${ }^{41} \mathrm{Al}$ igual que Rancière, veo toda esa confusión como un efectismo que conduce al embrutecimiento del discurso. Como una molicie intelectual insoportable.

Hago hincapié en las nociones biológicas de la consiliencia, porque existe otra rama en la unidad del conocimiento que es crítica con ellas. Me refiero a la tesis emergente-convergente de Mario Bunge. El filósofo argentino comparte las intenciones del sociobiólogo americano, pero las sigue viendo incorrectas al considerarlas un reduccionismo no solo metodológico, también epistémico. Bunge incide ${ }^{42}$ en que no toda expresión o convivencia social y cultural se puede reducir a la norma biológica, como si Wilson no hubiera advertido también de ello.

\footnotetext{
${ }^{39}$ EPSTEIN, Jean, La lyrosophie, París: Éditions de la Sirène, 1922.

${ }^{40}$ RICOEUR, Paul, op. cit., p. 170.

${ }^{41}$ RANCIÈRE, Jacques, El espectador emancipado, Castellón: Ellago Ediciones, 2010, p. 26.

42 BUNGE, Mario, Emergencia y convergencia. Novedad cualitativa y unidad del conocimiento, op. cit., p. 351.
} 
Donde hay poca discusión es a la hora de diagnosticar que las humanidades todavía no se han recuperado del desastre -diría más, de la tragedia- de la posmodernidad. Como dice José Luis Molinuevo, es necesario volver a pensar con conceptos híbridos propios de estéticas transitivas. ${ }^{43} \mathrm{Si}$ Román Gubern hubiera ido un poco más allá en sus tímidos apuntes biológicos ${ }^{44}$, quizá todo habría sido más permeable en según qué círculos de la historiografía hispanoamericana del audiovisual.

Podría decirse que todo es una cuestión de sentido común, de no ser por la tenacidad con la que se ha evitado esta integración en el ámbito académico. El sentido común lo pone el citado E. O. Wilson:

Los científicos sociales no han sido nunca (...) capaces de encajar sus narraciones en las narraciones físicas de la biología humana y de la psicología, aunque con certeza es de aquí, y no de algún plano astral, de donde ha surgido la cultura. ${ }^{45}$

No me gusta esa conjugación del verbo ser, ni la presencia del adjetivo capaces y aun menos el adverbio nunca, pero la segunda mitad de la cita puede tomarse como un aliento para este trabajo. Un punto de referencia en el que subrayar tres palabras que ya vamos conociendo: narraciones, físicas y biología. Al imperativo cultural le debe acompañar el biológico, de la misma manera que el idealismo asociado a la creatividad debe ser contrarrestado por la presencia ancestral de nuestro instinto como especie. Es imperdonable no atender a los avances científicos que nos pueden ayudar a comprender mejor la experiencia estética. Empezando por los relativos al sistema nervioso. Hay que escuchar a neurólogos y neurobiólogos aunque sus teorías sean incompletas desde un punto de vista histórico y estético. Aunque tengan fallas y aunque provoquen fuertes discrepancias. Es imperdonable que el historiador se adocene en su correcta tradición. Muchas veces lo hacemos porque somos prisioneros de un moralismo que censura -como dijo Pasolini- el derecho y el placer a escandalizar y de ser escandalizado. Sobre todo cuando no ha lugar al escándalo, solo a la verdad.

\footnotetext{
${ }^{43}$ MOLINUEVO, José Luis, La vida en tiempo real. La crisis de las utopías digitales, op. cit., p. 140.

${ }^{44}$ Pienso, sobre todo, en determinados pasajes de: GUBERN, Román, La mirada opulenta. Exploración de la iconosfera contemporánea, Barcelona: Gustavo Gili, 1992; GUBERN, Román, Del bisonte a la realidad virtual. La escena y el laberinto, Barcelona: Anagrama, 1996; GUBERN, Román, El eros electrónico, Madrid: Taurus, 2000.

${ }^{45}$ WILSON, Edward Osborne, op. cit., p. 269.
} 
Cualquier teoría estética que no se base sustancialmente en la actividad del cerebro, será una teoría incompleta y superficial (...) Entender la base biológica de la experiencia estética (...) Ninguna teoría estética podrá estar completa, y no digamos ser profunda, a menos que tenga una base biológica. ${ }^{46}$

Tal es mi objetivo (...) convencerte de que nuestro conocimiento de la visión humana y del cerebro ya es lo suficientemente sofisticado para que podamos reflexionar con fundamento sobre las bases neuronales del arte y para que quizá podamos empezar a construir una teoría científica de la experiencia artística. ${ }^{47}$

Paradójico que el humanismo -contagiado hasta el tuétano de oscurantismo posmodernohaya terminado por rehuir del hombre, de su naturaleza y de su carne, para instalarse en la superstición, en la mística y en un moralismo vergonzante. Igual que aquella mestiza de Imitación a la vida (Imitation of life, Douglas Sirk, 1959), el humanista renegó de su propia condición. Como si ser un animal del orden de los primates, de la familia de los homínidos y de la especie sapiens fuera una deshonra. La torre de marfil humanista resultó ser una prisión cognitiva. Hago mías las palabras de Bryan Boyd:

Muchos han denunciado la noción de naturaleza humana como esencialismo, como una creencia en la esencia humana. Para las humanidades y las ciencias sociales contemporáneas no existe naturaleza humana alguna, solo las construcciones de la cultura. ${ }^{48}$

Una de las aporías en las que desembocan algunas teorías cinematográficas, es la negación de la naturaleza humana y el rechazo frontal a cualquier esencia o poder determinista de la biología para, acto seguido, defenderlo sin rubor en la tecnología y en el arte. Un arte que, faltaría más, ha sido creado por el hombre: "las artes no son en esencia ni religiosas, ni morales, ni políticas". ${ }^{49}$ Ideas opuestas a las originadas por una Teoría del aparato que

\footnotetext{
${ }^{46}$ ZEKI, Semir, Visión interior. Una investigación sobre el arte y el cerebro, Madrid: Antonio Machado Libros, 2005, pp. 19 y 234.

${ }^{47}$ RAMACHANDRAN, Vilayanur S., The tell-tale brain. A neuroscientist's quest for what makes us human, Londres: W.W. Norton \& Company, 2012, p. 374. [Paginación correspondiente a la edición epub] [La traducción es mía]

${ }^{48}$ BOYD, Bryan, On the origin of stories. Evolution, cognition and fiction, Londres: Harvard University Press, 2009, p. 19. [La traducción y las cursivas son mías]

${ }^{49}$ DUTTON, Denis, op. cit., p. 313.
} 
consideraba la técnica ${ }^{50}$ y ciertos mecanismos de representación como recipientes y transmisores de una ideología que el espectador asumía sin rechistar. Herencia de una Teoría crítica según la cual las élites y el poder modelaban dispositivos tecnológicos que, sin ser en esencia instrumentales y discursivos, propiciaban formas de control surgidas de las necesidades y de los usos.

La perspectiva siempre ha sido el ejemplo recurrente. Señalada como herramienta de dominación burguesa mientras se olvidaba que, además de invento racionalista ${ }^{51}$ también era y es la lógica trasposición del espacio realizada por un cerebro que ha evolucionado durante cientos de miles de años, no durante los últimos seis siglos. Jacques Aumont tuvo una gran intuición al dudar de que la perspectiva fuera una "forma ideológica" burguesa, en lugar de ser solo una "comodidad de pensamiento".$^{52}$ Digo intuición porque no hacía referencia a la causa biológica subyacente y porque se centraba en su condición de forma cultural. Por lo demás, estaba en lo cierto.

En este aspecto, mi punto de vista -más cercano al de Rancière, Gombrich y Morin- es más optimista respecto a la capacidad cognitiva del espectador para discernir mensaje, técnica e ideología. De lo contrario, esta tesis doctoral debería terminar justo en este punto y aparte. Las fuentes abiertas a partir de la Tercera cultura $^{53}$ de John Brockman, denostada y considerada con ignorancia supina como de derechas, desaguan en las humanidades y en la estética para regar uno de los campos más fértiles en décadas: la estética evolucionista. Que la aparición de esa tercera vía durante la década de los noventa coincidiera con el apogeo de las teorías digitales y con los estertores posmodernos, no hace sino acrecentar la necesidad de

\footnotetext{
${ }^{50}$ Los principales teóricos: Jean-Louis Comolli, Jean-Louis Baudry y, un poco más tarde, Pascal Bonitzer. En el ámbito anglosajón: Colin McCabe, Ben Brewster, Stephen Heath y Peter Wollen.

El artículo seminal: BAUDRY, Jean-Louis, "Cinéma: effets idéologiques produits par l'appreil de base" en Cinéthique, no 7-8, 1970. Yo he manejado la traducción inglesa de Alan Williams: "Ideological effects of the basic cinematographic apparatus" en Film Quarterly, vol. 28, no 2, invierno 1974-1975, pp. 39-47.

${ }^{51}$ GUBERN, Román, La mirada opulenta. Exploración de la iconosfera contemporánea, Barcelona: Gustavo Gili, 1992, p. 130.

${ }^{52}$ AUMONT, Jacques, El ojo interminable. Cine y pintura, Barcelona: Paidós, 1997, pp. 106-107.

El análisis de la perspectiva como mecanismo ideológico-cinematográfico fue una de las derivadas de la temprana Teoría del aparato. COMOLLI, Jean-Louis, "Technique et Idéologie" en Cahiers du Cinéma. La publicación de las seis partes en las que se dividió el estudio, abarcó de la primavera de 1971 al otoño de 1972. Los números de la revista son los siguientes: 229 (5-21), 230 (52-57), 231 (43-49), 233 (39-45), 234 (95-100), 241 (20-24). Entre paréntesis la paginación original.

Para una actualización y una repercusión histórica de aquellas ideas: FAIRFAX, Daniel (ed.), Jean-Louis Comolli. Cinema against spectacle. Technique and ideology revisited, Amsterdam: Amsterdam University Press, 2015.

${ }^{53}$ BROCKMAN, John, The Third culture. Beyond the scientific revolution, Londres y Nueva York: Simon \& Schuster, 1995.
} 
ponerla en valor. Es a partir de aquel movimiento de donde luego surgió un nuevo humanismo o un humanismo regenerado que "recogía el arsenal de metáforas suministrado por las ciencias duras".$^{54}$ Integrar estos extranjerismos en esta investigación solo será posible si me enfrento a dos sesgos cognitivos: el de conformidad y el de confirmación.

Me resisto a aceptar la desidia profética que muestra Raymond Bellour hacia esas nuevas quizá no tan nuevas- oportunidades. Aunque el error de Bellour -lo volveré a indicar un poco más adelante- no se debe a una cuestión nacionalista o de endogamia metodológica, sino a una desorientación y limitación en el enfoque.

Algún día, los historiadores de las ideas reconocerán en ello [la apelación a las ciencias cognitivas] un episodio menor de la guerra de descolonización que finalmente tuvieron que llevar a cabo los americanos con respecto del pensamiento francés que por un tiempo les sedujo en demasía. ${ }^{55}$

Cuando uno lee esta cita piensa que Bellour ha reducido el pensamiento francés a Lacan y Derrida. Si tal fue su intención, no cabe duda de que estaría cargado de razón. Sin embargo, y dando por sobreentendido el uso irónico del símil político, poca o nula descolonización de la influencia de Aumont, Morin, Rancière, Epstein o Mitry necesitarán los intelectuales y los científicos americanos. Aquí y ahora, desde la neutralidad española, quiero pasear por la Isla de los Cisnes y por Liberty Island con la misma tranquilidad.

Mi posición metodológica definitiva es la de un Jano bifronte que ya no aprecia el movimiento de las dos culturas-galaxias en rumbo de colisión, sino en danza. Por mucho que nuestro destino irrevocable, en tanto habitantes de la Vía Láctea, sea el de una colisión con Andrómeda dentro de cinco mil millones de años. Espero que, para entonces, la Historia haya resuelto sus conflictos. No quiero parecer un idealista, asumo -es más, exijo- las fricciones en tanto el consenso ${ }^{56}$ puede resultar innecesario y hasta nocivo. Hay situaciones que no lo admiten y que requieren elegir entre lo verdadero y lo falso. La fricción y el conflicto -tanto

\footnotetext{
${ }^{54}$ BROCKMAN, John (ed.), El nuevo humanismo y las fronteras de la ciencia, Barcelona: Kairós, 2007, p. 10. [Primera edición del año 2003]

${ }^{55}$ BELLOUR, Raymond, El cuerpo del cine. Hipnosis, emociones, animalidades, Santander: Shangrila Textos Aparte, 2013, p. 206.

${ }^{56}$ Lyotard decía que el consenso "no es más que un estado de las discusiones y no su fin". LYOTARD, Jean-François, La condición posmoderna, Madrid: Cátedra, 1989, p. 117.
} 
como el sacrificio- son elementos fundamentales si se quiere elaborar un relato. Quedo, entonces, mirando cómo se aproxima la ciencia prudente por un costado del Jano bifronte:

Tanto la historia como mis conocimientos me hicieron dudar de que quienes practicaban las ciencias naturales poseyeran respuestas más firmes 0 permanentes (...) que sus colegas de las ciencias sociales. ${ }^{57}$

Mientras que por el otro perfil veo a Edgar Morin -disculpen la ordinariez del símil- cayéndose del caballo. El Morin de un paradigma perdido que intentaba ser recobrado a principios de los setenta. El Morin que avisaba de la insularidad humanista y de la necesidad de una reconversión teórica que, en lugar de intentar construir sobre el barro el reino independiente de la cultura, se abrochara al eslabón biológico para gozar de autenticidad científica. Una scienza nuova que dejara atrás la "vida que parecía ignorar la materia físico-química" y que clausurara los guetos noológicos:

La teoría dominante sobre el hombre se funda no solamente sobre la separación, sino sobre la oposición entre las nociones de hombre y de animal, de cultural y de naturaleza. Todo lo que no encaja en este paradigma viene condenado como biologismo, naturalismo, evolucionismo. ${ }^{58}$

En definitiva, busco una interdisciplinariedad ${ }^{59}$ correcta -alejada de la bulimia ${ }^{60}$ - donde los niveles de análisis culturales y biológicos no se solapen, ya que "en la evolución humana, lo cultural nunca ha podido sustituir de modo integral a lo biológico".$^{61}$ Interdisciplinariedad que, como advertía Barthes, "no es una balsa de aceite" ${ }^{62}$, pero que sí es adecuada y propia de sociedades complejas que se resisten a ser definidas con etiquetas y prefijos intercambiables. Conexión, repito, susceptible de chispas y de cortocircuitos. Conjuro el miedo a una absorción hostil de las humanidades y del arte a manos de los intrusos de la bata blanca, y me posiciono

\footnotetext{
${ }^{57}$ KUHN, Thomas, op. cit., p. 13.

58 MORIN, Edgar, El paradigma perdido. Ensayo de bioantropología, Barcelona: Kairós, 1974, p. 9. [original de 1973].

59 Para una historia curricular básica de la aplicación del concepto y sus protagonistas: TORRES SANTOMÉ, Jurjo, "Las razones del currículum integrado" en Globalización e interdisciplinariedad: el currículum integrado, Madrid: Ediciones Morata, 2006, pp. 29-96.

${ }^{60}$ Lagny utilizaba el símil alimenticio para referirse a la multiplicación ilimitada de métodos y objetos. Una ampliación de territorios conceptuales y geográficos que llevaba a la dispersión, a la complejidad, a la discontinuidad y a la inarmonicidad.

${ }^{61}$ GUBERN, Román, El eros electrónico, op. cit., p. 97.

62 BARTHES, Roland, “De la obra al texto" en WALLIS, Brian (ed.), Arte después de la modernidad. Nuevos planteamientos en torno a la representación, Madrid: Akal, 2001, p. 169.
} 
de cara a una revolución cognitiva que suture la brecha, que derribe el muro -no por maltrecho menos perjudicial- que todavía divide:

(...) la materia de la mente, lo material de lo espiritual, lo físico de lo mental, la biología de la cultura, la naturaleza de la sociedad y las ciencias de las humanidades y las artes. ${ }^{63}$

\section{Relato, estilo y rigor}

De la misma manera que habrá una relación íntima entre tesis-métodos, habrá otra entre tesis y narración. La narración como construcción de mi versión de los hechos, como objeto analítico y como elemento que acompaña a las imágenes. Siendo consciente de mis limitaciones literarias, defiendo la necesidad de cierta voluntad de estilo en un relato enunciado en primera persona del singular. Hemos pasados por momentos dolorosos donde para disfrutar de una lectura fluida y agradable en el ámbito académico, había que huir de las facultades de letras y refugiarse en las de exactas. Una de las disputas más recientes y relevantes entre bandos, tiene a la escritura como rehén. Hasta el punto de ver cada vez más cerca la concesión del Nobel de literatura a un científico.

El conocimiento científico -a diferencia de lo que pensaba Lyotard $^{64}$ - fue y sigue siendo principalmente narrativo. Cualquier tipo de saber, incluido el estrictamente científico, debe recurrir al relato para su organización y transmisión. Creo que la degeneración literaria en las humanidades parte en buena medida de la confusión entre rigor y rigorismo. También del olvido del "uso de la imaginación como principio de método" ${ }^{65}$ y del miedo a la creatividad. Porque la Historia no es solo un oficio descriptivo y normativo, lo es también interpretativo. Algo que no compartía Paul Veyne ${ }^{66}$, para quien la Historia -además de no ser ciencia y de carecer de método- ni busca rigor, ni es normativa, solo busca la verdad. Steven Pinker ${ }^{67}$ es quien más ha incidido en este asunto de la escritura. Pero seríamos injustos si no reconociéramos que las humanidades también han hecho dura autocrítica:

\footnotetext{
63 PINKER, Steven, La tabla rasa. La negación moderna de la naturaleza humana, Barcelona: Paidós, 2003, p. 60. 
Una de las desgracias de nuestra época es que la expresión de las ideas y de las emociones, transita con demasiada frecuencia en maneras de escribir anfigúricas o cloróticas, cuando no parecen un elefante en una tienda de porcelanas. ${ }^{68}$

Esta situación adquirió visibilidad pública a finales del siglo XX con el denominado Affaire Sokal. Digo visibilidad pública y ahí incluyo también la académica. Las Facultades y sus departamentos se había limitado a vivir aquella degradación literaria con la cabeza bajo el ala y los brazos cruzados. Cuando los descruzaban era para aplaudir. Todo el conocimiento quedó afectado, cuando el físico norteamericano Alan Sokal envió un artículo a la publicación Social Text. Por aquel entonces, una revista de marcado corte posmoderno editada por la Universidad de Duke. Transgressing the boundaries. Towards a transformative hermeneutics of quantum gravity $^{69}$ fue el rimbombante título de un artículo que, según su autor, era del todo ininteligible y carecía de base científica. Su único propósito era desvelar que bajo ciertas convenciones como una orientación ideológica concreta (left-wing cant), múltiples referencias entre áreas de conocimiento (matemáticas, física), dudosas correspondencias y un lenguaje críptico, podía construirse un discurso vacío. Un texto ensimismado, puro pastiche que, además, levantaba una barrera entre legos e iniciados. Un ejercicio de categorización y jerarquía criticado por la militancia posmoderna, que quedaba al desnudo con disposiciones como esta. Ni rastro de conocimiento, ni rastro de divulgación.

En paralelo a esta publicación, Sokal descubrió la patraña mediante otro artículo en la revista Lingua Franca. Tras el revuelo provocado, el debate no cayó en el olvido. Apenas un año después, Sokal escribió junto a Jean Bricmont un libro cuyo título era una auténtica declaración de intenciones: Imposturas intelectuales. ${ }^{70}$ En él, siguiendo las ideas y la escritura de diferentes pensadores considerados afines la posmodernidad (entre otros: Lacan, Kristeva, Baudrillard o Virilio), desarrollaron con mayor profundidad los vicios detectados. También la posible solución a un problema que traspasaba la barrera del lenguaje y del estilo para instalarse en el núcleo de la epistemología. La logorrea, la ambigüedad y la vaciedad retórica solo eran síntomas de una causa subyacente: el corporativismo. El temor a la deslegitimación

\footnotetext{
${ }^{68}$ LIANDRAT-GUIGUES, Suzanne; LEUTRAT, Jean-Louis, op. cit, p. 129.

69 Artículo publicado en Social Text, Durham: Duke University Press, no 46-47, primavera-verano de 1996, pp. 217-252.

${ }^{70}$ BRICMONT, Jean; SOKAL, Alan, Imposturas Intelectuales, Barcelona: Paidós, 1999. [Original en francés: Intellectual Impostures. París: Odile Jakob, 1997]. Otro texto que puede considerarse como precedente de esta línea crítica, así lo han reconocido los autores, es: WEIGHTMAN, John, "On not understanding Michel Foucault" en The American Scholar, no 58, verano de 1989, pp. 383-406.
} 
intelectual y académica. Indiscretas guerras de pasillos libradas entre camarillas. Sokal y Bricmont cerraban su libro con una ilusión que comparto:

Nuestras esperanzas, sin embargo, van en otra dirección, a saber: la aparición de una cultura intelectual racionalista pero no dogmática, con mentalidad científica pero no cientificista, amplia de miras pero no frívola, políticamente progresista pero no sectaria. Pero esto, por supuesto, es sólo una esperanza y, quizá, sólo un sueño. $^{71}$

En esta investigación habrá -y no poca- importación conceptual. Espero ejecutarla sin caer en la impostura y en la logorrea. La convivencia de valores estadísticos, hechos historiados en relación a su contexto, interpretaciones estéticas y razones biológicas, buscarán la complementariedad sin supremacías a priori. Será de su argumentación, de su aplicación a una determinada situación, de donde esta se podrá deducir. Porque una mentalidad cuantitativa no es incompatible con una mentalidad moralmente ilustrada. Será de la reciprocidad de esas medidas de control, de donde obtendré datos con el grado justo de fiabilidad. La ventaja principal reside en la posibilidad de introducir herramientas auxiliares que un método con cierre no permitiría. Esta apertura metodológica es, de suyo, un valor positivo, pero también conlleva una mayor responsabilidad a la hora de manejar aquello que de manera descriptiva queda fuera del ámbito de mi disciplina. La erudición necesaria para acometerla, como apuntaba Georges Duby, es una cuestión de ética. Rigor epistemológico para recibir y ajustar modos ajenos a los del historiador. Algo que supone un déficit pendiente en los destartalados planes de estudio, a pesar de sus eternas reformas y contrarreformas. Cambios que no han logrado arreglar el problema raíz de las camarillas académicas y de las sectas metodológicas.

La necesidad de elaborar instrumentos de investigación acaba a menudo con el predominio de la exploración sobre los hechos reales; los modelos que se aplican corren el peligro de ser más importantes que los resultados derivados de su aplicación. $^{72}$

[Las teorías] son sospechosas cuando pretenden tener la llave de la verdad y se convierten en un fin en sí mismas. ${ }^{73}$

\footnotetext{
${ }^{71}$ BRICMONT, Jean; SOKAL, Alan, op. cit., p. 229.

${ }^{72}$ CASETTI, Francesco, Teorías del cine, Madrid: Cátedra, 1994, p. 20.

${ }^{73}$ LIANDRAT-GUIGUES, Suzanne; LEUTRAT, Jean-Louis, op. cit., pp. 108-109.
} 
Que la Historia como disciplina y ciencia ${ }^{74}$ tenga respuestas desde sus principios básicos al planteamiento anterior, no significa que sus miembros olviden o ignoren la capacidad para modificarlos y transgredirlos. Sin la necesidad de reclamar o recomendar juramentos deontológicos con mayor o menor validez jurídica o académica, hay que ser consciente de esta problemática. Si en algo se sustenta el conocimiento científico es en la permanente provisionalidad de sus resultados. En el constante cuestionamiento para saber si siguen guardando el índice de verdad que demostraron en un momento determinado. Asumo esta responsabilidad desde los diferentes puntos de vista ya mencionados: Homo sapiens, ciudadano, historiador, creador, espectador, cliente y usuario. En todos los casos, me distancio de todo aquello que implique:

a) La recepción del fenómeno y su contexto mediante un acto de fe o mediante un acto sobrerrecomendado. Camino que lleva a la fulminación de cualquier metodología y conocimiento científico: la religión, la cinefilia.

b) Enfrentarse a la obra como un objeto oscuro. El misterio, la incertidumbre, el enigma y la conspiración aparecen como situaciones propicias al momento actual. Camino que conduce a la nigromancia y a la egolatría.

Decía Raymond Bellour que no hay verdadera ciencia del cine, ni ciencia del espectador. Y que la importación de las neurociencias y de la neurobiología podía desembocar en la paradoja del cognitivista. ${ }^{75}$ Esto es, caer en viejos mecanicismos y en un cientificismo de cartón piedra. Pero al comprobar que, al menos en los últimos veinte años, ha florecido el cognitivismo y que yo mismo recurro a él, pregunto: ¿qué significa o qué es exactamente el cognitivismo cinematográfico? Para introducirlo recurro a la síntesis realizada por Noël Carroll y David Bordwell. El cognitivismo cinematográfico no es tanto una metodología, como una postura. Esto que puede parecer una generalidad para escurrir el bulto, tiene sentido. Las herramientas del cognitivismo científico -por complejas y específicas- o no son trasladables al cine, o lo son solo de manera parcial. No puede haber un trasvase íntegro de su caudal.

\footnotetext{
${ }^{74}$ Estoy solicitando la confluencia entre humanidades y ciencia, porque el estatuto científico de las ramas de la primera no es reconocido como absoluto. Tenemos, sin ir más lejos, la catalogación de un Karl Popper que situaba a la Historia dentro de las calificadas "filosofías reveladoras" o, lo que es lo mismo, aquellas seducidas por la facilidad para aplicar sus teorías en todas partes. POPPER, Karl Raimund, La responsabilidad de vivir. Escritos sobre política, historia y conocimiento, Barcelona: Paidós, 2006. En el lado contrario, Michele Lagny defiende la Historia como rama legítima de la ciencia.

${ }^{75}$ BELLOUR, Raymond, op. cit., p. 208.
} 
Un análisis o una explicación cognitivista busca comprender el pensamiento humano, la emoción y la acción, apelando a procesos de la representación mental, a procesos naturalistas y a (cierto sentido de) la voluntad racional. ${ }^{76}$

Bordwell y Carroll avisaban de que, a pesar de esta precaución metodológica, seguirán surgiendo roces y enfrentamientos. Allí donde aparece una postura, surge la contraria. Estoy de acuerdo con la síntesis citada, sobre todo en lo relativo al naturalismo y al protagonismo de la mente; aunque quede en el aire esa voluntad racional. Queda en el aire porque, desde que los autores escribieron esas líneas, el debate sobre el libre albedrío ha venido a impugnar o cuando menos matizar el reinado de la voluntad racional.

Siguiendo y terminando con Bellour, comparto la humildad y la precaución necesarias para la inspiración científica, pero discrepo totalmente de su temor ante la puesta en práctica y el posible reduccionismo.

(...) al intentar inspirarme, modestamente, en estos científicos, tomando prestado de ellos lo que pueda hacerme avanzar, no aspiro a la ciencia, solo a cierto grado de seriedad. Por eso me parece siempre preferible quedarme en la sugerencia analógica, por precisa que pretenda ser o sueñe que es, y resistirme a la aplicación, por naturaleza doblemente reductora, tanto para la teoría como para el objeto. ${ }^{77}$

El error básico de Bellour es que solo ve el cognitivismo como un patrón aplicable a la obra y a la teoría, no como una herramienta para el conocimiento biológico y cultural de la especie que las ha creado.

\footnotetext{
76 BORDWELL, David; CARROLL, Noël (eds.), Post-Theory. Reconstructing film studies, Madison: University of Wisconsin Press, 1996, p. xvi. [La traducción es mía]

${ }^{77}$ BELLOUR, Raymond, op. cit., p. 220.
} 


\section{Hipótesis de la investigación}

La hipótesis principal para la que busco confirmación es la siguiente. La doble supervivencia de la narración y de la materia en las imágenes, en especial las cinematográficas. Esta doble supervivencia responderá a una continuidad histórica, biológica, social y artística. La hipótesis se desarrollará acudiendo a las técnicas y a las estéticas que operan esa supervivencia. La continuidad, a su vez, no encubrirá los posibles cambios y rupturas. Empleo el término supervivencia porque a lo largo de los últimos años se ha puesto en cuestión su salud y hasta su existencia. Utilizo el término en su estricta acepción biológica -además de por cuestiones metodológicas ya anunciadas- porque sobre estas dos realidades se ha ejercido una desvirtuación altamente perjudicial para la epistemología y para el propio ser humano.

Esta hipótesis adquiere mayor importancia dentro del contexto en el que tiene lugar su defensa. Los análisis surgidos a partir de la idea del fin de los metarrelatos, así como la fórmula de la virtualización, vivieron y viven un momento en el que prevalece más el deseo de ir hacia que la realidad de ser. La narración no ha muerto y la desmaterialización no es tal. Este no será el típico relato -aquí invertido- sobre la muerte de. La hipótesis de la supervivencia no se queda en la descripción y en la afirmación de un estado vital, sino que se explicará atendiendo a una serie de mecanismos de deseo instrumental. El relato y la materia siguen estando igual de presentes que en el siglo XIX. El problema ha surgido a la hora de maquillar o de ocultar dos aspectos fundamentales de la vida del hombre empeñados en rebosar por los márgenes de los encuadres. Materia y narración siguen obstinadas en mostrar y en mostrarse.

Narración y materia en ningún caso son conceptos residuales y anecdóticos de las imágenes. Mi objetivo no es la catalogación reduccionista y cuantitativa propia de un químico, sino la identificación propia de un historiador $-y$ de un biólogo ${ }^{78}$ - que, luego de ella, es consciente de que aun falta por desentrañar el misterio del arte y de la vida. La implacable realidad material del dispositivo cinematográfico y su desmesurada logística desnudan la idea de una desmaterialización presentada ante las sociedades contemporáneas como una imagen ideal. Muchas imágenes cinematográficas del siglo XXI están en la base de esta deriva. Imágenes elaboradas de acuerdo a un tipo muy codificado y con un carácter que exalta como rasgo principal su muralidad. Composiciones destinadas a la consecución de una lozanía icónica marcada por la eliminación de cualquier tipo de residuo, de huella o de imperfección material.

\footnotetext{
${ }^{78}$ AUMONT, Jacques, Materia de imágenes, redux, op. cit., p. 17.
} 
Esa búsqueda sin descanso de la asepsia se realiza, paradójicamente, mediante un relato cuya principal función es fulminar a los de su especie. Para ello, se proyecta en la tecnología un ansia de fiabilidad extrema. Un ideal mecanicista de la perfección y de la belleza donde los defectos deben ser eliminados o al menos estar maquillados. Una perfección anhelada que encuentra en esa muralidad de las imágenes vehículo propagandístico. El relato caló porque el paciente, un imaginario colectivo enfrentándose a situaciones de inseguridad, era receptivo. El fenómeno necesitó poco tiempo para engendrar auténticas - $y$ en absoluto originalesideologías digitales que conectaban la voluntad de poder con la voluntad de lo inmaterial. ${ }^{79}$ Espacio liminar donde la ideología daba la bienvenida a la teología.

La asepsia y la hipertrofia iconográfica han sido empleadas para rebajar el umbral de la percepción sobre la materia y para sobredimensionar su valor figurativo en detrimento de la narración a la que contribuyen. El relato que conduce al alejamiento de lo tangible y de las narraciones, no redunda en la búsqueda de una idea de lo trascendente ni en una narrativa experimental, sino en mecanismos de simplificación y rentabilidad. Desde comienzos de siglo, este relato ha ido quedando en evidencia. Ha fracasado, primero, por su falsedad y, solo luego, por un cambio de necesidades y de tendencia en el gusto. Estas últimas también han comenzado a influir. Así, lo que antes fue belleza, asepsia, tersura, muralidad y lozanía no ha dejado de incorporar la fealdad, la infección, la arruga, la ruina y la decrepitud. Esto es, al mismo tiempo que la corriente principal se adueñaba del mercado y del imaginario, ha resurgido una imagen material asociada durante décadas a la vanguardia y a lo experimental. Esta imagen material aparece ahora en el jardín de manera refractaria, violentando y contaminando el modelo dominante. Lejos de quedar restringida en guetos, la imagen material se propagará de manera vampírica con toda su fascinante repulsión. Resistiéndose, con escasa suerte, a su normalización por parte del sistema.

Así pues, la hipótesis queda inscrita en un tiempo que la coloca en una posición comprometida para la argumentación. La hipótesis parte en desventaja contextual. Haré esto último argumentar- sin extraer la imagen a un espacio esterilizado en el que actuar sobre ella con impunidad. Bien al contrario, se tratará de identificar los flujos y las corrientes que la envuelven, la hieren y la manchan. Más aun, ciertos tipos de imágenes poseen una causa inmediata de naturaleza azarosa, simplemente temporal o espacial que demandan dicho análisis. A pesar de haber dividido las imágenes cinematográficas en dos bloques enfrentados,

\footnotetext{
${ }^{79}$ MOLINUEVO, José Luis, op. cit., p. 57.
} 
demostraré que el primero -dominado por la asimilación definitiva del digital y las (ultra)altas definiciones- pierde su aparente -que no verdadera- condición monolítica. Que la materia y la narración siguieron y siguen presentes y que se expresan en el reciclaje y en la importación de recursos propios de una imagen precaria e históricamente minoritaria.

Así las cosas, esta investigación puede considerarse el relato histórico sobre un fracaso social y teórico que promulgó un cine y unas imágenes presuntamente desnarrativizadas y desmaterializadas. Fracaso al que se llega porque todo se urdió ignorando la existencia de, en ambos casos, de una incuestionable narratividad y materialidad en sus respectivas bases biológicas, técnicas y sociales. 


\section{Estructura de la tesis}

El trabajo se dividirá en tres partes cuya autonomía quedará siempre limitada por una íntima relación entre las partes. Habrá fragmentación pero también continuidad, coherencia y relato ininterrumpido. Previamente a estos tres apartados, desarrollaré una suerte de preámbulo, una introducción avanzada donde poder aclarar el objeto de análisis: la imagen en sí misma. A partir de principios fisiológicos y semióticos, explicaré la naturaleza de las imágenes mentales y de las imágenes externas convencionales. Terminaré avisando de cómo algunas teorías esencialistas y exhibicionistas han olvidado la función mediadora de dichas imágenes.

La primera parte tomará como referente la fórmula del cine de atracciones para discutir su validez y su progresiva desnaturalización. Con el texto de Tom Gunning constituido en emblema de toda una corriente analítica y de pensamiento, hurgaré en los entornos y en los principios narrativos implicados en la imagen, en el cine y en nuestra vida cotidiana social e íntima.

En la segunda parte, siguiendo el mismo esquema de la anterior, tomaré otro emblema contemporáneo: la desmaterialización. Mi objetivo será desarrollar un discurso crítico que, después de secuenciar su genealogía, la desafíe a través de las imágenes actuales. Sin la genealogía citada, no sería posible comprender su enorme éxito como correlato de las sociedades posindustriales.

Entre ambos situaré un interludio donde discurriré sobre el papel de las vanguardias a la hora de integrar y de conectar narración y materia en sus imágenes y en sus discursos. Pondré en cuestión la idea de vanguardia cinematográfica como entidad eminentemente antinarrativa. Además, algunas de sus prácticas servirán para indagar de manera directa en aspectos biológicos y científicos como la conciencia y la percepción.

Finalmente, realizaré un análisis de las ideas vertidas valiéndome de la filmografía del estudio de animación Pixar. Tanto el análisis como el corpus estarán más enfocados a servir de conclusiones prácticas que de simple ilustración. 



\section{TECNOLOGÍA Y BIOLOGÍA DE LA IMAGEN}

\subsection{Esencia, destino y mediación}

El estudio de la tecnología ha estado históricamente marcado por relaciones deterministas, esencialistas, relativistas y teleológicas. El ansia por identificar el fenómeno como un concepto unívoco para que resulte funcional, ha condicionado los factores y el resultado. Personalmente, considero que cualquier discurso articulado en torno a "la pura inmanencia tecnológica, implica una mitificación". ${ }^{1}$ Conviene volver la vista a un marco global tan real, eficaz y emocionante como la evolución: mutación azarosa, retención selectiva. Al contrario que el determinismo y la teleología, la evolución carece de propósito y de previsión. La evolución es un sistema abierto, impredecible y, sobre todo, libre. La evolución es cierta, no depende de un punto de vista, ni de una construcción cultural. La evolución no tiene ni necesita una causa que la guíe.

Lo que pretendo aclarar citando los rudimentos de la evolución, es que la tecnología carece de vida propia. La tecnología no tiene una ruta, su meta no es replicar la realidad, suplantar al ser humano o fundirse con él. Su futuro no es ser perfecta. La tecnología, como el arte, vino a satisfacer necesidades surgidas de nuestras crecientes habilidades cognitivas. Del puro e improductivo placer, al utilitarismo más banal. Para el hecho tecnológico conviene descartar desde ya la equivalencia entre evolución y progreso. La suya no es una historia lineal y sus cambios de paradigma pueden albergar retrocesos, discursos paralelos o yuxtaposiciones. Son los suyos sistemas incompletos y en desarrollo -intencional, accidental o coyunturalmenteconstante, igual que los de las propias teorías científicas que propician su creación y explican sus fundamentos.

Al introducir la dimensión tecnológica de la imagen cinematográfica en esta tesis, aunque sólo sea por un instante, lo hago sin precipitarla fuera de los conjuntos delimitados al principio de este escrito. De haber optado por aislar el cine como fenómeno independiente, habría sido propio de una búsqueda esencialista con la que discrepo. En concreto, habría sido el proceder habitual de la instrumentalización primaria en la que se sustentan las teorías esencialistas de la tecnología. Las herramientas de dicha instrumentalización son la descontextualización, el reduccionismo y la autonomía.

\footnotetext{
${ }^{1}$ PALAO, José Antonio, La profecía de la imagen-mundo. Para una genealogía del paradigma informativo, Valencia: Ediciones de la Filmoteca, 2004, p. 332.
} 
Para evitarlo, no basta con irse al polo opuesto, al de una instrumentalización secundaria donde los sistemas, la mediación y la iniciativa conformen una visión de la tecnología como construcción puramente social restringida a un lugar $y$ a un tiempo. Estos últimos y perturbadores aspectos de la tecnología -arrinconados por el esencialismo al considerarlos extrínsecos-, no podemos tratarlos como meramente contingentes, pero tampoco como valores absolutos. Lo correcto es alcanzar la idea de una tecnología no como destino, sino como lugar en el que configurar dicho destino. ${ }^{2}$ Una idea de la tecnología asistida por cierta universalidad práctica que reconozca momentos, agentes y lugares sin quedar limitada a fronteras e identidades.

De la misma manera que resulta inviable aislar el cinematógrafo como hecho tecnológico independiente, es necesario considerar las imágenes como entidades mediadoras entre sujeto y objeto. Las imágenes como mediación a un doble nivel que entiendo inherente al concepto de mediación tecnológica. Ese doble nivel debe ser característico de cualquier acercamiento riguroso al cinematógrafo: el lingüístico y el material. ${ }^{3}$ La imagen entendida como mediación responde a factores diversos. Es producto de una tecnología, adquiere presencia mediante todo tipo de materiales y queda inscrita en una industria y en una sociedad -en una industria social y cultural, dirán otros. Así, sus posibles rasgos esenciales, si es que existen y son detectados, enseguida se ven afectados por la estrecha convivencia de los entornos y de los usos. La imagen es porosa y, como dice Josep María Català, compleja. ${ }^{4}$

Conviene avisar sobre una característica derivada de la anterior catalogación: las imágenes contienen una carga autorreflexiva producida tanto por ensimismamiento lingüístico ambiguo desde un punto de vista barthesiano-, como por la capacidad residual de la materia empleada en su formación y presentación. Es en este momento, teniendo presente esta realidad de las imágenes, cuando puedo acercarme al tipo concreto que me interesa y, desde ahí, al objeto tecnológico específico que las produce. De esta forma, puedo apreciar cómo el cinematógrafo delata su base tecnológica a través de sus manifestaciones textuales -las imágenes- y de su impacto ambiental. Más complejo, más confuso y más impreciso sería que lo

\footnotetext{
2 FEENBERG, Andrew, "From essentialism to constructivism. Philosophy of technology at the crossroads", en HIGGS, E.; STRONG, D.; LIGHT, A., (eds.), Technology and the good life, Chicago: University of Chicago Press, 2000, pp. 294-315.

${ }^{3}$ VILCHES, Lorenzo, La migración digital, Barcelona: Gedisa, 2001, p. 185.

${ }^{4}$ CATALÀ, Josep M., La imagen compleja. La fenomenología de las imágenes en la era de la cultura visual, Barcelona: Universitat Autònoma de Barcelona, 2005.
} 
hiciera desde una hipotética primera persona del singular que no responde ante nada ni nadie, solo ante la prosopopeya.

La tecnología cinematográfica, igual que sus textos, puede adquirir diferentes significados. Si como afirma Jameson, "lo mismo que todo tiene más de un significado, también lo tiene la tecnología", es gracias a la polisemia derivada de esta idea de tecnología entendida como lugar y de la imagen como mediación.

\subsection{Imagen, mente y materia}

«Cause we're living in a material world» Material girl (Madonna, 1985) ${ }^{5}$

«El cine es inmaterial» Manoel de Oliveira ${ }^{6}$

«El cine es un fenómeno idealista. La idea que los hombres se habían hecho existía ya totalmente definida en su cerebro, como en el cielo platónico; y lo que nos sorprende es más la tenaz resistencia de la materia ante la idea que las sugerencias de la técnica a la imaginación» André Bazin ${ }^{7}$

Fondeado en el lugar, ahora hay tiempo para entender cómo ejercen las imágenes su estratégica función mediadora entre aparato y espectador. En este apartado daré cuenta de la problemática que siempre ha acompañado a las imágenes mentales. A partir de un ligero apunte semiótico y de otro biológico más denso, devolveré las imágenes mentales al mundo material del que nunca debieron salir.

\subsubsection{El Big Bang semiótico}

Durante gran parte de su historia, la razón fotográfica de las imágenes remitían de inmediato a lo profílmico oscureciendo el resto de los aspectos. Por decirlo de alguna manera, las imágenes se formaron mediante procesos de interiorización que, una vez modelaban la representación

\footnotetext{
${ }^{5}$ BROWN, Peter; RANS, Robert, Material girl, Site Records, 1985.

${ }^{6}$ Declaración realizada en el documental Oliveira - L'architecte, dirigido por Paulo Rocha en 1993 para la serie Cinéma, de notre temps.

${ }^{7}$ BAZIN, André, “El mito del cine total” en ¿Qué es el cine?, Madrid: Rialp, 1990, p. 33.
} 
del mundo exterior, rebotaban con fuerza hacia éste. Las imágenes se expandían a la manera de un Big Bang como consecuencia directa de un Big Crunch profílmico. Algo similar a la relación que ya establecía Peirce entre signo y objeto y que estaba regida por los principios de continuidad, conexión e iconicidad.

¿Qué sucede con la imagen de síntesis y la digital? Sucede que mantiene intacto el proceso de expansión, mientras que ve modificado el de contracción por la inmersión del operador en el lenguaje gracias a las herramientas y al código. Esto es fundamental, el proceso de contracción queda modificado -en el caso de la imagen digital solo en parte-, pero no eliminado. Es más, esta tesis doctoral quiere argumentar que tal modificación no siempre es lábil, sino intensa y de doble vertiente: material y narrativa.

La imagen que carece de referente real pone en crisis la conexión peirciana donde la semejanza y la identificación, por poderosas que fueran, nunca convertían el signo en cosa, en ese algo, en objeto. Una imagen de síntesis que carezca de referente real, es un signo que puede terminar siendo la cosa. Esa imagen no podría quedar asociada al icono peirciano porque, a diferencia de este, la imagen de síntesis como signo no remite a una idea abstracta, sino a una concreta y determinada por la representación y/o la narración. Lo representado solo existe en tanto imagen: "la imagen de la cosa es la única cosa en sí". ${ }^{8}$ La Torre de Mordor no existe, pero puede ser construida. Esto es, la imagen de síntesis puede ser el signo de la cosa por hacer. Sucede lo mismo en la imagen digital, en la que partiendo de la misma necesidad lumínica de lo profílmico que en la analógica, se pueden alcanzar grandes niveles de transformación. Nótese que distingo síntesis de digital. Siendo la primera aquella elaborada íntegramente en una computadora. Siendo la segunda aquella que, aun compartiendo raíz y procesos numéricos, se inicia con el registro de lo profílmico.

La conexión peirciana era, entonces, una idea de emanación que ignoraba la imagen de síntesis no por incapacidad profética, sino por un error cardinal: distinguir entre mental y material. Para Peirce, en la reformulación ${ }^{9}$ de su teoría, iconos y símbolos eran signos regidos por asociaciones mentales, mientras que el índex siempre mantenía una relación física. En el terreno de la imagen, el índex peirciano quedaría ligado a la imagen analógica en tanto herida

\footnotetext{
${ }^{8}$ GONZÁLEZ QUIRÓS, José Luis, op. cit., p. 145.

9 Original: PEIRCE, Charles Sanders, "On the algebra of logic. A contribution to the philosophy of notation" en American Journal of Mathematics, № 2, vol. 7, enero de 1885, pp. 180-202. Versión manejada: KLOESEL, Christian (ed.), Writings of Charles S. Peirce. Volume 5: 1884-1886, Bloomington: Indiana University Press, 1993, pp. 162-190.
} 
o huella ${ }^{10}$, pues se refiere al objeto que denota en virtud de estar realmente afectado por dicho objeto a través de la luz. Esta terminología peirciana puede parecer inofensiva y no pretendo negar su maravillosa funcionalidad. Pero induce a una confusión definitiva: la del dualismo cartesiano y su fantasma en la máquina:

No es, meramente, un conjunto de errores. Es un gran error y un error de tipo particular: un error categorial. Presenta los hechos de la vida mental como si pertenecieran a un tipo o categoría lógica (o conjunto de tipos o categorías) cuando en realidad pertenecen a otra. En consecuencia (...) es un mito filosófico. ${ }^{11}$

Un error heredado en buena medida del hombre interior de San Agustín ${ }^{12}$ y que ya apreciaba, entre otros, Diderot en su Carta sobre los ciegos. El mismo Diderot que, no sin ironía, mentaba aquel imposible hombre creado de acuerdo a la norma cartesiana por un filósofo sordociego cuyo alma residiría en la punta de los dedos. Para el ilustrado, el error categorial radicaba en la peligrosa separación de:

... las cualidades sensibles de los cuerpos, o las unas de las otras, o del propio cuerpo que les sirve de base; y el error nace de esa separación mal hecha, o hecha de forma inadecuada; mal hecha en las cuestiones metafísicas y hecha de forma inadecuada en las cuestiones físico-matemáticas. ${ }^{13}$

\subsubsection{Imágenes mentales. Posmodernidad frente a verdad fisiológica}

La segregación de cualquier tipo de imagen respecto del mundo material-de las leyes físicas y fisiológicas que rigen la vida- se agudizó durante el fenómeno digital. No era nada nuevo, siempre había estado presente. Desde la concepción platónica ${ }^{14}$ que discriminaba los ojos del cuerpo (discernimiento primario, la visión, el ojo y las imágenes sensoriales) de los ojos del alma (discernimiento profundo, las esencias y las ideas puras), y desde la contemplación intelectual aristotélica donde "las imágenes son como sensaciones sólo que sin materia". ${ }^{15} \mathrm{En}$

\footnotetext{
${ }^{10}$ DUBOIS, Philippe, El acto fotográfico. De la representación a la recepción, Barcelona: Paidós, 1994, p. 42.

${ }^{11}$ RYLE, Gilbert, El concepto de lo mental, Barcelona: Paidós, 2005, pp. 13-14.

12 "No quieras derramarte fuera; entra dentro de ti mismo, porque en el hombre interior reside la verdad". DE HIPONA, San Agustín, De vera religione, XXXIV, 72.

13 DIDEROT, Denis, Carta sobre los ciegos, seguido de Carta sobre los sordomudos, Aldaia: Pre-Textos, 2002, p. 24.

${ }^{14}$ PLATÓN, República, Madrid: Gredos, 1988.

${ }^{15}$ ARISTÓTELES, Acerca del alma, Madrid: Gredos, 1983, p. 242.
} 
cuanto a la actualidad, el momento decisivo llegó con la equiparación que, en un alarde de lo que Pinker denomina estupidez convencional ${ }^{16}$, hicieron los teóricos de la posmodernidad entre imágenes y pensamientos. Al tiempo, nos declaraban en un estado conspiranoico de hiperrealidad-irreal donde no podíamos distinguir entre realidad y ficción dada la rampante crisis de representación. La posmodernidad, en sus ilusiones ${ }^{17}$, prefería un revoltijo profundamente idealista, rancio y diríase que hasta escolástico, a la razón biológica del cerebro y a nuestra capacidad de emancipación. Decía buscar la pluralidad y el progreso, pero terminó en el totalitarismo -fulmina los conceptos de discernimiento y discrepancia- y el arcaísmo. $^{18}$

La percepción posmoderna instauró la dictadura de una imagen que derogaba la realidad. Esta pasaba a convertirse en una nueva irrealidad construida por la mente, ajena a cualquier rastro de un mundo externo sin rastro de verdad y reglado por las visiones de los grupos dominantes. Frente a esto, no podemos olvidar que la realidad, "aun siendo filtrada por nuestra biología"19, es nuestra única realidad conocida y demostrable. La deriva posmoderna -tan rancias e imprecisas eran sus ideas- podría quedar explicada con la glosa de Copleston a Berkeley:

Berkeley habla (...) de "sensaciones o ideas" como si ambos términos fueran sinónimos, lo que dejando aparte la impropiedad general que encierra equiparar ideas y sensaciones, sugiere inevitablemente que las cosas sensibles son meras modificaciones subjetivas de nuestro espíritu, ya que la palabra "idea" se refiere a algo subjetivo, y, en realidad, privado. Sugiere, por lo tanto, que no existe realmente un mundo sensible público, sino tantos mundos sensibles privados como sujetos perceptores. El mundo sensible se convierte de este modo en algo muy cercano al mundo del ensueño. ${ }^{20}$

Antes de continuar, conviene realizar un excurso idiomático. El inglés diferencia entre image y picture, mientras que el español puede utilizar la palabra imagen en toda su extensión semántica. Para los anglosajones, picture es la imagen fabricada, mientras que image responde a ese deje inmaterial que siempre ha acompañado a las representaciones simbólicas. Para un

\footnotetext{
${ }^{16}$ PINKER, Steven, El instinto del lenguaje. Cómo crea el lenguaje la mente, Madrid: Alianza, 1995, p. 59.

${ }^{17}$ EAGLETON, Terry, Las ilusiones del posmodernismo, Buenos Aires: Paidós, 1997. "La idea de que la totalidad sea absolutamente algo mental es una notable doctrina idealista", p. 31.

${ }^{18}$ DEBRAY, Regis, El arcaísmo posmoderno. Lo religioso en la aldea global, Buenos Aires: Manantial, 1996.

${ }^{19}$ MORA, Francisco, op. cit., p. 51.

${ }^{20}$ COPLESTON, Frederik, Historia de la filosofía vol. V. De Hobbes a Hume, Barcelona: Ariel, 1993, p. 216.
} 
anglosajón, no cabe la existencia de pictures en el cerebro, solo images o, de manera excepcional, mental-pictures.

Que no comparta la disyuntiva mente-materia -lo excepcional es que siga existiendo el dilema no en pleno siglo XXI, sino en gente con estudios en pleno siglo XXI-, no quiere decir que no reconozca la existencia de las imágenes mentales (alucinaciones, sueños, recuerdos, predicciones motrices, patrones abstractos). Por supuesto que existen, pero no en un sentido ideal y fantasmagórico ${ }^{21}$, sino en otro puramente fisiológico cuyo funcionamiento todavía no hemos descifrado por completo. ${ }^{22}$ El misterio es, en este caso, la espera, la incertidumbre y hasta la angustia de no encontrar un camino del que se intuye su existencia. A pesar de esta dificultad, puedo definir la imagen mental, siguiendo el principio de Stephen Kosslyn ${ }^{23}$, como aquello que vemos en ausencia del común e inmediato estímulo sensorial. Es decir, la imagen mental no es consecuencia directa de un nuevo input, sino de una elaboración autosuficiente donde entran en juego muchos factores como la reconstrucción de un recuerdo ${ }^{24}$ o su idealización- realizada por nuestro cerebro. Pero esto sería una especie de imagen mental pura, el cerebro se vale de otros tipos de imágenes mentales mixtas -donde cabe el inputpara seguir operando. Lo veremos en seguida.

Nótese la cursiva que he utilizado en vemos, porque imaginar no es lo mismo que ver. De la misma forma que imaginar tampoco es lo mismo que alucinar. Las imágenes mentales no se ven, se experimentan. En el caso de las alucinaciones, en un grado tan alto que tienden a confundirse con la percepción y la visión cotidiana. Al menos es lo que aseguran las investigaciones realizadas en las últimas décadas sobre la base nerviosa de las alucinaciones. Este punto, este vitalismo de la imagen alucinatoria, fue recogido con habilidad por Oliver

\footnotetext{
${ }^{21}$ Existe un problema recurrente en la traducción y el uso del phantasma de Aristóteles. De la literalidad de fantasma en algunas versiones españolas, a mental-picture en otras inglesas. El phantasma sería la imagen sin cuyo concurso "el alma jamás intelige" (ARISTÓTELES, op. cit., p. 239). Véase: CULIANU, Ioan, Eros y magia en el Renacimiento, Madrid: Siruela, 2007, p. 31.

${ }^{22}$ GLYNN, lan, An anatomy of thought. The origin and machinery of the mind, Nueva York: Oxford University Press, 2003.

${ }^{23}$ KOSSLYN, Stephen, "Mental imagery" en KOSSLYN, Stephen; OSHERSON, Daniel (eds.), An Invitation to Cognitive Science. Visual cognition, Volume 2, Cambridge: The MIT Press, 1995, pp. 267-296. Si bien resulta conveniente la matización y actualización -diez años en este campo son demasiados- realizada de manera global en KOSSLYN, Stephen; THOMPSON, William; GANIS, Giorgio, The case for mental imagery, Nueva York: Oxford University Press, 2006.

${ }^{24}$ Bergson articulaba la imaginería mental a partir de tres conceptos interrelacionados: percepción, recuerdo-puro y recuerdo-imagen. BERGSON, Henri, Materia y memoria. Ensayo sobre la relación del cuerpo con el espíritu, Buenos Aires: Cactus, 2010, p. 155.
} 
Sacks ${ }^{25}$ para sembrar la duda con una vieja cita de Charles Bonnet (1760): “La mente no sería capaz de distinguir la visión de la realidad". Que el cerebro utilice las mismas regiones y conexiones cerebrales para producir imágenes alucinatorias y para percibir la realidad, no significa que, en la normalidad, seamos incapaces de establecer con claridad los límites y las diferencias entre el resto de imágenes y la realidad. Con esto sobre la mesa, se podría pensar que la posmodernidad fue un estado alterado de conciencia, una mistificación colectiva que provocó la confusión entre imagen y realidad. La otra opción que nos queda es que fue, simplemente, un engaño inicuo y premeditado.

También conviene diferenciar entre imagen o patrón mental, de mapa o patrón neural. Los segundos son etiquetas para identificar actividades fisiológicas del cerebro, no sus productos. ¿Quiere esto decir que ahora abrazo el dualismo? No, siguiendo a Damasio ${ }^{26}$, me limito a utilizar un dualismo de punto de vista, que no de naturaleza, para poder atender a los modos en que las cosas emergen y se experimentan. La imagen está en la mente, el mapa en el cerebro. ¿Cómo se ejecuta el tránsito entre ambas? Damasio introduce la conciencia como mediadora, como mecanismo que nos permite apreciar los mapas como imágenes. Todo ello sin dejar de considerar la mente como algo inherente al cerebro y sus procesos.

Las imágenes presentes en la mente son los mapas momentáneos que el cerebro levanta de todo y de cualquier cosa, tanto dentro de nuestro cuerpo como a su alrededor, tanto concreta como abstracta, real o previamente grabada en la memoria (...) Las imágenes representan propiedades físicas de entidades y las relaciones espaciales y temporales que se dan entre las entidades, así como sus acciones. ${ }^{27}$

A estas alturas, la proposición de experimentar como acto de percibir en ausencia de estímulo externo, no debería resultar paradójica y mucho menos esotérica. Hace tiempo que la literatura médica superó las limitaciones y debilidades del empirismo. La percepción sin estímulo, además, no implica necesariamente daño o mal funcionamiento cerebral. Puede darse y se da con el órgano en perfecto estado. Un ejemplo extremo, pero contundente, serían

\footnotetext{
${ }^{25}$ SACKS, Oliver, Alucinaciones, Barcelona: Anagrama, 2013.

26 DAMASIO, Antonio, Y el cerebro creó al hombre. ¿Cómo pudo el cerebro generar emociones, sentimientos, ideas y el yo?, Barcelona: Destino, 2010, p. 109 y ss.

${ }^{27}$ Ibíd., p. 120.
} 
los estudios realizados sobre los miembros amputados denominados fantasmas. ${ }^{28}$ No existen, no reciben estímulo alguno, pero para el paciente siguen ahí, los siente, le duelen y los incorpora a la coordinación de movimientos del resto del cuerpo.

¿Por qué he utilizado input cuando podría haber utilizado, por ejemplo, aisthesis? Para limitar la deriva semántica y el peso filosófico que contiene la segunda. Utilizando input-sin ser del todo apropiado y siendo, sobre todo, menos poético- el estímulo sensorial queda reducido a un acto concreto y direccional, real y computacional; por lo tanto, no mítico y sin margen para la idealización. En cualquier caso, no es cometido de esta investigación trazar un recorrido ${ }^{29}$ histórico de la imagen mental, pero sí, al menos, dejar constancia de la otra corriente que -con muchos matices en su interior- se opone a la elegida. Su principio: considerar que la imaginería mental no es un producto obtenido en ausencia de percepción, sino que, bien al contrario, es en sí misma un proceso cuasi-sensorial.

Así las cosas, la imagen mental queda todavía hoy -en plena vorágine de las neurocienciasentre dos aguas: aquella que ve la imaginería mental como un fenómeno conceptualmente diferente de la percepción, y la que considera que tanto esta imaginería como la común percepción sensorial son dos fenómenos de la misma especie apenas diferenciados por grados y tipos de experiencia. Un enfrentamiento que, en el fondo, es la vieja lucha escocesa entre Reid y Hume. ${ }^{30}$ En la actualidad y lejos de aclararse por completo, el debate sobre la naturaleza de la imagen mental sigue incorporando fenómenos sorprendentes como el de la aphantasia. ${ }^{31}$

${ }^{28}$ CRAWFORD, Cassandra, Ghost in the Machine. A genealogy of phantom-prosthetic relations, San Francisco: University of California, 2007. Los miembros fantasma ya preocuparon a Descartes, que los calificaba como un engaño o un descuido causado por el cerebro, o por alguna de sus partes, a la mente. Merleau-Ponty también se refería a la experiencia con miembros fantasma utilizando dos términos muy sugerentes: semipresente y percepción renaciente. Semipresente como oposición a rememoración, y percepción renaciente como oposición a fantasma. MERLEAU-PONTY, Maurice, Fenomenología de la percepción, Barcelona: Planeta De Agostini, 1993, p. 104.

${ }^{29}$ Remito a: NIGEL, Thomas, "Mental Imagery" en ZALTA, Edward (ed.), The Stanford encyclopedia of philosophy, Edición de otoño del 2014, <http://plato.stanford.edu/archives/fall2014/entries/mentalimagery/> [consulta: 15-10-2015].

${ }^{30}$ Hume distinguía entre impresiones e ideas. Estas últimas terminan identificándose con las imágenes. Para Hume ambas eran productos de dos percepciones cuya principal diferencia responde al grado de "vivacidad". HUME, David, Tratado de la naturaleza humana, Albacete: Diputación de Albacete, 2001, pp. 20-36.

${ }^{31}$ Este término de raigambre aristotélica se refiere a la incapacidad para imaginar o visualizar imágenes mentales. Una especie de ceguera interna: ZEMAN, Adam; DEWAR, Michaela; DELLA SALLA, Sergio, "Lives without imagery. Congenital aphantasia" en Cortex, 3 de junio de 2015.

<http://medicine.exeter.ac.uk/media/universityofexeter/medicalschool/research/neuroscience/docs/th eeyesmind/Lives_without_imagery.pdf> [consulta: 15-10-2015] Este estudio se centra en la aphantasia congénita, existe otro anterior donde se abordaba la aphantasia como suceso sobrevenido: ZEMAN, Adam; DELLA SALA, Sergio; et al., "Loss of imagery phenomenology with intact visuo-spatial task 
Al margen de esta fascinante discusión, lo que de verdad importa es que la realidad y la verdad cognitiva difiere de la debilidad epistemológica posmoderna. No estamos determinados por las imágenes, ya sean mentales o externas. No somos lo que vemos, como aseguraba McLuhan. Las imágenes tampoco conforman la realidad. Las imágenes mentales (no visuales, fantasmáticas, imaginarias), eso sí, son fundamentales en nuestra economía y ecología cognitiva. Afectan, son esenciales para los procesos de simulación y de predicción y pueden llegar a condicionar nuestros pensamientos y razonamientos, pero en ningún caso son los pensamientos o los razonamientos.

Durante el acto mismo podemos diferenciar y evaluar lo que vemos valiéndonos del resto de nuestro conocimiento. En su atrevida y discutible tesis sobre el arte entendido como extensión de la función del cerebro, el neurobiólogo Semir Zeki afirma ${ }^{32}$ que ver y comprender no son aspectos fácilmente separables. Algo que, en principio y de manera quizá no muy sorprendente dadas sus brillantes y atrevidas intuiciones, enlazaría la neurociencia con la práctica cinematográfica de vanguardia. En concreto con la americana de posguerra. Volveré a esto durante el interludio, pero cabe adelantar lo que Paul Adams Sitney, el teórico de cabecera del momento, decía al respecto: "la aspiración no reconocida del filme de vanguardia americano ha sido la de la reproducción cinematográfica de la mente humana" (...) Es el cine de la mente, en lugar del cine del ojo". ${ }^{33}$ La de Zeki es una correspondencia peliaguda que recuerda menos al pobre Santo Tomás, que a uno de los principios básicos del neoplatonismo: ver es creer. Lema que fue exprimido por las políticas absolutistas de la edad moderna basadas en el derecho divino y dinástico.

Sin embargo, Zeki termina matizando los conceptos cuando añade que vemos con V1 -la corteza visual primaria- y que comprendemos con la corteza asociativa que la rodea. Ver y comprender son, así, dos facultades relacionadas, que no idénticas. Una de las maravillosas capacidades cerebrales adquiridas durante la evolución, fue la de producir imágenes mentales como modelos sobre los que predecir y ensayar. Una experiencia semivicaria que nos eximía de los riesgos -o al menos nos permitía evaluarlos- derivados de su ejecución directa en la realidad. Esta herramienta subraya lo que podría denominar como una conciencia de la

performance. A case of 'blind imagination'” en Neuropsychologia, no 1, vol. 48, enero de 2010, pp. 145155.

${ }^{32}$ ZEKI, Semir, op. cit., 2005, p. 78, véanse también pp. 35-38.

${ }^{33}$ SITNEY, Paul Adams, Visionary Film. The american avant-garde 1943-1978 (Second edition), Nueva York: Oxford University Press, 1979, p. 370. 
diferencia entre imagen y realidad. Si ver y comprender ofrecen dudas fisiológicas y filosóficas, ver e imaginar, también. Según indicios obtenidos a través de PET y $\mathrm{fMRI}^{34}$, tanto ver y comprender, como ver e imaginar activan las mismas regiones cerebrales. ${ }^{35}$

El mapeo y el inventario de esa conectividad cerebral es uno de los retos contemporáneos. Pero quizá estemos sobreestimando su realización, de la misma manera que se sobreestimaron los logros inmediatos que acarrearía la secuenciación de nuestro genoma. ${ }^{36}$ Quiero decir -y en esto me adhiero a la tesis de Scott Atran-, identificar los modelos y las rutas conectivas, así como sus resultados y correspondencias, tal vez no resuelva los problemas críticos y creativos del pensamiento humano. De hecho, algunos de los cambios en el paradigma científico de nuestra historia, necesitaron de escenarios ideales que desecharan el condicionamiento al que le sometía las leyes hasta entonces vigentes. Como dice Atran, Newton o Einstein necesitaron imaginar mundos ideales -sin fricción, en el vacío- sin ataduras con el pasado o con hipótesis futuras. En ocasiones sigue siendo necesario aceptar la abstracción, por supuesto la ficción y también cierta dosis de idealización para concebir aquello que, de otra forma, siempre sería más que inimaginable, imposible. Atran hace referencia a esa ausencia de inferencia y de falibilidad, como una de las posibles causas del cuello de botella al que puede verse abocada la inteligencia artificial:

El énfasis actual de gran parte de la inteligencia artificial y de la neurociencia, basado en sustituir planteamientos de estructuras psicológicas abstractas por redes neuronales físicas y palpables, parece ir en la dirección equivocada. ${ }^{37}$

\footnotetext{
${ }^{34}$ Siglas inglesas de Tomografía por emisión de positrones e Imagen por resonancia magnética funcional, respectivamente.

${ }^{35}$ RAMACHANDRAN, Vilayanur S., op. cit., p. 465. También: TOPOL, Eric, "Seeing is believing. From placebos to movies in our brain" en BROCKMAN, John (ed.), This explains everything. Deep, beautiful and elegant theories of how the world works, Nueva York: Harper Collins, 2012, pp. 373-374. [paginación correspondiente a la edición epub]

36 "Se decía que, al tener el genoma secuenciado, sabríamos lo que somos (...) Hemos aprendido algunos párrafos aquí o allí, alguna palabra. Tenemos 500 volúmenes del tamaño del Quijote, pero no entendemos el idioma aunque conozcamos las letras". Entrevista con Francisco José Ayala en El País, 22 de julio de 2015. <http://elpais.com/elpais/2015/07/21/eps/1437498561_652239.html> [consulta: 1510-2015]. Este aspecto es francamente interesante y no solo por lo que dice Ayala. A nuestra incapacidad y a nuestro imperfecto estatuto científico y tecnológico, hay que añadir una discusión creciente y de calado sobre ese sueño prometido y hasta el momento incumplido por la genómica. Me refiero al surgimiento de un conflicto expreso entre lo público y lo privado, al negocio de la biología del cuerpo y a la indeterminación de los límites bioéticos. Véase: ROSE, Hilay; ROSE, Steven, Genes, cells and brains. The promethean promises of the New Biology, Londres y Nueva York: Verso Books, 2012.

${ }^{37}$ ATRAN, Scott, "What neuroscience and machine models of the mind should be looking for" en Edge.org, <http://edge.org/response-detail/26079> [consulta: 15-10-2015] [La traducción es mía]
} 
Así pues, en el ínterin de ese mapeo durante el que -seguro- se descubrirán nuevos conocimientos anclados en la fisiología del cerebro, debemos seguir utilizando las humanidades para explicar esa iluminación cerebral. ${ }^{38} \mathrm{Si}$ antes he utilizado la palabra indicio, ha sido por precaución epistemológica. Las imágenes por PET y fMRI deben ser tenidas en cuenta en cualquier explicación rigurosa contemporánea. De ahí a convertirlas en pruebas de cargo, queda camino. Hay que seguir insuflando mirada en ese ver fisiológico localizado en una imagen. Es decir, seguir pensando la mirada como dimensión estética del ver. Como una de las herramientas para la emancipación con las que contamos en tanto espectadores del mundo. Tal vez aparcar el tiempo necesario el debate entre ver y comprender, para reafirmar y defender la equivalencia entre mirar y actuar. ${ }^{39}$ Quién sabe si llegará el momento de reconciliar, a través de la estética, a las ciencias de la cognición con ese oxímoron de la izquierda intelectual:

Y así se establece, poco a poco, la engañosa ilusión de que ver es comprender y que cualquier acontecimiento, por abstracto que sea, debe tener forzosamente una parte visible, mostrable, televisable. ${ }^{40}$

La imagen material-externa, al margen de trampantojos y conspiraciones posmodernas, siempre ha presentado un problemática menor que la imagen mental-interna. En principio, la imagen externa es pragmática.

Nuestros sistemas de percepción aprovechan las imperfecciones de una imagen -las pinceladas, los píxels o el marco- y nuestros sistemas conceptuales captan el hecho de que estamos considerando un mundo hipotético que está separado del mundo real. ${ }^{41}$

Decía que en principio porque la materia puede ser eliminada de la ecuación con independencia del grado en el que esté presente. En su defensa de la imagen como relación de

\footnotetext{
${ }^{38}$ La cursiva en iluminación no es estética y caprichosa. Recurrir a una composición del tipo "se ilumina esta región cerebral" es literatura común pero científicamente incorrecta. Ningún área cerebral se ilumina. En las MRI funcionales, la ilustración cromática (a mayor actividad: tonos rojos y naranjas; a menor actividad: amarillos, azules y verdes) no se corresponde con la actividad cerebral per se, sino con la absorción de oxígeno realizada por las neuronas. Esta respiración neural es uno de los mejores indicadores que tenemos para cuantificar de manera indirecta la actividad cerebral. Dicho esto, no encuentro mayor inconveniente para seguir empleando la fórmula, al menos como metáfora.

${ }^{39}$ RANCIÈRE, Jacques, El espectador emancipado, op. cit., p. 19.

${ }^{40}$ RAMONET, Ignacio, La tiranía de la comunicación, Madrid: Debate, 1998, p. 22.

${ }^{41}$ PINKER, Steven, La tabla rasa. La negación moderna de la naturaleza humana, op. cit., p. 318.
} 
conciencia con el objeto, Sartre sostenía ${ }^{42}$ que no resultaba posible desligar el medio de representación del objeto representado. Lo que equivaldría a la desaparición de aquella enunciación enunciada citada en la introducción. Al contrario que Sartre, aquí sí defiendo la posibilidad de un disyunción. Me encuentro más a gusto cuando Richard Wollheim ${ }^{43}$ consideraba que esta escisión no sólo es posible, sino necesaria al constituir un valor adicional en la apreciación y el análisis artístico. ${ }^{44}$ Justo lo que propongo en esta investigación.

La contaminación de una imagen mental idealizada hacia la imagen material-externa se refuerza, así, por concepción ontológica y por alteraciones prácticas. Para concluir con la ontológica, basta recordar lo que sucedió -y sucede- con una de las nociones estrella de la teoría cinematográfica: la fotogenia. De Ricciotto Canudo y Louis Delluc a su triunfo rotundo con Jean Epstein, pasando por Abel Gance y Germaine Dulac o Émile Vuillermoz y Louis Aragon, el inicio de la teoría cinematográfica propiamente dicha estuvo marcado por una exploración tautológica del misterio, la revelación y la magia fotogénica. Pocas voces en contra, antaño el poeta y buen amigo de Epstein, Blaise Cendrars; más tarde Aumont, Rancière y un Malcolm Turvey ${ }^{45}$ que ha dedicado un estupendo estudio a este proceso de revelación. En él deja constancia de la desconfianza de cierta modernidad intelectual para con nuestra emancipación cognitiva. La revelación fotogénica -conceptualmente débil y de cariz esotéricono ha dejado de ser apreciada como estrategia teórica. Lo ha hecho, además, con una persistencia histórica desesperante.

Para anunciar las contaminaciones relativas a las alteraciones prácticas, citar a modo de aviso la rebajada presencia de la materia gracias a nuevos o perfeccionados materiales y tecnologías. El píxel se multiplica para, paradójicamente, desaparecer. La imagen no desaparece ni se desmaterializa, todo lo contrario: se densifica desde un punto de vista informativo. También se vuelve profunda y descomunal desde un punto de vista escalar. Nuestra imperfección cognitiva, nuestras limitaciones sensoriales, derrotadas por exceso y saturación del agente, no por defecto o desaparición.

\footnotetext{
${ }^{42}$ Así es como interpreto los sintagmas elemento representativo (medio, soporte) y acto sintético (percepción unificada del fenómeno, sin escisión posible en la atención al elemento representativo) en la siguiente cita: "En el acto de conciencia, el elemento representativo y el elemento de saber están unidos en un acto sintético". SARTRE, Jean-Paul, Lo imaginario. Psicología fenomenológica de la imaginación, Buenos Aires: Losada, 1976, p. 23.

${ }^{43}$ WOLLHEIM, Richard, El arte y sus objetos. Introducción a la estética, Barcelona : Seix Barral, 1972.

${ }^{44}$ PANESSE, Alessia, "La mente y la imagen" en Vértebra. Revista de arte y literatura, no 11, 2009, p. 23. <http://revistavertebra.files.wordpress.com/2009/10/051.pdf> [consulta: 16-10-2015]

${ }^{45}$ TURVEY, Malcom, Doubting vision. Film and the revelationist tradition, Nueva York: Oxford University Press, 2008.
} 
La erosión epistemológica que ha sufrido el estatuto de la imagen, ha empeorado por tres razones. Primera, por no conceder estatuto material y real a la imagen mental; como si ese fluir informativo se generara en el éter -en el alma- y no en el cerebro. Todo estado mental es un estado físico. Esto no es una evidencia, pero tampoco una boutade, es una hipótesis útil con serio viso de convertirse en verdad gracias a la acumulación de pruebas, no tanto a un descubrimiento único y grandioso. Segunda, por la contaminación de ese misterio cerebral -de una concepción de la mente como teatro, que diría Ryle- en las representaciones externas. Tercera, por la dificultad que introducen los términos formato -¿qué dimensiones?, ¿qué proporciones?- y soporte -¿qué zonas cerebrales?, ¿qué conectividad neuronal?. La imagen mental no puede considerarse una réplica, no obedece a criterios de reproductibilidad.

No pretendo reescribir una teoría del cine basada en la redención de la realidad física ${ }^{46}$, pero sí ampliar esta realidad física a la inmaterialidad dogmática. Recuperar su concreción en un contexto que la ha dejado maltrecha y que, a su vez, ha negado al cine la posibilidad de convertirse -o de volver a ser- un instrumento de conocimiento, placer y exploración del intelecto fisiológico.

Valoro la imagen mental como real y auténtica. Tan rotunda como la imagen material, nunca como un fantasma irreal e inmaterial en sentido peyorativo. ${ }^{47}$ La imagen mental no es una segunda cosa, es la textura imaginaria de lo real. La imagen mental, siguiendo a MerleauPonty, no es el camino hacia el corazón del ser, no es el grial espiritual, "es todavía un pensamiento apoyado en indicaciones corporales" ${ }^{48} \mathrm{Y}$ tanto, a partir de neuroimagen, del estudio de lesiones cerebrales localizadas, de resultados neurofisiológicos realizados en primates no humanos y de patrones conocidos de conectividad anatómica, la neurobiología

\footnotetext{
${ }^{46}$ KRACAUER, Sigfried, Teoría del cine. La redención de la realidad física, Barcelona: Paidós, 1996. Aquí, Kracauer cae en una especie de fantasma en la máquina invertido. Habla de comprometer fisiológicamente los sentidos del espectador, antes de que se halle en condiciones de responder con el intelecto (p. 205). Kracauer quiere rehabilitar la dimensión material sobre la abstracción predominante (pp. 365-365), pero sigue segregando fisiología e intelecto.

${ }^{47}$ ZAMORA ÁGUILA, Fernando, Filosofía de la imagen. Lenguaje, imagen, representación, México D. F.: UNAM, 2007, pp. 148-149.

${ }^{48}$ Obviamente no comparto el uso que hace de la palabra pensamiento. MERLEAU-PONTY, Maurice, EI ojo y el espiritu, Barcelona: Paidós, 1985, p. 32. La concepción de Merleau-Ponty, hoy superada en muchos aspectos por las ciencias de la cognición, puede llegar a resultar algo mecanicista: los "ojos de carne" como "computadoras del mundo", frente al "tercer ojo" de la mente (pp. 20-21).
} 
contemporánea las ha localizado con algo más de acierto que el obtenido por Descartes ${ }^{49}$ a la hora de ubicar la sede y las funciones del alma.

Las cortezas sensoriales primarias de todas las modalidades elaboran, en colaboración con estructuras del tálamo y de los colículos, representaciones neurales que constituyen el fundamento de las imágenes. Este proceso parece precisar de la acción cooperativa de diversas regiones corticales primarias densamente interconectadas. Pese a que no se conocen con precisión los mecanismos subyacentes a este proceso, parece que la actividad temporalmente coordinada entre estas diversas cortezas primarias y las estructuras subcorticales con las que se interconectan, origina la esencia de lo que entendemos por «imagen». ${ }^{50}$

¿Cómo no conceder estatuto real a aquello que surge de nuestra biología más íntima, compleja e irrefutable? Que la imagen mental sea real y material, no significa que la imagen mental sea la realidad. Ahí es donde desembocó el solipsismo posmoderno, en un nivel aun más extremo que el insinuado y confuso de un Berkeley que, a pesar de identificar idea y cosa, seguía defendiendo la existencia una rerum natura en la que, sin embargo, las cosas reales percibidas no podían existir con absoluta independencia de la mente. Esa frontera entre mente, materia y realidad siempre ha sido porosa. Bertrand Russell discutía si nuestro conocimiento del mundo físico, limitado a una serie de rasgos abstractos, era suficiente para revelar si esa rerum natura percibida era "o no diferente, intrínsecamente, del mundo de la mente".$^{51}$ Russell no era preciso, pero acertó al señalar que había que puentear el abismo que establece nuestro sentido común y nuestra historia entre mente y materia.

\subsubsection{Escisiones constituyentes}

«- Creo que es la calle de los naturalistas.

- Esa calle no existe. - ¿Y la calle de los patriotas? - Esa sí. Dígame el número» ${ }^{52}$

\footnotetext{
${ }^{49}$ DESCARTES, René, Las pasiones del alma, Madrid: Tecnos, 1997, pp. 102-105 y notas 48-49.

50 DAMASIO, Antonio; DAMASIO, Hanna, "Generación de imágenes y creación de subjetividad" en CHURCHLAND, Patricia; LLINÁS, Rodolfo (eds.), El continuum mente-cerebro. Procesos sensoriales, Bogotá: Universidad Nacional de Colombia, 2006., p. 24. [Las comillas son originales. La cursiva es mía]

${ }^{51}$ RUSSELL, Bertrand, El conocimiento humano, Barcelona: Folio, 2002, pp. 234-238.

${ }^{52}$ Del extraordinario filme: Infinitas (Marlen Khutsiev, 1991)
} 
No se puede marginar lo mental de lo real y de lo material, pero tampoco confundir lo mental con la realidad. Es justo ahí, en ese espacio liminar donde se quiere ver la suplantación de la realidad por la imagen mental -siempre en ausencia de enfermedad o de una teoría del conocimiento defectuosa o malintencionada-, donde introduzco el hermoso sintagma que Dubois $^{53}$ utilizó para matizar los conceptos fotográficos (analógicos) de proximidad e identificación. Hablo de la escisión constituyente. ¿Qué es una escisión constituyente? Toda escisión constituyente está formada por un hecho material diferencial y por una serie de procesos cognitivos. El primero debe ser detectado y analizado por los segundos para imposibilitar la identificación plena o la suplantación de lo real por la imagen o por lo imaginario. Esto es, las representaciones fotográficas rompen la continuidad mente-imagenrealidad que guía la planificación y la ejecución de un modelo mental preconcebido. ${ }^{54}$ Que, paradójicamente, esta escisión haya contribuido a reforzar la confusión, abre las puertas a un idealismo neoplatónico y a otro concepto que nos visitará más adelante: el tecnofetichismo.

Es por todo esto que, a pesar de que mi enfoque puede ser catalogado fácilmente como monista y materialista, prefiero otras etiquetas como naturalista y no-idealista. Sobre todo porque el monismo es demasiado complejo y variado como para reconciliarme con el idealismo hegeliano o con el inmaterialismo ${ }^{55}$ de Berkeley. A su vez, el materialismo está lo suficientemente desvirtuado por relecturas marxistas como para intentar rescatar las enternecedoras y en ocasiones deslumbrantes intuiciones de algunos presocráticos $y$, sobre todo, de estoicos y epicúreos. ${ }^{56}$ Respecto al positivismo, no puedo caer en la grandilocuencia de asumirlo. Los métodos y los análisis aquí vertidos ni son, ni aspiran a poder ser replicados y

\footnotetext{
${ }^{53}$ DUBOIS, Philippe, op. cit., p. 91.

${ }^{54}$ Para entender el nacimiento de la materialización de la imagen artística (digamos no mecánica, porque la imagen siempre es, en mayor o menor grado, tecnológica) como resultado de un modelo mental preconcebido: MITHEN, Steven, Arqueología de la mente. Orígenes del arte, de la religión y de la ciencia, Barcelona: Mondadori, 1998, pp. 163-197.

55 "Lo único que niego es eso que los filósofos llaman materia o sustancia corpórea (...) El ateo realmente necesita el color de un nombre vacío para apoyar su impiedad" en: BERKELEY, George, Tratado sobre los principios del conocimiento humano, Barcelona: Folio, 1985, p. 48.

${ }^{56}$ Siempre tengo presente no tanto el atomismo de Epicuro -tomado de Demócrito, pero llevado mucho más lejos- como su concepción material que vertebra la cadena formada por las sensaciones, los sentimientos y las imágenes. También el precoz y sagaz corte que establece entre imagen y verdad. Para Epicuro, las imágenes -a pesar de ser emanaciones de los cuerpos exteriores- no garantizan veracidad. Son ideas presentes a lo largo de su obra, que alcanzan su máximo refinamiento en la "Epístola de Epicuro a Herodoto": EPICURO, Obras completas, Madrid: Cátedra, 2012, pp. 49-72.

Mayor aprecio siento aun por la reelaboración epicúrea realizada por Lucrecio en su hermosísimo poema De rerum natura, Barcelona: Acantilado, 2012. En especial el Libro IV, donde desarrolla su teoría de los simulacros y donde, además, discurre sobre la relación de las imágenes con la materia, con los diferentes fenómenos lumínicos, ópticos y corporales (pp. 317-353).
} 
validados por el método científico. No rechazo el mundo inmaterial, sino su confusión y propagación indiscriminada. Negar por sistema la existencia y la importancia de una serie de valores no mensurables en la estética y en la biología, sería caer en el error epistemológico que Susanne Langer ${ }^{57}$ denominó material mode. Esto es, la paradoja de un positivismo que niega toda inmaterialidad, pero que debe explicar todos los fenómenos a partir del más abstracto de todos los elementos, el número.

Así pues, mi concepción responde a un naturalismo no-idealista de cariz biológico. Biológico porque para entender la relación entre mente e imagen hay que asumir -siendo consciente de los posibles reduccionismos- que "cualquier explicación convincente debe referirse a (...) la materia de la mente (...) [y al] funcionamiento electroquímico del cerebro".$^{58}$ Un cerebro que, por otra parte, evolucionó primero de todo como máquina de supervivencia y de reproducción, no como herramienta de autocomprensión. De ahí que las creencias y los paradigmas obsoletos no solo sigan vivos, sino que se yerguen sobre el peso de los siglos y de las evidencias. Es esta una tragedia propia de la humanidad: construir vidas, sociedades y civilizaciones cuyo rasgo común es la creencia en seres inmateriales. ${ }^{59}$

La mente humana evolucionó para creer en dioses. No (...) para creer en la biología (...) La esencia del dilema espiritual de la humanidad es que evolucionamos genéticamente para aceptar una verdad y descubrimos otra. ${ }^{60}$

\footnotetext{
${ }^{57}$ LANGER, Susanne, Philosophy in a new key. A study in the symbolism of reason, rite and art, Nueva York: Mentor Books, 1954.

${ }^{58}$ LEWIS-WILLIAMS, David, La mente en la caverna. La conciencia y los orígenes del arte, Madrid: Akal, 2005, p. 107.

${ }^{59}$ Las obras en las que me he apoyado para comprender estas creencias desde un punto de vista biológico (como subproducto de la evolución, no como adaptación evolutiva) son dos: ATRAN, Scott, In gods we trust. The evolutionary landscape of religion, Nueva York: Oxford University Press, 2002. LEWISWILLIAMS, David, Conceiving God. The cognitive origin and evolution of religion, Nueva York: Thames \& Hudson, 2010.

La obra fundacional -en los últimos veinte años se ha convertido en un tema con gran presencia en el debate intelectual (Dawkins, Jay Gould, Dennett, Shermer) y editorial- para entender el sustrato biológico de esta creencia podría ser: BOYER, Pascal, The naturalness of religious ideas. A cognitive theory of religion, San Francisco: University of California Press, 1994.

De cómo la cultura y la expresión artística se convirtieron en un medio natural y material para comunicar y hacer perdurar las ideas, especialmente las consideradas mágicas o religiosas: MITHEN, Steven, "A creative explosion? Theory of mind, language and the disembodied mind of the upper Palaeolithic" en MITHEN, Steven (ed.), Creativity in human evolution and Prehistory, Londres y Nueva York: Routledge, 1998, pp. 120-140.

${ }^{60}$ WILSON, Edward Osborne, op. cit., pp. 382 y 385.
} 
¿Y Kant? Hay en este discurso un deje kantiano, pero con la boca pequeña. Kant es importante porque, en un momento delicado y poco propicio, vinculó la realidad con las nociones de cuerpo y materia mientras la amplia y variada tradición idealista se entregaba a los manejos de los espíritus y del subjetivismo. ${ }^{61}$ Su crítica del idealismo escéptico ${ }^{62}$ o problemático (cartesiano) resulta fundamental para entender la Teoría representativa de la percepción ${ }^{63}$ y la herencia idealista en la posmodernidad. Aquella que no se atrevía a afirmar la existencia de la realidad y de la cosas materiales. Pero antes que Kant estaba Spinoza, quien ya desmontó la lerda equivalencia posmoderna entre imágenes y pensamientos. Porque, para Spinoza, tanto la imaginación como las imágenes eran pura materialidad, eran "afecciones del cuerpo humano".

Pues no entiendo por «ideas» las imágenes que se forman en el fondo del ojo, o, si se quiere, en medio del cerebro, sino los conceptos del pensamiento. ${ }^{64}$

¿Y el emergentismo? Parece que todo lo que acabo de exponer conduce a él y a cierto holismo materialista, pero solo lo considero una opción más. Me interesan más los argumentos en sí, que la manera en la que estos puedan compartir o reunirse bajo una etiqueta. Porque si dices que tu punto de vista es naturalista no faltará quien te vea, en el mejor de los casos, con un cazamariposas y unos pantalones bombachos; y en el peor, enroscado en una bandera arcoíris a bordo del Rainbow Warrior. Del emergentismo ${ }^{65}$ importa que sigue abierto. Aunque después de leer las últimas -las hay anteriores y bien despectivas ${ }^{66}$ - críticas y las terribles

\footnotetext{
${ }^{61}$ Por el contrario, discuto del parecer kantiano cuando, en su Crítica del juicio, asocia (re)presentación mental del objeto artístico con reproducción. Al tiempo que, cumplida su función, rebaja el interés de la existencia física de dicho objeto artístico. KANT, Immanuel, Prolegómenos a toda metafísica del porvenir. Observaciones sobre el sentimiento de lo bello y lo sublime. Crítica del juicio, México D.F.: Editorial Porrúa, 1991, pp. 203-205.

${ }^{62}$ ECHEVERRI, Santiago, La existencia del mundo exterior, Medellín: Universidad de Antioquía, 2008, p. 83 y ss.

${ }^{63}$ La Teoría representativa de la percepción rompía en un punto la idea de conexión física peirciana entre sujeto y objeto percibido. Los objetos se declaran ajenos e independientes a un sujeto que solo puede comprenderlos mediante la representación -mediante la idea- interna que se ha hecho de ellos. Esta idealización interna del objeto prevalece sobre una realidad externa de la que se cuestiona su existencia. "Lo percibido provoca representaciones internas que tienen una relación de semejanza con los objetos percibidos sin (...) poseer necesariamente el carácter de imágenes reales" en: NÖTH, Winfried; SANTAELLA, Lucía, Imagen. Comunicación, semiótica y medios, Kassel: Reichenberger, 2003, pp. 17-18.

${ }^{64}$ SPINOZA, Baruch, Ética demostrada según el orden geométrico, Madrid: Orbis, 1990, p. 115. [Original circa 1661-1675] Entrecomillado superior en p. 91.

${ }^{65}$ BUNGE, Mario, "Monismo psiconeural emergentista" en El problema mente-cerebro. Un enfoque psicobiológico, Madrid: Tecnos, 2002, pp. 42-46.

${ }^{66}$ BUNGE, Mario, "Una muestra de proyectos reduccionistas fallidos" en Emergencia y convergencia. Novedad cualitativa y unidad del conocimiento, Barcelona: Gedisa, 2004, pp. 191-213.
} 
simplificaciones ideológicas que ha hecho Mario Bunge ${ }^{67}$ de la psicología experimental y evolucionista, uno tiene la sensación de que sigue sin querer entender nada sobre estos avances en el estudio de la mente. Además, el concepto analítico y lingüístico de emergencia me interesa mucho menos -es demasiado rígido- que el de supervivencia.

En conclusión, enviar la imagen a un plano mental es el primer escalón de una falsa desmaterialización que diferencia mente e idea de fisiología y materia. La imagen se había mantenido, no sin dificultades, dentro del plano material gracias a la semejanza, a la retórica neorromántica de la luz y a su acto-huella sobre el material fotográfico-analógico. La química de elementos siempre gobernó estos casos a pesar de las metáforas fantasmales, espirituales y hasta espiritistas. No se discutía la existencia y el funcionamiento de la luz y de las sales de plata. En cambio, el advenimiento de la electrónica y de los patrones numéricos pareció resucitar leyes divinas "como si la huella del mundo físico no tuviera legitimidad en el mundo de los píxeles" ${ }^{68}$ Ante la dificultad de apreciar reacciones químicas básicas, la teoría digital se entregó a la brujería y a la simulación.

El árbol cayó, cae y seguirá cayendo aunque nadie esté allí para escucharlo. El significado de una proposición empírica no tiene por qué identificarse con el modo de verificación de la misma. Lo contrario es un error de Beethoven neopositivista.

\subsection{Semiosis: expresión y contenido}

La naturaleza interna de las imágenes materiales $-\mathrm{y}$ desde ahora ya me refiero solo a las imágenes materiales externas- no es mero depósito. La base material afluye a lo semántico y a lo afectivo, poniendo en duda un hipotético grado cero. En términos de semántica estructural y casi como eco de la filosofía heideggeriana del objeto, es indispensable alcanzar la sustancia conformada. ${ }^{69}$ Coincido con José Vicente Benet cuando señala, siguiendo a Louis Hjelmslev, que "existiría una narratividad intrínseca referida a la materia de la expresión". ${ }^{70}$ No obstante, esta definición de sustancia conformada como elemento icónico consumado, no puede realizarse sin atender al proceso de producción. Toda semiosis desencadenada por la imagen debe tener en cuenta los procesos de materialización. Una idea que fulmina el sintagma

\footnotetext{
${ }^{67}$ BUNGE, Mario, Materia y mente. Una investigación filosófica, Pamplona: Editorial Laetoli, 2015.

${ }^{68}$ QUINTANA, Ángel, Después del cine. Imagen y realidad en la era digital, Barcelona: Acantilado, 2011, p. 45.

${ }^{69}$ GUTIÉRREZ ORDÓÑEZ, Salvador, Introducción a la semántica funcional, Madrid: Síntesis, 1989, pp. 12 13.

${ }^{70}$ BENET, José Vicente, "Montaje y narratividad en el cine primitivo" en Archivos de la Filmoteca, Valencia: Filmoteca de la Generalitat Valenciana, no 2, junio-agosto de 1989, p. 97.
} 
baziniano de la génesis automática ${ }^{71} \mathrm{y}$, por consiguiente, la virginal y esencial neutralidad y objetividad derivada de una inmaculada concepción.

El estudio -y hasta el propio funcionamiento del texto- se desvirtúa si se atiende a la expresión o al contenido por separado. No cabe aquí, de nuevo, el dualismo. Una independencia imposible donde, a la manera semiótico-binaria de Hjelmslev ${ }^{72}$, las separaciones devienen asociaciones. La expresión y el contenido del signo son solidarios. Hjelmslev, reciclando el fundacional significante y significado de Sausurre, llegaba a desarrollar una terminología que adapto y modifico para explicar la doble naturaleza interna y externa de la imagen:

a) Sustancia del contenido: aspectos contextuales, profílmicos o de síntesis de la representación iconográfica (históricos, culturales, ideológicos, sociales) que pautan la imagen a través de la forma del contenido: géneros, movimientos, cine, televisión, fotografía, Internet, etc.

b) Sustancia de la expresión: aspectos sensoriales directos de la imagen o el sonido, a los que hay que sumar los concernientes a las esferas materiales y tecnológicas (soportes, formatos, estándares, espacios, almacenamiento y distribución, etc.). Todo articulado por una forma de la expresión cuyo objetivo es el lenguaje y la estética.

Como contaba en uno de los apartados anteriores, las imágenes contienen y transmiten componentes de expansión y de contracción. En la contracción, las imágenes sugieren o directamente ponen de relieve su base material. Como se deducía del enfrentamiento entre Sartre y Wollheim, detectar e identificar dicha base material puede no resultar sencillo e inmediato. Es más, a según quién puede que le resulte innecesario. Para esta investigación, la base material de las imágenes sí tiene un valor indiciario en medio de un acto proyectivo que nunca cesa y que es compatible con la contracción reflexiva. La base material no es un residuo extrasemiótico, es una submediación -más o menos sensible- capaz de aportar sentido.

\footnotetext{
${ }^{71}$ BAZIN, André, ¿Qué es el cine?, op. cit., p. 28.

72 HJELMSLEV, Louis, “Expresión y contenido" en Prolegómenos a una teoría del lenguaje, Madrid: Gredos, 1980, pp. 73-89.
} 
La materia, en este sentido, puede ser calificada como una entonación (George Trager) que por definición- puede poseer valores contextuales o individuales, intencionados o fortuitos, coyunturales o permanentes. Y toda entonación, lógicamente, implica variación y parcialidad. La materia como entonación o como interpretante dinámico, que diría Peirce, significa por convención. Es decir, la materia interviene en el efecto real producido por el signo.

Volviendo y cerrando con Hjelmslev, la imagen en tanto signo tiene dos direcciones: hacia el exterior, hacia la sustancia del contenido; y hacia el interior, hacia la sustancia de la expresión. ${ }^{73}$ Si el signo puede ser considerado en cuanto a sí mismo, en cuanto al objeto al que se refiere y en cuanto al interpretante, a la imagen hay que añadirle el aparato que la produce y los medios empleados. En el terreno de la teoría cinematográfica, se ha tratado la autorreferencialidad como una característica emanada del aparato tecnológico (esencialismo) o, por el contrario, como un constructo social e industrial (constructivismo y determinismo).

Como avisaba, mi hipótesis sostiene que lo apropiado es atender a los factores constituyentes de las imágenes. Después, volver la vista hacia el aparato que las produce para comprobar si existe tal autorreferencialidad y, en caso positivo, en qué grados. Para justificar el enfoque, me ha parecido obligado establecer este fundamento semiótico de la imagen como signo y como mediación.

\subsection{El peso del cine}

Imágenes como mediación, imágenes hijas de un aparato. Si hacemos caso a Gombrich ${ }^{74}$, las imágenes difícilmente pueden ser interpretadas como agentes aislados. De hacerlo, sus resultados serán parciales o erróneos, aunque en apariencia encajen dentro de los principios de la metodología empleada para su descodificación. La tecnología productora de esas imágenes sufre idéntico problema: no puede independizarse de manera gratuita. Como anota Gubern a propósito del cruce incesante de referencias y escenarios a la hora de exponer la evolución tecnológica del cine, "una reducción simplista de la génesis de la evolución tecnológica explicada por un único factor, es necesariamente falaz". ${ }^{75}$

\footnotetext{
${ }^{73}$ HLEMSLEV, Louis, op. cit., p. 86.

${ }^{74}$ GOMBRICH, Ernst, El sentido del orden, Madrid: Debate, 1999.

${ }^{75}$ GUBERN, Román, La mirada opulenta. Exploración de la iconosfera contemporánea, op. cit., p. 262.
} 
El eterno -y muchas veces deformado- aforismo de Heidegger: "la esencia de la tecnología, nada tiene que ver con lo tecnológico". La tecnología nunca revela ${ }^{76}$ su especificidad material y funcional en un contexto neutro, como tampoco posee un efecto neutro. De esta forma, el estudio de las hipotéticas esencias tecnológicas ha podido ser solventado sin caer en la aporía, gracias a la idea de lugar y a cierta fenomenología que inyectan impurezas y que resitúan dichas esencias dentro de la existencia y de la facticidad..$^{77}$

Michelle Henning lleva esta postura aún más lejos, al cuestionar de plano el incierto don tecnológico para determinar. Es decir, la tecnología no determina, sino que se ve determinada en su valor y en sus significados dependiendo de las formas en que es movilizada. "Un avance técnico sólo adquiere significado a través de los usos sociales para los que se emplea". ${ }^{78}$ Esta afirmación me interesa ahora como contrapeso, de manera temporal y parcial. Quedará muy matizada según avance el relato desde que esos "usos sociales" no pueden quedar limitados al funcionalismo, sino que deben ampliarse a una amplia red de significados y de metáforas. Resumiendo, el desarrollo de la tecnología desde la autonomía y la autosuficiencia es, a día de hoy, la ciencia ficción de la singularidad..$^{79}$

Por desgracia, la disputa teórica de la naturaleza tecnológica del cine se ha venido realizando a partir de un único concepto que la abrazaba por completo, como si de una unidad se tratara. Aquello que los anglosajones denominaron apparatus itself..$^{80}$ Un aparato en sí mismo capaz de albergar la gran herencia secular del cinematógrafo. Un aparato que arrastra desde su nacimiento -como buen amigo de los fantasmas-, ruidosas cadenas que le impiden pasar desapercibido. Un lastre tecnológico que encajaría sin problemas en la sentencia que Akira Asada le transmitió a su amigo Paul Virilio: "nuestras técnicas no tienen porvenir, sólo tienen pasado. Incluso se podría decir que iun pesado pasado!" ${ }^{81}$

\footnotetext{
${ }^{76}$ Para Heidegger, la esencia de la tecnología radica en dos ideas: la tecnología funciona como lugar y como modo de revelación (alétheia). Como se ha visto con anterioridad, conceptualmente comparto solo la primera parte. HEIDEGGER, Martin, "The question concerning technology" en FARRELL KRELL, David (ed.), Martin Heidegger. Basic writings, San Francisco: Harper \& Row, 1993, pp. 311-341. El aforismo se encuentra en la página 311.

${ }^{77}$ MERLEAU-PONTY, Fenomenología de la percepción, Barcelona: Planeta De Agostini, 1993, p. 7.

${ }^{78}$ HENNING, Michelle, "Encuentros digitales: pasados míticos y presencia electrónica” en LISTER, Martin (ed.), La imagen fotográfica en la cultura digital, Barcelona: Paidós, 1997, p. 289.

79 KURZWEIL, Ray, La singularidad está cerca. Cuando los humanos transcendemos la biología, Berlín: Lola Books, 2012.

${ }^{80}$ No confundir este sintagma con la Teoría del aparato. Existe una relación evidente y en no pocas ocasiones se utiliza la traducción inglesa apparatus para sintetizar a Comolli y a Baudry.

${ }^{81}$ VIRILIO, Paul, La máquina de visión, Madrid: Cátedra, 1989, p. 41.
} 
Es inútil entrar en la discusión sobre el futuro luctuoso del cine, pero si algún día llega su extinción, habrá que cavar una fosa gigantesca. Decía Wim Wenders que el cine tiene un "lenguaje duro, consciente de su forma, un lenguaje que en realidad es de otra época" ${ }^{82}$ No le faltaba razón si observamos cómo el cine ha resistido, impertérrito, todos los envites históricos. De manera paradójica, los dispositivos cinematográficos -no sólo el aparato y sus imágenes- han sobrevivido gracias a esa dificultad para la renovación de sus instancias. El cine, en cierta forma, puede considerarse un anacronismo, si no un fósil viviente.

El camino que ha recorrido, además de no resultar plácido, le ha servido para ir remolcando todas esas piedras que parecían impedir su avance. El cine se ha convertido en "archivo vivo de las formas del pasado" ${ }^{83}$ Más un caracol que un Sísifo, más un percherón que un purasangre. El cine ha continuado moviéndose mientras no dudaba en replegarse sobre sí mismo ante cada amenaza. La desmaterialización como unos de los estandartes -¿̇o de los mitos?- de la historia contemporánea, puso de nuevo a prueba a este tenaz caracol.

\subsection{Exhibicionismo}

No puedo negar la existencia de un enfoque esencialista que siempre ha visto la condición autorreferencial del cine como un hecho ontológico. Sería contraproducente ignorarlo porque, entre otras cosas, ha sido y es la teoría dominante. No obstante, considero que esa perspectiva desde la que observar la autorreflexividad del cine se debe seguir matizando. Porque a su tinte esencialista cabe añadir el animista. En su discurso sobre el autorreferente cinematográfico se puede identificar el empleo no de un agente mediador, sino de un impregnador: el hombre. El hombre en contacto directo con el aparato, como si de una relación entre iguales se tratara.

Esta relación quedaría establecida desde el mismo instante de la creación de la propia tecnología. Según este enfoque, los objetos tecnológicos siempre se han caracterizado por su marcado carácter exhibicionista. Así, cualquier manifestación tecnológica existe en primera instancia, antes incluso que por motivos prácticos, como autorreferente, como demostración de sus propias capacidades. Puro animismo que asume una transferencia mítica de poder entre creador y objeto, en la que éste último lo recibe y lo digiere dotándose de un aura vital. La figura humana del creador quedaría, así, en la trastienda, con tendencia a diluirse. El ego termina por volcarse en el aparato y el ser humano se desvanece en la historia como un dato

\footnotetext{
82 WENDERS, Wim, El acto de ver, Barcelona: Paidós, 1992, p. 89.

${ }^{83}$ MONTERDE, José Enrique, op. cit., p. 23.
} 
en una enciclopedia. La debacle de la visión antropocéntrica -que no humanista- de la tecnología.

El sueño de este plan es obtener una expresión tecnológica como reclamo de sí misma, a la que si dotáramos de voz recitaría: “iEh, míreme. Mire lo que hago y de qué manera lo hago!". ${ }^{84}$ A lomos de la interjección entramos en el terreno, salta a la vista, de una conducta exhibicionista. El exhibicionismo, el animismo y la prosopopeya son recursos habituales del esencialismo. Y nos recuerdan que, pensar -no hablo de la retórica de la metáfora- los objetos inertes con ideas relativas a los seres vivos, produce discursos infestados de errores.

Lo que en el ámbito cinematográfico nos lleva, de forma irremediable, a la relación de esa condición exhibicionista con la pulsión escópica del espectador. Recurriendo a un vulgarismo: el encuentro del hambre con las ganas de comer. La letanía que asocia la tecnología al mensaje -a pesar de la diversificación ejercida por las extensiones ${ }^{85}$ - se coló en la fiesta de la virtualidad de los noventa con un traje aparentemente nuevo. Cuando, en realidad, no era otra cosa que la reformulación de un determinismo heredero de la Escuela de Frankfurt y de Mayo del $68 .{ }^{86}$ Una letanía que aspiraba a la esencia y al todo. No tanto al análisis de los textos, de los usos y de las influencias.

\footnotetext{
${ }^{84}$ Quien desee defender el animismo autorreferencial de la tecnología, podría encontrar ilustración en las sesiones de presentación del sistema sonoro Vitaphone a finales de los años veinte del siglo pasado. Porque el Moisés de Miguel Ángel, qué lástima, nunca llegó a hablar.

85 MCLUHAN, Marshall, Compender los medios de comunicación. Las extensiones del ser humano, Barcelona: Paidós, 1996.

${ }^{86}$ MOLINUEVO, José Luis, La vida en tiempo real. La crisis de las utopías digitales, op. cit., p. 118.
} 
NARRACIÓN 


\title{
2. LECTURA CRÍTICA DE LA TEORÍA DE ATRACCIONES
}

\author{
«Mis películas están más cerca de una atracción de feria, \\ que de una obra de teatro o de una novela. \\ Ponte a la cola para volver a montar» \\ Georges Lucas \\ «Me niego a creer que no esté familiarizada \\ con el concepto de atracción» \\ Parque Jurásico (Jurassic Park, Steven Spielberg, 1993)
}

\subsection{Atracción: creación}

El cinematógrafo explicado como aparato exhibicionista, llega a esa última frontera a la que que todas las teorías aspiran. El confín sacramental, al bautizo nominal que la identifique entre el bullicio para perdurar. En esta tesitura surge el criterio de atracción. Concepto nacido para designar el poder exhibicionista inherente al cine en particular y a la tecnología como objeto de estudio en general. El término implica matices que trascienden una simple evocación de la diversión. Atracción, de su invitación inocente al recreo, pasa a concepto no lúgubre, pero sí sospechoso. Su enorme capacidad de síntesis para albergar representaciones de todo tipo, facilitó su arraigo.

El concepto de atracción triunfa durante el último tramo del siglo $\mathrm{XX}$, justo cuando la tecnología se convierte de manera definitiva -algunos dirían que hasta grosera- en brazo armado-televisado del capitalismo global. La tecnología como protagonista mundial, como una de las causas inmediatas de la pérdida de credibilidad y legitimidad de los grandes relatos. La tecnología finisecular, especialmente la tecnología asociada a las imágenes, fue sospechosa de poner el "acento en los medios de acción más que sobre sus fines" ${ }^{1}$

Por esas mismas fechas (1986), Tom Gunning hizo fortuna con su teoría: The cinema of attraction. $^{2}$ Digo que hizo fortuna porque el tiempo ha borrado cualquier linaje. Empezando

\footnotetext{
${ }^{1}$ LYOTARD, Jean François, La condición posmoderna, op. cit., p. 73.

2 GUNNING, Tom, "The cinema of attraction. Early film, its spectator and the avant-garde" en Wide Angle, vol. 8, no 3-4, otoño, 1986, pp. 63-70. Nótese el singular de la palabra attraction. El singular pasará a plural en la revisión del texto llevada a cabo en 1990 por el propio Gunning. Versión que, para él, es la correcta y definitiva: GUNNING, Tom, "The cinema of attractions. Early film, its spectator and the avant-garde" en ELSAESSER, Thomas, Early cinema. Space, frame, narrative, Londres: BFI, 1990 [mi ejemplar es la reimpresión del 2006], pp. 56-62. Para observar las pequeñas diferencias entre ambas versiones, lo más práctico es acudir a STRAUVEN, Wanda (ed.), The cinema of attractions, reloaded,
} 
por André Gaudreault ${ }^{3}$, con quien compartió y confrontó ideas y terminando con los precedentes inmediatos de Ben Brewster, Donald Crafton o Adam Simon. Sin olvidar las conferencias y proyecciones de materiales silentes inéditos realizadas por la FIAF desde 1978, o toda una legión de influencias confesadas. ${ }^{4}$ Pero, como todo buen estribillo, la teoría de la atracción ha quedado grabada en la memoria de las siguientes generaciones de historiadores a costa de simplificar fondo y actores.

En esta teoría se defendía una tesis según la cual el cine primitivo -en concreto el anterior a los años 1906-1907-, asentaba su capacidad de fascinación en el poder que ejercía la tecnología. En su periodización del cine de los orígenes, Gunning profundiza en el nicho del MRP -modelo de representación primitivo- como preludio al MRI típicamente burchiano. ${ }^{5}$ EI MRP es aquel dominado por unas atracciones que, sin llegar a desaparecer, se integrarán en el posterior modelo narrativo de la representación institucional. Sin embargo, de este primer enfrentamiento surgido tras el énfasis analítico que puso Gunning en el MRP, se puede extraer algo positivo. A pesar de que el MRP termina diluyéndose $-y$, en parte, integrándose-, el MRI nunca puede considerarse su consumación. Como muy bien apuntaba Francisco Javier Gómez Tarín $^{6}$, no existe una linealidad histórica ni una progresión teleológica que convierta el MRP en MRI.

Amsterdam: Amsterdam University Press, 2006, pp. 381-388. En esta reedición que celebra el vigésimo aniversario del texto, se hacen notar los cambios entre las versiones de 1986 y 1990 mediante corchetes. El libro de Strauven, además, puede servir para establecer la compleja cronología del concepto (pp. 11-16).

${ }^{3}$ GAUDREAULT, André; GUNNING, Tom, “Le cinéma des premiers temps: un défi à I'histoire du cinéma?" en Gendai Shiso. Revue de la pensée d'aujourd'hui, vol.14, n 12, noviembre 1986, pp. 164-186. Reeditado tres años más tarde en AUMONT, Jacques; GAUDREAULT, André; MARIE, Michel (eds.), Histoire du cinéma. Nouvelles approches, París: Publications de la Sorbonne, 1989, pp. 49-63.

Gunning y Gaudreault no habían comenzado a estudiar los matices narrativos del cine primitivo en este momento. Como menciono en el texto, los congresos de Brighton (1978) o Bruselas (1982) habían despertado el interés teórico. Gunning y Gaudreault ya habían firmado artículos que recogían esas inquietudes: "Le Style non continu du cinéma des premiers temps" y "Les détours du récit filmique. Sur la naissance du montage paralléle" en Les Cahiers de la Cinémathêque, № 29, Perpiñán, invierno de 1979, pp. 24-34 y 88-107, respectivamente.

${ }^{4}$ GUNNING, Tom, "Attractions: How they came into the world" en STRAUVEN, Wanda (ed.), op. cit., pp. 31-39.

${ }^{5}$ BURCH, Noël, El tragaluz del infinito. Contribución a la genealogía del lenguaje cinematográfico, Madrid: Cátedra, 1999. [Primera edición de 1987]

${ }^{6}$ GÓMEZ TARÍN, Francisco Javier, "Tensiones en la constitución del modelo de representación institucional (M.R.I.): David Wark Griffith como paradigma" en VV. AA., Imatge i viatge. De les vistes òptiques al cinema: la configuració de l'imaginari turístic, Girona: Fundació Museu del Cinema Col.lecció Tomàs Mallol - Ajuntament de Girona, 2004, pp. 251-258. Versión en red:

<http://www.bocc.ubi.pt/pag/tarin-francisco-tensiones-mri.pdf> [consulta: 17-10-2015] 
De entrada, atender solo al criterio de narratividad para clasificar un modelo como primitivo, puede ser considerado como empobrecedor. Primitivismo entendido como narración sin refinar, sin clausura y, por lo tanto, sin relato estructurado. Modelo donde la espectacularidad del aparato aparece por la doble vía de los entretenimientos populares y de los descubrimientos científicos y ópticos precedentes. Esto es, por la condición de heredero de un legado que intenta ser sincretizado:

Parece que se juegan demasiadas bazas en ese primitivismo como para decantarse únicamente por su relación con la narratividad. (...) Hablar de los primitivos ha de suponer siempre considerar un periodo (...) en el que multitud de fuerzas procedentes de ámbitos muy dispares se encontraron en una tensión no resuelta hasta que una de ellas, la orientada hacia las actitudes narrativas del naturalismo literario, logró un predominio histórico (...) De ahí que el hecho de utilizar el parámetro de la narratividad como único criterio para abordar el cine de los primitivos se presente como parcial y claramente insuficiente. ${ }^{7}$

Es necesario recordar desde un principio, que dentro de ese modelo primitivo existe una cantidad de estímulos del todo diversos donde la "empatía proviene de formas que no están emparentadas con la identificación narrativa". ${ }^{8}$ Es decir, se quiere ver la totalidad de los estímulos como atracciones incapaces de constituir al espectador de manera uniforme, como sí hará el fluir narrativo del MRI. Entre otros motivos, esa heterogeneidad de los estímulos lleva a Vicente José Benet a declarar con acierto que "la idea de atracción sólo puede ser empleada de una manera limitada". ${ }^{9}$ Limitación que, como comprobaremos, fue y es ignorada.

En ese presunto modelo de atracción primitiva, el descubrimiento tecnológico era apreciado no tanto como vía de exploración y aventura, sino como impacto e inmediatez. El espectador asistía a lo novísimo, al gran estímulo emanado de un aparato y de algunas de sus producciones. Entre estas últimas estaban los filmes tipo keyhole. Uno de los ejemplos más socorridos que encontró la prosopopeya exhibicionista para no resultar tan abstracta. El contenido de los keyhole, al supeditar la narración al formato y al hacer que prevaleciera la pulsión sobre la lectura, favorecía la tesis del cine de atracciones en una línea similar a como pudieron hacerlo noventa años después los filmes de catástrofes. Porque el caso del slapstick,

\footnotetext{
${ }^{7}$ BENET, José Vicente, "Montaje y narratividad en el cine primitivo" en op.cit., pp. 94-99.

8 Ibid., pp. 89-90.

${ }^{9}$ Ibid., p. 99.
} 
un cine también considerado de impacto por pura definición, era ubicado por Gunning -a diferencia de Crafton ${ }^{10}$ - en un limbo entre narración y atracción.

\subsection{Atracción: difusión}

La separación entre aparato y producciones es importante. Primero, porque nos devuelve a ciertos planteamientos metodológicos de esta investigación: mantengo la idoneidad de acercarse a la tecnología a través de sus productos; lo cual no quiere decir que sea una manera indirecta o evasiva. Segundo, porque ya deja entrever, sin instaurarla, una dialéctica perniciosa que condicionará el devenir del concepto de atracción. Tal dialéctica es la de la atracción versus narración. Para los defensores de la Teoría de las atracciones, no ha lugar a una salida en forma de síntesis: la atracción someterá a la narración. El cometido de este apartado será hacer un inventario significativo de estas posturas. Digo significativo porque es obligatorio filtrar o renunciar a la exhaustividad a la hora de inventariar una teoría tan popular, por no decir dominante y tiránica. Al tiempo que doy cuenta de una breve y condensada historia de las atracciones, dibujaré tres conceptos clave para comprender su contexto: institución, revolución y percepción.

El propio Gunning tenía dudas sobre la idoneidad de convertir su teoría en una especie de suma que condensara la concepción exhibicionista del cine. Sin embargo, alimentó al monstruo extendiendo ese legado hasta el Nuevo Hollywood de los setenta (Spielberg, Lucas, Coppola, De Palma, etc.). Este enlace directo entre décadas buscaba justificación en la alusión que hacía el nuevo espectáculo hollywoodiense a lo que Gunning consideraba unas de las raíces del cine: la mencionada primacía del estímulo, la exhibición-seducción del aparato y la vinculación de todo ello con una serie de divertimentos que iban del carnaval a la feria. Espacios e itinerancias que quedaban emparentados con los grandes parques de atracciones. Lugares no nacidos, pero sí consolidados como marcas y negocios durante la gran explosión suburbana de los años cincuenta, los parques de atracciones ejercieron gran influencia en la educación sentimental de muchos de los directores consagrados durante los años setenta.

Los principios elementales de la teoría de atracciones se generalizaron, no sin perder en el camino cualquier matiz que dificultara su aplicación. Poco o nada importó que su autor dejara

\footnotetext{
${ }^{10}$ Para Crafton, el gag estaba concebido y construido para mantenerse totalmente alejado de la estructura narrativa. CRAFTON, Donald, "Pie and chase: Gag, spectacle and narrative in slapstick comedy" en STRAUVEN, Wanda (ed.), op. cit., pp. 355-364. [Original en: BOWSER, Eileen (ed.), The slapstick symposium, Bruselas: FIAF, 1988, pp. 49-59]
} 
por escrito que declarar la teoría de atracciones como un programa irreconciliable y opuesto al desarrollo del cine narrativo, sería un ejercicio demasiado sentimental y ahistórico. ${ }^{11} \mathrm{Ni}$ caso, la atracción devino recurso de primera mano para etiquetar cualquier manifestación cinematográfica concebida como gran espectáculo: desde los orígenes a las películas con ostentosos efectos especiales, pasando por el cine experimental o por el desarrollo de cualquier tecnología relacionada con lo que Bazin consideraba suplemento de realidad (color, sonido) y Morin suplemento de presencia objetiva. El estatuto de las imagen, queda en una situación confusa cuando se asume el concepto de atracción como esencia del aparato.

Una de las aporías a las que conduce asumir la atracción como esencia, es la idea subyacente de que las imágenes terminan por emanciparse del aparato que las produce. De la inocente propuesta de Morin cuando, para hablar de los formatos panorámicos o las tres dimensiones, mencionaba "la misma tendencia a la emancipación de la imagen fuera de la pantalla"12, a la radicalidad de la teoría de atracciones en la que la imagen en movimiento se desvincula de la narración. Esa presunta emancipación conllevaría la subordinación de los parámetros narrativos a las nuevas relaciones espaciotemporales establecidas entre la imagen y el sujeto. Cumpliendo, así, la prefiguración del cine de los orígenes y de las sucesivas reclamaciones de las vanguardias de los sesenta y setenta y de los medios digitales de los ochenta y noventa.

Es exactamente eso lo que proponía Sean Cubitt ${ }^{13}$ para analizar los shocks que producían en el espectador los filmes de comienzos de siglo XXI. La alteración de las relaciones espaciotemporales de la representación cinematográfica, instaba a la liberación no solo de la narración, también de la propia representación. Con esto presente, la Teoría de atracciones puede ser calificada como un subproducto -en el sentido evolucionista ${ }^{14}$ del término- de la posmodernidad. Reconoce la emancipación de las imágenes, pero no la de los seres humanos. En el camino que conducía a la emancipación, quedaban arrumbados los (meta)relatos. La facilidad para aplicar la teoría a periodos y obras tan distintos, lejos de descubrir sus puntos débiles, sirvió para revalorizarla:

\footnotetext{
${ }^{11}$ GUNNING, Tom, "The cinema of attractions. Early film, its spectator and the avant-garde" en ELSAESSER, Thomas, Early cinema. Space, frame, narrative, op. cit., p. 61.

${ }^{12}$ MORIN, Edgar, El cine o el hombre imaginario, Barcelona: Paidós, 2001 [original de 1956], p. 128.

${ }^{13}$ CUBITT, Sean, "Digital filming and special effects" en HARRIES, Dan, (ed.), The new media book, Londres: $\mathrm{BFI}, 2002$, pp. 17-29.

${ }^{14}$ Su aparición no responde a una serie de rasgos seleccionados por sus beneficios directos para la adaptación. La adaptación, en este caso, correspondería a la integración/supervivencia en el contexto de la posmodernidad. Esto es, no es una teoría estructural, simplemente viene a mejorar o a decorar los, por otra parte inestables, cimientos de la posmodernidad.
} 
Su verdadera atracción consiste en su aplicabilidad a otros periodos de la historia del cine y a otras prácticas similares más allá del cine de los orígenes (incluso más allá del propio cine). ${ }^{15}$

Así, la Teoría de atracciones utilizada como pauta -por no decir doctrina- transhistórica y omnímoda (all-purpose), puede ser calificada -también y desde este mismo momento- como una teoría reveladora en el sentido popperiano del término. La capacidad práctica de esta condición reveladora, se advierte en su destreza taxonómica. Thomas Elsaesser ${ }^{16}$ considera que los periodos históricos en los que han prevalecido los modelos narrativos -léase cine clásico americano-, pueden considerarse épocas de "transición". ${ }^{17}$ Es esta una visión límite de las atracciones, en la que los grandes bloques dominantes son aquellos que anteponen el impacto tecnológico al resto de características. En su lógica, todo arranca en el cine primitivo y concluye a principios de los noventa del siglo veinte. Elsaesser escribió su artículo en 1990.

Un cuarto de siglo más tarde, la teoría de las atracciones sigue estando presente en cualquier crítica de gaceta, en cualquier paper académico y en cualquier ensayo sobre tecnología y narratología. Y con ese estar presente me refiero a que sigue siendo defendida y validada de manera mayoritaria. La teoría de las atracciones se introdujo con la timidez que ofrecía un artículo de seis páginas, para terminar colonizando la historiografía a la manera del mejillón cebra. Algo solo puede tener -que no adquirir- valor transhistórico, si es un valor esencial del fenómeno, si forma parte de su naturaleza. En este caso, la defensa de la atracción como forma transhistórica radica en la mencionado exhibicionismo del aparato. Enfoque colorista y festivo, pero de una debilidad epistemológica manifiesta. La Teoría de atracciones contiene toda una serie de -ismos ya glosados: reduccionismo, dualismo, animismo, esencialismo e idealismo. Analizada hoy, la cruda realidad de la teoría de atracciones es la de una herramienta tautológica.

\footnotetext{
${ }^{15}$ STRAUVEN, Wanda, "Introduction to an attractive concept" en STRAUVEN, Wanda (ed.), op. cit., p. 20. [La traducción es mía]. Como diría Viva Paci: "No importa en qué década nos encontremos (...) el cine siempre será, sobre todas las cosas, una attraction machine", Ibíd. p. 123. [La traducción es mía, la cursiva es original]

${ }^{16}$ ELSAESSER, Thomas, "Early cinema: from linear history to mass media archeology" en ELSAESSER, Thomas (ed.), op. cit., pp. 1-8.

${ }^{17}$ Entrecomillado también en el original. Ibíd., p. 4.
} 


\subsection{Atracción: institución}

En prestigio industrial recae en el envoltorio final. La atracción se constituye como último y lustroso representante de una enorme y compleja cadena de trabajo y negocio. En detrimento de la construcción narrativa, la ostentación y el espectáculo. Su presentación podrá carecer de muchas cualidades excepto de la seducción. La atracción como elemento estético y como mercadotecnia. Digna heredera de Thalberg y Selznick. Ya lo vislumbraba, como tantas otras cosas, Roberto Rossellini: "la vida de una industria, en todas sus articulaciones, sólo puede revelarse eficazmente merced a la imagen". ${ }^{18}$

Si el concepto de atracción, que traspasa el siglo XX y llega hasta nuestros días, tenía como destino el pasado remoto, una vez alcanzado este seguirá viaje por décadas posteriores. Una referencia del fenómeno son los años cincuenta. John Belton, en su indispensable Widescreen cinema ${ }^{19}$, explicaba el resurgimiento de la atracción gracias a las "nuevas" y ensanchadas imágenes. Al fondo, el aparato como verdadero prestigio de la institución. Que la institución requiera de la atracción como medio para combatir dificultades e intrusismos, no es un fenómeno aislado y lejano, es periódico. Por ejemplo, de los años cincuenta diseccionados por Belton, a la reestructuración industrial de los años ochenta y noventa. A propósito de estos, Justin Wyatt ${ }^{20}$ desarrolló su idea del High concept. El High concept era un exceso entendido como aquello que venía a enfrentarse con la idea de estilo acuñada por Kristin Thompson. Es decir, el exceso estaría formado por todos los recursos que no constituyen un patrón a lo largo del filme. El exceso, desde su aparición puntual pero poderosa, subvertía el devenir de la construcción narrativa. El relato se congelaba para dar paso a los recursos formales facilitados por los últimos avances tecnológicos. "El espectáculo exhibe y, simultáneamente, se exhibe."21

De aquel incipiente digital del High concept, llegamos a su explosión en el nuevo siglo. Para Jean-Pierre Geuens ${ }^{22}$, los avances tecnológicos penetran en las imágenes con el objetivo de seducir al ojo a través de sus bellas superficies. La búsqueda de un look agradable e impactante. Todo se vuelve una cuestión de apariencias. La claridad, la continuidad y la transparencia que para él habían sido las características básicas del cine dominante, ceden

\footnotetext{
${ }^{18}$ ROSSELLINI, Roberto, Un espíritu libre no debe aprender como esclavo, Barcelona: Paidós, 2001, p. 148.

${ }^{19}$ BELTON, John, Widescreen cinema, Londres: Harvard University Press, 1992.

${ }^{20}$ WYATT, Justin, High Concept. Movies and marketing in Hollywood, Austin: University of Texas Press, 2000, pp. 27-28.

${ }^{21}$ DARLEY, Andrew, Cultura visual digital, Barcelona: Paidós, 2000, p. 167.

22 GEUENS, Jean-Pierre, "The grand style" en Film Quarterly, vol. 58, no 4, Berkeley: University of California Press, 2005, pp. 27-38.
} 
ahora paso a lo incierto, a la interrupción y a una reflexividad que invita a pensar la propia tecnología. Algo muy parecido a la metáfora que Chris Petit ${ }^{23}$ le tomaba prestada un año antes a Mark Cousins. Las historias devienen historietas. La densidad y la sustancia narrativas son las de una pompa de jabón. El filme se desvanece, ya ni siquiera importa la tradición del storyteller porque, para Petit, todo se centraba en una cuestión de venta (selling) y beneficios.

Geuens acuñó el término Grand style, pero uno piensa que -igual que hizo Wyatt- solo estaba rebautizando una derivada de la atracción. La forma desbordando el contenido. Geuens profundizaba en la crisis del relato. Esto es, al tiempo que la narración, se desvanece la idea moderna de autor. La tecnología es la autora, apoyada en el software y en esa idea epidérmica de lo bello y de lo cool. Un callejón tecnocrático que Geuens no dudó en reconocer. ¿A dónde iremos a parar?, se preguntaba de manera cándida.

La capacidad de seducción ofrecida por la tecnología se potenció, porque tuvo lugar en un contexto donde el sujeto aparecía repleto de desequilibrios, de carencias y de confusión. La atracción era la expresión canónica de un cine rotundamente tecnológico. Una autorreferencialidad que se volvía todavía más narcisista y ensimismada al anular aquello que creía representar. "Lo que verdaderamente deseamos es su artificiosidad técnica y nada más." ${ }^{24}$ La pregunta de Geuens era cándida, pero insinuaba la nueva reencarnación de la atracción: el fin del arte.

En el cambio de siglo las ideas de Arthur Danto ${ }^{25}$ seguían siendo influyentes. La de Danto fue, en esta ocasión, una visión frívola sustentada en el parecer sobre el ser. La suplantación simbólica del ser a través de la simulación y del isomorfismo. Su veneración de la autoproclamada vaciedad warholiana incidía en la superación del contenido -narrativo y comunicativo- a través del apego, firme y seductor, a la superficie del medio. El mismo Jonas Mekas también tuvo el atrevimiento de emparentar esa superficialidad warholiana con el cine primitivo por haber dinamitado el modelo de representación institucional. El mantra de Warhol era uno y quiero respetarlo al pie de la letra:

\footnotetext{
${ }^{23}$ PETIT, Chris: "You'll never eat dog-meat in this town again" en The Guardian, 20 de noviembre de 2004, p. 14. Versión en red utilizada:

$<$ http://www.theguardian.com/books/2004/nov/20/highereducation.film> [consulta: 17-10-2015]

${ }^{24}$ BAUDRILLARD, Jean, The ecstasy of communication, Nueva York: Semiotext(e), 1988, p. 44.

25 DANTO, Arthur, Después del fin del arte. El arte contemporáneo y el linde de la historia, Barcelona: Paidós, 1999.
} 
No tienes más que mirar la superficie de mis cuadros, de mis películas y a mí mismo, y ahí estoy. No hay nada detrás (...) me ilumina el flash, luego existo. ${ }^{26}$

Régis Debray, igual que Geuens, más que extender desplazó la noción de autoría hasta los laboratorios y sus ingenieros. El arte deja de residir en el arte. De nuevo un ideal neorromántico de la obra y del oficio, que ve en la evolución de la tecnología audiovisual la causa directa de un enfriamiento creativo donde lo cool se convierte en cold. De esta forma, la atracción cinematográfica se convirtió en un ente hiperformalizado. Y, como tal, se desliga de la narración para remitir a los artilugios empleados en su construcción. Hay un descorazonador hálito pesimista en toda esta concepción tautológica del espectáculo cinematográfico como atracción. Ahora no discuto su validez, ni su fundamento teórico, solo su irónico deambular. La atracción parece exponerse y asumirse como una maldición atávica contra la que es imposible luchar. La atracción se hereda porque forma parte del genoma del aparato. La existencia de la atracción no se discute, pero sí -y mucho- su función y sus resultados. Para gran parte de los que hacen uso del concepto, el innegable éxito comercial del cine contemporáneo "ha ido acompañado de un fracaso estético". ${ }^{27}$ Difícil sostener esta generalización, por no decir banalidad.

En un tiempo donde se sigue poniendo en cuestión -ipor fatalista!- la existencia de una naturaleza humana ligada a la genética, resulta llamativo que nos hayamos entregado de esta forma tan enternecedora a defender la existencia de la atracción como esencia que aboca el cine de la corriente dominante a un fracaso estético. Esto sí que puede considerarse fatalismo. Un fatalismo más masoquista que irónico.

Así las cosas, la atracción no necesitó adquirir permiso de residencia en la nación del postespectáculo y de la técnica como poética. Lo visual empapaba un paradigma comunicativo donde no había otro deseo que el mostrar. En ese contexto, la capacidad para impactar dejaba de obedecer al pathos para buscar métodos más contundentes e inmediatos: "hoy [1994] se observa que no se llega y se impresiona tanto con una imagen fija y muda, como con una gran pantalla, sonido Dolby estéreo". ${ }^{28}$ Veinte años después de los lamentos de Debray, resulta deprimente que, en nuestros escritos, nos hayamos limitado a cambiar el Dolby por las 3D.

\footnotetext{
${ }^{26}$ HUGHES, Robert, "El Ascenso de Andy Warhol” en WALLIS, Brian (ed.), op. cit., pp. 49 y 55.

${ }^{27}$ QUINTANA, Ángel, Después del cine, op. cit., p. 115.

28 DEBRAY, Régis, Vida y muerte de la imagen. Historia de la mirada en Occidente, Barcelona: Paidós, 1994, p. 245.
} 
Mientras tanto, seguimos sin cuestionar la raíz teórica. Modificando el dicho del abuelo, nos sentamos ante la pantalla y, entre el enfado y la melancolía, susurramos: "Antes, todo esto era narración".

La atracción como estrategia de legitimación institucional, ¿̇es realmente novedosa? ¿Es una característica exclusiva de cierta producción cinematográfica contemporánea? A estas alturas, es evidente que para los creyentes en la Teoría de atracciones, el cinematógrafo siempre ha tenido esa cualidad exhibicionista. Solo se trataría de recuperarla de una manera acorde a los nuevos tiempos. Las atracciones aun sufren más si quedan inscritas en una teoría indígena del cine. Una teoría que no contemple ni siquiera el audiovisual como supraconjunto. La historia y la estética del cine no pueden ser tan autistas.

Aceptar sin chistar este proyecto de legitimación, supone descubrir otro de los grandes problemas epistemológicos de la Teoría de atracciones. La historia del arte se convertiría en una historia de las atracciones que no respondería a una genealogía, sino a una teleología: la función última e indispensable de la representación es estar al servicio de la institución. A esto se debería referir Wanda Strauven cuando hablaba de la validez de la teoría más allá del cine. Siguiendo el curso de un hilo que nos saca cual Teseo del laberinto posmoderno, tropezamos con múltiples formas de prestigiar instituciones. Como cantaba Battiato, cambian los reinos, las estaciones, los presidentes y las religiones. Todos están di passaggio. Lo único que se mantiene es la representación del poder.

Gran parte de las artes plásticas, arquitectónicas y musicales serían susceptibles de quedar catalogadas bajo una Teoría de atracciones. Empezando por las dinastías egipcias y terminando en el fervor constructor y comisionista de los gobiernos contemporáneos. No sin antes pasar por periodos paradigmáticos, bien diferentes en su orientación y prácticamente concatenados, como el mecenazgo humanista ${ }^{29}$, el barroco contrarreformista $^{30}$ y el despotismo ilustrado. ${ }^{31}$ De la misma manera que la representación como fasto y atracción

\footnotetext{
${ }^{29}$ STRONG, Roy, Arte y poder. Fiestas del Renacimiento 1450-1650, Madrid: Alianza, 1988.

30 SEBASTIÁN, Santiago, Contrarreforma y barroco. Lecturas iconográficas e iconológicas, Madrid: Alianza, 1989.

${ }^{31}$ En este aspecto, la reconstrucción que hizo Rossellini en La prise de pouvoir par Louis XIV (1966) es ejemplar. El maestro italiano hurgó en los mecanismos de poder y en su actualizada y potenciada -que no nueva- arma: la retórica. El propio Rossellini decía que en ese episodio histórico se podía ver cuándo y cómo concebimos el Estado moderno, el Estado que todavía tenemos hoy. A partir de la retórica, se construye una gran representación de fácil parentesco con los simulacros posmodernos. Afinaba José Luis Guarner [GUARNER, José Luis, Roberto Rossellini, Madrid: Fundamentos, 1985, p. 173] al señalar que todo el gobierno y la corte se transforman en una puesta en escena. El simple hecho de no
} 
siempre ha sido herramienta de propaganda, la iconoclasia se convirtió en su némesis: en método para deslegitimar, condenar y aterrorizar. Los budas nunca han cesado de explotar de vergüenza.

\subsection{Atracción: revolución}

Este epigrama puede resultar contradictorio con lo recién expuesto sobre la institución. Si la institución tiene enemigas, una es la revolución. Al traerla aquí y ahora no busco una nueva dialéctica, sino una convergencia insólita. Los ejemplos que acabamos de ver sobre la atracción como legitimación, poseían un tono tendencioso y hasta peyorativo que concluía con el lamento por su fracaso estético. La atracción como revolución permite acreditar que algunos de sus seguidores no resignan su enfoque estético. Así, la atracción pasa de criterio descriptivo a normativo. Es decir, la atracción debe dejar de ser una herramienta al servicio de la institución, para convertirse en su azote. La atracción como caballo de Troya.

El punto de cruce entre ambas concepciones -la resignada y la revolucionaria- es la narración. Andrew Darley ${ }^{32}$ empalmaba el cine de atracciones de las últimas dos décadas con el primer cine. Más en la línea de Gunning que de Elsaesser, Darley apreciaba el soterramiento de las atracciones. La narración solo consiguió domesticarlas, permaneciendo latentes durante el largo invierno del cine clásico, para rebrotar con fuerza en el contexto de las nuevas superproducciones y del estallido digital. Domesticar, traducción fiel y adecuada del tame inglés. Es un verbo capital, nada inocente. De nuevo el poder del lenguaje: solo se domestica lo salvaje. $Y$ solo se domestica en busca de beneficios que rara vez son recíprocos. Se utiliza domesticar cuando quizá -esta es mi interpretación maliciosa- se quiere decir sojuzgar.

Los verbos tame y untame aparecen en el texto fundacional de Gunning y se diseminan con mayor o menor carga ideológica entre los defensores de la teoría. Al valor estético de la atracción, hay que añadirle una nueva carga: la política. Cuando las atracciones sufren periodos históricos de latencia, es porque han perdido esta segunda condición. Es una proposición lógica, pero perversa. ¿’Por qué? porque decreta, de facto, una ideología para cada bando. No hace falta estar muy despierto para darse cuenta de que la atracción pertenece el bando de la revolución, y la narración al de la institución. Warren Buckland lo pone negro sobre blanco: "las atracciones están domesticadas porque han perdido su impacto político,

conocerla equivalía a no existir. Al mismo tiempo que un ensayo histórico, el filme era y es una meditación sobre la atracción como medio, más o menos espurio e indecente, de legitimación.

${ }^{32}$ DARLEY, Andrew, op. cit., p. 87. 
quedando solo el estético". ${ }^{33}$ Este es el germen de un enfrentamiento larvado durante décadas en las tripas de la historiografía anglosajona. En esta disputa de académicos, críticos y cinéfilos con alma de pandilleros, la defensa de los modelos narrativos quedará vinculada a posturas conservadoras.

Postura opuesta, pero compartiendo ambas la existencia de una crisis del relato, la encontramos en Robin Wood. Wood no aprecia carga revolucionaria alguna en la atracción. Bien al contrario, la atracción puede considerarse una extensión del poder capitalista que -con la complicidad del espectador- pisotea y banaliza el relato. "Impáctanos, haznos reír, pero por favor, no nos hagas pensar". ${ }^{34}$ Esta nueva configuración del entorno llevó a Elizabeth Cowie ${ }^{35}$ a hablar de un Hollywood en la era postestudio. En ella, los cambios industriales, logísticos y económicos, deberían haber alterado la antigua hegemonía del modelo comercial y narrativo. El punto de vista de Cowie apunta hacía la posibilidad de un sistema clásico global capaz de asimilar cualquier cambio, por traumático que sea. Es decir, la elasticidad de esa noción de lo clásico, asentada por los trabajos teóricos de David Bordwell, necesitaba ser reexaminada a la luz de la era post.

Lo que Cowie deja entrever es, de nuevo, la necesidad de una revolución en sentido estricto. Esto es, una acción política. Destronar al rey, guillotinar el sistema clásico y el MRI asociado, por su voraz e indestructible despotismo a la hora de asimilar los cambios y de organizar el relato. La autora ilustraba esa voracidad con una metáfora nada ambigua: "la iglesia en tan amplia que la herejía resulta imposible". ${ }^{36}$ Esa etapa postestudio de Cowie es una visión finisecular (1998) -algo catastrofista y de coyuntura- que será neutralizada por la computadora antes de la llegada del apocalipsis.

\subsection{Atracción: percepción}

Las consideraciones sobre la percepción del sujeto enfrentado a la atracción cinematográfica, quedaron intervenidas por una serie de ideas posmodernas. Casi todas ellas negativas y, cómo no, pesimistas. Llantos que regaron los últimos tres lustros del siglo XX, pero de los que todavía escuchamos gemidos. Años marcados por la desconfianza hacia las capacidades cognitivas de

\footnotetext{
${ }^{33}$ BUCKLAND, Warren, "A rational reconstruction of The cinema of attractions" en STRAUVEN, Wanda (ed.), op. cit., p. 52. [La traducción es mía]

${ }^{34}$ WOOD, Robin, Hollywood from Vietnam to Reagan... and beyond, Nueva York: Columbia University Press, 2003, p. 335

${ }^{35}$ COWIE, Elizabeth, "Classical Hollywood cinema and classical narrative" en NEALE, Steve; MURRAY, Smith (eds.), Contemporary Hollywood cinema, Londres: Routledge, 1998, pp. 178-190.

${ }^{36}$ Ibíd., p. 178. [La traducción es mía]
} 
un espectador sometido. Teniendo en cuenta el riesgo que supone desligar por completo lo moderno de lo posmoderno, se puede acordar que el mensaje moderno estaba caracterizado por una autorreflexividad y una ambigüedad positivas que la posmodernidad invierte o pervierte. Con la posmodernidad, la autorreflexividad del medio deviene maligna y controladora, mientras que la ambigüedad del mensaje se convierte, directamente, en algo inmediato pero inasible. Esto es, la paradoja de la inmediatez inasible no está causada por su complejidad, sino por su interpretación no jerárquica e ilimitada. Todos los significados están permitidos y hasta previstos. Así, la posmodernidad termina convirtiéndose en cómplice, que no en crítica, de las formas mediáticas que comienzan entonces su dominio global. ${ }^{37}$

Es el momento donde Paul Virilio ${ }^{38}$ formula su industrialización de la mirada (y de la nomirada) y la automatización de la percepción. La tecnología y sus productos ejecutan la asonada informática. La realidad, destronada, cede el paso a las apariencias. La eliminación de la mirada. Una visión sin mirada que, según Virilio, no es más que la expresión de una intensa ceguera. Donde el verlo todo es equivalente a no ver nada. La industrialización de la mirada viene a sumarse a lo desarrollado en la información y en las construcciones narrativas. La primera, afectada por la saturación y por la incapacidad de filtrado y cotejo. Las segundas, por la exploración de todas las combinaciones posibles entre los objetos y los sujetos de una trama. El todo suma cero.

La mecanización de la mirada también estaba presente, casi al mismo tiempo, en Gilles Deleuze. Las fábricas de imágenes -especialmente la televisión- también exhibían su lado aparentemente menos embaucador. La tramoya desvelada -pronto empiezan a producirse en serie los making of- para un público fascinado por las entrañas del artificio. Las implicaciones directas del evento huyen de lo individual y de lo sensorial para instalarse en el devenir global:

La enciclopedia del mundo y la pedagogía de la percepción han dejado su lugar a la formación profesional del ojo, un mundo de controladores y controlados que comulgan en su admiración por la técnica, por la mera técnica. Lentillas por todas partes. $^{39}$

\footnotetext{
${ }^{37}$ FOSTER, Hal, “Asunto: Post” en WALLIS, Brian (ed.), op. cit. p. 199.

${ }^{38}$ VIRILIO, Paul, La máquina de visión, Madrid: Cátedra, 1989.

39 DELEUZE, Gilles, Conversaciones, 1972-1990. Valencia: Pre-Textos, 1996, pp. 119-120. [Original: Pourparlers, París: Éditions de Minuit, 1990].
} 
Terreno límite al que también llegaba Jean Baudrillard. El simulacro como crimen perfecto. Una hiperrealidad donde los fenómenos, tras ser convenientemente mediatizados, devienen más reales que una (des)fallecida realidad. Las nuevas imágenes encuentran en la Alta Definición (no solo de la imagen, también una alta definición del tiempo, del pensamiento, del lenguaje, del cuerpo y del sexo) coartada para el crimen en tanto "la sustancia referencial se hace cada vez más escasa." ${ }^{40}$ Eliminada la médula del referente, emerge con todo su fuerza la tecnología. Imágenes diabólicas ${ }^{41}$ cuya emanación tecnológica resulta inmoral y perversa. Un tiempo y un lugar donde la sobreabundancia de información no encuentra correspondencia en la producción de significados que de ésta se espera.

La información se devora a sí misma para, acto seguido, hacer lo propio con la comunicación y su función social. Esta preponderancia de la información ya había preocupado a Walter Benjamin tras la disolución de la República de Weimar. Allí donde el alemán se mostraba nostálgico, Baudrillard será, faltaría más, apocalíptico. El primero tuvo muchas más razones que el segundo para pensar ese extremo. Benjamin se quejó con amargura del desplazamiento que, a su juicio, había ejercido la información sobre la narración. También del vaciamiento que los juegos formales modernistas habían provocado en el valor del lenguaje y de la experiencia. Para Benjamin, el arte de la narración estaba tocando a su fin porque estaba íntimamente ligada a una facultad que creía inalienable: la de "intercambiar experiencias". ${ }^{42}$

Las ideas de Baudrillard son, en el fondo, una Teoría de atracciones pura y dura. Responden a una concepción global de la imagen, de la información y de la tecnología, pero poseen los mismos resortes y efectos. La Teoría de atracciones es una línea secante de todos estos presupuestos posmodernos. A Baudrillard le resultaba traumática la insuficiencia de la masa informativa contemporánea, por dos motivos: su elefantiásica puesta en escena y su alarde impúdico. Ante semejante despliegue, la información quedaba exhausta. En ese descomunal proceso de simulación, el receptor no alcanzaba más que a satisfacer las expectativas planteadas, nunca a procesarlas para obtener significados y conocimiento. El contenido, para

\footnotetext{
${ }^{40}$ BAUDRILLARD, Jean, El crimen perfecto, Barcelona: Anagrama, 1997, p. 47.

${ }^{41}$ BAUDRILLARD, Jean, The evil demon of images, Sídney: Power Institute of Fine Arts, 1987.

42 BENJAMIN, Walter, "El narrador" en STOOPEN GALÁN, María (coord.), Sujeto y relato. Antología de textos teóricos, México D.F.: Universidad Nacional Autónoma de México, 2009, p. 32. Para un estudio sobre la relación entre experiencia y narración en Benjamin: VIGNALE, Silvana, "Experiencia y narratividad en Walter Benjamin" en Revista Páginas de Filosofía, Departamento de Filosofía de la Facultad de humanidades de la Universidad Nacional del Comahue, vol. 12, no. 15, pp. 5- 16.
} 
el teórico francés, quedaba reducido a un fantasma donde el significado ha implosionado. ${ }^{43}$ Baudrillard, como bien apunta Andreas Huyssen ${ }^{44}$, seguía la estela de McLuhan:

Después de tres mil años de explosión a través de tecnologías fragmentarias y mecánicas, el mundo occidental está implosionando. Durante las eras mecánicas habíamos prolongado nuestros cuerpos en el espacio. Hoy [1964] (...) lo hemos hecho con nuestro propio sistema nervioso central mediante un acto de dimensiones globales, aboliendo tanto el espacio como el tiempo, en lo que concierne a nuestro planeta. Nos acercamos rápidamente a la fase final de las extensiones del hombre, a la simulación tecnológica de la conciencia. ${ }^{45}$

A partir de Lev Manovich se puede realizar la transición de una atracción como fenómeno posmoderno global, hacia otra como fenómeno puramente visual. Lindando con el concepto de atracción audiovisual, se redefinen ahora los de revolución, entorno y realismo. Puede parecer extemporáneo volver a introducir aquí el realismo, pero abunda en la deriva advertida. Para el gurú de los nuevos medios, la tecnología digital cierra el círculo. Ya no se trata de atracciones que engarzan lo digital con el cine primitivo, sino con la arqueología del invento, con el precine, con los juguetes y trucos ópticos de siglos precedentes. Si Elsaesser confinaba el modelo narrativo a periodos de transición, lo que hace Manovich es degradar el modelo realista del cinematógrafo para colocarlo como una opción más entre otras. Realismo y narración dejan de ser los referentes principales. En la conspiración finisecular contra la rerum natura, aun no sabemos qué fue antes, si la posmodernidad o lo digital.

Así, los nuevos medios digitales vendrían a redefinir por completo la identidad del cine. Hoy quien dice hoy, en historiografía puede decir el último lustro-, todavía se sigue manteniendo esta idea. La era digital irrumpió en la imagen -y por lo tanto irrumpió en Hollywood"arrasando las taquillas y transformando la esencia del cine" ${ }^{46}$ Constatar si una taquilla ha sido arrasada, es una cuestión que se soluciona en treinta segundos con una visita al Box Office; comprobar si una esencia ha resultado transformada, es bastante más complejo y requiere de

\footnotetext{
43 BAUDRILLARD, Jean, "The implosion of meaning in the Media" en Simulacra and simulation, Ann Arbor: University of Michigan Press, 1994, pp. 79-86.

44 HUYSSEN, Andreas, "In the Shadow of McLuhan: Jean Baudrillard's Theory of Simulation" en Assemblage, no 10, Cambridge: The MIT Press, diciembre de 1989, pp. 7-17.

${ }^{45}$ McLUHAN, Marshall, Understanding Media. The extensions of man, Londres: Routledge, 2001, p. 3. [La traducción es mía].

${ }^{46}$ RIAMBAU, Esteve, Hollywood en la era digital. De Jurassic Park a Avatar, Madrid: Cátedra, 2011, p. 324.
} 
mayor esfuerzo intelectual. Primero habría que determinar que el cine posee una esencia, después exponer sus principios básicos para ver, finalmente, qué es lo que cambia y en qué cosa se convierte. Un ejercicio de trazabilidad analítica al que, por desgracia, no siempre asistimos. Manovich, consciente de las lagunas que puede dejar su apuesta, busca aprobación en la teleología:

No sería del todo inapropiado leer la corta [1999] historia la imagen digital en movimiento como un desarrollo teleológico que vuelve a mostrar el nacimiento del cine (...) Justo un siglo después de su nacimiento oficial, el cine fue reinventado en una pantalla de ordenador. ${ }^{47}$

Otro de los recursos que utiliza Manovich para empalmar la historia, es el fetichismo. Manovich tira un lazo entre décadas que se anuda en la computadora de Konrad Zuse. Aquella máquina pionera necesitaba una película de celuloide de $35 \mathrm{~mm}$. (reutilizada, estaba impresionada) sobre la que perforar una serie de patrones destinados a guiar las rutinas de trabajo. La iconicidad de la imagen cinematográfica, sustituida por un medio más eficiente: "el cine se convierte en un esclavo de la computadora" ${ }^{48}$

Poco antes que Manovich, Raymond Bellour ${ }^{49}$ había insinuado algo muy parecido. Sin mencionar esa relación de esclavitud, cuestionaba la capacidad analógica de la imagen para con su referente. Según Bellour, cuando una imagen se digitaliza accede a un proceso imparable de des-analogización. La imagen se convierte en su propio referente. Mito de Narciso reactualizado. La imagen circula entre programas informáticos que, incapaces de escapar de una red creada por ellos mismos, remiten los unos a los otros en bucle. Las imágenes reflejando la condición endogámica del software. Autorreferencialidad reconcentrada. Un escenario que Lorenzo Vilches ${ }^{50}$, a través de las visiones de Douglas Hofstadster, aplicó al problema identitario del sujeto y a su imposible autotrascendencia dentro de la red digital.

\footnotetext{
${ }^{47}$ MANOVICH, Lev, "What is digital cinema?" en LUNENFELD, Peter (ed.)., The digital dialectic. New essays on new media, Cambridge: The MIT Press, 1999, p. 186. [La traducción es mía]

${ }^{48}$ MANOVICH, Lev, "What is new media?", en HASSAN, Robert; THOMAS, Julian, (eds.), The new media theory reader, Maidenhead: Open University Press, 2006, p. 9.

${ }^{49}$ BELLOUR, Raymond, "The double helix" en DRUCKERY, Timothy (ed.), Electronic culture. Technology \& visual representation, Nueva York: Aperture, 1997, pp. 173-199.

${ }^{50}$ VILCHES, Lorenzo, op.cit., p. 206.
} 
Teñidos por el contexto, los efectos de la atracción sobre la percepción pueden englobarse en un ataque directo y masivo al modo clásico de representación. Elsaesser insistía en su tesis ${ }^{51}$ ilustrándola con un análisis del Drácula de Francis Ford Coppola (Bram Stoker's Dracula, 1992). Allí avistaba un cambio en el paradigma del espectador, que pasa de una identificación especular (specularity) a otra de inmersión (engulfment). El cambio vendría provocado por el choque que ejercían ciertas secuencias. Choque e impacto, sin entrar en debates semánticos más o menos rigoristas, empiezan a funcionar como sinónimos de atracción. Para Elsaesser, el presunto choque quedaba asociado a técnicas tan antiguas y castas como el escamoteo del contraplano y la dilatación temporal.

La atracción se aprovechó de un siglo extenuado y de la multiplicación de los puntos de vista para emanciparse. Décadas antes lo había intentado sin éxito. El contexto -industrial y narrativo- supo asimilarla en los años cincuenta. Aquellas imágenes de grandes dimensiones, ya propiciaron un nuevo tipo de participación física y afectiva en el espectador. El impacto tecnológico fue considerable, pero no absoluto. La tradición del cine clásico en la que se inscribía aun ejercía una fuerza considerable. Toda la producción de la por entonces nueva tecnología, además, estaba centralizada en los propios estudios. La atracción, además de por escala, venía dada por un ejercicio espacial y estilístico de centramiento y descentramiento. El espectador seguía posicionado físicamente de acuerdo a la idea ortogonal del proscenio, pero era desbordado por el nuevo área de visión. La normalización ${ }^{52}$ plástica y narrativa de esta atracción se realizó, grosso modo, a través de un leve -y pronto olvidado- alargamiento en la duración del plano, y mediante el recentramiento de la acción o, en su defecto, mediante una descompensación mesurada que era contrarrestada por el peso de las miradas.

Todos los planteamientos que vinculan la atracción audiovisual con una nueva forma de percibir, siguen un esquema similar. Nacen en la tecnología, se expresan a través de la técnica y concluyen en la mutación espectatorial. Puro determinismo. El mismo que utilizaba Omar Calabrese cuando argumentaba que el desbordamiento tecnológico activaba los cambios en la percepción y en el gusto, en tanto la "fruición ya está prevista, incluso inscrita en las obras

\footnotetext{
${ }^{51}$ ELSAESSER, Thomas, "Specularity and engulfment. Francis Ford Coppola and Bram Stoker's Dracula" en NEALE, Steve; MURRAY, Smith (eds.), op.cit., pp. 191-207.

${ }^{52}$ Esa normalización plástica y temporal de unos planos que tendían a desequilibrarse y a alargarse, está ampliamente estudiada por Bordwell. BORDWELL, David; STAIGER, Janet; THOMPSON, Kristin, El cine clásico de Hollywood. Estilo cinematográfico y modo de producción hasta 1960, Barcelona: Paidós, 1997, pp. 401-407 [Primera edición de 1985]. "Expanding the image and compressing depth" en BORDWELL, David, On the history of film style, Cambridge: Harvard University Press, 1998, pp. 237-252.
} 
mismas".$^{53}$ El predominio de la visión sobre la mirada, el triunfo de la pulsión y de la inmersión en la fábula.

En cierto sentido, el cine comercial parece estar anclado en una lógica cada vez más distante del horizonte clásico, y que se aproxima mucho más al cine de atracciones..$^{54}$

Company y Marzal veían la utilización del término atracciones como "especialmente afortunada", pero también expresaban su cautela sobre la extrapolación indiscriminada. Hacerlo era y es un problema historiográfico y estético desde que las características del cine comercial de finales e inicios de siglo no son tan sencillas de reducir y de fijar.

El cine de acción contemporáneo parece haber privilegiado, de un modo radical, la dimensión espectacular sobre la narrativa. Sin embargo, con ello no queremos decir que el cine de acción norteamericano actual pueda verse como una simple actualización de algunas estrategias discursivas propias del cine de los primeros tiempos. El problema es, sin duda, mucho más complejo, ya que en el cine contemporáneo comercial la narratividad no ha llegado a ser ni mucho menos extinguida. $^{55}$

Volveré con calma sobre esa no-extinción que merece ser aclarada. Ahora recojo este debate de la recuperación que hace lo nuevo de lo viejo. Para Jay David Bolter y Richard Grusin ${ }^{56}$, los filmes comerciales del cambio de siglo estaban más cerca del espíritu del cine de atracciones tránsito del XIX al XX- de lo que lo han estado nunca. No satisfechos con ello, desarrollaron tres conceptos que estaban llamados a condicionar la genealogía de los nuevos medios: immediacy, hypermediacy, remediation. El cometido de las nuevas tecnologías no era otro que deglutir los viejos. La computadora como centro de operaciones obedecía a lo que Jan

\footnotetext{
${ }^{53}$ CALABRESE, Omar, La era neobarroca. Madrid: Cátedra, 1989, p. 103. Utilizo esta cita de Calabrese, entre otras disponibles, por ser prácticamente coetánea al planteamiento de Elsaesser; no por la bonita aliteración entre sus apellidos. La publicación original de Calabrese es de 1987. No se trata de una filiación entre ambos, solo de realzar el contexto donde se mueven dos europeos estudiosos de la imagen y de la misma generación.

${ }^{54}$ COMPANY, Juan Miguel; MARZAL, José Javier, La mirada cautiva. Formas de ver en el cine contemporáneo, Valencia: Generalitat Valenciana, 1999, p. 29 y p. 38.

${ }^{55}$ Ibíd., pp. 38-9.

${ }^{56}$ BOLTER, Jay David; GRUSIN, Richard, Remediation. Understanding New Media, Cambridge: The MIT Press, 1999.
} 
Simons $^{57}$-en la línea de Bellour y Manovich- consideraba la integración en un único entorno de todo aquello que en la teoría de Cowie iba camino de la desintegración.

La computadora se convertía, así, en el paradójico centro de una posmodernidad acéntrica y excéntrica. Un conglomerado, un magma amorfo donde la atracción trascendía lo puramente audiovisual para regresar a las viejas representaciones físicas. Toby Miller ${ }^{58}$ ha perfilado ese nuevo mapa en el que quedó inscrito el cine de atracciones, rememorando la pertenencia del cine primitivo a un espectáculo matriz: el vodevil, las variedades. La idea de Miller es, en cierta medida, buena sin él saberlo. Miller considera el vodevil como espacio unificador, digamos a la manera de la computadora de Manovich, cuando el vodevil era un espacio netamente descentralizado y hasta anárquico e inconexo en sus partes. Donde Miller dice vodevil, habría que decir audiovisual contemporáneo.

Han pasado entre quince y veinte años de todas estas propuestas.De lo único de lo que podemos estar seguros es de que la computadora, como hipotético elemento centralizador de la imagen, ha permitido seguir viviendo $-\mathrm{y}$ hasta ayudando- a prácticas ajenas-analógicas. Además de favorecer, desde su maleabilidad, la diversificación y la multiplicación de las propias.

La teoría de atracciones sigue vigente porque representa la sensualidad del retorno a un pasado que se encabalga con un regreso al futuro. En la superficie de la teoría flota el arcaísmo posmoderno. En su fondo, bucean los antiguos sueños altamiranos. Fondo y superficie abrazados por un neorromanticismo involuntario -humano- o mal disimulado -intelectual- que confluye con el mito del buen salvaje.

El futuro del cine, o el cine del futuro, presentado no como desdoblamiento eterno del ser, sino como edén donde recuperar la "inocencia originaria del medio". ${ }^{59}$ El regreso a la fascinación primitiva más pura e inocente a través de un aparato milagroso. La originaria "emoción de la técnica que se dio durante la etapa anterior al nacimiento de la industria, ha vuelto a resurgir en los últimos años". ${ }^{60}$ Capacidades tecnológicas extraordinarias que ya golpearon a los espectadores de hace un siglo y que ahora se reencarnan en un desbordante

\footnotetext{
${ }^{57}$ SIMONS, Jan, “New media as old media: cinema” en HARRIES, Dan, (ed.), op. cit., pp. 231-241.

${ }^{58}$ MILLER, Toby, El nuevo Hollywood. Del imperialismo cultural a las leyes del marketing, Barcelona: Paidós, 2005.

${ }^{59}$ QUINTANA, Ángel, op. cit., p. 108.

${ }^{60}$ COUSINS, Mark, Historia del cine, Barcelona: Blume, 2005, p. 12.
} 
catálogo de efectos especiales y trucajes que "parecen querer mantener la magia del espectáculo per se (...) una especie de neoprimitivismo cinematográfico" ${ }^{61}$ Las atracciones como encarnación del "espíritu de la vieja barraca de feria". ${ }^{62} \mathrm{El}$ cine que, antes de consumar su muerte, se dispone a renacer. El cine, resucitado de todas las épocas, vuelve con las armas de su infancia. Un cine post mortem ${ }^{63}$ que, desde el momento de su invención ha anticipado sus numerosos renacimientos.

${ }^{61}$ RUIZ JIMÉNEZ, Antonio Gabriel, El cine. Muerte o transfiguración, Sevilla: Comunicación Social, 2005, p. 196.

62 GUBERN, Román, "El cine después del cine" en PALACIO, Manuel; ZUNZUNEGUI, Santos (eds.), Historia general del cine. vol. XII. El cine en la era del audiovisual, Madrid: Cátedra, 1995, pp. 305-306.

${ }^{63}$ BULLOT, Érik, El cine es una invención post mortem, Santander: Shangrila Textos Aparte, 2015, p. 140. 


\title{
3. ATRACCIÓN VERSUS NARRACIÓN
}

\author{
«Permítaseme dudar \\ de que el arte cinematográfico \\ sea un arte narrativo» \\ Germaine Dulac ${ }^{64}$
}

Partiendo de Tom Gunning y siguiendo con algún coletazo de las teorías de los nuevos medios, he podido exponer cómo el uso del concepto atracción en el estudio de las tecnologías de la imagen, ha sido un hecho incuestionable durante las últimas tres décadas. La Teoría de atracciones estuvo acompañada por toda una serie de variaciones que no eran otra cosa que travestis nominales. Este amplio consenso teórico que discurre en plena época de la inestabilidad, del relativismo y de la subjetividad, estuvo apoyado por dos hechos fundamentales. Uno histórico y epistemológico, otro estético e industrial: la posmodernidad y el neoespectáculo hollywoodiense.

Descrito el panorama, hay que explicar el punto más importante. El último porque antes era necesario comprender el sustrato y el proceso de evangelización. El elemento cuyo análisis es decisivo para reafirmar, refutar o matizar la Teoría de atracciones. En este apartado esbozaré el actual contexto histórico-tecnológico. De él saldrán ciertos usos sociales que también deberán ser atendidos. Luego me preguntaré de donde surge la dialéctica atracción versus narración. Si tiene alguna raíz no cinematográfica y si es una dialéctica fundada o forzada.

Puedo comenzar condensando al máximo lo que podría ser el statu quo teórico de la narración cinematográfica en la corriente dominante. Este dicta que la narración carece de articulación, delega en su discurso, prima el fragmento, es difícil de reconocer o simplemente desaparece. Como se puede apreciar, introduzco de entrada una gradación que fulmina cualquier atisbo de pureza -y de incomunicación- en los presuntos bandos enfrentados. Negando la dialéctica, tampoco veré necesaria una síntesis entre términos, aunque sugeriré las vías que otros han tomado. No considero estar hablando de opuestos, solo de variaciones de un mismo fenómeno.

64 DULAC, Germaine, "Las estéticas. Las trabas. La cinegrafía integral” en ROMAGUERA i RAMIÓ, Joaquim; ALSINA THEVENET, Homero (eds.), Textos y manifiestos del cine, Madrid: Cátedra, 1998, p. 97. 


\subsection{Metarrelatos}

«Siglo veinte, cambalache

problemático y febril»

Cambalache (Enrique Santos Discépolo, 1934)

Más allá de la estética y del audiovisual, hoy pervive la discusión sobre las grandes explicaciones del mundo. La aparente necesidad que algunos han notado no para su vuelta pues nunca se fueron-, sino para su revisitación y restauración en las sociedades actuales. Cuando apostillo que los metarrelatos nunca desaparecieron, quiero concluir que no se puede habitar el planeta sin explicarlo. Habitar es narrar. Este aforismo puede parecer una cursilería, pero toda esta parte de la investigación tiene como objetivo demostrar su validez. Investigar, en buena medida, es trazar el camino que va del aforismo y de la hipótesis al axioma.

Todos los ojos de este siglo fueron enjuagados el 11 de septiembre de 2001. Inverosímil pero real, el cemento pulverizado nos devolvió la vista. El capitalismo inmaterial y la posmodernidad evanescente, resultaron ser terroríficamente concretos. Aquella nube de aerosoles, cemento, cristal y cuerpos pulverizados fue lo más cerca que estuvo nunca la posmodernidad de tener razón. La posmodernidad era expulsada de nuestras vidas, mientras se ejecutaba de manera grosera uno de sus edictos: la desmaterialización.

Pero el 11 de septiembre no puede tomarse como un remake en clave de atracciones de la caída del muro de Berlín. El derrumbe del World Trade Center no fue la demolición posmoderna porque no puede derribarse aquello que nunca estuvo en pie. El mundo cambió para siempre, dijeron. Pero de los escombros no emergió un nuevo metarrelato. El polvo se depositó en las aceras y fue entonces cuando advertimos que los viejos metarrelatos, como el dinosaurio, seguían allí. Justo en ese instante, en el mismo segundo en el que el cielo descolorido de la capital del mundo regresó al azul cobalto, deberían haber proyectado en una de las pantallas de Times Square alguno de los lemas que habían querido reducir la realidad a "residuo que se deposita en el fondo del conflicto de las interpretaciones". ${ }^{65}$ La realidad volvía, sangrante, macilenta y hasta irónica. El metarrelato, dado por muerto y enterrado, asomaba como un mugriento zombi de Lucio Fulci.

\footnotetext{
${ }^{65}$ VATTIMO, Gianni: Filosofía, política, religión. Más allá del pensamiento débil, Oviedo: Nobel, 1996, p.
} 42. 
$\mathrm{Ni}$ siquiera los enemigos podían considerarse nuevos. El trauma fue mayor porque nuestras herramientas epistemológicas para hacer frente - de nuevo- a lo viejo estaban corroídas por la roña posmoderna. La angustia que generó el suceso, no fue consecuencia exclusiva del hórrido atentado. La ansiedad del paisaje después de la batalla acrecentó el pavor. Cómo, quién, cuándo y por qué cuatro aviones se convierten en misiles, eran explicaciones sencillas. Regresar a fórmulas que se creían agotadas por pensadas hasta la extenuación, era lo complejo. La mullida almohada del relativismo dejó de serlo porque, entre otras cosas, habíamos descubierto que una de sus funciones era ocultar la pistola. ${ }^{66}$ El despertar era un abandono por la fuerza de la -narcótica más que estéril- introspección, para volver a enfrentar el yo en y con el mundo. Un desafío: la realidad y el nosotros; la materia y la narración.

Cuando el 11 de septiembre sonaron las alarmas, fue porque el recreo había terminado. Los juegos de la Deconstrucción, la anecdótica lógica fuzzy, el pensamiento débil, el solipsismo y hasta los herederos de los Estudios culturales y del Estructuralismo, tenían que recoger los juguetes y volver a las aulas. Cuentan que la hermenéutica, cuando le arrebataron el cubo de Rubik de entre las manos, no dejó de llorar el resto del día. Para otros muchos solo era el momento de dejar de confundir el derecho a saber con el derecho a opinar. Hacer caso a Wittgenstein y callar. ${ }^{67}$ El tango llegaba a su fin, la pareja se enroscaba dramáticamente en cuartas mientras se echaba el cierre sobre la vidriera irrespetuosa del cambalache.

Porque la posmodernidad -aquel lugar donde se había mezclado la vida despreciando cualquier atisbo de jerarquía- había conseguido amaestrar hasta la sociedad del espectáculo. Otrora radical denuncia de las estructuras de poder, la denuncia debordiana fue abrazada hasta por la curia romana ${ }^{68}$ Demandar verdad, querer construir nuevamente un relato que no naufragara en el conflicto de las interpretaciones, era caer de facto en lo reaccionario. Los intelectuales posmodernos - muchos de ellos autoconsiderados de izquierdas- dejaron que tal cosa sucediera. ¿Qué intelectual o académico se iba a alinear con una denuncia compartida por la Iglesia? Era mucho más cómodo y transgresor el discurso de la virtualidad.

\footnotetext{
${ }^{66}$ Como Plato en Rebelde sin causa (Rebel without a cause, Nicholas Ray, 1954). A gun under my pillow fue el título de trabajo de lo que luego acabaría siendo We can't go home again (Nicholas Ray, 1973)

${ }^{67}$ WITTGENSTEIN, Ludwig, Tractatus logico-philosophicus, Madrid: Alianza, 2010, p. 132.

${ }^{68}$ IOANNES PAULUS II, Veritatis splendor, Ciudad del Vaticano: Santa Sede, Carta Encíclica 06-08-1993. $<$ http://w2.vatican.va/content/john-paul-ii/es/encyclicals/documents/hf_jp-ii_enc_06081993_veritatissplendor.html> [consulta: 01-04-2015]
} 
Al margen de los nombres -capitalismo de ficción ${ }^{69}$, cultura de la irrealidad, sociedad virtual-, todos esos discursos concluían en la existencia de una conspiración global articulada a través de la imagen y, en última instancia, de lo intangible: del número y del poder; o del poder del número. El presunto espíritu crítico de la posmodernidad occidental había decidido entregarse al goce y a la fascinación del modelo. Incluida su propia autodestrucción. El apocalipsis jaleado hasta convertirse en flamante utopía estética.

En el rincón de la izquierda, afines posmodernos clamando contra un totalitarismo que ellos mismos ejercieron. El posmodernismo resultaba tan exclusivista y censor como las ortodoxias a las que decía oponerse. Se podía hablar de "cultura humana pero no de la naturaleza humana; de género, pero no de clase; de cuerpo, pero no de biología (...) una heterodoxia evidentemente ortodoxa que, como forma imaginaria de identidad, necesita sus cucos y sus espantapájaros para seguir en el negocio".$^{70}$ En el rincón de la derecha, nostálgicos modernos lamentándose por el relativismo imperante, por la eterna degradación moral y por un igualitarismo tramposo. Uno entiende y hasta se identifica con con las quejas de Rudolf Arnheim $^{71}$ sobre las etiquetas modernismo y postmodernismo. Para él no eran otra cosa que frivolidades de teóricos que pontificaban sobre sucesos banales, mientras el verdadero desarrollo cultural ${ }^{72}$ pasaba inadvertido.

La idea de verdad y de razón intentaron ejercer de árbitros. Si bien urgía revestir de carne y de sentido la realidad, no era lógico y recomendable reimplantar el siglo XVIII en el XXI. No es de extrañar que, en el intento, se recuperaran planteamientos fenomenológicos y pragmáticos. Rehabilitar el concepto de verdad continuó como asignatura pendiente en tanto suponía no solo una capitulación humillante, sino un perdón explícito y una restitución a las víctimas. Para muchos teóricos -no solo posmodernos- regresar a la idea de verdad era equivalente a entrar en un confesionario. Lo cierto es que había llegado el momento de reexaminar -que no a reconstruir- la rerum natura.

\footnotetext{
${ }^{69}$ VERDÚ, Vicente, El estilo del mundo. La vida en el capitalismo de ficción, Barcelona: Anagrama, 2006. Si bien aporta matices y desvíos a su tesis en Yo y tú. Objetos de lujo, Barcelona: Debolsillo, 2007.

${ }^{70}$ EAGLETON, Terry, op. cit., p. 51.

${ }^{71}$ ARNHEIM, Rudolf, Ensayos para rescatar el arte, Madrid: Cátedra, 1992, pp. 17-20.

72 En el original inglés Arnheim utiliza "achievement", que en este contexto podría traducirse como "logro". La versión española citada opta por "desarrollo" (p. 13) y no es desacertado. Para acompañar a "cultural", tanto "logro" como "desarrollo" son mucho más adecuados que "progreso". Realizo esta breve nota porque existe a lo largo de toda esta investigación, una crítica a cierto uso histórico de "progreso". Versión y página originales del libro de Arnheim: To the rescue of art: Twenty-six essays, Berkeley: University of California Press, 1992, p. ix.
} 


\subsection{Tecnofetichismo}

Existe un factor que, sin ser exclusivo de los últimos años de este siglo, sí ha alcanzado una visibilidad pocas veces conocida. Como marco global y nada ajeno a lo estrictamente cinematográfico, el tecnofetichismo como uso social y tecnológico ha sido una fuerza determinante a la hora de querer ocultar los relatos. Al albur del desarrollo masivo de Internet y del perfeccionamiento de los terminales de entretenimiento caseros y portátiles, la proliferación del tecnofetichismo ayudó a asentar la idea de un relato ausente. El aparato tecnológico glorificado. El gadget como atracción, moda y estatus social.

Recuerdo ahora que lo mejor de Passion (Brian De Palma, 2012) era una correspondencia formal entre objetos. El valor del diseño y de la utilería. Materia convertida en metáfora. Era curioso comprobar cómo un fetichista de la imagen y del objeto como De Palma, declaraba su fobia a la tecnología construyendo una cancela donde plantar el aforismo "La tecnología os hará libres". El problema era que dicha cancela poseía idéntica doblez semántica que la de Auschwitz. El versículo noveno del canto tercero de la Divina comedia nunca perderá su vigencia. Porque más que con Hitchcock, De Palma sigue obsesionado con Antonioni. La correspondencia visual entre el teléfono móvil y la puerta de la cárcel era tan nítida como determinante en el desarrollo de la película. Al parecer no lo suficiente para que la crítica la reconociera y la explicara. La protagonista juntaba las manos tras la puerta del presidio como en actitud de orar. Ella solo quería recuperar su vida. Quería recuperar su teléfono.

La tecnología del ocio al rescate de las insuficiencias afectivas, sociales y cognitivas. Una tecnología rotundamente audiovisual. Tecnología que hipnotiza con la espiral dibujada por una estrategia comercial insaciable. Estrategia destinada a crear falsas necesidades y carencias intencionadas. La espiral gira, indefinida y abisal, creando ciclos de consumo en los que la reducción de plazos responde a un criterio artero. La manida artimaña de la obsolescencia programada como heredera del antiguo y menos eufemístico imperativo de innovación. ${ }^{73}$

Acciones a medio camino entre la vulgar picaresca, las leyes de un libre comercio donde no ha lugar al azar y el empirismo de la ley de Moore. ${ }^{74}$ Pero las conductas fetichistas no siempre

\footnotetext{
73 QUINTANILLA, Miguel Ángel, Tecnología. Un enfoque filosófico, Madrid: Fundesco, 1989, pp. 45-46.

${ }^{74}$ Uno de los fundadores de Intel, Gordon Earl Moore, formuló dicha teoría el 19 de abril de 1965. Según esta, el desarrollo en términos informáticos o electrónicos responde a criterios exponenciales, duplicándose cada año las capacidades de las respectivas tecnologías. La innovación es rápida, así como la sustitución de una tecnología que deviene obsoleta apenas ha sido terminada. Esta ley, como no podía ser de otra manera, también ha quedado obsoleta.
} 
entierran la dimensión funcional y social de la tecnología. Al contrario, el fetichismo tecnológico puede sublimarlas. En esa sublimación residen también la limitación y la repetición. Esto es, la patología y la dependencia. Euforia, sentimiento de omnipotencia y sueño de capacidades ilimitadas son otras de las características del tecnofetichismo según Kevin Robins. ${ }^{75}$ No hace falta forzar la situación para terminar hablando de la tecnología como estupefaciente.

Pero aquí me interesa, siquiera de manera episódica, un enfoque psicoanalítico -lacaniano, para ser exacto- del fetichismo. No como extensión edípica, sino como mensaje y síntoma obtenidos a partir de la relación con un objeto. Antes de desarrollarlo en varios de sus seminarios, Lacan -junto a Granoff- (1956) recogió el artículo (1927) de Freud donde el austríaco destacaba que el fetichismo debía abandonar lo accesorio -y la eventual satisfacción que producía- para ser descifrado dentro de un marco patológico. Lacan y Granoff apoyan concederle mayor relevancia, al tiempo que advierten que para logar la descodificación solicitada por Freud se requiere del lenguaje -los síntomas hablan en palabras- antes que de vagas analogías del campo visual. ${ }^{76} \mathrm{~A}$ lo largo del cuarto seminario ${ }^{77}$, Lacan aprecia que el fetichismo, en cuanto a relación establecida entre objeto y sujeto, viene a cumplir una función de protección contra la angustia. Para concluir en el décimo con un apunte esclarecedor y sintético: "el fetiche es la condición de la que se sostiene el deseo". Sentencia que necesita de otra -anterior en el proceso- para comprender su peligrosidad: "[en el fetiche] se revela la dimensión del objeto como causa del deseo". ${ }^{78}$

Angustia y deseo entretejidos por un objeto diseñado a tal efecto. La situación parece bajo control. Pero, como intuía Freud, el fetichismo es incapaz de ejecutar la sutura. Al menos de forma definitiva. Esto es, el fetiche provoca -excita- y después parasita para terminar desencadenando en el sujeto una reacción autodestructiva. En ese último estadio, podría concluirse que el fetichismo adquiere los mecanismos propios de una enfermedad

\footnotetext{
75 ROBINS, Kevin, "Post-photography, the highest state of photography" en TRIGGS, Teal (ed.), Communication design, Londres: Batsford, 1995, p. 56.

${ }^{76}$ Las versiones de los textos que he manejado son: FREUD, Sigmund, "Fetichismo" en Obras completas. El porvenir de una ilusión, El malestar en la cultura, y otras obras (1927-1931) Volumen XXI, Buenos Aires: Amorrortu, 1992, pp. 141-152. GRANOFF, Wladimir; LACAN, Jacques, "El fetichismo: lo simbólico, lo imaginario y lo real" en AUGÉ, M.; DAVID-MÉNARD, M.; GRANOFF, W.; LANG, J.L.; MANNONI, O., EI objeto en psicoanálisis. El fetiche, el cuerpo, el niño, la ciencia, Buenos Aires y Barcelona: Gedisa, 1987, pp. 19-32. [artículo original de 1956]

${ }_{77}$ LACAN, Jacques, Seminario 4. La relación de objeto, Buenos Aires: Paidós, 2008.

${ }^{78}$ LACAN, Jacques, Seminario 10. La angustia, clase 8, 16 de enero de 1963, Buenos Aires: Escuela Freudiana de Buenos Aires, sin paginar.
} 
autoinmune. El fetichismo, en su vertiente tecnológica contemporánea, parece superar las dudas metodológicas del psicoanálisis a la hora de catalogarlo como perversión o neurosis.

El fetiche, dice Lacan, "es preciso que esté alli", el fetiche es -literalmente- cualquier cosa menos un fantasma, una alucinación o una quimera. Siguiendo -más bien interpretando- esta idea de Lacan, quiero concluir afirmando que el fetiche es uno de los representantes máximos de la materialidad tecnológica contemporánea. Expresión última y refinada que explica los modos de una industria y las reacciones de un sujeto. El fetiche tecnológico, además, desmonta dos de los sofismas habituales de los nuevos medios: la desmaterialización y el animismo. El fetiche es, ante todo, objeto material inanimado.

Que el fetiche sea inerte es fundamental para su buen funcionamiento. $Y$, desde un punto de vista epistemológico, también lo es para esta tesis. El tecnofetichismo encuentra sentido analítico al descubrir la materia y lo inanimado en una relación afectiva. El tecnofetichismo es una de las muselinas que componen el velo lacaniano. ¿Por qué ese velo le es al hombre más precioso que la realidad? ¿Por qué el dominio de esta relación ilusoria se convierte en un constituyente esencial de su relación con el objeto?, se pregunta Lacan. Hoy podríamos responderle que, de la misma forma que el tecnofetichismo es una capa del velo, el propio velo es, a su vez, un estrato de la naturaleza humana. Concretamente un estrato localizado en el registro sedimentario de las narraciones y del lenguaje como estructuras biológicas innatas.

En el fetichismo, el propio sujeto dice encontrar más satisfactorio su objeto, su objeto exclusivo, por cuanto es un objeto inanimado. Así al menos puede estar tranquilo, seguro de que no va a decepcionarle. ${ }^{79}$

De esta última cita se puede extraer otro concepto interesante: la exclusividad. Es imposible negarle este mérito a la industria tecnológica. En la época de la reproducción infinita y de la fabricación en serie, no es sencillo transmitir exclusividad. En cierto modo, la industria tecnológica consigue rehabilitar -aunque sea de manera fraudulenta- el aura tan añorado por Walter Benjamin. Lo hace por dos caminos. Primero, más que por habilidad y persuasión, por lógica narrativa. Segundo, por el conocimiento del destinatario. Especialmente por el conocimiento de sus debilidades, incluyendo la libidinosa. Muy en el fondo, tan en el fondo que es su propio fundamento, la industria sigue preocupándose por el ser humano. En

\footnotetext{
${ }^{79}$ LACAN, Jacques, Del análisis como bundling y sus consecuencias, Seminario 4, clase 5, 19 de diciembre de 1956, Buenos Aires, Paidós, 2008, p. 88. [La cursiva es mía]
} 
términos discutibles y precarios, la industria sigue siendo humanista. Tomando el enfoque optimista de Coccia, las mercancías y la publicidad son un campo propicio para seguir apreciando el bien en las cosas. Coccia plantea esta hipótesis como superación de las sucesivas relecturas marxistas basadas en el fetichismo de la mercancía ${ }^{80}$ Las mercancías siguen hablando, todo adquiere una voz porque el fetichismo es un fenómeno político, no económico. Cómo y con qué fines se utilice ese humanismo -más o menos funcionalista e interesado- que se encuentra sumergido en la política y en el símbolo -o en la política del símbolo-, es bien distinto. Porque, al igual que sucede con la idea de progreso, la idea de humanismo no responde a un único patrón bienintencionado.

La afuncionalidad tecnológica como hecho coaligado al tecnofetichismo no es, entonces, consustancial al fenómeno. La afuncionalidad aparece cuando las necesidades verdaderas del usuario no se atienden, se fabrican. El objeto activa -que no porta- una cadena de necesidades. El objetivo no es otro que disminuir el umbral de desconsuelo y confusión que el propio mercado tecnológico fomenta. El freudiano malestar de la cultura, es ahora un malestar tecnológico. Esta perversa afuncionalidad tecnológica, generadora de angustia en lugar de progreso cabal y humano, podría recordar al Lyotard de Lo inhumano. ${ }^{81}$

La industria tecnológica es la banca, nunca pierde: inocula la enfermedad y vende la cura. La sanación mediante el deseo excitado por el fetiche, ya hemos visto que es un lenitivo de doble cara. Otra forma que aspira a superar lo paliativo para convertirse en tratamiento sistémico, es lo que Albert Borgmann llamó paradigma del dispositivo. ${ }^{82}$ La búsqueda de la felicidad y la eficiencia mediante la disponibilidad y facilidad tecnológicas. El precio a pagar puede ser el alejamiento de la realidad. Este paradigma, aunque rebaja el grado de visibilidad -de exhibicionismo- de la tecnología mediante los usos y funciones ofrecidas, continúa determinando la relación entre hombre y tecnología. Con ello, Borgmann realiza el típico tránsito del instrumentalismo al esencialismo.

Cultivar una dimensión narrativa y metanarrativa en un mundo tecnologizado hasta el tuétano que pretende negarlas, es lo que solicitaba Lucien Sfez. Comparto su idea. El proyecto de Sfez

\footnotetext{
${ }^{80}$ COCCIA, Emanuele, El bien en las cosas. La publicidad como discurso moral, Santander: Shangrila Textos Aparte, 2015, pp. 45-47.

${ }^{81}$ LYOTARD, Jean-François, Lo inhumano. Charlas sobre el tiempo, Buenos Aires: Ediciones Manantial, 1998. [Primera edición de 1988]

82 BORGMANN, Albert, "La tecnología y la búsqueda de la felicidad" en Revista lberoamericana de Ciencia, Tecnología y Sociedad, vol. 2, no 5, junio 2005, pp. 81- 93.
} 
es reseñable porque el relato solicitado no vendría impuesto por el objeto o la técnica, como era tradición en tantos análisis sobre dominación tecnológica desde la Teoría crítica. La ficción y el relato aparecen como antídotos del tautismo. ${ }^{83}$ La ficción no es una ilusión, para Sfez la ficción es un componente más de la realidad. Esto es fundamental para el propósito de esta investigación. La ficción es rescatada del idealismo en tanto fenómeno biológico-diegético. La ficción deja de vagar por la costura del velo lacaniano y de la conspiración posmoderna. Deja de ser incognoscible y se reincorpora como herramienta para el ordenamiento y el análisis de la realidad.

Lo que Sfez bautizó como tautismo, era una forma enfermiza y terminal de la comunicación tiranizada por el componente tecnológico. El tecnofetichismo podría considerarse como la versión social, sofisticada y hasta amable de ese tautismo. Fuera de la importancia -vitalnarrativa señalada, la novedad del concepto de Sfez termina diluyéndose. Porque el tautismo, lejos de ser un concepto plenamente original, termina desempolvando la vieja autorreferencialidad tecnológica. El tautismo es un sucedáneo del exhibicionismo tecnológico que, al no dejar de remitirse a sí mismo, ofrece como resultado un valor comunicativo nulo.

Detalles menores -y como se ha podido ir comprobando, inevitables- al lado de su propuesta para la rehabilitación del relato. Cuando la narración no solo regresa, sino que lo hace de manera ejecutiva, es para que el estudio de la técnica se convierta en objeto de discurso. ${ }^{84}$ Con anterioridad, el orden de los factores sí había alterado el producto. Esto es, la técnica como objeto de discurso libera una narración que en la técnica como discurso del objeto estaba cautiva. El discurso del objeto, como tal, era la celebración del progreso como fetiche. El progreso era el efecto último e irrevocable de la tecnología. Sfez tiene claro que los objetos se agotan. $\mathrm{Y}$ antes de extinguirse, son incapaces de solventar las necesidades y los problemas. Entre su fulgurante aparición y su crepuscular e ignorada despedida, ven cómo declina su capacidad para fascinar. Para alargar el ciclo vital de los objetos, es necesario un relato que los justifique. Aunque esa justificación sea la de un ocio banal e intrascendente. Superar el tecnofetichismo supondría dejar de ser seducidos por la cosa en sí, para hacerlo por el discurso construido a partir de ella.

\footnotetext{
${ }^{83}$ Concepto acuñado por el autor y desarrollado en SFEZ, Lucien, Crítica de la comunicación, Buenos Aires: Amorrortu, 1995. El nombre es una contracción entre tautología y autismo. El neologismo resultante busca ilustrar el cariz casi totalitario de ese uso y enfoque tecnológico.

${ }^{84}$ SFEZ, Lucien, Técnica e ideología: un juego de poder, México: Siglo XXI, 2005, p. 14.
} 
Por desgracia, la polarización ideológica de estos razonamientos históricos y estéticos distorsiona el debate. La rigidez de este enfrentamiento -bien en la totalidad, bien en las partes- es lo que intentó desentrañar con acierto -y casi de manera testamentaria- Stephen Toulmin en Regreso a la razón. ${ }^{85}$ Propuestas para mejorar la siempre dolorosa, por poco ejercitada, flexibilidad metodológica. Humanizar y concretar ásperas teorías del conocimiento que parten de nociones demasiado abstractas. Alcanzar un punto de encuentro donde la primera complejidad sea la del ser humano y no la de un aparato o, peor aun, la de una entelequia global como la posmoderna.

El principal problema de los debates sobre el tecnofetichismo y la tecnofobia, es el de sustituir el análisis por la sentencia. No es una cuestión de neoluditas contra tecnófilos; los unos reaccionarios, los otros progresistas. Se trata de saber hasta qué punto nuestra capacidad de emancipación puede resistir a un modelo económico y social. Cuándo la ley de la oferta y la demanda queda trágicamente descompensada. Hasta dónde los modelos y los mercados son o no responsables de lo que finalmente realice el ciudadano. Un ciudadano que asiste -aunque él no lo sepa- a la redefinición biológica del tradicional concepto de emancipación mediante el cuestionamiento científico del libre albedrío.

La filia y la fobia tecnológica también son asuntos de juicio moral. Como, me temo, ya he deslizado alguno, sirvan estos párrafos como presentación de un tema que seguirá latente en próximos apartados.

\subsection{La muerte del fetiche y la industria de los contenidos}

La delicada relación entre tecnología y relato se aclara al pasar de lo particular-los objetos y el tecnofetichismo- a lo general -la industria y los contenidos. Las industrias no pueden venderse a la manera de un objeto. No son bellas ni pueden resumirse más allá de logotipos y marcas corporativas. Su estrategia requiere de la publicidad y de la mercadotecnia para resultar amables y atractivas. En un principio las industrias carecen de poder de seducción en sí mismas. De ahí que las compañías que las integran deleguen en los objetos, pero también en los contenidos.

Los contenidos podrían considerarse, a un mismo tiempo, elementos narrativos y metanarrativos. Los contenidos buscan en el relato forma y estructura para conseguir público

${ }^{85}$ TOULMIN, Stephen, Regreso a la razón, Barcelona: Península, 2003. 
o audiencia. Los contenidos explican sucesos e historias. La suma de dichos contenidos, a su vez, conforma una línea editorial y de producción que explica la propia industria. ¿Qué buscamos cuando accedemos a las tecnologías -viejas y nuevas- audiovisuales?

It's the content, stupid!, porque los consumidores no compran ni pagan por soportes y tecnologías sino por cadenas, contenidos, servicios. ${ }^{86}$

Así es, al menos en parte. Es este otro fenómeno reiterado que encuentra ejemplos relativamente recientes -años ochenta y principios de los noventa- en el fracaso de la introducción de las emisiones televisivas en alta definición. ${ }^{87}$ Hoy tampoco parece muy factible que Internet, la televisión, las telecomunicaciones o el cine puedan resultar viables si no cimientan sus productos a mayor profundidad que la ofrecida por el tecnofetichismo. El objeto fetiche, desmarcándome ahora del pesimismo avisado páginas atrás, es mero anzuelo. Importante, sí, pero un resorte más del mecanismo general. El objeto tecnológico no es un ente diabólico que permite la penetración del capitalismo en el cuerpo y en la casa. Tampoco es un mecanismo perverso que destruye las relaciones humanas. El objeto fetiche, además, ayuda a producir y transmitir relatos, mientras se inscribe en el gran metarrelato de una compañía y de una industria.

Un iPhone pude llegar a ser considerado más bello y funcional, pero no más fiel y cariñoso que una mascota o que una pareja. Lo contrario no es tecnofetichismo, es simplemente un patología mental que -como expuse en el apartado anterior- necesita de otros medios que los históricos para ser diagnosticada y tratada. Un iPhone no puede pasar por ente diabólico que nos someterá, nos aislará del mundo y nos dejará sordos. Patologías y trastornos obsesivocompulsivos al margen, el iPhone solo se relaciona con la destrucción de una vida cuando sirve de cauce o de registro de ciertos contenidos: comunicar una muerte, una ruptura sentimental, detonar un explosivo, filmar o fotografiar un accidente o un asesinato, etc.

Un iPhone no es un ser. No hasta donde sabemos. Los algoritmos computacionales todavía no tienen vínculo alguno con los aminoácidos o con cualquier otro elemento esencial para la formación de la vida. Cualquier idea que pueda desprenderse de su uso y presencia, requiere

\footnotetext{
${ }^{86}$ BUSTAMANTE, Enrique, La televisión económica, Barcelona: Gedisa, 1999. p. 167.

${ }^{87}$ El debate entre contenidos y tecnología televisiva digital está presente desde: NEGROPONTE, Nicholas, Being digital, Nueva York: Vintage Books, 1995. Especialmente el capítulo tercero: "Bitcasting", p. 37 y ss. En España lo recupera un poco más tarde Gubern en El eros electrónico, op. cit., pp. 72-75.
} 
de explicaciones encadenadas. Si es diabólico habrá que analizar sus procesos de fabricación, diseño, publicidad y ventas, así como al mercado donde tienen lugar. En el hipotético caso de que en todos estos escalones exista explotación laboral, malversación de fondos, fraude en materiales, espionaje y engaño, se podría plantear el uso de tal calificativo. En ese teórico escenario, saber y consentir haría extensible lo diabólico del objeto y de la compañía al cliente. Y si el aparato produjera sordera o cáncer, habría que realizar idéntico examen con las instituciones pertinentes que regulan dicho mercado.

Todo esto puede parecer obvio y hasta ridículo, pero si nos paramos a pensar descubriremos que la prosopopeya tecnológica -siquiera como metáfora- es un error categorial e histórico. No hace falta repetir que de nefastas consecuencias para el conocimiento científico.

En definitiva, el objeto tecnológico como fetiche funciona en primera instancia. Ayuda en la construcción del deseo y a una imagen de marca. Su agotamiento, en cambio, espera a la vuelta de la esquina. Uno de los objetivos de toda buena hoja de ruta comercial, es disminuir la incertidumbre: regular la demanda y restringir el azar. Cuando la nueva estrella pierde su lustre tecnológico, son las narraciones las que sostienen la industria. Las narraciones son el esqueleto de una industria que puede generar tautismo, pero que no puede valerse de él. En ese sentido, alimentar el tecnofetichismo sería equivalente a utilizar una fuente de energía no renovable. Hacer un uso estructural y productivo de las narraciones sería emplear energías renovables.

La pervivencia del relato no es solo una cuestión de consideración hacia el cliente, también es pura rentabilidad comercial. La narración siempre es biológica, pero no siempre es humanista. Que un relato sea perverso o que esté al servicio de una mentira, no lo invalida como tal. Pensar que el relato desaparece o se desvirtúa porque su función deja de servir a unas normas morales, es un postulado -además de falso- ingenuo y buenista.

No se puede negar la importancia y el influjo de las industrias de los contenidos como agentes sociales. Generan desfases culturales y educativos, pueden promover modelos y comportamientos deplorables, no estimulan el desarrollo intelectual y suelen ser más zafias que brillantes. De la misma manera que a las farmacéuticas no les interesan aquellos países que no pueden costear su infraestructura, las industrias de los contenidos no suelen preocuparse por el espectador crítico y exigente. A nadie se le ocurriría ir a buscar oro a una mina de sal. Las industrias de los contenidos, sin embargo, también han facilitado cambios 
que, sin ellas, habrían sido irrealizables. También han contribuido a concluir otros tantos ya empezados o estancados. Bien es cierto que no pocas veces parasitando supraestructuras como la cibernética y la investigación aeroespacial.

Seguir manteniendo la célebre tesis de McLuhan en el siglo XXI, implica una ignorancia manifiesta. Las tecnologías como medios ejercen de actores y actrices. Aportan glamour, distraen y emboban para que sintamos o no -según los intereses- la inyección de los contenidos. Son estos, los contenidos culturales e informativos los que ejecutan y hacen perdurar los cambios simbólicos. Conviene huir de la repetición ad náuseam de la coletilla de McLuhan. Sin embargo, es muy necesario reaprovechar uno de sus brillantes matices: la tecnología posee materia semántica. El medio no es el mensaje, es un contribuyente más. Este corolario extraído del reciclaje de los detritos generados por la explotación masiva de las ideas de McLuhan, viene a instalarse entre las proposiciones de esta investigación. Es ahí, en ese cenagal, donde hay que tantear las relaciones existentes entre medio, materia y forma.

Negar o minimizar la narratividad y los servicios del mercado, por alta que sea la sensualidad del objeto o de las imágenes, sería caminar hacia la pérdida del gran público-espectador. Aunque su ofuscación e idolatría invite a pensar lo contrario, muchos de los tecnófilos también terminan desengañados. Lo hacen por diferentes motivos. El principal quizá sea la necesidad de establecer pautas de identificación y de comprensión duraderas. Una demanda no sólo histórica, también y primero genética. La importancia de tener un hilo conductor, un relato al que aferrarse. Un relato a través del cual imaginar, perseguir y conseguir.

Que los medios, las formas y las imágenes utilizadas para expresar esa necesidad narrativa hayan cambiado hasta dejarla irreconocible, no es equivalente a decir que ha muerto.

\subsection{Genealogía de una dialéctica}

«El caos debe resplandecer en el poema

bajo el velo incondicional del orden» Novalis ${ }^{88}$

\footnotetext{
${ }^{88}$ Citado en: TRÍAS, Eugenio, Lo bello y lo siniestro, Barcelona: Ariel, 2001, p. 28.
} 
Ahora ha llegado el momento de conocer cuál es la raíz conceptual de la Teoría de atracciones. Comprobar que en su genealogía se rastrean ancestros literarios y, por ende, narratológicos. Que la atracción como concepto anarrativo es una falacia derivada de, primero, una contaminación terminológica y, segundo, de una tergiversación de las ideas planteadas en origen por Gunning y Gaudreault. Antes de comenzar, quisiera hacer un breve apunte sobre la ligereza con la que estoy utilizando de manera casi intercambiable los términos narración y relato. Espero ir aclarando su uso a lo largo de este y siguientes apartados.

Para comprender la atracción como concepto exclusivo del relato cinematográfico, se deben examinar, aunque sea sobre la marcha, una serie de conexiones que conducen a la teoría literaria y a la narratología. Lo que en principio puede parecer una relación tangencial, resulta determinante. Cuando la atracción terminó convertida en antagonista de la narración, culminaba un proceso de filiación guiado por dos herramientas demasiado habituales en la teoría cinematográfica: la apropiación y la deformación.

Que la Teoría de atracciones terminara induciendo la dialéctica conocida, era lógico. La tradición literaria había funcionado a lo largo de los siglos con la misma fórmula. La dialéctica como forma de constituir el análisis siempre ha sido confortable. La oposición entre los términos tiende a empequeñecer los matices $-\mathrm{y}$ con ellos el esfuerzo- a favor del gran enfrentamiento. La dialéctica es maximalista por naturaleza, lo cual no quiere decir que dichos matices puedan ser reexaminados y rescatados. Como no podía ser de otra manera, la dialéctica atracción-narración ya estaba formulada -en otros términos y grados- desde los primeros análisis del relato literario. De los términos y de los grados daré rápida cuenta. Haciéndolo, quedará en evidencia que el absolutismo de la Teoría de atracciones es una huida hacia adelante y una hipérbole, cuando no una mala praxis. En todos los precedentes literarios, nunca se llegó a cuestionar de manera tan radical la existencia de la narración. Es más, ni siquiera los padres de la Teoría de atracciones llegaron a tanto.

El estudio de la representación ya había enfrentado mimesis y diégesis. La primera quedaba unida lo que luego vendría a ser la mostración, mientras que la segunda terminaría desembocando en la narración. La mostración, como veremos, será el preludio de la atracción. Como sucedía con las imágenes, regresan Platón y Aristóteles. República y Poética como referencias ineludibles. Narrar y mostrar, la presencia del narrador -0 del poeta- y su desaparición. Hechos descritos, hechos apalabrados; hechos representados, hechos mostrados. 
Esta primera división conduce más a modos enunciativos que a la preeminencia de un concepto sobre otro. Obviamente, Platón privilegiaba la diégesis-relato por considerar la mimesis-imitación un modo superficial -no interno- ligado a los sentidos. Mientras que Aristóteles consideraba la mimesis como forma nodriza que albergaba un modo directo -la mimesis propiamente dicha, platónica- y otro narrativo -la diégesis platónica. A destacar para el todavía lejano encuentro con la atracción, la manera en la que Aristóteles liga la mímesis en su modo directo a los medios escénicos de la representación dramática. El aparente enfrentamiento entre maestro y discípulo era más una cuestión de gusto que de valor, aunque seguro que ellos consideraban que era al revés.

La diferencia entre las clasificaciones de Platón y de Aristóteles se reduce, pues, a una simple variante de términos: estas dos clasificaciones coinciden sin duda en lo esencial, es decir, la oposición de lo dramático y lo narrativo, siendo considerado el primero por ambos filósofos como más plenamente imitativo que el segundo. ${ }^{89}$

A partir de esta cita ya se pueden intuir dialécticas posteriores, más o menos rigurosas a la hora de retorcer términos y sentidos. Sin embargo -y esto es capital- también se deduce que las divisiones se realizan atendiendo a criterios narratológicos. Es decir, a modos y grados, nunca a la aniquilación o al desfallecimiento de un término a manos de otro. Con ello se demuestra que dialéctica, además de maximalista y aunque pretenda lo contrario, no es una buena herramienta taxonómica. Es confortable, dije, pero confortable no es sinónimo de correcto; al menos en epistemología.

La reactualización definitiva del conflicto se realiza en la teoría literaria a partir del siglo XIX. Con la novela y el narrador como referentes, surge la demanda de privilegiar el showing sobre el telling. De nuevo el mostrar -el showing- consiste en modificar o eliminar la instancia enunciadora y mediadora del narrador. El contar -el telling-comienza a verse como un modo esclerótico ligado a una tradición formal e ideológica burguesa. Se quiere evitar con ello la primera muerta de la novela. La novela, como el cine, nunca ha cesado de morir. Reseñable el texto de Henry James ${ }^{90}$ sobre el futuro de la novela. Bailando entre siglos, James insiste en la necesidad de trascender el contar mediante el mostrar. Algo que llevaría a la práctica en sus

\footnotetext{
${ }^{89}$ GENETTE, Gérard, "Fronteras del relato" en AA.VV., Análisis estructural del relato, Buenos Aires: Tiempo Contemporáneo, 1970, p. 195.

${ }^{90}$ JAMES, Henry, El futuro de la novela, Madrid: Escuela de Letras, 1994.
} 
propios relatos. Menoscabada o fulminada la figura del meganarrador, inicia una búsqueda magistral para manejar y otorgar el punto de vista entre los personajes. Para potenciar la mostración, al igual que Dostoievski, James también jugará con el dentro-fuera de los personajes. Esa capacidad para hurgar en la conciencia de los personajes, es otro detalle que anticipa -no se puede decir que prefigura- el triunfo inminente de lo visual. Ahí prende la ensoñación, el delirio y la angustia: imágenes mentales como materia narrativa. La focalización narrativa interna tenderá a fusionarse con la ocularización interna.$^{91}$ Siempre se dijo que la fotografía liberó a la pintura, pero poco se ha hablado de la sacudida que ejercieron la fotografía y el cine en la novela.

De Grecia partió una ruta que, dejando de lado los primeros años de la Belle Époque, hizo escala prolongada en el siglo XX. Durante el trayecto se reforzaron dos líneas de identificaciones. Por un lado, mimesis y representación afines a cierta primacía visual. Por otro, diégesis y relato afines a la supremacía narrativa. En la primera pareja, la importancia de los actores y de los personajes enjuagan la ausencia o la disolución del narrador. En buena medida se hacen con sus capacidades mientras suman otras nuevas con implicaciones no verbales: el gesto. Que la mimesis sea capaz de albergar ese factor, digamos no-lingüístico, es otra pieza a tener en cuenta de cara a la futura desvirtuación ejercida en primera instancia por la mostración y en segunda por la atracción.

François Jost ${ }^{92}$ ya advirtió que la división entre representación y relato era una herencia de la dialéctica mímesis-diégesis. División que pudo funcionar para el análisis de las letras y el teatro clásicos de acuerdo a los modos de su tiempo. Después, cuando al teatro cupo añadirle el cine:

Resulta difícil de mantener porque significa rechazar la actividad mediadora de un eventual mostrador, despreciar la del espectador y negarse a comprender las diferencias entre cine y teatro. ${ }^{93}$

En su análisis, Jost era consciente de la necesidad de diferenciar entre representación teatral y cinematográfica. Para ello consideraba decisivo estudiar los diferentes tipos y construcciones

\footnotetext{
${ }^{91}$ Dos términos emparentados -el primero acuñado por François Jost-, pero diferentes según JeanMarie Schaeffer.

92 JOST, François, "Le film comme œuvre" en Protée, vol. 19, n³, Le cinéma et les autres arts, Chicoutimi: Universidad de Quebec, 1991, pp. 9-16.

${ }_{93}$ PÉREZ BOWIE, José Antonio, “La adaptación cinematográfica a la luz de algunas aportaciones teóricas recientes" en Signa. Revista de la Asociación Española de Semiótica, ISSN 1133-3634, № 13, 2004, p. 291.
} 
de mirada en cada espectáculo. Jost concluía que "el teatro se distingue ontológicamente de toda adaptación cinematográfica por su manera dirigir la mirada del espectador o, mejor dicho, de indicarle qué es necesario mirar". ${ }^{94}$ En este punto surge un intercambio productivo entre narratólogos franceses: François Jost y Jean-Marie Schaeffer. ${ }^{95}$ En su análisis de la ficción cinematográfica, Schaeffer evitaba considerarla como un relato en sentido técnico y estricto.

Para Schaeffer, que la representación cinematográfica sea susceptible de análisis a través de nociones narratológicas no la convierte per se en relato. Eso en el apartado teórico, porque en el práctico la adopción de ciertas técnicas literarias (asincronías, analepsis, prolepsis) para la organización y presentación temporal de los hechos, tampoco convierte la representación fílmica en narración. Schaeffer, como vemos, sigue segregando conceptos hasta concluir en los modos de presentación y percepción. Allí donde Jost matizaba miradas escénicas, Schaeffer lo extiende a la percepción global del relato de ficción y del relato cinematográfico. Al primero se accede mediante la narración, al segundo mediante mimemas perceptivos. Ambos son y requieren del fingimiento.

Schaeffer se muestra todavía más tajante: presentar verbalmente acciones, es narrar; la representación cuasi perceptiva de acontecimientos no es un acto narrativo, es mostrar ante ojos y oídos. Esta última separación, formulada más de una década después de la Teoría de atracciones, es otro caso interesante para comprender el porqué de su triunfo: existió, existe y existirá una tendencia a mantener la dialéctica representación-relato. Esta dualidad nos recuerda, además, el debate sobre la naturaleza de la imaginería mental como producto surgido sin la mediación de un input, o como acto cuasi-sensorial. En cualquier caso, Schaeffer queda en clara oposición, primero con Kate Hamburger ${ }^{96} y$, como expondré en el siguiente apartado, con la biología y conmigo. La narración como hecho consustancial del relato cinematográfico, es calificada por Schaeffer -con cierto tono peyorativo- como una teoría de la autonarración. ${ }^{97}$

Pero con Jost y Schaeffer he avanzado demasiado en el tiempo. La genealogía debe regresar a los ancestros, no a los herederos. Y hacerlo por una doble vía. Primera, por la vía teórico-

\footnotetext{
${ }^{94}$ Ibíd., p. 292.

95 SCHAEFFER, Jean-Marie, ¿Por qué la ficción?, Madrid: Lengua de Trapo, 2002. [original de 1999]

96 "Al ver una película vemos algo narrado, vemos una novela", HAMBURGER, Kate, La lógica de la literatura, Madrid: Visor, 1995, p. 150.

${ }^{97}$ SCHAEFFER, Jean-Marie, op. cit., p. 291.
} 
barthesiana de mitad de siglo XX, segunda, por la convulsa transición -la narratología no fue ajena al contexto- que tiene lugar entre los años sesenta y setenta.

Barthes se preguntó sobre las diferentes posibilidades a la hora de alterar escritura y lenguaje. Barthes examinó la ruptura pendiente de la gran estructura narrativa reglada en los periodos anteriores. El camino que atisbó Barthes para poner en crisis el modelo precedente, requería de una gran energía. Para alterar definitivamente la estructura, antes había que tener en cuenta una fuerza trascendente: la forma. Aquel lenguaje marcado por una tradición cercana a lo artesanal y por su aterciopelada alianza con el espíritu burgués del relato, podía quedar afectado por la fuerza de la forma en un doble nivel: por ruptura y por intensificación. Dos opciones que veremos reflejadas años más tarde en la teoría cinematográfica en tanto extensiones metodológicas e ideológicas del conflicto atracción vs. narración.

La intensificación o el refuerzo tenían como objetivo alcanzar nuevas cotas de maestría, pero sin abandonar el vasto sendero existente. La ruptura o la liberación del lenguaje, en cambio, acarreaba otro doble ordenamiento:

a) Conocer las normas y la orografía del sendero para cuestionarlo y crear nuevos desvíos. Acción llevada a término mediante una radicalización formal que conduce al silencio. Un silencio que, por su parte, no puede ser empujado más allá del horizonte de sucesos: el silencio performativo.

b) El desvanecimiento de la forma en una escritura amodal y neutra: el grado cero.

El primer supuesto cobija una serie de variantes del lenguaje que desembocan en la utopía de ser -o, más bien, de querer ser- revolucionarias por siempre. Pero su grado de torsión posee umbral, tanto por arriba -grito- como por abajo -silencio. Alcanzados estos, las soluciones revolucionarias terminan por asumir la impureza, los baremos y los condicionantes. Es decir, la ansiada agrafía deviene entelequia. La ruptura del relato histórico prevista, queda reducida a mera transgresión formal cuyos resultados más apreciables son la abstracción y el impacto. Una suerte de atracciones literarias teñidas por un neoprimitivismo naif.

Otros escritores pensaron que podían exorcizar esta escritura sagrada dislocándola: atacaron entonces el lenguaje literario, hicieron estallar a cada 
instante el renaciente envoltorio de los clisés, de los hábitos, del pasado formal del escritor; en el caos de las formas, en el desierto de las palabras, pensaron alcanzar un objeto absolutamente privado de Historia, reencontrar la frescura de un estado nuevo del lenguaje. ${ }^{98}$

En el análisis de Barthes se advierte la llegada inminente de un tiempo conflictivo. El tiempo de una modernidad convulsa y vandálica -de fuego. Momento en el que Genette examinó las funciones diegéticas de la descripción dentro del relato. Genette otorgaba dos funciones básicas a los pasajes descriptivos: una decorativa o retórica, otra explicativa y simbólica. Genette divide el relato en narración y descripción pero avisa de las limitaciones de tal dialéctica. No existen diferencias semiológicas entre ellas, solo -como ya hemos visto- de contenido, de modo y de grado. Relatar y describir son dos operaciones similares que requieren de los mismos recursos lingüísticos:

La descripción no se distingue con suficiente nitidez de la narración (...) como para que sea necesario romper la unidad narrativo-descriptiva (con dominante narrativa) que Platón y Aristóteles Ilamaron relato. ${ }^{99}$

Parece que vuelvo a alejarme de lo importante pero no es así. Justo antes de esa cita, Genette acababa de introducir un matiz clave para el devenir de las atracciones. Al menos tal y como yo consideraré la atracción en tanto concepto teórico aplicado a un análisis textual. Sin adelantar acontecimientos, puedo avanzar que la atracción -una vez asumida como concepto- será explicada y utilizada siguiendo ese perfil dibujado por Genette para la descripción. Esto es, consideraré la atracción como ente narrativo que, dentro de una película convencional, jugará el papel de aquello que Genette denomina descripción y que, en no pocos casos, será una especie de trasunto visual de la digresión literaria. Tomo desde ahora esta otra cita de Genette como referencia e invito a ir cambiando descripción por atracción:

La descripción (...) se detiene en objetos y seres considerados en su simultaneidad y (...) enfoca los procesos como espectáculos, parece suspender el curso del tiempo y contribuye a desplegar el relato en el espacio. ${ }^{100}$

\footnotetext{
${ }^{98}$ BARTHES, Roland, El grado cero de la escritura, seguido de nuevos ensayos críticos, México D.F.: Siglo XXI, 2006, p. 76. [original de 1953]

${ }^{99}$ GENETTE, Gérard, “Fronteras del relato" en op. cit., p. 202.

${ }^{100}$ Ibíd., p. 201.
} 
"Desplegar el relato en el espacio", guarden la frase porque en esta tesis doctoral su aplicación narratológica y fílmica llegará a ser textual.

Concluyendo, la alteración narrativa a través de la forma no puede alcanzar en y por sí misma un estadio sistemático, duradero y puro. La dislocación barthesiana, al igual que el tecnofetichismo y, como expondré dentro de poco, el impacto audiovisual, son eventos pasajeros que pueden transformar -no sustancialmente-, pero no destruir la estructura narrativa del medio donde aparecen. El esfuerzo puesto en la liberación del relato a través de la forma y de la negación del contexto (histórico, social, humano) es propio de un vocablo, como diría el propio Barthes, suicida.

\subsection{Mostración}

Cuando al inicio del anterior apartado avisaba de la posible falta de diligencia a la hora de utilizar los términos narración y relato, estaba pensando en la -sucinta pero necesariagenealogía expuesta. Una vez conocida conviene ser escrupuloso. Narración y relato no son lo mismo. La narración, igual que la descripción y la mostración, son componentes estructurales del relato. El relato es un conjunto -según Gennete una unidad- que, a su vez, queda englobado en otros dos. A saber, en el campo teórico-práctico: el de las representaciones (cine, teatro, poema épico); en el campo histórico y filosófico: el de los metarrelatos.

A su vez, la atracción como destino y como espacio, cuenta con un concepto que funciona como delta y como atrio: la mostración. El concepto de mostración funciona como atrio de la Teoría de atracciones en un sentido temporal y epistemológico. Existía, como he señalado, desde hacía siglos, pero es formulado de manera exhaustiva a partir de $1984 .{ }^{101} \mathrm{Gran}$ parte del fundamento teórico que adquiere la atracción, es obtenido del desarrollo narratológico acumulado por la mostración. El poder de la atracción terminará por devorarla, cuando en un principio eran instancias del relato definidas y separadas. Ambas compartían, eso sí, su condición litigante -con matices- contra la narración.

\footnotetext{
${ }^{101}$ GAUDREAULT, André, "Film, récit, narration; le cinéma des frères Lumière" en Iris, 1984, pp. 61-70. Versión inglesa manejada: "Film, narrative, narration: The cinema of the Lumière Brothers" en ELSAESER, Thomas (ed.), Early Cinema. Space, frame, narrative, op. cit., pp. 68-75. También: GAUDREAULT, André, "Narration et monstration au cinéma" en Hors Cadre, no2, abril de 1984, pp. 8798.
} 
$\mathrm{Y}$, decía, la mostración como delta funciona en un sentido metafórico. Es decir, como lugar donde van a parar todos los sedimentos del curso alto y medio del río narratológico. El estudio del relato cinematográfico es, pues, un fenómeno aluvial. En este nuevo espacio sedimentario, el concepto de mostración recoge y sintetiza el pasado literario y escénico para aplicarlo al cinematógrafo. El nuevo producto o la nueva especie resultante no podrá renegar de su pasado, forma parte de él. He ahí uno de los errores capitales de la teoría del cine que se ve agudizado con la reactivación de las atracciones: el indigenismo. En su deriva, que no en su fundación, la Teoría de atracciones querrá hacer tabla rasa con su genética y con su sedimento escénico y literario.

Lo escrito, la escena, la película. Con la mostración, Gaudreault busca delimitar las fronteras del relato textual, escénico y cinematográfico. El uso que Gaudreault hace de fronteras es reconocido por el propio autor como evocación genettiana. Las líneas divisorias, desde el mismo momento que dibujan estadios terminales de procesos históricos, no son límites infranqueables. Las fronteras del relato dan cuenta, también, de los flujos y de los intercambios. Gaudreault pretende establecer una teoría narratológica del cine, pero sin suprimir este intercambio constante. Es decir, sin indigenismo. Gaudreault, de hecho, cuestiona que el narrador cinematográfico naciera al tiempo que los filmes Lumière.

Lo cinematográfico parece ser un objeto narratológico más complejo que el textual y el escénico por el hecho de que resulta de la combinación de las posibilidades narrativas de ambos o, más precisamente, de la fusión de los dos modos fundamentales de la comunicación narrativa: la narración y lo que yo llamo la mostración. ${ }^{102}$

Gaudreault culmina ahora la insinuación de Genette: la separación clásica entre mimesis y diégesis ha sido forzada más de la cuenta. Dependiendo del interesado, la mimesis era un epifenómeno de la diégesis y viceversa. Aceptando que la separación entre términos no es tan profunda como se pensaba y en plena declaración de intenciones, Gaudreault se posiciona del lado platónico. Ya sabemos lo que eso significa: preponderancia de lo visual. El teórico francés no lo esconde: "la primacía que le otorga a la imagen hace posible emprender el estudio sobre un material menos complejo que la película hablada". ${ }^{103}$

102 GAUDREAULT, André, Cine y literatura. Narración y mostración en el relato cinematográfico, México D.F.: Unarte, 2011, p. 39. [Las cursivas pertenecen al autor] [Original: Du littéraire au filmique, 1988]

${ }^{103}$ Ibid., p. 41. 
Gaudreault intenta rebajar la complejidad narratológica mencionada, escudriñando el nivel estrictamente visual. De ahí que su corpus analítico se asiente en el cine mudo. Con esta serie de datos podemos ir entendiendo el porqué del regreso del concepto de atracción a un cine primitivo entendido como periodo histórico del cine mudo más o menos definido y delimitado: Modelo de Representación Primitivo (1895-1915). Esto es, junto a una explicación basada en la pura fascinación primigenia suscitada por un aparato exhibicionista, el regreso también se produce por una rigurosa cuestión metodológica de cariz narratológico. Gaudreault vuelve con espíritu genettiano, para descifrar la genética del relato cinematográfico. La primera justificación del retorno al pasado queda, pues, matizada no por una interpretación mía, sino por un simple ejercicio de trazabilidad histórica. La idea exhibicionista triunfó y triunfa porque es sugerente y grácil, pero también es débil y, en última instancia, incompleta.

La opción de Gaudreault es la de una narratología de la expresión, en lugar de una narratología del contenido. Lógico cuando en el cine se incrementan y, en buena medida, se difuminan las instancias mediadoras entre autor, narrador y espectador. La mostración supone una sucesión de imágenes, en vez de una sucesión de planos. Ahí entra en juego un aspecto básico para Gaudreault: el montaje. También entra en juego otro aspecto básico para esta investigación: el intersticio del fotograma. Esto último lo explicaré más adelante. Ahora concluyo con la difícil convivencia que se establece dentro del relato cinematográfico entre atracción, mostración y narración. Cómo la primera termina fagocitando a la segunda para derrotar a la tercera.

Para apreciar la desvirtuación progresiva de los conceptos, es necesario recordar que tanto Gunning como Gaudreault consideraron atracción y narración como elementos diferentes y hasta contradictorios pero, al tiempo, integrantes de una misma infraestructura del relato. Gunning prefería considerar la atracción no como simple forma antinarrativa, sino como una variación en la experiencia del espectador. La atracción, la mostración -término que implica representación, pero que no debe ser confundido con ella- y la narración configuraban un sistema de capas en la que la superposición de unas sobre otras siempre estaba en movimiento y en juego de fuerzas. Cabe matizar que dicha relación de fuerzas no equivale a un juego de suma cero en el que lo perdido por una es ganado directamente por otra.

Como avisé, una vez que el concepto de atracción es lanzado por Gunning y Gaudreault, su uso se radicaliza. Mientras que la mostración tenía una innegable raíz narratológica, a la atracción 
se le ofrece una raíz espectacular, diríase que abstracta, donde los precedentes y las influencias apenas son reconocibles. Mientras que la mostración implicaba un afán fílmico por enseñar -lo que implica modos y formas- al espectador, la atracción se articula sobre el exhibicionismo del aparato. La idea de una estética de la atracción ${ }^{104}$ se convertirá en el triunfo del hardware del dispositivo. Toda la ferretería cinematográfica, cuyo último elemento era el rectángulo blanco, superará en interés al contenido proyectado. Lo que fue un concepto quiérase o no- narrativo, termina siendo un concepto antinarrativo ligado de manera irreversible a la discontinuidad, al exhibicionismo, al asombro y al impacto.

La atracción, en tanto exaltación de unas ideas previas discutibles pero mesuradas, caminó hacia un fundamentalismo cuyo objetivo era ejecutar la enésima muerte del relato burgués.

104 Original de Gunning. Propuesta realizada durante las sesiones de trabajo del congreso de Cerisy en 1985. 


\section{NARRATIVA ESPECTACULAR}

En este punto de la investigación hay que tomar una decisión trascendental. Proseguir con el inventario del negacionismo narrativo, o adoptar una posición constructiva. Considero que hay que aportar más análisis. En concreto uno que no se limite a denunciar ideas ajenas, sino a razonar y validar las propias. Al fin y al cabo, eso es de lo que trata una tesis doctoral. Considero suficientemente explicado el contexto y las líneas maestras de la anhelada pero nunca consumada defunción narrativa. Yo tampoco deseo caer en una macrodialéctica perpetua más o menos encubierta y, sobre todo, redundante. De ahí que ahora quiera exponer por qué considero que las narraciones nunca sucumbieron y siguen vigentes. Para ello solicitaré ayuda allende los confines cinematográficos.

No es que la atracción fuera en origen compañera de relato de la narración, que también, sino que la atracción poseía un valor narrativo intrínseco. Además, si por algo se ha caracterizado la narración a lo largo de su existencia es por haber sido ella misma una atracción. Nada en la historia del hombre ha generado mayor atracción que la narración. Desde un doble nivel de condición biológica y representación cultural, la narración ha sido una necesidad fisiológica más desde el Pleistoceno. La narración fue uno de los factores que en mayor grado contribuyó a modelar la evolución de nuestro cerebro. Aun hoy, sigue ejerciendo su fuerza sobre los todavía indefinidos- mecanismos de plasticidad neuronal.

Las narraciones son un vehículo propicio para el estudio de los intercambios y de las influencias entre nature y nurture. La narración -con raíz biológica pero permeable y activa como pocas en los ambientes- ha sufrido procesos de regresión, de deconstrucción, de legitimación y defenestración, de inflación y de espectacularización. Lo ha hecho sin dejar de ser ella misma para convertirse en otra cosa. En este apartado daré cuenta de algunas de esas modulaciones -más que modificaciones-, tomando el cine como campo de acción -nunca mejor dicho. He elegido aquellas modulaciones cuya aparición y reactivación fueron y son izadas como emblemas de un cine de atracciones. 


\subsection{Impacto narrativo}

«Lee muy deprisa, se quejó,

y cuando le pregunté dónde había aprendido a leer tan rápido, contestó,

"En las pantallas de los cines"» 105

Igual que hicieron algunos seguidores de la Teoría de atracciones estableciendo gruesos parentescos entre representaciones actuales y pasadas, Deac Rossell, en su agudo estudio ${ }^{106}$ sobre el pionero -pero ya por entonces brillante- desarrollo tecnológico de la Biograph, anunciaba que el énfasis puesto en ese tipo de modelos que privilegiaban la ferretería cinematográfica sobre el hecho narrativo, podía ofrecer resultados fulgurantes en un principio, pero escaso recorrido posterior. La cruel y bien cierta metáfora de Hollywood como máquina de picar carne humana, convertida en máquina de fabricar y compactar chatarra. Tecnología y grandilocuencia, fuego fatuo esclavo de la (auto)obsolescencia:

Así como ahora leemos cada día sobre nuevas y más sofisticadas tecnologías de la imagen (...) el auge y caída de la tecnología de la Biograph y de la serie de experimentos que le siguieron, debería convertirse para todos en una buena moraleja. ${ }^{107}$

He elegido este recóndito estudio de Rossell con toda la intención y por cuatro motivos. Porque su análisis sobre cómo afecta la innovación y la materialidad del formato, tiene valor en sí mismo. Porque quería jugar con las ventajas que ofrece la descontextualización. $\mathrm{Y}$, por último, porque quería remitir a un periodo de la historia del cine que suministraba los nutrientes a la raíz de la Teoría de atracciones. Nacida casi al tiempo que el mismo cine, la Biograph comprobó empíricamente cómo la seducción tecnológica, en un medio industrial, artístico y social, decaía antes que la narración. Tras esto, la Biograph se convirtió en una de las diabólicas compañías que más aportó a la hora de institucionalizar la narración como modelo estético y comercial.

\footnotetext{
${ }^{105}$ FIRBANK, Roland, The flower beneath the foot, Londres: Grant Richards, 1923, p. 12. [La traducción es mía]

${ }^{106}$ ROSSELL, Deac, “The Biograph large format technology” en TURCONI, Davide (ed.), Griffithiana, no 66-70, 1999-2000, pp. 79-117.

${ }^{107}$ Ibíd., p. 108. [La traducción es mía]
} 
Decía que buscaba el ventajismo de la descontextualización, porque extrapolar situaciones alejadas en el tiempo cuando entre ellas media el desarrollo secular de una industria y de un arte, solo puede aceptarse como anécdota o como figura retórica, no como argumento. A nadie se le ocurriría manejar como equivalentes los recursos de finales del XIX y principios del $\mathrm{XX}$, con los de la transición del XX al XXI. El aire teleológico de estos patrones tienen como destino lo que Rossell, con prudencia exquisita, cita: la moraleja. El motivo final para la elección de este estudio de Rossell es, pues, un juego retórico que quiere usar la moraleja de Rossell para trasladarla a la metodología de esta investigación: las fábulas no pueden tomarse como modelos analíticos. La moraleja apunta a juicios éticos y morales. Esta investigación no quiere explicar los fenómenos en tanto buenos o malos.

El impacto, por pura definición y haciendo caso a la moraleja de Rossell, implica una magnitud determinada -alta- y una duración limitada -corta- en el tiempo. El estudio de la percepción humana no ha parado de desnudar nuestras limitaciones. De la psicofísica a la neurociencia cognitiva. Igual que -alcanzado determinado punto de saturación- un disolvente es incapaz de seguir diluyendo un soluto, nuestro cerebro deja de procesar cualquier tipo de estímulo que supere cierta magnitud. ${ }^{108}$ Ya sea doloroso o placentero, el sistema nervioso responde al impacto infinito con la indiferencia propia de la impotencia. Hay que asumir desde ya esta penuria fisiológica. Penuria que, sin embargo, facilitó sobremanera nuestra supervivencia como especie. Sesgamos, simplificamos y desechamos información por pura ecología y funcionalidad cognitiva. Nuestro cerebro aborrece las redundancias. Entre otros motivos porque, mientras nuestros sentidos son capaces de entregarnos cerca de 11 millones de bits por segundo -la mayoría, unos 10 millones, provienen de nuestro sofisticado sistema visual-, solo somos capaces de procesar de manera consciente -dependiendo de la operación- entre 12 y 50 bits por segundo. Esto no es óbice para que parte de la información ignorada siga afectando de manera inconsciente y subliminal. ${ }^{109}$

Frente al -precipitado- optimismo tecnófilo que siempre ha ido más allá de lo cabal a la hora de apreciar nuestra evolución cognitiva, desconexiones como estas nos enseñan que los arcaicos mecanismos de defensa -auténticos fusibles de la concentración- desarrollados por el sapiens hace decenas de miles de años, siguen latentes. Esta frustración derivada de nuestra

\footnotetext{
${ }^{108}$ BAARS, Bernard J.; GAGE, Nicole, M., Cognition, brain and consciousness. Introduction to cognitive neuroscience, Oxford: Elsevier-Academic Press, 2010.

${ }^{109}$ BARGH, John; HASSIN, Ran; ULEMAN, James (eds.), The new unconscious, Nueva York: Oxford University Press, 2005, p. 82. 45 bits por segundo es la información procesada en una lectura silenciosa, 30 si es en voz alta. Una multiplicación de dos números es una docena de bits por segundo.
} 
naturaleza humana -de nuestro funcionamiento exclusivo en rangos de estímulo muy limitados- es lo que siempre se han negado a admitir, por ejemplo, los transhumanistas y bastantes teóricos de los nuevos medios. Poco importa si se trata del cine mudo -véase la cita que encabeza este apartado- o de la realidad virtual, el sueño es trascender la inmediatez de los sentidos mediante extensiones tecnológicas y conceptos recurrentes como la velocidad y la descorporeización.

El impacto es un elemento extático y pasajero dentro de la estructura del relato en su concepción clásica, esto es, aristotélica. El impacto como momento álgido que puntúa las firmes barras de redundancia que, a pesar de su aparente irrelevancia, son el sostén de la narración. La redundancia como valle y meandro rutinarios por los que discurre el deslomado y pacífico río decimonónico. El impacto aporta irregularidad, variedad, funciona como evento, quiebra o modifica expectativas. Entre la redundancia y el impacto media lo que en psicología se conoce como umbral diferencial. Esto es, la variación introducida en la magnitud de un estímulo para que seamos conscientes de ella.

Es aquí donde surge uno de las confusiones capitales de la actualidad, en la modulación $n^{110}$ de los umbrales de impacto. La confusión tiene lugar en todos los niveles del relato. ¿Cuáles? Orden, duración y frecuencia. Estos tres niveles, estrictamente temporales, fueron los elegidos por Jost y Gaudreault para explicar la temporalidad de la imagen dentro del relato cinematográfico. ${ }^{111}$ Un relato que, a su vez, cuenta con otros dos niveles estructurales: el de los hechos relatados y el correspondiente al mismo acto de relatar. De esta forma, la temporalidad del relato no tiene por qué coincidir con la de la historia contada. A estos tres niveles cabe añadirle un cuarto de cosecha propia. Más que dramático, emocional y, por ende, fisiológico: la intensidad.

Para apreciar el valor narrativo del impacto audiovisual, es necesario atender a la doble estructura citada. Digo necesario no solo para resultar claro en la organización y en la exposición del contenido, también por puro rigor epistemológico. Así, hay que dividir el análisis de la narratividad del impacto en una doble vertiente: la narratología de la expresión y la

\footnotetext{
${ }^{110}$ Sigo resistiéndome a utilizar modificación en lugar de modulación. Modificación conlleva la posibilidad de una transformación más o menos futura y definitiva de lo uno en lo otro. Modulación, aun sometiéndola a cambios, resguarda la naturaleza de la cosa. En cualquier caso, considero que es esta no debe ser una terminología rigorista. La elección es más sentimental que científica.

111 GAUDREAULT, André; JOST, François, El relato cinematográfico. Cine y narratología, Barcelona: Paidós, 2001, p. 112.
} 
narratología del contenido. La primera de orden estructural, la segunda de orden ostensivo e iconográfico. Ahora, de momento, solo me interesa la primera, la narratología de la expresión.

En principio, el orden de aparición del impacto cinematográfico ha dejado de ser, digamos, aritmético, geométrico o incluso exponencial. El orden del impacto no responde necesariamente a las estructuras de planteamiento, nudo y desenlace. El impacto comienza a ser distribuido de acuerdo a criterios de complejidad. No podría decir que en todas y cada una de esas distribuciones se aprecian patrones algorítmicos o fractales, pero sí que no existe miedo o veto al caos. Entendido el caos como ausencia premeditada de orden. Incluso como un orden precario. El autor -guionista y/o cineasta- elige racionalmente el momento de aparición del impacto, pero no existe una constante de la matemática simple que explique su distribución a lo largo del relato.

El orden del impacto en tanto sucesión sigue, pues, sujeto al instinto creativo y a unas normas de estilo más o menos implícitas. Lo que parece seguro es que, bajo estas normas y en contra de la tendencia crítica, aun sigue latiendo el corazón de una dosificación -que no de una estructura- aristotélica. Nótese cómo he jugado con lo aristotélico cuando podría haberlo hecho con el Modelo de Representación Institucional. ¿Por qué? Por dos motivos. Primero, porque el MRI, en su enorme variedad, no quedó restringido al cine clásico de Hollywood. Segundo, porque el MRI ya incorporaba la distribución y el orden del impacto de acuerdo a criterios de complejidad que transgredían lo aristotélico.

Ahora, la duración. El impacto, como el deseo que sostenía el fetichismo, opera en los tiempos cortos. Hoy, en cambio, el factor tiende a encajar con una idea de dilatación temporal que podría calificarse de clásico-soviética. Eisenstein estaba en el germen de la Teoría de atracciones. De manera tangencial y vía Aumont, su uso teórico y práctico del término atracciones fue tenido en cuenta por Gunning. Dicho esto, la dilatación como efecto principal que afecta a la duración, no siempre es eisensteiniana. No se puede olvidar que, en paralelo, Dovzhenko empleaba técnicas de dilatación muy diferentes -a veces hasta opuestas- a las de Einsenstein. Allí donde este dilataba el tiempo mediante multiplicación del corte y ensamblaje, el otro optaba por la continuidad espacial jugando, por ejemplo, con la velocidad de los fotogramas. Una técnica del ralentí que nada tenía que ver con la mofa surrealista y sí -algo 
más- con el brillante y constante desarrollo del concepto que llevaría a cabo Epstein ${ }^{112}$ durante toda su obra teórica y fílmica.

Cuando el impacto se dilata sin mesura, corre el riesgo de superar el umbral de saturación y resultar contraproducente desde un punto de vista narrativo. También hay que recordar que en este estado de dilatación temporal, hoy día podemos encontrar expresiones contrapuestas que redefinen la misma idea de impacto. Quiero decir, las reminiscencias de la atracción eisensteiniana conviven con los ecos y las modificaciones del cine contemplativo.

Un último apunte sobre la duración del impacto que no es nada baladí. Hablo de la dilatación temporal como expresión dominante, pero no como única posible. La contracción también está muy presente. Lo hace no tanto desde una construcción secuencial, como desde el plano como unidad espaciotemporal. Este último caso, el del plano como unidad de impacto fue otro de los ganchos para justificar la pertenencia de las películas primitivas filmadas en un solo plano (pongamos hasta 1903) a la Teoría de atracciones.

Tercer punto del primer estadio estructural: la frecuencia. Lógicamente está ligada, por no decir condicionada, al orden. Puede decirse que existe una reducción en los intervalos de aparición del impacto. La reducción puede llegar al punto de entrar en concatenación. Sin embargo, como apuntaba a propósito del orden, sigue sin apreciarse una ruptura total de la maquinaria narrativa a favor del impacto. Hasta el cineasta más pirotécnico y salvaje es consciente de la necesidad de airear la escena. La concatenación indubitada del impacto pertenece, en exclusiva, a cierto cine estructural y a técnicas de vanguardia como el singleframing o el flicker. Ni siquiera de la animación abstracta se puede decir que esté elaborada sobre un modo de impacto encadenado.

Último escalón: la intensidad. No es necesaria una relación directa entre intensidad y temporalidad. En el impacto, la intensidad no es un correlato de la temporalidad. La primera puede seguir aumentando o decreciendo ajena al tiempo. Es decir, la intensidad necesariamente no desciende según se dilata el tiempo. La intensidad del impacto -poseedora de una gradación propia- puede funcionar -narrativa y estéticamente- como anacoluto dentro

\footnotetext{
${ }^{112}$ Hasta el último momento -léase su Dramaturgie dans le temps de 1946- tanto el ralentí como el resto de manipulaciones temporales (time lapse, rebobinado) preocuparon sobremanera a Epstein. Para este cineasta, domador de tempestades, el ralentí era una cuestión de "perspectiva temporal". Remito a mi ensayo sobre su cine: AMABA, Roberto, "Jean Epstein" en BELMONTE NAVARRO, Antonio (coord.), Ojos sin rostro. Semblanza de trece directores europeos, Madrid: Ártica, 2015, pp. 111-139.
} 
del relato cinematográfico. La intensidad del impacto audiovisual en el cine contemporáneo, viene a culminar los tres niveles anteriores mientras actualiza uno de los legendarios aforismos del Hollywood dorado: "la película debe comenzar con un terremoto para ir subiendo en intensidad hasta llegar al clímax". ${ }^{113}$

No he definido lo que yo considero impacto audiovisual. Creo que quien haya leído hasta aquí no lo habrá necesitado. Y habrá sido porque el impacto ejerce de arquetipo cognitivo, no de cliché cultural. Esto es, el impacto en tanto arquetipo es aquello que sacude nuestros umbrales perceptivos, no la simple representación excesiva o el desborde audiovisual provocado por movimientos de cámara, por los efectos especiales, por un montaje sincopado o por estruendosos sistemas de sonido. El impacto actúa sobre nuestros mecanismos innatos de la percepción, mientras estos evolucionan de acuerdo al contexto. De esta forma, el impacto como integrante del relato puede ejercer, además de como anacoluto, como oxímoron.

Estoy utilizando figuras retóricas y psicológicas como arquetipo, anacoluto y oxímoron. No son gratuitas. Son anuncio riguroso de una idea que considero primordial en esta parte de la investigación: el impacto audiovisual se engendra en la mismísima matriz literaria. Por consiguiente, el impacto audiovisual no es indigenista, no nace por generación espontánea ni es el último vocero del exhibicionismo del aparato. Es difícil sostener por más tiempo la dialéctica atracción versus narración, así como la hipotética sumisión de esta última al espectáculo. A saber, el relato cinematográfico sufre desde diferentes frentes literarios, no solo desde el audiovisual. Los más destacables:

a) La dislocación narrativa. La lógica como principio regulador deja de regir. Juegos y multiplicaciones de los puntos de vista. Mise en abyme. Sistemas acronológicos. Diferentes niveles de realidad o -directamente- diferentes realidades. Giros bruscos de guión. Escamoteo de información. Triunfo de subgéneros como el de las películas puzle.

b) La sublimación narrativa. Inflamación literaria de episodios que van más allá de los microclímax y de los desenlaces. Dramatismo, comicidad, violencia o erotismo -pulsiones básicas no ya del relato, sino del ser humano- pueden ser

\footnotetext{
${ }^{113}$ Cita puesta en boca de tantos personajes que se hace imposible su rastreo y anclaje definitivo. Los mejores candidatos son, por este orden, Samuel Goldwyn y Cecil B. DeMille.
} 
recargados y explotados hasta adquirir autonomía. ${ }^{114}$ Escenas de contenido sexual, combates, batallas, persecuciones y -recordando aquellos ecos de lo contemplativo y el reciente oxímoron- la misma mostración de los paisajes.

En conclusión, el impacto audiovisual o, si se quiere, la atracción, no sólo no impone, sino que deriva de y reside en. El impacto no es la única instancia que puede aturdir-que no excluir- la narración. Existe una concepción del guión que, además de asimilar condicionamientos del tratamiento visual, contiene una estructura donde tienen cabida formas literarias de por sí impactantes o exageradas. En ese mismo cine que dice ser una continuación a (mega)escala del story board, anidan suficientes planteamientos y problemas estrictamente narrativos y narratológicos como para ser obviados. A la atracción audiovisual le precede una grandilocuencia narrativa que, por regla general, termina reconducida -con más o menos trompicones- a un devenir convencional. Una de las conclusiones del último libro de Fredric Jameson $^{115}$ se aproxima a este punto de vista. No importan los vericuetos, los experimentos y las metamorfosis que la modernidad extrema y la posmodernidad han aplicado sobre la forma y el relato, la cuestión narrativa siguió y sigue su curso a través de la historia. Se quiso renegar de ella pero, a la hora de la verdad, fue (re)utilizada para satisfacer una ambición: abarcar el mayor campo y público posibles.

Como no podía ser de otra manera, todo esto no es una aportación del cine aparatoso y contemporáneo. No es un novedad inherente o propiciada por las nuevas tecnologías y las nuevas estéticas. Aún hoy seguimos discutiendo quién mató al chófer de los Sternwood. ${ }^{116}$

\footnotetext{
114 Celestino Deleyto no hace alusión a este tipo de exaltaciones de los pasajes, sino a los géneros globales a los que pertenecen. El predominio del espectáculo sobre la narración no es patrimonio del blockbuster de acción Todo para seguir argumentando que lo que interesa es resaltar ese espectáculo del gag, de la música, del cuerpo asaltado o del sexo en detrimento de un "contexto narrativo generalmente muy tenue". De nuevo la disociación y la simplificación en el enfoque.

DELEYTO, Celestino, Ángeles y demonios. Representación e ideología en el cine contemporáneo de Hollywood. Barcelona: Paidós, 2003, pp. 49-50.

115 JAMESON, Fredric, The ancients and the postmoderns. On the historicity of forms, Londres y Nueva York: Verso Books, 2015.

${ }^{116}$ Sirva esta referencia a El sueño eterno (The big sleep, Howard Hawks, 1946) como anécdota que, dicho sea de paso, sigue en un limbo entre la leyenda cinéfila y la verdad. Cuando Bogart le preguntó a Hawks -la guionista Leigh Brackett dijo más tarde que fue ella quién se lo preguntó a Bogart- por el asesino del chófer, el director no supo qué responderle. Los guionistas, Brackett y William Faulkner, tampoco fueron de ayuda. Contactado por telegrama el autor de la novela -Raymond Chandler- este contestó con un lacónico "No lo sé". McCARTHY, Todd, Howard Hawks. The grey fox of Hollywood, Nueva York: Grove Press, 1997, p. 382.
} 


\subsection{Materialidad y clausura del relato}

«... por qué contar historias, las narraciones siempre presuponen una serie de eventos ordenados, una cronología (...) No hay historias, nunca ha habido historias, solo hay situaciones sin pies ni cabeza; sin principio, sin nudo y $\sin$ fin...» Jean Epstein ${ }^{117}$

El punto y final del relato merece atención aparte. Sobre todo, en dos casos particulares. Primero, cuando quiere condicionar o matizar todo lo relatado antes de su llegada. Segundo, cuando quiere renegar de su condición bien disfrazándose, bien procrastinando.

El primer supuesto es el de los denominados desenlaces de relectura. ${ }^{118}$ Su aparición ha repuntado dentro de la producción comercial del nuevo siglo. La fórmula no es precisamente original ya que cuenta con ilustres precedentes a lo largo de la historia del cine. ${ }^{119}$ Su aparición, hoy, viene marcada por el énfasis y por la mercadotecnia. En estos desenlaces puede apreciarse con total claridad la importancia del elemento narrativo en un relato que, probablemente, ha estado inundado por los impactos audiovisuales. Si quisiera apropiarme de la Teoría de atracciones para explicar estos desenlaces, diría que son ejercicios de mostración de los encantos literarios, cuyo objetivo es instar a un espectador urgido a la reconsideración de lo visto. El desenlace como atado de lazos definitivo o como nacimiento de una nueva ruta que se proyecta más allá de la diégesis vivida. Esto es, los finales abiertos o inconclusos, los finales en suspenso.

La ausencia de clausura en el relato es un desafío a la ortodoxia narratológica. Digo desafío porque, según esta, si no hay clausura, tampoco hay relato. De nuevo es una cuestión de niveles. A saber, un relato cinematográfico puede quedar abierto en relación a su contenido.

\footnotetext{
117 JASON, Paul; KELLER, Sarah (eds.), Jean Epstein. Critical essays and new translations, Amsterdam: Amsterdam University Press, 2012, p. 86 [La traducción es mía]. Noël Burch también utiliza esta declaración, de forma abreviada, en una nota al pie de: BURCH, Noël, Praxis del cine, Madrid: Fundamentos, 1979, p. 71.

${ }^{118}$ RUBIO ALCOVER, Agustín, La postproducción cinematográfica en la era digital. Efectos expresivos y narrativos, Castellón: Universitat Jaume I. Departamento de Filosofía, Sociología, Comunicación Audiovisual y Publicidad, Tesis doctoral inédita, 2006, p. 453.

${ }^{119}$ Una pequeña e ilustre lista de ejemplos: Das kabinett des Doktor Caligari (Robert Wiene, 1920), The mark of the vampire (Tod Browning, 1935), The planet of the apes (Franklin J. Schaffner, 1967), Psycho (Alfred Hitchcock), Witness for the prosecution (Alfred Hitchcock), Woman in the window (Fritz Lang), Dead of night (Alberto Cavalcanti et. al), Laura (Otto Preminger), Citizen Kane (Orson Welles), etc.
} 
Un relato cinematográfico siempre está clausurado en tanto objeto real-que el espectador detecta y que no confunde con la propia realidad- y material. Que el relato posea principio y final lo segrega del mundo y, en cierta medida, lo enfrenta al mundo. Recupero estas ideas, de evidente inspiración metziana ${ }^{120}$, porque vuelven a desafiar al desconcierto posmoderno. Quiero decir, el relato actúa dentro de lo real y de lo material, mientras proyecta ilusiones y genera afectos.

Que el final sea en forma de suspense o cíclico no altera en absoluto la naturaleza del relato en tanto que objeto: todo libro tiene una última página, toda película tiene un último plano, y los héroes pueden seguir vivos en la imaginación del espectador. ${ }^{121}$

La secuencialidad narrativa posee materialidad. Una materialidad que nunca queda afectada por una clausura evasiva. Es la sustancia semántica del relato la que se dispara a una hipotética continuación, a un bucle o al infinito. Se me podría echar en cara -también a Metzque esta caracterización de la sustancia semántica es un nuevo ejemplo de fantasma en la máquina, pero nada más lejos de la realidad. El relato es un objeto material inanimado y siempre clausurado. Por lo tanto, sujeto a la mecánica de sus componentes. El relato cinematográfico ni es el mundo real, ni es un cuerpo humano. Su enorme poder realizante admite transferencias con la realidad, nunca una suplantación -el golpe de estado posmoderno- o una identificación completa. De ahí que me sienta más cómodo con Metz que con, por ejemplo, Manovich.

De lo anterior se deduce que el aplazamiento o la ausencia de clausura en la sustancia semántica, genera una ilusión de desmaterialización en la secuencialidad narrativa. Este punto sirve, pues, para apreciar uno de los remontes de la posmodernidad y, por extensión, de la era digital que deben ser refutados.

Los juegos con la clausura del relato afectan a la sutura del espectador. Películas que juegan con la baraja marcada para obtener dos objetivos. Primero, disfrazar la participación del espectador de interactividad, al tiempo que se sugiere un respeto hacia sus capacidades cognitivas. Segundo, habilitar una serialidad amparada en la demanda fisiológica de ese

\footnotetext{
${ }^{120}$ METZ, Christian, Ensayos sobre la significación en el cine [1964-1968], Barcelona: Paidós, 2002, pp. 43-44.

${ }^{121}$ GAUDREAULT, André; JOST, François, op. cit., p. 26.
} 
espectador seducido pero frustrado en el interruptus. Pura estrategia de guión, digo de mercado. La prolongación o está planificada o viene avalada por el libro de cuentas. ¿Se puede entonces considerar como cierta la interactividad asociada a este tipo de aperturas en el relato? No. Persiste la jerarquización piramidal del espectáculo: el absolutismo del que muestra y un tributario que recibe. Una condición que seguirá presente, más allá de las narraciones, en el proceder del hombre como usuario de los entornos digitales y multimedia.

En contra del principio de ruptura que plantea, los juegos con la clausura del relato resultan tan previsibles y retóricos como un cliffhanger. Para suplir la sutura del espectador, los filmes con estructuras enmarañadas de guión y los finales aplazados y de relectura, conducen al mito del visionado múltiple. Revisionado no tanto por el placer de revivir, como por la necesidad de comprensión. El relato niega la sutura, pero el espectador se resiste a aceptarlo. No toleramos la incertidumbre narrativa bajo ningún concepto. Nuestro cerebro ha evolucionado para conseguir lo contrario: normalizarla. Deseamos prolongar la experiencia, dilatar el placer como medio para retrasar el fin, porque no toleramos su indefinición. En nuestro ansia por simplificar, nos encontramos con que el nivel de complejidad y contradicción de nuestro cerebro siempre será mayor que el del guión.

Esta situación desemboca en la aporía de la película puzle estándar. Aquella cuya propuesta de complejidad, diversidad y expansión deviene mecanicismo, rutina y clausura hermética: masturbación. La industria -conocedora de la situación- se ha esmerado en complacer a un espectador que demandaba sutura fabricando consoladores pluscuamperfectos.

¿Qué hace cualquier persona cuando termina un puzle? Exacto: destruirlo, arrumbarlo o, si su mal gusto se lo permite, enmarcarlo. Ni siquiera los niños quieren hacer el mismo puzle dos veces. La confusión y hasta la oscurantismo narrativo sirven como excusa para una hermenéutica peregrina y cinéfila. Por acudir a una metáfora pictórica, esas películas puzle quedarían enfrentadas con el clasicismo institucional de las películas cuadro. ¿Cuántas veces se puede mirar un un Rothko o un Carpaccio? Que una película pertenezca a ese hipotético género puzle no es incompatible con ser -o llegar a ser- una película cuadro. En esa compatibilidad, intuyo que un filme alcanza la nobleza del cuadro porque, en realidad, no era un puzle; o al menos no era un puzle masturbatorio. Pienso en David Lynch. Las ocasiones en las que parece ofrecerte un puzle, no se tarda en comprobar que hay piezas que pertenecen a rompecabezas diferentes, o que cuando encajan lo hacen sin respetar los tamaños, los colores o las iconografías. 
Para terminar, como muestra de lo delicado que resulta la generalización en estos casos, tengo que dejar sobre la mesa otro recurso narrativo reactualizado durante el advenimiento digital. Junto a los finales abiertos y de relectura, se reactivó un tipo de final que era pura prolepsis. Mostrado de diferentes maneras, el espectador se adentraba en una historia que sabía cómo iba a terminar desde el mismo inicio. En algunas ocasiones desde el mismo título. No eran tanto finales sobre los que ejecutar el típico flashback de filme noir, como un nuevo modo de ostentación de los mecanismos del relato. Lo que los anglosajones denominan upfront story y que en español podríamos traducir -con una literalidad inexacta que recuerda a Fernando Fernán Gómez- como la historia por delante.

\subsection{Serialidad}

«La forma bastarda de la cultura de masas
es la repetición vergonzosa»
Roland Barthes ${ }^{122}$

«Sabiendo con certeza que, en nuestras sociedades mediáticas, repetición equivale a demostración» Ignacio Ramonet ${ }^{123}$

«Nosotros nunca terminamos nada. Hombres infinitos» Man Ray ${ }^{124}$

La serialidad juega un papel decisivo en la cacareada doble muerte del relato. La de la propia función presenciada y la conceptual. La serialidad excita y promete. Su función es atenuar la frustración del espectador que asiste a una narración abierta sine die. El espectador -en su jaula- recibirá una dosis más que se contemplará como merecida siempre y cuando hayan cumplido con los compromisos interpuestos. Siempre y cuando, en el horizonte, se siga divisando la rentabilidad. Company y Marzal lo esclarecen:

\footnotetext{
122 BARTHES, Roland, El placer del texto y lección inaugural de la Cátedra de Semiología Lingüística del Collège de France, México D.F.: Siglo XXI, 1991, p. 68.

123 RAMONET, Ignacio, "La pensée unique" en Le Monde Diplomatique, enero de 1995, <http://www.monde-diplomatique.fr/1995/01/RAMONET/6069> [consulta: 20-10-2015].

${ }^{124}$ DIDI-HUBERMAN, Georges, En la cuerda floja, Santander: Shangrila Textos Aparte, 2015, p. 16.
} 
La serialidad, común al relato moderno, principalmente el relato electrónico, se erige en la solución del problema, compensando así la muerte del relato. El espectáculo cinematográfico moderno funciona, pues, como una estructura episódica que repite, de un modo serial, las mismas fórmulas narrativas y espectaculares. ${ }^{125}$

Esta idea de serialidad resulta funcional para una investigación de este corte, pero también insuficiente. Digo que es práctica y quizá lo es demasiado. Conviene ampliar su rango histórico y teórico. Es necesario recordar cómo era y es entendida la serialidad en tanto agente sistémico. Esta serialidad narrativa a la que vengo haciendo referencia, queda alejada en cuanto a importancia de la significación y del peso que le otorgó Claude Lévi-Strauss. El antropólogo, utilizando la composición musical, no como excusa pero sí con cierto aire metafórico, estableció una partición entre pensamiento tonal y pensamiento serial. Esta división, a su vez, fue recogida por Umberto Eco para enriquecer el marco metodológico de su teoría de una obra abierta como integrante de una poética del pensamiento serial. ${ }^{126}$

Este pensamiento serial straussiano, luego reelaborado por Eco, entronca con la experimentación y la vanguardia al "poner en crisis los sistemas de expectativas y los sistemas de formación tradicionales". ${ }^{127}$ La forma de llevarlo a cabo es mediante la evolución y el cuestionamiento constante y prolongado de los criterios reglados de la comunicación tradicional. La partición de Strauss -haciendo valer ese valor sistémico citado- no queda reducida a norma epistemológica y estética. Los dos tipos de pensamiento parecen quedar separados por una línea de Pizarro: son dos maneras de explorar el mundo. Lévi-Strauss recurre a Pierre Boulez para ilustrar una tesis musical que deviene estructural. Conviene señalarlo porque la crítica que Lévi-Strauss hace de la serialidad puede ser fácilmente caricaturizada como mero y reaccionario ataque a la representaciones experimentales de la música, de la literatura y del arte abstracto. Lévi-Strauss citando a Boulez:

\footnotetext{
${ }^{125}$ COMPANY, Juan Miguel; MARZAL, José Javier, op. cit., p. 55.

${ }^{126}$ Eco publica Opera aperta en 1962 y Lévi-Strauss Le cru et le cuit en 1964. Pero es muy llamativo cómo Eco recoge el planteamiento del francés para incorporarlo durante esa década a sus investigaciones. Con este ejercicio, en buena medida, valida en la práctica uno de los puntos de su teoría.

${ }^{127}$ ECO, Humberto, op. cit., p. 358.
} 
El pensamiento tonal clásico se funda en un universo definido por la gravitación y la atracción, el pensamiento serial en un universo en perpetua expansión. ${ }^{128}$

Esa serialidad vendrá caracterizada por la ausencia de estructuras generales como la escala y las formas. El creador -el compositor- elabora, da forma y organiza los elementos en un proceso abierto inmediatamente anterior a su expresión. Después de la monodia y la polifonía, la serialidad facilita la llegada una polifonía de polifonías. Lévi-Strauss es crítico con el pensamiento serial porque aprecia en él un desprecio gratuito por otra idea básica de su obra: las estructuras mentales comunes. No supone ningún mérito compartir esta última idea con él. Cualquiera que esté no ya al día, sino que posea una propedéutica de antropología y psicología -más la evolucionista y la experimental que la analítica y la terapéutica-, la asumirá sin dudarlo. Esas estructuras generales, entre las que está el lenguaje y los universales ${ }^{129}$ narrativos, formales y de conducta humanos, suponen un "fundamento objetivo más acá de la conciencia".

Estamos ante actividades que son nuestras y de los demás, condiciones de todas las vidas mentales de todos los hombres de todos los tiempos. ${ }^{130}$

El pensamiento serial vendría a socavar esa objetividad latente, biológica y material, mediante una expansión, modificación y afirmación de su libertad. Lévi-Strauss habla literalmente de libertinaje y, con ello, parece anunciar la llegada de la serialidad posmoderna:

La escuela serial se coloca en las antípodas del estructuralismo y ocupa frente a él un puesto comparable al que en otro tiempo tuvo el libertinaje filosófico frente a

\footnotetext{
${ }^{128}$ LÉVI-STRAUSSS, Claude, Mitológicas I. Lo crudo y lo cocido, México D.F.: Fondo de Cultura Económica, 2002, p. 32.

${ }^{129}$ La lista elaborada por Donald Brown en 1989 y publicada en 1991, continua siendo operativa. Sin embargo, ha visto como la experimentación científica del nuevo siglo ha matizado y ampliado su espectro. Los universales de Brown son, como indica Pinker, "superficiales". No en un sentido peyorativo, sino metodológico. Es decir, están más ligados a la etnografía y a la evolución cultural y del fenotipo que a la estructuras internas o cerebrales más complejas. BROWN, Donald, Human universals, Nueva York: McGraw-Hill, 1991. Para una reconsideración y puesta al día: KAPPELER, Peter; SILK, Joan (eds.), Mind the gap. Tracing the origins of human universals, Heidelberg: Springer, 2010. Especialmente las partes VI y VII dedicadas al lenguaje, la comunicación y la cultura, pp. 283-450.

Los universales humanos, sobre todo los relacionados con las ventajas adaptativas y la psicología, siguen siendo motivo de disputa. No son unánimemente aceptados o son explicados de acuerdo a criterios y métodos no adaptativos o evolucionistas, véase: LEVY, Neil, "Evolutionary psychology, human universals and the Standard Social Science Model" en Biology and Philosophy, n 19, 2004, pp. 459-472.

${ }^{130}$ LÉVI-STRAUSS, Claude, Introduction to the work of Marcel Mauss, Londres: Routledge \& Kegan Paul, 1987, p. 35. [Primera edición de 1950]
} 
la religión. Con la diferencia, en todo caso, de que hoy es el pensamiento estructural el que defiende los colores del materialismo. ${ }^{131}$

Como avisé, Eco amplió y matizó notablemente las nociones de Lévi-Strauss para preguntarse si ha lugar a una tregua, incluso a una colaboración, entre las estructuras y la serialidad. Donde Lévi-Strauss veía una dialéctica -dos metarrelatos: uno estructural, otro herético-, Eco advirtió que la serie puede concebirse y analizarse en términos estructurales. Personalmente aprecio la capacidad de anticipación -fruto de su conocimiento del presente- de Lévi-Strauss, pero resulta demasiado rígido, incluso dogmático -no en la concepción de los universales, sino en la dialéctica expuesta. Me resulta indispensable la aportación que hizo el italiano. Eco transformó la anticipación, la permanencia y el cierre straussiano en transición, en devenir y en apertura. Para rastrear las estructuras no se apoyó en la matemática y en la física de la complejidad ${ }^{132}$ (estructuras disipativas, catástrofes, fractales, partículas), sino profundizando en el conflicto vital y metodológico de un semiólogo embarcado en un proceso de obra abierta. Eco analizó y encontró avenencia gracias a la semiótica y a la Historia. Para él, la serialidad no niega necesariamente la estructura. Es más, puede convertirse en representación de una estructura en crisis -autocuestionada- dentro de un proceso temporal y, por lo tanto, histórico. Es decir, la estructura deviene hipótesis reguladora de una investigación en marcha:

La series serán una estructura que, sabiéndose una manifestación temporal de un código oculto, lo busca sin descanso mediante un principio de tensión constante y de duda metodológica permanente como única herramienta capaz de mostrar el significado. ${ }^{133}$

En conclusión, existe una sutura histórica y metodológica en el pensamiento serial desde el mismo momento en que este deja de ser excluyente con la estructura. Por esta razón consideraba imprescindible la aportación de Eco a la dialéctica propuesta por Lévi-Strauss. Aquella era una vía para la supervivencia de unos metarrelatos que empezaban a sentirse amenazados. Que en esta investigación defienda la persistencia de los relatos, no puede servir de coartada para abrazar el sesgo de confirmación. Gracias a Eco, la dialéctica deja de ser una

\footnotetext{
${ }^{131}$ LÉVI-STRAUSS, Claude, Mitológicas I. Lo crudo y lo cocido, op. cit., p. 35.

${ }^{132}$ PRIGOGINE, llya, Las leyes del caos, Barcelona: Crítica, 1997.

${ }^{133}$ ECO, Umberto, The open work, Cambridge: Harvard University Press, 1989, p. 232. [La traducción es mía]
} 
falacia filosófica donde el estructuralismo quedaba ligado a un fetichismo del código y el serialismo a un fetichismo del mensaje.

Teniendo en cuenta el fundamento antropológico y semiótico descrito, la serialidad cinematográfica de la que hablaba al comienzo de este punto, no puede quedar adscrita al pensamiento serial. De nuevo, ¿por qué?, porque realiza una excitación de expectativas que sólo pone en cuestión las convenciones comunicativas de manera superficial, transitoria y bajo la fachada de una falsa interactividad. Nada tiene que ver esta serialidad cinematográfica - ni para bien, ni para mal- con los juegos del lenguaje propuestos por el propio semiólogo italiano o con la agonística posterior de Lyotard. ${ }^{134}$ La agonística vendría a ser una versión exacerbada y menos rigurosa en lo metodológico, de la búsqueda de las estructuras de la serialidad realizada por Eco. Aunque diría que, desvistiéndola de la pompa lyotardiana, la agonística se asemeja más a la retórica nutritiva ${ }^{135}$ también propuesta por Eco. La agonística hablaba de la necesidad de extremar los juegos y los desplazamientos del lenguaje durante la comunicación para eliminar o dificultar una reacción programada. Es este un camino que algunos teóricos de la posmodernidad tomaron demasiado en serio. Esto es, la incertidumbre pasó de oportuno, decente y cartesiano principio de método, a fin en sí misma.

No es el caso de la serialidad del relato cinematográfico contemporáneo propiciada por una clausura hurtada. Este tipo de serialidad deviene, de manera paradójica, patrón. No hay cuestionamiento, solo reafirmación de las estrategias. Abandona las premisas básicas de expansión continuada, de ruptura, de duda y de tensión, para convertirse en una tautología reaccionaria. Podríamos decir que orientada hacia o por un conductismo de mercado. Es decir, un planteamiento sustentado en poderosos estímulos a la espera de una respuesta lo menos consciente y lo más mecánica posible. Bien por coyuntura o azar económico favorable, bien por la partición premeditada de un todo en series.

La serialidad cinematográfica es un juego, sí, pero de repetición. La industria del audiovisual ${ }^{136}$ no pretende -ni quiere- que el espectador se tome al pie de la letra a Lévi-Strauss, Eco, Lyotard

\footnotetext{
${ }^{134}$ LYOTARD, Jean-François, La condición posmoderna, op. cit., p. 39.

${ }^{135}$ ECO, Umberto, La estructura ausente. Introducción a la semiótica, op. cit., p. 166 y ss.

${ }^{136}$ Durante todo este apartado me estoy refiriendo a la serialidad cinematográfica y, en concreto, a aquella suscitada por mecanismos narrativos como los guiones intrincados y los finales abiertos. Ahora utilizo la palabra "audiovisual" porque quiero incluir la inevitable referencia a la serialidad televisiva, a la del videojuego y a otras manifestaciones multimedia (aquí sería muy interesante hablar, por ejemplo, de la serialidad del software: de la cultural del updated y de una teoría de la apps seriality). No analizo la serialidad televisiva porque su carácter estructural es mucho más evidente que el cinematográfico y
} 
y a la neurociencia. No quiere espectadores diligentes en el proceso comunicativo, ni siquiera espectadores enfermos o neuróticos incapaces de manejar la incertidumbre. Quiere, simplemente, espectadores que cumplan, que paguen. La dimensión comercial del cine es consciente de la necesidad humana -animal- de mantener cierto control sobre los acontecimientos de la vida como medida psicológica decisiva para la buena salud.

En resumen, estos mecanismos narrativos tan habituales en las ficciones del nuevo siglo, son tan Ilamativos como los propios estímulos audiovisuales. Mecanismos que se muestran y se exhiben de tal forma que cualquiera podría elaborar una nueva Teoría de atracciones a partir de ellos. Sabiendo lo innecesario y equivocado que sería esto último, la matriz conceptual y narratológica expuesta sirve para dejar constancia de la tozuda supervivencia de los relatos dentro del audiovisual. Esta resistencia es más poderosa y posee un soporte teórico más riguroso que el enfoque ofrecido por teorías digitales tan novísimas como rancias. Aquellas que, en su reduccionismo, solo estiman la continuidad histórica y estética del relato -eso sí, mutado, maleable e indefinido- como una emanación de la tecnología que lo produce. Es decir, lo digital imprimiría el sello oficial de la apertura infinita y del posibilismo hasta convertir en circular lo que en otro momento fue lineal.

Un solo ejemplo. Cuando Peter Lunenfeld ${ }^{137}$ consideraba lo inacabado -unfinished- como definitorio de los medios y la estética digitales. Para Lunenfeld, el unfinished digital residía en lo tecnológico y se expresaba a través del software. Programas cuyas múltiples extensiones, herramientas y opciones convierten los estadios de la postproducción ${ }^{138}$ en procesos no lineales. No le puedo negar a Lunenfeld su acierto en la apostilla: las formas del relato sin un final pactado -never-ending- siempre han existido. En la era digital solo muestran diferencias que pueden llegar a ser estructurales o simplemente cosméticas. La cautela histórica del autor es de agradecer, pero no tarda en sepultarla cuando menciona al borrado de fronteras entre texto y contexto llevado a cabo por, como explicaré en el futuro interludio, ese disolvente universal llamado computadora.

La seducción irresistible del érase una vez y de una literatura oral sustentada en el mito, la fábula y el cuento. Universales y variaciones narrativas que se suceden en cada época y en

porque se escapa en extensión. Me centro solo en lo cinematográfico porque es uno de los elefantes en la habitación de las teorías digitales y de los nuevos medios.

137 LUNENFELD, Peter, "Unfinished business" en LUNENFELD, Peter (ed.), The digital dialectic. New essays on new media, Cambridge: The MIT Press, 1999, pp. 6-22.

${ }^{138}$ Ampliamente rebatido en la obra citada de Agustín Rubio Alcover (2006). 
cada representación, pero que en ningún caso pueden tomarse como prefiguraciones del hipertexto y de la última representante de ese modelo digital presuntamente abierto, libre e interactivo: la narrativa transmedia. 


\section{SUPERVIVENCIA. INTENSIFICACIÓN Y RAZÓN BIOLÓGICA}

«Cuando despertaron del sueño digital, el lápiz seguía allí» ${ }^{139}$

Expuestos los criterios estrictamente narrativos -impacto, clausura, complejidad, serialidadque, como dije, fueron elegidos a conciencia por ser considerados marcas distintivas del digital y del relato cercenado, llego ahora a un punto decisivo del análisis.

Para proseguir, tomaré la idea de supervivencia acuñada por Aby Warburg y recuperada de manera brillante por Georges Didi-Huberman. ${ }^{140}$ Sin embargo, es mi deseo reelaborar también a este último. Me interesa la idea de Warburg porque es hermosa y, con toda su carga intuitiva, verdadera. Me interesa el relevo que ofrece Didi-Huberman porque confirma la carga de verdad y porque amplía el campo de acción tanto en la iconografía de la historia del arte, como en la psicología. Cuando digo reelaborar, quiero decir introducir un criterio distintivo que modifique esta imposible línea sucesoria. A la psicología, le añadiré un apéndice evolucionista. Con parecida intención, utilizaré una metáfora anatómica que ha sido dispersada por el tiempo y que aquí trataré de unificar y actualizar a los nuevos tiempos: el nervio del fotograma.

Así las cosas, en este apartado explicaré a qué me refiero cuando hablo de una naturaleza biológica de la narración sustentada o ilustrada por imágenes. En última instancia y casi como ucronía metodológica, veré si realmente existe la posibilidad de que la narración como producto de las imágenes desaparezca por completo. Si tal cosa es factible desde un punto de vista iconográfico y biológico.

Antes de ello, realizaré dos escalas. La primera, en un último y brevísimo apunte sobre las estrategias industriales. La segunda, en las ideas que ciertos teóricos de corte neoformalista y cognitivista utilizaron para demostrar no ya la supervivencia o la latencia narrativa, sino una intensificación de la misma en plena era de las atracciones. Es este un periodo donde se atisba el camino que lleva a la rehabilitación y a la reafirmación de estrategias creídas obsoletas o muertas. Camino de tres vías asfaltado por la narración como elemento vehicular de la

\footnotetext{
${ }^{139}$ Viñeta de El Roto. El País, 20-04-2015, <http://elpais.com/elpais/2015/03/19/vinetas/1426769288_121995.html> [consulta: 20-10-2015] 140 DIDI-HUBERMAN, Georges, La imagen superviviente. Historia del arte y tiempo de los fantasmas según Aby Warburg, Madrid: Abada, 2009.
} 
industria, de la forma y de los modelos históricos y sociales. Estos últimos, de la mano de los metarrelatos, ya están analizados. Ahora es el turno de los otros dos.

\subsection{Narrativa industrial}

Puede sonar extraño, pero la gran industria del cine -con todos sus conglomerados y diversificaciones- ha adoptado modos típicos de una industria cultural en el sentido epistemológico desarrollado por la Escuela de Frankfurt. Es decir, los flujos mercantiles y sociales afluyen a una estética que no puede ser ajena a ellos. Antes he desechado la idea tecnológica que surgió amparada por dicha escuela. Aquella donde la tecnología acarreaba una ideología desde el mismo momento de la creación del aparato y del establecimiento de sus funciones. Creo que esta bipolaridad no es una contradicción, es más bien un fruto obtenido al rehuir del dogma y de la descalificación del todo por la parte.

¿Cuál ha sido siempre uno de los objetivos primordiales de la industria del cine? Primordial y, como tal, expresado con mayúsculas y negrita: la internacionalización absoluta de sus productos. Los medios empleados para conseguirlo: relato publicitario y reconcentración de la producción en torno a las grandes compañías en detrimento de las independientes. ¿Cuál de las dos ha sobrevivido hasta hoy?, solo el primero. Porque la estrategia de reconcentración se vio rápidamente frenada a partir del bienio 2006-2007 debido a dos factores. Uno, la globalización de la crisis económica incubada en las subprime norteamericanas. Dos, la instalación ${ }^{141}$ definitiva de una logística digital -de la grabación a la exhibición, pasando por la edición y la distribución- de alta calidad y de precios menguantes.

Según las estadísticas de la MPAA (Motion Picture Association of America), la reconcentración fue un hecho durante la última década del siglo XX y principios del XXI. La aplicación de estos datos al debate académico, cuadra. Fueron los años donde el digital comenzó a ser jaleado como profecía y como mutación definitiva del cine y de sus instancias. Un supuesto cambio de paradigma que explicaré más adelante. En aquel tiempo, se pasó de una producción independiente del 87\% (1992), a un dominio de las majors fijado en torno al 50-60\%. A partir

\footnotetext{
${ }^{141}$ Utilizo instalación de forma deliberada. Primero, porque juguetea con la terminología propia del software. Segundo, porque la alternativa era utilizar democratización, un símil que a estas alturas de la historia del cine, tras haber visto pasar a los formatos subestándar, a los fluorescentes, al vídeo y al nagra, se encuentra exhausto.
} 
de la crisis y hasta nuestros días, se ha vuelto a invertir la tendencia. El año 2014 devolvió las producciones independientes a cifras del $80 \% .{ }^{142}$

Ha sido el relato publicitario el que ha seguido en pie como la herramienta industrial más efectiva. La narración como estrategia que busca ser asertiva con público y mercado. Como hemos comprobado estos años, la depredación económica está sujeta a sacudidas, leyes y coyuntura. La narración, en cambio, no puede desaparecer porque forma parte -a todos los niveles- del programa humano. Además de artefacto cultural, su elaboración, su expresión y su recepción son auténticas funciones orgánicas.

La industria también buscó o renovó otras prácticas. Regresó al control obsesivo del sector de la exhibición, ${ }^{143}$ perfeccionó la distribución worldwide -el importador extranjero impaciente y extorsionado por la venta en lotes- y se esmeró en el diseño de la obra como fenómeno que trasciende la película en sí. El filme amplió su condición de objeto para convertirse en evento. Esto es, la fórmula del High concept -que, a su vez, ya hilaba con los clamorosos triunfos del Nuevo Hollywood de finales de los setenta- reactualizada como blockbuster. ${ }^{144}$ El ejercicio culminante de este proceso fue la reforma de los estrenos: el todo o nada del primer fin de semana (opening weekend). Método predictivo definitivo para conocer la explotación del filme. También termómetro para perfilar la futura diversificación del producto y su explotación en las diferentes ventanas comerciales.

Vertebrando todo el sistema, fuera y dentro de la película, la narración. Médula interna, brazo ejecutor externo. Soporte vital de toda una industria. Vehículo para un éxito que aspira al mercado mundial. Pasado, presente y futuro.

\footnotetext{
${ }^{142}$ Producciones independientes son, literalmente, aquellas realizadas fuera de las majors (Walt Disney, Paramount, Sony, Twentieth Century Fox, Universal y Warner) o de sus compañías subsidiarias. Conviene no identificar independiente de acuerdo al viejo criterio romántico: producción de bajo presupuesto al margen de la industria. Hoy día, eso es solo una parte de lo que puede ser considerado independiente. Las estadísticas de la última década pueden consultarse en los informes anuales elaborados por la MPAA: <http://www.mpaa.org/> [consulta: 20-10-2015].

${ }^{143}$ Cabe recordar que en 1986 se revocó el Consent Decree del caso Paramount fallado en 1948. Suceso que favoreció el posterior rearme de las compañías que acabo de explicar. Leyes antitrust (derecho a la competencia) cuya lucha en los tribunales se ha convertido casi en un hilo conductor de la historia del cine como industria.

${ }^{144} \mathrm{El}$ término blockbuster, en rigor, tampoco es nuevo. Ya era la etiqueta que se daba a las grandes producciones con afán taquillero de los años cincuenta. Más de medio siglo después, ha adquirido matices hasta quedar identificado, más que con un filme taquillero, con uno adscrito al concepto de espectacularidad.
} 
Las estrategias comerciales de Hollywood, no han experimentado una radical transformación desde que la televisión se ha convertido en el modo de recepción mayoritario de imágenes cinematográficas, sustituyendo a las tradicionales salas. $^{145}$

La vieja maquinaria del bosque del acebo dispuesta a seguir luciendo -ajena a la cursileríacomo eterna fábrica de sueños.

\subsection{Continuidad e intensificación}

Durante todos estos años han seguido vigentes métodos analíticos que nunca dieron por depuesto el reino narrativo. Han seguido operativos y con una razonable capacidad de influencia en el mundo anglosajón. En Europa, en cambio, quedaron en clara minoría y sufriendo la indiferencia -cuando no el desprestigio- crítica y académica. Todo sucedía en paralelo al triunfo de la atracción o ligeramente por detrás. Un conflicto en pleno milenarismo. Que las críticas más llamativas surgieran con ese ligero retraso y como discrepancia a una expansión imparable, fue la excusa perfecta para que, aquellos que las hicieron, fueran acusados de reaccionarios. La atracción como fenómeno disruptivo que se derramaba sobre un posclasicismo radical, fue puesto en cuestión. Para estos teóricos, el colapso y la postrera desaparición narrativa provocada por el cine de atracciones, no fue tal.

La narrativa de Hollywood no ha cambiado en lo fundamental desde los tiempos del sistema de Estudios (...) En la representación del espacio, del tiempo y en las trazas narrativas (...), los filmes actuales, por lo general, se adhieren a los principios de la cinematografía clásica (...) Lejos de rechazar la continuidad tradicional a favor de la incoherencia y de la fragmentación, el nuevo estilo viene a ser una intensificación de las técnicas ya establecidas. ${ }^{146}$

Esta era la decidida postura de David Bordwell y que hoy aun mantiene. El historiador americano afirmó que su razonamiento estaba respaldado por un cotejo serio y minucioso de las obras. A través de su fundacional artículo, Bordwell intentó demostrarlo atacando uno de

\footnotetext{
${ }^{145}$ RUIZ JIMÉNEZ, Antonio Gabriel, op. cit., p. 191.

146 BORDWELL, David, "Intensified continuity. Visual style in contemporary american film" en Film Quarterly, Berkeley: University of California Press, vol. 55, no 3, 2002, p. 16. [La traducción y la cursiva son mías].
} 
los puntos fuertes del posclasicismo de atracciones: la rapidez del montaje. ${ }^{147}$ Bordwell reconoció que en ese momento histórico se había alcanzado la velocidad punta. Sin embargo, los mecanismos de transición, las uniones entre planos, el empleo regularizado de focales largas graduables, los primeros planos para ilustrar secuencias dialogadas -"los actores son principalmente rostros" ${ }_{-148}$ y la gran movilidad de las cámaras, seguían campando por las películas. Extensiones más o menos enfatizadas de una arcaica normalización ya lograda en la década de 1930.

Lejos de ilustración endémica, estos rasgos no quedarían circunscritos al mainstream norteamericano. Alcanzarían a directores independientes del país (John Sayles, Allison Anders, Alan Rudolph, Jim Jarmusch, etc.), a la cinematografía europea (Werner Herzog, Leos Carax, Jean-Jacques Beneix, Tom Tykwer, Jean-Claude Brisseau, Luc Besson, Neil Jordan, etc.) y a la asiática (Korea del Sur, Tailandia, China, Hong Kong y Japón). Para otros, esa intensificación se convierte en sublimación. Gracias a ella, la narración intensificada encuentra su lugar hasta en las cinematografías periféricas. Con Kiarostami como ejemplo, Jean-Luc Nancy recita lo siguiente:

La mirada: la precisión de un encuadre, la de una sensibilidad del negativo, la de una iluminación -estación, momento del día, un coche que ha caído presa del objetivo- en una palabra, nada más que el cine... pero si se puede decir así: el cine intensificado, empujado desde el interior hacia una esencia que lo separa en gran medida de la representación para dirigirlo hacia la presencia" ${ }^{149}$

La estética de la continuidad intensificada tampoco será ajena al tremendo influjo de la televisión, a la manera en la que ésta ordenaba las imágenes y a su condición de contenedor y transmisor terminal. Por último, aquella inflamación y sublimación narrativa (cfr. 4.1) sufrida por ciertos pasajes de un filme, para Bordwell es un argumento que confirma la teoría. Hasta en sus ejemplos más banales, responden al criterio descrito y se convierten en justificación nominativa de la intensificación.

\footnotetext{
${ }^{147}$ Si bien dedica el primer apartado de su artículo a la edición, más tarde retomaría ese aspecto para escribir uno nuevo, ampliado y específico sobre las características del montaje actual en relación con los mecanismos clásicos. Me refiero a "Intensified continuity revisited" en Observations on film art, 27 de mayo del 2007, <http://www.davidbordwell.net/blog/2007/05/27/intensified-continuity-revisited/> [consulta: 20-10-2015].

${ }_{148}$ BORDWELL, David, "Intensified continuity", op. cit., p. 20.

${ }^{149}$ NANCY, Jean-Luc, La evidencia del filme. El cine de Abbas Kiarostami, Madrid: Errata Naturae, 2008, p. 82. [La cursiva es mía]
} 
Para Bordwell no existe, ni mucho menos, una ruptura tan evidente como se quiso y se quiere hacer ver. Bordwell y su mujer Kristin Thompson no se incorporan al debate de nuevas, su aparición es una prolongación lógica de sus estudios precedentes. Extiende así sus ideas de una estética de la continuidad -que no de la reacción- ya expuestas en anteriores publicaciones, en especial Film art: an introduction. ${ }^{150}$ En su célebre volumen, Bordwell ya mencionaba diferentes formas de estructurar las imágenes durante las primeras décadas del invento. Antes de que la Teoría de atracciones fuera formulada, Bordwell hablaba de conflictos entre narración e imagen a partir de estructuras retóricas, asociativas, categóricas y abstractas.

Más tarde, retomó y centró el debate en el cine contemporáneo con The way Hollywood tells $i t .{ }^{151}$ Se puede observar que no es una teoría que Bordwell elaborara específicamente para un tema y un momento determinado. Tampoco se puede olvidar que el autor conocía muy bien las ideas de Gunning y Gaudreault y que, durante esos años, supusieron un acicate más para reforzar su punto de vista. Buena parte del capítulo quinto de On the history of film style ${ }^{152}$, estuvo dedicado a discutir las teorías de Gunning. De las estrictamente históricas y formales, a las sociales. Bordwell también discrepó con Gunning a la hora de valorar el papel del rugir moderno y del capitalismo en el espectáculo cinematográfico. Donde uno veía síntomas de alienación, otro observaba una rica congruencia.

Dicho esto, Bordwell no puede ser considerado como una especie de némesis de la atracción, como, en su momento, tampoco lo fue Charles Musser. Pero ambos son, sin duda, los representantes que más han incidido en los puntos débiles de la Teoría de las atracciones. En especial, en el papel jugado por la narración durante y después del primer cine silente. Para ambos, las estructuras y los contenidos narrativos fueron mucho más importantes de lo admitido por Gunning. Recordemos cuando Musser ${ }^{153}$ advertía de la existencia de un cine de contemplación, de discernimiento y de narrativa, también durante la década de 1890 . Aunque también reconocía el dominio de la atracción durante el periodo 1895-1897. Musser era

\footnotetext{
${ }^{150}$ BORDWELL, David; THOMPSON, Kristin, Film Art. An introduction, Nueva York: McGraw-Hill, 1979. [En español: El arte cinematográfico, Barcelona: Paidós, 2002].

${ }^{151}$ BORDWELL, David, The way Hollywood tells it. Story and style in modern movies, Berkeley: University of California Press, 2006.

${ }^{152}$ BORDWELL, David, On the history of film style, Cambridge: Harvard University Press, 1997, pp. 116157.

153 MUSSER, Charles, "A cinema of contemplation, a cinema of discerniment: spectatorship, intertextuality and attractions in the 1890s" en STRAUVEN, Wanda (ed.), op. cit., pp. 159-179.
} 
incapaz de aislar el concepto de atracción de las nociones de periodo y estilo. Es decir, daba una de las claves del éxito de la teoría: cierre metodológico y seducción aderezada por nostalgia y melancolía en plena modernidad.

De nuevo en el cambio de siglo, encontramos a otro opositor: Geoff King. En la línea de Bordwell y Thompson, King consideraba que la narración -también la ideología- continuaba siendo un ingrediente vital no solo del espectáculo cinematográfico de fin de milenio, también de la realidad virtual, de los videojuegos y de los parques temáticos. Asumiendo que durante los periodos de innovación tecnológica -nacimiento del cine, formatos panorámicos, CGI-, el espectáculo tiende a aparecer en primer plano, King aseguraba que la narrativa estaba lejos de quedar eclipsada. Los cambios tecnológicos aportaban cualidades específicas que, en ningún caso, cambiaban de manera esencial la materia del relato. King defendía una de las premisas de esta investigación: la narración puede verse perturbada y modificada por la atracción o el exceso, pero continua vigente y operativa dentro del relato cinematográfico. Lo hace mediante diferentes patrones de integración y de coherencia. Para King, la narración nunca dejó de ejercer y nunca lo hará.

Además, King aportaba una metáfora brillante. En términos mitológicos, la narración responde a la idea de civilización, mientras el espectáculo -el exceso, la atracción, el impacto- hace lo propio con la idea de frontera. Organización, identidad, estructura y rutina frente a inestabilidad, disonancia, lucha y tránsito. La construcción del mundo y la escritura de la historia reflejados y condensados en el pequeño discurrir de una película. Ese arraigo y esa continuidad del mundo también es compartida por Robert Gottschall en el presente (2012) al afirmar que el futuro verá una intensificación, incluso un perfeccionamiento de las historias. Ni siquiera la tecnología logrará afectar su esencia, una esencia que el autor identifica con la resistencia al cambio. Para Gottschall, lejos de la decadencia y de la enajenación proclamadas, la fuerza gravitatoria de las narraciones no dejará de aumentar y de diversificarse. ${ }^{154}$

\footnotetext{
${ }^{154}$ GOTTSCHALL, Jonathan, The storytelling animal. How stories make us human, Nueva York: Houghton Mifflin Harcourt, 2012, pp. 243 y 248 [paginación correspondiente a la edición epub]. Me interesan mucho estas palabras de Gottschall porque encajan con el discurso del apartado, no porque comparta su punto de vista. Es más, no puedo compartir ni refutar su tesis debido a que él habla del futuro y yo, ignorante, lo desconozco. Sé que las historias seguirán existiendo y lo explicaré más adelante, pero no bajo qué formas y con qué grado de perfección e intensidad. Cuando el autor menciona el perfeccionamiento de las historias se vuelve especialmente resbaladizo. En esa perfección futura se intuye cierto transhumanismo o, cuando menos, la disolución del hombre en la tecnología de las historias: la realidad virtual. Intuición confirmada pocas páginas (253-258) después.
} 
Volviendo y terminando con Bordwell, su neoformalismo todavía no se había decidido a explorar el cognitivismo, como sí haría años más tarde. Una actitud muy parecida a la de Warren Buckland, ${ }^{155}$ a quien el propio Bordwell citaba ${ }^{156}$ a propósito del contenido y de la estructura narrativa del blockbuster norteamericano. Buckland, en concreto, se centraba en el análisis textual de En busca del arca perdida (Raiders of the lost ark, Steven Spielberg, 1981). Uno de los hitos en la transición ya comentada entre el Nuevo Hollywood, el High concept y el cine de atracciones. La tesis de Buckland era clara: la continuidad narrativa dentro de ese gran cine de efectos especiales. No dudó en darle voz al cineasta:

Necesitas una buena historia para compensar el espectáculo que la audiencia demanda para abandonar sus televisores. Creo que la gente dejará de lado sus televisores, antes que por cualquier otra cosa, por una buena historia. Antes que incendios, rascacielos, inundaciones, aviones estrellados, rayos láser y naves espaciales, el público prefiere buenas historias. ${ }^{157}$

La cita habla menos de una realidad comercial y analítica del momento -ya fuera en los ochenta o en el 2015-, como de la educación sentimental de Spielberg. Amamantado por el cine clásico de Hollywood, profundo admirador y conocedor de aquellas narraciones y gran reciclador de la iconografía del pasado. Buckland cerró su artículo con un tímido alegato a favor del blockbuster, al cual consideraba víctima de numerosos prejuicios y de una escasa consideración y atención por parte de los estudiosos. Buckland ya decía apreciar una compleja estructura narrativa bajo tanto artificio audiovisual. Trayendo a Buckland -bastante anterior al discurso de Bordwell y King-, lo único que pretendo es volver a mostrar que el debate no fue una novedad. ¿Cómo confirmar esta idea? Acudiendo a, quizá, el germen de la discusión.

Christian Metz -no tanto precedente como origen- ya se preguntaba en uno de sus ensayos por ese hipotético vaciado narrativo. El arranque de El cine moderno y la narratividad nos deja este párrafo memorable:

\footnotetext{
${ }^{155}$ BUCKLAND, Warren, "A close encounter with Raiders of the lost Ark: notes on narrative aspects of the Hollywood blockbuster" en NEALE, Steve; SMITH, Murray, (eds.), op. cit., pp. 166-177.

${ }^{156}$ También lo hace con su mujer: THOMPSON, Kristin, Storytelling in the New Hollywood, Cambridge: Harvard University Press, 1999.

${ }^{157}$ BUCKLAND, Warren, "A close encounter with Raiders of the lost Ark: notes on narrative aspects of the Hollywood blockbuster", op. cit., p. 170. [La traducción es mía]
} 
Un gran y permanente equívoco gravita sobre la definición del cine «moderno». A menudo se deja entender, y en ocasiones se afirma, que el «joven cine», el «nuevo cine», ha superado el estadio del relato, que el filme moderno es objeto absoluto, obra transitable en todos los sentidos, que en cierta manera ha desalojado de su seno la narratividad constitutiva del filme clásico. Este es el gran tema del «estallido del relato». ${ }^{158}$

En su escrito, Metz invierte la noción de espectáculo. Al margen de restarle importancia por no considerarlo mero vocablo del metalenguaje crítico. El filme moderno es el que -para algunos, entre los que no está Metz- se despega de la noción de espectáculo que siempre estuvo prendida al clasicismo. Es decir, el espectáculo como rito social, como condición artística y expresiva y como motivo psicológico. El autor desgrana los cambios $^{159}$ que se aprecian en aquellos nuevos cines de los sesenta para concluir que las presuntas alteraciones y mutaciones devienen "ejemplos de agilización y enriquecimiento sintácticos", y que "lejos de abandonar el relato, nos proporcionan relatos más diversos, más ramificados, más complejos" ${ }^{160}$ Metz acierta al notar que muchos de los que contribuyeron a firmar el divorcio con el espectáculo clásico para acercarlo -iquién lo iba a decir!- a una escritura novelesca capaz de decirlo todo de decir tanto a su autor como al mundo-, lo hicieron a través de la despreocupación, cuando no de la vulneración de la sintaxis cinematográfica. ${ }^{161}$

De esta forma, el anuncio de la muerte del relato cinematográfico fue diseccionado y contrarrestado por la prosa analítica de Metz. Los años sesenta avanzaban en tromba levantando unos adoquines bajo los que, además de la playa, estaba el relato.

\subsection{Burbujas digitales}

Esta diacronía del relato es fascinante. Pero no se pueden enlazar los sesenta con el nuevo siglo a través del doble estallido de Mayo del 68 y del 11-S. No se pueden enlazar, pero tampoco se puede negar que son estampidas y colapsos que, paradójicamente, terminan

\footnotetext{
${ }^{158}$ METZ, Christian, Ensayos sobre la significación en el cine [1964-1968], Barcelona: Paidós, 2002, p. 207. [Las comillas pertenecen al original]. Original en francés: "Le cinéma moderne et la narrativité" en Cahiers du Cinéma, París: Éditions de l'Étoile, no 185, Film et roman: problèmes du récit, diciembre de 1966, pp. 43-68.

${ }^{159}$ Lo hace mediante epígrafes, algunos de los cuales son colocados, no sin ironía, entre interrogaciones: ¿Muerte del espectáculo?, ¿Cine de improvisación?, ¿Cine de la desdramatización?, ¿Un realismo fundamental?, ¿Un cine de cineasta?, ¿Un cine del plano?, ¿Un cine de poesía?

160 Ibid., p. 244.

${ }^{161}$ Ibíd. pp. 73-74.
} 
rehabilitando la continuidad. El relato como recordatorio histórico y como lenitivo frente al estrés postraumático.

Lenitivo y rehabilitación son dos conceptos que, en este caso, podrían conectar con la fórmula de la paradoja traumática de Janet Walker. ${ }^{162}$ La manera de elaborar las respuestas ante un hecho límite, necesita de las cuestiones formales y narrativas. El objetivo es superar los traumas y los tabúes, tanto los de nueva aparición como los ya presentes por razones culturales. Walker ve práctico y apropiado trascender la realidad directa de los sucesos para ubicarse en un tiempo posterior -postraumático- donde el testimonio pueda surgir -vía narración- liberando la angustia. La idea de Walker es respetar la veracidad de los hechos y su crueldad mediante un relato encauzado a tal propósito. Lógicamente, los mecanismos mentales de autoprotección como la amnesia, la distorsión y la fantasía deben ser tenidos en cuenta durante el proceso. Walker no abjura de las ficciones y las considera, en según qué casos, fieles y efectivas. La paradoja puede parecer una vuelta de tuerca teórica y narrativa a la funcionalidad de ciertos procesos psicoanalíticos. Pero, en el fondo, lo que de verdad sigue palpitando es la capacidad biológica del arte y de la narración para la terapia emocional, el entrenamiento cognitivo, la labor de predicción, la habilidad social, el placer y la autorrecompensa.

En ese estado de paradoja traumática parecían encontrarse, durante el cambio de siglo, hasta los grandes defensores de la desmaterialización del relato como Lev Manovich. Con el nuevo milenio, Manovich no podía evitar deslizar sus dudas y hasta sus certezas sobre el aguante y la intensificación de la forma, de la materia y de la narración tras la llegada y el asentamiento de la digitalización. El mercado del arte contemporáneo -en toda su variedad- parecía no haberse liberado del yugo material y narrativo. Es más, la informática veía cómo su primera tarea consistía en ayudar a perfeccionar lo ya existente. Las herramientas informáticas quedaban sometidas antes de crear (de creacionismo) ex nihilo atendiendo a la autosuficiencia que muchos le otorgaban.

\footnotetext{
${ }^{162}$ El enfoque de la autora -orientado en buena medida por el discurso de género- busca esclarecer los abusos sexuales como fenómeno narrativo crítico. Walker también reseña la importancia del testimonio como forma narrativa de la Shoah. El origen del concepto en: WALKER, Janet, "The Traumatic Paradox. Documentary films, historical fictions, and cataclysmic past events", en Signs, № 4, verano de 1997, pp. 803-825. Un poco más tarde revisa la idea en: WALKER, Janet, "The Traumatic Paradox. Autobiographical documentary and the psychology of memory" en HODGKIN, Katharine; RADSTONE, Susannah (eds.), Contested past. The politics of memory, Nueva York: Routledge, 2003. De manera monográfica en: WALKER, Janet, Trauma cinema. Documenting incest and the Holocaust, Berkeley: University of California Press, 2005.
} 
Esa situación descolocaba a Manovich. La encajaba a regañadientes y acudía al dolor que provoca la paradoja cuando la realidad no acepta una boda concertada.

La paradoja continúa: con unas pocas excepciones notables como el Museo Guggenheim de Frank Gehry, la adopción de herramientas informáticas en arquitectura, diseño, fotografía y cine no ha llevado a la invención de formas radicalmente nuevas, al menos no en una medida comparable a las revoluciones formales de los años veinte. De hecho, más que actuar como un catalizador de nuevas formas, el ordenador parece potenciar las ya existentes. ${ }^{163}$

Este discurso rebosa desilusión. Potenciar lo ya existente como mal menor, como resignación. El autor intentará encontrar una salida, en ese mismo texto, mediante una idea que enlace contemporaneidad con vanguardia y que veremos un poco más adelante. Pero quiero concluir hurgando en esa herida por la que respiraba la academia digital durante el cambio de siglo. He mencionado hechos históricos concretos como el 11-S y un clima milenarista poco fiable como marco histórico. Existe otro acontecimiento que fue igual de concreto pero menos llamativo que el primero. También menos abstracto y retórico que el segundo. Para los intereses de esta investigación, quizá sea más influyente que ambos desde un punto de vista fáctico.

¿A qué acontecimiento me refiero? Al estallido de la burbuja puntocom. Entre los años 1997 y 2000, tuvo lugar una sobreestimación monstruosa de las compañías tecnológicas surgidas bajo el laurel digital, las nuevas tecnologías y la expansión de Internet. A partir de la primavera del año 2000, cuando los activos alcanzaron su máximo, los unos y los ceros se despeñaron NASDAQ abajo. Pérdidas masivas y quiebras definitivas. La Burbuja puntocom ejerció de tamiz inexorable. Los supervivientes salieron saneados y hasta fortalecidos. Recordemos un ejemplo de estos últimos. Noviembre de 1995, Pixar estrena Toy Story (John Lasseter, 1995) -primer largometraje realizado íntegramente en CGI- al tiempo que lanza su OPV (oferta pública de venta) en Bolsa. El primer día, Pixar casi dobló el precio inicial por acción fijado en 12 dólares. En apenas una semana, sus acciones siguieron revalorizándose hasta alcanzar picos cercanos a los 50 dólares. A día de hoy y desde octubre del 2006, Pixar cotiza en el interior del

\footnotetext{
${ }^{163}$ MANOVICH, Lev, "La vanguardia como software" en Artnodes, Revista de Arte, Ciencia y Tecnología, Barcelona: Universitat Oberta de Catalunya, no 2, ISSN 1695-5951, 2003. [El texto original es del año 2002. La cursiva es mía] <http://www.uoc.edu/artnodes/espai/esp/art/manovich1002/manovich1002.html> [consulta: 20-102015].
} 
conglomerado Disney. El precio de la acción levita ajena a turbulencias por encima de los 100 dólares. ${ }^{164}$ Pixar, como explicaré más adelante, buscó y cabalgó el tsunami finisecular sobre la tabla del relato cinematográfico más ortodoxo.

La segunda mitad de la década de los noventa fue la de la euforia digital. El Muro se había desmaterializado hasta convertirse en souvenir. Mandela se enfundaba la springboks. Un hombre armado con bolsas de supermercado había derrotado simbólicamente -iel relato, los relatos, que hizo y hace Occidente a partir de esa imagen- a los tanques en Tiananmén. Europa -harta de automutilarse- cantaba a Beethoven. Estados Unidos seguía preservando la democracia y el petróleo allende sus fronteras. Fukuyama ${ }^{165}$ proclamaba el fin de la Historia mientras el Prozac y la Viagra declaraban el estado de felicidad química. Todo iba a ser digital, virtual y automático. Lo que, en aquellos momentos, era sinónimo de global y mejor. Más rápido, más liviano, más fácil, más libre, más barato y más bello. Días de vino y rosas patrocinados por la New Media Theory y la New Economy. Todo iba a ser mío y tuyo al mismo tiempo. Sin clases ni fronteras. El mundo desarrollado no veía necesario renunciar a la lógica de la abundancia. ${ }^{166}$ Tampoco al optimismo. Había encontrado la fórmula del crecimiento perpetuo y amenazaba con erradicar la pobreza del resto del planeta.

Es muy tentador, pero esta euforia no puede ser vista -a toro pasado- como una leyenda milenarista que, con el apocalipsis a la vuelta de la esquina -no resultó ser el paranoico efecto 2000-, observa a sus protagonistas entregarse al desenfreno. El ascenso y la caída no respondían a ese tipo de universos legendarios, sino a hechos irrefutables. La sensación de desplome fue mayor no porque fracasaran los principios sobre los que se estaba construyendo -que también-, sino porque, como dije páginas atrás, había que seguir pensando con las viejas fórmulas de siempre. En una utopía precipitada donde aseguraban haber liberado a los cuerpos y a las representaciones artísticas y sociales de la materia y de los relatos, resultó agónico volver a enfrentarse a ellos.

\footnotetext{
${ }^{164}$ Para hacerse una idea de lo que suponen esas cifras, se puede comparar la cotización de Pixar y Disney con la alcanzada por uno de los paradigmas de la Burbuja puntocom dos décadas atrás. TheGlobe.com, una compañía fundada por veinteañeros en 1994 cuyos difusos y primarios servicios digitales consistían en chat, foros y una miscelánea de noticias, realizó su OPV en noviembre de 1998 fijando un precio inicial por acción de 9 dólares. Ese mismo día cerró a más de 63 después de haber alcanzado los 97 . Menos de doce meses después, la acción pasó a cotizar a 10 céntimos.

${ }^{165}$ FUKUYAMA, Francis, El fin de la Historia y el último hombre, Barcelona: Planeta, 2002.

166 URRUTIA, Juan, "Redes de personas, Internet y la lógica de la abundancia. Un paseo por la Nueva Economía" en Ekonomiaz. Revista vasca de economía, San Sebastián: Departamento de Hacienda y Finanzas, no 46, Panorama de las industrias de red, ISSN 0213-3865, 2001, pp. 182-201.
} 
No es tanto una cuestión de verdadero o falso, como de ansiedad profética, de mala praxis académica, de plazos urgidos por beneficios y, sobre todo, de un deficiente conocimiento y análisis científico -y por lo tanto humano- del momento histórico. Visto con perspectiva de casi tres lustros, esos errores pueden resultar comprensibles. Lo inaudito es edulcorarlos o perseverar en ellos.

Efectivamente, la tecnoutopía despertó y el lápiz seguía allí.

\subsection{Supervivencia y biología de las narraciones}

Tras el inicial planteamiento semiótico y después de haber dado cuenta de la evolución histórica y estética del relato, incluyendo los años de plomo de la teoría digital, llega el momento de concluir el recorrido. Lo hago regresando al comienzo, cerrando el círculo. Es el momento de hablar de la unidad significante: de la imagen y del fotograma. Para ello recojo la idea de supervivencia que une a Warburg con Didi-Huberman. Aquí me interesa menos la genealogía trazada por el segundo que el concepto en sí mismo. Quiero decir, ahora no aplicaré la supervivencia de la imagen en términos iconográficos y formales, sino como extensión biológica y como metáfora.

Por lo tanto, hablaré de una imagen alejada de la típica historia estetizante. El análisis de la imagen -y del resto de las artes visuales- ha sido víctima de la filiación indiscriminada. Hemos sobreestimado las nociones de herencia y estilo. En el caso específico del cine, han constituido el soporte de toda una (in)cultura de la cinefilia. En todo caso y sin excepción, las ideas de estilo y herencia -presentes e indiscutibles en la historia del arte-, deben ser redefinidas y delineadas por la fisiología humana. La mejor manera de entender esta relación es abrir los oídos a todo lo que pueda decir la psicología evolucionista y la neurociencia sobre la base fisiológica de las imágenes. Lo que son en sí mismas y lo que supone para nuestro cerebro enfrentarse a ellas.

Es decir, historiar la imagen no consiste en saber quién fue el primero en modelarla con unas formas determinadas, ni cómo ese modelado se expande a través del tiempo de acuerdo a estructuras más o menos flexibles (la fórmula esquema+corrección de Gombrich, por ejemplo). La historia de la imagen tampoco es la historia de la memoria tal y como la entendía Bergson, esto es: "una supervivencia de las imágenes pasadas"167 que se mezclarán con nuestra

\footnotetext{
${ }^{167}$ BERGSON, Henri, op. cit., p. 83.
} 
percepción del presente, contaminándola y sustituyéndola. Toda historia de las imágenes debe comenzar por la asunción de criterios universales de formación y lectura. Es decir, los universales formales ya citados son producto de un factor suprauniversal: la evolución de las habilidades cognitivas del Homo sapiens. Sin posible registro fósil de los cuerpos blandos, hoy todavía se sigue discutiendo -a través de restos indirectos- cómo aconteció tal evolución. Superada en parte, pero de gran influencia durante su aparición, tenemos la teoría del Big Bang cultural. Steven Mithen recibió críticas feroces por su teoría de los módulos mentales según la cual el Big Bang cultural (60.000 - 30.000 a. C.) fue un producto directo de "la gran configuración final de la mente" ${ }^{168}$ La culminación de un proceso gradual iniciado con la especie. Teoría que luego sería reformulada varias veces sustituyendo la metáfora de las capillas de Mithen por la de los módulos cerebrales y la navaja suiza. A esta teoría de Mithen deberíamos añadirle dos hipótesis complementarias: la simple -pero decisiva, retenida y replicada- mutación genética, y la incidencia -desapariciones, supervivencias y reinvencionesde severas fluctuaciones climáticas.

Como todo lo relativo a la evolución pertenece a esos intrusos de la bata blanca que hozan el suelo de las humanidades, conviene aclarar lo que Didi-Huberman señala sobre el posible darwinismo de la supervivencia en Warburg. ${ }^{169}$ El criterio puede manejarse -como lo hizo su autor- en un sentido darwiniano, no en uno spenceriano. ${ }^{170}$ La historia del arte no puede adoptar la selección natural como agente ejecutivo que criba formas y estilos débiles. Aplicar la supervivencia spenceriana del más apto, sería el sueño de una historiografía determinista cuyo proyecto teleológico fuera el de un progreso lineal destinado a lograr la Singularidad.

La supervivencia darwiniana en términos estéticos encuentra acomodo en dos sucesos. Uno, cuando el tiempo histórico se vuelve complejo. Esto es, asumir tiempos no-naturales: convenciones, anacronismos, imbricaciones y una periodización artificial ajena, digamos, a la cósmica y geológica. Dos, la forma superviviente no triunfa sobre sus congéneres, más bien acepta su propia desaparición temporal, su tránsito, su latencia y las posibles mutaciones en su

\footnotetext{
${ }^{168}$ MITHEN, Steven, Arqueología de la mente. Orígenes del arte, la religión y la ciencia, op. cit., p. 169.

169 DIDI-HUBERMAN, Georges, op. cit., pp. 58-59.

${ }^{170}$ Tomar la interpretación de Herbert Spencer ha sido una de las falacias recurrentes a la hora de hablar de Darwin y de la evolución. Por desgracia, la historia del arte no iba a ser una excepción. Cualquier intento de introducir la evolución como criterio operativo de las humanidades, ha quedado ligado sin remedio a la idea de darwinismo social. La ideología neoconservadora y el liberalismo económico, lo emplea como legitimación ventajista de su ausencia de ética y de sus tropelías. La izquierda, por su parte, agita el espantajo del darwinismo social como demonio y obstáculo de un proyecto que más que humanitario o humanista es simplemente buenista.
} 
reaparición. Quiero asemejar la universalidad de la forma y de la imagen superviviente a un sintagma evolucionista certero y, mutatis mutandis, apropiado: la evolución convergente. Este matiz nos habla del surgimiento de características comunes -morfológicas y funcionales- en especies no emparentadas que tienen que hacer frente a un desafío medioambiental y fisiológico similar. La imagen superviviente no puede tomarse al pie de la letra como imagen convergente porque es el producto de una misma especie: nosotros. Sin embargo, la imagen superviviente adquiere el estatus de convergente cuando el creador accede a ella sin la mediación de la herencia o del estilo, tanto en un sentido estético como filogenético. Es decir, la imagen superviviente-convergente-universal no es una respuesta obtenida del catálogo cultural de la historia, es la forma innata -instintiva- que tenemos de expresar una idea ante unas necesidades determinadas. La presión selectiva-adaptativa de la evolución convergente, es aquí una presión de orden creativo-expresivo. Igual que con la imagen, sucede con el argumento. Es decir, con las constantes narrativas no explicables por transmisión cultural. Está Jung y luego citaré a Campbell, pero en términos actualizados tenemos a Christopher Booker. ${ }^{171}$ Más adelante pondré un ejemplo que unifica imagen, forma y narración.

De esta manera, agregar la evolución y la supervivencia al estudio de la imagen conlleva aceptar una temporalidad compleja, modelos narrativos no canónicos y un depósito de formas innatas modificadas o no por la memoria y la cultura. A su vez, en la imagen reposa la supervivencia de un relato que ha sufrido fracturas, declives y entierros en vida. En el vaivén de las estructuras del relato cinematográfico se quiso ver su disolución, sin prestar atención a las maniobras en la oscuridad realizadas por la imagen. Como he repetido ya en demasiadas ocasiones, declive, cambio, dislocación o intermitencia no son lo mismo que destrucción y desaparición. Coincido con Didi-Huberman cuando lo sintetiza de la siguiente manera:

Si la imagen (...) es un operador temporal de supervivencias -portadora, a este título, de una potencia política relativa tanto a nuestro pasado como a nuestra «actualidad integral» $y$, por ende, a nuestro futuro-, entonces hay que tratar de comprender mejor su movimiento de caída hacia nosotros, esa caída o ese «declive», incluso esa declinación, que no es (...) desaparición. ${ }^{172}$

\footnotetext{
171 "El punto de partida inexcusable es (...) el reconocimiento de que todos los tipos de historias, no importa lo profundas o banales que sean, surgen en última instancia de una fuente común, son modeladas por los mismos patrones básicos y están guiadas por las mismas leyes universales": BOOKER, Christopher, The seven basics plots. Why we tell stories, Nueva York: Continuum, 2004, p. 13.

172 DIDI-HUBERMAN, Georges, Supervivencia de las luciérnagas, Madrid: Abada, 2012, p. 92. [Las comillas y las cursivas son originales]
} 
De la cita de Didi-Huberman me interesan varias ideas, sobre todo, por su interrelación. No puedo separar la noción de imagen como operador temporal de supervivencias, de su potencia política y de una idea de declinación que invalida la de la desaparición. Es el momento de abandonar la obsoleta asociación entre relato y espíritu burgués que heredamos de las teorías analíticas de la segunda mitad de siglo XX, para entregar el relato a una raíz conductual que nada tiene que ver con grupos o sensibilidades sociales: la biología humana. El relato como privilegiado elemento de cohesión social, no es un constructo cultural, o al menos no es solo un constructo, es también una naturaleza. Somos productores y consumidores compulsivos de historias. Nuestro apetito es insaciable. En su ausencia o en su desequilibrio, reaccionamos como lo haríamos frente al hambre o frente a un virus, esto es, de manera puramente fisiológica.

Así como puse y pondré en duda el hipotético grado cero de la materia de la imagen, aviso también de su imposible grado cero lingüístico y comunicativo. En el caso de la imagen cinematográfica, esta imposibilidad deviene narrativa por tres causas fundamentales: analogía, movimiento y percepción.

Primera causa: el poder para la analogía. Descártese el uso de analogía como antónimo de digital. Existe analogía en la imagen digital y en la de síntesis más allá de la semejanza -del grado de iconicidad- con el referente. La imagen cinematográfica digital y de síntesis también poseen un poder analógico en lo relativo a las formas, a los atributos, a los comportamientos y a los estados. Son imágenes que, como no podía ser de otra manera y hasta en los casos de la ciencia ficción más extrema, siguen remitiendo a procesos vitales y estéticos conocidos por la cultura y/o vislumbrados por el instinto. Rodowick certificaba a regañadientes la supervivencia de la analogía en el medio digital. Lo hacía aceptando su indispensable función en el reconocimiento de los espacios, a pesar de haber perdido sus anclajes con la sustancia y el índex. ${ }^{173}$ En su apostilla virtualista, Rodowick ignoraba que la analogía implica diferencia entre los términos comparados o reflejados, no una identificación física y emocional exacta. Por pura definición, la analogía es una relación de semejanza entre cosas diferentes. Así, la analogía abre un hueco al concepto semiótico de isomorfismo. O lo que es lo mismo, la analogía abunda en la imposible identificación absoluta del signo con lo representado, al tiempo que introduce el proceso de percepción como condicionante biocultural.

\footnotetext{
${ }^{173}$ RODOWICK, D. N., The virtual life of film, Cambridge y Londres: Harvard University Press, 2007, p. 9.
} 
Segunda causa: el movimiento no solo genera, también -como diría Metz- actualiza. Esto podría ser explicado de acuerdo a una división más importante de lo que Deleuze ${ }^{174}$ dejaba entrever en su estudio. La diferencia entre imagen-movimiento e imagen en movimiento. La imagen-movimiento sería aquella capaz de albergar o de formar parte de todos los procesos cinematográficos regidos por o relacionados con el movimiento: el discurrir de $\mathrm{x}$ imágenes por segundo, el movimiento interno de lo representado, la movilidad de la cámara, la relación entre imágenes y el montaje externo y físico de los fragmentos. La imagen en movimiento sólo cumpliría con los dos primeros requisitos. Sería un tipo de imagen representativo pero no exclusivo del modelo de representación primitivo.

En todo caso, la ausencia de cualquier tipo de movimiento no implica, necesariamente, la desaparición del componente narrativo. No es el lugar para desarrollar cómo la imagen estática sigue narrando en subgéneros como el fotoperiodismo, la fotonovela, el retrato, el collage o el fotomontaje. También mediante la participación humana, haciendo la imagen pensativa, que diría Barthes.

Tercera causa: la percepción. Aquí cabe introducir un factor nuevo: la abstracción. Decía Arnheim que, durante el siglo XX, el hombre superó la dificultad de percibir y descifrar las representaciones abstractas. No estoy de acuerdo ni en lo novísimo del fenómeno, ni con las razones que ofrecía Arnheim para tal superación. Él -desde su concepción gestáltica- lo atribuía a una especie de entrenamiento o costumbre cultural a la hora de contemplar formas puras:

Tras medio siglo contemplando arte abstracto nuestros ojos se han acostumbrado a apreciar el impacto físico y visual de una acción llevada a cabo por formas puras. ${ }^{175}$

La realidad es que nunca fue una superación, solo fue una de las manifestaciones -quizá forzada o evidenciada por la mayor producción de arte abstracto- de nuestra facultad universal e innata para dotar de valor narrativo a lo abstracto. Ya fuera en el siglo XX o en la Prehistoria, la búsqueda de patrones narrativos en conjuntos abstractos es una de las manifestaciones decisivas de la biología de las imágenes. Hay que olvidar la falsa equivalencia entre

\footnotetext{
${ }^{174}$ DELEUZE, Gilles, La imagen movimiento. Estudios sobre cine I, Barcelona: Paidós, 1984.

${ }^{175}$ ARNHEIM, Rudolf, El poder del centro, Madrid: Alianza, 1998, p. 130.
} 
representación y figuración, ya que dichos patrones narrativos no tienen por qué ser figurativos. La Gestalt (similitud, continuidad, contraste, proximidad, cierre, destino, pregnancia) no es suficiente, hay que pedir ayuda a la fisiología del cerebro. Todo empieza en nuestra infancia como especie y en nuestra infancia como individuos. La biología nos da la bienvenida a la exploración visual de la vida a través de un tipo de mirada que conocemos como preferencial. No es un derivado de la impronta con la que algunos animales quedan ligados a sus madres, sino algo más interesante para esta investigación. La mirada preferencial nos habla de nuestro impulso innato para atender y preferir, en igualdad de condiciones lumínicas y angulares, los patrones historiados (rayados) a los lisos. El temprano test de Teller valida el fenómeno.

Allí donde la imagen no llega o se empeña en conservar o provocar afasia y ceguera, aparece nuestro cerebro para zurcir lo que nosotros queremos que diga. El verbo zurcir parece una nueva metáfora, pero es escrupuloso lenguaje recto si de lo que se trata es de describir -que no de interpretar- el funcionamiento cerebral a la hora de procesar ciertas imágenes de apariencia irreductible. Quizá parezca un mero cambio nominal de la compleción gestáltica, pero zurcir la abstracción va más allá. Fue y es uno de los recursos de supervivencia básicos urdidos por nuestro cerebro sapiens. Algunos han llegado a definir el arte -de manera biológica pero reduccionista- como el juego cognitivo de los patrones destinado a combatir la entropía y a resolver contradicciones. ${ }^{176}$ El arte abstracto, así, encontraría su razón de ser fisiológica si fuera considerado como un estímulo supernormal intencionado, esto es, como clímax del juego.

Esta actividad cerebral tuvo y tiene numerosos correlatos y dos objetivos básicos: identificar hacer manejable- la información y ejercer de pegamento social, de alimento y de material para la organización, la evaluación, la estrategia, la predicción y la construcción grupal. ${ }^{177}$ Entre sus correlatos destacan: el entrenamiento cognitivo -el fitness, como se denomina en la jerga científica no solo anglosajona- y la relación con los centros de recompensa. ${ }^{178}$ En estos dos últimos casos, entran en juego los grados de aleatoriedad y complejidad de los patrones.

\footnotetext{
${ }^{176}$ BOYD, Brian, op. cit., p. 15

${ }^{177}$ Las historias como herramienta social están muy ligadas a la Teoría de la mente. Abandonada -o identificada como insuficiente e insatisfactoria- la introspección, nos buscamos y nos comprendemos en los otros al tiempo que evaluamos deseos, intenciones y decisiones. La Teoría de la mente, más allá de la cognición y de la aun discutida labor de las neuronas espejo, debe suponer un escalón ineludible en el estudio de la ética, de la moral y de las emociones.

${ }^{178}$ RAMACHANDRAN, Vilayanur S., The tell-tale brain. A neuroscientist's quest for what makes us human, op. cit., p. 390.
} 
Nuestra enorme capacidad predictiva, fruto de un impulso neuronal desesperado, modifica el rango de atención, comodidad y placer dependiendo de la dificultad encontrada. La búsqueda de este tipo de soluciones visuales, en lugar de ser frustrante es intrínsecamente placentera. ${ }^{179}$ Tal vez sea el placer el elemento más estudiado por la ciencia. El uso de la imagen cerebral para rastrear, localizar y medir la respuesta a los estímulos, se ha convertido en una herramienta fiable. Del mismo modo, el placer también es el correlato cuya trazabilidad histórica más ha avanzado. La rápida y satisfactoria resolución de patrones, ha quedado emparentada con la necesidades de supervivencia de nuestros ancestros. Por ejemplo, a la hora de descubrir el camuflaje de posibles depredadores o de una primaria identificación de formaciones $-\mathrm{y}$ hasta de paisajes enteros- geológicas beneficiosas.

La necesidad fisiológica de las historias encuentra una referencia originaria en esas actividades. La historia ya estaba ligada a los criterios de estructura, ritmo, patrón, regularidad, exceso, contraste, distorsión, placer y simetría en su vertiente biológica antes que estética. Cuando Aristóteles quiso estructurar el relato, lo que de verdad estaba haciendo era transcribir el orden que su cuerpo le susurraba. Nuestras necesidades, durante decenas de miles de años, siempre fueron amigas del orden y de la regularidad.

La capacidad terapéutica y reguladora del arte debe buscarse en estos niveles, no en los de una espiritualidad indefinida y, más que borrosa, borrascosa. Así mismo, la religión y lo sobrenatural necesitan del arte de la historia como precursor, no al revés. Ambas toman forma histórica y nos llegan a parecer naturales gracias a las narraciones y a las imágenes. Las historias y las imágenes modelan -que no dictan- nuestras creencias. En ambos casos y con Joseph Campbell en el recuerdo, esas narraciones y sus imágenes asociadas son formas supervivientes -no siempre convergentes-, porosas y sensibles a la mutación.

Después del trabajo de los psicoanalistas quedan pocas dudas de que los mitos sean de la naturaleza de los sueños (...) Con su descubrimiento de que los patrones y la lógica del cuento de hadas y del mito corresponden a los del sueño, las hace mucho desacreditadas quimeras del hombre arcaico han regresado dramáticamente al campo de la conciencia moderna (...) Aquí, como un fluoroscopio, están revelados los escondidos procesos del enigma del Homo sapiens, occidental y oriental, primitivo y civilizado, contemporáneo y arcaico. El

${ }^{179}$ Ibíd., pp. 441 y 448-450. 
espectáculo completo está ante nuestros ojos. Solo debemos leerlo, estudiar sus patrones constantes, analizar sus variaciones y llegar a un entendimiento de las fuerzas profundas que han dado forma al destino humano y que deben seguir determinando nuestras vidas, tanto privadas como públicas. ${ }^{180}$

La cita es un poco larga, pero quería respetarla. En ella encuentro ideas que han visitado esta primera parte de la investigación. A destacar el arcaísmo, el eterno regreso de los viejos problemas, sus estructuras y alteraciones, nuestra obstinada fisicidad, el destino desligado del progreso y un determinismo biológico abolido por la apertura, la libertad y impredecibilidad ${ }^{181}$ de la evolución. Campbell, de acuerdo a la lógica del momento (1949), apuntaba al sueño. Hoy, sin haber concluido la exploración onírica, sin haber descifrado por el completo el sueño, tenemos herramientas para profundizar en su función como origen de los mitos. Dentro de la psiquiatría y de la cognición, es Allan Hobson ${ }^{182}$ quien más crítico se ha mostrado -negando su validez científica- con el método y el legado del psicoanálisis. Su modelo analítico (activaciónsíntesis) parte de una idea que abunda en el error categorial de la dualidad cartesiana: la fuerza primaria que motiva el sueño no es psicológica, sino fisiológica. Una fisiología neuronal en vías de esclarecimiento.

Así, el Homo sapiens resultó ser el Homo fictus. El gran simio de mente fabuladora para el que las narraciones son tan importantes como el agua para el pez. ${ }^{183}$ Somos románticos -en sentido dieciochesco- por naturaleza, necesitamos el mito y el dogma. Mito y dogma son dos de las formas que hemos habilitado para, a través de estructuras narrativas repletas de constancias, intentar explicar problemas irresolubles. Lo cual no supone que seamos adictos a la ficción, esto sería declararla un simple artefacto cultural cuando es parte consustancial de nuestro ser. A lo que sí somos adictos es, primero a la forma, luego a su significado y, por último a los sentidos que ese significado pueda generar. Somos románticos porque, como diría Schlegel, ${ }^{184}$ buscamos representar una materia sentimental de forma fantástica.

\footnotetext{
${ }^{180}$ CAMPBELL, Joseph, El héroe de las mil caras. Psicoanálisis del mito, México D.F.: Fondo de Cultura Económica, 2006, pp. 233-234.

${ }^{181}$ Al menos hasta que la evolución admita la volición como mecanismo regulador. Quizá llegue personalmente estoy seguro de que lo hará-, pero aún no estamos en ese escenario y, por lo tanto, no tiene sentido jugar a profetas.

${ }^{182}$ Su fundacional artículo: HOBSON, Allan; MCCARLEY, R., "The brain as a dream-state generator. An activation-synthesis hypothesis of the dream process" en American Journal of Psychiatry, no 134, 1997, pp. 1335-1348. Sus estudios sobre el sueño actualizados: HOBSON, Allan, Psychodynamic Neurology. Dreams, consciousness, and virtual reality, Boca Ratón: CRC Press, 2014.

${ }^{183}$ GOTTSCHALL, Jonathan, op. cit., p. 9.

${ }^{184}$ SCHLEGEL, Friedrich, op. cit., p. 79.
} 
Todas las células y programas vitales están sostenidos por narraciones, de lo más profundo a lo más banal: de la religión a la nación, de la familia al ocio. Huizinga estuvo acertado cuando reclamó algo similar para el juego: el Homo ludens. ${ }^{185}$ De hecho, su tesis esencial es idéntica, porque el juego no es más que una narración donde florecen la implicación corporal y los verdaderos principios de la interactividad. El juego, en tanto innatismo que precede a la cultura -los animales también juegan-, fue otro de nuestros mecanismos de supervivencia y socialización. Huizinga hablaba de un acto que trascendía el simple instinto de conservación. El juego poseía una función que ayudaba a otorgar sentido a la ocupación vital. El juego narrativo fue el primer metarrelato de nuestra especie: fue su contenido y fue su estructura.

A través de la narración, del sueño, del mito y del juego llegamos a la religión. Si nos hemos convertido en una especie mayoritariamente religiosa, no ha sido por una cuestión propagandística o por una evolución espiritual, sino por la predisposición narrativa y por el apetito semántico. Que la evolución carezca de sentido y de propósito, no impide -más bien propicia- que sigamos buscándolos. Siempre lo hemos hecho a través de las historias:

Si la mente fabuladora no puede encontrar patrones con significado en el mundo, buscará imponerlos (...) La mente humana está calibrada para detectar patrones. ${ }^{186}$

El arte griego se convirtió en nuestro referente universal porque fueron los que mejor entendieron esa necesidad. Institucionalizaron el orden. Pollitt dio en el clavo cuando extendió esta característica arraigada en todo individuo a la colectividad. Había que manifestar y, si era necesario, superponer el orden sobre "el flujo de la experiencia". El siguiente párrafo de Pollitt es magistral y, aunque no lo parezca, muy atrevido. Digo esto porque es una formulación encubierta del principio neurocientífico que rige la narración en tanto fenómeno productor y organizador de sentido.

Si la aparente mutabilidad del mundo físico y de la condición humana era una fuente de dolor y perplejidad para los griegos, el descubrimiento de un esquema permanente o un substrato inmutable (...) era una fuente de satisfacción, incluso de alegría, que tenía algo de religioso en su naturaleza. Pues el reconocimiento

\footnotetext{
${ }^{185}$ HUIZINGA, Johan, Homo ludens, Madrid: Alianza, 2007.

${ }^{186}$ GOTTSCHALL, Jonathan, op. cit., p. 141. [La cursiva es mía]
} 
del orden (...) hacía algo más que satisfacer su curiosidad intelectual (...) servía también como base de un ideal espiritual. ${ }^{187}$

De la Grecia clásica a las ciencias del cuerpo. Primero buscar, luego encontrar y, en el caso de hallar, fijar. De no hallar, inventar. Cadena que puede sintetizarse en un término acuñado por Michael Shermer: agenticity. ${ }^{188}$ Sin traducción directa (¿agenticidad?) al español, agenticity vendría a ser la tendencia natural a conferir significado, intención y voluntad a patrones más o menos dispersos, aleatorios y desprovistos de sentido. No existe una traducción, pero sí un concepto clínico previo, equivalente y riguroso: la apofanía de Klaus Conrad. ${ }^{189}$ La vivencia apofánica fue una de las fases en las que Conrad dividió el brote psicótico. El enfermo, en ese estadio, dejaba de controlar nuestra predisposición innata para atar cabos y patrones. La apofanía era el anormal desbordamiento en esa atribución de conexiones y significado a aquello que, a priori, no lo tiene. La apofanía era la disfunción -por exceso- de una facultad común e inherente a la especie, no la aparición de una nueva capacidad. Una "conciencia de significación anormal" que nos ofrece, aun hoy, otra de las claves para seguir levantando fronteras entre la imagen y la realidad. No hacerlo es la enfermedad:

Este simple saber el significado, sin tener que preguntar por qué se sabe, caracteriza toda percepción delirante. El enfermo delirante se comporta como un hombre ante una revelación. El significado se le impone de un modo manifiesto (revelado), y por ello el enfermo no puede comprender las dudas que las demás

\footnotetext{
${ }^{187}$ POLLITT, J. J., Arte y experiencia en la Grecia clásica, Bilbao: Xarait Ediciones, 1987, p. 12.

${ }^{188}$ SHERMER, Michael, The believing brain. From ghosts and gods to politics and conspiracies. How we construct beliefs and reinforce them as truths, Nueva York: Times, 2011, p. 84. [paginación correspondiente a la edición epub]. Este libro de Shermer puede calificarse como la puesta al día teórica del esqueleto que recorre su obra: el fundamento biológico de las creencias humanas. Su preocupación arrancaba en 1997 con una publicación más pragmática construida sobre casos concretos: SHERMER, Michael, Why people believe weird things. Pseudoscience, superstition, and other confusions of our time, Nueva York: Henry Holt, 1997. Yo he manejado la reedición revisada de 2002 de First Owl Books.

${ }^{189}$ El neurólogo alemán elaboró su estudio sobre la esquizofrenia recopilando casos prácticos del hospital militar que dirigió durante la Segunda Guerra Mundial (1941-1942). Conrad se acercó al delirio bélico desde la fenomenología y los postulados gestálticos. La apofanía fue rescatada, antes de la agenticity de Shermer, por Peter Brugger para analizar y rastrear la psicosis de Strindberg en pasajes de su obra: BRUGGER, Peter, "From haunted brain to haunted science. A cognitive neuroscience view of paranormal and pseudoscientific thought" en HOURAN, James; LANGE, Rense (eds.), Hauntings and Poltergeists. Multidisciplinary perspectives, 2001, pp. 195-213. Su alusión a Conrad se puede encontrar en la página 204.

Una traducción del original (1958) de Conrad: CONRAD, Klaus, "La Esquizofrenia incipiente. Intento de un análisis de la forma del delirio" en Revista de la Asociación Española de Neuropsiquiatría, vol. 14, no 49, 1994, pp. 319-328.

<http://www.revistaaen.es/index.php/aen/article/viewFile/15377/15238> [consulta: 20-10-2015]
} 
personas tienen. Hemos elegido para el modo de vivenciar de la conciencia de significado anormal la palabra apofanía. ${ }^{190}$

En la salud o en la enfermedad -¿en la posmodernidad?-, una vez hallado o recreado el significado, el patrón originario deviene creencia. Y, como bien sabemos, ante una creencia se abren dos caminos: la sacralización y la herejía. La historia, ahí, se convierte en un mecanismo de poder y de control sin igual gracias al encadenamiento de estas actividades cerebrales. En el nombre de los mitos y de los relatos religiosos se ha derramado más sangre que por cualquier otra consigna, pero también han sido fundamentales en la ordenación y en la regulación de nuestras sociedades. Han sido claves a la hora de digerir la angustia y la confusión provocadas por la incomprensión de nuestra propia existencia: in gods we trust. ${ }^{191}$ Hölderlin ya sufrió la angustia que genera preguntarse por los dioses en lugar de entregarse a ellos. En la triple escritura de la última estrofa de Vocación del poeta dejó constancia del problema y quién sabe si de la solución.

Pero el hombre puede quedarse, cuando es preciso, solo frente a Dios. Su candor lo protege.

$Y$ no necesita armas y argucias, hasta el momento en que la ausencia de Dios lo ayude. ${ }^{192}$

Los mitos levantados en torno a la creación y sus dioses son -para desgracia de muchos- una estrategia darwiniana de supervivencia individual y colectiva. Evolucionamos para creer en ellos. Es más, son una de nuestras mejores creaciones. Todo dios es un relato más o menos

\footnotetext{
${ }^{190}$ Ibíd., p. 322.

${ }^{191}$ Título de la que, más de una década después, tal vez siga siendo la obra de referencia del estudio de las creencias religiosas desde los postulados de la psicología y la biología evolucionistas y de las ciencias de la cognición, la ya citada: ATRAN, Scott, In gods we trust. The evolutionary landscape of religion, op. cit., 2002.

192 HÖLDERLIN, Friedrich, Hölderlin. Poesía completa, Barcelona: Ediciones 29, 1977, p. 257.

Procedo a citar la perfecta nota que Federico Gorbea incorpora en esa misma edición: "En las dos redacciones anteriores de este poema, Hölderlin había escrito: 'en tanto Dios no falte' y: 'en tanto Dios se mantenga cerca de nosotros'. El texto de la última versión se opone a los otros dos. No se trata ya de que Dios afirme, con su presencia, al hombre. El verso definitivo puede tener el sentido paradojal y realista de que, librado de la presencia demasiado absoluta, abrumadora del Ser total, el hombre queda en condiciones de lograr la síntesis de su naturaleza singular por esa vía negativa que, sin embargo, exige toda su capacidad de despojamiento, crudeza y flagrancia."

Exacto: crudo despojamiento de nuestra propia naturaleza. Es posible que prescindir de Dios o de los dioses no sea solo una opción intelectual aprendida, sino un error. Es decir, un comportamiento anómalo desde un punto de vista biológico. ¿Se puede nacer ateo? Tal es la pregunta.

Esta estrofa y la breve explicación a su reescritura también aparece en uno los diálogos de Fritz Lang en El desprecio (Le mépris, Jean-Luc Godard, 1963).
} 
original, más o menos cruel, más o menos funcional, más o menos ridículo. Los dioses nos ponen en valor, nos hablan de lo fascinantes y de lo poderosos que somos. Unamuno lo condensó en uno de sus penetrantes aforismos: "el hombre, que ha hecho a los dioses a su imagen y semejanza, es capaz de todo" ${ }^{193}$ En un mundo de utopías impacientes y de deslumbrantes avances científicos, esta realidad sigue generando contrastes:

Hemos creado una civilización de la Guerra de las Galaxias compuesta por emociones de la Edad de Piedra, instituciones medievales y tecnología demiúrgica. ${ }^{194}$

Lo que queda claro es el origen: el cerebro. Al mismo tiempo, una máquina de reconocimiento de patrones, un motor de creencias y un generador de causalidad. El cerebro, y en buena medida el mismo arte, más que en lo permanente y en lo inmutable está interesado en las constantes y en la coherencia. En su frenesí obsesivo-compulsivo, convierte la visión en un proceso activo destinado a extraer la información esencial para discernir y categorizar. ${ }^{195} \mathrm{La}$ evolución y funcionamiento del cerebro estuvo enfocado a la supervivencia tan a fondo y durante tanto tiempo, que hoy sigue analizando los hechos en términos causales. ${ }^{196}$ Un aspecto que, en su momento -en los orígenes del género Homo-, fue clave para desarrollar las

\footnotetext{
${ }^{193}$ de UNAMUNO, Miguel, Amor y pedagogía, Madrid: Espasa Calpe, 1968, p. 24.

${ }^{194}$ WILSON, Edward Osborne, The social conquest of Earth, Nueva York y Londres: Liverlight Publishing Corporation, 2012, p. 18. [La traducción es mía]

${ }^{195}$ ZEKI, Semir, "El cerebro: en la búsqueda de lo esencial" en Elementos. Ciencia y cultura, Puebla de Zaragoza: Universidad Autónoma de Puebla, vol. 7, no 40, diciembre-febrero 2000-2001, p. 6.

${ }^{196}$ La causalidad está en la raíz evolutiva de nuestras creencias. David Hume ya atisbó este problema: a partir de un efecto no siempre se puede inferir la causa. No es susceptible de, valga la metáfora, una ingeniera inversa. El método científico se vale con frecuencia de la cadena causa-efecto dando por sentadas numerosas constantes que, en algún momento, podrían dejar de serlo. La correspondencia se toma como un axioma suscitado, según Hume, por pura intuición. La necesidad de las causas es una de las "máximas que, aunque pueden ser negadas de palabra, es imposible que los hombres duden en el fondo de ellas". La causalidad, así, deja de ser una explicación definitiva para convertirse en una esperanza o en una costumbre. HUME, David, Tratado de la naturaleza humana. Ensayo para introducir el método del razonamiento experimental en los asuntos morales, op. cit., [entrecomillado en p. 72] Bertrand Russell -con el primer escepticismo de Hume en el recuerdo- afirmó que el concepto de causa era primitivo y acientífico. Diríase que una superstición. RUSSELL, Bertrand, El conocimiento humano, op. cit., p. 461. El mismo Russell al que, durante una brillante entrevista para televisión realizada a finales de los años cincuenta, le preguntaron: “¿Cree que hay una razón práctica que explique las creencias religiosas?" El filósofo inglés contestó: "No puede haber una razón práctica para creer en lo que no es verdad". Se equivocó. Existió una razón que, además, completaba un sintagma perfecto con el adjetivo práctica. (cfr. WILSON, Edward Osborne, Consilience. La unidad del conocimiento, op. cit., pp. 382 y 385.) La entrevista se puede ver en: <https://www.youtube.com/watch?v=mpJZsNbC7Pg> [consulta: 20-10-2015].

Para una crítica funcional e histórica del concepto de causalidad y de su operatividad científica: BUNGE, Mario, Causalidad. El principio de causalidad en la ciencia moderna, Buenos Aires: Eudeba, 1961.
} 
primeras herramientas ${ }^{197}$, pero que con el tiempo -abandonadas las praderas del Pleistoceno y asentados en las universidades del Holoceno- se ha convertido en el pecado original de numerosas metodologías. Todo debe tener una causa y un efecto; un motivo y un fin. Por desgracia, la realidad no siempre responde a esta simplicidad.

Todavía no está resuelto si debemos considerar las narraciones como una adaptación evolutiva, como un subproducto o como un modo mixto. ${ }^{198}$ Lo que parece indudable es que estamos ante un factor primitivo, innato, decisivo y perenne que ha modelado nuestras mentes $-y$ por lo tanto nuestro arte y nuestras emociones- como ningún otro. Preinstaladas a modo de software en un cerebro que es cualquier cosa menos una tabla rasa, las historias igual que los rudimentos del lenguaje- se descomprimen, se expresan, se enriquecen, se diversifican y se alteran durante nuestro aprendizaje y experiencia. Esta profunda y carnal inscripción narrativa es lo que Damasio conoce como la naturalidad de la narración sin palabras.

Contar historias, en el sentido de registrar lo que sucede en forma de mapas cerebrales, es probablemente una obsesión del cerebro que, quizá, comience relativamente pronto, tanto en términos evolutivos como en términos de complejidad de estructuras neurales requeridas para generar relatos. Contar historias precede al lenguaje desde que es, de hecho, una condición indispensable para su existencia, y queda sita no solo en la corteza cerebral, sino en cualquier región del hemisferio derecho o izquierdo. ${ }^{199}$

En conclusión, existe un imperativo biológico para producir y consumir historias que preexiste y trasciende los conceptos de literatura, sueño y fantasía. Respecto a las imágenes, en ausencia de figuración y en presencia de la abstracción, prevalece la pura representación -

\footnotetext{
${ }^{197}$ Para un estudio actual sobre esa primitiva y directa relación entre cerebro, creencias, causalidad y herramientas: WOLPERT, Lewis, Six impossible things before breakfast. The evolutionary origins of belief, Londres: Faber \& Faber, 2010.

${ }^{198}$ Por ejemplo, Steven Pinker -defensor del arte como subproducto evolutivo de las adaptacionessugiere, que no afirma, que la narrativa de ficción podría haber evolucionado directamente como una adaptación. Denis Dutton es de la misma opinión: la narrativa de ficción no es una derivada cultural de las descripciones realistas, sino "una ramificación que existía de modo adaptativo en las primeras fases de la mente humana": DUTTON, Denis, op. cit., p. 162. Joseph Carroll es el más radical, su darwinismo literal y literario ha sido muy cuestionado. Carroll -en disputa parcial con Pinker- afirma que la narrativa de ficción trasciende de largo el placer y la cultura, siendo una de las constantes reguladoras de nuestra organización mental. El autor, además, incide en el papel de las narraciones dentro de nuestra capacidad social adaptativa: CARROLL, Joseph, Literary darwinism. Evolution, human nature, and literature, Nueva York: Routledge, 2004.

${ }^{199}$ DAMASIO, Antonio, The feeling of what happens. Body and emotion in the making of consciousness, San Diego: Harcourt Incorporated, 1999, p. 195. [La traducción es mía]
} 
artística o accidental- como vehículo de la historia. Lo que aquí he denominado de forma pedestre zurcir la abstracción, en términos neurológicos es conocido como constancia implícita. ${ }^{200}$ Esto es, aquellas representaciones donde el cerebro encuentra libertad o, mejor dicho, tiene la necesidad de completarlas y de interpretarlas de diferentes maneras. Parafraseando a Godard, si miramos una pared blanca el tiempo suficiente, terminaremos por ver algo. Parafraseando a Picasso mientras recordaba la capacidad de Miguel Ángel para ver en el interior del mármol:

El hombre comenzó a elaborar imágenes porque las descubrió en formación a su alrededor, a su alcance. Las vio en un hueso, en los salientes de una cueva, en un trozo de madera. Una forma le sugirió el cuerpo de una mujer, otra un búfalo, otra la cabeza de un monstruo. Hemos regresado a los tiempos prehistóricos. ${ }^{201}$

Este pequeño relato de Picasso no es científico, pero sirve como ilustración de algunas de las ideas tratadas en este apartado. Y algo más, sus palabras adquieren valor poético si las cruzamos con aquellas inolvidables escenas de El misterio Picasso (Le Mystère Picasso, HenriGeorges Clouzot, 1956) donde, sobre el inicial y absoluto vacío, las formas comenzaban a aparecer, a sobrevivir y a mutar. Junto a la abstracción como germen de la imagen y de la historia, cabe señalar con carácter de anuncio el mundo de la hipoformalización (lo veremos más adelante) y el del non finito, el de la continuidad (el efecto Kuleshov) y el de las pareidolias (de las constelaciones a las plastias paranormales). Con esto presente, ¿cómo extrañarnos del éxito de las teorías conspirativas? La conspiración podría ser calificada como una perversión quizá una parafilia- cultural de dicho imperativo biológico-narrativo. Shermer nos sugiere una paradoja final: creemos en cosas raras por la necesidad evolutiva de creer en cosas no raras.

En uno de los fragmentos del manifiesto de David Shields, encontramos la tragedia de los que proclamaron y proclaman el fin de las historias. Vuelvo a utilizar la palabra tragedia sin sensacionalismo. Lo hago porque ellos mismos, implícitamente, reconocen su inopia

\footnotetext{
${ }^{200}$ ZEKI, Semir, Visión interior. Una investigación sobre el arte y el cerebro, Madrid: Antonio Machado Libros, 2005, p. 41. Frente a la constancia implícita, la constancia situacional: representaciones donde el cerebro identifica y cataloga de inmediato a partir de la presencia de elementos comunes a otras situaciones.

${ }^{201}$ BRASSAÏ, Conversations with Picasso, Chicago: The University of Chicago Press, 1999, p. 95. [La traducción y la cursiva son mías]. Igual que Picasso, Carol Reed utilizó las nubes en El tormento y el éxtasis (The agony and the ecstasy, 1965) para ilustrar esta tesis.
} 
intelectual: "la ficción nunca ha sido menos importante para el sentido de la cultura". ${ }^{202}$ La frase, una de las muchísimas que se pueden extraer de su libelo, sintetiza dicha tragedia a nivel temporal (año 2010) y social (éxito de crítica y ventas). Efectivamente, la ficción, las historias, la narración y los relatos pueden variar su importancia y su influencia cultural. De hecho, puede que llegue un momento en el que -cumpliendo los deseos de Shields- su importancia sea igual a cero. La tragedia reside en ignorar que todos esos artefactos narrativos, antes que culturales fueron, son y serán biológicos. Como el fuego de Farocki: inextinguibles.

\title{
5.5. Corolario y metáfora. El intersticio del fotograma
}

\author{
«Un atisbo, a través de un intersticio capto» \\ Hojas de hierba (Walt Whitman, 1855) 203
}

«¿Qué intersticio escondido entre cada imagen, inexplorado?» Marcel Hanoun 204

Una de las razones por las que el relato cinematográfico siguió y sigue siendo una entidad funcional, es la capacidad de la unidad para narrar por sí misma. La imagen puede hacerlo desde el más absoluto aislamiento, desde el autismo. Este símil del autismo -recordemos el tautismo de Sfez- tampoco es gratuito. Cuando la imagen parece replegarse ${ }^{205}$ sobre sí misma, negando cualquier conexión o interacción con su entorno, sigue manteniendo una capacidad comunicativa residual pero esencial. La imagen se resiste a aceptar la terminología clínica de la afasia, de la anestesia, de la ceguera, de la agnosia y del autismo. En ocasiones, la relación de las imágenes y su capacidad para el relato con el autismo va más allá del símil.

Pienso en imágenes. Las palabras son como un segundo idioma para mí. Traduzco las palabras, tanto las habladas como las escritas, a películas de cine a todo color, acompañadas de sonidos, que pasan por mi mente como una cinta de video.

\footnotetext{
202 SHIELDS, David, Reality hunger. A manifesto, Nueva York: Knopf, 2010, epígrafe 523. [La traducción es mía].

${ }^{203}$ Verso original: "A glimpse, through an interstice caught".

He tomado la traducción de Pablo Ingberg para esta edición: WHITMAN, Walt, Hojas de hierba, Buenos Aires: Losada, 2009, p. 271. En la traducción de Eduardo Moga para la edición más reciente llevada a cabo por Galaxia Gutenberg (Barcelona, 2014, p. 405), la traducción es la siguiente: "Un vislumbre, atisbado por un resquicio".

${ }^{204}$ HANOUN, Marcel, Cine, cineasta. Notas sobre la imagen escrita, Santander: Shangrila Textos Aparte, 2014, p. 61.

${ }^{205}$ Primera acepción de autismo en el DRAE: “Repliegue patológico de la personalidad sobre sí misma”.
} 
Cuando alguien me habla, sus palabras se me traducen instantáneamente en imágenes (...) Uno de los misterios más profundos del autismo ha sido la notable capacidad de la mayoría de los autistas para sobresalir en su habilidad visual espacial. ${ }^{206}$

Está demostrado que el pensamiento visual es uno de los recursos cognitivos más eficaces del individuo autista. La capacidad del ser humano para hilar o detectar patrones como los relacionados con la simetría en un conjunto abstracto o sembrado de ruido, puede ser superior -no siempre- en casos estudiados ${ }^{207}$ de autismo. Paradójicamente, esta capacidad choca con la limitación del autista en el terreno del reconocimiento y de la aplicación de los patrones incluyendo los rostros ${ }^{208}$ - a las relaciones sociales y afectivas. Podríamos decir que esa puntual destreza del autista a la hora de manejar visualmente objetos y de resolver una constancia implícita, no encuentra correspondencia en las habilidades sociales que perfilan nuestra Teoría de la mente.

Después de lo expuesto en los últimos capítulos, puedo colegir que la imagen habilita la narración desde una naturaleza doble: la suya y la del espectador. La imagen está predispuesta $y$, al tiempo, predispone. Este argumento puede ser tomado como esencialista, como la ontología narrativa de la imagen. No puedo negarlo, pero hay que tener presente su estricto cariz semiótico y biológico. Hablo de signos y de fisiología, no de objetos poblados o vivificados por espíritus. Con los signos y la fisiología presentes, toda imagen predica en mayor o menor medida porque siempre "narra apoyándose en la función ostensiva". ${ }^{209}$ Gubern condensaba el triunfo y el asentamiento definitivo del cine en su capacidad para narrar mostrando. El cine reconciliaba, así, "las dos funciones fundamentales de la representación, la ostensiva (basada en la indicialidad peirciana inherente a la fotografía) y la fabuladora". ${ }^{210}$ A modo de corolario:

\footnotetext{
${ }^{206}$ GRANDIN, Temple, Thinking in pictures. My life with autism, Nueva York: Vintage Books, 2006, p. 20. [La traducción es de Marcos Giménez-Zapiola]

207 PERREAULT, A.; GURNSEY, R.; DAWSON, M.; MOTTRON, L.; BERTONE, A., "Increased sensitivity to mirror symmetry in autism" en PLoS One, 6(4): e19519. doi:10.1371/journal.pone.001951929-04-2011, 29-04-2011. <http://journals. plos.org/plosone/article?id=10.1371/journal. pone.0019519> [consulta: 21 10-2015]

${ }^{208}$ VALDIZÁN, J.R.; ZARAZAGA ANDÍA, I.; ABRIL VILLALABA, B.; SANS CAPDEVILA, O.; MÉNDEZ GARCÍA, M.; "Reconocimiento de caras en el autismo" en Revista de Neurología, vol. 36, no 12, 16-06-2003, pp. 1186-1189. Sobre los rostros y la incapacidad para descifrar identidad y empatía, cómo no recordar las dificultades de Hitler para dibujarlos: HILBERG, Raul, Perpetrators victims bystanders. The jewish catastrophe, 1933-1945, Nueva York: Harper Collins, 1992, p. 4.

${ }^{209}$ RUBIO ALCOVER, Agustín, op. cit., p. 72.

${ }^{210}$ GUBERN, Román, "100 años de cine" en Historia general del cine Volumen XII. El cine en la era del audiovisual, Madrid: Cátedra, 1995, p. 267.
} 
Incluso una imagen cinematográfica despojada de todo evento narrativo, de un estatismo en apariencia absoluto, y carente del ritmo sintáctico que propicia el montaje con otros planos, estaría ontológicamente impregnada de la temporalidad tanto en su producción como en su recepción. ${ }^{211}$

Aceptar estas explicaciones no resuelve el crucigrama narrativo, ni exime a este investigador de una penúltima pesquisa. ¿Es la narración una consecuencia lógica de esta temporalidad inherente de la imagen? Esta pregunta podría ser el lema de una plaza imaginaria donde lucharan Metz y Deleuze. Aquí he recurrido al primero para defender la supervivencia del relato y la del reinado de la historia; y he hecho lo propio con el segundo para mostrar mi disconformidad. Pero, llegado este punto, no tengo más remedio que invertir mis preferencias. Para Metz, la imagen como unidad constitutiva del cine queda eclipsada por la intriga que ella misma ayuda a tejer. El cine es un arte de las imágenes solo en la teoría porque:

El filme, que parece susceptible de dar lugar a una lectura transversal mediante la libre exploración del contenido visual de cada «plano», es casi siempre objeto de una lectura longitudinal, precipitada, desfasada hacia delante y ansiosa por la «continuación». La secuencia no suma los «planos», los suprime. ${ }^{212}$

Lo que nos cuenta Metz en su ensayo es que la narratividad necesita algo más que la imagen en sí para constituirse. ¿Cómo lo logra? Mediante el montaje -esa lectura longitudinal a la que alude- y mediante acumulación histórica. Metz y, como acabamos de ver Gubern, retoma las tesis de Morin en El cine o el hombre imaginario para manifestar que el cinematógrafo -el aparato, el invento, la cosa- devino cine -la historia, el relato, el afecto- gracias a la vía narrativa. Metz tiene razón, pero solo en parte. Suprime con demasiada ligereza la presencia de la imagen. $Y$ lo hace por culpa de nuestro cerebro, siempre ansioso por el significado, siempre dispuesto a simplificar en pos de un sentido. Metz no habla explícitamente de la fisiología del cerebro porque no eran años para ello, pero la prefigura con una imagen que para muchos, lamentablemente, sigue sin ser equivalente:

\footnotetext{
${ }^{211}$ PIÑERA TARQUE, Ismael, Mundos literarios. Relato literario y relato filmico, Kassel: Reichenberger, 2009, p. 147.

${ }^{212}$ METZ, Christian, "El cine: clengua o lenguaje" en op. cit., p. 71. [Las comillas son originales y denotan la precaución y el aviso del autor a la hora de emplear el término "plano" como sustituto de "imagen"]
} 
Logomorfismo, narratividad... es como si una especie de corriente de inducción enlazase las imágenes entre sí, se haga lo que se haga, como si al espíritu humano (tanto el del espectador como el del cineasta) le fuese imposible rechazar un «hilo» desde el momento en que dos imágenes se suceden. ${ }^{213}$

Es este punto donde Deleuze y esta investigación entran a puntualizar. Deleuze, frente a la narración como depósito histórico adquirido, recupera el valor de la unidad. Para el filósofo, la narración no es solo un dato, es un correlato de la ilustración: "una consecuencia de las propias imágenes aparentes (...) de las imágenes sensibles en sí mismas, tal como se definen primeramente por sí mismas" ${ }^{\prime 14} \mathrm{y}$, solo después, de sus combinaciones directas. Deleuze como casi siempre- es redundante y farragoso, pero su prosa, en esta ocasión, no menoscaba la razón. El punto de vista de Metz -recurriendo al fascinante y nunca finalizado debate de la antropología- sería nurture, mientras que el de Deleuze sería nature. Esta concepción deleuziana de una narración instalada en la imagen-tiempo, queda enfrentada con la de uno de sus discípulos, Parente: "la narración y el relato no son consecuencias de las imágenes (...) El relato cinematográfico, así como las imágenes y los enunciados que lo componen son resultado de procesos narrativos que ponen en imágenes." 215

¿Qué ha hecho Deleuze? detener el proyector y escrutar fotograma a fotograma. Detener, aislar y focalizar ni rompe la representación, ni fractura la narración. Con mayor o menor acierto, esto supone un síntoma evidente de que entre los tiempos y las metodologías de Metz y las suyas existe un salto. Deleuze pertenece a la generación que, al margen de etiquetas, convertirá ese fluir y devenir analítico en algo objetual y, en según qué casos, fetichista. Recurriendo a una analogía cinematográfica, la metodología de Metz sería parecida a una película de Antonioni, de Astruc y hasta del primer Godard. La de Deleuze, encontraría la suya en algún trabajo estructural de Sharits, Jacobs o Gehr.

\footnotetext{
${ }^{213}$ Me refiero a la equivalencia entre "cerebro" y "espíritu humano". Metz utiliza ese sintagma como podría haber utilizado solo la palabra "mente", "conciencia" o "espíritu". Que incluyera ese "humano" quizá permita apreciar que el autor intuía esa fisiología como verdadero hacedor del espíritu. Respecto a ese "se haga lo que se haga", cómo no relacionarlo con un determinismo biológico también latente.

Ibíd., p. 72. [Las comillas de "hilo" y la cursiva de "se haga lo que se haga" son originales. La cursiva de "espíritu humano" es mía]

${ }^{214}$ DELEUZE, Gilles, La imagen tiempo. Estudios sobre cine 2, Barcelona: Paidós, 1987, p. 45.

${ }^{215}$ PARENTE, André, Cinéma et narrativité, París: L'Harmattan, 2005, pp. 55-56. [Citado en BELLOUR, Raymond, El cuerpo del cine. Hipnosis, emociones, animalidades, op. cit., p. 187]
} 
Antes de desarrollar mi punto de vista sobre este problema, concluyo con un segundo y último corolario tomado de Raymond Bellour. Quien, por otra parte, conoce de sobra la relación entre Metz, Deleuze y Parente:

Así, casi siempre, hay consustancialidad entre imagen y relato, sean cuales fueren los modos de imágenes y de relatos, desde el cine clásico más orgánico a las disyunciones más flotantes del cine moderno, y hasta en la muy amplia mayoría de obras del cine de vanguardia o experimental. La dificultad procede más bien de la posibilidad de mostrar esa identidad, es decir, de saber cómo nombrarla. ${ }^{216}$

¿Qué hacer con la lasitud de ese casi siempre o con la de esa amplia mayoría? Considero que, más que precaución epistémica, es una indeterminación comprensible. También una representación de la impotencia de las humanidades. Sin un experimento replicable, sin una pauta o una fórmula común a todos los conjuntos, ante la imposibilidad de analizar todas y cada una de las obras so pena de convertirnos en los cartógrafos del poema de Borges ${ }^{217}$, el problema se vuelve una cuestión de irresponsabilidad: afirmar o negar. Como historiadores, debemos aceptar nuestras limitaciones, no camuflarlas. En lo que a mí respecta, prefiero seguir explorando el nexo entre ambos verbos. Y lo haré convirtiendo ese nexo disyuntivo en motivo para desplegar la metáfora del nexo entre imágenes. Lo hago volviendo a los orígenes, al cine mudo para, más tarde, alcanzar el momento actual.

Ya fuera en el genuino cine de atracciones del Modelo de Representación Primitivo o en su distorsionada reutilización para definir cierto cine espectacular contemporáneo, la imagen -en su individualidad- no ha dejado de generar significados. Aquel vetusto MRP podía sembrar dudas en la identificación de un relato complejo y estructurado, pero, cuidado, el modelo ya albergaba una narratividad identificable en aspectos inconexos pero indiscutiblemente concretos. En primera instancia por el gran poder referencial de una imagen que, en lugar de la transitividad alcanzada con la consolidación del Modelo de Representación Institucional, quedaba encerrada en la dimensión autárquica de un cuadro ajeno -con frecuencia- al fuera de campo. En segunda instancia por las composiciones plásticas de raigambre teatral o pictórica. Sin la necesidad de que esas composiciones recurrieran al cultismo propiamente

\footnotetext{
${ }^{216}$ BELLOUR, Raymond, op. cit., p. 188. [Las cursivas son mías]

217 "Con el tiempo, esos Mapas Desmesurados no satisficieron y los Colegios de Cartógrafos levantaron un Mapa del Imperio, que tenía el tamaño del Imperio y coincidía puntualmente con él”. BORGES, Jorge Luis, "Del rigor en la ciencia" en El hacedor, Madrid: Alianza, 2005, p. 119.
} 
dicho, toda organización de los elementos del cuadro recaía, por lógica y por costumbre cultural, en modos precedentes de esas dos formas artísticas. Además, el punto de vista del espectador continuaba gobernado por una disposición ortogonal y por la idea de proscenio. En tercera instancia, por el zurcido entre fotogramas como articulación espacio-temporal primaria.

A partir de este tercer punto pido licencia para la metáfora anunciada. Figura retórica que, entre otras cosas, servirá para probar la vigencia de la hipótesis de este apartado. Hablo de la metáfora del intervalo, del intersticio o del nervio del fotograma. De cómo cineastas y teóricos han partido o han llegado a una misma idea que explique el misterio narrativo. En el fondo y en la forma, la metáfora que ahora despliego es una continuación de la idea de supervivencia ya vista. Una supervivencia teórica que, además, introduce nociones de transmisión y herencia cultural. El intersticio entre fotogramas deviene meme con alto poder de supervivencia y con alto poder de contagio. ${ }^{218} \mathrm{Al}$ hablar del intersticio como meme, asumo que durante su propagación existe evolución y transformación. Porque aunque el meme, como el gen, es eminentemente conservador e imitativo -asegurar el núcleo informativo durante los procesos de replicado- su inserción en un contexto cultural o en un acervo de memes, facilita y acelera la mutación del original.

El meme del nervio del fotograma es, así, una metáfora anatómica y fisiológica que enlaza el antiguo mecanismo cinematográfico con el cerebral. No es una metáfora del montaje como mecanismo cerebral o de pensamiento (Eisenstein) ${ }^{219}$, ni del cine en su totalidad como máquina de pensar o como reemplazo de nuestro cerebro (las teorías del Epstein mecanicista de posguerra), sino una imagen retórica y biológica del intersticio en sí mismo. Ahora estamos explorando la neurona, sus dendritas y sus sinapsis. Su conjunto conforma un sistema nervioso primario que termina reflejándose en el zurcido cognitivo. El espacio entre imágenes considerado como unidad funcional y como entidad sináptica. El paso siguiente dentro de la escala narrativa en el que nos había dejado la autarquía narrativa de la imagen. Señalar que la metáfora es anatómica y fisiológica no es redundante. Avisa de un suceso que, en tanto

\footnotetext{
${ }^{218}$ DAWKINS, Richard, El gen egoísta. Las bases biológicas de nuestra conducta, Barcelona: Salvat, 1993, p. 219.

${ }^{219}$ El montaje como forma desplegable del pensamiento y de los mecanismos del cerebro, era donde se dirigía Eisenstein en su inconclusa y póstuma La no-indiferente naturaleza. EISENSTEIN, Sergei, Nonindifferent nature. Film and the structure of things, Cambridge: Cambridge University Press, 1987. Algunas de sus ideas son recogidas por Deleuze en el capítulo "Cine, cuerpo y cerebro, pensamiento" de La imagen-tiempo, op. cit., pp. 251-295.
} 
anatómico, forma parte -estática- de un conjunto y que, en tanto fisiológico, posee unas funciones -dinámicas- determinadas.

Me atrevo a decir que todo surge con Vertov, porque fue él quien antes (1919) y con mayor fuerza insinuó el poder de esa minúscula entidad que, a la vez, separaba y unía los fotogramas. Pero cuando Vertov acuñó el término intervalo no lo hizo para referirse directamente al nervio entre fotogramas, sino para designar la unión entre movimientos: "Una obra está hecha con frases, al igual que una frase lo está con intervalos de movimiento" ${ }^{220}$ Sin embargo, la idea de hallar y diferenciar una separación en medio de la contigüidad, acerca su teoría de los intervalos a la metáfora expuesta. Con Vertov se puede empezar a convertir la frontera entre movimientos, en frontera entre fotogramas. Ahí, en el intersticio, Vertov instala una fábrica literal de pensamientos. Poco después (1923-1928), Artaud ${ }^{221}$ rondaría la fina linde del intervalo cinematográfico para hacerle partícipe de aquella especie de vibración sináptica que el poeta apreciaba en la colisión entre imágenes del cine mudo. Un lugar donde el sentido lógico y articulado de las imágenes daba paso, a través de la unión y del choque, al sentir inconsciente del pensamiento.

Vertov, como Artaud, trasciende lo estrictamente material y espacial para desplegar todo su arsenal teórico. El nervio entre fotogramas no posee suficiente materialidad para obstaculizar la continuidad. De hecho, su razón de ser y su fuerza radican en su delgadez y en un poder ejecutivo invisible. Porque para Vertov, el intervalo deviene tiempo, ciencia y visión. El intervalo es el germen de la discontinuidad. Un agitador cerebral e intelectual, el cine-ojo que ilumina la visión. La liviana materialidad del intervalo y la continuidad visual simulada por el movimiento quedan ligados, por el contrario, a cuestiones de índole formal: a la noción de espacio, de puesta en escena, de drama y de rácord. Aspectos secundarios, convenciones, velos y nieblas para ojos; cosquillas para los nervios. ${ }^{222}$ Para Vertov, la ilusión de movimiento y continuidad son mero correlato de la sinapsis que acontece en los intervalos. El intervalo deviene disyunción, fuerza de diferenciación, salto intelectual y perceptivo. ${ }^{223}$ Esto es, el intervalo deja de ser un corte para representar y ejecutar la transición entre el tiempo estático

\footnotetext{
${ }^{220}$ VERTOV, Dziga, El cine ojo. Textos y manifiestos, Barcelona: Fundamentos, 1974, p. 18. [Traducción y selección de Francisco Llinás].

${ }^{221}$ ARTAUD, Antonin, El cine, Madrid: Alianza, 1982, p. 5. El poeta desarrolla la idea para hablar de $L a$ concha y el reverendo (La coquile et le clergyman, Germaine Dulac, 1928).

222 lbíd., p. 61.

${ }^{223}$ AUMONT, Jacques, Las teorías de los cineastas. La concepción del cine de los grandes directores, Barcelona: Paidós, 2004, p. 25.
} 
y el pensamiento móvil. ${ }^{224}$ Como dice Aumont: "es en esa distancia que aparece algo, ¿qué? un sentido, forzosamente" ${ }^{225}$

Es en esta articulación entre fotogramas donde según Francisco Javier Gómez Tarín ${ }^{226}$, comienza a operar la capa narrativa de la mostración. El principio de la ilusión de movimiento continuo. Una de las primeras contribuciones para que el cine terminara siendo una máquina semiótica y una herramienta de sentido. El intersticio es la encrucijada entre la narratividad inherente del fotograma y la narración desplegada -con dirección al relato- gracias al movimiento y la continuidad. Todas las miradas dirigidas a lo invisible, que no a lo inmaterial. Buscar la claridad "en el negro de los intervalos"227 en lugar de en el centelleo de las luces sobre la pantalla. El intersticio desvela la oportunidad de detener el movimiento para comprender el tiempo y el espacio. El intersticio nos desnuda el temor a que lo importante suceda a nuestras espaldas y de forma subrepticia. Los relatos y los gobiernos se constituyen en privado, en un claustro, entra la penumbra y el humo de una habitación. El intersticio es gatillo narrativo y punto de ignición de nuestra pulsión por el significado. Pero también de nuestro sentimentalismo. Mientras la película se desenrolla, el intersticio -como decía Daney $^{228}$ - se convierte en el lugar de acogida y de recogimiento de nuestros afectos. Uno no puede amar los planos sin pasear entre intersticios.

En los años cincuenta, Norman McLaren sintetizaba el valor del intervalo apelando también a la anatomía:

Lo que pasa entre cada imagen es mucho más importante que lo que hay en cada imagen. La animación es el arte de manipular los intersticios invisibles situados entre las imágenes. Los intersticios son los huesos, la carne y la sangre de la película, lo que aparece en cada imagen, sólo sus vestidos. ${ }^{229}$

\footnotetext{
${ }^{224}$ Esta aspiración se sitúa en el núcleo de la definición de "nuevo arte paracinemático" que hace Esperanza Collado en: Paracinema. La desmaterialización del cine en las prácticas artísticas, Madrid: Trama Editorial, 2012, p. 30.

${ }^{225}$ AUMONT, Jacques, Materia de imágenes, redux, op. cit., p. 217. [La cursiva es mía]

${ }^{226}$ GÓMEZ TARÍN, Francisco Javier, "Ficcionalización y naturalización. Caminos equívocos en la supuesta representación de la realidad" en POYATO SÁNCHEZ, Pedro (coord.), Documental, carcoma de la ficción, Córdoba: Filmoteca de Andalucía y AEHC, 2004, Tomo I, p. 63.

${ }^{227}$ HANOUN, Marcel, op. cit., p. 44.

228 DANEY, Serge, L'exercice a été profitable, Monsieur, París: P.O.L., 1993, pp. 32-33. Citado en BELLOUR, Raymond, op. cit., p. 164.

${ }^{229}$ JOUBERT-LAURENCIN, Hervé, “Le joujou du riche" en Trafic, París: P.O.L, no 2, primavera de 1992, p. 107. [Cito la traducción de Aumont en Las teorías de los cineastas. La concepción del cine de los grandes directores, op. cit., p. 25]
} 
Pasando de la metáfora sináptica a la esquelética, nos encontramos con que la neurona se ha convertido en hueso. En hueso cuyo tamaño también es inversamente proporcional a su importancia histórica: el hioides. Longitudinal, simétrico y astado, el hioides fue pieza decisiva para conformar el aparato fonador del género Homo. La narratividad incipiente a la que aludía Tarín, es ahora la guturalidad primitiva del Antecessor que precedió al lenguaje moderno del Sapiens. El intersticio como lugar del habla. De Vertov y McLaren pasamos a Peter Kubelka y Jonas Mekas. En una conversación entre ambos, con Eisenstein de fondo, Kubelka matiza las ideas de choque -dialéctica- y atracción -cinestésica- del soviético. Según el artista austríaco, hay un problema de base a la hora de discutir dónde se articula el cine:

Es muy extraño que nadie haya dicho que NO ES ENTRE LOS PLANOS, SINO ENTRE LOS FOTOGRAMAS. Es entre los fotogramas donde el cine habla. ${ }^{230}$

La inquietud de Kubelka era la de trabajar con cada fotograma por separado. Una forma de aumentar la condición rítmica del metraje a partir de la unidad material y de la materialidad de esa unidad. Porque para Kubelka, el cine nunca ha sido movimiento. La técnica del single framing que cultivarían muchos de sus colegas de generación, sería un ejemplo práctico de lo que, en principio, parecía un brindis al sol. Es más, el single framing sería la actividad digamos convencional -y hasta mainstream, por cómo se extendió y por cómo pervive en la actualidadsi tenemos en cuenta el trabajo escultórico que realizaría el propio Kubelka desde Arnulf Rainer (1960) hasta Antiphon (2012). ${ }^{231}$ Mekas debió recordar las palabras de su amigo y las replicó en forma de meme mientras deslizaba su voz y las pulsaciones de una vieja y simbólica máquina de escribir sobre los fotogramas de Walden: Diaries, notes and sketches (1964-1969): "Eso es el cine, fotogramas individuales. Fotogramas. El cine está entre los fotogramas". ${ }^{232}$ Los fotogramas de su Bolex de $16 \mathrm{~mm}$. recogían la luz y el movimiento mientras el cineasta los

\footnotetext{
${ }^{230}$ MEKAS, Jonas, “An interview with Peter Kubelka" en Film Culture, no 44, 1967, p. 45. [Las mayúsculas pertenecen al original. La traducción es mía]

${ }^{231}$ El reciente Antiphon forma parte de un proyecto -Monument Film- más ambicioso que trasciende la obra individual. De hecho, pone en cuestión la noción de individualidad de la obra con un maravilloso juego material antes que conceptual. En Monument Film, Kubelka juega con las combinaciones tanto en las proyecciones (proyección simultánea y proyección superpuesta) como en los panales expositivos. Antiphon es la inversión total de Arnulf Rainer: el negativo deviene positivo y viceversa; el silencio deviene sonido y viceversa. Ambos están compuestos por 9216 fotogramas de una película de $35 \mathrm{~mm}$. en blanco y negro y sonido óptico. La duración, seis minutos y veinticuatro segundos.

232 "That's what cinema is, single frames. Frames. Cinema is between the frames". Edición DVD manejada, París: Re:Voir Video.
} 
deletreaba y se los entregaba, como no, a la fisiología: "El cine es... luz ... movimiento ... sol ... luz ... el latido del corazón ... respiración ... luz... fotogramas".

Sin salir de la fértil vanguardia americana de los años sesenta y setenta, cambio la pareja Mekas-Kubelka por el dúo Beavers-Markopoulos. En uno de sus artículos más citados, Gregory Markopoulos abundaba -con su ímpetu habitual- en el misterio del intersticio:

Robert Beavers ha insinuado con brillantez esa imagen invisible que se encuentra entre los fotogramas y que nunca ha sido fotografiada; y esa otra imagen invisible entre fotogramas nunca proyectada. Esto es una prueba fundamental para la Revelación en el Filme. Es la realidad de un Pensamiento Visual Dinámico no solo percibido sino materializado (...) uno comienza a darse cuenta de que existe una ruta secreta hacia una dimensión del filme nunca antes sospechada. ${ }^{233}$

Ímpetu poético y esoterismo que Markopoulos intenta redirigir y concretar en el intersticio. Cuando Markopoulos habla de revelación y de nueva dimensión, está vistiendo de mística el pragmatismo lingüístico de Kubelka y Mekas. El meme original, continúa su proceso de mutación. Un meme que contaba con otra rama evolutiva paralela. Casi al mismo tiempo que la lírica declaración de Markopoulos, Werner Nekes iniciaba T-WO-MEN (1972) con un cartel que volvía a preguntar por aquel between the frames de Mekas y Kubelka: "Whatever happened between the pictures?" ¿Qué sucedió entre las imágenes? Fuera lo que fuera, Nekes reintroduce el intervalo como lugar de misterio. Y lo hace antes de comenzar su película, condicionando no tanto los sucesos narrados como el punto de vista y el ánimo del espectador. En este juego de Nekes uno advierte su amor e interés por todo el mundo de los juguetes ópticos y del precine. ${ }^{234}$ Aquellos cacharros donde el intersticio reinaba y tramaba desde la más absoluta visibilidad.

Hasta aquí, el intersticio como meme vinculado a prácticas de vanguardia. Lejos de la exclusividad y de la linealidad, acontece un salto evolutivo que lo convierte de misterio narrativo vanguardista a elemento diferenciador del cine moderno. Gilles Deleuze empleó la

\footnotetext{
${ }^{233}$ MARKOPOULOS, Gregory, "The intuition space" en Millenium Film Journal, no 32-33, otoño de 1998. [El texto original es de 1973. La traducción es mía, las mayúsculas pertenecen al original]. El artículo también aparece en la reciente compilación realizada por Mark Webber: Film as Film. The collected writings of Gregory J. Markopoulos, Nueva York: The Visible Press, 2014.

${ }^{234}$ Inquietud y sabiduría que le llevó más tarde (1995-1996) a realizar la maravillosa serie Media Magica. Las seis partes están editadas en DVD por Re:Voir Video.
} 
figura del intersticio para escindir el clasicismo de la modernidad. No solo en un sentido estilístico -aunque tal vez esa fuera su intención inicial-, también filosófico. Deleuze, al observar que otras transgresiones (fuera de campo, falso rárcod) siempre encontraban un correlato que las mantenía atadas a la contigüidad, a la intensificación y a la transitividad del cine clásico -a la representación indirecta del tiempo-, recurrió al intersticio para declarar un nuevo estatuto del Todo en el cine moderno:

La cuestión ya no es la de la asociación o atracción de las imágenes. Por el contrario, lo que cuenta es el «intersticio» entre imágenes, entre dos imágenes: un espaciamiento que hace que cada imagen se arranque al vacío y vuelva a caer en él. ${ }^{235}$

Para Deleuze, el intersticio encarnaba el corte irracional del cine moderno. El intersticio no es un corte racional que señala el comienzo de una imagen o el final de otra, es una entidad independiente que, en la modernidad, "comienza a valer por sí mismo". ${ }^{236}$ En su cabeza están Bresson, Godard y Garrel. El primero como fundador, el tercero como ejemplo de la magnitud máxima en su empleo y el segundo como trabajador esforzado que, al igual que Nekes, vuelve a cuestionar la función y las consecuencias del intersticio hasta convertirlo "en un método sobre el cual el cine, al mismo tiempo que lo utiliza, debe interrogarse" ${ }^{237}$ Lo que Deleuze quiere decir sobre Godard es muy parecido a lo que decía Aumont ${ }^{238}$ de la unión disyuntiva o contrapuntística de otro maestro del cine, el armenio Artavazd Pelechian. En ambos casos y con el eco de Vertov todavía audible: el intersticio no asocia las imágenes, las separa y las diferencia. Por utilizar unos términos menos radicales que se ajusten mejor a las mínimas variaciones figurativas y motrices entre fotogramas, personalmente diría que el intersticio entre imágenes permite escalonar las semejanzas.

Pero Deleuze no recurre al intersticio de manera inocente y solo gracias al cine. Si volvemos a leer Lógica de la sensación, no tardamos en apreciar que este tipo de separación activa entre

\footnotetext{
${ }^{235}$ DELEUZE, Gilles, La imagen tiempo. Estudios sobre cine 2, op. cit., pp. 239-240. [Las comillas pertenecen al original]

Tom Conley dedicó un ensayo a discutir las diferencias deleuzianas entre intervalo (La imagenmovimiento) e intersticio (La imagen-tiempo): CONLEY, Tom, "The film event. From interval to interstice" en FLAXMAN, Gregory (ed.), The brain is the screen. Deleuze and the philosophy of cinema, Minneapolis: University of Minnesota Press, 2000, pp. 303-325.

${ }^{236}$ DELEUZE, Gilles, La imagen tiempo. Estudios sobre cine 2, op. cit., p. 265.

${ }^{237}$ Ibíd., p. 240.

${ }^{238}$ AUMONT, Jacques, op. cit., pp. 94-95.
} 
imágenes que representa el intersticio, ya era una preocupación pictórica. A partir de la obra de Francis Bacon -en especial algunos de sus trípticos- Deleuze examina el porqué del aislamiento al que somete el pintor a sus figuras. Bacon, separa y aísla para no caer en el carácter figurativo, ilustrativo y, en última instancia, narrativo que la figura obtendría y mostraría necesariamente si no estuviera aislada. Porque en cuanto se rompe el aislamiento: "en el espacio existente entre dos figuras, siempre se desliza -o tiende a deslizarse- una historia que anima toda la ilustración" ${ }^{239}$ Los intentos de Bacon basados en el aislamiento y en la abstracción son eso, experimentos exorcizados por la actividad de los intersticios -entre figuras y entre paneles- pictóricos y cerebrales.

Después de Deleuze el meme ha continuado vigente. Rancière ha vuelto a recuperar (2014) la figura del intervalo (écart) para su análisis. Un bello intento de materializar esta idea de tránsito, de crisis y de fricción espaciotemporal. El intervalo, en tanto noción ampliada y conceptual -vertoviana- de la estricta fisicidad del intersticio, es uno de los mecanismos que, según el filósofo, encontró el cine para su emancipación de la literatura. Su dialéctica incesante: unir y separar, continuidad y fragmento, unidad y conjunto. Para Rancière, es este devenir entre intervalos lo que siempre frustra la ansiada unificación material y teórica del fenómeno cinematográfico. Porque el arte del cine no consiste únicamente en el despliegue los "poderes específicos de su máquina", sino en "una representación de intervalos y de incorrecciones" ${ }^{240}$ Entendiendo estas incorrecciones como manifestaciones típicas de un arte impuro, no-idealista y no-indigenista.

Tras Deleuze y Rancière, aun cabe otro escalón. Y lo hace, contra todo pronóstico, profanando el entorno digital del siglo XXI. Entre las explicaciones profundas, bellas y elegantes seleccionadas por John Brockman para explicar cómo sigue funcionando el mundo de la segunda década del presente siglo, encontramos una dedicada al movimiento de las películas. El encargado de la explicación es Alvy Ray Smith, ingeniero electrónico de prestigio, experto en imágenes generadas por ordenador y cofundador de la compañía Pixar. El ingeniero regresa al origen vertoviano preguntándose: ¿por qué se mueven las películas? Su regreso, lógicamente, no es consciente y no es puro; de la misma manera que su texto no es la culminación de una teleología del intersticio. Acabamos de comprobar cómo lo que primero fue metáfora y luego

\footnotetext{
${ }^{239}$ DELEUZE, Gilles, Francis Bacon. The logic of sensation, Londres y Nueva York: Continuum, 2003, p. 3 [Primera edición de 1981. La traducción es mía]

${ }^{240}$ RANCIÈRE, Jacques, The intervals of cinema, Londres y Nueva York: Verso Books, 2014, p. 32 [La paginación corresponde a la edición epub. La traducción es mía]
} 
meme, ha evolucionado y se ha adaptado con cada replicación a cada contexto. Alvy Ray Smith inicia su texto -cómo no- cuestionando el movimiento, su raíz y su primitivismo. Las películas no son suaves [smooth], dice, porque "el tiempo entre fotogramas está vacío". ${ }^{241}$ No sé hasta qué punto puede un tiempo determinado estar vacío, pero la frase -en términos literarios- se comprende.

Ese vacío participa de la eterna ilusión de percibir movimiento mientras vemos imágenes estáticas. La caduca explicación de la persistencia retiniana o del fenómeno phi, solo aclara por qué no vemos ese vacío entre fotogramas, no el movimiento en sí. ${ }^{42}$ Ese vacío espaciotemporal del intersticio, evita que cualquier iconografía de las imágenes se duplique. El vacío del intersticio siempre estuvo tentado por lo virginal, por lo sagrado y por la iconoclasia. El vacío como lugar prohibido o, cuando menos, como lugar para iniciados. El intersticio, desde su disyunción, individualiza. Ray Smith nos explica que el movimiento aparente del interior de las imágenes, condicionado como está por el intersticio, debe seguir una pauta suave -not too far, not too fast- que salvaguarde la continuidad. Ahí entra en juego la labor del animador digital. También del tradicional animador de cartoons y de stop-motion que debía manejar de manera intuitiva las distancias y los movimientos entre imágenes.

Con esto presente, el autor nos revela por qué las películas de Pixar sí son suaves. La clave es su tratamiento del denominado motion blur. El desenfoque resultante de tomar la fotografía de un objeto en movimiento con una exposición larga, se convierte en el salvoconducto de la continuidad y de la maestría en la renderización de los movimientos. Lo que puede ser considerado como un defecto en fotografía estática, deviene herramienta dinámica de trabajo en el cine de animación contemporáneo. El viejo intersticio condicionando y, al mismo tiempo, facilitando la labor de la última tecnología CGI de la que disponemos. El efecto motion blur le indica a nuestro cerebro la ruta y la magnitud del movimiento: cuanto mayor sea el desenfoque, más rápido será el movimiento. ¿Dónde queda el papel del intersticio? El ingeniero lo aclara con brillantez:

${ }^{241}$ RAY SMITH, Alvy, "Why do movies moves?" en BROCKMAN, John (ed.), This explains everything. Deep, beautiful and elegant theories of how the world works, op. cit., p. 185 [La paginación corresponde a la edición epub].

${ }^{242}$ BROOKS, Virginia; HOCHBERG, Julian, "Movies in the mind's eye" en BORDWELL, David; CARROLL, Noël (eds.), op. cit., nota 2, p. 368 y 383. 
En lugar de descartar la información temporal sobre el movimiento contenida entre fotogramas, la almacenamos en términos espaciales dentro de cada fotograma en forma de desenfoque. ${ }^{243}$

Parece sencillo, pero a pesar de partir de los fundamentos del antiguo pero vigente Teorema de Nyquist-Shannon, la labor requiere una potencia computacional no alcanzada hasta finales de siglo XX. Con todo, Pixar puede llegar a emplear multitud de computadoras $y$, en algunos casos, hasta treinta horas de trabajo por fotograma. Esta idea del intersticio como metáfora y meme evolutivo concluye en ese punto, con las nuevas tecnologías y algoritmos de compresión de datos. Lo que en términos técnicos se conoce como interframe compression. Esto es, la información de cada fotograma individual es codificada de acuerdo a su relación con los fotogramas adyacentes. La información resultante, la intraframe compression, responderá así al escalonamiento de semejanzas y discrepancias encontrado durante la exploración de la cadena de fotogramas. El objetivo es el de una ecología cognitiva con base matemática: eliminar las redundancias.

Esta pericia y esta peripecia suponen no tanto una entrada como una definición de la imagen y del mundo contemporáneos. Además, anuncia y fulmina algunos de los sofismas de la era digital que han aparecido y que seguirán apareciendo en este trabajo: velocidad e inmediatez, desmaterialización y descorporeización. Gracias a la reinterpretación del intersticio como desenfoque del movimiento y como compresión intra y entre fotogramas, la sucesión de imágenes puede prescindir de nuestro compañero para solaparse mínimamente. ${ }^{244}$ Del resto se encargan los mecanismos de inferencia de nuestro cerebro y la región V5, sin la cual no podría existir ningún efecto estético producido por el movimiento. ${ }^{245}$

El intersticio, así, viene a cumplir lo que el hombre -equivocándose- dijo buscar en la fotografía y en el cine: la inmortalidad. El intersticio (trans)muta para seguir operando a la manera de una supervivencia.

\footnotetext{
${ }^{243}$ RAY SMITH, Alvy, op. cit., p. 186. [La traducción es mía]

${ }^{244}$ No es extrapolable al ciento por ciento, pero este capítulo del artículo de Brooks y Hochberg ayuda a comprender el principio que rige esta relación entre movimiento, corte, solapamiento y continuidad: "Overlapping and nonoverlapping cuts", op. cit., pp. 376-379.

${ }^{245}$ ZEKI, Semir, Visión interior. Una investigación sobre el arte y el cerebro, op. cit., p. 106. Para una explicación más avanzada de las operaciones cerebrales asociadas al movimiento y de cómo pueden darse procesos de sincronización neuronal entre la región extraestriada V5 y la corteza visual primaria: SINGER, W., “¿Constituye la sincronización neuronal una solución al problema de la unificación?” en CHURCHLAND, Patricia; LLINÁS, Rodolfo; (eds.), op. cit., 2006, p. 139 y ss.
} 
INTERLUDIO VANGUARDISTA 
«En cuanto se nombra la vanguardia cinematográfica,

ya es demasiado tarde»

Marcel Hanoun ${ }^{1}$

No hace falta recordar que la Teoría de atracciones era rancia desde un punto de vista histórico, y débil desde un fundamento epistemológico. Sin embargo, conviene añadir algo más a lo expuesto hasta el momento: al margen de sus grietas estructurales, la teoría sufre nuevas y sensibles deficiencias cuando se aplica a contextos y expresiones diferentes. No es lo mismo utilizar una Teoría de atracciones para analizar cierto cine comercial actual, que para realizar lo propio con el cine primitivo silente o con las vanguardias del siglo XX. No en vano, la idea de atracción vanguardista circula en sentido contrario a la manejada para mentar la narrativa degenerada del cine espectacular contemporáneo.

El maximalismo alcanzado por la Teoría de atracciones, así como su banalización nominal, han prevalecido sobre otros matices que, curiosamente, estaban presentes en las palabras del story consultant de Begotten (Elias Merhige, 1991). En su artículo, Gunning estableció un vínculo menos tajante y más dubitativo entre la atracción y el cine contemporáneo que entre la atracción y las vanguardias cinematográficas. Que el primero haya monopolizado el debate, resulta todavía más incomprensible desde que la segunda luce en el título del texto y desde que daba el pie con una cita de Fernand Léger a propósito de La rueda (La roue, Abel Gance, 1922). La Teoría de atracciones ha terminado por devorarse a sí misma, traicionando un ánimo más diverso e impreso en su propia letra:

Cada cambio en la historia del cine implica otro en la relación con el espectador, y cada periodo construye a su espectador de una nueva manera. ${ }^{2}$

Las vanguardias insuflan significados diferentes a las discutidas ideas de autorreferencialidad y exhibicionismo. La funcionalidad de la atracción en un contexto vanguardista está alejada y es bien distinta -como no podía ser de otra manera- de la aplicada a la era del blockbuster. Querer compartir un punto de partida similar -anteponer la dimensión ostensiva sobre la narrativa-, además de incorrecto es insuficiente. Atendiendo a esto, si aquí y ahora utilizara con la misma despreocupación la atracción para comentar prácticas de vanguardia

\footnotetext{
${ }^{1}$ HANOUN, Marcel, op. cit., p. 66.

2 GUNNING, Tom: "The cinema of attractions: early film, its spectator and the Avant-Garde" en ELSSAESER, Thomas (ed.), Early cinema. Space, frame, narrative, op. cit., p. 61.
} 
cinematográfica, podría llegar a la conclusión de que el cine estructura ${ }^{3}$, tal y como lo definió por Paul Adams Sitney y tal como lo redefinió, diferenció y amplió Peter Gidal, podría considerarse un embrión del gran cine de efectos especiales. Parece obvio que promover semejante vínculo sería una locura. Pues bien, además de no faltar insinuaciones peregrinas ${ }^{4}$, es lo mismo que ha sucedido de manera global e indiscriminada con el periodo silente prenarrativo.

\footnotetext{
${ }^{3}$ Las dos definiciones de referencia -desarrolladas por Sitney y Gidal- sobre las que han pivotado todas las posteriores, cruzan sus caminos en los años setenta. Sitney publica el primer tratamiento de su idea en un artículo de Film Culture (no 47, verano de 1969): "Structural film", pp. 1-10. El texto se reedita al año siguiente en Film Culture Reader, Nueva York: Praeger Publishers, 1970, p. 327 [Hay otra reeimpresión del año 2000 a cargo de Cooper Square Press, pp. 326-348].

Sitney fue duramente criticado durante años por colegas y teóricos que entendieron cierta relajación, ligereza y ambigüedad en el uso de los términos "forma" y "estructura". En las reediciones citadas, el propio Sitney recogió un texto donde era reprendido por Georges Maciunas. En un artículo con forma de tabla, Maciunas desgranaba tres tipos de errores: terminológicos (los ya citados), prácticos (a la hora de elegir los ejemplos) y cronológicos (a la hora de establecer orígenes y fuentes): "Some comments on Structural Film by P. Adams Sitney", op. cit., p. 349.

Poco después, durante una charla con James Broughton en abril de 1977, fue Hollis Frampton quien se opuso al enfoque de Sitney. Frampton, clasificado -junto a George Landow- por Sitney dentro en un subconjunto del cine estructural denominado "participatory film", rechazaba la banalidad y la inutilidad de las etiquetas, la caprichosa relación establecida entre cine y poesía y, sobre todo, el neorromanticismo inveterado y superficial de Sitney: "Hollis Frampton in San Francisco" publicada originalmente en Cinemanews, vol. 77-6, noviembre-diciembre de 1977, pp. 8-9. La versión que he manejado se encuentra recopilada en el magnífico volumen: MACDONALD, Scott, Canyon Cinema. The life and times of an independent film distributor, Berkeley: University of California Press, 2008, pp. 265270. Le Grice tampoco se privó de criticar a Sitney en: Abstract film and beyond, Londres: Studio Vista, 1977.

Luego llegaron dos nuevos artículos de cariz revisionista: ARTHUR, Paul, "Structural Film. Revisions, new versions, and the artifact" en Millennium Film Journal, no 2, primavera-verano de 1978 y "Structural Film: Revisions, new versions, and the artifact: part two" Millennium Film Journal, no 4-5, verano-otoño de 1979. Bruce Jenkins se sumó a la crítica con: "A case against 'Structural Film"' en Journal of the University Film Association, vol. 33, no 2, primavera de 1981, pp. 9-14.

En 1979, el cineasta Gary Doberman también participó de la crítica a la moda conceptual del cine estructural: DOBERMAN, Gary, "New York cut the crap" en Cinemanews, vol. 79, no 5-6, primavera de 1980. También se puede encontrar en el volumen citado de MacDonald: p. 352.

En la primera edición (1974) de Visionary film, el autor volvió a recoger su texto. Así como en posteriores reediciones. En la tercera y última hasta la fecha (Nueva York: Oxford University Press, 2002), Sitney da cuenta de la literatura crítica en el bloque de notas al pie. El apartado dedicado al cine estructural puede encontrarse en las páginas 369-397 [paginación correspondiente a la segunda edición].

La otra definición corresponde a Peter Gidal, quien corregirá y retocará su ensayo inicial de 1974 "Theory and definition of structural/materialist film" para publicarlo en un volumen -igual de fundacional, pero quizá menos famoso y controvertido que el de Sitney- que procedo a citar: GIDAL, Peter (ed.), Structural film anthology, Londres: BFI, 1978, pp. 1-21. [La primera edición data de 1976. En esta reedición de 1978, Gidal añade un pequeño post scriptum]. Gidal desarrolla con mayor profundidad el cine estructural-materialista y, además, incorpora en su estudio la producción europea.

${ }^{4}$ DOBERMAN, Gary, "New York cut the crap" en MACDONALD, Scott, Canyon Cinema. The life and times of an independent film distributor, op. cit., p. 364.
} 
Lev Manovich no dudó a la hora de desarrollar este paralelismo. Uno de sus textos más aclamados es toda una declaración de intenciones desde un título que no puede pasar desapercibido: Avant-garde as software. ${ }^{5}$ En él asegura que "la visión vanguardista se materializó en el ordenador". Manovich utiliza el término materializar y con ello siembra de incertidumbre y confusión el enunciado. Para el autor, los movimientos y las expresiones del siglo anterior -las de los años veinte, pero también las impulsadas a partir de los sesenta-, cristalizan en la máquina. O para ser más exactos, "en la visión de la máquina". De manera implícita, aquellas prácticas quedan instauradas como precedentes cuyo destino estaba fijado de antemano.

Esto implica un fin de trayecto entendido como consumación. Es decir, Manovich apelaba a lo material como reafirmación y encarnación de lo teleológico. La teleología no solo permite que el poder sintético y sincrético de la computadora integre representaciones pasadas en un nuevo entorno, también elimina o neutraliza cualquier valor diferencial. Partiendo de este viaje sin escalas, la ausencia de una escisión constituyente en la imagen queda fijada como axioma cruel. El compás y el objetivo de este interludio será recuperar el sentido histórico, semántico, material y biológico de la vanguardia cinematográfica. Lo haré de forma breve a través de una serie de ideas -collage, conciencia y prefiguración- que considero ilustrativas para seguir entendiendo cómo la narración se desliza con sigilo universal entre periodos a través y gracias a la materia.

\footnotetext{
${ }^{5}$ MANOVICH, Lev, "La Vanguardia como Software" en Artnodes, Revista de Arte, ciencia y tecnología, Barcelona: Universitat Oberta de Catalunya, no 2, ISSN 1695-5951, 2003.
} 


\section{A. Un nuevo collage}

El parentesco establecido por Manovich podría ser calificado como el de una convergencia absoluta o, mejor, absolutista. La segunda lo define mejor. Un absolutismo no ideológico, sino metodológico. Esto es, los nuevos medios digitales terminan otorgando a la construcción binaria el poder último y universal. Ejecutada la atribución desde los hechos consumados, se ignora la problemática de esa aparente y nueva uniformidad. Porque, al menos para mí, no basta con entregarse a reflexiones mitológicas sobre una nueva forma de alquimia digital. Como la siguiente, donde Lunenfeld ya anunciaba la posterior tesis de Manovich: "la computadora es el disolvente universal donde todas las diferencias entre los medios quedan diluidas en una corriente de impulsos de bits y bytes". ${ }^{6}$ Aquí, sobre esas palabras de Lunenfeld, se cierne la sombra -alargada, como la de Max Schreck escaleras arriba; venerada como la de un tótem chamánico durante los noventa- de Nicholas Negroponte. ${ }^{7}$

A partir de ese mismo instante, la reunión y asimilación de diferentes narraciones y materias en un mismo espacio dejaría de ser la seña de identidad del collage. Casi un siglo después de aquellos papiers collés afilados -tijeras en ristre, armas que apuntaban a las instituciones artísticas, empezando por las autorales y las museísticas- por las manos de surrealistas, dadaístas, futuristas y demás prole, el collage es neutralizado. O ese parece ser el objetivo: (con)fundir la voluntad creativa con la de un (meta)relato de legitimación. Esto no puede tener validez alguna siempre y cuando se acepte que el collage, en tanto mascarón vanguardista, cumplía con la máxima de destruir la unidad, el ilusionismo y la organicidad de la obra de arte clásica. Y desde que, más concretamente, las variación (no solo entre materiales, también entre tiempos y velocidades, espacios y dimensiones) del collage cinematográfico "juega con una heterogeneidad dentro de la imagen que rompe el carácter único o unitario de la misma”. 8 Resulta peliagudo hablar de la omnipotencia de un disolvente universal porque, de ser cierto,

\footnotetext{
${ }^{6}$ LUNENFELD, Peter, "Unfinished business" en LUNENFELD, Peter (ed.) op. cit., p. 7. [La traducción y la cursiva son mías]

${ }^{7}$ NEGROPONTE, Nicholas, El mundo digital, Barcelona: Ediciones B., 1995.

${ }^{8}$ WEINRICHTER, Antonio, "Notas sobre collage y cine" en GARCÍA LÓPEZ, Sonia; GÓMEZ VAQUERO, Laura (eds.), Piedra, papel y tijera. El collage en el cine documental, Madrid: Ocho y Medio, 2009, p. 52. El autor aporta otra idea muy interesante que abunda en las dificultades a la hora de homogeneizar una pieza de collage cinematográfico: el sonido. Con más fuerza que el propio montaje (ver p. 56 y nota 39 de la obra citada) de los fotogramas, la banda sonora intentó ejercer de disolvente universal no solo en los primeros collages cinematográficos de Cornell o Conner, lo ha hecho también hasta nuestros días. Ya sea en cine, televisión, videoarte o en cualquier pieza audiovisual amateur y doméstica. El efecto contorno surgido por el choque entre materiales necesitaba de una normalización sonora que suavizara las transiciones. Sin embargo, ese mismo efecto contorno sería realzado no pocas veces -piezas de Fluxus, de la Culture jamming y del Situacionismo- de manera intencionada para subrayar la naturaleza diversa de la obra y de sus partes.
} 
estaría aludiendo o cumpliendo las funciones de una construcción canónica y, por lo tanto, no vanguardista:

Mientras que en la obra de arte orgánica el principio de construcción domina sobre la parte y la subordina a la unidad, en las obras de vanguardia las partes tienen una independencia esencial frente al todo; pierden valor como ingredientes de una totalidad de sentido y lo ganan como signos relativamente independientes. ${ }^{9}$

La vanguardia como software de Manovich tenía un precedente en el disolvente universal de Lunenfeld, y ambos son resonancias prolongadas y apenas distorsionadas del electrobricolaje de William John Mitchell:

La imagen digital difumina la distinción tradicional entre pintura y fotografía, y entre imágenes mecánicas y manuales. Una imagen digital puede ser parte fotografía escaneada, parte perspectiva de síntesis informática y parte "pintura" electrónica, todo mezclado con fluidez en un conjunto de apariencia coherente (...) Las imágenes digitales otorgan significado y valor a estos readymades computacionales a través de la apropiación, de la transformación, del reprocesado y de la recombinación; hemos entrado en la era del electrobricolaje. ${ }^{10}$

Estas ideas de Manovich, Lunenfeld y Mitchell no han dejado de ser atrevidas y sugerentes, pero con el tiempo han perdido validez explicativa. Tal vez porque esa validez ya era endeble desde el principio. Es obvio que la computadora ha centralizado multitud de procesos y productos creativos, lo cual no quiere decir que los haya unificado -o simplificado y reducido, como avisé páginas atrás- en su razón más íntima: la histórica y la estética. Pero, ojo, también en la estrictamente funcional.

\footnotetext{
${ }^{9}$ BÜRGER, Peter, Teoría de la vanguardia, Barcelona: Península, 1997, p. 151.

${ }^{10}$ WILLIAM MITCHELL, John, The reconfigured eye. Visual truth in the post-photographic era, Cambridge: The MIT Press, 1992, p. 6 [La traducción y las cursivas son mías. Resalto la palabra fluidez porque he preferido utilizarla en lugar de suavidad. Mitchell, como Alvy Ray Smith, utiliza smooth. Esta suavidad digital es un sintagma hermoso y recurrente que no debe maquillar sus limitaciones. Las comillas de "pintura" pertenecen al original]
} 
Si por algo se han ido caracterizando los entornos digitales es por la descentralización ${ }^{11}$, tanto a nivel operativo y mecánico, como creativo y humano. La imagen de un supercomputador ha demostrado ser otra mala -o al menos inexacta- profecía realizada no solo por la ciencia ficción, también por cierta historiografía. Las arquitecturas han camuflado las entrañas. La descentralización y el funcionamiento colectivo son las fuerzas que han guiado el avance. La potencia no aumenta -solo- desde la individualidad del chip, sino desde la recombinación de múltiples procesadores. De la misma forma que nuestro cerebro no valida la metáfora del dictador que acapara y ejecuta, sino la de la los módulos, las capillas o la navaja suiza. Deleuze se equivocaba, quién sabe si fruto de la improvisación que reina en cualquier entrevista, en uno de sus más célebres veredictos: "El cerebro es unidad. El cerebro es la pantalla". ${ }^{12}$ Jamás, en ningún caso, el cerebro solo aparenta unidad y solo se vale de las pantallas para alimentarse.

Tanto el cerebro como los entornos digitales asumen, estructuran y envían el trabajo y el conocimiento como organizaciones en red y lugares de intercambio. El tráfico de datos es asimétrico y existe una redistribución constante de procesos y energía. ¿Por qué creímos y seguimos creyendo en la centralidad digital omnipotente? Por la misma razón por la que creemos en aquellas cosas raras que decía Shermer. Necesitamos atribuir fenómenos complejos a causas inmediatas dictadas por agentes superiores.

La concepción de la imagen digital como lugar de concentración ${ }^{13}$ iconográfica que asume un rol de suave y terso collage, parece nueva y funcional, pero es vieja y utópica. Tanto, que tras leerla es imposible no recordar y asociar aquella sociedad $\sin$ clases $^{14}$ con una computadora social y política avant la lettre. Una vez consolidada esa nueva tecnología sin clases, una vez

\footnotetext{
${ }^{11}$ Uno de los escasos "des-" tan frecuentes en la teoría digital contemporánea, que puede ser argumentado de manera empírica. Hablar hoy de descentralización es constatar una evidencia. Hacerlo durante los años ochenta y noventa tenía más mérito. Era indicio de un conocimiento profundo del terreno. Marvin Minsky, uno de los grandes teóricos de la inteligencia artificial, comenzó a desentrañar las partes y el todo, los agentes y las agencias, las conexiones y las heterarquías: MISNKY, Marvin, La sociedad de la mente. La inteligencia humana a la luz de la inteligencia artificial, Buenos Aires: Galápago, 1986.

A rebufo del avance digital se situó el mito de una poderosa centralidad que ordenaba el conocimiento, la economía, los grupos sociales y la tecnología. Esta corriente fue desmontada con prontitud por Mitchel Resnick en una obra de referencia: Turtles, termites, and traffic jams. Explorations in massively parallel microworlds, Cambridge: The MIT Press, 1994.

${ }^{12}$ FLAXMAN, Gregory (ed.), op. cit., p. 366 [La traducción es mía]

${ }^{13}$ Sin entrar ahora en la contradicción inherente que supone la aparición del píxel, de las capas -layersy de las numerosas herramientas -tools- como elementos constituyentes y transformadores.

${ }^{14}$ MARX, Karl, "Carta a Joseph Weydemeyer (Londres, 5 de marzo de 1852)" en Obras escogidas. Tomo I, Moscú: Progreso, 1980, p. 283.
} 
ampliada la velocidad y la (omni)potencia del uno y del cero, se procede a revocar el reinado de la materia. A partir de ahí, el sueño continúa. Las relaciones iconográficas se transforman y los medios y procesos de producción se colectivizan gracias a la democratización informática. En la computadora desaparecen las jerarquías y los tipos iconográficos quedan reducidos a uno. En ese uno que es también un cero, radica una armonía digital que absorbe, vía interfaz, el trabajo manual para disiparlo en trabajo intelectual.

La imagen digital, en esos términos de utopía marxista redactados en el último párrafo, cambiaría el paraíso en la tierra por el paraíso en el silicio. Este apresurado símil vale como parábola fugaz y colorista, pero es excesiva, forzada e inservible. Prefiero no regresar tan atrás $y$, sobre todo, no provocar interpretaciones groseras. Para ello invoco la obra fundacional de Richard Hamilton: Just what is it that makes today's homes so different, so appealing? (1956). Con las vanguardias de comienzos de siglo en la memoria, en ella encontramos un ensayo, que no una prefiguración, de la imagen como lugar de reunión y unificación de la narración y de la materia. Sin embargo, y a pesar de la relevancia que le otorga la categoría o el género pop, en ella seguía presente y activa la condición multilaminar del collage. Tanto el pop como el falso igualitarismo digital son dos variaciones del mito de la tabla rasa que no logran fulminar lo inmediato, lo superficial y lo perceptual de las texturas. Tampoco los relatos que germinan en el intersticio abierto entre las distintas referencias culturales y sociales. Era el año 1956 y $A$ movie de Bruce Conner -que prefería hablar de montage ${ }^{15}$ en lugar de collage- estaba a la vuelta de la esquina (1958).

¿Cuál es entonces el error categorial que aprecio en esta idea del nuevo collage digital como culminación de los anhelos de vanguardia? Antes quiero decir los que seguro que no son: el collage siempre fue una expresión crítica y lúdica, intermedial y proteiforme. ${ }^{16}$ Estatutos que su digitalización, por mucho que insistan, no ha vulnerado. Como tampoco lo hicieron, en un principio, las obras de Man Ray, Duchamp, Léger o Moholy-Nagy. Y, más tarde, las de Larry Jordan, Stan Vanderbeek o Craig Baldwin.

El error al que quiero hacer referencia es el reduccionismo de las vanguardias a simples movimientos técnico-artísticos. Lo cual, hasta cierto punto, es comprensible si tenemos en cuenta lo que ellos mismos declaraban. Una lectura de sus manifiestos -recuerdo ahora el del Rayonismo- nos devuelve indicaciones enfáticas y recurrentes a la técnica pura: "Habría que

\footnotetext{
${ }^{15}$ WEES, William C., Recycled images, Nueva York: Anthology Film Archives, 1993, p. 85.

${ }^{16}$ GARCÍA LÓPEZ, Sonia; GÓMEZ VAQUERO, Laura (eds.), op. cit., p. 18.
} 
mirar (....) una obra de arte considerándola sólo desde el punto de vista de los medios y de las leyes que han animado su creación" ${ }^{17}$ En ese plano, Manovich reconocía la marginalidad de las manifestaciones de las viejas vanguardias, pero no prestaba la debida atención a que su delirante- reencarnación tenga lugar en pleno corazón del modelo político, social y estético dominante. Su interés estaba restringido a la profecía escrita por unas técnicas determinadas (el collage o el celuloide pintado). El error, repito, es considerar el fenómeno exclusivamente en términos de técnicas y expresiones, más o menos innovadoras, olvidando o prescindiendo de su inscripción histórica.

¿Por qué es tan importante esta última? Porque establece un conflicto decisivo entre dos frentes: asimilación y refracción. Antes de poner el foco en sus valores estéticos, una de las certidumbres generadas por las vanguardias es su credencial de -en palabras de Jim Hoberman- "significado histórico" ${ }^{18}$ Sobredimensionar la importancia de las técnicas sobre este significado, es un desliz sangrante. Siguiendo a Bürger, la vanguardia es un fenómeno con "conciencia histórica" donde lo artístico y lo estético son irreductibles. Un fenómeno histórico donde sus "atributos físicos" son, al mismo tiempo, "categorías de su conocimiento". Si se ignora su proyecto histórico-estético "pierde su condición de ruptura epistemológica".

La obra de arte vanguardista contiene lo real en calidad de juicio respecto al uso de los materiales -instrumentos técnicos, valores, mitos- que la historia ofrece (...) expresa su modo particular de referirse a lo existente. ${ }^{19}$

El uso que hacía Manovich del término vanguardia conmemoraba otra realidad: la normalización y la institucionalización del mismo. A lo largo de las décadas, la vanguardia ha sido incorporada al discurso hegemónico. No es ninguna novedad. Como todo aquello que posee nutrientes, la vanguardia es deglutida y digerida de manera periódica; se tenga o no apetito. Pero es ahí, en ese significado histórico, donde sigue librando una batalla, donde sigue probando su actitud levantisca, su capacidad para herir y alterar. La estética es grácil, y su maleabilidad -en la producción y en la percepción- posibilita una integración inmediata en la corriente dominante. El lenguaje y sus cambios semánticos son más lentos y toscos, pero también más resistentes y fieles a su forma primigenia.

\footnotetext{
${ }^{17}$ DE MICHELI, Mario, Las vanguardias artísticas del siglo XX, Madrid: Alianza, 1998, p. 383.

${ }^{18}$ HOBERMAN, Jim, "Tras el cine de vanguardia" en WALLIS, Brian (ed.), op. cit., p. 60.

${ }^{19}$ BÜRGER, Peter, op. cit., entrecomillados en p. 13 y 14, cita en p. 15.
} 


\section{B. Narración y atracción trascendidas. El cine como meditación}

Cada periodo construye a su espectador de diferente manera, decía Gunning. Es cierto, al menos en parte. Porque también sabemos que hay límites biológicos y culturales que ese constructivismo no puede ignorar. Ningún movimiento estético y ninguna etapa histórica pueden aspirar a modelar por completo y desde cero a su espectador. Nuestras herramientas cognitivas, así como nuestra base de datos cultural, nos impiden jugar el papel de buenos salvajes frente a la pantalla. Este ansia neoprimitivista, esta concepción del arte como representación pura, ideal y no contaminada, siempre ha supuesto una frontera frustrante para las prácticas de vanguardia. Muchas se equivocaron al elegir el camino de la inocencia primitiva como medio y método tanto para movilizar al espectador, como para lograr una emancipación de las formas. ${ }^{20}$

Pero en ciertos momentos históricos, se pueden encontrar desvíos que merece la pena explorar. Es el caso de la conflictiva y prolongada relación que establece la vanguardia cinematográfica de posguerra -hablo en concreto de la norteamericana y de la 2a Guerra Mundial- con la narración. Ahí hallamos una búsqueda intensiva cuyo objetivo es trascender no solo la narrativa convencional, también cualquier idea parecida a la posterior atracción. El origen de esa búsqueda se encuentra en el estrecho y discutible criterio de retroalimentación -el feedback anglosajón- que tiene lugar entre el aparato, la obra y el espectador. Una cadena que no está ligada a un enfrentamiento rígido, sino a la reflexión entre componentes y a la intromisión puntual de intermediarios como el autor. Una tercera vía que ansiaba desembocar en la meditación. Para muchos de aquellos cineastas, el cine como meditación no era una quimera que estuviera por venir. Para ellos, la meditación siempre había sido y seguía siendo la razón de ser del cinematógrafo.

Pero cuando he dicho el origen no he sido riguroso. Habría sido mejor decir la continuación. ¿Continuación de qué? del vínculo histórico que siempre ha existido entre invento técnico e intuición psíquica. Como apuntaba Bellour a través de Balzac, existen "medios para llegar a las

\footnotetext{
${ }^{20}$ Algunas de las vanguardias de comienzo de siglo XX fueron pioneras en rescatar el arte negro africano, el precolombino $y$, en general, cualquier manifestación de pueblos históricamente olvidados o colonizados. Tanto sus artes aplicadas como religiosas. No fue el caso de los dadá, de los futuristas y de otras corrientes más vinculadas a la glorificación de la industria y de los modos de vida modernos. Gombrich discutió está relación, que quiso ser más espiritual que formalista, en: La preferencia por lo primitivo. Episodios de la historia del gusto y el arte de Occidente, Barcelona: Debate, 2003.
} 
visiones". ${ }^{21}$ Ese hipotético intercambio sensorial entre aparato, obra y espectador es, pues, una vieja tríada que puede ser interpretada de diferentes maneras. Jugando y trocando nombres, atribuyendo y quitando funciones, este circuito ha constituido un lugar de fértiles elucubraciones artísticas y metodológicas. Tanto, que en ocasiones ha servido como plantilla para cartografiar toda la historia del cine. Se dijo que Serge Daney la utilizó para una especie de agrimensura cinematográfica: tres elementos y tres periodos donde la percepción y los flujos emocionales iban cambiando de sentido. Primero, del sujeto hacia a la imagen. Segundo, de la imagen al sujeto. Tercero, de la imagen al sujeto y de nuevo hacia la imagen. ${ }^{22}$ Recientemente, David Lynch quiso integrar estas vagas propuestas:

Hay un círculo que se despliega desde el público hasta la película y desde ésta de nuevo hacia la audiencia. ${ }^{23}$

Son divisiones interesantes, pero más poéticas que pragmáticas e imposibles de asumir como marcos de una investigación seria. Lo que pretendía la vanguardia cinematográfica citada era convertir la cadena aparato-obra-espectador en un todo que no priorizara elementos. Su deseo era abolir vértices y jerarquías. Esta postura tiene aun interés porque, en paralelo, la política de autores y la crítica cinematográfica como lábaros de la modernidad, pusieron el foco sobre el creador. Lo hicieron a través de una cinefilia psicologista solo contrarrestada por

\footnotetext{
${ }^{21}$ BELLOUR,, Raymond, op. cit., pp. 38-39.

22 LEUTRAT, Jean-Louis; LIANDRAT-GUIGUES, Suzanne, op. cit., p. 26.
}

La cronología que se vislumbra es bastante intuitiva. Primer periodo: del nacimiento del cine al establecimiento del modelo industrial dominante llevado a término por el MRI y por el star system. EI espectador encara la novedad con fascinación, pendiente y atento a ese nuevo medio en constante evolución. Ambos evolucionan a la par en una especie de vorágine donde, curiosamente, se invierte el flujo que dijo apreciar la Teoría de atracciones. Segundo periodo: asentamiento definitivo del cine como espectáculo donde una narración cada vez más refinada e identificable canaliza las proyecciones sentimentales. Cine e industria. La temporalidad prefijada contribuye a centrar a un sujeto más pasivo. Tercer periodo: la ruptura de la modernidad y el agotamiento del modelo comercial precedente. El espectador, cada vez más experto en códigos, se plantea preguntas sobre la realidad fotográfica y sobre los medios de reproducción.

${ }^{23}$ Para Lynch, la forma invariable del filme (mismos fotogramas proyectados siempre en el mismo orden y tiempo) deviene mecano sentimental e intelectual en los ojos y en la mente de cada espectador (The world is as you are. The film is as you are). LYNCH, David, Catching the big fish. Meditation, consciousness, and creativity, Nueva York: Penguin, 2006. Cita extraída de la versión audiolibro de la publicación. Las palabras se localizan en la pista no 10 del disco no 1 [La traducción es mía].

Las reflexiones de Lynch sobre la meditación no pueden tomarse en serio y no están relacionadas directamente con el cine, más bien lo están con una psicología amateur y, por momentos, con la autoayuda. Carecen de razón científica más allá de compartir algunas etiquetas con las neurociencias. En particular, con las investigaciones de Fred Travis, director del centro de EEG/Psicofisiología de la Maharishi University de Fairfield. Su extraño y por momentos caricaturesco programa meditativo fue articulado a través de una fundación propia, la David Lynch Foundation for Consciousness-Based Education and World Peace. 
el eventual talento literario y la agudeza crítica. Poco después, las nuevas teorías de los medios privilegiaron el componente tecnológico. Y, finalmente, el estructuralismo haría lo propio con el lector y con su capacidad infinita para establecer lecturas allí donde el autor se desvanecía en el texto como un fantasma. El gran problema de ese feedback, es no haber tenido en cuenta uno superior, estructural: el establecido entre cerebro-cultura-mente, con el lenguaje como intermediario. Es de este feedback y no de otro de donde, como explicaré en seguida, emerge la conciencia. ${ }^{24}$

Lo que buscaba la vanguardia parecía encontrarse fuera de las identificaciones primarias, en esa tierra de nadie que, dejando atrás el texto de placer -texto que, producido de acuerdo a las convenciones culturales, inducía una fruición confortable-, se adentraba en los confines del goce. ${ }^{25}$ Parajes agrestes, horizontes lejanos del romanticismo que querían hacer de la lectura un ejercicio intenso. Textos agresivos para la estabilidad sentimental que ponían en crisis los mecanismos de representación y las normas del lenguaje. Una vía teórica transitada a posteriori por Laura Mulvey. ${ }^{26}$ Para la autora, esta "compleja interacción de miradas" era específica del cine. Mulvey criticaba a fondo el (falo)antropocentrismo al que había estado sometido el invento y la tiranía de un placer voyerista y ególatra.

Pero las demandas de Mulvey, como las de sus compañeras Lippard, Sontang o Kristeva, no eran originales. Su carga crítica y reivindicativa -discurso de género, psicoanálisis- recogía, además de las aperturas teóricas sobre la experiencia del espectador provocadas por Metz, la evocación meditativa realizada por la vanguardia. Así como una actitud y una veta contestataria que, larvadas desde la posguerra, explotaron en los sesenta. Sin la intención de fijar un nuevo e imposible estándar para el deleite, lo que se pretendía era soltar el enorme lastre que arrastraba el dispositivo cinematográfico. Ser conscientes de esa enorme tradición, estarle incluso muy agradecidos, pero dejarlo atrás, trascenderlo. He traído a colación solo a Mulvey porque en ella encontramos otra de las semillas del mito que nos visitará en la segunda parte de esta investigación: la desmaterialización.

\footnotetext{
${ }^{24}$ MORIN, Edgar, La identidad humana. El método V. La humanidad de la humanidad, Barcelona: Círculo de Lectores, 2004, pp. 38-41.

${ }^{25}$ BARTHES, Roland, El placer del texto y lección inaugural de la Cátedra de Semiología Lingüística del Collège de France, op. cit., p. 25.

${ }^{26}$ Original escrito en 1973 y publicado en 1975: MULVEY, Laura, "Visual pleasure and narrative cinema" en Screen, vol. 16, no 3, otoño de 1975, pp. 6-18.

En español he manejado dos versiones:

"Placer visual y cine narrativo" en WALLIS, Brian (ed.), op. cit., pp. 365-377. "Placer visual y cine narrativo" en Eutopías, 2a época, vol. 1, Valencia: Episteme, 1988.
} 


\section{B.1. La conciencia}

«La existencia de la conciencia es,

en cierto modo, algo trágico» Andrei Tarkovski $^{27}$

La vanguardia quería un cine de la mente que, en un principio fue mero enlace ${ }^{28}$ entre vanguardias. A posteriori, ese cine total pasó a ser considerado como esbozo o predicción de las tecnologías ligadas a la biónica y a la realidad virtual. Los cineastas no quisieron fulminar cualquier atisbo de narración, más bien crearon grandes relatos en primera persona. El soliloquio, el monólogo interior y hasta el rezo o la plegaria ya eran ejercicios de simulación de conciencia, pero no eran equiparables a este deseo de auténtica representación de la conciencia. La vanguardia buscaba un discurso del yo como texto, no del yo en el texto.

No se trataba de ver a alguien meditando en pantalla, sino de dos objetivos bien distintos. Uno, desplegar una serie de estrategias visuales e iconográficas encaminadas a generar un pulso meditativo. Dos, aceptando la máxima barthesiana ${ }^{29}$ de que el cine -al contrario que la fotografía- no permite cerrar los ojos para volverse pensativo, se pretende acceder a la representación mental para volcarla en la obra. Literalmente, materializar la conciencia. A modo de ejemplo preliminar y no del todo exacto, la diferencia entre estos dos objetivos primordiales -activar el pulso meditativo o tratar de representarlo- podría ilustrarse con dos filmes de Takahiko limura: In the river (1969) y Shutter (1971). ${ }^{30}$ Digo que es un ejemplo

\footnotetext{
${ }^{27}$ TARKOVSKI, Andrei, Esculpir en el tiempo, Madrid: Rialp, 2005, p. 221.

${ }^{28}$ El vínculo tuvo lugar a través de Hans Richter. Mediados los años cincuenta, el artista alemán residía y ejercía labores docentes en el City College de Nueva York. Justo en ese momento y en ese lugar emergía un grupo de cineastas del todo diverso que llegaría a conformar el ala vanguardista del New American Cinema. Jonas Mekas solicitó a Richter un artículo para el primer número de Film Culture. Richter entregó un texto titulado "The Film as an original art form" (1955), una continuación de sus inquietudes sobre el absolute film: el cine como forma artística original que debía proceder a un ejercicio de purificación de cualquier medio y expresión adyacente. Un enfoque muy en la línea de lo que había ya había movido a la pionera teoría cinematográfica de los años veinte parisinos. Aquella quimera del cine puro desligada de la estética tradicional que se puede rastrear en textos de Baroncelli, L'Herbier, Epstein o Dulac. Absolute film también fue el sintagma utilizado por Alberto Cavalcanti para designar de manera no despectiva pero sí irónica, a una variante de esa misma vanguardia parisina de los veinte. En concreto al Ballet mécanique de Léger (1924) y al À quoi rêvent les jeunes films promovido por el Conde de Beaumont (1924) y que contaba con las colaboraciones de, entre otros, Chomette y Man Ray.

El artículo en cuestión: RICHTER, Hans, "The film as an original art form" en Film Culture, no 1, enero de 1955. Reeditado en SITNEY, Paul Adams, Film Culture Reader, op. cit., pp. 15-16.

Para la relación entre Richter y la nueva vanguardia americana: ELDER, Bruce R., "Hans Richter and Viking Eggeling: the dream of universal language and the birth of the absolute film" en GRAF, Alexander; SCHEUNEMANN, Dietrich (eds.), Avant-garde film, Amsterdam: Rodopi, 2007, pp. 3-54.

${ }^{29}$ BARTHES, Roland, La cámara lúcida, Barcelona: Paidós, 1995, p. 81.

${ }^{30}$ Están recopilados en un DVD, bajo el significativo título For filmic meditation, por la editora Re:Voir. EI autor los introduce con la siguiente sentencia: "I hope you could re-experience through these two films
} 
inexacto porque el primero -como puede suceder con Meditation on violence de Maya Deren (1948)-, a pesar de introducir una iconografía (el orientalismo de un baño sagrado en el Bagmati) y una metáfora (fluir del río enjugado por el fluir -interrumpido- material del filme) relacionadas con la meditación, también se vale de otros mecanismos técnicos y visuales que explicaré poco más adelante. Mientras que el segundo, Shutter, es un flicker film canónico.

Representar la conciencia, ese segundo y místico objetivo que podría ser definido como un cine inmanentista, está en el origen del Expanded cinema de Gene Youngblood:

Cuando hablamos de Expanded cinema, en realidad queremos decir conciencia expandida. Expanded cinema no es realizar un filme por computador, ni vídeos fosfóricos, ni la luz atómica, ni proyecciones esféricas. El Expanded cinema no es un filme en absoluto: al igual que la vida, es un proceso de transformación, el devenir histórico del hombre hasta culminar con la representación de su conciencia fuera de la mente, frente a sus ojos. ${ }^{31}$

Pero, ¿qué es la conciencia? Hasta ahora he hablado de ella dando por supuesto que todos sabemos de qué se trata. Es más, todos creemos entender cómo funciona y cuál es su cometido. Por desgracia, la conciencia no es un arquetipo que pueda reducirse a un axioma neurofilosófico. No hace falta asegurar que ninguno seríamos capaz de explicarla con rigor. Podríamos escribir relatos y cuentos sobre ella, pero entraríamos en crisis a la hora de hacer lo mismo con sus fundamentos científicos. Por lo tanto, pido exención parcial. No estoy capacitado para explicar qué es la conciencia, cuáles son sus mecanismos y sus funciones. Tampoco creo que este sea el lugar. Sin embargo, puedo recoger algunas ideas de aquellos que han intentado estudiarla y que me parecen apropiadas para este análisis.

Antonio Damasio argumentaba que el hecho de que la conciencia fuera una experiencia exclusivamente privada, no la convertía en un suceso objetivo. Damasio confluye aquí con Varela. ${ }^{32}$ El chileno, además de diferenciar con pertinencia introspección de meditación, consideraba que mediante este "método de observación de la mente in situ" interferimos con el modo habitual de estar en el mundo. La conciencia crea lo que él denomina una reflexión

in which I found that a thinking in film comes through silent meditation from the experience of the memory of a man in sacred river in Katmandu and the hallucination of flickering lights."

${ }^{31}$ YOUNGBLOOD, Gene, Expanded cinema, Nueva York: Dutton \& Co., 1970, p. 41. [La traducción es mía]

${ }^{32}$ VARELA, Francisco, Ética y acción, Santiago de Chile: Dolmen Ediciones, 1996, pp. 99-101. 
abierta. De cualquier modo, la conciencia no modifica aquello que está siendo observado, en este caso la propia mente. La conciencia solo trastoca la magnitud de nuestro compromiso activo con el mundo. Esto es, la conciencia no funciona en los términos de la incertidumbre de Heisenberg, sino en los de la fenomenología de la percepción.

Damasio y Varela tenían razón. Pocas cosas tan ciertas: somos el relato que cada uno hacemos de nosotros mismos. $Y$ aquí, a pesar de vulnerar los términos narratológicos, no es descabellado cambiar relato por ficción. Los estados mentales asociados a la conciencia "siempre tienen contenidos". ${ }^{33}$ Ya no se trata de defender la presencia de los contenidos en los medios de comunicación o el cine frente al poderío tecnológico y la atracción. Esto es, ahora no es cuestión de reconocer la existencia de una raíz narrativa, sino la raíz narrativa de la existencia. Pero no quiero jugar demasiado con las palabras, no quiero que ese ir y venir de palabras se convierta en un enunciado oscuro, en una atracción. Al igual que Damasio, opino que la conciencia vino a nuestra especie para quedarse y para triunfar, porque es la mejor forma narrativa que encontramos para, primero, asegurar nuestra supervivencia y, segundo, para hacer de esa supervivencia una actividad llevadera y hasta placentera.

En concreto, la relación de este apartado con la conciencia puede resumirse en una pregunta: ¿Cómo es posible que yo pueda contar lo que está ocurriendo en mi cabeza? En la correspondencia entre Freud y Karl Abraham, el primero daba motivos para el escepticismo:

Mi principal objeción es que no creo que sea en absoluto posible realizar, todavía, una representación plástica satisfactoria de nuestras abstracciones. ${ }^{34}$

Freud no estaba cómodo con el proyecto y puede que viera en esa adaptación cinematográfica de los sucesos mentales, una especie de banalización. Falta de rigor y demasiado lost in translation. En la actualidad, Murray Smith ha intentado relacionar y explicar la conciencia ayudándose de la representación cinematográfica con resultados parciales y quizá

33 DAMASIO, Antonio, Y el cerebro creó al hombre. ¿Cómo pudo el cerebro generar emociones, sentimientos, ideas y el yo?, op. cit., p. 242. Véase el capítulo 9 para entender esa construcción de "el sí mismo autobiográfico" a partir del operar conjunto entre conciencia y memoria. Especialmente las páginas 319-323. Para el triunfo narrativo de la conciencia, p. 399 y ss.

${ }^{34}$ FALZEDER, Ernst (ed.), The complete correspondence of Sigmund Freud and Karl Abraham, Londres: Karnac Books, 2002, p. 547. Esta parte de la correspondencia tuvo lugar en 1925, durante el intercambio motivado por el proyecto cinematográfico para el que se le había pedido colaboración y consejo científico a Abraham. El proyecto en cuestión sería realizado al año siguiente por Pabst bajo el título Secretos de un alma (Geheimnisse einer Seele, 1926). [La traducción y la cursiva son mías] 
decepcionantes. ${ }^{35}$ Por eso prefiero seguir con Damasio y, ahora también con Daniel Dennett.

Este último respondía con una fórmula atractiva que quiero hacer mía: la idea del yo como centro de gravedad narrativa. ${ }^{36}$ Dennett - desde la heterofenomenología- ${ }^{37}$ buscaba,

35 MURRAY SMITH, Greg, "Consciousness" en LIVINGSTONE, Paisley; PLANTINGA, Carla (eds.), The Routledge Companion to Philosophy and film, Londres y Nueva York: Routledge, 2009, pp. 39-51. Digo decepcionante porque, en ocasiones, parece la recurrente ilustración de las pasiones humanas a través de modos, técnicas y conductas de personajes y directores cinematográficos. A veces parece una vuelta al método de Paul Schrader y su estudio sobre el estilo transcendental. SCHRADER, Paul, El estilo trascendental en el cine, Ozu, Bresson, Dreyer, Madrid: Ediciones J. C., 1999.

Antes ya se había acercado -de manera más satisfactoria- al papel jugado por la conciencia, por los diferentes grados de atención en la percepción y por las interrelaciones de las expresiones anatómicas (gestuales, vocales, faciales) con las respuestas autónomas y automáticas del sistema nervioso, para desarrollar su teoría sobre la emoción cinematográfica. Desde postulados -no solo- cognitivistas, Murray Smith le otorgó un papel destacado, pero no crucial, a la conciencia como agente modulador de las emociones. Su modelo de las emociones se centra en la red asociativa descrita. Este sistema descentralizado puede iniciarse independientemente de que un estímulo active la cognición consciente. Su planteamiento teórico abarca los cuatro primeros capítulos de: MURRAY SMITH, Greg, Film structure and the emotion system, Nueva York y Londres: Cambridge University Press, 2003.

Una exploración cerebral por (f)MRI durante el visionado de diferentes contenidos audiovisuales, nos devuelve la localización y la magnitud de su actividad. Traducir esos datos visuales, esas frecuencias y esas ondas cerebrales es términos de emoción y de conciencia es todavía un campo abierto. Esta exploración a la que hago referencia, puede verse en: HASSON, Uri et al., "Neurocinematics. The neuroscience of film" en Projections, vol. 2, no 1, verano del 2008, pp. 1-26. Una de las conclusiones del experimento es proporcionar un nuevo paradigma (ISC: inter-subject correlation of brain activity) para ayudar a cuantificar ese compromiso, esa emoción o esa conciencia del espectador frente a un filme.

El experimento utilizó un capítulo de Alfred Hitchcock Presenta (Bang!, you're dead), una película de Sergio Leone (El bueno, el feo y el malo), una serie de televisión contemporánea (Curb your enthusiasm) y un fragmento filmado de la realidad tomado del parque Washington Square en Nueva York.

${ }^{36}$ DENNETT, Daniel, La conciencia explicada, Barcelona: Paidós, 1995, p. 421.

${ }^{37}$ El otro método para la simplificación de la conciencia es el neurobiológico. En este enfoque el centro de gravedad narrativa deviene punto de vista como representación corporal. A diferencia de la heterofenomenología de Dennett, se busca localizar por neuroimagen las áreas del cerebro asociadas a los estímulos y percepciones conscientes para diferenciarlos de los inconscientes o de los recibidos en desatención. Estos estudios también incorporan a pacientes con lesiones cerebrales determinadas para ayudar a fijar y explicar los fenómenos. Es el caso de: DAMASIO, Antonio, El error de Descartes. La razón de las emociones, Santiago de Chile: Andrés Bello, 1999 [original de 1994]. La conciencia es un ítem transversal en la obra de Damasio, no se puede extirpar, pero vuelve a tratar su arquitectura neurológica en: DAMASIO, Antonio, Y el cerebro creó al hombre. ¿Cómo pudo el cerebro generar emociones, sentimientos, ideas y el yo?, op. cit., p. 366 y ss.

Véase también una crítica de las ideas de Dennett en: CHURCHLAND, Patricia, "Hacia una neurobiología de la mente", en CHURCHLAND, Patricia; LLINÁS, Rodolfo; (eds.), op. cit., p. 332 y ss. Churchland no evita dar explicaciones sobre el hipotético reduccionismo neurobiológico, porque los avances científicos apoyan y perfilan la conciencia como "un patrón de actividad de las neuronas". La conciencia no es ninguna abstracción, solo depende de tener las herramientas y el desarrollo apropiados para terminar comprendiéndola. Churchland legitima la ingeniería inversa: descifrar los productos mentales a través del estudio de los componentes cerebrales. Patrones neurales y regiones cerebrales que hacen que la conciencia y la cognición no estén "en el cielo de Platón, sino en el competitivo mundo de Darwin".

En este apretado repaso, obvio el cénit del reduccionismo (Reducción Objetiva Orquestada: "Orch OR") de la conciencia, según el cual la conciencia puede ser explicada mediante la computación cuántica que tiene lugar en el cerebro: HAMEROFF, Stuart; PENROSE, Roger, "Consciousness in the universe. A review of the 'Orch OR' theory" en Physics of Life Reviews, vol. 11, no 1, marzo de 2014, pp. 39-78.

Por último, dos teorías más. Una que sigue a la búsqueda de unos criterios mensurables de la misma: TONONI, Giulio, "An information integration theory of consciousness" en BMC Neuroscience, vol. 5, n으 42, 2004. <http://www.biomedcentral.com/1471-2202/5/42> [consulta: 17-07-2015]. Esta teoría es 
obviamente, simplificar el "tejido narrativo del cuerpo humano". Y lo hace, a pesar de que la individualidad del yo y del peso gravitatorio empujen a pensar lo contrario, desde un modelo de versiones múltiples donde no hay un solo flujo de conciencia, sino varios. De acuerdo al funcionamiento cerebral, hablamos de un modelo descentralizado, no lineal, sinérgico y de trabajos y elaboraciones paralelas: "no existe un sólo punto en el cerebro al cual acuda toda la información" ${ }^{38}$ Ese yo narrativo es, por lo tanto, una abstracción. Diría más, es una variante de la ficción que, al menos, cumple la función de atraer y divulgar propiedades tangibles sin caer en la tautología.

¿Por qué encaja esta fórmula en el cine meditativo? Porque ese centro de gravedad narrativa no es un estilema, ni siquiera una corriente estética sólida, es un vínculo que hace que la propia existencia dependa de la persistencia de la narración. ${ }^{39} \mathrm{Y}$, precisamente, esta última sentencia es una de las hipótesis de esta investigación. También resulta curioso que Damasio llegara a utilizar extended, un adjetivo similar al expanded de Youngblood, para referirse a la evolución de la conciencia humana. Aquella que se despliega durante un periodo de tiempo más amplio que la típica fulguración biológica. La conciencia extendida ${ }^{40}$ conecta con el pasado e intenta predecir el futuro sin perder la referencia del yo como primera articulación. Además, Damasio ya había recurrido de manera explícita a la metáfora de "la película en el cerebro" (movie-in-the-brain) ${ }^{41}$ para, sin solución de continuidad, calificarla como rough -dura o quizá basta. Damasio debía ser consciente -valga la redundancia- del bucle que se establecía al situar una película en el cerebro que, a su vez, debía ser presenciada por un espectador que, además de generarla, tenía que ser consciente de sí mismo para poder observarla.

especialmente interesante por la crítica implícita que realiza del reduccionismo binario. Su hipótesis parte de que la información neural que da lugar a la conciencia es irreductible -0 , de momento, lo parece. De ahí que la conciencia siga sin responder a la supercomputación del big data no ya para explicarla, sino para reducir algo la incertidumbre.

Y esta otra -extravagante- que invierte los términos: el cerebro no crea la conciencia, es esta la que crea el cerebro. La tesis pertenece al psicólogo cognitivo Donald Hoffman, quien considera que explicar la conciencia a partir de la materia no ofrecerá los resultados deseados. Su opción, puramente matemática, se despliega a través de lo que llama Realismo Consciente. Hoffman también es el desarrollador de la TIP (ITP en inglés) o Teoría de la Interfaz de la Percepción. Entrevista y bibliografía esencial en:

<http://ilevolucionista.blogspot.com.es/2015/09/vivimos-en-matrix-entrevista-donald.html> [consulta: 09-09-2015]

Mi postura sobre la conciencia sería un híbrido entre el naturalismo paciente de Churchland, la metáfora narrativa de Dennett y la inestimable labor descriptiva y exploradora de Damasio.

${ }^{38}$ DENNETT, Daniel, op. cit., p. 117. El modelo de versiones múltiples está estrechamente relacionado con las ideas de Minsky.

${ }^{39}$ Ibíd., p. 440.

${ }^{40}$ DAMASIO, Antonio, The feeling of what happens. Body and emotion in the making of consciousness, San Diego: Harcourt Incorporated, 1999, pp. 201-239.

${ }^{41}$ Ibid., p. 17 y ss. 
¿Existe algún intento científico para desvelar y relacionar de manera directa esa actividad cerebral de la conciencia con las imágenes? Sí, primitivo y aislado. Pero, a buen seguro habría interesado a todos aquellos cineastas que, ante la imposibilidad tecnológica o por simple convicción, decidieron realizar una reinterpretación estética. Reconstructing visual experiences from brain activity evoked by natural movies ${ }^{42}$, es el esclarecedor título de la investigación en cuestión. Movernos por el mundo o ver una película, suscita un patrón dinámico y siempre diferente en el cerebro. La premisa del experimento fue tan sencilla como compleja de llevar a término: recrear lo observado a partir del patrón evocado. Es decir, una suerte de ingeniería inversa. Generar modelos de datos que describieran el proceso mediante el cual una película se transforma en actividad cerebral. A continuación, utilizar dichos modelos para descodificar la actividad y reconstruir el estímulo original. Nuevos modos para explicar la indisoluble comunión entre materia y mente. Nuevas puertas de comunicación entre los estímulos externos y el mundo interno. Nuevos intentos de estudio empírico y hasta matemático de la percepción que no nos hagan volver la vista a la psicofísica de Weber y Fechner. ${ }^{43}$ En resumen, establecer un modelo cuantitativo de la actividad cerebral para sentar las bases de una rudimentaria descodificación de las imágenes del cerebro.

Como se puede imaginar, todo fue mucho más complejo que lo contado en el párrafo precedente. Se sucedieron las horas de visionado y se utilizó un catálogo cambiante de estímulos visuales. El estudio estuvo basado en exploración de la corteza visual por (f)MRI y en complejos algoritmos computacionales. La conclusión: demostrar por primera vez que las experiencias visuales dinámicas pueden ser recuperadas a partir de la baja actividad cerebral que puede registrar una resonancia magnética funcional. El resultado tangible es muy interesante para los intereses de esta investigación. Las imágenes devueltas por los modelos, comparadas con las originales, evidenciaban lo primario del acercamiento. Formas difusas y fuertemente hipoformalizadas que parecían remitir antes al viejo celuloide descompuesto que a la alta tecnología digital. ¿Cabe un símil entre el cerebro y el celuloide? No. No se puede

\footnotetext{
${ }^{42}$ NISHIMOTO, Shinji; VU, An T.; NASELARIS, Thomas; BENJAMINI, Yuval; YU, Bin; GALLANT, Jack L., "Reconstructing visual experiences from brain activity evoked by natural movies" en Current Biology, vol. 21, no 19, octubre de 2011, pp. 1641-1646.

<http://www.stat.berkeley.edu/ binyu/ps/papers2011/NishimotoVNBYG11.pdf> [consulta: 21-10-2015]

${ }^{43}$ URTUBIA VICARIO, César, Neurobiología de la visión, Barcelona: Ediciones UPC, 1997, pp. 50-51.

Una verificación crítica y actualizada de los postulados de Weber-Fechner: DEHAENE, Stanislas, "The neural basis of the Weber-Fechner law. A logarithmic mental number line" en Trends in Cognitive Sciences, vol. 7, no 4, abril del 2003, pp. 145-147.

<http://homepages.uni-tuebingen.de/andreas.nieder/Dehaene(2003)TICS.pdf> [consulta: 21-10-2015]
} 
equiparar cerebro con soporte, córtex visual con emulsión y neuronas y dendritas con sales de plata. Poder se puede y lo acabo de hacer, pero en realidad el cerebro y sus centros visuales operan más -salvando las diferencias- a la manera de una computadora que de una bobina de película.

Ante el mismo estímulo, ese patrón cerebral siempre diferente nos habla de la dificultad en la reconstrucción, pero también de la volatilidad del yo consciente-narrativo y de una experiencia cinematográfica que, como diría Cherchi Usai ${ }^{44}$, está más cerca de las alteraciones típicas de la tradición oral o de las suscitadas por un paseo en un flâneur benjaminiano. ${ }^{45}$ Patrón cerebral cambiante que parece remitir al río o al flujo heraclíteo, a su vez, metáfora implícita del río de Takahiko limura.

Para ir concluyendo, solo deseo añadir que la propuesta de este subapartado, así como la del siguiente, es más descriptiva que analítica. Da cuenta de las intenciones ajenas y no supone la asunción por mi parte de una teoría que legitime la metáfora del cine como la materialización de los procesos mentales. Es más, soy crítico con la conceptualización mental del cine más allá de su validación como figura retórica. Todo esto a pesar de que, si acudimos a la neurobiología, podría existir un paralelismo cierto entre el cine expandido y la conciencia. Por ejemplo, cuando Damasio utiliza la conciencia como mediadora entre mapa cerebral e imagen, o cuando describe el proceso de la mente como un "continuo fluir" de lo que aquí he denominado imágenes mentales mixtas.

Esta labor descriptiva no es óbice para apuntar técnicas y razones que hoy todavía conservan vigor. El cine de la mente en tanto fundamento teórico -igual que le sucedió al sueño-, no es un fenómeno tan reciente -segunda mitad del siglo XX. En parte surgió y fue difundido en un intento por revitalizar un psicoanálisis fílmico que ya había empezado a mostrar síntomas de agotamiento. El cine de la mente nunca quedó constituido como alternativa rigurosa y cognitivista. Con esto presente, remito a la temprana crítica del método que ya realizó Noël Carroll. ${ }^{46}$ El filósofo no vio productiva o apropiada la analogía entre mente y cine, como tampoco lo hizo con otras comparaciones recurrentes como la cartesiana entre mente y teatro y la más reciente entre mente y realidad artificial. Ni siquiera una entre mente y computadora.

${ }^{44}$ CHERCHI USAI, Paolo, The death of cinema. History, cultural memory and the digital dark age, Londres: BFI, 2001, p. 17, 59 y 103 entre otras.

${ }^{45}$ BENJAMIN, Walter, Libro de los pasajes, Madrid: Akal, 2004.

${ }^{46}$ CARROLL, Noël, Theorizing the moving image, Nueva York: Cambridge University Press, 1996, pp. 293412. 
Siendo esta última la que -teniendo en cuenta los problemas a los que aludía Atran- mejores resultados ofrece a la luz de las experiencias vertidas por la psicología experimental contemporánea. Como apuntaba en la introducción de esta investigación, el cognitivismo como postura y enfoque ofrece soporte para cuestionar el cine de la mente.

Y lo hace de manera especialmente atractiva con el cine de vanguardia. En este aspecto, comparto la conclusión a la que llega James Peterson ${ }^{47}$ tras ponerlo en práctica. Para Peterson, el análisis cognitivista aplicado a esta vanguardia cinematográfica concreta -entre otros se centra en Stan Brakhage, J. J. Murphy, Ernie Gehr y, sobre todo, en Bruce Baillie- lejos de resultar perverso, es apropiado. No es esencialista, ni idealista, ni insensible a la historia o al contexto cultural. Igual que Peterson, considero que un cognitivismo ejercido a través de las metáforas y de la inferencia, puede resolver viejos problemas y abrir nuevos y sugerentes caminos para la investigación. A esa apelación que hace la vanguardia al más allá racional, a la comprensión espiritual de la obra, no se le puede contestar sumando más esoterismo. Están los códigos, está la semiótica; están los procesos, está la historia; y están también las ciencias de la cognición.

Hace tiempo que el cognitivismo cinematográfico ${ }^{48}$ dejó de ser un acercamiento atrevido, pedante y altanero, como llegó a ser calificado por Dudley Andrew ${ }^{49}$ a finales de los ochenta.

\footnotetext{
${ }^{47}$ PETERSON, James, "Is a cognitive approach to the avant-garde cinema perverse" en BORDWELL, David; CARROLL, Noël (eds.), op. cit., pp. 108-129.

${ }^{48}$ El análisis cognitivista superó una etapa en la que se hizo esclavo de las repercusiones que tenían la planificación o el ritmo de la imagen. Como si se tratara de una prolongación, apenas actualizada, del viejo debate entre David Bordwell y Barry Salt sobre la metodología correcta para establecer la duración media del plano en una película. SALT, Barry, Film style \& technology: History \& analysis, Londres: Starword, 1983.

En la actualidad, el cognitivismo cinematográfico es comúnmente aceptado aunque persisten recelos. En esta tesitura, todavía corre el riesgo de convertirse en una nueva y exclusiva camarilla -como ha sucedido casi siempre con los modelos analíticos-, antes que un boom o en una moda masiva. Los estudios cognitivistas parecen haberse arremolinado en torno a una nómina de nombres, de publicaciones y de congresos. Véase: <http://scsmi-online.org/> [consulta: 24-06-2015]

${ }^{49}$ ANDREW, Dudley, "Cognitivism: quests and questionings" en Iris, no 9, Cinema and cognitive psychology, 1989, pp. 1-10.

Justo durante esos años comenzó a generalizarse dentro de la teoría cinematográfica la cuestión cognitivista. Y lo hizo, cómo no podía ser de otra forma, con polémica y hasta con acritud. A principios de los noventa la teoría de los nuevos medios y del fenómeno digital era ya hegemónica y cualquier atisbo cognitivista era visto como reaccionario. Con la perspectiva que dan más de dos décadas, resulta esclarecedor leer el suplemento que dedicó Journal of Dramatic Theory and Criticism (Lawrence: Departamento de Teatro de la Universidad de Kansas) a la incipiente (Edward Small, autor de la introducción, reconoce no haber escuchado el término cognitivismo hasta tres años antes. 1989, justo el año del editorial de Dudley Andrew en Iris, a quien lógicamente cita) relación entre ciencia cognitiva y cine: vol. VI, no 2, primavera de 1992, pp. 165-231.
} 


\section{B.2. El ojo y la cámara}

¿Cuáles fueron los recursos técnicos y estéticos más utilizados para intentar convertir en realidad la quimera del cine como meditación? Antes conviene aclarar que todo el arsenal expresivo parte de la compleja relación establecida entre una percepción que se desgaja en diferentes maneras de ver y una tecnología del medio que busca ser deconstruida, que no desmaterializada. Esta dualidad deviene dialéctica productiva: la del el ojo -y, por ende, la del cerebro- y la de la cámara. Uno de los principios sobre los que William Wees asentó sus inspiradores análisis de la estética cinematográfica avant-garde. ${ }^{50}$

La dialéctica ojo-cámara no queda satisfecha con la mera movilización de un globo ocular que vaga por la pantalla tras aquello que Edgar Morin denominaba el "elemento emocional" ${ }^{51}$ Tampoco con aquel "ojo variable" tramado por Jacques Aumont. ${ }^{52}$ La meditación -el poso de la conciencia, si se quiere- no emana de la tecnología, sino que se presenta o se adquiere con la toma de conciencia de los propias mecanismos de visión. En tanto en nuestra vida percibimos igual que respiramos -esto es, sin conciencia del acto-, una percepción desautomatizada deberá superar algo más que el principio de extrañamiento ${ }^{53}$ y el distanciamiento típicos de la modernidad.

La dialéctica del ojo-cámara busca situarse en un plano donde la percepción entre a formar parte de la cognición. Para lograrlo, con los serios matices biológicos que ya conocemos, se necesita un compromiso mayor:

Destaca el artículo de Noël Carroll: "Cognitivism, Contemporary Film Theory and Method. A Response to Warren Buckland". En el texto, Carroll no esconde el enfrentamiento dentro de la teoría anglosajona entre la emergencia cognitivista y el fuerte arraigo psicoanalista. Se defiende de los que ven su cognitivismo como una nueva extensión del imperialismo científico. El cognitivismo era visto -¿̇lo es aún hoy?- como algo totalitario por su ansia de verdad objetiva.

Publicación disponible online: <https://journals.ku.edu/index.php/jdtc/issue/view/138> [consulta: 2306-2015]

${ }^{50}$ WEES, William C., Light moving in Time. Studies in the visual aesthetics of avant-garde film, Berkeley: University of California Press, 1992.

${ }^{51}$ MORIN, Edgar, El cine o el hombre imaginario, op. cit., p. 95.

${ }^{52}$ AUMONT, Jacques, El rostro en el cine, Barcelona: Paidós, 1997. p. 62.

${ }^{53}$ Fue el escritor y crítico Viktor Shklovski quien acuñó el término y quien defendió la necesidad de una experimentación técnica y formal que convirtiera la percepción en un ejercicio menos automatizado. La percepción era demasiado amiga de los hábitos, nos inducía a una contemplación perezosa e hipnótica; a una especie de molicie estética. Había que desautomatizarla a través de la forma. Hasta donde sé, Sobre la teoría de la prosa, escrito en 1925, no conoce edición en español, solo traducciones parciales de algunos de sus capítulos, por ejemplo: "El arte como artificio" en CUESTA ABAD, José Manuel; JIMÉNEZ HEFFERNAN, Julián (eds.), Teorías literarias del siglo XX, Madrid: Akal, 2005, p. 68-73. He manejado una edición en inglés: SHKLOVSKI, Viktor, Theory of prose, Londres: Dalkey Archive Press, 1991. 
Los espectadores no pueden quedar reducidos a receptores pasivos de imágenes. Deben llegar a comprometerse con el filme mediante un proceso creativo continuo de renovación visual. ${ }^{54}$

Esa cierta meditación alcanzada a través de un firme compromiso fisiológico, se acerca menos a una idea de autoconciencia que a otra de mediación y de agente creativo. La rotunda presencia de factores corporales y materiales que tienen lugar en estas propuestas vanguardistas, deberían llevar a replantear el vínculo que algunos han establecido entre cine de vanguardia, descorporeización y desmaterialización. Así como entre vanguardia y los entornos digitales y virtuales. ${ }^{55}$ Scott MacDonald es más certero a la hora de señalar al acto cinematográfico como el camino que concilia mente y materia, narración y abstracción:

Destacados cineastas han luchado por honrar la capacidad del cine a la hora de conciliar lo espiritual y lo material, de manera que ambos puedan ser apreciados en profundidad, cada uno a través del contexto del otro. ${ }^{56}$

Ahora sí, sin más digresión, procedo a relatar los recursos técnicos y estéticos anunciados. A pesar de dividirlos en cuatro grandes bloques, no son compartimentos estancos. Comparten conexiones y un mismo fin meditativo. Primero, la mecanización de los movimientos. Segundo, la humanización de la cámara. Tercero, la iconografía ad hoc. Cuarto, la luz. Su explicación contará con la brevedad que dicta todo interludio, no busco la exhaustividad y solicitaré la ayuda de nombres y obras muy concretas.

\section{B.2.1. Movimientos}

El primer conjunto sería el reino de Michael Snow. Sus desplazamientos visuales sistemáticos que terminan por formar un discurso sobre la concepción del espacio -no solo el cinematográfico- y sobre nuestra percepción del mismo. Para ello, nada mejor que recurrir a las panorámicas preprogramadas de La Région Centrale (1971), al metaencuadre y al zoom de Wavelenght (1967) y a la modulación de los movimientos de Back and forth (1969). Pero Snow era más un artista integral que un cineasta. Estos juegos entre espacio, movimiento, ritmo y percepción, no estarían completos sin tener en cuenta el amplio espectro de sus inquietudes

\footnotetext{
${ }^{54}$ WEES, William C., op. cit., p. 81. [La traducción es mía]

${ }^{55}$ La exploración más sugerente del difícil vínculo, procede de las reediciones y relecturas de un tipo con perspectiva completa, Malcolm Le Grice: Experimental cinema in the digital age, Londres: BFI, 2001.

${ }^{56}$ MACDONALD, Scott, A critical cinema 5. Interviews with independent filmmakers, Berkeley: University of California Press, 2006, p. 8.
} 
plásticas, visuales y musicales. Afanes que fueron creciendo hasta la actualidad y que encuentran en la práctica de la instalación la manera más armónica de integración.

Lo que busca Snow con la automatización de los movimientos es desautomatizar la percepción. El canadiense crea sistemas dinámicos que contrasten y asalten al espectador anclado y monótono. Desde que Griffith subiera una cámara en globo -algo que ya había hecho seis décadas antes Nadar- para filmar la Babilonia de Intolerancia (Intolerance, 1916) o desde que Murnau atara otra en el pecho de Karl Freund para recorrer el vestíbulo de El último (Der letzte mann, 1924), la cámara desencadenada siempre ha sido debatida en este sentido. Pero existe una diferencia notable entre ejercicios tan específicos como los de Snow y el movimiento inscrito en un filme convencional. Arthur Danto sobrevaloró la importancia de estos últimos con aquello de la kinetificación de la cámara.

Danto trasladaba de manera poco fina una práctica de vanguardia a la alta tecnología contemporánea. E igualaba intenciones y resultados: a lo que conducía esa kinetificación era a "explicar el impacto interior que los filmes ejercen sobre nosotros". ${ }^{57}$ Empujándonos a la escena como fantasmas en movimiento o asistiendo al espectáculo como espectadores cartesianos descorporeizados. Pero esta kinetificación dantiana también implica que el espectador pueda dejar de asumir el movimiento de la cámara para, de algún modo, somatizarlo. Para Danto, llega un momento donde, debido a la imposibilidad fisiológica del movimiento contemplado, la acción de la película se desliga de nosotros en una nueva suerte de atracción. Esto es, la historia representada se convierte en excusa para lucir los medios de representación. El último objetivo de esta escalada es, lógicamente, asegurar que el filme trata sobre él mismo. A partir de aquí, la única desencadenada es la capacidad de Danto para la tautología:

El filme se convierte en su propio tema, la conciencia de lo que el filme es, es la misma conciencia del filme. $\mathrm{Y}$ en este avance hacia la autoconciencia, el cine desfila junto a las demás artes del siglo veinte en el sentido de que el arte se convierte en el sujeto último del arte. ${ }^{58}$

\footnotetext{
${ }^{57}$ DANTO, Arthur D., "Moving Pictures" en CARROLL, Noël; CHOI, Jinhee (eds.), Philosophy of film and motion pictures. An anthology, Malden: Blackwell Publishing, 2006, p. 110. [La traducción es mía]

${ }^{58}$ Ibíd., p. 111. [La traducción es mía]
} 
Danto y Snow al margen, en este apartado también caben los juegos focales de Ernie Gehr en Serene velocity (1970). ${ }^{59}$ Ritmo y estructuración de la naturaleza de las ópticas que dinamitan la ilusión de movimiento. Además, en esta mecanización de los movimientos se puede introducir -y hacerlo con la fuerza justa- la idea de un estatismo que, en el devenir interno del encuadre, no hace más que reflejar el discurrir material de los fotogramas. Afirmo esto con algunos trabajos del James Benning predigital (pre Ruhr, 2009) en la memoria. Recientemente, Justin Remes ${ }^{60}$ ha seguido discutiendo una idea que no ha dejado de importunarnos. Idea vieja pero no superada: la dudosa supremacía física y estética del movimiento frente a la imagen más que detenida o inmóvil- sin movimiento interno real o aparente, o con un movimiento interno en los límites de la percepción.

El movimiento mecanizado, en el fondo, utiliza la misma estrategia de construcción que el gag silente. Esto es, la repetición del acto hasta llegar a un punto de ruptura o de variación. Allí donde el gag nos desvela la risa, el movimiento mecanizado hace lo propio con los automatismos del aparato y de nuestra mirada. Cómo interpretar ese desvelo consumado es más discutible. Para el citado Michael Snow, el hecho se acerca a la meditación: "mis filmes, (para mí) son intentos por inducir la mente a un cierto estado o a ciertos estados de conciencia". ${ }^{61}$

\section{B.2.2. Humanización}

El segundo conjunto, el de la humanización de la cámara, es el dominio de Stan Brakhage. Su deseo frenético de convertir la cámara en un apéndice del cuerpo o, directamente, de prescindir de ella para asumir e interiorizar sus funciones. Rechazar cualquier limitación técnica para acceder a la imagen primigenia. Ese acceso a la dimensión meditativa y alucinatoria del cine solo es posible a partir de una retórica profundamente neoprimitiva. Esto es, neorromántica y hasta chamánica ${ }^{62}$ que, paradójicamente, termina encontrando la razón

\footnotetext{
59 El mismo año Standish Lawder realiza Corridor. Un análisis comparado nos devolvería similitudes y discrepancias estéticas maravillosas. Compartiendo escenario, Lawder abandona el férreo estructuralismo de Gehr para jugar con el movimiento real, con el sonido, con la luz, con el flicker y con la incorporación de la figura humana. La mecanización pura de Gehr deviene filme de terror en Lawder. La meditación convertida en angustia.

60 REMES, Justin, Motion[less] pictures. The cinema of stasis, Nueva York: Columbia University Press, 2015.

${ }^{61}$ Son palabras extraídas de una carta enviada a Paul Adams Sitney y Jonas Mekas fechada el 21 de agosto de 1968: SNOW, Michael, The collected writings of Michael Snow, Waterloo: Wilfrid Laurier University Press, 1994, p. 44. [La traducción es mía].

62 La práctica chamánica de Brakhage puede ser relacionada con el neoprimitivismo iconográfico a través de las teorías de Clottes y Lewis-Williams. Los estados alterados de conciencia, el trance y la
} 
científica de las primeras imágenes. Los escenarios y las imágenes solo son imposibles porque no han sido imaginados. No se trata del teatro cartesiano de la mente, ni de las geometrías de Escher; sino de un ruidoso taller iconográfico denominado cerebro y de unas mazmorras diseñadas por Piranesi. La manera que tiene Brakhage de enfrentarse con el espacio y con la imagen queda resumida en la célebre apertura de Metaphors on vision:

Imagina un ojo desvinculado de las leyes humanas de la perspectiva, un ojo no condicionado por la lógica compositiva, un ojo que no responde al nombre del todo sino al conocimiento de cada objeto encontrado en la vida a lo largo de la aventura de la percepción (...) ¿Cuántos arcoíris puede crear la luz en un ojo ignorante? (...) Imagina un mundo repleto de objetos incomprensibles que tilila con una infinita variedad de movimientos y con innumerables gradaciones de color. Imagina un mundo antes de que al "principio fuera el Verbo". ${ }^{63}$

Brakhage termina invocando a San Juan para dejarlo atrás, para continuar adentrándose en la prehistoria. “El Verbo estaba en Dios, y el Verbo era Dios" ${ }^{64}$, proseguía el evangelista. Por eso Brakhage busca un punto donde no rija condicionamiento alguno; menos aun el divino. Lo suyo son las "aventuras del ojo" que van "más allá de cualquier expresión lingüística". ${ }^{65}$ Cuando Lewis-Williams estudió el arte paleolítico europeo para, más adelante, enlazarlo con el bosquimano de ciertas regiones del sur de África ${ }^{66}$, necesitó una explicación neurofisiológica que suturara la herida que un relato rigurosamente cultural era incapaz de explicar. Allí donde la geografía y los milenios imposibilitaban el uso de los puntos de contacto, apareció la fisiología del cerebro para coser los universales iconográficos, ya fueran abstractos o naturalistas.

Brakhage, sin saberlo, formulaba en celuloide las teorías que hoy parecen las más sensatas para explicar el primer arte de nuestra especie. El cineasta deseaba un untutored eye externo,

\footnotetext{
alucinación como fundamento biocultural de ciertas representaciones parietales: CLOTTES, Jean; LEWISWILLIAMS, David, Los chamanes de la Prehistoria, Barcelona: Ariel, 2001.

${ }^{63}$ BRAKHAGE, Stan, Metaphors on vision, Nueva York: Film Culture, 1963. [La traducción es mía]

${ }^{64}$ SAN JUAN, "El Santo Evangelio de Nuestro Señor Jesucristo según San Juan" en Sagrada Biblia, Zaragoza: UNALI, 1974, p. 972.

${ }^{65}$ BRAKHAGE, Stan "My eye" en op. cit. Metaphors on vision no estaba paginado. La versión digitalizada a color que yo manejo es la de un original con el diseño y maquetación de George Maciunas. En una edición italiana a la que también he tenido acceso (Milán: Feltrinelli, 1970) sí existe paginación: "II mio occhio" p. 66.

${ }^{66}$ CHALLIS, Sam; LEWIS-WILLIAMS, David, Deciphering ancient minds: the mystery of San bushmen rock art, Londres: Thames \& Hudson, 2011.
} 
la cámara, que tuviera correspondencia con otro interno, el ojo-cerebro. Explorar en lugar de registrar. El propio cineasta declaraba ${ }^{67}$ que su cometido era idéntico al de un documentalista, pero, en su caso, el objeto de estudio y de plasmación no era lo profílmico, sino la mente. Brakhage trató de filmar el acto de ver en sí mismo mediante las variantes que le brindaba la luz neural.

¿Cómo lograrlo? con la closed-eye vision. La representación de toda una serie de motivos y patrones lumínicos que aparecen una vez cerrados los ojos: granos, puntos, rayas, bloques, etc. Formas, colores, tamaños, geometrías y abstracciones que Brakhage trasladó a la película con técnicas no fotográficas como la acción directa, la pintura y el collage orgánico. Aunque, en rigor, el término closed-eye vision no es del todo correcto desde que algunas de algunas figuras incorporadas son percibidas a ojo abierto o provienen de otro tipo de estímulos. Es decir, bien responden a fenómenos curiosos de nuestra percepción como las imágenes entópticas (el fenómeno de Scheerer y el fosfeno), la polarización lumínica (Cepillo de Haidinger) y las miodesopsias, o bien están relacionadas con alucinaciones, con estados alterados de conciencia y hasta con lesiones (poliopia).

Brakhage fue quien más cerca estuvo de interpretar el papel de Galahad. El grial vanguardista de la primera imagen, repleta de pureza y santidad, estaba en el interior de cada uno de nosotros. Y no tenía nada de cultural, de mística o de religiosa. Ni siquiera podía considerarse un subproducto del placer o del goce, de la angustia o de la locura. Era pura fisiología. A veces era la mismísima visualización de los glóbulos blancos: fenómeno de Scheerer. Otras, era una suerte de eco electrovisual de nuestras funciones y disfunciones mentales. Las más, la traducción estética de las señales del nervio óptico ${ }^{68}$ que ya habían consumado nuestros ancestros sobre las rocas del Paleolítico Superior. ${ }^{69}$ Brakhage no quería un cine en forma de o como vehículo para la meditación ${ }^{70}$, su aspiración era encontrar el fundamento orgánico de

\footnotetext{
${ }^{67}$ WEES, William C., op. cit., pp. 78-79.

68 BRAKHAGE, Stan, Brakhage Scrapbook. Collected writings 1964 - 1980, Kingston: McPherson \& Company, edición y compilación de Robert Haller, 1982, p. 134.

69 LEWIS-WILLIAMS, David, et. al., "The signs of all times: entoptic phenomena in upper paleolithic art" en Current Anthropology, vol. 29, no 2, abril de 1988, pp. 201-245.

${ }^{70} \mathrm{Su}$ tetralogía titulada Visions on meditation (1989-1990), a pesar de incorporar el concepto en el título, responde a otras intenciones y a otra ortodoxia -si cabe utilizar este término en Brakhagetécnica (single framing, sobreexposiciones, barridos) e iconográfica (paisaje). Son películas más figurativas que funcionan como atlas sentimental particular. Especialmente afortunada la segunda entrega Mesa Verde. Algo similar ocurre con su serie Sexual meditation (1970-1972).
} 
esta, igual que hará el flicker filme con "la sinapsis eléctrica del cerebro como pensamiento visual activo" ${ }^{71}$

\section{B.2.3. Iconografía: el mandala}

El tercer campo, el de la iconografía, es transversal en cuanto a tipos y protagonistas. Dentro de esa condición quiero señalar aquella que considero fundamental para entender el concepto de meditación asociado a la vanguardia. Me refiero a las iconografías del mandala. Iconografías en plural porque hablo de un motivo mutante y dinámico. El mandala es la combinación de formas cuadrangulares y circulares (mandala en sánscrito significa círculo) cuya ordenación pictórica como objeto de rito oracular, deífico o meditativo es universal. La forma mandala nunca fue exclusiva y nunca estuvo restringida al pensamiento y a la práctica oriental. Como demostró Jüng ${ }^{72}$, el mandala se extiende a lo largo de todo el planeta tocando diferentes periodos históricos. El mandala aparece como expresión destacada en el arte egipcio, en el de los indios navajos, en el culto budista, en el / Ching chino, en la emblemática medieval y renacentista, en la concepción del hombre vitruviano, en el yin y yang del taoísmo, en el crismón cristiano, en el Sello de Salomón y hasta en la vulgaridad lucrativa de la numismática.

Esta constancia le sirvió a Jüng para apuntalar su idea del Inconsciente Colectivo. Aquí, en la vanguardia cinematográfica de la segunda mitad del siglo XX, el mandala me interesa más en un sentido pragmático, fisiológico e histórico. El mandala como expresión estética universal y como ejemplo canónico de una forma -que es también un relato- superviviente. Lo es y lo será porque, igual que las imágenes parietales abstractas, sus principios visuales responden a la electrogeometría cerebral. La forma universal y la forma superviviente es también la forma constante. Fue el psicólogo alemán Heinrich Klüver quién primero estudió y sistematizó la aparición de patrones geométricos ${ }^{73}$ durante estados alterados de conciencia. Klüver realizó estudios de las formas y texturas percibidas tras la ingesta de mescalina. ${ }^{74}$

\footnotetext{
${ }^{71}$ COLLADO, Esperanza, op. cit., p. 53.

72 JÜNG, Carl Gustav, Formaciones de lo inconsciente, Barcelona: Paidós, 1990, p. 129.

73 Las formas que todos los pacientes experimentaron quedaban organizadas en cuatro grandes bloques: uno, patrones enrejados, de damero y de panal; dos, patrones de tela de araña; tres, patrón de túnel o embudo; cuatro, espirales. Las tempranas evidencias encontradas por Klüver, muy apegadas a las teorías gestálticas, siguieron apuntalando su vigencia con los años. Hoy, las nuevas evidencias aportadas por la exploración neurocientífica no hacen más que ratificarlas. Lo que sí han hecho los avances es convertir este tipo de visiones alucinatorias en un fenómeno menos dependiente de la anatomía cerebral que de sus conexiones. Es decir, se ha pasado de un estudio topológico de la alucinación a otro hodológico en el que no se puede atribuir la alucinación a una disfunción o a una hiperactividad en una región concreta -en este caso a la V1-, sino a una serie de interconexiones entre
} 
Si Brakhage invocaba a San Juan, en este apartado podríamos encontrar un Ilamamiento directo a las asombrosas vivencias del libro o profecía de Ezequiel. Su visión de la gloria divina, lejos de interpretaciones sobrenaturales y extraterrestres, tenía mucho que ver con la geometría y el suceso alucinatorio de un mandala cinematográfico proyectado en el cielo. ${ }^{75}$ Visiones místicas con explicación fisiológica, igual que las de Hildegarda de Bingen. Las fuerzas del universo simbolizadas en círculos imbricados, luminosos, de fuego brillante, patrones repetidos que buscaban la eternidad del orden divino. Teofanías que resultaban ser las representaciones visuales originadas durante, por ejemplo, episodios de migraña. La migrañosa y sinestésica Santa poseía la visión interior de la vanguardia. "Simultáneamente veo y oigo y sép ${ }^{76}$, maravillosa sentencia que habría firmado Semir Zeki. Visión despierta, sin sueños ni éxtasis o, si se prefiere, con un éxtasis ininterrumpido.

Para hacer esto he dirigido hacia arriba la mirada para aprender del auténtico y viviente resplandor lo que tuve que escribir, ya que todas las cosas que escribí desde el principio de mis visiones, o que vine aprendiendo sucesivamente, las he visto con los ojos interiores del espíritu y las he escuchado con los oídos interiores, mientras, absorta en los misterios celestes, velaba con la mente y con el cuerpo, no en sueños ni en éxtasis, como he dicho en mis visiones anteriores. No he expuesto nada que haya aprendido con el sentido humano... ${ }^{77}$

diferentes zonas. La conciliación de ambos modelos es el análisis hodotópico: FFYTCHE, Dominic, H.; CATANI, Marco, "Beyond localization: from hodology to function" en Philosophical Transactions of The Royal Society of London. Series B: Biological Sciencies, vol. 360, no 1456, pp. 767-779.

Para una taxonomía científica, amena y actualizada de la alucinación: FFYTCHE, Dominic H., "Visual hallucinatory syndromes: past, present, and future" en Dialogues in Clinical Neuroscience, no 9, junio de 2007, pp. 173-189.

${ }^{74}$ KLÜVER, Heinrich, Mescal and mechanisms of hallucinations, Chicago: University of Chicago Press, 1966.

${ }^{75}$ Especial atención a estos fragmentos extraídos de los versículos 15-20 del primer capítulo:

“... apareció una rueda sobre la tierra (...) la cual tenía cuatro caras o frentes. Y la rueda y la materia de ellas eran a la vista como del color del mar (...) y su forma y su estructura eran como de una rueda que está en medio de otra rueda (...) y toda la circunferencia de todas cuatro estaba llena de ojos por todas partes (...) A cualquier parte donde iba el espíritu, allá se dirigían también en pos de él las ruedas: porque había en las ruedas espíritu de vida".

EZECHIEL, "La profecía de Ezechiel" en Sagrada Biblia, op. cit., p. 748.

${ }^{76}$ CIRLOT, Victoria; GARÍ, Blanca, La mirada interior. Escritoras misticas y visionarias en la Edad Media, Madrid: Siruela, 2008, p. 63.

77 DE BINGEN, Hildegarda, "Libro de las obras divinas", en hildegardiana.es, febrero de 2013, traducción y notas de Rafael Renedo, p. 27. [consulta: 02-07-2015] 
Todas esas formas que están en nuestra pulsión artística y religiosa, se expanden de manera natural -no solo cultural- a lo largo de los tiempos y de las civilizaciones hasta concluir en unas estéticas que han buscado reordenar la vibración y el ruido para transformarlos en música e información: el arte caleidoscópico y la psicodelia, el op art, las artes electrónicas y digitales, la matemática y la cibernética. ${ }^{78}$

A partir de estos factores se puede entender mejor la práctica vanguardista del mandala y su relación con la percepción del espectador. Porque el mandala, en tanto objeto aislado y aún cargado con todo su poder simbólico, necesita de la integración en un conjunto superior -una obra- para desplegar lo que Arnheim denominaba la "presencia poderosa de fuerzas espirituales". ${ }^{79} \mathrm{El}$ objetivo terapéutico jungiano del mandala era el de un autoconocimiento profundo que condujera al reordenamiento de las anomalías. Dejar atrás la confusión y el caos gracias a un acto expresivo y contemplativo que adquiría el rango de meditación una vez superadas las etapas que la geometría había planteado. Reconciliar los opuestos. Balancear la mente hasta obtener un equilibrio que transmitiera la armonía del ser en el universo.

La vanguardia norteamericana adoptó la iconografía del mandala atendiendo a esa inquietud, pero también como variante de una magnífica tradición de animación abstracta que contaba con pioneros como Viking Eggeling, Marcel Duchamp, Fernand Léger, Hans Richter, Walter Ruttmann, Oskar Fischinger, Len Lye, Berthold Bartosch, Man Ray o Mary Ellen Bute. Dos figuras destacan en la práctica de este nuevo subgénero cinematográfico del mandala: James Whitney y Jordan Belson. Otros como Harry Smith se movieron en un círculo muy parecido de intereses: la danza, la cábala, la quiromancia y otras prácticas esotéricas. A menudo se ha utilizado la etiqueta de animadores espirituales ${ }^{80}$ para referirse a una nómina de cineastas más o menos consensuada. En el caso de Smith, basta con ver algunos de los trabajos pictóricos de finales de los años setenta o sus Early abstractions (1946-1957), para apreciar la persistencia de las formas.

\footnotetext{
${ }^{78}$ Las relaciones entre formaciones visuales geométricas, la corteza visual y las matemáticas, es uno de los campos de estudio de Paul Bressloff. De entre sus numerosos artículos he manejado dos que consideraba apropiados para la investigación. El primero, relacionado con los trabajos de Klüver: BRESSLOFF, Paul, et. al., "Geometric visual hallucinations, Euclidean symmetry and the functional architecture of striate cortex" en Philosophical Transactions of the Royal Society B: Biological Sciences, vol. 356, no 1407, pp. 299-330. El segundo, más específico sobre la procedencia y la formación de los patrones visuales: BRESSLOFF, Paul., et. al., "What geometric visual hallucinations tell us about the visual cortex" en Neural Computation, vol. 14, no 3, marzo de 2002, pp. 473-491.

${ }^{79}$ ARNHEIM, Rudolf, Ensayos para rescatar el arte, op. cit., p. 33.

${ }^{80}$ MacDONALD, Scott, op. cit., p. 7.
} 
James Whitney había estudiado a Jüng, se había interesado por la alquimia y por distintos cultos y deidades orientales. También por las nuevas ideas aportadas por la física cuántica. Whitney tendrá una gran influencia sobre su hermano John -autor de otra obra clave: Permutations (1966)-, y deja con Yantra (1955), Lapis (1966) y Dwija (1976) una trilogía fascinante. Lapis sigue siendo considerado el ejemplo más refinado del mandala cinematográfico. La capacidad para dar forma a las alucinaciones es la nueva frontera a la que accede Jordan Belson. Las representaciones que, de entrada, aluden a formaciones del cosmos en expansión, terminan por reconcentrarse, por corporeizarse. El mismo Belson se consideraba "un artista de la imagen interior".

He alcanzado un punto en el que soy capaz de reproducir externamente con mi equipo, lo que estoy percibiendo en mi interior (...) Siempre he considerado la tecnología de las imágenes como una extensión de la mente. ${ }^{81}$

A pesar de que los primeros filmes de Belson no son mandalas propiamente dichos, su firme voluntad es la de realizarlos como objetos destinados a la meditación, por ejemplo Mandala (1953). Sus otros trabajos ${ }^{82}$ estaban concebidos con idéntica intención, perfeccionando a cada paso una técnica del vortex que culmina en Allures (1961). Utilizo el verbo perfeccionar porque Belson trabajaba de manera totalmente artesanal, en su apartamento de San Francisco y con presupuestos mínimos. Los brillantes resultados no transmitían ninguna de esas circunstancias. En la obra de Belson no cabe alusión al error de Beethoven, todo lo contrario, su virtuosismo parece estar respaldado por la alta tecnología.

A pesar de la mutación y de la expansión de las formas, del movimiento orgánico (disecciones a través del microscopio), cósmico (viajes astrales) y musical (Visual Music), la imaginería de Belson posee la raíz geométrica y la inspiración básica del mandala. Su desbordante despliegue

\footnotetext{
${ }^{81}$ YOUNGBLOOD, Gene, Expanded cinema, op. cit., p. 173. [La traducción es mía]

${ }^{82}$ Mambo (1951), Caravan (1952), Flight (1958), Raga (1959), Seance (1959), Phenomena (1965), Samadhi (1967), Meditation (1971), Chakra (1972), Light (1973). Entre 1957 y 1959 colabora con el compositor Henry Jacobs en los Vortex Concerts: presentaciones en el planetario Morrison de San Francisco compuestas por animaciones abstractas acompañadas de sonidos electrónicos. El mejor acceso posible a parte de su obra lo encontramos en la edición DVD: Jordan Belson. 5 essential films, Los Ángeles: Center for Visual Music, junio del 2007. Una buena ocasión para volver a reflexionar sobre la conservación de este tipo de obras tan particulares, sobre su soporte y sus técnicas de dibujo, pintura, fotografiado, copiado, etc. Como bien apunta el gran teórico de la Visual Music, William Moritz en: O'GRADY, Gerald; POSNER, Bruce (eds.), The articulated light. The emergence of abstract film in America, Boston: Harvard Film Archives, 1996, p. 12.
} 
visual tampoco era ajeno a la experimentación con drogas, a los estados de tránsito como la hipnagogia y a la sinestesia.

\section{B.2.4. Luces}

El cuarto y último punto, el referido a la luz, resulta todavía más difícil de compartimentar. Se extiende de manera notable por los tres apartados anteriores y por cualquier ejercicio de vanguardia. La luz deja de bañar la escena, ni siquiera la define o la perfila. La luz no otorga volumen a las formas ni profundidad a los espacios. La luz se convierte en la materia prima de trabajo. Filmes no solo realizados con la luz, sino, también, sobre la luz. Podría argumentarse que gran parte de la filmografía de Dreyer y de otros tantos cineastas convencionales también responde a este criterio, pero debo restringirlo a prácticas concretas de vanguardia: ausencia figurativa, manipulaciones, multiplicaciones y solapamientos en la proyección, alteraciones durante el registro, refotografía, bucles, actuaciones sobre los fotogramas y sobre las ópticas. En un artículo posterior, Wees llevó al extremo su seminal idea de Light moving in time para explicar este protagonismo lumínico:

En los filmes de vanguardia, la luz puede convertirse en toda una fuerza creativa con implicaciones estéticas, filosóficas, religiosas e incluso místicas, que trascienden las preocupaciones modernas [modernist] sobre la especificidad del medio y la semiótica del lenguaje fílmico. ${ }^{83}$

A partir de la experimentación intuitiva o de lecturas en diagonal de los afanes cuánticos, los cineastas de vanguardia aciertan con una síntesis conjuntiva de la luz: ondas y partículas, que no ondas o partículas. Se podría pensar que solo se encuentra total justificación semántica a la vanguardia como expresión antagónica de lo clásico, en este tratamiento lumínico. La vanguardia deja atrás la mecánica clásica, aquella que promulgaba la división entre la materia y la onda. En la vieja dualidad onda-corpúsculo, la primera, por su ausencia de masa, sirvió como explicación definitiva a la desmaterialización del medio y de las imágenes. En los nuevos modelos -aun en plena experimentación- la materia -o en términos precisos, los campos de materia- sigue reinando. La onda como fenómeno asociado a la materia fue otra de las grandes intuiciones -lógicamente en términos rudimentarios e inocentes- de la filosofía naturalista de Epicuro y Lucrecio. En conclusión, la luz no puede rehabilitar la fórmula del fantasma en la máquina -en este caso del Espíritu Santo en el proyector- para engendrar

83 WEES, William C., "Light-play and the aesthetics of avant-garde film" en GRAF, Alexander; SCHEUNEMANN, Dietrich (eds.), op. cit., p. 184. 
dentro del espectador un filme a la manera -virginal, himen trasmutado en tímpano- de una Anunciación de Fra Angelico o Jean van Eyck.

Si la naturaleza de la luz no puede ser dividida de manera absoluta, su dimensión estética sí admite fracciones. Más allá del fenómeno físico, se pueden rastrear correspondencias lumínicas con la conciencia. De esta forma, la luz oscilante viene a reemplazar la mecanización del movimiento vista en Snow. A diferencia de este, Paul Sharits jugará con la ilusión de movimiento, no con los desplazamientos reales. La luz de Sharits -excitada a través de algunas de las técnicas descritas y de otros actos performativos- también desvela los mecanismos de la percepción. En muchas ocasiones lo hace desde la abstracción absoluta, creando un conjunto donde las vibraciones lumínicas insisten en la temporalidad del medio. En el flicker film subyace -o quizá debería decir se expresa- tanto una idea del inconsciente como del infinito.

La técnica más destacada es el flicker o parpadeo. En los flicker films de Sharits o Tony Conrad durante los años sesenta, la aparente separación que parece darse entre lo físico y lo mental queda abolida por el empleo de un parpadeo que deviene nexo entre ambos. El parpadeo como nueva mutación del intersticio. Poco después, en los setenta, a este uso fisiológico, psicológico y pulsante del flicker, le sucederá otro más geométrico y racional. Hasta tal punto que dejan de considerarse flicker films. Es el caso de Kubelka ${ }^{84}$ o de Anthony McCall, que realizará en sus Solid light films minuciosas distribuciones rítmicas hasta conseguir un uso escultórico de la luz parpadeante.

El proyector queda convertido en un "revolver audiovisual" cuya función es atacar la retina hasta conseguir "la aniquilación temporal de la conciencia normativa del espectador." ${ }^{85}$ Como parece evidente, entiendo esa "conciencia normativa" como sintagma nodriza dentro del que integrar otro: "percepción reglada". Sharits veía casi imposible ${ }^{86}$ deshacerse del componente narrativo porque lo consideraba un elemento inherente a la temporalidad del medio. Un desarrollo narrativo que nada tenía que ver con contar una historia o con albergar un argumento. En términos estructurales, esa narratividad nacía y significaba a partir de la

\footnotetext{
${ }^{84}$ Laura Mulvey hace un uso laxo y poco ortodoxo -al menos fuera de la ortodoxia de Sitney- del término flicker en Death 24x second. Stillness and the moving image, Londres: Reaktion Books, 2006, p. 68 y ss.

${ }^{85}$ Declaraciones de Paul Sharits en: WEES, William C., Light moving in time, op. cit. p. 151. [La traducción es mía]

${ }^{86}$ "It's almost impossible to get rid of the narrative". SPIELMAN, Yvonne, "Paul Sharits: from cinematic movement to nondirectional motion" en GRAF, Alexander; SCHEUNEMANN, Dietrich (eds.), op. cit., p. 209.
} 
progresión temporal y de la conexión entre movimientos. Para Sharits, mientras hubiera temporalidad la narración seguiría deslizándose. Quiere esto decir que, para él, la abstracción era mucho menos eficaz que el estatismo a la hora de buscar la eliminación del componente narrativo.

En el flicker film, el parpadeo se comporta a la manera de un mandala. Independientemente de que ese parpadeo abstracto sugiera o induzca diferentes colores y formas, entre las que se encuentran las circulares. ${ }^{87} \mathrm{El}$ parpadeo es un motivo que juega con esa extraña pareja formada por la representación y la introspección. Dúo donde los flujos no son unidireccionales. Tony Conrad estudió al detalle el fenómeno durante sus años universitarios en Harvard. Lejos de la pureza estructural a la que parece remitir el flicker film, Conrad llegó a él a través de las matemáticas, materia en la que se licenció; y de la música, materia que le apasionaba. Matemáticas, música y fisiología del sistema nervioso reunidas en torno al cine. Si las tres primeras eran inquietudes propias, en la cinematográfica tuvo una influencia decisiva su amistad con Jack Smith. ${ }^{88}$ Conrad nos cuenta qué pretendía y qué buscaba en un flicker film. La cita es larga, pero considero que merece la pena respetarla íntegramente:

Cuando realicé The flicker en 1965-66, mi principal objetivo era explorar las posibilidades de la expresión armónica utilizando un estímulo sensorial diferente al sonido. La experiencia del parpadeo -su peculiar inducción del sistema nervioso central mediante el ojo- ocurre a partir de un rango de frecuencia de entre 4 y 40 flashes por segundo (fps). Utilicé la película (a $24 \mathrm{fps}$ ) a modo de "tónico", e ideé patrones de fotogramas que pudieran representar diferentes combinaciones de frecuencias -heterodinas en lugar de multiplexadas-. Estaba interesado en ver si en el parpadeo podían darse efectos producidos por la combinación de

\footnotetext{
${ }^{87}$ En (nostalgia) de Hollis Frampton (1971), aquel quemador circular sobre el que se achicharraban y, por ende, mutaban los objetos, terminaba por adquirir la estructura formal de un mandala. Una abrasión casi meditativa.

${ }^{88}$ Conrad, estudioso de las ideas de John Cage -figura a tener muy en cuenta como referente global de este contexto cinematográfico marcado por la experimentación mental y las ideas orientalizantes-, fue miembro estable del Theatre of Eternal Music. Ya licenciado en matemáticas y siguiendo sus afanes musicales -trabajar junto La Monte Young- se desplazó de Boston a Nueva York en 1962. Allí conoció a Jack Smith. Gracias a esta relación se introdujo de manera definitiva, primero, en el cine experimental del New American Cinema -luego más o menos rebautizado como Film-maker's Coop- $y$, poco después, en el vídeo y la electrónica de Fluxus.

Puede leerse un relato en primera persona de su faceta musical durante aquellos años en el siguiente artículo: CONRAD, Tony, "Lyssophobia. On Four Violins" en COX, Christoph; WARNER, Daniel (eds.), Audio Culture: readings in modern music, Londres: Continuum Books, 2004, pp. 313-318.
} 
frecuencias, de la misma manera que sucedía con la consonancia del sonido musical mediante los efectos obtenidos en la combinación tonal.

Fue una idea sofisticada. Aunque el rango de frecuencia del parpadeo es en teoría lo suficientemente amplio -si bien muy ajustado- para que la modulación armónica dé resultados, The flicker no demostró de manera convincente la existencia de una estructura armónica del parpadeo. Aún así, el fenómeno hipnótico y los estados de trance característicos del parpadeo volvieron a llamar mi atención cuando trabajé durante los años 70 y 80 en los estados alterados de conciencia [altering-mind], los estados de atención y en Music and the Mind of the World. ${ }^{89}$

De forma más críptica y con intenciones menos empíricas, Sharits tampoco estaba lejos de los objetivos de Conrad. A propósito de Ray gun virus (1966) afirmaba que todo el filme debía ser visto como un ejercicio que indujera "al sentido de una conciencia que se autodestruye, debido a un esfuerzo lineal obsesionado con alcanzar la azulada visión interior". ${ }^{90}$ Además, el término mandala también le sirvió a Sharits para conceptualizar otros filmes: Piece mandala/End war (1966) es descrito por Sharits como un "mandala temporal". El desarrollo del color en N:O:T:H:I:N:G (1968) está "parcialmente basado en el mandala tibetano". EI comienzo de Razor blades (1968) aparece como "un mandala visualmente abierto por la mitad" y $T, O, U, C, H, I, N, G(1968)$ es un "mandala íntegro y sin arañazos". ${ }^{91}$

${ }^{89}$ Entrevista de Brian Duguid a Tony Conrad realizada por correo electrónico en junio de 1966. <http://media.hyperreal.org/zines/est/intervs/conrad.html> [consulta: 19-06-2015] [La traducción es mía]

${ }_{90}$ Ibíd., p. 209. [La traducción es mía]

${ }^{91}$ WEES, William C., op. cit., p. 149. [Las traducciones son mías] 


\section{El fin de la ficción. Prefiguraciones expandidas}

El heterogéneo y amplio panorama de la vanguardia asimila el, a su vez, mixto y dilatado Expanded cinema de Gene Youngblood. La expansión derriba la puerta que separaba la práctica cinematográfica del celuloide del magma electrónico audiovisual. Lo hace mediante las nuevas tecnologías y la desacralización del medio y de los espacios. En un principio fueron los artilugios electrónicos sonoros, luego el vídeo y por último la televisión. De la misma manera que se expande la tecnología, se expande el espacio: las imágenes y los sonidos conquistan nuevos e insospechados lugares siguiendo una lógica pendular e indescifrable entre intimidad y orgía; entre anarquía e institución.

Youngblood contextualizaba los nuevos medios, no tanto las nuevas actitudes, dentro una nueva época: la paleocibernética. Podría parecer un término con rigor histórico, pero Youngblood no se esconde. Su paleocibernética es un visión lisérgica y utópica del momento y del futuro. El estadio inicial de la propuesta no le es obstáculo para prever el desarrollo de la actividad creativa del hombre y de sus relaciones con la tecnología, con la naturaleza, con la ficción, el drama y la realidad:

Gracias a la tecnología hemos alcanzado el punto en el que es posible manipular la realidad en sí misma para crear nuevas leyendas. ${ }^{92}$

Después de leer esto, no hace falta manipular la realidad para darse cuenta de qué fenómeno está prendiendo en el interior de esas palabras: el milagro digital. La paleocibernética de Youngblood avisa de la omnipotencia redentora del número y de la resurrección de los muertos. Los cadáveres dejan de conservarse entre sales y nitratos para resucitar en forma de electrones. Más tarde lo harán como números. La momia fotoquímica se convierte en detrito novelesco, en el camafeo de la abuela, en la superficie impotente del recuerdo. Este entusiasmo tan característico de Youngblood recuerda sobremanera a la efusividad, a la hipérbole y a las profecías -casi nunca verificadas- de las teorías de los nuevos medios. Lo virtual reemplaza a la realidad, el símbolo a la cosa y la copia al original. Los problemas dejan de ser problemas para convertirse en posibilidades. Un nuevo mundo donde el cine dejará de ser solo el cine para entrar a formar parte del audiovisual o, de manera aun más genérica, de

\footnotetext{
${ }^{92}$ YOUNGBLOOD, Gene, op. cit., p. 108. [La traducción es mía]
} 
aquello que Debord describía como "una ley general de funcionamiento de lo espectacular integrado [donde] todo lo que puede hacerse debe ser hecho". ${ }^{93}$

Para el autor, la paleocibernética materializaba la intuición y secularizaba la religión mediante la electrónica. Y no tarda en citar a Nam Juin Paik para alimentar una utopía metafísica, orientalizante $y$, por supuesto, desmaterializada:

La electrónica es esencialmente oriental... pero no confundan electrónica con eléctrico (...) La electricidad implica masa y peso; la electrónica implica información: una es músculo, la otra nervio. ${ }^{94}$

Youngblood asiente y declara el estado de optimismo. A finales de siglo (XX) el hombre se volverá global y asistirá al poderoso reinado de lo intangible sobre lo tangible y de lo metafísico sobre lo físico. Todo se volverá viejo, hasta nuestra visión del espacio. Nuestra conciencia se expandirá mientras una inteligencia preexistente -un trasunto del diseño inteligente-, omnioperativa y omnipresente seguirá impregnando y gobernando cada átomo, cada estructura y cada comportamiento de todos los fenómenos físicos. Las leyes de la naturaleza dejarán de regir porque descubriremos que eran pura metafísica. Youngblood acertó, hemos vivido años en los que, empujados por la tecnofilia digital, triunfaron todas esas ideas. Youngblood acertó una predicción que no era más que aquello que él aseguraba haber fulminado: la ficción.

El punto de vista y las ideas de Youngblood no eran una teoría elaborada y estructurada sobre la tecnología y las imágenes. Pero me interesan, más allá de su triunfo predictivo, porque constituye un enlace inesperado entre la reflexión de vanguardia y lo que podemos denominar el mainstream teórico. Llegados a este momento, cabe preguntar qué delirios tienen más pecado. Parece evidente que la prosa de Youngblood responde a un contexto y a unas intenciones que, sin justificar su teoría, le ofrecen una mínima coartada. Que en el siglo XXI, habiendo dejado atrás el prefijo paleo, la intelectualidad y la universidad siga habilitando conceptos de nula operatividad científica, es más grave.

\footnotetext{
${ }^{93}$ DEBORD, Guy, Comentarios sobre la sociedad del espectáculo, Barcelona: Anagrama, 1990, p. 28. [original de 1988]

${ }^{94}$ YOUNGBLOOD, Gene, op. cit., p. 137.
} 
Youngblood, así, puede ser leído como un nuevo embrión no solo del milagro digital, también de conceptos adyacentes como las atracciones. Su crítica radical de la narrativa convencional clásica o dramática- debido a su falta de poder sinérgico, a su linealidad y a su progresividad, habla de una conexión evidente. Esa demanda de sinergia enlaza, de manera gordiana, con otra idea capital: la sinestesia. Para Youngblood, la narración debía ser concebida como crisol estético que condujera a diferentes modos de conocimiento y de visión. Un cine sinestésico donde la lógica claudicara ante la sensualidad de la conciencia de un cineasta que realizaría -a la manera de Brakhage- "un documental sobre su propia percepción" ${ }^{95}$ La representación de un Big Bang mental de hechuras cósmicas que destrozara las restricciones del racionalismo y del materialismo.

Su enfoque está, en definitiva, más cercano a una filosofía vital que a una relato epistemológico. No se le puede negar su ímpetu, su colorido y, en ocasiones, una calidad poética heredera de un periodismo encendido. En este sentido, sí se puede comprender su recuperación y hasta su reivindicación como producto literario. La post-estilización reseñada por Youngblood como último escalón en la historia de las formas, nos acerca a una (ir)realidad como (des)encuadrada por Baudrillard. Es decir, el post-estilo define una realidad desprovista de condición organizativa. Y ahí, justo donde Baudrillard plantó luego el simulacro, Youngblood recurrió a algo más protegido: el mito y la conciencia.

El filme convertido en vehículo para ver. Igual que el titulo de uno de los artículos de James Broughton para Film Culture: "Film as a way of seeing". ${ }^{96}$ Donde ese seeing es entendido, de nuevo, como aventura, como descubrimiento $y$, sólo al final, como reconocimiento $y$ aprobación. Broughton hacía una puntualización verbal significativa al distinguir entre seeing y looking. Al primero le otorgaba valores positivos, entre los que destacaba, además de los citados, la generosidad. Al segundo negativos: avaricia, hostilidad, agresividad y generador de problemas. Una separación que trasciende la semántica para buscar una equivalencia imposible con la dualidad mirada-visión.

En conclusión, tanto Youngblood como Broughton y el resto de cineastas mencionados buscaron segregar el mundo de la vanguardia, del espectáculo puramente escópico a través de una exploración de las simas de la percepción.

\footnotetext{
${ }^{95}$ Ibíd., p. 108.

${ }^{96}$ BROUGHTON, James, "Film as a way of seeing" en Film Culture, no 29, verano de 1963, pp. 19-20.
} 


\section{Vanguardia narrativa}

«Cerco un centro di gravita' permanente » Franco Battiato $^{97}$

La dimensión mental del cine o, mejor, de los cines de vanguardia adopta diferentes nombres, pero su presencia se rastrea allende la terminología. Ya sean los filmes inner eye, el Ultimate cinema $^{98}$ de William Wees, la closed-eye vision de Brakhage o el Expanded cinema de Youngblood. Todo era una travesía destinada a alcanzar aquel Dorado del "cine Absoluto, el cine de nuestras mentes". ${ }^{99}$ Sin embargo, al margen de las etiquetas utilizadas, la narración nunca quedó arrinconada. Desde la idea de meditación como sublimación del relato, a la de conciencia como centro gravitatorio narrativo. Sin olvidar la presencia del mito como actor contumaz y de reconocido valor diegético y temporal: "todo mito es una búsqueda del tiempo perdido". ${ }^{100}$

Para Mekas, y lo señalo ahora por su ascendiente como miembro fundador de la vanguardia americana, era menos importante profundizar en la investigación y en el desafío de las nuevas técnicas que en la faceta temática. Aquí surge aquella demanda que realicé más arriba y que no pocos obviaron: la restricción de las vanguardias a simples fenómenos de experimentación técnica y formal. Para Mekas, los temas necesitaban nuevas dosis de profundidad para conseguir un "tratamiento más penetrante de la naturaleza y del drama del hombre de nuestra época" ${ }^{101}$ Esto es, lo que Mekas demandaba era un zeitgeist en toda regla. Una suerte de relato generacional que, lógicamente, debía construirse sobre pautas narrativas o, mejor dicho, metanarrativas para poder ser compartido. Las palabras de Mekas adquieren toda su importancia en el contexto original de su publicación ${ }^{102}$, en pleno amanecer del movimiento. Su dura crítica de la deriva victimista, autocomplaciente y frívola de sus compañeros de generación a la hora de desarrollar con solidez y, sobre todo, madurez el poema cinematográfico americano, no pasó inadvertida.

\footnotetext{
${ }^{97}$ Álbum: La voce del padrone, corte 6, EMI Italia, 1981.

${ }^{98}$ El autor lo resume como "un cine de y para el ojo de la mente" en WEES, William C., op. cit., 124.

99 MEKAS, Jonas, "Movie Journals" en Film Culture, no 43, invierno de 1966, p. 11. [La traducción es mía].

${ }^{100}$ LÉVI-STRAUSS, Claude, Antropología estructural, Barcelona: Paidós, 1995, p. 227.

101 MEKAS, Jonas, "The experimental film in America" en SITNEY, Paul (ed.), Film Culture Reader, Nueva York: Cooper Square Press, p. 26 [La traducción es mía].

${ }^{102}$ El número 3 de la revista Film Culture, mayo-junio de 1955, pp. 15-20.
} 
Ese valor demandado, ese nuevo empuje a la vertiente narrativa ponía de manifiesto el interés y la preocupación ante una banalización del relato. Urgía la incorporación de tramas y de mecanismos para una reactualización -y hasta una potenciación- narrativa. Al igual que Mekas, Gregory Markopoulos escribía sus propuestas en las páginas de Film Culture:

Propongo una nueva narrativa que fusione la técnica del montaje clásico con un sistema más abstracto (...) de ritmo cambiante, de repentina interjección dentro de la aliteración, de la metáfora, del símbolo, de cualquier discontinuidad que, introducida en la estructura de la película, cautive la atención del espectador, de manera que el cineasta logre convencerlo gradualmente no solo para ver y escuchar, sino para participar, tanto a nivel narrativo como introspectivo, en aquello que está siendo creado sobre la pantalla. Exponer toda una nueva escala de valores para enriquecer el potencial narrativo de la película. ${ }^{103}$

Mekas y Markopoulos no podían ser más claros. Obviamente no buscaban una intensificación bordwelliana, pero su insistencia y su vehemencia temática y narrativa hacen que resulte imposible desatenderlos. El énfasis excesivo -o exclusivo- en los aspectos técnicos de las prácticas de vanguardia, más que una realidad uniforme y nuclear, me atrevo a asegurar que es un sesgo introducido por los estudios académicos. Pero ya sabemos cómo funcionan los sesgos, son implacables a la hora de condicionar no solo nuestra toma de decisiones, también nuestra concepción del mundo.

La reflexión más sugerente y directa que nos ha llegado por escrito sobre la estrecha relación entre narración y vanguardia cinematográfica, se la debemos a Hollis Frampton. Sus textos, tantas veces crípticos, esotéricos e indescifrables, terminan por alumbrar el debate. Al preguntarse por qué cosas podían ser consideradas dentro del cine y de todos sus patrones de energía como constantes e inmutables, acudía al frame -los límites de la imagen visible- y al acto fotográfico que, sin remedio, despertaba un reflejo mental, una ilusión. Acto seguido y acordándose de una conversación con Brakhage, aparecía otra más. Una última "condición inevitable", una tercera máxima fílmica: la narración.

El Teorema de Brakhage era una fórmula matemática dispuesta para establecer una relación de constancia y relación entre los fotogramas de una serie. Frampton nos dice que ciertos

${ }^{103}$ MARKOPOULOS, Gregory, "Towards a new narrative film form" en Film Culture, no 31, invierno 1963 1964, pp. 11-12. [La traducción es mía] 
algoritmos derivados de su fórmula fueron testeados con éxito ${ }^{104}$ en filmes de Kubelka, Conrad y Belson. En cualquier caso, es evidente que el punto de vista de Frampton sobre la narración priorizaba la secuenciación a la historia. Frampton intentaba concretar esa vaguedad narrativa atendiendo a la irrebatible -por material y matemática- sucesión de fotogramas. Por lo que la narración, llegado ese punto, se convierte para él en un axioma. La narración es inevitable y "todo lo que es inevitable, sin importar los arbitrarios que sean sus orígenes, adquiere a través de la costumbre algo parecido a masa gravitatoria" ${ }^{105}$ De nuevo la narración hermanada con la gravitación, del centro de gravedad narrativa de Dennett, a esta masa gravitatoria de Frampton que regula los "universos afectivos" contenidos en la imagen.

Según avanzó la década de los setenta, Frampton siguió fiel a esta concepción narrativa de la película. Sin embargo, se fue volviendo cada vez más escéptico en lo referido a la viabilidad de un paradigma cinematográfico único y mostró sus dudas sobre la existencia de una narrativa maestra, de un metarrelato que ayudara a comprender y a expresar la historia artística y cultural. Frampton asumía y defendía la tradición cultural y estética pero, a diferencia de Mekas, rechazaba un relato generacional o geográfico conjunto.

Un conflicto ${ }^{106}$ que se expresa a través de la teoría y de la práctica. De su concepto del cine como metahistoria -“Para la historia del cine toda la historia del arte no es más que una masiva nota al pie- y de su magnífico ciclo -utópico, desmesurado y, cómo no, inconclusoMagellan (1974-1978). A través de Magellan, Frampton buscaba convertir el cine en crisol (fotografía, sonido ${ }^{107}$, pintura, animación, vídeo, música, expresión oral y escrita ${ }^{108}$ ) sin perder de vista la composición axiomática del filme. En Frampton se apunta una especie de doble naturaleza fílmica a la manera de los genes y el ambiente. $O$, si se quiere, entre innatismo lingüístico e idioma. A saber: la dimensión estructural -axiomática y sujeta a mínimos cambios

\footnotetext{
${ }^{104}$ Entra en contradicción con lo explicado por Conrad a propósito de sus experimentos con el parpadeo. 105 FRAMPTON, Hollis, Circles of confusion: film, photography, video. Texts 1968 - 1980, Rochester: Visual Studies Workshop, 1983, p. 64. [Las traducciones son mías] Las ideas pertenecen, concretamente, al ensayo titulado "A pentagram for conjuring the narrative", fechado en 1972.

${ }^{106}$ Léase el pertinente y agudo artículo de ZRYD, Michael, "History and ambivalence in Hollis Frampton's Magellan" en October Magazine, no 109, verano del 2004, pp. 119-142.

${ }^{107}$ La relación del sonido con la narración era clave para Frampton. El principal uso que pretendía darle al sonido era quebrantar la linealidad, la sintaxis y el significado de lo que él denominaba "eje horizontal" (abscisas) narrativo.

${ }^{108}$ En este sentido, en el de los efectos secundarios narrativos derivados de un tipo de expresión o de otra, sería muy sugerente un análisis comparativo -teniendo en cuenta su contenido irónico y hasta paródico- entre Critical mass (1971) y Poetic justice (1972).
} 
o mutaciones- y la morfológica -discutible y dinámica. ${ }^{109} \mathrm{Y}$ no conviene olvidar que para él la narración forma parte del genotipo, no del fenotipo.

Visto el panorama, se afianza la idea de que no frente a ella, sino más bien en plena convivencia, la vanguardia incorpora la narración como elemento medular de la experimentación fílmica. Para rematar con Frampton, decir que una de las razones que le llevó al tratamiento y a la instauración de modelos tan radicales y heterogéneos como Magellan, fue imaginar una práctica cinematográfica que pudiera resolver, o cuando menos dificultar, las arcaicas oposiciones establecidas entre cine narrativo y no narrativo. ${ }^{110}$ Esta misma postura la comparte Jackie Hatfield ${ }^{111}$ en su crítica a ciertos análisis que pasan de la marginación a la negación de la vertiente narrativa, apoyándose en criterios como la antinarratividad, el antiilusionismo, la liberación y la discontinuidad. Hatfield señala algunas celebridades que, desde sus escritos, promovieron y ayudaron a implantar la creencia: Paul Adams Sitney, Peter Gidal y Peter Wollen. ${ }^{112}$ Para éste último, estrecho colaborador de Laura Mulvey, la división en dos de la vanguardia estaría condicionada, precisamente, por la bisagra narrativa.

Pero Wollen no podía llegar a esa conclusión sin antes proponer una primera división que él mismo consideró, si no fallida, si al menos insuficiente por su complejidad y carga contradictoria. Esa primera partición estaba marcada por el modo de organización o filiación social. Una, quizá más organizada, las cooperativas de artistas -no solo cineastas- asentadas en el mundo anglosajón (Estados Unidos e Inglaterra). Otra, quizá más difusa, ligada a los movimientos políticos que, rondando mayo del 68 , tomaba un cariz europeo-continental. Un poco más tarde, apenas un lustro, Wollen reformula su idea para, ahora sí, otorgarle una importancia decisiva a la narratividad como gozne entre hojas:

Una tendencia refleja la preocupación por la especificidad del significante, manteniendo el significado en la incertidumbre o esforzándose para eliminarlo. La

\footnotetext{
109 Atención a su diatriba "Notes on composing film" en FRAMPTON, Hollis, op. cit., p. 117-126, especialmente la p. 123.

${ }^{110}$ RAGONA, Melissa, "Hidden noise: strategies of sound montage in the films of Hollis Frampton" en October Magazine, no 109, verano del 2004, pp. 97-118.

${ }^{111}$ HATFIELD, Jackie, "Expanded Cinema and Narrative. Some reasons for a review of the Avant-Garde debates around narrativity" en Millennium Film Journal, no 39-40, invierno del 2003, pp. 50-65.

${ }^{112}$ WOLLEN, Peter, "The two avant-gardes" en Studio International, noviembre de 1975, pp. 171-175. La versión que he manejado es una reedición que se puede encontrar en: SIMPSON, Philip; UTTERSON, Andrew; STEPHERDSON, K. (eds.), Film theory. Critical concepts in media and cultural studies, Londres y Nueva York: Routledge, 2004, pp. 127-137.
} 
otra tendencia ha intentado desarrollar nuevos tipos de relación entre significante y significado mediante el montaje de elementos heterogéneos. ${ }^{113}$

Esta segunda tendencia descrita por Wollen encaja con su "vanguardia política europea". Aquella más política, ideológica y narrativamente dislocada -Godard, Gorin, Hanoun, Jancsó, Straub y Huillet. Al tiempo que parecen un eco de las palabras de Markopoulos. La primera, en cambio, parece señalar a la radicalización -mayor desarrollo teórico, más rigor taxonómico, prácticas más específicas, el materialismo de la escuela inglesa, Gidal, Wyborny, Hein y Le Grice- sufrida por el cine estructural a partir de la segunda mitad de los setenta. De ahí que la diatriba de Hatfield tenga que ser matizada, al menos en lo que ataña a Wollen. Este evoluciona, se muestra flexible y avisa de la grave problemática derivada de considerar la vanguardia como un fenómeno homogéneo y antinarrativo.

La postura de Jackie Hatfield es más impetuosa que la de Wollen, pero posee fuertes tangencias. Las más importantes tratan de la ampliación de los espacios de la experiencia narrativa. Sacarla de la misma pantalla o, en su defecto, arrebatarle a esta su condición dominadora. Es decir, desacralizar la idea de proscenio. Abolir la pantalla como ventana albertiana, ilusionista y de apariencia transitable para abrazarla en su desnuda condición de superficie plana y blanca. Habilitar la inmersión del espectador sin la necesidad de la recurrente apelación a la realidad virtual.

Un cine expandido que en términos materiales $y$, por ende, lumínicos, tecnológicos y corporales, significa: multipantallas, multiproyectores, sucesiones de capas y fotogramas, espacios abiertos o comunicados, veladuras y luces interpuestas. La huida de la tradicional experiencia ortogonal deriva en nuevas formas de expresión como la performance, el happening, las instalaciones y diferentes tipos de entornos electromedia. El cine, que ya había dejado de ser solo el cine, busca más que la fusión la sinergia con el teatro moderno, con la danza, con la música experimental y, por lo tanto, con el ruido. Lejos de totalidades wagnerianas y como ya he señalado a propósito de Frampton, se abrían posibilidades infinitas de hibridación. Algunos, Wollen entre ellos, lamentaban que la vanguardia no las aprovechara:

\footnotetext{
${ }^{113}$ WOLLEN, Peter, "The avant-gardes: Europe and America" en Framework, primavera 1981, p. 10. Citado en KAPLAN, Ann, Women \& film. Both sides of the camera, Londres: Routledge, 2000, p. 86. [La traducción es mía]
} 
El entrelazado y la aportación recíproca entre pintura, escritura, música y teatro, podría llegar a ser parte integrante del mismo campo cinematográfico. ${ }^{114}$

En conclusión, las vanguardias cinematográficas, en tanto expresión histórica heterogénea, no pueden ser consideradas esencialmente antinarrativas. No puede aludirse a ese anti-como característica común y constante en todos los grupos y durante todos los periodos. Aquí he tratado un momento puntual que veía concordante con las inquietudes estéticas y biológicas de esta investigación. Pero, como señala Hatfield, la preocupación por una línea narrativa -ya fuera de carácter maestro o de carácter específico- se extiende a gran parte de otros movimientos históricos: Futurismo, Dadaísmo, Surrealismo, la Bauhaus, la Black Mountain Collage, Fluxus, etc. Porque una cosa eran las proclamas de sus manifiestos y otras muy distintas cómo las llevaron a cabo.

Una larga ristra de outsiders que hacen sentenciar a la -por desgracia fallecida- autora que los grupos han estado preocupados, han experimentado y han mimado el componente narrativo. Que Hatfield terminara relacionando toda esta genealogía de la apertura con el cine de atracciones $^{115}$, es toda una ironía del destino. Hatfield deseaba imaginar una filosofía del cine experimental que, partiendo del cine expandido y del cine de atracciones, incluyera la electrónica, la computadora, un espectador activo, la escultura, el collage y la dramaturgia. Para Hatfield el cine era un lugar de encuentro práctico y teórico que trascendía cualquier purismo materialista y estructuralista.

\footnotetext{
${ }^{114}$ WOLLEN, Peter, “The two avant-gardes" en op. cit., p. 136. [La traducción es mía]

${ }^{115}$ Hatfield hace un empleo no anecdótico pero casi del cine de atracciones. En realidad, Hatfield hace el uso común al que estamos -¿̇estábamos?- acostumbrados. Lo menciona como etiqueta fascinante que en pleno siglo XXI enlaza el presente digital con el cine primitivo y con los juguetes ópticos.

HATFIELD, Jackie, "Expanded cinema and 'cinema of attractions"” en Art in-sight, no 14, 2005, pp. 5-9.
} 

MATERIA 


\section{DESMATERIALIZACIÓN Y FUGA HISTÓRICA}

Antes de comenzar a desarrollar la idea y la genealogía de la desmaterialización, quiero utilizar una fórmula que me permita contextualizarla como un concepto más cercano al mito que a los hechos probados. He bautizado esta fórmula utilizando el sintagma fuga histórica. De la misma manera que puse en valor la necesidad de las humanidades en medio de la vorágine (neuro)cognitivista, reclamo de nuevo la necesidad de la Historia y de la Estética como herramientas indispensables para seguir hablando de las ciencias de las imágenes y, por ende, de la materia y de las ciencias del cuerpo.

A esta fuga histórica la definiré, de manera recta y sin dobleces, como el alejamiento voluntario o involuntario de la realidad cierta y de sus avisadores. ¿Por qué se produce tal alejamiento? En el primer supuesto -voluntario-, por mala praxis y por intereses espurios; en el segundo -involuntario-, por ignorancia, por accidente o por la inercia de modas y corrientes. Estas dos categorías de la fuga histórica podrían encontrar paralelismo -permítaseme la truculencia- en las circunstancias que separan el asesinato del homicidio.

La fuga histórica es una postura que yace implícita en las diferentes disciplinas de la Historia. Y, por supuesto, en todas sus metodologías nativas, mestizas o de importación. Historiar de manera sincrónica sobre un tiempo presente nunca resultó sencillo. Esta dificultad, tomada como coartada, puede derivar en una serie de frustraciones y desvíos. La insatisfacción de la Historia que veíamos encarnada en la maestra de Alexander Kluge, cristaliza cuando no proporciona todas las respuestas deseadas y, sobre todo, cuando no lo hace con la rapidez y la claridad necesarias. Es justo ahí, donde la fuga histórica abandona la latencia para manifestarse en el discurso.

¿Cuáles son los dos rasgos básicos que hacen de esta fuga o desprendimiento histórico un desvío tan seductor? Primero, si los avisadores y los parámetros históricos del momento no ofrecen un corpus sólido -no tanto completo como coherente- para el análisis, se toman prestados los de momentos precedentes de acuerdo a criterios de semejanza y de repetición. Esto puede implicar la aceptación de causas finales y de un determinismo guiado por patrones y ciclos. Segundo, la incorporación al discurso de un excesivo contenido literario y fabulador. El símil organicista, los juegos proféticos y las intenciones visionarias como atajos para el prestigio académico. Ambos casos quedan condicionados por la imposible emancipación del historiador, primero de su entorno y, al tiempo, de su mismo cuerpo. 
Si alguna disciplina humanística ha sufrido la fuga histórica de manera feroz desde finales del siglo XX hasta el momento actual, esa ha sido la cinematográfica y, por extensión, cualquier manifestación asociada al audiovisual. La conjunción de la fuga histórica (organicista, teleológica, historicista) con el esencialismo tecnológico y con la apropiación y puntual mistificación conceptual entre áreas de conocimiento, produce un objeto cine contemporáneo que abandona la ciencia para abrazar la ficción. La fuga histórica puede parecer, además de seductora, natural. Esto es, dar cuenta de los hechos cotidianos nos parece banal.

Un enfoque en fuga viene a desplazar o a embellecer aquello que nos parece aburrido. Lo anodino parece ser evitado cuando los tiempos muertos, lo mecánico y lo tristemente funcional, son nuestro soporte vital. Vivimos vidas aristotélicas apenas sacudidas por clímax efímeros y, en su mayoría, planificados. De la misma forma que zurcíamos la abstracción, renegamos de la sobresaliente capacidad significante del tiempo. Enriquecemos las historias. En el caso de la historiografía del cine, lo hacemos como si fuera necesaria una correspondencia entre la dimensión épica y espectacular del cine y su estudio. El presente no basta, es una restricción vulgar. Incluso el presente como tiempo y lugar globalizados resulta una dimensión estrecha e insatisfactoria. Tomando el título de una de las entregas de James Bond: el mundo nunca nos parece suficiente.

Aquí entra en juego uno de los subproductos de la fuga histórica: el gusto por el futurolenguaje. La apropiación, la criptografía y la logorrea -triunvirato de la prosa posmoderna- tampoco colmaron nuestro apetito por el color $-y$ por la oscuridad. No solo había que adivinar el futuro, había que hacerlo con un lenguaje propio de ese futuro. Fredric Jameson fue muy agudo al descubrir una de las funciones sociales del filme de ciencia ficción en general y de algunos de sus recursos narrativos y formales en particular. Jameson rompía la impepinable linealidad del tiempo vivido para convertir la representación del futuro en una especie de remembranza proustiana. Jameson ejecutaba la fuga histórica pero con sentido crítico y reflexivo.

Es decir, valerse de los discursos sobre el futuro como medios para experimentar y conocer el ahora. Este objetivo se logra gracias a una serie de estrategias indirectas que nos desvelan el momento actual no por semejanza o repetición, sino por contraste. No se trata de dictar profecías ni de acostumbrar al individuo a un hipotético y traumático encuentro con el futuro. En tanto el espectador precede a la materialización del tiempo histórico mostrado, la 
iconografía y la narrativa de ciencia ficción sirven para "desfamiliarizar y reestructurar la experiencia que tenemos de nuestro propio presente". ${ }^{1}$ Ese tipo de narraciones son herramientas que nuestro cerebro, en tanto máquina eminentemente predictiva, generatriz de futuro y enlazadora de hipótesis sociales, agradece. Son relatos especulativos que, en conclusión, siempre han respondido a una pulsión civilizadora. Su funcionalidad cerebral y su necesidad cultural, sin embargo, pueden entrar en conflicto con las metodologías de las humanidades.

Recuperando este mínimo pero inestimable apunte de Jameson, pretendo aportar una visión optimista de la fuga histórica. Utilizo el ejemplo para comprobar que no me interesa hacer teoría e historia del cine solo desde el enfrentamiento o, mejor, desde el negativo de la película. Con esto presente y forzando el símil, me gustaría ver la hábil maniobra de Jameson casi como un lavender. ${ }^{2}$ Esto es, realizar una copia positiva del negativo sobre el que hemos impresionado el presente para, a partir de ella, realizar nuevos negativos. Ese lavender es una acción de futuro ejecutada sobre un tiempo presente. El objetivo de esa acción de futuro no es ver -el lavender es un positivo no apto para proyección- ese futuro, sino preservar, modificar copia sobre la que realizar efectos de laboratorio- y multiplicar las visiones del presente, esto es, del negativo original.

Por consiguiente, cabe una variante rigurosa de la fuga histórica siempre y cuando ejerza de contrapeso y de resistencia entre extremos. Siempre y cuando conlleve una conciencia de las diferencias existentes entre la literatura de los mundos posibles (utopías, distopías, ucronías) y la epistemología. Por lógica, el historiador no puede abstraerse en su presente. Es imposible y, aunque fuera posible, sería desaconsejable- sacralizar el espacio-tiempo cerrando las puertas y elevando templos. El presente no es un témenos. Aquí mismo he propuesto una línea de investigación histórica flexible. Por no volver sobre el aviso de Scott Atran sobre la posibilidad y hasta la necesidad de imaginar escenarios ideales que posibiliten el desarrollo de nuevas ideas. Historiar el presente tiene una obligación con el pasado: conocerlo; pero historiar el presente no excluye la mirada -rigurosa- en lontananza.

\footnotetext{
${ }^{1}$ JAMESON, Fredric, “Progreso versus utopía; o ¿podemos imaginar el futuro?” en WALLIS, Brian (ed.), op. cit., p. 244.

${ }^{2}$ El lavender o duplicado positivo (dup-positivo) es el término utilizado para una copia positivada cuando la emulsión original es en blanco y negro. Cuando es en color se utiliza interpositivo. El uso de lavender (lavanda) proviene del inglés, donde resulta intercambiable con purple print, y hace referencia al tono azulado y de muy bajo contraste que proporciona el grano fino de la emulsión. De ahí que no sean copias funcionales para la proyección, sino para preservar el negativo original y como material de trabajo en efectos de laboratorio.
} 
Aunque es importante especular sobre posibilidades futuras y reconocer el extraordinario ritmo de los progresos técnicos, su desmoronamiento genera un incómodo futurolenguaje que puede pasar a sustituir un análisis más cuidadoso de cómo se producen las tecnologías y cómo forman parte de un conjunto complejo de condicionantes para la producción y consumo de los medios en una sociedad concreta (...) El futurolenguaje es el idioma de un reino tautológico que implica un alejamiento del presente en el que la tecnología está aislada y en última instancia mitificada. ${ }^{3}$

Respecto al futuro, es difícil no estar de acuerdo con esta cita. Sin caer en la resignación y en el conformismo, hay que ser conscientes de que, en ocasiones, la resolución de los problemas no radica en encontrar y aplicar la metodología correcta. Tampoco en la recomendable salvaguarda de la ética, sino en una pura y simple imposibilidad fáctica. Esa que hace de la desmaterialización de las imágenes y de la previsión del futuro aporías biológicas, estéticas e históricas. De lo que no cabe ninguna duda es de que el cine ha sido el arte que más ha intimado con el mañana. Mañana... aquella extraordinaria y ophulsiana película de José María Nunes (1957), manifiesto moderno de la procrastinación resignada.

Respecto al pasado, el principal problema reside en su borrado y en su extracción quirúrgica para someterlo a filiación. Si hay algo que prende con facilidad en la historia del arte, es el gusto por las filiaciones inmediatas. En el caso de la historia del cine es, directamente, el inconsistente -por no decir inexistente- fundamento metodológico de la cinefilia. A lo largo de esta investigación ya ha quedado demostrado que ni las formas ni las historias dependen únicamente de los flujos culturales para su difusión, asimilación y reelaboración. En cuanto a su borrado, puedo traer a colación la tabla rasa con la que Danto emprendía su particular fuga histórica. Para Danto la Historia era una carga insoportable de la que había que deshacerse. La Historia no podía condicionar el arte. Los artistas debían afrontar el reto de "hacer arte en cualquier sentido (...) o sin ningún propósito". ${ }^{4}$ El problema surge al trasladar esta unión de tabla rasa y fuga histórica a la historiografía.

\footnotetext{
${ }^{3}$ BOYD, Frank; DEWDNEY, Andrew, "La televisión, los ordenadores, la tecnología y la forma cultural” en LISTER, Martin (ed.), op. cit., pp. 197-198.

${ }^{4}$ DANTO, Arthur, Después del fin del arte. El arte contemporáneo y el linde de la historia, op. cit., p. 37.
} 
José Enrique Ruiz-Domènec terminaba uno de sus libros afirmando que "el futuro depende de cómo se escriba el pasado". ${ }^{5}$ No estoy de acuerdo. Siempre podrá quedar un hilo suelto en ese dobladillo rebelde. Siempre llegaremos a ese futuro a través de un modo determinado enraizado en el pretérito. Pero, cuidado, la imprevisibilidad y la bendita variedad de escrituras dificultan el cumplimiento del aforismo. Con todo, no conviene menospreciar la capacidad del cine y de sus alrededores como vehículos narrativos y como depósito semántico -por no decir como vivero de semillas- del futuro.

Una posible historia del futuro -un inventario puntual de las diversas profecías y filosofías con las que el hombre del siglo XX ha ido construyendo sucesivamente sus ideas y sus creencias acerca del mañana- no podría hacerse al margen de las numerosas narraciones escatológicas de hora y media que el cine ha sido produciendo y reproduciendo sin cesar. ${ }^{6}$

Tras este preludio, mi objetivo es explicar por qué el concepto de desmaterialización se consolidó como eje axial de la cultura contemporánea. Utilizo el pretérito perfecto simple porque, en este instante, me refiero a su origen. Bien podría haber utilizado el compuesto para insinuar su prórroga y su vigencia. Durante esta explicación se apreciará una relación, de amistad y de conflicto, entre los grandes modelos socioeconómicos y las representaciones artísticas coetáneas. El hilo conductor quedará fijado por una genealogía acronológica del concepto. A su vez, esta genealogía se estructurará alrededor de la siguiente hipótesis: el relato sobre el desvanecimiento o la desaparición de la materia no es una cuestión endémica y exclusiva de las diferentes tecnologías -incluida la digital- de las imágenes, es un error categorial derivado de una serie de metarrelatos históricos característicos de las sociedades posindustriales. Pocos han escapado a su influjo. Por ejemplo, cómo pasar por alto la barbarie conceptual perpetrada por la UNESCO con su denominación de Patrimonio Cultural Inmaterial. ${ }^{7}$

Dentro de estos metarrelatos, me centraré en una serie de fenómenos y movimientos específicos: el arte conceptual y su relación con las vanguardias artísticas del siglo XX, la dimensión estética y social de algunos cambios introducidos por la modernidad histórica en el

\footnotetext{
${ }^{5}$ RUIZ-DOMÈNEC, José Enrique, op. cit., p. 103.

${ }^{6}$ CUETO, Juan, Exterior noche, Madrid: Ediciones Júcar, 1985, p. 182.

${ }^{7}<$ http://www.unesco.org/culture/ich/index.php?pg=00002> [consulta: 10-09-2015]
} 
siglo XIX, la diversificación de los materiales del arte, la guerra, el auge de la cibernética y de los nuevos medios y la corporalidad.

\subsection{Paciente cero}

El origen del término en su vertiente artística, no se obtiene ni por verticalidad ni por un vector dirigido de lo global a lo particular. La desmaterialización surge y se expande a lo largo de los años de acuerdo a una combinación imparable entre mecanismo y método. Es decir, posee un mecanismo viral: se acopla a otras células, desbloquea sus defensas, coloniza su núcleo y comienza a replicarse. $Y$ posee un método rizomático ${ }^{8}$ : abre nuevos e inesperados senderos y lo hace en todas direcciones -descentralizado-, deroga las jerarquías, tiene función conjuntiva -serial- e interfiere sobre las estructuras que se encuentran a su alcance. Ambos sucesos ocurren bajo la piel y bajo la tierra; a hurtadillas. Su éxito reproductivo radica en esa discreción. La desmaterialización: primero mito, luego plaga y epidemia.

La desmaterialización del arte llegó, según algunos, de la mano de la filosofía. Lo extraño -lo imposible- habría sido que hubiera llegado de la mano de la ciencia. Sin embargo, hay verdad en esta consideración de la filosofía como una de las causas originarias. La filosofía no fue el paciente cero, fue el laboratorio de donde se escapó el patógeno. Aunque sería más gráfico decir que fue la filosofía quien extendió su manto sobre el pueblecito del arte a la manera del Mefistófeles de Murnau. Con razón diría Danto que, tras su irrupción, lo visual -para él tan poco relevante como lo bello- desapareció: "para que exista arte ni siquiera es necesaria la existencia de un objeto". ${ }^{9}$ Mefistófeles cubrió con manto negro, lanzó sus gases y esperó resultados. La epidemia fue fulminante. Empezaron a aparecer los primeros bubones, pero algunos lo disfrutaban. Fiebre y supuración mientras Kosuth publicaba su ensayo "El arte después de la filosofía". ${ }^{10}$

\footnotetext{
${ }^{8}$ Empleo el concepto deleuziano no sólo como metáfora. En seguida se verá su implicación en el panorama socioeconómico y digital. DELEUZE, Gilles; GUATTARI, Félix, Mil mesetas. Capitalismo y esquizofrenia, Valencia: Pre-textos, 2002, pp. 9-32.

${ }^{9}$ DANTO, Arthur, op. cit., p. 38.

${ }^{10}$ Original en tres partes: KOSUTH, Joseph, "Art after philosophy" en Studio International, vol. 178, no 915, 916 y 917, octubre, noviembre y diciembre de 1969, pp. 134-137, 160-161, 212-213; respectivamente.

También se encuentra recogido en el seminal volumen de MEYER, Ursula, Conceptual art, Nueva York: Dutton, 1972, pp. 155-170.

Existe una versión en español recogida en BATTCOCK, Gregory (ed.), La idea como arte. Documentos sobre el arte conceptual, Barcelona: Gustavo Gili, 1977, pp. 60-81.

Versión que he manejado y a la que pertenece la cita: KOSUTH, Joseph, Art after philosophy and after. Collected writings, 1966-1990, Cambridge: The MIT Press, 1991, pp. 13-32. La cita en pp. 19-20. [Edición
} 
El arte "vive" a través de influir en otro arte, su existencia no depende del residuo físico de las ideas del artista (...) Una obra de arte es una tautología en tanto es la presentación de la intención del artista. Esto es, está diciendo que esa obra de arte en particular es arte, lo que significa, por tanto, que es una definición del arte (...) La idea del arte y el arte son una misma cosa.

Toda una declaración de intenciones donde la filosofía desmaterializa obra y descorporeiza idea. Se suprime la Estética y, con ella, la Historia. Esta concepción inicia el bucle en el que queda instalado un movimiento capaz de aglutinar cualquier forma precedente gracias a la tramposa infalibilidad de la propuesta. Cualquier forma también incluía la antiforma ${ }^{11}$, esto es, lejos de exterminarse mutuamente, generan una transformación. "Todo arte (después de Duchamp) es conceptual (por naturaleza) porque el arte sólo existe conceptualmente" ${ }^{12}$, diría también Kosuth. Gombrich, sin alambique tautológico, fue más pragmático e inteligente: todo arte es conceptual, porque todo arte se origina en la mente humana. ${ }^{13}$

En el año 1967, Lucy Lippard y John Chandler escriben un ensayo titulado "The dematerialization of art" ${ }^{14}$ Artículo que no será divulgado hasta febrero del año siguiente en la publicación suiza Art International. En él, los autores -ella y él-concluyen que en ese momento -finales de los años sesenta e inicios de los setenta- una serie de corrientes artísticas hasta entonces soterradas, están por fin brotando con la fuerza necesaria. Durante este proceso de emergencia y consolidación, toda tarea creativa privilegiará un enfoque antiintelectual, emocional e intuitivo. La consecuencia más destacable es el triunfo de un arte ultraconceptual donde el énfasis recae sobre el proceso mental, sobre la concepción interna de la obra. Pero, cuidado, no de manera cerrada, sino en correspondencia con un espectador que debía completarla. La eterna relectura, más o menos informal, de la interactividad. A este respecto,

de Gabriele Guercio. Prólogo de Jean-François Lyotard] [La traducción y la cursiva son mías. Las comillas pertenecen al original]

${ }^{11}$ MEYER, Ursula, "De-objectification of the object" en Arts Magazine, vol. 43, no 8, verano de 1969, pp. 20-21.

${ }^{12}$ KOSUTH, Joseph, op. cit., p. 18. [La traducción es mía. Los paréntesis pertenecen al original]

${ }^{13} \mathrm{GOMBRICH}$, Ernst, Art and illusion. A study in the psychology of pictorical representation, Londres: Phaidon Press, 1984, pp. 72-73. [En español: "La verdad y el estereotipo" en Arte e ilusión. Estudio sobre la psicología de la representación pictórica, Madrid: Debate, 2002]

${ }^{14}$ CHANDLER, John; LIPPARD, Lucy, "The dematerialization of art" en Art International, vol. XII, no 2, Lugano, febrero de 1968, pp. 31-36. Reedición: "The dematerialization of art" en LIPPARD, Lucy, Changing: essays in art criticism, Nueva York: E. P. Dutton, 1971, pp. 255-276.

He manejado la versión editada en: ALBERRO, Alexander; STIMSON, Blake (eds.), Conceptual art. A critical anthology, Cambridge: The MIT Press, 1999, pp. 46-50. 
Michael Corris, uno de sus practicantes, restaba importancia a la etiqueta de la desmaterialización: "nuestro juego no giraba sobre la desmaterialización, sino sobre la conversación, la interrupción y, en lo posible, sobre la idea de comunidad [community building]" ${ }^{15}$ De este planteamiento se deduce otra de las discusiones del arte conceptual: la autoría.

Se quiere promover una nueva noción de autor que se desprenda de cualquier tic asociado a la idea de propiedad, de comercio y de una fatua intelectualidad. Conviene recordar que, justo en aquellos años, estaba discutiéndose el título y las funciones del autor. Michel Foucault ${ }^{16}$ se preguntaba qué demonios era un autor:

Hablaba allí de la situación del discurso acerca del autor en la cultura europea, en un contexto revolucionario en el que entreveía una posibilidad de cambio. La pregunta ¿qué importa quién habla?, era ya una respuesta. Frente a la autoridad del autor, frente a su ser ya casi únicamente sujeto de beneficios derivados de su posesión de las obras en función de un discurso históricamente obsoleto, planteaba una posibilidad quizás cercana que transformarse radicalmente el discurso sobre el autor y la práctica autoral. ${ }^{17}$

El arte como idea, despersonalizado, pero también como acción: prosperan la performance, las instalaciones y el happening. Una apertura que, en plena encrucijada histórica y al igual que la referida con anterioridad en Wollen y Hatfield, transformaba las fórmulas artísticas. Lippard resumía este peculiar clima histórico atendiendo a una suerte de inconsciente colectivo que había empujado a los artistas -muchos de ellos desconocidos entre sí- a experimentar y a reaccionar. En Estados Unidos y en Canadá, en Europa y en Sudamérica, Lippard confirmaba a través de viajes y contactos su creencia en una conexión inmaterial y globalizada. Lippard hacía alusión al éter, a las "ideas en el aire". ${ }^{18}$

${ }^{15}$ CORRIS, Michael, "The dialogical imagination: the conversational aesthetic of conceptual art" en HOPKINS, David (ed.), Neo-Avant-Garde, Amsterdam y Nueva York: Rodopi, 2006, p. 307. [La traducción es mía]

${ }^{16}$ FOUCAULT, Michel, “Qu'est-ce qu'un auteur?” en Bulletin de la Société Française de philosophie, vol. 63, no 3, julio-septiembre de 1969. En español, “¿Qué es un autor?” en Entre filosofía y literatura, Barcelona: Paidós, 1999, pp. 329-360.

17 GONZÁLEZ GARCÍA, Fernando, "Mohsen Makhmalbaf: importa quién actúa” en GONZÁLEZ GARCÍA Fernando (ed.), Mohsen Makhmalbaf: del discurso al diálogo, Granada: Consejería de Cultura de la Junta de Andalucía, Filmoteca de Andalucía y Festival de Granada cines del Sur, 2008, p. 186.

18 LIPPARD, Lucy, Six years. The dematerialization of the art object from 1966 to 1972, Berkeley: University of California Press, 1997, p. ix. Es inevitable que la fórmula "ideas in the air" no recuerde el 
La débil explicación racional que encontraba Lippard para esa espontánea y casi telepática reacción en cadena -al margen del malestar frente a las instituciones- eran las fuentes artísticas -con Duchamp al frente- que los participantes de esas ideas desvelaban como comunes. Esta imagen del arte conceptual deslizándose por el aire, activando una serie de resortes y generando una serie de reacciones en cadena sin perder la dosis necesaria de alea, nos devuelve otra metáfora evidente: un móvil de Calder; aquel hacedor de aire como lo llamó Prévert. Pero, teniendo en cuenta que aquel tiempo ya contaba con una red de comunicaciones avanzada, incluso para los circuitos alternativos y minoritarios, la coincidencia no sorprende demasiado. Por no hablar del papel jugado por las supervivencias formales y narrativas.

En aquel momento, una obra materializada era una obra ejecutada en el sentido condenatorio del participio. El presente del objeto físico, su modelado último, era intrascendente. Su futuro solo conocía un destino: la obsolescencia. Es llamativo el uso que Lippard y Chandler realizan del término obsolete para referirse al objeto artístico. Antes de que la obsolescencia tecnológica se convirtiera en estrategia comercial y en debate ciudadano, introducir un adjetivo tan específico ofrece pistas de cuál sería la deriva de la desmaterialización del arte conceptual: la comunión, lo espiritual, la abolición de las distancias entre el arte y el espectador. El todo en el uno.

Así, no es extraño que la inmersión conceptual figure como otra de las prefiguraciones del engulfment digital. En lugar de presagio digital, a mí me gustaría relacionar ese deseo espiritual emanado de lo presuntamente inmaterial, con algo tan lejano como el arte del siglo XIII. El Gótico, primer gran ejercicio de desmaterialización artística sistemática. A partir del arte de la Baja Edad Media obtenemos una correspondencia simple: a menor materia, mayor luz; a mayor luz, más espiritualidad. ${ }^{19}$ ¿Por qué?, dejando a un lado el simbolismo lumínico y la iconografía doctrinaria de las vidrieras, por nuestra capacidad para la elucubración en ausencia -o en disminución sensible- de materia. Miramos y no vemos, luego imaginamos. De ahí que

título de la canción -del himno- de Dylan (Blowin' in the wind) escrita apenas un lustro antes (Columbia Records, 1962). Idéntico contexto histórico, mismo vehículo de comunicación.

${ }^{19}$ El tópico de una edad pintada de oscuro por la enfermedad y la brutalidad rampantes, ya quedó desacreditado hace tiempo. La Baja Edad Media como resquicio -icómo intersticio!- por el cual comienza a derramarse la luz que, tras su apogeo flamígero, se vierte sobre el Renacimiento, es hoy tesis aceptada no solo por los estudios medievalistas: VAUCHEZ, André, La espiritualidad del Occidente medieval, Madrid: Cátedra, 2001. Especialmente los epígrafes 2, 3 y 4 del capítulo IV. 
los discursos sobre la desmaterialización suelan ser tan fértiles. Porque el otro camino es bien distinto y también lo conocemos: miramos y vemos demasiado, luego simplificamos.

Aunque, en rigor, el Gótico tampoco desmaterializó nada, solo cambió una materia por otra: la piedra por el vidrio. Este equívoco no dejará de sucederse a lo largo de los tiempos. La espiritualidad no permitió rebajar peso, estilizar formas y duplicar o triplicar alturas. Fueron los nuevos materiales, las mejoras tecnológicas y el mayor conocimiento científico quienes lo propiciaron. Exactamente como sucedió con la arquitectura del hierro o con la informática. La materia no desaparece, al igual que la energía, se transforma. Todo esto sin adelantar la explicación fisiológica que nos aclarará las bases corporales y, por ende, materiales de cualquier expresión de la espiritualidad.

Una espiritualidad que, en abundancia de definiciones, quiero considerar como el ensimismamiento del hecho religioso. La manera individualizada en la que cada uno hace suya la necesidad de creer en entes y actos no sensibles. La religión -como la ética- es un fenómeno social; la espiritualidad -como la moral- es huella dactilar, única e intransferible. De ahí la reclamación que de ella hace el arte conceptual frente a la industrialización del arte. La espiritualidad como refugio corporal. El arte conceptual deviene Sainte Chapelle para albergar el aura objetual extinguido tras la caída de un meteorito llamado reproductibilidad.

Para la nueva tendencia conceptual, el valor del objeto físico, en el mejor de los casos, se acercaba al de una obra de artesanía; en el peor, al de un objeto industrial. Como digo, la industrialización, la mecanización y la reproductibilidad del arte -no tanto de la obra en sí misma- estaban en la raíz de un giro que aparentó ser copernicano. La obra materializada no era más que otro vulgar elemento de una cadena de producción de reminiscencias tayloristas. Este símil del arte materializado como mercancía capitalista, no debe ser menospreciado. Tiempo después y aún antes del triunfo informático, la automatización, la robotización y la telemática, en tanto sustitutas de las - pringosas- labores humanas, serán tenidas en cuenta como serios precedentes de la desmaterialización contemporánea.

\subsection{Conceptual going south}

El artículo de Lippard y Chandler, igual que sucedió con el texto de Tom Gunning, se convirtió en referencia inexcusable, en hito único para la historiografía. Ensayos brevísimos con altas dosis de coyuntura que prevalecen sobre todos lo demás. Para explicar su preeminencia, podría esgrimirse su condición de pioneros o su excelencia literaria, pero incluso en estos 
aspectos resultan discutibles. En cualquier caso, no seré yo quien, a pesar de todas las desvirtuaciones que han sufrido, les reste un ápice de valor. Menos cuando sirven de manera tan sustancial a esta investigación.

Óscar Massota -figurada controvertida del panorama artístico argentino durante aquellos mismos años. Crítico literario, introductor del psicoanálisis lacaniano, teórico y práctico de vanguardia- también empleó el término desmaterialización. Lo hizo durante un baile de fechas que tuvo lugar entre la elaboración de una conferencia (1967) y su publicación definitiva (1968). Para algunos, la comunicación tuvo lugar en el Instituto Di Tella en $1966^{20}$, mientras que, para otros, habría sido en ese mismo lugar pero un año después, en julio de $1967 .{ }^{21}$ Lo más probable es que su escritura se realizara en 1966 y su lectura en 1967, el 21 de julio para ser exactos. Aunque la referencia directa que Masotta hace a un artículo publicado en enerofebrero de 1967 y que es mostrado como impulsor de su idea, añade confusión.

Al grano, la comunicación se titulaba: "Después del Pop, nosotros desmaterializamos". Su contenido arrastraba y reelaboraba motivos de un trabajo colectivo anterior publicado bajo el título "Happenings". ${ }^{22}$ Este último recogía las experiencias artísticas del año 1966. En su prólogo -con fecha del 15 de enero de 1967- anunciaba el problema de la materia y el de las nuevas formas del arte. En definitiva, "Después del Pop, nosotros desmaterializamos" fue publicada en 1968 dentro de una recopilación ${ }^{23}$ de artículos y ensayos escritos por Masotta entre 1956 y 1967.

Es difícil fijar la ventaja temporal de Masotta sobre Lippard. Tampoco lo considero vital, me interesa más el hecho en sí que unas fechas solapadas. Massota había viajado varias veces a Estados Unidos durante los años 1966 y 1967. A su vez, Lippard viajó en septiembre de 1968 a Argentina como miembro de un jurado para entregar el premio "Materiales: nuevas técnicas, nueva expresión". Allí entró en contacto con el Grupo de Rosario (Rosario Group). Comparte ideas y absorbe el ímpetu político -Masotta identificaba el nuevo arte desmaterializado con un arte revolucionario- de la vanguardia argentina. Un clima que iba desde Rosario a Buenos Aires pasando por Santa Fe, mientras se preparaba la insigne obra colectiva Tucumán Arde. Al

\footnotetext{
${ }^{20}$ RIZZO, Patricia, Instituto Di Tella. Experiencias '68, Buenos Aires: Fundación Proa, 1998, p. 43.

${ }^{21}$ LONGONI, Ana, "Óscar Masotta: vanguardia y revolución en los años sesenta" en Séptimas jornadas de artes y medios digitales, Córdoba (Argentina), jueves 18 de agosto de 2005.

He manejado la siguiente versión en Red: <http://www.liminar.com.ar/pdf05/longoni.pdf> [consulta: 23-10-2015] p. 28.

${ }^{22}$ MASSOTA, Óscar, et al., Happenings, Buenos Aires: Jorge Álvarez, 1967.

${ }^{23}$ MASSOTA, Óscar, Conciencia y estructura, Buenos Aires: Jorge Álvarez, 1968.
} 
mismo tiempo, entraban en incandescencia las dos instituciones más cercanas a la vanguardia: el Instituto Di Tella y la Centro de Arte y Comunicación (el CayC, que en un principio había sido el CEAC: Centro de Estudios de Arte y Comunicación). Con o sin encuentro ${ }^{24}$ físico entre Masotta y Lippard, es evidente que, tanto el uno como la otra se movieron durante un tiempo por los mismos círculos.

De Roberto Jacoby, otro argentino coetáneo de Lippard y Masotta, obtenemos una información de primera mano. ${ }^{25}$ El artista ofrece una visión crítica y hasta ácida de los laureles con los que la historiografía del arte conceptual coronó a Lippard. Y lo hace sin aire patriotero, prestando más atención a las corrientes conceptuales norteamericanas que a las argentinas. Jacoby, además de precisar fechas y datos de aquella nebulosa, no solicita recompensa, rectificación o revisionismo. La demanda de Jacoby se puede reducir a una cuestión más prosaica que comparto: los modos, que no los métodos, de historiar.

No se trata aquí de una reivindicación localista ni de una discusión por las precedencias, sino de la restitución de las nociones a su proceso histórico de gestación. ${ }^{26}$

\subsection{Herencias recibidas}

En cuanto a las fuentes que inspiraron esta espiral conceptual transnacional, se puede convenir que, a pesar de la novedad y de su profunda voluntad de ruptura, reformulaban ideas y actitudes heredadas. $Y$ digo bien, ideas y actitudes, porque muchas de aquellas propuestas quedaron truncadas. Algunas porque eran quimeras o apuntaban al infinito, otras porque fueron traicionadas. Querer rehabilitar la desmaterialización a partir de los intentos realizados por las vanguardias históricas es comprar un billete de ida al fracaso. La desmaterialización artística comenzó a fraguar su condición de mito durante aquellos años de vanguardia. Quedó prendida a un ideal sociopolítico corrosivo y desobediente que, a la hora de ser trasladado a la

\footnotetext{
${ }^{24}$ En $A$ short history of dutch video art, Sebastián López lo asegura, pero sin ofrecer mayores datos: "Lippard viajó a Buenos Aires en 1968 y se encontró con Masotta" [p. 16. La traducción es mía]. Catálogo de la exposición homónima editado por Episode Publishers en el año 2005. Longoni (op. cit., p. 28) deja en el aire ese posible encuentro: "No es descabellado pensar que Lippard y Masotta hayan entrado en contacto, si no personalmente, al menos a través de sus textos o sus ideas".

${ }^{25}$ JACOBY, Roberto, "Después de todo, nosotros desmaterializamos. La teórica del conceptualismo olvidó citar unos cuantos antecedentes argentinos" en Ramona. Revista de Artes Visuales, Buenos Aires: Fundación Start, no 9-10, diciembre del 2000 - marzo del 2001, pp. 34-35.

${ }^{26}$ Ibid., p. 35.
} 
práctica, continuó recurriendo al objeto. De hecho, las vanguardias históricas terminaron siendo un triunfo rotundo de la materialidad.

En primer lugar, Lippard y el conceptual norteamericano tenían muy presente la transgresión del antiarte dadaísta. Es así como la obra de Marcel Duchamp y, diría más, como un relato de corte hagiográfico de su vida y de sus pensamientos, sobrevuela el movimiento. Si bien lo hace de manera desordenada, como la misma Lippard llegó a reconocer. ${ }^{27}$ Su burla del objeto serial, de la institución y de una representación ya encaminada a la acción -o cuando menos a la ruptura de las coordenadas prefijadas para la experiencia- son cuestiones recuperadas en los sesenta y setenta.

En el arte conceptual, la iconoclasia abandona la religión pero abraza con idéntica fuerza la militancia. Signo de los tiempos. Ya no se trataba de aquellas discusiones teológicas en torno a las imágenes que llevaron a Nicéforo a declarar que, si se suprimía la imagen no sólo desaparecía Cristo, sino el universo entero. El conceptual, pasado por el tamiz de las vanguardias, refunda una iconoclasia activista. Su objetivo: trascender lo concreto para desvincularse del sistema. Esto es, el punto de vista de la desmaterialización conceptualista bebía del anarquismo dadá, pero también del Constructivismo revolucionario y del Levyi Front (Frente de Izquierdas de las Artes y su mítica publicación LEF como principal canal divulgativo). Aquellos que lucharon por revitalizar los nuevos medios frente al intento oficial del Partido de instaurar un Realismo Socialista totalmente acartonado.

El conceptual también hurgaba en el Futurismo. Aunque con estos últimos existía una contradicción directa: su elogio de la máquina, de la repetición, del producto y del modelo industrial. Por no hablar de -en algunas de sus versiones nacionalistas- su ideología. Fueron los pintores futuristas unos de los pioneros en el arte de desmaterialización. De manera torpe y naif en la práctica, pero con mayor vehemencia en la teoría: "Que el movimiento y la luz destruye la materialidad de los cuerpos". ${ }^{28}$ Siempre me ha resultado enternecedor que, en el fondo, quisieran reinventar a Tiziano y a Velázquez, a Turner y a Seurat, a los pintores de Chauvet y a los de Lascaux. Estudios como el de Marinetti ${ }^{29}$ sobre la tipografía e incluso la

\footnotetext{
${ }^{27}$ LIPPARD, Lucy, Six years. The dematerialization of the art object from 1966 to 1972, op. cit., p. ix.

${ }^{28}$ DE MICHELI, Mario, op. cit., p. 381.

${ }^{29}$ MARINETTI Filippo Tomaso, "Destruction of syntax-untrammeled-imagination words-in-freedom" en MARINETTI, Filippo Tomaso, Critical writings, Nueva York: Farrar, Straus \& Giroux, 2006.
} 
poesía y los caligramas de Apollinaire, abundaban en la búsqueda de otras coletillas como simultaneidad y densidad semánticas ${ }^{30}$, luego asociadas al conceptual y a la era del hipertexto.

Sin embargo, hay dos herencias-referencias inexcusables que suelen pasar desapercibidas en los inventarios. Ortega y Kandinsky (1912), tan diferentes entre sí. Empezaré, de forma acronológica, con Ortega (1925).

Cuando Lippard y Chandler incitaron a que la desmaterialización llamara a las puertas del arte, lo hicieron desde una postura contestataria. Sin objeto no hay mercancía; sin mercancía, no hay capitalismo. Tal postura, vista hoy, además de inocente puede ser malinterpretada como elitista. ¿A qué me refiero con elitista? Al margen de las miradas de soslayo que siempre despertaron las propuestas del arte conceptual, cuando escribo elitismo quiero emparentar la desmaterialización con esta otra des- histórica: la deshumanización. Un nuevo enlace entre conceptual y vanguardia que, en ausencia de vínculo nominal y contextual, ponía de relieve cuatro deseos compartidos. Uno, separar el arte de la dictadura del mercado. Dos, promover la devaluación del objeto. Tres, el acceso a un arte puro, ideal e idealista. Cuatro, derrocar la realidad y, con ella, el metarrelato reinante. Así, el arte, en tanto actividad desmaterializada y deshumanizada deviene, más que aristocrático, impopular: "Cree el vulgo que es cosa fácil huir de la realidad, cuando es lo más difícil del mundo (...) ¡Cuánta astucia supone la fuga genial!". ${ }^{31}$ Vulgo y genio, o genio frente a vulgo; lenguaje diáfano que no necesita ser interpretado.

En síntesis: "entre la idea y la cosa hay siempre una absoluta distancia". ${ }^{32}$ Esa aristocracia creativa, esa grieta, ese cierto elitismo no eran, pues, distanciamientos a lo Brecht. Lo que se buscaba era eliminar los residuos humanos, sentimentales y autorales por medio de la estilización, de la atomización y de la abstracción, hasta poner en crisis los modelos y los modos de representación. La deshumanización, que decía abjurar del contagio psíquico típico de los relatos tradicionales, acabará convertida en una de sus principales figuras: la metáfora. Lejos de conseguir la revocación de la realidad que predicaba su letra, la deshumanización se convirtió, con el paso de los años, en un símbolo contradictorio. Por un lado, fue bandera de un nuevo humanismo que intentaba alejarse de la devaluación asociada al poder, al dinero y a

\footnotetext{
${ }^{30}$ ALONSO, Rodrigo; MERCADO, Leonardo, "Arte y diseño editorial: de la revolución tipográfica al libro del futuro" en Encuentro Nacional de Investigación en Arte y Diseño ENIAD 2001, Facultad de Bellas Artes de la Universidad de La Plata, 2001. Versión digital manejada:

<http://www.roalonso.net/es/arte_y_tec/revolucion_tipografica.php> [consulta: 22-10-2015]

${ }^{31}$ ORTEGA Y GASSET, José, La deshumanización del arte y otros ensayos de estética, Madrid: Austral, 2004, p. 61. [Primera edición de 1925]

32 Ibíd. p. 72.
} 
la ignorancia. Por el otro -y es esta la que más me interesa- se tomó como coartada intelectual para legitimar ciertas imposturas intelectuales. Félix Duque supo verlo a finales del siglo XX, justo cuando la desmaterialización nos iba a permitir atravesar los muros del nuevo milenio sin perder el alma en el intento:

Es preciso constatar que la deshumanización en sentido orteguiano (y su correlato: la desmaterialización de lo real) ha proseguido insidiosamente su marcha ascendente hasta nuestros días. ${ }^{33}$

Duque emplea el adverbio de modo insidiosamente aludiendo a la restauración de cierto nihilismo humanista. No puedo estar más de acuerdo. La desmaterialización como subproducto de la deshumanización, terminó por infligirnos el lógico sufrimiento -la torturaque se obtiene cuando uno pone toda su esperanza en una falacia.

Resulta extraño que el manifiesto de Kandinsky tampoco figure entre las citas de cabecera. De los espiritual en el arte ${ }^{34}$ es una diatriba constante e infatigable contra el demonio material y materialista. Esto es, tanto en el terreno ideológico, como en su extensión -contaminaciónartística. El texto de Kandinsky es uno de los prototipos, parafraseando a Pinker, de la negación moderna de la naturaleza humana. ${ }^{35}$ Kandinsky acusa al grosero canto del materialismo de haber separado el espíritu del hombre moderno del de los primitivos.

La reivindicación del -trascendente- alma del arte frente al -intrascendente- duro y material objeto, como único camino para recuperar a un espectador que, cegado por lo externo, es incapaz de descubrir su propia vida interior. En Kandinsky estaba parte del idealismo conceptual. Su ansia de pureza reflejada en el color, en la forma, en la vibración y en el movimiento. Aunque pudiera parecer que entre ambos existe una notable fisura ideológica, cabe preguntarse en qué se diferencia la ideología conceptualista de la metafísica -a ratos ciertamente ingenua- de Kandinsky.

\footnotetext{
${ }^{33}$ DUQUE, Félix, "El arte y el cuerpo" en MOLINUEVO, José Luis (ed.), ¿Deshumanización del arte?, Salamanca: Ediciones Universidad, 1996, p. 66.

${ }^{34}$ KANDINSKY, Vasili, De lo espiritual en el arte, México D.F.: Premia Editora, 1989.

${ }^{35}$ Para Kandinski el cuerpo no es el objeto, sino la forma, el cómo. En un determinado momento realiza un inciso para avisarnos de que el dualismo materia-espíritu que recorre todo su texto no puede discutirlo de manera extensa. Ibíd., pp. 120-121.
} 
En el caso de Masotta, en cambio, la herencia quedaba anclada en una referencia mucho más concreta: la lectura de El futuro del libro ${ }^{36}$ de El Lisitski. En esta obra, el polifacético artista soviético exponía sus pensamientos sobre la edición y el diseño durante el primer tercio del siglo XX. Contexto febril marcado por las revoluciones y el nuevo orden político. Además de la influencia directa sobre Massota, me interesa la visión que tenía Lisitski de la materia tecnológica. El devenir del libro no sólo como elemento cultural, artístico y didáctico, sino como simple objeto material que debe enfrentarse a una nueva realidad. Para Lisitski, la tecnología no respondía a un curso lineal y progresivo de perfeccionamiento que concluía en un dispositivo superior. Tampoco a la de una recuperación y actualización de objetos y motivos obsoletos o abandonados. Todo era más sencillo, lo tecnológico surgía como un mecanismo paralelo a la revolución. Es decir, como extensión de un nuevo metarrelato cuyas consecuencias debían ser el desplazamiento y la modificación de todas las prácticas existentes. “Toda innovación artística es única y no tiene desarrollo", tal es la apertura del texto de Lisitski.

Masotta incorporó este punto de vista de manera directa a su comunicación sobre la desmaterialización del arte. El célebre texto de Lisitski, extractado por el argentino, rezaba lo siguiente:

Hoy los consumidores son todo el mundo, las masas. La idea que actualmente mueve a las masas se llama materialismo; sin embargo, la desmaterialización es la característica de la época. Piénsese en la correspondencia, por ejemplo: crece el número de cartas, la cantidad de papel escrito, se extiende la masa de material consumido, hasta que la llegada del teléfono la alivia (...) Resultado: la materia disminuye; el proceso de desmaterialización aumenta cada vez más. Pesadas masas de materia son reemplazadas por energía liberada. Esta es la característica de nuestra época. ${ }^{37}$

El teléfono vino a pulverizar las toneladas de material celulósico empleado en la decadente y romántica tradición epistolar. Al teléfono le seguirán otros artilugios que, como la radio,

\footnotetext{
${ }^{36}$ En concreto de esta edición: LISITSKI, EI, "The future of the book" en New Left Review, enero-febrero de 1967, pp. 39-44. [Primera edición de 1926].

He manejado la versión reeditada en: Ramona. Revista de Artes Visuales, op. cit., pp. 43-45.

${ }^{37}$ Ibíd., p. 43. [Las cursivas son mías]
} 
impulsarán la frenética cadena de la desmaterialización. Cuando Andreas Huyssen ${ }^{38}$ discurría sobre las vanguardias de los años veinte, también advertía esas tecnologías como reflejos de los enormes cambios sociales, económicos y políticos que tuvieron lugar desde el cambio de siglo XIX-XX. Para el autor, además de calar en el arte a la manera heideggeriana ${ }^{39}$, las tecnologías modelaban las ciudades, impulsaban el desarrollo de los medios de transporte y excitaban los mercados de dinero.

La inteligencia y la imaginación empujadas por la furia tecnológica. Sin embargo, esa nueva imaginación tecnológica, lejos de convertirse en fantasma se cosificó. Como bien apunta Sánchez Biosca -muy en la línea de Bürger-, esa "disgregación en la visión del mundo" ${ }^{40}$ enlaza con el despedazamiento, que no con la licuefacción, de la representación. Ya he hablado del collage, pero no fue un caso aislado. La forma y el fragmento se citan con la materia a través del assemblage, el dé-collage, el fotomontaje y, por supuesto, el cinematógrafo. Aquí se abre otra brecha entre vanguardias históricas y las teorías de los nuevos medios. En palabras de Masotta:

Las "obras de comunicación" definen ellas también el área de su propia materialidad. La "materia" ("inmaterial", "invisible") con la que se construyen obras informacionales de tal tipo no es otra que los procesos, los resultados, los hechos y/o los fenómenos de la información desencadenada por los medios de información masiva (Ej. de "medios": la radio, la televisión, los diarios, los periódicos, las revistas, los afiches, los "pannels", la historieta, etcétera). ${ }^{41}$

A partir de esto se puede colegir que la asimilación que realiza Massota de las tesis de El Lisitski están teñidas por un nuevo contexto. Massota se vale de Lisitski como pretexto para lanzar el pensamiento emergente ${ }^{42}$ en torno a la comunicación y a los medios masivos de producción, difusión y presentación. También para defender que el verdadero arte rompedor

\footnotetext{
${ }^{38}$ HUYSSEN, Andreas, "The hidden dialectic. Avant-garde, technology, mass culture" en After the great divide. Modernism, mass culture, postmodernism, Londres: MacMillan Press, 1988, pp. 3-15.

39 Esto es, como furia de la técnica: HEIDEGGER, Martin, "La pregunta por la técnica" en Conferencias y artículos, Barcelona: Ediciones del Serbal, 1994, pp. 9-37. [Conferencia original fechada en 1953]. En otra traducción es el frenesí de la técnica: HEIDEGGER, Martin, Filosofía, ciencia y técnica, Santiago de Chile: Editorial Universitaria, 1997, p. 147.

40 SÁNCHEZ-BIOSCA, Vicente, Cine y vanguardias artísticas. Conflictos, encuentros, fronteras, Barcelona: Paidós, 2004, p. 19.

41 MASSOTA, Óscar, "Después del Pop, nosotros desmaterializamos" en Ramona. Revista de Artes Visuales, Buenos Aires: Fundación Start, no 9-10, diciembre del 2000 - marzo del 2001, p. 37.

${ }^{42}$ Recordemos que Understanding Media. The extensions of man es publicado en 1964.
} 
era el pop. La vanguardia, así, queda desubstanciada como referente. Tanto, que en seguida deviene pretexto y olvido en cuanto las nuevas teorías adoptan la desmaterialización como uno de sus fundamentos metodológicos. Años después de la separación, Lyotard expediría el certificado de divorcio: "Hemos convenido en reír delante de las vanguardias, a las que consideramos expresión de una modernidad perimida". ${ }^{43}$

Pero, llegado este punto, habiendo retrocedido cuatro décadas hasta ver cómo el enlace entre arte conceptual y vanguardias históricas se tambalea, me pregunto si la apreciación originaria de Lisitski puede ser ampliada. Creo que sí, diría que es susceptible de ser exacerbada. Con ello me refiero a que puedo ampliar su árbol genealógico. Porque la desmaterialización de Lisitski, reformulada por Massota, volvía a centrarse en el hecho y en los usos tecnológicos dejando en un segundo término la naturaleza del problema. ¿Cuál?, en este caso, la propia escritura. Su individualización, su identidad caligráfica y su posterior socialización con la imprenta. La escritura como mancha, como reencarnación y rematerialización del lenguaje oral. Es una lástima que la escritura pueda verse aun hoy como lo contrario, como un acto de desmaterialización y descorporeización donde la enunciación, objetivada mediante signos, deviene simulacro no encarnado: no hay yo, si acaso un fantasma diluido en el texto. Dejes estructuralistas que, contra todo pronóstico, parecen ecos platónicos.

¿Te refieres a ese discurso lleno de vida y de alma, que tiene el que sabe y del que el escrito se podría justamente decir que es el reflejo $?^{44}$

La escritura como reflejo desvaído, como simulacro del verdadero conocimiento y de la mayéutica. La escritura como acto que engendra vanidad, engaño e ignorancia. La escritura, en definitiva, como banalización del arte interno radicado en el alma. Leemos -que no escuchamos- el mito de Theuth y Thamus ${ }^{45}$ glosado por Fedro y Sócrates e intuimos que la desmaterialización, ya sea como gestora del arte conceptual o como causa global de la modernidad, siempre estará ligada al dualismo cuerpo-mente y a las mitologías generadas por la tecnología.

\footnotetext{
${ }^{43}$ LYOTARD, Jean-François, La posmodernidad explicada a los niños, Barcelona: Gedisa, 2003, p. 93. [Primera edición de 1986]

${ }^{44}$ PLATÓN, Diálogos III. Fedón. Banquete. Fedro, Madrid: Gredos, 1988, p. 407. [La cursiva es mía]

${ }^{45}$ Ibíd., pp. 401-404.
} 


\subsection{Espíritus de la modernidad. Energía y dualismo}

Industria y movimiento, energía y dinamismo; dos pares que, casi a la manera de idea y espíritu, ejercieron de viandas y de sinónimos de la desmaterialización. Narrado en tiempo real, como en el caso de Lisitski; narrado medio siglo después, como en el caso de Huyssen, las dos ideas subyacentes de la desmaterialización de la modernidad histórica están claras. Primera: "La materia ya no existe". ${ }^{46}$ Segunda: "un fantasma recorre Europa". Dos sentencias para tres nombres: Michael Faraday, Karl Marx y Friedrich Engels. Mientras el físico inglés realizaba sus experimentos sobre diferentes fenómenos de la luz y del electromagnetismo, los prusianos pergeñaban el Manifiesto Comunista.

Empiezo por Faraday, que ejerció de enlace entre las viejas teorías de la materia particulada (de Demócrito a Schrödinger pasando por Dalton), y los avances cuánticos que llegarían a partir de Max Planck. Lo hizo en un tiempo -pleno siglo XIX- donde la fascinación por la electricidad iba a adquirir, sin casi, una dimensión estética. Una continuación, que no una culminación, de aquello que los siglos XVII y XVIII ya habían empezado a satisfacer: una creciente sed visual. Todos recordamos la linterna mágica, la cámara oscura y el telescopio; también toda la serie de los dispositivos -orama (vista) y hasta el magnetismo animal de Mesmer. Pero tampoco es despreciable recordar el cadalso, en sus diferentes versiones punitivas -laicas como la guillotina, religiosas como los autos de fe-, como serios precedentes de espectacularización ${ }^{47}$ de la pulsión visual. Bellour acertaba al citar un pasaje de Los miserables (1862), donde Víctor Hugo encabezaba una deliciosa y terrible digresión con la siguiente frase: "El cadalso es [una] visión". ${ }^{48}$ Sentencia a la que yo añadiría otra: "[El cadalso es] un espectro que parece vivir".

La electricidad como fenómeno estético irrumpía en un escenario donde, con el cine en el horizonte, ya lucían la fotografía, la familia de los -scopio (observar) y la de los -tropo (giro).

\footnotetext{
${ }^{46}$ No he podido anclar la cita exacta en una obra o en una declaración concreta de Michael Faraday. Procedo a ofrecer una referencia indirecta: EPSTEIN, Jean, La lyrosophie, op. cit., p. 198.

${ }^{47}$ Iba a utilizar colectivización, pero sería inexacto. La pulsión es algo íntimo, pero, a su vez, es elemento compartido por todo ser humano. La manera de expresar esa dualidad es el espectáculo organizado en torno a un dispositivo.

48 BELLOUR, Raymond, op. cit., p. 32. Hay otro pasaje de Los miserables que, con crueldad nada soterrada, habla del cadalso como espectáculo. El pequeño Gavroche trata de animar a sus nuevos amigos vagabundos: "Ya veréis cómo nos divertiremos. En el verano (...) nos bañaremos en el estanque; correremos desnudos por el camino frente al puente de Austerlitz. Esto hace rabiar a las lavanderas (...) Iremos a ver al hombre-esqueleto (...) Luego os llevaré al teatro (...) Iremos a ver a los salvejes (...) Luego iremos a la ópera (...) Y después iremos a ver guillotinar. Os presentaré al verdugo (...) iAh, lo vamos a pasar en grande! HUGO, Víctor, Les miserables. Vol. 2, Ware: Wordsworth Editions, 1994, p. 656. [La traducción y la cursiva son mías]
} 
Donde triunfaba la arquitectura del $\operatorname{cristal}^{49}$ y donde se desataba un interés insólito por las ciencias psíquicas. La hipnosis, el espiritismo y el sonambulismo fueron otros ejemplos de la estetización científica y paracientífica que terminaron aliándose con la óptica. La relación entre ciencias psíquicas, fotografía y cine, debe ser revisada más acá de la metáfora. Es decir, como relación factual -genérica- e histórica -contextual. No hace falta decir que, por regla general, ha prevalecido la metáfora. La muerte eludida y el espíritu momificado gracias al artificio. De Morin a Bazin pasando por Barthes. Cuando Guy Maddin logre estrenar Séances, regresará, rediviva, la efigie de la fotografía y del cine como embalsamadores de espíritus.

Resulta tentador -tanto que no puedo remediarlo- citar El libro de los espíritus ${ }^{50}$ de Allan Kardec. Publicado en 1857, apenas una década después del Manifiesto Comunista, sirvió como emblema de toda una corriente social espírita y espiritista que, en fondo y forma, era una invocación a la desmaterialización. Llamativa y sintomática la correspondencia que Kardec estableció entre materia y espíritus: cuanto más desmaterializado el espíritu, más puro, perfecto y feliz será. Por el contrario, aquellos que conservaran remanentes materiales serían de categoría inferior, especialmente maliciosos y sufridores. De nuevo, como vimos a propósito del Gótico, un juego de fuerzas entre mente y materia; entre la aparición de la abstracción y la necesidad del relato para combatirla. De cómo la creencia en seres inmateriales ha sido rasgo común en todas las religiones. Tanto, que bien podría ser considerado como un universal. ${ }^{51}$

\footnotetext{
${ }^{49}$ El Crystal Palace de Joseph Paxton es de 1851. Tal fue y es el emblema, pero existió antes, durante y después, una corriente arquitectónica civil que hizo de la desmaterialización mural una ilustración de la modernidad. El vidrio sirvió para exponer mercancía y espacio comercial mientras facilitaba la comunicación con el espacio público. A ello se sumaba la iluminación eléctrica del escaparate. Véase: SERRANO SÁSETA, Rafael, "Los orígenes comerciales del fenómeno de la desmaterialización de la fachada en la arquitectura moderna. Transparencia y luz eléctrica" en Revista Europea de Investigación en Arquitectura (REIA), Madrid: Universidad Europea, no 2, 2014, pp. 163-180.

La vitrificación de la arquitectura traspasó la modernidad hasta llegar a nuestros días. Lo que un principio fue símbolo de una época fascinada por los nuevos descubrimientos, devino mecanización geométrica y fiabilidad científica. Para algunos, esta deriva fue perversa. Tom Wolfe reía frente a los muros vítreos de la Bauhaus en ¿Quién teme al Bauhaus feroz? El arquitecto como mandarín, Barcelona: Anagrama. Barcelona, 1988 [Primera edición de 1981]. Jacques Tati se adelantó a la mordacidad del periodista en películas como Mon oncle (1958) y Playtime (1967).

Para la evolución posterior -más estructural y científica- de la desmaterialización arquitectónica véase: FERNÁNDEZ-GALIANO, Luis (coord.), Voces de vidrio. Foster, Fuksas, Norten, Perrault, Piano, Zwimpfer, no 82 de la revista Arquitectura Viva, Madrid, 2002.

${ }^{50}$ KARDEC, Allan, El libro de los espíritus, Brasilia: Consejo Espírita Internacional, 2008. [Original, París, 1957]. Especial atención a la nota 29 de la página 51, donde el traductor explica la adaptación al contexto del neologismo desmaterializado a partir del original francés dématérialisés (separar de la materia).

${ }^{51}$ Pascal Boyer defiende esta teoría en BOYER, Pascal, op. cit., 1994.
} 
Faraday fue, quizá, el elemento más destacado de todos lo que contribuyeron a abrir la puerta de una utopía que pronto dejó de serlo: la fusión entre la Belle Époque y la Segunda Revolución Industrial. Un punto de inflexión donde el élan vital de Bergson encontraría mullido colchón. La brillante -pero en ciertos aspectos equivocada- filosofía del francés marcaba la transición entre siglos. Su reconocido dualismo, su elogio de la energía espiritual y de la conciencia como muestras de la superioridad interna. La importancia de atributos como la flexibilidad, la variedad y la deformación. La inyección de indeterminación, imprevisibilidad y discontinuidad en los procesos vitales. ${ }^{52}$ La obra de Bergson, como la de otros filósofos de la mutabilidad y de la movilidad, se convirtió en la biblia de numerosos artistas e intelectuales.

Entre Faraday y Bergson, se desliza un pulso guiado por la energía y por el espíritu -o por la energía del espíritu- que Rancière condensaba de la siguiente manera:

El sueño estético, científico y político de un mundo nuevo, donde todo el lastre material e histórico iba a disgregarse en el reino de la energía luminosa. Desde la década de 1890 a la de 1920, esa utopía (...) de la materia disuelta en energía,

\footnotetext{
52 Para el dualismo bergsoniano: BERGSON, Henri, Materia y memoria. Ensayo sobre la relación del cuerpo con el espíritu, Buenos Aires: Cactus, 2010. [Primera edición de 1896].

Para el élan vital: BERGSON, Henri, "La evolución creadora" en Obras escogidas, Madrid: Aguilar, 1963, pp. 433-755. [Primera edición de 1907].

Para su concepción de la conciencia: BERGSON, Henri, Ensayo sobre los datos inmediatos de la conciencia, Salamanca: Sígueme, 1999. [Primera edición de 1888].

Bergson nunca escondió su defensa del dualismo, pero con matices. Los introduce desde el primer párrafo de Materia y memoria (2010, p. 27): "Este libro afirma la realidad del espíritu y la realidad de la materia, e intenta determinar la relación entre ambas". Bergson busca conciliar materia y espíritu mediante un enlace entre las tesis realistas -materialistas- y las idealistas -espiritualistas. Ahí, en la encrucijada, introduce el concepto de "imagen" como una "cierta existencia que es más que lo que el idealista llama una representación, pero que es menos que lo que el realista llama una cosa" (2010. p. 28). Su dualismo no es, pues, categórico o cartesiano, sino analítico. En cualquier caso, erróneo. Crítico con el reduccionismo y con el determinismo físico y fisiológicos; escéptico con la teoría atómica de la materia, su dualismo tenía una intención más armónica -diría que en un sentido puramente moral- que integradora. Su mayor empecinamiento, visto hoy, es la negación continuada de la mente y de la conciencia como fenómenos materiales radicados en el cerebro: "la vida mental desborda la vida cerebral" (2010, p. 298). Para Bergson, el cerebro es mecanicista, centro ejecutivo limitado a traducir ideas en movimientos. Un burócrata que ni piensa ni elabora.

Bergson ha sido malinterpretado con frecuencia. Quizá yo esté haciéndolo al simplificarlo de esta forma, con un párrafo y una nota al pie. Cuando Bergson hablaba de que "el papel de la vida consiste en insertar la indeterminación en la materia" (1963, p. 547), no era tanto una apología de desmaterialización como la constatación de un hecho que él mismo aclara: el azar y la falta de predicción de la evolución humana. Lo mismo sucede cuando se refiere al sistema nervioso y a su red neural como un "depósito de indeterminación". De hecho, Bergson reconocía la dictadura de la materia. No tenía más remedio, era inteligente y tenía ojos. Cosa bien distinta fue que esa tiranía no le gustase y deseara trascenderla mediante ese impulso vital (1963, p. 650).
} 
inspiró tanto las ensoñaciones simbolistas del poema inmaterial como la empresa soviética de construcción de un nuevo mundo social. ${ }^{53}$

La cita de Rancière sirve como ilustración y como pie para volver a Marx y Engels. El dúo había partido por la mitad algo más que el siglo XIX. Una de sus frases había ejercido de cuchillo: "todo lo quera sólido y estable es destruido". ${ }^{54}$ Cuando las vanguardias o cuando Huyssen señalaban a la industrialización, al desarrollo de las telecomunicaciones, al transporte y a la incipiente globalización como causas del cambio de los modos de producción y del derrumbamiento progresivo de todo el sistema social, solo estaban recitando a Marx. Resulta paradójico, por no decir cómico, que el anticristo materialista albergara uno de los huevos de la desmaterialización modernista.

Marshall Berman no ocultó las fuentes y firmó el impuesto de sucesiones en el título de un libro: Todo lo sólido se desvanece en el aire..$^{55}$ La crónica de Berman es especialmente valiosa porque enlaza, de manera crítica, los modernismos y los antimodernismos de los años sesenta con periodos precedentes. Berman alababa aquella vitalidad y el fervor comunitario ya mencionado por Lippard, pero revela su fracaso desde que, como vimos, quisieron recuperar de manera apresurada el pasado. Berman certifica el desengaño en la década siguiente cuando, tras la irrupción estructuralista, desaparece aquella vitalidad. La desgracia definitiva llega con la destrucción del espacio público, con la falta de transitividad y con la mística posmoderna. ${ }^{56}$ La lucidez de Berman resulta ejemplar en el momento de analizar el dualismo generado por el hombre moderno:

Nuestra visión de la vida moderna tiende a dividirse entre el plan material y el espiritual: algunos se dedican al "modernismo" que ven como una especie de

\footnotetext{
53 RANCIÈRE, Jacques, La fábula cinematográfica. Reflexiones sobre la ficción en el cine, Barcelona: Paidós, 2005, p. 12.

${ }^{54}$ ENGELS, Friedrich; MARX, Karl, Manifiesto comunista, Ediciones elaleph.com, 2000, p. 31.

Hay multitud de traducciones diferentes de esta frase. He elegido una de las variantes que más han prendido en el imaginario colectivo. Por poner solo un par de ejemplos: "Todo lo que se creía permanente y perenne se esfuma", "Todo lo estamental y estancado se esfuma". En ninguno de los casos se cambia el sentido de la frase. Sigo prefiriendo una traducción literal de la versión inglesa: "All that is solid melts into air": Todo lo sólido se desvanece en el aire. Las ideas y las respuestas en el aire de Lippard y Dylan.

${ }^{55}$ BERMAN, Marshall, Todo lo sólido se desvanece en el aire. La experiencia de la modernidad, Madrid: Siglo XXI, 1988.

${ }^{56}$ Ibíd., p. 23. "que se esfuerza en cultivar la ignorancia de la historia y la cultura modernas, y habla como si todos los sentimientos, la expresividad, el juego, la sexualidad y la comunidad (...) acabaran de ser inventados -por los posmodernistas- y fueran desconocidos e incluso inconcebibles una semana antes."
} 
espíritu puro que evoluciona de acuerdo con sus imperativos artísticos e intelectuales autónomos; otros operan dentro de la órbita de la "modernización", un complejo de estructuras y procesos materiales (...) que, supuestamente, una vez que se ha puesto en marcha, se muere por su propio impulso, con poca o nula aportación de mentes o almas humanas. Este dualismo que impregna la cultura contemporánea, nos aparta de uno de los hechos que impregnan la vida moderna: la mezcla de sus fuerzas materiales y espirituales, la íntima unidad del ser moderno y del entorno moderno. ${ }^{57}$

Vuelvo a poner las manos sobre el teclado después de aplaudir la cita de Berman. Su mayor mérito no reside en su agudeza y precocidad, sino en su redacción contracorriente. Ayer y también hoy. Berman tuvo el tiempo y la habilidad suficientes para sacar la cabeza, respirar y deducir que tanta agua tenía que venir, por fuerza, de algún sitio. Me siento incapaz de mejorar ese párrafo de Berman porque, en pocas líneas, expone y resuelve parte de la dimensión semántica e histórica de los materiales y de las técnicas vanguardistas que aquí he reclamado.

Recurro a Berman en este momento y no antes, porque sirve de enlace exacto con la crítica al fenómeno de la desmaterialización. La escisión dualista iniciada en la modernidad histórica post Marx, es una de las causas de su posterior triunfo. Berman utilizaba de manera ejemplar a Baudelaire para luego apostillar que la lucha del escritor contra la confusión reinante entre progreso material y espiritual era reaccionaria, pero totalmente racional. Confusión que, además de persistir durante el siglo XX, no deja de repuntar en los periodos de expansión económica. Las dos décadas -digitales- precedentes a la crisis del 2007 son esclarecedoras. Será Zygmunt Bauman ${ }^{58}$ quien, tres lustros después, reelabore la tesis de Berman con otra nueva escisión -generada por una disolución global y multidisciplinar de los compromisosentre modernidad sólida y modernidad líquida.

Así, desde esa suerte de monismo proclamado por Berman, se observa mejor la artificiosidad y el error de un concepto incubado en la modernidad, eclosionado en las vanguardias y emancipado durante los conceptualistas años sesenta y setenta.

\footnotetext{
${ }^{57}$ Ibíd., p. 129.

${ }^{58}$ BAUMAN, Zygmunt, Modernidad líquida, Buenos Aires: Fondo de Cultura Económica, 2003. [Primera edición del año 2000]
} 


\subsection{Materiales desacralizados. Espacios vaciados}

Asumiendo que ni las vanguardias históricas, ni el arte conceptual suponen el fin de los materiales, conviene explicar cuáles eran dichos materiales. En un principio, la desmaterialización no era otra cosa que un ataque dirigido contra los materiales considerados dignos, nobles y burgueses. He querido elegir bien estos tres adjetivos porque, además de definir los materiales, abarcan otras instancias artísticas. Dignos hace referencia a la lucha vanguardista y conceptual por eliminar el estatus de la obra de la ecuación museística. En los años veinte, los museos eran espacios a demoler; a finales de los sesenta, simplemente, se quería enviar la Gioconda al Metro. Nobles apunta a las esencias técnicas y temáticas del arte perpetuadas por las academias y las instituciones de enseñanza. Burgueses viene a desestabilizar el contenido y los modos de fruición estándar de la obra.

En cualquier caso, no cesaron las divisiones entre los que siguieron reclamando la necesidad material para expresarse y los que, desde el purismo, demandaban la desmaterialización absoluta. Los primeros serían rápidamente etiquetados como reaccionarios.

El repertorio de materiales en el arte conceptual era infinito. Todo era susceptible de ser incorporado a la obra. Podría decirse que todo era susceptible de ser reciclado. Sin embargo, el término reciclaje ha adquirido a través del cine un significado demasiado concreto, como para presentar plena validez en la extrapolación. Por ejemplo, allí donde el cine busca investir con un nuevo significado y, por ende, con una nueva función -aunque Sandusky ${ }^{59}$ se oponga- a la imagen reciclada y remontada, el arte conceptual puede limitarse a intensificar las que ya tiene. Obviamente esta separación es artificial e incompleta, desde que el cine también participa de la segunda opción. Pienso ahora mismo en los filmes de Yervant Gianikian y Angela Ricci-Lucchi.

La desacralización de los materiales artísticos encontró su primer gran alegato a finales de los cincuenta. Luego, se prolongó durante toda la década hasta su paroxismo conceptual. El encargado de tirar la línea fue Allan Kaprow. En su ensayo "The legacy of Jackson Pollock" fechado en 1958, Kaprow enumeraba una lista de nuevos materiales disponibles. La lista pintura, sillas, comida, luces eléctricas, neones, humo, agua, calcetines viejos, un perro, películas y mil cosas más- concluía de la siguiente manera: "todo se convertirá en material para

\footnotetext{
${ }^{59}$ SANDUSKY, Sharon, "Toward archival film. The archaeology of redemption" en Millenium Film Journal, no 26, Archaeologies, otoño de 1992, pp. 2-25.
} 
este nuevo arte". Y avisaba del futuro inmediato: "Estoy seguro de que así será la alquimia de los sesenta". ${ }^{60}$

Para Kaprow dejaba de tener sentido ser pintor, poeta o bailarín; se era artista o no se era nada. De la misma forma, se dejaba de distinguir entre lo orgánico, lo industrial y lo sintético. La introducción de los nuevos materiales debía contribuir al conocimiento a través de lo ordinario. El lugar para adquirir el material ya no era un mercado arancelario y la fuente de inspiración ya no se encontraba en el museo, sino en los cubos de basura, en archivos policiales, en salones de hotel, en escaparates callejeros, en los sueños y en horribles accidentes. Uno de los subtextos latentes en la desacralización de los materiales, era tomar conciencia de la obsolescencia prematura a la que les abocaba el consumismo del american way of life. Punto de encuentro y de choque con la sensualidad y hasta la exaltación que realizaría el arte pop de muchos de esos materiales.

En 1970, Mary Douglas escribió el maravilloso -y muy discutible- libro Pureza y peligro. ${ }^{61}$ Allí hablaba de la relación entre suciedad y desorden. De la suciedad como "materia puesta fuera de su sitio". La manera en la que aparecieron todos aquellos materiales y hasta detritos artísticos, no era más que un ataque a la ortodoxia de la materia como símbolo del sistema. Douglas se preguntaba, hacia el final de su obra, por qué algo de carácter destructor como la suciedad podía volverse instrumento de creación. Obviamente, Douglas no parecía estar al tanto de este panorama artístico donde, una vez constatado el fracaso de la desmaterialización, la suciedad, la basura y el despojo fueron la forma de atacar la tradicional y "sistemática ordenación y clasificación de la materia". La suciedad y el desorden adoptaron configuraciones de potencial indefinido. Es decir, eran el vestido con el que provocar y sembrar peligro frente al poder. La desmaterialización necesitaba al menos de un rito y, como señalaba la antropóloga, los ritos actuaban "sobre el cuerpo político mediante el instrumento simbólico del cuerpo físico".

Con el cambio de década y con ocasión de la muestra neoyorkina -e hito neodadá- titulada New Media-New Forms (1960), la teoría de los nuevos materiales se amplió. En el catálogo de

\footnotetext{
${ }^{60}$ KAPROW, Allan, Essays on the blurring of art and life, Berkeley: University of California Press, 2003, p. 9. [Nueva edición extendida a cargo de Jeff Kelley]

${ }^{61}$ DOUGLAS, Mary, Pureza y peligro. Un análisis de los conceptos de contaminación y tabú, Madrid: Siglo XXI, 1973. [Primera edición de 1970]. Los entrecomillados corresponden a las pp. 54 y 173, respectivamente. La alusión a la suciedad como elemento creativo se encuentra en la p. 213.
} 
la exposición, junto a otro ensayo de Kaprow, figuraba uno de Lawrence Alloway ${ }^{62}$ donde se ponía nombre a la nueva tendencia: la estética chatarra, la estética basura o del desecho (junk aesthetic). Alloway ampliaba la lista de la compra a manteles, utensilios de cocina, bombillas, animales, pelotas de béisbol, sombreros, cajones, tiras de cómics y coca-colas. Lo hacía recordando al futurista italiano Umberto Boccioni, que ya en 1912 realizó una lista donde incluía cristal, madera, cartón, hierro, cemento, crin de caballo, cuero, ropa, espejos y luces eléctricas. De la experiencia con la vulgaridad material, surgía una forma exaltada de creación y de participación. Diríase que, siguiendo a Dezeuze ${ }^{63}$, toda una histeria que permitiría sondear -en lugar de suturar- el intersticio abierto entre vida y arte.

En 1961, The art of assemblage, muestra itinerante -con su correspondiente catálogocomisariada por William Seitz, expandiría la buena nueva. No parece coincidencia, sino un nuevo signo de los tiempos que, también en 1961, Manzoni terminara de enlatar -mal, sin prever los gases emanados- su Merda d'artista. Diez años más tarde de su fundacional ensayo, Kaprow volvería a insistir en "The shape of the art environment". ${ }^{64}$ Estaba legitimado para hacerlo porque había asistido en primera fila a la materialización de su profecía. Kaprow veía cómo aquella chatarra rehabilitada por el expresionismo abstracto seguía vigente en el conceptual. Materiales irregulares y más o menos maleables como la malla de alambre, el plástico y el cartón, la paja y los trapos, periódicos y gomas, papel de aluminio y hasta simples escombros. Lo que en un principio sirvió para el expresionismo abstracto, un poco más tarde para los neodadá y para el arte objetual y conceptual, proseguiría durante la década siguiente suministrando formas al arte povera, al land art, a la antiforma y al arte procesual.

La principal innovación para los intereses de esta investigación es la siguiente: la introducción de criterios de transformación e indeterminación en los materiales. ${ }^{65}$ Los residuos dejaban de responder a su origen y a su forma para ejecutar una transición de la materia al movimiento. En plenos años sesenta y setenta, como vemos, seguía prendida la ingenuidad de desmaterializar cinética y cinemáticamente.

\footnotetext{
${ }^{62}$ ALLOWAY, Lawrence, "Junk culture as a tradition" en New Media-New Forms, Nueva York: Catálogo de la exposición en la Galería Martha Jackson, del 6 al 24 de junio de 1960.

${ }^{63}$ DEZEUZE, Anna, "Neo-Dada, Junk aesthetic and spectator participation" en HOPKINS, David (ed.), op. cit., pp. 49-71.

${ }_{64}^{64}$ Ibíd., pp. 90-96.

${ }^{65}$ MARCHÁN FIZ, Simón, Del arte objetual al arte de concepto, Madrid: Akal, 2012, p. 317. [Primera edición de 1972]
} 
Es necesario tener en cuenta la actividad galerista, ya fuera sedentaria o itinerante, porque en ella creció un apéndice nada trivial de la desmaterialización. La alteración de la obra y de sus métodos no se entendía o no se culminaba si su entorno no cambiaba con ella. El espacio, de repente, se vació. Lo hizo para llamar la atención sobre los huecos y sobre el proceso de rellenado. Porque, llegado el caso, el acto de rellenar podía ser la obra en sí. Muros desnudos, materiales vistos o pasillos encalados, puertas ausentes y salones desamparados. Elogio del éter donde echar a volar los fantasmas; las ideas. Museo y galería que, en lugar de volver a la Bauhaus, regresaron al castillo del espectro. ${ }^{66}$ La neutralidad o la adecuación contextual lógica -y hasta ese momento ortodoxa- de los espacios de exposición, tomaba partido desde una desolación que quiso ser abstracción. Sobre los pasillos desiertos, empero, se escuchaba un eco perfectamente audible por no decir atronador, el del 4'33" (1952) de John Cage.

En 1958, Yves Klein -con sus zonas de sensibilidad pictórica inmaterial- ya había expuesto el Vacío (Le Vide) en la Iris Clert parisina. Joseph Kosuth y Seth Siegelaub discurrirían sobre esta desmaterialización del entorno en la célebre exposición neoyorquina (44 East - 52nd Street) de enero (del 5 al 31) de 1969. Los espacios vacíos que conformaban la galería suponían -obras, ideas, instalaciones y happenings al margen- una expresión independiente. Kosuth quería utilizar el valor del espacio vacío para acentuar la inmaterialidad de la obra -una de sus photostat. Su intención: borrar cualquier conexión con la pintura. Seth Siegelaub, comisario del evento, proclamaba que el catálogo era lo verdaderamente importante de la muestra. Mientras que la exposición física solo era una forma auxiliar del primero. Ese mismo año, el simposio "Art without space", moderado por el propio Siegelaub y con la participación de Lawrence Weiner y Kosuth entre otros, dejaba claro desde el mismo título su punto de vista sobre la materia y el valor del espacio.

A su vez, Lippard, en Six years, recogía otra multitud de referencias entre las que se podría rescatar, a modo de precedente, la obra de Robert Rauschenberg Erased de Kooning drawing, de 1953. También los trabajos de Claes Oldenburg, Eva Hesse, Barry LeVa, Robert Morris, etc. Eran años donde Ben Vautier clamaba que el agujero era, por naturaleza, una cosa extraordinaria, y donde Bruce Nauman lo trasladaba a un árbol para, después, escuchar sus sonidos. Un tiempo en el que Keith Arnatt se preguntaba si podía contribuir con nada -o, para ser exacto, haciendo nada [I have done nothing]- a una exposición, y donde Mel Ramsden

${ }^{66}$ ROAS, David, El castillo del espectro. Antología de relatos fantásticos españoles del siglo XIX, Barcelona: Círculo de Lectores, 2002. 
entregaba su Pintura secreta (1968). ${ }^{67}$ Años para que Les Levine ideara su Película para ciegos (1969), para que William Anastasi filmara paredes haciendo luego hacer coincidir imagen y lugar y para que Robert Smithson asegurara que había que enfrentarse a las "cuestiones fundamentales de la materia y la mente" ${ }^{\prime 68}$ despojándolas de todo interés antropomórfico. Encrucijada temporal donde Robert Barry llevaría al nanosíncope la desmaterialización de la obra -y de la morfología- con sus Inert gas series (1969).

En resumen, lo que más me interesa de este apartado no es tanto el catálogo de materiales o la estructuración espacial, como la constatación histórica de que, durante el periodo comprendido entre finales de los cincuenta y principios de los setenta, la desmaterialización del arte tuvo que hacer frente a severas contradicciones. Diría que hasta a aporías. Lo cual no invalida la genealogía, más bien todo lo contrario: valida la prueba histórica a través del nacimiento del concepto al tiempo que refuta su cumplimiento. Dogma y aporía conceptual al margen, la desmaterialización del arte sirvió de alegoría teórica a la desacralización del material. El fantasma no solo seguía conservando su sábana, sino que lo hacía con ella repleta de suciedad. El fantasma comenzaba a dejar de frustrarse por residir en la máquina porque, para su asombro, tomó conciencia de que él era la máquina. Sol LeWitt lo había predicho, también, en 1967: “La idea se convierte en la máquina que produce arte". ${ }^{69}$

Arraigado, encarnado el fantasma, cuando todas las corrientes artísticas del periodo volvieron la vista hacia la suciedad de su sábana, lo hicieron como consuelo. Como medio para llamar la atención sobre lo que escondía. De nuevo fue Kandinsky quien primero avisó de que la suciedad "como representación material y como entidad concreta" poseía "su propio sonido interior". ${ }^{70}$ Más de medio siglo después, Joseph Beuys, abjurando de los objetos, reinterpretaría ese sonido interior hasta "Ilegar al origen de la materia, al pensamiento detrás de ella". ${ }^{71}$

\footnotetext{
${ }^{67}$ Esta obra, quizá la más conocida del colectivo Art \& Language, es susceptible de un análisis comparado con So is this (1982) de Michael Snow. Dicho análisis serviría para desvelar muchos de los tópicos vertidos sobre la relación entre pintura y cine y sobre imagen -cine- y letra -ensayo.

${ }^{68}$ LIPPARD, Lucy, Seis años, Madrid: Akal, 2004, p. 143. [p. 89 de la edición inglesa citada con anterioridad]

${ }^{69}$ LeWITT, Sol, "Paragraphs on conceptual art" en Artforum, vol. 5, no 10, verano de 1967, pp. 79-83. [La traducción es mía]

${ }^{70}$ KANDINSKI, Vasili, op. cit., pp. 75-76.

${ }^{71}$ SHARP, Willoughby, "An interview with Joseph Beuys" en Artforum, vol. 8, no 4, diciembre de 1969, pp. 40-47. Versión en español: “Una entrevista con Joseph Beuys por Willoughby Sharp, 28 de agosto de 1969” en KLÜSER, Bernd (ed.), Joseph Beuys. Ensayos y entrevistas, Madrid: Síntesis, 2006, pp. 29-43.
} 


\title{
7. HORIZONTE DE SUCESOS
}

\author{
«Moonshot, Woodstock, Watergate, punk rock. \\ Begin, Reagan, Palestine, terror on the airline. \\ Ayatollah's in Iran, russians in Afghanistan» \\ We didn't start the fire (Billy Joel, 1989) ${ }^{72}$
}

Expuesta la tradición y la función de la desmaterialización artística, es el momento de preguntarse por su extensión social y política. Si el arte se valió de la desmaterialización para cuestionar toda una serie de valores establecidos, los modelos socioeconómicos recurrirán a ella para lo contrario: para afianzar sus estructuras de poder. He aquí una de las razones por las que resulta inexcusable realizar toda esta contextualización: la ambivalencia del concepto. Su condición de chica para todo convirtió a la desmaterialización en una práctica apetecible en cualquier ámbito. Tal es la hipótesis de este apartado: se inyecta desmaterialización a todos los niveles para que esta pueda operar en el interior y a escala de metarrelato. Una vez dentro del mismo adquirirá dos significados opuestos: la desmaterialización como derrota, como pérdida de valor de los modelos precedentes; y la desmaterialización como nueva estrategia de la retórica del poder. Es, por lo tanto, necesario conocer su dimensión social y política para comprender mejor sus dispositivos estéticos.

Uno de sus atractivos fue $-\mathrm{y}$ es- la facilidad para infiltrarse y calar en un corpus teórico preexistente. De esta forma, la idea de desmaterializar se propagó por las teorías de los nuevos medios, por la semiótica y por el arte pop. Otro de sus atributos fue su enorme potencial retórico. Así, la desmaterialización se instaló en la sala de máquinas del poder para borrar los hilos. A partir de entonces, la retórica del poder se convertiría en una película de wire fu donde todos los cables fueron sabiamente camuflados, que no desmaterializados. Por último, la desmaterialización parasitó nuevos y viejos relatos gracias al misterio y a la curiosidad inherentes a todo lo invisible. Citaré algunos de los más llamativos.

La informática comienza su desarrollo imparable. Las computadoras queman generaciones acceden a la tercera durante esta década-, los microprocesadores aumentan su potencia mientras se reduce el tamaño del hardware. El avance de la tecnología de circuitos integrados es la primera ficha del efecto dominó. Arranca una miniaturización de los objetos que debe

\footnotetext{
${ }^{72}$ Columbia: House of Blue Light, 1989.
} 
quedar realzada por el diseño y la moda. La tecnología impulsa objetos normativos: la máquina debe ser y, además, debe ser bella. Esta desmaterialización vía miniaturización estilizada y bien visible, devino flagrante contradicción. El láser se perfecciona y se convierte en el objeto desmaterializado por excelencia. Primero restringido a uso científico e industrial, después como artefacto visual -sólo o acompañado- espectacular. Otras tecnologías científicas como la fibra óptica, corren la misma suerte. Existe un trasvase ininterrumpido entre innovación científica y experimentación estética.

Por ejemplo, el primer experimento satisfactorio -en cuanto a recreación gráfica y a dispositivo head mounted- de realidad virtual, lo encontramos en aquella misma encrucijada de 1968: The sword of Damocles (Ivan Sutherland, Bob Sproull). Los videojuegos, en tanto correlatos del desarrollo del software genérico, salen al mercado a lo largo del primer lustro en forma de máquinas recreativas y de consolas. La arquitectura, cada vez más abstracta y desnuda gracias al vidrio y a las aleaciones, hace cumbre en 1972 con la construcción del World Trade Center. El vídeo doméstico triunfará a finales de la década -cambiando hábitos y metodologías analíticas-, pero antes ya había sido objeto de experimentación científica y creativa. Igual que sucedería en la era digital, aquella estandarización creciente del vídeo ya fue considerada ${ }^{73}$ como el paso definitivo hacia el fin del material fílmico.

Durante la década, la astrofísica -como le sucedió a la física cuántica- adquiere un didacticismo cada vez mayor gracias a la popularidad de autores como Stephen Hawking. Su teoría sobre la radiación de los agujeros negros abundaba en aquel orgasmo de la desmaterialización: horizonte de sucesos -en 2014 puesto en duda por él mismo y rebautizado como horizonte aparente- donde la luz es devorada. Similar apertura divulgativa se apreció en las ciencias del caos -la termodinámica- y en las ocupadas de lo minúsculo: la genética y la biología molecular. La exploración espacial tomó el relevo de las anteriores aventuras materialistas. El vacío cósmico por el hielo polar, plástico y comida liofilizada por toneladas de víveres, tracción mecánica por por tracción animal, combustible por perros. Adiós a los barcos y bienvenida a unos cohetes que perforan y derrotan a la gravedad.

\footnotetext{
${ }^{73}$ Michelangelo Antonioni diría lo siguiente sobre sus experimentos llevados a término en El misterio de Oberwald (II mistero di Oberwald, 1980): "Sí, puedo decir que la cinta magnética tiene todos los papeles en regla para sustituir la película tradicional. Dentro de una década el cambio ya se habrá realizado". Tomo la declaración como pura anécdota, pero también como aviso necesario a la hora de elaborar discursos proféticos con o sobre el cine. ANTONIONI, Michelangelo, Para mí hacer una película es vivir, Barcelona: Paidós, 2002, p. 175.
} 
La década se cerraría con un nacimiento, el de Louise Brown. Primer ser humano fecundado in vitro. Aborigen de la desmaterialización. Princesa la posmodernidad. Primera espectadora de un circo de cuerpos ingrávidos.

\subsection{Retórica del poder. De Vietnam a Irak}

La Internacional Situacionista cerró su corta (1957-1971) e intensa vida con su autodisolución a comienzos de la década. Esta efeméride puede servir como capitulación última y simbólica de las vanguardias. Aunque su influencia -transfigurada y puede que irreconocible, como bien apreciaba Sadie Plant ${ }^{74}$ - acabaría extendiéndose hasta la posmodernidad. Sin embargo, si algo caracterizó aquella vanguardia periclitada fue -grosso modo- su mojigatería, su frivolidad y su estrechez de miras. Hasta la abstracción había sido domesticada para que pudiera pastar sobre las paredes de los despachos ejecutivos porque, entre otras cosas, había demostrado ser más dócil que un arte legible. Ahora la lectura y el mensaje dependían del propietario o del rito funerario en torno a la tela. Además, muchos artistas se convirtieron en cortesanos ${ }^{75}$ de la nueva y creciente oligarquía.

El fervor antiinstitucional de los sesenta se centró en la desmitologización y en la desmercantilización del arte, para lograr una independencia artística que no estuviera sometida a la compraventa de un sector avaro y todopoderoso que se aprovechaba del mundo y que promocionaba la guerra en Vietnam (...) Dije esto en 1969. Visto hoy era una utopía. ${ }^{76}$

Con este último despojamiento, quedaba lista la apropiación por parte del sistema paradójicamente el apropiacionismo había sido una de las armas situacionistas- de la herencia, del carácter y de los ejercicios de vanguardia. ¿Qué sistema? Uno que no entendió de fronteras. Uno que se arrogó el mérito de haber desmaterializado un Muro: el neoliberalismo. Las dudas que despertaban los modelos económicos, incapaces de ofrecer respuestas estructurales a los problemas, se vieron agudizadas en 1973 tras la crisis del petróleo derivada

\footnotetext{
${ }^{74}$ PLANT, Sadie, El gesto más radical. La Internacional Situacionista en una época postmoderna, Madrid: Errata Naturae, 2008.

${ }^{75}$ Robert Hughes advirtió ese papel cortesano del artista, centrando su crítica en la figura y en el papel desempeñado por Andy Warhol dentro de la administración de Ronald Reagan. HUGHES, Robert, "El Ascenso de Andy Warhol", op. cit., pp. 49 y 55.

${ }^{76}$ LIPPARD, Lucy, Six years. The dematerialization of the art object from 1966 to 1972, op. cit., p. xiv. [La traducción es mía] En la elipsis representada por los puntos suspensivos del paréntesis, la autora introduce una autocita de época sobre la desmaterialización del arte como solución drástica al chalaneo y a la idea de propiedad de la obra.
} 
de la guerra del Kippur. Fue cuestión de tiempo y de inercia que las tesis neoliberales, cultivadas en el vivero de la Escuela de Chicago desde los años cincuenta, accedieran y coparan las esferas de poder. $\mathrm{Y}$ en el término esferas de poder incluyo también las académicas. El triunfo del nuevo modelo quedó sancionado con la concesión del Premio Nobel de Economía a Milton Friedman en 1976. La aplicación inmediata del ideario corrió a cargo de las administraciones británica (Margaret Thatcher) y estadounidense (Ronald Reagan). Bauman invocaría esta nueva dimensión inmaterial y especulativa del dinero, perfeccionada y sobredimensionada según pasaban los años, como uno de los maestros de ceremonias de su modernidad líquida. Las grandes ganancias y el capital del futuro dejarían de pertenecer a los objetos materiales para entregarse a las ideas. ${ }^{77}$

Más que la derrota final en Vietnam, fue toda la agobiante experiencia precedente la que despertó a un gigante dormido: los asesores políticos. Habían pasado demasiado tiempo tumbados en la vieja poltrona de la Guerra Fría. Butacón viejo pero perfectamente acomodado al cuerpo, individualizado, conocedor de cada pliegue corporal. Aquella manera tan física de confrontación a la que les invitó el Vietcong, era el guisante bajo el colchón de la princesa. Cuerpo a cuerpo, bayoneta calada, túneles y arrozales, jungla y sudor, serpientes y malaria. Las acciones más asépticas que habían concebido para resolver el conflicto se limitaron a los baños de napalm, a los de agente naranja y a las fumigaciones masivas contras el Anopheles. Con ellos solo pudieron derretir la piel y la carne de miles de vietnamitas, defoliar las hojas de los árboles y derribar el vuelo de un mosquito. Simulacros de desmaterialización.

Algo más que el molde para fabricar tácticas había caído en Vietnam: la representación de lo sucedido. Además de reelaborar ${ }^{78}$ los vetustos ${ }^{79}$ patrones del arte de la guerra, los consejeros

\footnotetext{
${ }_{77}$ BAUMAN, Zygmunt, Modernidad líquida, op. cit., p. 161.

${ }^{78}$ Estados Unidos comenzaría a patrocinar de manera encubierta, pero impúdica, golpes de Estado y grupos armados extranjeros. Allende cae en 1973. A partir de 1978 Afganistán se defenderá de la invasión soviética gracias a su apoyo, igual que hará Irak con Irán en la guerra de los ochenta. A finales de los setenta también comienzan a operar las Contras nicaragüenses. Llegado el momento de tomar la iniciativa, Estados Unidos lo hará mediante acciones fugaces y clandestinas como las llevadas a cabo, por ejemplo, en Centroamérica. Actividades invisibles que dificultaban su catalogación como terrorismo de estado. Véase: CHOMSKY, Noam; HERMAN, Edward, The Washington connection and third world fascism. The political economy of human rights, Boston: South End Press, 1979. Más recientemente el vídeo: Noam Chomsky. Distorted morality: America's war on terror? (John Junkerman, 2002).

${ }^{79} \mathrm{~A}$ raíz de la 1a Guerra Mundial, ya hubo un debate enconado sobre el papel de la tecnología aplicada a la guerra. Sectores del Futurismo italiano quedaron enfrentados a otros del Dadaísmo, al considerar aquella lucha a gran escala como la liberación absoluta, la clave y la puerta del porvenir. La visión dadá, por el contrario, vio el enfrentamiento como la muestra definitiva de una estulticia burguesa despedazada en el campo de batalla por el nuevo poder tecnológico. Tampoco conviene olvidar el uso de las primeras armas desmaterializadas: los gases.
} 
políticos debían inventar nuevos relatos que los sustentaran. Cuando un cuerpo se tambalea, siempre hay un relato que dibuja su viaje a la lona. La derrota era inconcebible -como inconcebible fue la caída del Worl Trade Center-por las formas en las que se articuló la narración de los hechos. El relato victorioso que había cultivado hasta aquel instante el pueblo norteamericano, tenía que ser reemplazado. Cargado de razón, Tom Engelhardt resume el trance: "no había relato americano posible que pudiera sostener la historia de una derrota a cámara lenta infligida por humanos de raza no-blanca en una guerra fronteriza" ${ }^{80}$

Para Engelhardt, las formas que habían ilustrado las anteriores victorias estadounidenses se desmaterializaron. Esto es, perdieron su vigencia. $\mathrm{Y}$ para ello recurre a un ejemplo de propaganda fracasada durante la contienda, el filme Why Vietnam? (Anónimo, 1965). Víctima del imperativo de innovación que se cernía sobre el relato, el filme mostraba la falta de recursos lingüísticos de una administración esclerótica. Tomando como modelo la serie Why we fight (1942-1945), este nuevo "por qué" no respondía a la realidad. La aureola de coraje, del orgullo y del valor que había acompañado a la guerra, perdía su lustre frente a una interminable procesión de body bags. Vietnam fue, así, el punto de inflexión a partir del cual la política comenzó a utilizar la desmaterialización como ansiolítico. Como perfume narrativo pulverizado en el éter. Como cuerpo escondido que genera nuevos mitos y nuevos misticismos.

La nueva y desmaterializada alianza entre relato y guerra estaba, pues, en ciernes. Este nuevo campo se convirtió en motivo de estudio. Se acercaba un momento histórico que debe ser visto como el vivero de una serie de pensadores posmodernos que reaccionan frente a la nueva retórica desde ideologías cercanas a la izquierda neomarxista y al marxismo estructural. El panorama estadounidense asiste a la edición de nuevas traducciones de Foucault, Baudrillard, Derrida y Lacan. También de la Teoría crítica y de los Estudios culturales y de género. Así las cosas, gran parte de las ideas en boga intentarán fiscalizar al poder.

Althusser hablaba ${ }^{81}$ de los aparatos ideológicos de Estado y de los mensajes que determinan la producción de sentido recurriendo a una codificación desleída en la iconografía y en la sintaxis. Esa dimensión soterrada, diríase que subliminal, que apelaba al subconsciente, esa intención de conducir conductas y de ordenar posibilidades, serán los motivos de la denuncia. Pero lo

80 ENGELHARDT, Tom, The end of victory culture. Cold War America and the disillusioning of a generation, Amherst: University of Massachusetts Press, 2007, p. 14. [La traducción es mía]

${ }^{81}$ ALTHUSSER, Louis, “Ideología y aparatos ideológicos de Estado" en Escritos, Barcelona: Laia, 1974. 
que más les preocupará será la estrategia narrativa que conduce a la ausencia de referente. Discusión que desembocará en la precesión de los simulacros de Baudrillard. ${ }^{82}$ Partiendo de una coyuntura propicia y de una intención loable, hoy seguimos lamentando que parte de aquellos intentos por desenmascarar la retórica del poder, terminaran enroscados en una espiral pretenciosa, autocomplaciente y, en última instancia, oscura.

La forma de contar las guerras solo fue el primer escalón. Había que actuar sobre la materia prima de la guerra y del terrorismo: la violencia... Y la violencia se desmaterializó. Como explicaba Jonathan Schell ${ }^{83}$, la violencia se trasladó del plano físico -el castigo corporal y la máquina- al psicológico -el miedo y la propaganda. El miedo volvía a demostrar su poder para causar destrozos desde una inmaterialidad irracional. Ante la inutilidad de controlar o de volver a utilizar las primitivas reacciones de la amígdala, había que cercar y manipular las zonas adyacentes. Estudiar las debilidades del sujeto para llegar a afectar su conducta requería de conocimientos narrativos profundos, esto es, biológicos.

El estudio del miedo -o de los miedos- siempre ha presentado problemas científicos. En un principio -con el desarrollo del psicoanálisis- se pensó que esa dificultad radicaba en nuestros mecanismos de represión. El miedo, atrincherado en el instinto del viejo sapiens y en los diques morales levantados por la civilización, dificultaba la exploración. Luego, sin abandonar el prurito criptográfico del psicoanálisis, descubrimos que la comprensión del miedo también presentaba problemas por una simple cuestión de arquitectura cerebral. En un ejercicio evolutivo realmente poético -uno de los muchos con los que cuenta la evolución-, las regiones

\footnotetext{
82 BAUDRILLARD, Jean, "The precession of simulacra" en BAUDRILLARD, Simulacra and simulation, op. cit., pp. 1-42. Traducción al español en: WALLIS, Brian (ed.), op. cit., pp. 253-281.

${ }^{83}$ Schell era apocalíptico, para él estábamos ante una sociedad enferma cuyo futuro no puede escapar a una autoaniquilación conducida por las armas, especialmente las nucleares, y por la alteración flagrante del equilibrio entre hombre y Naturaleza. Véase: SCHELL, Jonathan, El destino de la Tierra, Barcelona: Argos Vergara, 1982. También: BOYNTON, Robert, "A conversation with Jonathan Schell. People's power vs. nuclear power" en Daedalus, vol. 136, no 1, invierno del 2007, pp. 22-9.

Esta antropomorfización de la sociedad como ente enfermo cuenta con un interesante ejercicio visual que, desde una premisa y una forma documental, termina por deslizarse hacia el ensayo audiovisual: The corporation (Jennifer Abbot, Mark Achbar, 2003). Su tesis parte del funcionamiento de la sociedad capitalista y de sus mecanismos económicos y de poder, como si de un organismo humano se tratara. Su conclusión dictará que la enfermedad y los desórdenes psíquicos se han instalado en todos ellos de manera irremediable. El filme viene a ser una puesta en imágenes de la sentencia de Roberto Rossellini: "La sociedad capitalista es neurótica por naturaleza". ROSSELLINI, Roberto, Un espíritu libre no debe aprender como esclavo, Barcelona: Paidós, 2001, p. 24. O de la reflexión de Foucault sobre la catalogación y exclusión de los individuos: "Si nuestra sociedad se calificara como enferma mental, se excluiría a sí misma". DAVIDSON, Arnold, Foucault and his interlocutors, Chicago: University of Chicago Press, 1997, p. 140.
} 
implicadas quedaban en zonas recónditas. El miedo habitaba en el caserón de las sombras. En la cabaña del bosque.

Aludía más arriba a la inutilidad de controlar la amígdala. Lo hice porque, entre otros motivos, descubrimos que la amígdala no era el centro cerebral del miedo. El miedo se genera y se percibe a partir de una relación recíproca entre amígdala y cognición. ${ }^{84}$ Esto es, entre instinto y conciencia. Que la amígdala detecte la amenaza y se active, no implica que sintamos miedo. Podemos sudar, nuestros músculos pueden adquirir tensión y nuestro corazón puede acelerarse, pero seguimos sin sentir el miedo. Este viene en gran medida de su procesamiento consciente. Es decir, el miedo se refugia en lo subliminal, en el anonimato, pero debe abandonar su escondite para cometer el crimen. El miedo se materializa durante el tránsito. Quién sabe si el miedo es ese tránsito mismo: el que va de lo latente a lo expresivo. Una lástima que Bauman no incorporara esta concreción a su Miedo líquido ${ }^{85}$, porque es la más certera que existe para emplear con rigor su epíteto favorito. Así, en tanto emoción, el miedo es un fenómeno bastante más complejo y menos irracional de lo que pensábamos en un principio. El axioma del miedo como pulsión enfrentada a la razón tuvo que ser revisado.

No solo Bauman vio en el miedo una herramienta clave en la estrategia política de la desmaterialización. Sloterdijk y Virilio también lo hicieron. Los tres acertaron en la detección, pero a veces erraron en los análisis. Virilio, fiel a todos sus mantras, descompuso la guerra clásica y, con ella, el miedo. El miedo antiguo y mecanicista se corresponde con el Ministerio de la Guerra. El miedo moderno y etéreo con el Ministerio del Miedo. Las armas de destrucción masiva han pasado a ser las "armas de comunicación masiva destinadas a golpear los espíritus". ${ }^{86}$ Los impactos materiales de los proyectiles explosivos, devienen impactos audiovisuales, instantáneos, veloces y globales. Sloterdijk, también amigo de la volatilidad y de

\footnotetext{
${ }^{84}$ Un gran -comprensible y didáctico- análisis de esta relación en: PEHLPS, Elizabeth, "The interaction of emotion and cognition: the relation between the human amygdala and cognitive awareness" en BARGH, John; HASSIN, Ran; ULEMAN, James (eds.), The new unconscious, op. cit., pp. 61-76. Para la descentralización del miedo véase también: LeDOUX, Joseph, "The amygdala is NOT the brain's fear center. Separating findings from conclusions" en Psychology Today, 10 de agosto de 2015.

<https://www.psychologytoday.com/blog/i-got-mind-tell-you/201508/the-amygdala-is-not-the-brainsfear-center> [consulta: 20-08-2015]

${ }^{85}$ BAUMAN, Zygmunt, Miedo líquido. La sociedad contemporánea y sus temores, Buenos Aires: Paidós, 2007. Aunque Bauman está bien cerca de expresar la noción del tránsito biológico del miedo cuando cita a Adorno: "La presencia, en absoluto disminuida del sufrimiento, el miedo y la amenaza convierte en perentoria la necesidad de no descartar de por sí la idea o el pensamiento que no pueda materializarse", p. 219.

${ }^{86}$ VIRILIO, Paul, Ciudad pánico, Buenos Aires: Libros del Zorzal, 2006, pp. 41-42. [Primera edición del 2004]
} 
las espumas, enviaba el terror a la atmósfera. El miedo se había convertido en un organismo aeróbico que no solo necesitaba el oxígeno para alimentarse, también para propagarse. Más allá de la deflagración, el miedo se convierte en un fenómeno atmosférico. En un atmoterror que enlaza las nuevas tecnologías con la preocupación ambiental. El miedo como representante de una guerra evasiva pero total: no ataques a los cuerpos, ataca el medio donde se desenvuelven.

El mismo título, Temblores de aire, sugiere una moderna disolución -más mortífera, dada la ausencia de huecos- de aquella metralla que todo lo anegaba de fragmentos discretos, de alguna manera todavía visibles, que Jünger llamó Tempestades de acero. ${ }^{87}$

De lo que dieron cuenta Bauman, Virilio, Sloterdijk y tantos otros a comienzos de siglo XXI, fue de los coletazos de un movimiento que, partiendo de Vietnam, había tenido como destino los años noventa: la primera Guerra del Golfo. Comprobada su eficacia durante el cambio de siglo, el escrutinio continuó su marcha. No obstante, la existencia de una narrativa del miedo y del poder las pesadillas ${ }^{88}$ no valida -más bien perjudica su comprensión- exposiciones coolturalistas como las de Naomi Klein. ${ }^{89}$

Las guerras, finalmente, dejaron de tener lugar. La guerra se desmaterializó de manera

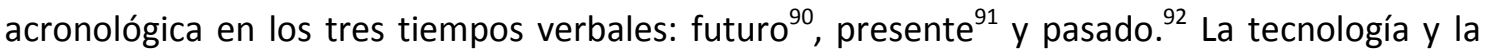
información -en tanto narrativa oficial camuflada por doquier en los mass media- fueron actualizadas para mantener en pie el axioma de Esquilo: "En la guerra, la verdad es la primera víctima". Simón Peres -La diplomacia y los servicios de inteligencia de Israel lo habían practicado antes incluso que Estados Unidos- lo tenía claro:

${ }^{87}$ Del prólogo redactado por Nicolás Sánchez Durá para: SLOTERDIJK, Peter, Temblores de aire. En las fuentes del terror, Valencia: Pre-Textos, 2003, pp. 14-15.

${ }^{88}$ The power of nightmares. The rise of the politics of fear fue una serie televisiva, compuesta por tres capítulos, dirigida por Adam Curtis para la BBC en 2004.

${ }^{89}$ KLEIN, Naomi, La doctrina del "shock". El auge del capitalismo del desastre, Barcelona: Paidós, 2007. La adaptación audiovisual realizada dos años más tarde por Mat Whitecross y Michael Winterbottom resultó tan burda como aquello que intentaba denunciar.

${ }^{90}$ BAUDRILLARD, Jean, "La Guerre du Golfe n'aura pas eu lieu" en Libération, 4 de enero, 1991, p. 5.

${ }^{91}$ BAUDRILLARD, Jean, "La Guerre du Golfe a-t-elle vraiment lieu?" en Libération, 6 de febrero, 1991, p. 10.

${ }^{92}$ BAUDRILLARD, Jean "La Guerre du Golfe n'a pas eu lieu" en Libération, 29 de marzo, 1991, p. 6. Se realizaría una compilación en: BAUDRILLARD, Jean, La Guerre du Golfe n'a pas eu lieu, París: Galilée, 1991.

He manejado la siguiente edición en inglés: BAUDRILLARD, Jean, The Gulf War did not take place, Bloomington: Indiana University Press, 1995. 
La información ya no es solamente una de las armas que tienen a su disposición los bandos enfrentados. Se ha convertido en el arma por excelencia, la verdadera bomba atómica de nuestra época. ${ }^{93}$

¿Nueva guerra, viejos medios de información? o ¿nuevas guerras, nuevos ${ }^{94}$ medios de comunicación? No me corresponde continuar la explicación, tan sólo facturar que la desmaterialización accedió a estas prácticas -pulidas y ampliadas en la era digital- desde Vietnam hasta la actualidad pasando por la primera Guerra del Golfo. Los muertos y la barbarie -lo real- continuaron y continúan presentes a pesar de las bombas teledirigidas, de los visores digitales, del láser, de los satélites, de los simuladores, de la guerra químicobacteriológica y de la información taimada. La desmaterialización devino espectacularización y esta última virtualización. Show televisado donde poder utilizar el fuera de campo como vertedero.

La guerra virtual, la que no existirá ni existió en imágenes, o la que existe en unas imágenes elegidas, para otros será, fue y es vivida. Cuestión de información, de conocimiento y de mirada. Los espacios conocidos no son los mismos que los espacios vividos, y no digamos que los meramente vistos. Espacios que en las últimas décadas han sido pintados con un "atributo ambigua y discutiblemente asociado a los medios digitales, $[\mathrm{y}]$ descrito como una tendencia esencial y necesaria de los mismos": ${ }^{95}$ virtual. A propósito de lo virtual, permítaseme el siguiente y mínimo excurso. Durante el juicio a los tres fundadores del portal The Pirate Bay, el fiscal le realizó la siguiente pregunta a uno de ellos: “¿Cuándo fue la primera vez que se encontraron IRL?” A lo que el muchacho contestó: “¿Conocerse IRL? ¿Qué es eso?” El fiscal, campanudo, apostilló: "En la vida real [In real life]". El joven, con la sonrisa pero también con la verdad derramándose por la comisura de los labios, le refutó: “No usamos esa expresión. Utilizamos AFK. Lejos del teclado [Away From Keyboard]. Creemos que Internet es la realidad

93 QUINTERO, Alejandro, Nuevas guerras, vieja propaganda. De Vietnam a Irak, Valencia: Universitat de València, 2005, p. 18.

94 CARRUTHERS, Susan, "New media, new war" en International Affairs, vol. 77, no 3, julio del 2001, pp. 673-681.

La bibliografía sobre el tema se dispara durante los años noventa. Un estudio genérico de la misma autora en: The media at war. Communication and conflict in the twentieth century, Nueva York: Palgrave Macmillan, 2002.

Para el nuevo siglo: SEIB, Philip, Media and conflict in the twenty-first century, Nueva York: Palgrave Macmillan, 2005.

El caso concreto de la Guerra del Golfo en: MacARTHUR, John, El segundo frente. Censura y propaganda en la Guerra del Golfo, Madrid: Cuadernos de Langre, 2003.

${ }^{95}$ RUBIO ALCOVER, Agustín, op. cit., p. 175. 
[We think Internet is for real]". ${ }^{96}$ La ignorancia del fiscal era comprensible, respondía al analfabetismo digital rampante que ni los medios de comunicación, ni gran parte de los teóricos han contribuido a paliar. Aunque pueda parecerlo, el muchacho no confundía lo virtual con lo real; no era un posmoderno. Solo consideraba al primero como una extensión o un atributo del segundo.

Peter Sloterdijk, en su crítica a la crisis general del espacio, lo explicó mejor de lo que yo pueda hacerlo aquí: "la experiencia del espacio es la existencia primaria del existir". ${ }^{97}$ Se trata de un encuentro de miradas y, por lo tanto, de cuerpos, en el que sólo algunas forman parte de un espacio vivido: la mirada de quien lanza una bomba desde su display difiere de la nuestra ${ }^{98}$ frente a la televisión. De la misma manera que la del fotógrafo o de la del reportero que recoge el hecho, difiere de la del civil o la del militar aniquilado a ras de suelo. Los espacios y las miradas difieren y admiten epítetos, pero todos quedan englobados en una única y última realidad necesaria.

\subsubsection{Más allá del atomismo}

En conclusión, hablar de desmaterialización y de virtualidad bélica es una obscenidad. Aunque sea para denunciar la retórica del poder que la legítima. Hiroshima y Nagashaki, junto a sus habitantes, fueron desmaterializadas a átomo limpio. Todavía podemos escuchar las palabras de Paul Tibbets recicladas en la inolvidable The atomic cafe (Jayne Loader, Kevin Rafferty, Pierce Rafferty, 1982):

Hice que se reunieran y se sirvió café. Les dije lo que hacíamos y lo que transportábamos en ese momento (...) El clima estaba despejado (...) Todo fue rutinario (...) No vimos nada que nos preocupara (...) Se soltó la bomba (...) En cierto modo, era inconcebible lo que estábamos viendo (...) tomamos fotos.

Sobre lo que se desmaterializó bajo aquel avión, mejor recurrir a otra excelente fuente de información, la de John Hersey. Edificios y cuerpos ausentes. Y, sin embargo, sus huellas. Siluetas recortadas en el tiempo y en la materia. Cuerpos que fueron y que, como último e

\footnotetext{
${ }^{96}$ Las citas están extraídas del documental sobre el proceso dirigido por Simon Klose en el año 2013: TPB AFK. The Pirate Bay away from keyboard. [La traducción es mía]

97 SLOTERDIJK, Peter, Esferas I, Madrid: Siruela, 2003. La cita entrecomillada pertenece al prólogo de Rüdiger Safranski, p. 14. La idea anterior en p. 70.

98 Una interesante reflexión, aun hoy, sobre cómo influye el registro iconográfico del horror en la sociedad contemporánea en: SONTAG, Susan, Ante el dolor de los demás, Barcelona: Círculo de Lectores, 2003.
} 
inútil acto de resistencia para no dejar de ser, se autografiaron sobre una Síndone de cemento. Deslumbrantes recuerdos de una mañana de verano.

... en algunos lugares la bomba había dejado marcas correspondientes a las sombras de las formas que su luz había iluminado. Los expertos encontraron, por ejemplo, una sombra permanente proyectada sobre el techo de la Cámara de Comercio (...) por la torre rectangular de esa misma estructura; encontraron varias en el puesto de observación, en el último piso del edificio de la Electrificadora Chugoku (...); otra más proyectada por la manija de una bomba de gas (...); y varias más sobre tumbas de granito en el templo Gokoku (...) Algunas siluetas vagamente humanas fueron encontradas, y esto dio origen a leyendas que con el tiempo llegaron a incluir detalles imaginativos y precisos. Una de las historias contaba que un pintor subido en su escalera había sido perpetuado, como monumento de bajorrelieve, en el acto de mojar su brocha en el bote de pintura, sobre la fachada de piedra del banco que pintaba; otra, que en el centro de la explosión, sobre el puente que hay cerca del Museo de la Ciencia y la Industria, un hombre y su carromato habían sido proyectados en forma de una sombra repujada que revelaba que el hombre había estado a punto de azotar a su caballo. ${ }^{99}$

Tanto la retórica del poder como la de la guerra virtual y/o desmaterializada quedan refutadas, en última instancia, por el conocimiento y el dominio de la materia como arma. El camino iniciado con el armamento atómico, cuyo desarrollo e innovación no ha hecho más que empezar en su vertiente nanotecnológica, quizá no llegue a cumplir la profecía de Einstein sobre el regreso a la lucha con palos y piedras. Bastará con su poder disuasorio, con su representación sobre una pantalla. Aunque tal representación tenga que durar, otra vez, trece días. Resulta pues extraño que cuando el conocimiento humano certifica la obstinada presencia de la materia en su dimensión no ya atómica sino subatómica y de partículas, se ponga tanto interés en avalar un concepto como el de la desmaterialización, moralmente rancio y epistemológicamente desfasado.

Convendría revisitar los filmes documentales que, durante las dos décadas posteriores al final de la Segunda Guerra Mundial, recogieron las diferentes pruebas atómicas realizadas por el

\footnotetext{
${ }^{99}$ HERSEY, John, Hiroshima, Barcelona: Mondadori, 2009, pp. 90-91. [Primera edición de 1946]
} 
Departamento de Defensa norteamericano. Aquellos filmes del Lookout Mountain Studio -más de seis mil quinientos. Muchos continúan clasificados-, en su absoluta pureza, desprovistos de cualquier otro contenido narrativo que no fuera la bomba en sí misma, siguen ofreciendo lecciones. Las formas, la modélica expansión del hongo, su acolchada y acogedora textura. El color y el calor maternal de la materia en fuga. Eliminar el contracampo y el fuera de campo: sus efectos sobre las maquetas y sobre los dummies. Obviar, por supuesto, el cáncer galopante que sufrieron muchos de los participantes en los experimentos, incluidos algunos necios espectadores apenas pertrechados tras unas gafas. ${ }^{100}$

Que la deflagración de la bomba atómica se convirtiera en un icono -en una atracción- aun hoy resulta comprensible. La tortura de la materia siempre desencadena una reacción estética. Cómo se utilizó dicho icono es algo bien distinto. No es casualidad que el hongo atómico sea socio fundador del found footage, Conner mediante. Tampoco es baladí que Pasolini le otorgara el papel decisivo -acunado por Albinoni- de su parte en La rabbia (1963). Antes de mentar la desmaterialización tenemos que volver a contemplar esas películas y preguntarnos por su origen. Porque para este punto de inflexión en la materia también tenemos imágenes: la tomadas por Harold Edgerton mediante la Rapatronic.

Una vez comprobado que la materia, en su intimidad, también es susceptible de retrato. Y que en su puesta de largo -como si de una adolescente victoriana se tratara- desata su capacidad para la seducción y el boato, deberíamos completar ese atomismo iconográfico no con una filmografía de ficción apocalíptica, sino con nuevos materiales documentales. Rebuscar entre el anodino metraje filmado tras el accidente de Chernóbil, para ver cómo la materia bombardea literalmente el celuloide. Nieve atómica cayendo sobre el desierto de lo real. La materia percutiendo sobre el material fotoquímico en un acto creativo despiadado. En las fotografías de Igor Kostin sucede algo similar, la materia emanada se filtra bajo la película abriendo un camino de blancor sobre las perforaciones del $35 \mathrm{~mm}$. A los surrealistas, a los dadaístas y a los futuristas les habría encantado. Puede que también a muchos cineastas de la vanguardia americana de posguerra. Estoy seguro de que los habitantes de Prípiat y los liquidadores de la central nuclear habrían preferido una comedia de Boris Barnet.

Todavía nos quedaría una coordenada más en esta geodesia de la imagen atómica. Del desierto de Nevada a las Islas Marshall, pasando por los bosques ucranianos y, finalmente,

\footnotetext{
${ }^{100}$ Véanse Trinity and beyond. The atomic bomb movie (1995) y Hollywood's top secret studio. Atomic Filmmakers: Behind the Scenes (1999), documentales dirigidos y producidos por Peter Kuran.
} 
Japón. Pensábamos que la materia solo era capaz de profanar el sueño de la emulsión. Los geles y las salas de la plata apenas ofrecían resistencia. La materia, profética, bailaba sobre la tumba analógica. Lo hacía y lo volvería a hacer veinticinco años después en Fukushima. En el 2011, como en el 2015, ya no se estilaban las cámaras de $16 \mathrm{~mm}$ ni las fotografías en $35 \mathrm{~mm}$. Para contemplar los estragos de la materia disponemos de avanzadas cámaras digitales empotradas en insensibles robots. Es lo que ha hecho la compañía Tepco para tratar de adivinar qué tramaba la materia dentro de su madriguera. Tres robots exploradores fueron enviados en misión especial; dos en primavera, uno más en otoño. Mensajeros equinocciales. Los dos primeros, se dijo, quedaron atascados en algún recoveco y fue imposible recuperarlos. Otra hipótesis es que, directamente, se quedaran fritos. Frito no atiende a ninguna voluntad de estilo, es la redundancia del epíteto. El estado natural que se alcanza junto a los reactores accidentados. Las imágenes que devolvieron los tres esforzados robots fueron llamativas. Al menos lo fueron para mí, porque presentaban los mismos trazos de la materia que las de Chernóbil. Allí la emulsión, aquí el sensor de imagen. En ambos, un único recordatorio: la danza del plutonio.

Ha sido ahí y ahora, coincidiendo con el cuarto aniversario del accidente, cuando se ha organizado una exposición de arte peculiar bautizada Don't follow the wind. La radiación y el viento de nuevo unidos, como en la desoladora película de Murakami -When the wind blows, estrenada, curiosamente, el mismo año del accidente de Chernóbil. Dentro de la zona de exclusión, artistas como Ahmet Öğüt, Ai Weiwei, Meiro Koizumi, Taryn Simon, Miyanaga Aiko, Takekawa Nobuaki o Trevor Paglen han dispuesto sus obras. Nadie puede verlas. El colmo de la desmaterialización del arte. El crítico del periódico The Guardian ironiza: "El arte es efectivamente invisible, como la radiación misma”. ${ }^{101}$ En su ironía, el crítico deslizaba una doble falacia.

$\mathrm{Si}$, a la manera de la impugnación de Aristóteles realizada por Galileo, dejáramos caer desde lo alto de la torre un kilogramo de mito y un kilogramo de verdad, ¿cuál de los dos llegaría antes al suelo?

\footnotetext{
101 JONES, Jonathan, "Apocalypse no! Why artists should not go into the Fukushima exclusion zone" en The Guardian, 20 de julio de 2015. <http://www.theguardian.com/artanddesign/jonathanjonesblog/2015/jul/20/fukushima-exclusionzone-art-politics> [consulta: 07-09-2015] [La traducción es mía]
} 


\section{DE LA CIBERNÉTICA A LA IMAGEN-CUERPO}

Hasta el momento me he limitado a trazar una genealogía de la desmaterialización partiendo de cinco elementos fundamentales: metodológicos -la fuga-, históricos -fantasmas de la modernidad-, artísticos -arte conceptual y vanguardias-, estéticos -filosofías de la mutabilidad- y sociopolíticos -retórica del poder y guerras. Ahora quiero situarme a mitad de siglo XX para concluir el trayecto. He querido terminar con este apartado porque sirve como síntesis. También porque supone un nuevo e importantísimo hito en la hibridación metodológica entre arte y ciencia. La cibernética aparece como el último ingrediente del caldo histórico donde maceraba la desmaterialización. La cibernética recoge el ímpetu de la modernidad, lo adapta a los nuevos tiempos y lo lanza hacia el futuro.

Sus implicaciones metodológicas son de doble cara. Por un lado, abrió escenarios de encuentro entre ciencias y humanidades al entroncar con la Tercera cultura. Por el otro, se convirtió en una fuente de inspiración que facilitó el salto al futurolenguaje y a la ciencia ficción disfrazada de discurso académico. Esto es, lo que en un principio propició la lógica contrafáctica y el pensamiento inductivo de Nelson Goodman ${ }^{102}$, degeneró a nivel práctico y lingüístico a lo largo de las décadas. La cibernética fue utilizada no pocas veces como coartada o, en términos de Sokal y Bricmont, como impostura. La cibernética ejecutó una brillante transición de la idea a la cosa dentro de una serie de valores constituyentes de la realidad. Pero, de pronto, esos valores perdieron tal condición. La realidad física comenzó a deslizarse ladera abajo con la suavidad -diríase que con una paradójica alegría de vivir- de quien ignora que todo concluye en el fondo de un barranco.

Las teoría cibernética emergente no renunció a la creatividad. Utilizó la analogía y la metáfora más allá de su función literaria y simbólica. Analogía y metáfora adquirieron el estatus de hipótesis de trabajo. El seminal trabajo de Norbert Wiener no solo fijó el término. ${ }^{103}$ Su ensayo se convirtió en plataforma para un nuevo grupo de intelectuales (John von Neumann, Warren McCulloch, Claude Shannon, Walter Pitts) que descubrieron y aprovecharon la posibilidades de un campo de conocimiento confluyente con las ciencias sociales. Luego, Gregory Bateson

\footnotetext{
${ }^{102}$ GOODMAN, Nelson, Fact, fiction and forecast, Cambridge y Londres: Harvard University Press, 1983. [Primera edición de 1955]

${ }^{103}$ Versión manejada: Cybernetics: or control and communication in the animal and the machine, Cambridge: The MIT Press, 1948. En español: WIENER, Norbert, Cibernética: o el control y comunicación en animales y máquinas, Barcelona: Tusquets, 1998.

Además de cibernética, Wiener manejará otro concepto clave: el feedback ya mencionado en esta investigación.
} 
ejercería de pionero en la exploración de esa adaptabilidad de la cibernética a las ciencias de la cognición y a la antropología. A través de la figura del metálogo, Bateson inyectó y exigió rigor a esta permeabilidad entre ciencia y humanidades. Su metálogo devino figura definitiva para cualquier investigación que buscara la imbricación entre tesis y método. ${ }^{104}$

Volviendo a Wiener debo señalar que, si bien su publicación de 1948 -el primer borrador fue redactado en noviembre de 1947- plantó la bandera, ya contaba con un estudio previo y con otro posterior que completaron la trilogía. En 1943, Wiener esbozó junto a sus compañeros de artículo en Behavior, purpose and teleology ${ }^{105}$ algunas de las características de lo que luego sería la cibernética canónica. Si es que cabe aplicar tal adjetivo a una disciplina transversal y mixta. Al mismo tiempo, aquel discreto paper ya dejaba abiertas las puertas a una consiliencia inevitable. En 1950, tras el éxito de su libro, el propósito de Wiener se centró en dotar de mayor carácter divulgativo a su teoría. Pulida la redacción y reacondicionadas algunas de sus ideas más complejas, The human use of human beings. Cybernetics and society ${ }^{106}$ abrió las puertas de la cibernética a la cultura popular.

¿Por qué surgió la cibernética justo en ese momento? No existe una razón única y definitiva, lógicamente. Al margen de los azares y de los condicionamientos -la Segunda Guerra Mundialque pautaron las investigaciones de Wiener, la cibernética surge como reacción a las tres corrientes dominantes que se ocupaban del comportamiento humano desde comienzos de siglo. A saber, la filosofía tradicionalista de la introspección, el psicoanálisis y el conductismo (behaviorism). El conductismo intentó resolver las abstracciones procedentes de la filosofía y del psicoanálisis a través del mecanicismo y de una sobreestimación de la influencia del entorno. Pero los procesos humanos de pensamiento seguían bailando en la indeterminación. La cibernética tampoco los resolvió, aunque encauzó definitivamente su estudio.

¿Cómo? Ya he mencionado algunas de sus consecuencias tempranas en las letras (Goodman y Bateson), pero fue en el desarrollo de la computación -Alan Turing colaboraría con Wiener- y

\footnotetext{
104 BATESON, Gregory, Steps to an ecology of mind. Collected essays in anthropology, psychiatry, evolution, and epistemology, Northvale: Jason Aronson, 1987. [Primera edición de 1972]

${ }^{105}$ BIGELOW, Julian; ROSENBLUETH, Arturo; WIENER, Norbert, "Behavior, purpose and teleology" en Philosophy of Science, vol. 10, no 1, 1943, pp. 18-24.

${ }^{106}$ Versiones manejadas: WIENER, Norbert, The human use of human beings. Cybernetics and society, Boston: De Capo Press, 1988. En español: WIENER, Norbert, Cibernética y sociedad, Buenos Aires: Editorial Sudamericana, 1988.
} 
posteriormente en el de las ciencias de la cognición ${ }^{107}$, donde la cibernética se infiltró para ayudar a desentrañar la mecánica del ser humano, incluida, faltaría más, la de la mente. La cibernética, la computación y las ciencias de la cognición propiciarían el avance de la lógica, de los sistemas no lineales, de los universales y de la información aplicada a modelos neuronales, a la robótica y a la inteligencia artificial. Es aquí y ahora, a partir del nacimiento de la cibernética, cuando la información se convierte en la materia prima que desmaterializará el resto de siglo XX y lo que llevamos de XXI:

La información es información, no materia o energía. Ningún materialismo podrá sobrevivir si no admite esto. ${ }^{108}$

Para Wiener, el viejo materialismo que reinó allende el XIX, había perdido su valor funcional y semántico. El materialismo solo sobrevive en el romanticismo de las palabras tras haber sido devorado por un término nuevo y superior: mecanismo. La dialéctica mecanicismo vs. vitalismo que había enfrentado de manera simbólica a los herederos de Newton con los filósofos de la mutabilidad y del élan vital, pasó a ser una discusión obsoleta. ${ }^{109}$ Así, la información estipuló su nueva unidad de medida en el dígito binario (bit) y, con ello, declaró su independencia. Esta nueva moneda de curso legal podía ser distribuida sin sufrir alteraciones por los diferentes dispositivos que la emitían o la procesaban. Incluido el corporal.

De esta fugaz aproximación a la génesis de la cibernética, extraigo tres ideas básicas. Primera, una interdisciplinariedad donde la metáfora y los paralelismos ejercen como hipótesis de

\footnotetext{
${ }^{107}$ La fecha oficiosa del establecimiento de la Cognitive Science como disciplina de pleno derecho es bien curiosa: un 11 de septiembre, el de 1956. La efeméride se localiza en el marco del simposio sobre Teoría de la Información organizado en el MIT. Ese mismo verano, había tenido lugar otra conferencia decisiva y fundacional sobre inteligencia artificial en la Dartmouth College. Al cabo de los meses, se publicará el póstumo, brevísimo e inacabado The computer and the brain de John von Neumann (New Haven: Yale University Press, 2012) y la Introducción a la Cibernética de William Ross Ashbey (Londres: Chapman \& Hall, 1956). Este tipo de conferencias, además de aumentar su número y frecuencia, contaban con otro precedente decisivo de finales de los cuarenta: el Hixon Symposium.

Durante la década de los sesenta y de los setenta se fundaron organizaciones y asociaciones (The American Society for Cybernetics, se crea en 1964) de estudios cibernéticos y aparecieron obras de gran influencia como: McCULLOCH, Warren, Embodiments of mind, Cambridge: The MIT Press, 1988. [Primera edición de 1965]. Todo esto sin olvidar que McLuhan y sus extensiones del hombre (1964) reciclarán numerosas ideas de este contexto.

En el ámbito hispano: MATURANA, Humberto; VARELA, Francisco, De máquinas y seres vivos. Una teoría sobre la organización biológica, Santiago de Chile: Editorial Universitaria, 1973. [2a edición revisada y prologada por el autor en 1994]

${ }^{108}$ WIENER, Norbert, Cybernetics: or control and communication in the animal and the machine, op. cit., p. 155. [La traducción es mía]

${ }^{109}$ Merece especial atención el último párrafo del primer capítulo: Ibíd., p. 56.
} 
trabajo. Consiliencia que tendía a la cooperación, no la fusión. $Y$, en esa cooperación, a respetar ciertas especificidades como la dimensión histórica, estética y humanística de los contextos. Justo lo que trato de realizar en esta investigación. Segunda, amplia divulgación y éxito académico, pero también una gran tergiversación y devaluación en su posterior reciclaje; amén de su calado popular y artístico. Tercera, la descorporeización como subproducto de la desmaterialización emprendida por la información. Procedo con esta última.

\section{1. [Des]corporeización. Símbolo, información, tecnología y distancias}

La cibernética catalizó definitivamente la desmaterialización y, en el proceso, generó un correlato clave de los últimos sesenta años: la descorporeización-disembodiment. El cuerpo humano $-y$ con él la materia- en tanto entidad ${ }^{110}$ física y activa, quedó diluido o integrado dependiendo del punto de vista, optimista o pesimista- en la máquina. A partir de ese momento y hasta el apogeo de la era digital, la descorporeización se convertirá en una fábrica de ideales y, por lo tanto, de frustraciones. Que la descorporeización sea un correlato clave, no significa que sea siempre positivo. Acabo de insinuar algunos de los peligros metodológicos derivados de la aplicación de las tesis cibernéticas, pero el lado oscuro de la descorporeización tendrá la magnitud y la duración de un invierno ártico.

La información a la que aludía Wiener culminó un proceso del que solo se podrá señalar con certeza su inicio cuando se daten las primeras expresiones simbólicas del sapiens. Esto es, la externalización de todo nuestro contenido, de nuestro ser, mediante el símbolo. Reconozco este proceso como un suceso histórico y antropológico irrefutable, pero me opongo a su consideración como un acto de descorporeización. En 1944, a las puertas del triunfo de la cibernética, Ernst Cassirer anunciaba lo que el mol y el bit consumarían en décadas sucesivas. El hombre había colaborado de manera decisiva en el triunfo del universo simbólico sobre el universo físico:

La realidad física parece retroceder en la misma proporción que avanza su actividad simbólica. En lugar de tratar con las cosas mismas, en cierto sentido, conversa constantemente consigo mismo. Se ha envuelto en formas lingüísticas, en imágenes artísticas, en símbolos míticos o en ritos religiosos, en tal forma que no puede ver o conocer nada sino a través de la interposición de este medio artificial. Su situación es la misma en la esfera teórica que en la práctica. Tampoco

\footnotetext{
${ }^{110}$ Quiero remarcar el sustantivo entidad porque implica, indefectiblemente, una ausencia de dualismo mente-cuerpo.
} 
en ésta vive en un mundo de crudos hechos o a tenor de sus necesidades y deseos inmediatos. Vive, más bien, en medio de emociones, esperanzas y temores, ilusiones y desilusiones imaginarias, en medio de sus fantasías y de sus sueños. ${ }^{111}$

Este párrafo de Cassirer es modélico, pero también erróneo. Es modélico en su alta estima de la primitiva e inagotable actividad simbólica del ser humano. De la existencia de la misma como necesidad vital modelada y expresada por distintos caminos. Evolucionamos para ello, para producir, para consumir y para permanecer en la cultura. La idea de Cassirer es refrendada en la actualidad por cualquier estudioso. Ahí está el rotundo trabajo de Roy Baumeister donde nos llama beast for culture. ${ }^{112}$ Cassirer también es modélico cuando atisba la espiral de la introspección en la que siempre nos hemos sumido. Y cuando constata cómo nos valemos de las emociones -contaminantes y condicionantes- para sobrellevar o enmascarar los hechos.

Cassirer, sin embargo, yerra en sus deducciones o en la apreciación de la naturaleza de las cosas. Los hechos ciertos y probados seguirán siendo los que son independientemente de nuestras emociones. La realidad física no retrocedió porque, entre otras cosas, nunca podrá hacerlo. Menos aún como consecuencia directa del empuje simbólico. Cassirer toma las formas lingüísticas, el arte, el mito y la religión como las armas del símbolo en su lucha contra la materia. Como desdoblamientos del ser, como actos donde la carne ha desaparecido a favor del espíritu, del placer o del conocimiento. Pero, como hemos ido viendo a lo largo de este estudio, todas esas formas responden a un doble criterio material: el de la mente y el de la narración.

El planteamiento de Cassirer, a pesar de todo, es comprensible. Primero porque parte de ideas verdaderas. Segundo porque -dejando a un lado su condición de judío- fueron formuladas en un contexto donde enfrentarse a cincuenta millones de muertos exigía, además de valor, el consuelo de lo simbólico.

\footnotetext{
${ }^{111}$ CASSIRER, Ernst, Antropología filosófica. Introducción a una filosofía de la cultura, México D. F.: Fondo de Cultura Económica, 1968, p. 27. Original: An essay on man. An introduction to a human philosophy of human culture, New Haven: Yale University Press, 1944, p. 43.

${ }^{112}$ Para Baumeister existen tres tipos de hábitat, el físico y el social -ambos limitados a los animales- y el cultural, propio solo de primates evolucionados. Un mundo donde la información, los símbolos y los significados -sin suprimir las bases biológicas establecidas- marcan la diferencia en el desarrollo. BAUMEISTER, Roy, The cultural animal. Human nature, meaning, and social life, Nueva York: Oxford University Press, 2005.
} 
Entonces, tenemos la unión de tres fuerzas colosales que, una vez coaligadas, darán lugar al desmantelamiento de la realidad física. Símbolo, información y tecnología formaron una triple entente que vendría a liberar al cuerpo de todo su dolor, de toda su angustia y, en última instancia, de su putrefacción. Un horizonte biónico donde, solucionado el problema del cuerpo, quedaría pendiente la excarcelación de la mente. Esto es, lo que comenzó en la cibernética, (no) concluirá en el post- y en el transhumanismo. El cuerpo en la máquina y el cerebro en la tina. Así quiso solucionarse el conflicto milenario entre máquina y cuerpo durante la segunda mitad de un siglo XX que, para algunos, fue rico en ejemplos de fusión entre ambos.

Sucedió que lo humano comenzó a pensarse en términos novedosos y sugerentes, pero que no guardaban concordancia métrica. Es decir, nunca se podrá medir el peso en segundos o la fuerza en grados. ¿Y el pensamiento en bits? A día de hoy, solo hay estimaciones. A rebufo de la cibernética, las explicaciones tecnológicas se aplicaron al individuo y a la colectividad. Y digo bien aplicar, casi a la manera de una cataplasma, sin limitarse a los tropos literarios. Esa confusión métrica terminó afectando a la percepción de las distancias entre objeto y sujeto. Rudolf Arnheim, con la ayuda de Heidegger, desgranaba un sentimiento que, en los noventa, había superado la infancia cibernética de los cincuenta y la adolescencia de la teoría de los nuevos medios de los sesenta, para alcanzar la madurez posmoderna. La tecnología era responsable de que se perdiera:

el significado de las relaciones espaciales y temporales. La tecnología moderna ha reducido a una distancia óptima y uniforme la relación que solía distinguir lo cercano de lo alejado, el presente del pasado. Heidegger afirma que esta conveniencia práctica ha destruido la verdadera proximidad entre el espectador y el objeto que contempla. ${ }^{113}$

La abolición de las distancias que habíamos conocido gracias a las consecuencias de dos revoluciones industriales, quedaba consumada. Pero las distancias, igual que la realidad física, seguían existiendo. Repito que lo que cambió fue la percepción y, en ciertos casos como el viaje o la telecomunicación, la experiencia de tales distancias. La pérdida del cuerpo, la velocidad y la instantaneidad fueron los sofismas más habituales para justificar una nueva relación que evidenció, ante todo, la falta de confianza -y en ocasiones de conocimiento- hacia

${ }^{113}$ ARNHEIM, Rudolf, op. cit., p. 26. 
el ser humano. El dominio político y tecnológico de los grandes medios de comunicación y la ubicuidad de las redes provocaron un pesimismo, a mi entender, exagerado y hasta injustificado. La filosofía de la virtualidad nació, así, del choque entre posturas ante un mismo fenómeno: el optimismo desmedido y tecnoeufórico poscibernético, frente al pesimismo casi ludita y por momentos misantrópico de parte de la posmodernidad. Cuando el virtualismo que nos convirtió -otra vez- en seres incorpóreos se hizo con el poder, llegó -platónicamente"justo a tiempo para tomar parte en la celebración del 2400 aniversario del descubrimiento de lo virtual" ${ }^{114}$

Aparece aquí una de las grietas por las que se filtra la suficiente luz como para discernir entre lo moderno y lo posmoderno. Antes que en metalenguajes o que en análisis de estilo, es en esta relación histórica entre el cuerpo, la mente, el espacio y la tecnología, donde lo moderno trazó su última linde. Ver o no ver los procesos. Esto es, la reflexividad y reciprocidad de lo moderno, frente a la invisibilidad y la inmersión de lo posmoderno. Apreciarlo no fue tarea sencilla, pues se rompía "con los hábitos intuitivos relacionados con las formas analógicas de hacer las cosas que hacemos". ${ }^{115} \mathrm{El}$ recurrente ejemplo de la máquina de escribir y del procesador de textos informático. O este otro que prefiero: un reloj con la esfera transparente, a través de la cual vemos el tiempo materializándose con la ayuda de balancines, muelles, motores y engranajes. Y un reloj digital opaco y sintético, formado por circuitos geométricos de nula referencialidad temporal, que no tiene la decencia de mostrarnos la llaga en la cual poder introducir nuestros dedos; nuestros ojos.

La modernidad fue preferentemente empírica. La posmodernidad rehabilitó la fe.

\subsection{El cuerpo y la máquina. Licuefacción de mercado}

«¿No hay que reconocer que espíritu y alma

constan de naturaleza corpórea? (...)

Así pues, esta sustancia del alma es contenida por el cuerpo entero, y ella es a la vez custodia del cuerpo y causa de subsistencia.

Pues alma y cuerpo son solidarios por su comunidad de raíces» De rerum natura (Lucrecio, s. I a. C.) ${ }^{116}$

\footnotetext{
${ }^{114}$ SLOTERDIJK, Peter, op. cit., p. 70.

${ }^{115}$ QUIRÓS, José Luis, op. cit., p. 74.

${ }^{116}$ LUCRECIO CARO, Tito, op. cit., p. 253 y 263.
} 


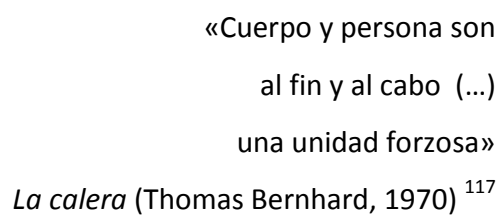

La disolución del hombre en la masa fue el primer paso. La manera de desenvolverse dentro de ella, el segundo y definitivo. La apelación al cuerpo desleído, cuando no desaparecido, se convirtió en el recurso de cabecera para ilustrar la decadencia de los metarrelatos. Narración y materia, malinterpretados o reducidos a simples atributos de la modernidad, debían evaporarse. La razón: no eran más que viejos impedimentos para la emancipación del hombre. Mamotretos esclavistas que nos recordaban que seguíamos siendo precisamente eso, seres humanos. Había que desprenderse o, en su defecto, licuar el cuerpo.

La pérdida del cuerpo fue -y por desgracia aun lo es- el correlato de una sociedad occidental tecnologizada hasta el tuétano y movilizada por un flujo desbordante pero intangible de dinero. La tecnología, la virtualidad y la prosperidad económica occidental vinieron para descorporeizar:

tanto a los sujetos como a las relaciones sociales (...) inauguran no tanto una nueva socialidad cuanto una mera "sociedad de almas», y entonces «el cuerpo individual se clausura o se enquista (...) como puro acumulador intransitivo de un deseo también incorpóreo». ${ }^{118}$

Es este el error categorial más doloroso de cuantas teorías se han ocupado del fenómeno digital. Acomodado en la desmaterialización electrónica de la información (impulsos, bits), desnacionalizado y henchido por un consumo creciente, el cuerpo creyó perder todas sus restricciones en el ciberespacio. El ciberespacio se convirtió en un lugar habitado donde, paradójicamente, no vivían los cuerpos. Se accedía a él por inmersión y asumiendo la promesa de una metamorfosis. Esto es, el ciberespacio era un logos capaz de cambiar el ontos. $\mathrm{Ni}$ siquiera el dinero resultó impedimento, el neoliberalismo se había lavado las manos en la pila del laissez faire mientras William Gibson ejercía de Barrabás. La nueva filosofía virtualista, hija malcriada de la posmodernidad, comenzó a producir fantasmagorías y mundos ensoñados.

\footnotetext{
${ }^{117}$ BERNHARD, Thomas, La calera, Madrid: Alianza, 2003, p. 81.

${ }^{118}$ ABRIL, Gonzalo, "El séptimo día. Notas sobre la comunicación en la era digital", conferencia dictada en el I Congreso Ibérico "La Sociedad de la Comunicación", Málaga, mayo de 2001.

<https://icjournal.files.wordpress.com/2013/01/1265039240-1abril1.pdf> [consulta: 10-08-2015]
} 
Siempre excesivos, a menudo distópicos; nunca realizados. Delirantes construcciones neobarrocas propias de una ideología decadente. El único tipo de combate permitido solo se podía ejercer desde el mismo plano inmaterial: el ciberpunk y sus universos paralelos, oscuros y entrópicos. ${ }^{119}$

La noción de disembodiment terminó formando en torno a ella una ortodoxia cultural, académica, social y política. En la lucha entre blancos y rojos existía un elemento común: la ausencia del cuerpo o la de un cuerpo transgredido por el símbolo. Posteriormente, la existencia de un cuerpo metamorfoseado en máquina. La novedad mecánica devino necesidad humana. El presente como profecía autocumplida donde la tecnoeuforia y el consumismo suburbano inventado durante una posguerra alegre, incitaron a pensar que todas las miserias precedentes estaban encaminadas a la consecución del reciente y eterno esplendor. Con los dioses enterrados o sumergidos en los campos y en los océanos de la batalla, era el momento de elaborar una nueva narrativa mesiánica estructurada en torno a la eficiencia y al idealismo. La epifanía de la hipermáquina:

La hipermáquina, es, pues, un mito irracional y por lo tanto no sólo es innecesaria para entender el sentido del progreso tecnológico, sino que en realidad es incompatible con este. ${ }^{120}$

A la espera de la integración biónica definitiva, el cuerpo devino "construcción lingüística y discursiva". ${ }^{121}$ Esto es, el cuerpo dejaba de ser un producto biológico para convertirse en un constructo cultural. A partir de esta premisa se podrán rastrear algunas de las mayores tragedias intelectuales de nuestro tiempo. De Foucault ${ }^{122}$ a Baudrillard ${ }^{123}$, pasando por

${ }^{119}$ GIBSON, William, Neuromante, Barcelona: Minotauro, 2006. [Original: Neuromancer, Nueva York: Ace, 1984].

${ }^{120}$ QUINTANILLA, Miguel Ángel, op. cit., p. 109. El cine contribuyó de manera decisiva al mito de la hipermáquina. Cómo no volver sobre Edgar Morin: "la absorción del hombre en el universo desdoblado para que la eternidad le salve" (...) "el mito latente del cinematógrafo es la inmortalidad, el cinematógrafo total es una variante de la inmortalidad imaginaria". MORIN, Edgar, El cine o el hombre imaginario, op. cit., p. 47.

${ }^{121}$ HAYLES, Katherine, How we became posthuman. Virtual bodies in cybernetics, literature, and informatics, Chicago: University of Chicago Press, 1999, p. 192.

122 FOCAULT, Michel; GORDON, Colin, Power/knowledge. Selected interviews and other writings $1972-$ 1977, Nueva York: Pantheon Books, 1977. Foucault siempre estuvo preocupado por las formas de pautar el cuerpo. Formas que partirían de una primera objetivación del sujeto por parte del poder para elaborar los procesos de subjetivación de los mismos. Una situación del sujeto dentro de una época hostil que recoge y matiza, a partir de Foucault, su amigo Deleuze desvinculando (descorporeizando) el sujeto de la subjetivación y de sus procesos: "Yo diría incluso que la subjetivación tiene poco que ver con el sujeto. Se trata más bien de un campo electrónico o magnético, una individuación que actúa 
Deleuze ${ }^{124}$, Hardison ${ }^{125}$ y Bauman. ${ }^{126}$ La licuefacción corporal se convirtió en el estribillo de la canción del verano. El cuerpo fue llevado ante el altar sacrificial de una ceremonia donde, según Silvino Onda, "todo lo que antes estaba relacionado con la materia, desaparece para volcarse en una dimensión inmaterial". ${ }^{127}$ En un tiempo saturado de imágenes y de información, el tema de la descorporeización había alcanzado, como dijo un preocupado Tim Lenoir $^{128}$, nuevas y radicales dimensiones.

Fue durante la primavera y el estío de 1985, poco después de la sentencia de Onda, cuando Lyotard organizó en el Centro Georges Pompidou parisino una exposición rotulada como Los inmateriales (Les immatériaux, del 28 de marzo al 15 de julio). Allí, el filósofo francés quiso ilustrar cómo el paradigma de la modernidad se estaba deshaciendo. Lo hizo mediante la ordenación de un espacio que, siguiendo una progresión general, iba del cuerpo al lenguaje. Un espacio donde se podían experimentar muestras del "teatro del no-cuerpo" y de "textos desmaterializados". ${ }^{129}$

En este punto, quiero quedarme con la recapitulación que realizaron Arthur y Marilouise Kroker $^{130}$ durante el auge de la idea, apenas dos años después de la exposición de Lyotard. Era

mediante intensidades (bajas o altas), campos de individuación y no personas o identidades. Lo que Foucault llamaba, en otras ocasiones, la pasión" en DELEUZE, Gilles, Conversaciones. 1972-1990, op. cit., p. 150.

${ }^{123}$ BAUDRILLARD, Jean, The ecstasy of communication, op. cit., p. 18.

Baudrillard también propone el abandono intencionado del cuerpo como ejercicio de resistencia. Frente a un sistema cuyos argumentos son la opresión y la represión, conviene la inacción. Renunciar a la condición de sujeto y a la necesidad de significado. Según el autor, todos los procedimientos (del voto al debate) subjetivizados están dirigidos por el sistema.

124 “¿Cómo deshacernos de nosotros mismos, y deshacernos a nosotros mismos?”, se preguntaba en $L a$ imagen-movimiento, op. cit., p. 101. Para Deleuze el cuerpo terminó -o empezó, porque en ocasiones, con sinceridad, me cuesta comprenderlo- siendo un mero ensamblaje de imágenes. Una idea con aires lacanianos. Aquellos que buscaban la definición materialista (Seminario 2, El Yo en la teoría de Freud y en la técnica psicoanalítica, clase 4, Buenos Aires: Paidós, 2008, pp. 67-85) de la conciencia a través de los reflejos en los objetos. La imagen en el lago como equivalencia de la imagen en el cerebro. Deleuze parece multiplicar los reflejos y, con ellos, las posibilidades de disolución del yo.

${ }^{125}$ HARDISON, O. B., Disappearing through the skylight. Culture and technology in the twentieth century, Nueva York: Viking, 1989, p. 335.

${ }^{126}$ BAUMAN, Zygmunt, "Individualidad” en op. cit., pp. 59-97.

127 STRANO, Carmelo, Il segno della devianza, Milán: Mursia, 1984. Citado y traducido en: VILCHES, Lorenzo, op. cit., p. 214.

128 LENOIR, Tim, "Haptic vision: computation, media, and embodiment in Mark Hansen's new phenomenology" en HANSEN, Mark (ed.), New philosophy for new media, Cambridge: The MIT Press, 2004, p. xii.

${ }^{129}$ FERRER, Esther, "La exposición 'Los inmateriales' muestra en París la decrepitud de la modernidad" en El País, 17 de mayo de 1985.

<http://elpais.com/diario/1985/05/17/cultura/485128816_850215.html> [consulta: 07-08-2015]

${ }^{130}$ KROKER, Arthur; KROKER, Marilouise, Body invaders. Panic sex in America, Nueva York: St. Martin's Press, 1987, pp. 20-21. 
el año 1987 y el SIDA -o, mejor dicho, el discurso amarillista ${ }^{131}$ sobre la enfermedadamenazaba con exterminarnos como especie. El cuerpo entraba en galopante liquidación. El cuerpo como andrajo. El cuerpo como repositorio de virus y bacterias. El cuerpo como organismo incapaz de reclutar a sus propias defensas o de hacerlo en forma negligente autoinmune. Su desaparición fáctica solo era cuestión de tiempo. El anuncio se imprimía siguiendo las normas de estilo de la sección de anuncios clasificados.

- Ideológicamente. El cuerpo era devorado por los signos de la moda y el comercio.

- Epistemológicamente. Asumida y recuperada la autoconciencia y el dualismo cartesiano, el cuerpo se había escindido y pasaba a ser un hecho aparte.

- Semióticamente. El cuerpo no era más que un constructo cultural que se desvanecía en el flujo informativo como un signo flotante más.

- Tecnológicamente. La hiperfuncionalidad, la omnipotencia y la versatilidad tecnológicas terminarían por convertirlo en un mecanismo obsoleto.

Katherine Hayles supo detectar el problema. Su riguroso argumentario mantiene todo el valor porque no restó ni una pizca de mérito a los atributos y a la repercusión del concepto. Comparto su postura. Sería de necios negar la importancia de la idea y su influencia a lo largo de los últimos veinte años. Pero aún más necio sería seguir considerando la descorporeización como un término vigente y operativo. Hayles exponía con claridad una buena lista de defensas para antes, durante y después de la exposición explicar un punto de vista ${ }^{132}$ que resultaba estar alejado de la unanimidad precedente. Igual que comparto las tesis de Hayles, comparto

\footnotetext{
${ }^{131}$ Cuando se pudo rastrear el origen del VIH hasta chimpancés y, más recientemente, hasta gorilas de montaña, fue tomado como una especie de maldición y de vicio biológico. Como una aberración a la que el sapiens, con toda su asepsia cultural, no quería hacer frente. Como si todos esos primates fueran el pariente borracho del que avergonzarse durante una reunión familiar.

D'ARC, Mirela, et. al., "Origin of the HIV-1 group O epidemic in western lowland gorillas" en PNAS, vol. 112 no 11, 2 de marzo del 2015. <http://www.pnas.org/content/112/11/E1343.full.pdf> [consulta: 2310-2015]

${ }^{132}$ Atención a los dos primeros capítulos de su obra citada: "Toward embodied virtuality", pp. 1-25 y "Virtual bodies and flickering signifiers", pp. 25-50.
} 
las de Anna Munster ${ }^{133}$, que ha dedicado otro gran estudio a esta necesaria reelaboración del pasado digital cartesiano.

Sus objetivos son los míos: intentar devolver al cuerpo su presencia a través de una contextualización histórica que frene el futurismo especulativo. Hay que recolocar las vendas sobre el rostro de un Claude Rains histérico aunque se niega a aceptarlas. La conclusión es simple: no podemos extirpar y trasplantar el molde cartesiano como prefiguración del fenómeno digital y de la licuefacción corporal. En términos de puesta en escena, la historia no es amiga del corte en el eje, ni siquiera del zoom. Tampoco podemos acceder al contenido de la historia como si de una postproducción no-lineal se tratara. La historia, más bien, es en un travelling de acompañamiento o, como diría Godard, la historia es acercamiento, montaje y relación entre la partes.

La descorporeización no era real, no era histórica. Menos aun cuando el 11 de septiembre de 2001 comenzaron a llover cuerpos. Cuerpos escamoteados, cuerpos no vistos en las breaking news como marcaba el decoro y la autocensura del libro blanco escrito tras Vietnam. Los cuerpos que llegamos a ver, si acaso, aparecían gráciles y miniaturizados, surcando en el aire. Diría que hasta estilizados y contrastados. Cuerpos acrobáticos, contra el cielo, como si la caída fuera eterna e indolora.

La enunciación abstracta de la descorporeización era y es síntoma de otra realidad más poderosa: la consolidación de una cierta subjetividad -o de un solipsismo indisimulado-nacida del cruce entre la materialidad informática y la inmaterialidad de la información. Hayles concretaba en una discreta pero esclarecedora nota al pie, lo que significaba "informática" en este contexto:

Por informática, entiendo las estructuras materiales, tecnológicas, económicas y sociales que hacen posible la era de la información (...) el último modo capitalista de acumulación flexible, el hardware y el software que han fusionado las telecomunicaciones con la tecnología de la computadora; los patrones vitales

\footnotetext{
${ }^{133}$ Munster nos dice que "para poder comprender las ideas de Descartes sobre la relación entre cuerpo y pensamiento, así como sus múltiples contradicciones, necesitamos situarlas dentro de un marco más amplio conformado por la estética barroca, por su contenido social y por las máquinas tecnocientíficas. Reexaminando a Descartes como integrante de esa cultura barroca, se complicará nuestra concepción actual del cartesianismo entendida como un sistema que perpetúa la descorporeización y la visión mecanicista de uno mismo". MUNSTER, Anna, Materializing New Media. Embodiment in information aesthetics, Lebanon: University Press of New England, 2006, p. 15 [La traducción es mía]
} 
surgidos de y por el acceso a grandes bancos de datos y la transmisión instantánea de mensajes, y los hábitos físicos -postura, enfoque óptico, movimientos manuales, conexiones neuronales- que están reconfigurando el cuerpo en conjunción con las tecnologías de la información. ${ }^{134}$

La desmaterialización -incluida la corporal-, la velocidad, la hipermobilidad, la ubicuidad o la instantaneidad son consecuencias de una serie de procesos, no formas independientes. Menos aun propiedades deíficas. Para alcanzarlas se obvian "múltiples condiciones materiales"135 y numerosísimas complejidades técnicas que las rondan y las provocan. Idas y venidas, rebotes y redirecciones, millones de kilómetros y de toneladas de cableados, baterías, satélites y servidores. Vericuetos insondables que, en su entrega de inmediatez, incorporan el borrado de las huellas. Cuando leemos al padre de Internet escribir lo siguiente, todo se entiende mejor: "la labor de los ordenadores y las redes consiste en quitarse de en medio, en no ser vistos". ${ }^{136}$ José Antonio Palao acertaba con una de las razones de esa declaración: "molesta el hardware". ${ }^{137}$ Y si molesta el hardware, molesta el cuerpo. Para la ciencia posbiológica, el cuerpo ya no era un medio o un mal necesario - un Necessary Evil, el segundo avión de Hiroshima, el encargado de fotografiar la hecatombe-, era un inconveniente. No hace falta irse hasta Kurzweill o Hans Moravec ${ }^{138}$, al propio Berners-Lee le repugna la materia hasta el límite de considerar su supervivencia como un acto de coprofilia. El cuerpo -incluso durante el placer sexual- solo engendra dolor-Tsukamoto- y pesadilla -Cronenberg.

Enlazando a Hayles con Palao, la verdad irreductible es la siguiente: "el ciberespacio está soportado por máquinas (...) la limpia imagen de lo virtual tiene un soporte material”. Verdad que enlaza y se complementa con esta otra:

\footnotetext{
${ }^{134}$ HAYLES, Katherine, op. cit., p. 313. [La traducción es mía]

135 SASSEN, Saskia, "Sited materialities with global span" en HOWARD, Philip; JONES, Steve (eds.), Society online. The Internet in context, Londres: Sage, 2003, p. 298.

${ }^{136}$ BERNERS-LEE, Tim, Tejiendo la red. El inventor del World Wide Web nos descubre su origen, Madrid: Siglo XXI, 2000, p. 163.

137 PALAO, José Antonio, La profecía de la imagen mundo. Para una genealogía del paradigma informativo, Valencia: Ediciones de la Filmoteca, 2004, p. 354.

${ }^{138}$ MORAVEC, Hans, Mind children. The future of robot and human intelligence, Cambridge: Harvard University Press, 1998.

MORAVEC, Hans, Robot. Mere machine to transcendt mind, Nueva York: Oxford University Press, 1999.
} 
La realidad virtual no es mundo aparte creado por arte de magia, sino por un programa de ordenador, en un individuo y mundo reales (...) los soportes tecnológicos no son los soportes de la inmortalidad. ${ }^{139}$

Decía Bunge ${ }^{140}$ que el ciberespacio -para él uno de los tres mitos contemporáneos- no puede reemplazar a los espacios físico y social. Que la imaginación que suscita y de la que se retroalimenta, puede complementar y enriquecer la realidad, pero no sustituirla. No puede reemplazarlos simplemente porque, como decía a propósito del chico de The Pirate Bay, el ciberespacio es una parte indisociable de esa misma realidad.

Sobre cómo se desenvuelve el cuerpo en los espacios virtuales, viene al caso recuperar la ecología del cuerpo de un biólogo conservacionista como Wilson, frente al transhumanismo de un visionario como Kurzweil. Dos citas que resumen con precisión dos posturas quizá no tan alejadas como pueda parecer. Se podrá estar de acuerdo o no con Kurzweil, de lo que no cabe duda es de su inteligencia. Hasta él vislumbra el cuerpo, eso sí cambiante, como inevitable compañero vital. Empiezo con Wilson:

En la fantasía de la teoría neurobiológica y de la ciencia ficción del cerebro en una tina, el órgano en su baño nutritivo ha sido despojado de los impedimentos del cuerpo y liberado para explorar el universo interior de la mente. Pero no es eso lo que resultaría en realidad. Toda la evidencia de la ciencia del cerebro apunta en la dirección opuesta, hacia el infierno encerrado en el ataúd del muerto despierto, donde el mundo recordado e imaginado se descompone hasta que el caos concede misericordiosamente el olvido. ${ }^{141}$

Una aplicación más controvertida que el escaneo del cerebro para su comprensión, es el escaneo del cerebro para alojarlo en una Red. "Cargar" un cerebro humano significa escanear toda su información para luego restaurarla en un substrato computacional potente y apropiado. Este proceso registraría la

\footnotetext{
${ }^{139}$ MOLINUEVO, José Luis, op. cit., p. 139 y 110.

140 BUNGE, Mario, Tres mitos de nuestro tiempo: virtualidad, globalización, igualamiento, Santa Fe: Universidad Nacional del Litoral, 2001, p. 27.

${ }^{141}$ WILSON, Edward Osborne, Consilience. La unidad del conocimiento, op. cit., pp. 167-168.
} 
personalidad al completo, su memoria, sus habilidades y su historia. Si realmente captáramos los procesos mentales de una persona, la mente resultante necesitaría de un cuerpo, ya que gran parte de nuestro pensamiento está regido por necesidades y deseos físicos (...) A lo largo del siglo XXI contaremos con diferentes tipos de cuerpos, tanto para humanos no-biológicos como para humanos-biológicos, que servirán como extensiones de nuestra inteligencia. El cuerpo humano versión 2.0 incluirá cuerpos virtuales desenvolviéndose en entornos reales, cuerpos físicos basados en la nanotecnología y mucho más. ${ }^{142}$

Wilson se preguntaba sobre los problemas derivados de la manipulación genética que conduce a lo que él denomina Homo protheus. ${ }^{143}$ Es más, no le gustaba un pelo que la fantasía se cumpliera o que, de cumplirse, lo hiciera sacrificando el bagaje humanista-naturalista creado hasta entonces. Kurzweil, en cambio, contempla bastante menos la cuestión ética y moral. Si los dispositivos funcionan correctamente y no producen aberraciones, el resto de aspectos son secundarios. Para Kurzweil la inmortalidad es una cuestión mecánica. ¿Se cumplirán todos esos augurios? Estoy convencido, tengo pocas dudas. ¿Debemos dedicar nuestro tiempo y nuestra literatura académica a adivinarlo? No, en absoluto. Por muy vulgar que pueda parecer, tenemos que seguir analizando el pasado y el presente. Las humanidades, si de verdad quieren ser tomadas en serio, deben apaciguar su entusiasmo por el oráculo.

Como las tecnologías -aun- no se desarrollan por su cuenta y riesgo y como la inteligencia artificial -aun- no está lista, de no mediar la Singularidad o alguna rebelión a la manera de Hal 9000 o Skynet, el factor humano seguirá presente. Acabo de hacer una predicción, sí, pero una predicción conservadora que no es más que una extensión del statu quo actual. Las reglas del juego que, de momento, debemos seguir respetando. Porque es ahora cuando todas las implicaciones directas e indirectas salen a la luz para demostrar que los cambios físicos y perceptivos de la materia, al margen de su magnitud y permanencia, no equivalen o acarrean su desaparición. En este delirio colectivo que nos hace gritar iviva la desmaterialización!,

\footnotetext{
${ }^{142}$ KURZWEIL, Ray, Singularity is near. When humans transcend biology, Nueva York: Penguin, 2005, p. 140. [La paginación corresponde a la versión epub] [La traducción y la cursiva son mías]

143 "Al poseer un conocimiento exacto de sus propios genes, en pocas décadas la humanidad puede, si quiere, seleccionar una nueva dirección en su evolución y moverse rápidamente en tal sentido (...) Homo protheus, el hombre de la forma cambiante (...) Cultural. Indeterminadamente flexible, con un potencial enorme. Cableado e impulsado por la información. Puede desplazarse casi a cualquier lugar, adaptarse a cualquier ambiente. Inquieto, cada vez más abundante y hacinado. Lamenta la pérdida actual de naturaleza y todas estas especies que se extinguen, pero es el precio del progreso y, en todo caso, es algo que tiene poco que ver con nuestro futuro". OSBORNE WILSON, op. cit., pp. 406-407.
} 
también subyace un grave problema de lectura. Polarizados, hemos sido incapaces de saber leer la tecnología. Unos la adoran, otros la odian. Muchos son o somos nativos digitales, pero esto no ha resuelto el problema. Existe una tasa indeterminada, pero intuyo que elevada, de analfabetismo tecnológico que nada tiene que ver con poseer dispositivos y aprender a usarlos. Ni siquiera con saber la manera en que nos influyen. El analfabetismo tecnológico del siglo XXI no es más que el resurgimiento de un animismo milenario.

El animismo es profundamente humano, pero carece de operatividad científica más allá de su explicación como fenómeno biocultural. De ahí que, siguiendo a Mark Poster ${ }^{144}$, confundamos mediación tecnológica con interacción, inmersión y suplantación. Esta lectura social deficiente se deja notar en la manera en la que concebimos la realidad y en la que nos concebimos a nosotros mismos. Bien entrado el siglo XXI, todavía nos falta -o quizá la hemos perdido- cierta cultura de la tecnología. Aquella que contemplaba la función tecnológica desde el humanismo pero $\sin$ humanizarla, con instinto y $\sin$ prosopopeyas. Aquella que, de manera casi socrática $^{145}$, no delegaba en el objeto, sino que asumía la responsabilidad estética ${ }^{146}$ de su uso.

\section{3. (Re)Corporeizar}

«En un momento de profunda crisis cultural (...) me ha parecido que la única realidad preservada era la del cuerpo» Pier Paolo Pasolini ${ }^{147}$

Maleabilidad, reversibilidad, elasticidad, sublimación. Todo aquél énfasis en la ausencia de límite y en las transiciones abruptas de los diferentes estados de la materia, nos hablaba de procesos ininterrumpidos e infinitos. El cuerpo era el aguafiestas, el vecino que llamaba a la

\footnotetext{
${ }^{144}$ POSTER, Mark, The mode of information. Poststructuralism and social context, Chicago: University of Chicago Press, 1990.

${ }_{145}$ "Pues bien, si te vas ahora, te vas condenado injustamente no por nosotras, las leyes, sino por los hombres". PLATÓN, “Critón" en Diálogos I, Madrid: Gredos, 1981, p. 210.

Esta sentencia, mutatis mutandi, la recogía Rossellini en un pasaje de su modélico y televisivo Socrate (1971).

${ }^{146}$ El sintagma responsabilidad estética posee evidentes reminiscencias del Prinicipio de responsabilidad de Hans Jonas. También menos carga idealista. En cualquier caso, la cualidad de responsable -y no digamos la de compromiso- ha sido tan vejada y devaluada por la vida pública y política, que resulta complicado restituirle su valor originario. Véase JONAS, Hans, El principio de responsabilidad. Ensayo de una ética para la civilización tecnológica, Barcelona: Herder, 1995. [Primera edición de 1979]

${ }^{147}$ NALDINI, Nico, Pier Paolo Pasolini. Una vida, Barcelona: Circe, 2001, p. 334.
} 
policía, la crisis que explotaba las burbujas. El cuerpo fue el amigo manazas que apretó el interruptor del perpetuum mobile:

La expresión (...) postula una máquina con movimiento -literalmente- perpetuo: una máquina que, una vez puesta en marcha, continúa en movimiento indefinidamente y sin recibir energía suplementaria de ninguna fuente externa a ella. La historia de tales construcciones consiste en curiosos relatos excéntricos o embaucadores, o de vagas mezclas entre ambos. En cualquier caso, la propuesta de una máquina aislada que funcione para siempre entra en contradicción con las leyes físicas epistémicamente más virtuosas. ${ }^{148}$

La mitología del perpetuum mobile se detiene al chocar contra los procesos precarios $^{149}$, aquellos que de verdad componen y organizan nuestra vida. El cuerpo -depósito de células herrumbrosas- es el proceso precario por excelencia. Apenas formado y ya en permanente oxidación. La descorporeización quiso subirse al carrusel del perpetuum mobile. La realidad quedó varada en los procesos precarios, repleta de conflictos y limitaciones; hambrienta, con la necesidad de consumir energía.

Nosotros, los cuerpos, somos artefactos biológicos que, desde el mismo instante en que somos modelados por procesos sociales, nos volvemos susceptibles de cambios de estatuto. Somos seres en transición en términos evolutivos, y somos seres en transición en términos biónicos. No somos parte de un perpetuum mobile, somos parte de una serie de procesos precarios como la evolución, la historia y la cultura. No es necesario esperar a la suplantación definitiva del cuerpo por el cíborg o al transhumanista upload de nuestro cerebro. Somos seres a medio cocinar por la evolución; somos seres a medio vestir por la prostética. Hemos utilizado muletas desde nuestros orígenes, gafas y ortopedias desde hace siglos, trasplantes desde hace décadas, implantes cocleares y de retina, transfusiones, marcapasos, clavos y placas, dentaduras y hasta prótesis motoras como los transportes. Andy Clark es de mi opinión, no necesitamos implantarnos un chip de silicio para convertirnos en ciborgs. El cíborg no es una combinación superficial de cables y carne.

No creo en modo alguno que la hibridación cognitiva sea un avance de los tiempos modernos (...) más bien un aspecto de nuestra naturaleza humana, tan

\footnotetext{
${ }^{148}$ PEREDA, Carlos, Vértigos argumentales. Una ética de la disputa, Barcelona: Anthropos, 1994, p. 315.

${ }^{149}$ Ibid., pp. 315-319.
} 
básico y ancestral como la facultad del habla (...) Es posible apreciar cierto "rastro fósil cognitivo" de nuestra cualidad de ciborgs en la procesión histórica de nuestras poderosas tecnologías cognitivas. ${ }^{150}$

Ha llegado el momento de comprobar que nunca nos desmaterializamos. ¿Por qué elucubrar sobre mi yo volcado en un robot cuando apenas puedo comprender mi yo en el cuerpo? Como decía al final del anterior apartado, es necesario seguir pensando esta dimensión actual porque, además, han surgido herramientas que pueden convertir los antiguos callejones sin salida en autopistas de seis carriles. Las humanidades deben abandonar la literatura blandengue de suplemento dominical para volver a discurrir sobre los procesos mentales en tanto acciones corporeizadas. Esto es, en tanto acciones históricas. ¿Estoy siendo normativo? Sin duda, pero considero que es una normatividad emanada de la responsabilidad y del sentido común.

El conocimiento depende, primero, de un tipo de experiencia sujeta a la tenencia de un cuerpo portador de diferentes capacidades sensomotoras, y segundo, que estas capacidades sensomotoras individuales están integradas, a su vez, en un contexto biológico, psicológico y cultural de amplias fronteras. ${ }^{151}$

Las acciones corporeizadas tampoco deben entenderse de un modo autárquico suscrito al individuo. La descorporeización, en tanto utopía que cerraba el círculo iniciado con la crisis de los relatos, caminaba hacia una distopía protagonizada por un individuo atomizado y por una colectividad dramatizada. Una narración idealista y de corte neoplatónico sobre cuerpos devaluados y obsoletos. Ejércitos sedentarios de máquinas solteras -masturbatorias, estériles e improductivas- que actualizaban los delirios de Duchamp y Picabia.

El regreso a la embodied action nos devolvería la implicación social y la capacidad para decidir, siempre y cuando el debate contemporáneo sobre el libre albedrío ${ }^{152}$ nos lo permita. La acción descorporeizada nos seguiría encajonando en las estructuras de poder y en una especie de sedentarismo autista. La acción corporeizada como emancipación real, como barrera material y cognitiva capaz de frenar los mecanismos de control que yacen implícitos en las filosofías

\footnotetext{
${ }^{150}$ BROCKMAN, John (ed.), El nuevo humanismo y las fronteras de la ciencia, op. cit., p. 105.

${ }^{151}$ VARELA, Francisco; THOMPSON, Evan; ROSCH, Eleanor (eds.), The embodied mind. Cognitive science and human experience, Cambridge: The MIT Press, 1991, pp. 172-173. [La traducción es mía]

${ }^{152}$ BAUMEISTER, Roy; MELE, Alfred; VOHS, Kathleen (eds.), Free will and consciusness. How might they work?, Nueva York: Oxford University Press, 2010.
} 
reaccionarias y posfascistas del virtualismo. La capacidad de elección es un elemento indispensable en las prácticas digitales. ${ }^{153}$ Por lo tanto, sigue vigente la ética del juicio como enlace entre identidad y estética. No podemos renunciar a ella porque, entre otros motivos, sigue presente en los entornos digitales. Elección, juicio y emancipación son elementos culturales cuya única barrera es la biológica del libre albedrio, no la del determinismo tecnológico ni la de la conspiración gubernamental.

Es ahí donde surge el uso de una habilidad ética ${ }^{154}$ que reactive ${ }^{155}$ a un sujeto inmerso en la era de los postsimulacros. Porque la descorporeización no ha sido más que un cilicio victimista y por momentos conspirativo. Hubo una gran dosis de beatería en todo su discurso sobre la incorruptibilidad y la inmortalidad. Sobre la contaminación o la superación -según se mirarade la naturaleza humana. Sermones donde el pan ácimo y el bit intentaron rozar sus dedos a la manera del Génesis sixtino. Una invención para escurrir el bulto y para sobrellevar frustraciones e injusticias. Otro relato que justificara la imposibilidad de una revolución o, en su defecto, que permitiera otra, la enésima, desde la cama.

La habilidad ética derivada de las acciones corporeizadas, adquiere ese calificativo porque facilita la explicación y la comprensión del comportamiento humano. Si en algo convergen las ciencias de la cognición es en detallar la importancia de los atributos físicos específicos implicados en los procesos de toma de decisiones, emoción y conocimiento. Digo bien detallar, porque los procesos requieren de una minuciosidad hasta hace poco inaccesible. $Y$ con ello no me refiero solo al sistema nervioso central, sino a elementos tan visibles como la piel; nuestro órgano más extenso y pesado. Con esto solo pretendo subrayar la conveniencia de ser cautos en la utilización del prefijo neuro-. Su creciente aparición en los encabezados de congresos y publicaciones de las humanidades puede derivar, si no lo ha hecho ya, en una rama de la autoayuda. En una actualización de las viejas imposturas intelectuales.

\footnotetext{
${ }^{153}$ Una crítica brillante -y muy bien ilustrada- al relato de la descorporeización en las prácticas artísticas electrónicas y digitales: RIDGWAY, Nicole; STERN, Nathaniel, "The implicit body" en RICARDO, Francisco (ed.), Cyberculture and New Media, Amsterdam y Atlanta: Rodopi, 2008, pp. 117-155.

${ }^{154}$ VARELA, Francisco, La habilidad ética, Barcelona: Debate, 1992. Existe otra edición que también compila las conferencias impartidas por Varela en la Universidad de Bolonia (16-18 de diciembre de 1991) y que difiere en parte de la anterior. Me refiero a la ya citada: VARELA, Francisco, Ética y acción, op. cit., 1996.

${ }^{155}$ Entendido como desintoxicación, como superación de una retórica botulínica y narcótica que devuelva la lucidez cognitiva. Paul Virilio utilizó el símil para hablar de un narcocapitalismo y de una narcoeconomía sustentada por "el poder sugestivo de las tecnologías virtuales". VIRILIO, Paul, "Alerte dans le cyberspace" en Le Monde Diplomatique, 28 de agosto de 1995. Traducción al español en: <http://aleph-arts.org/pens/speed.html> [consulta: 08-08-2015]
} 
La mente -o el concepto de mente- ha abandonado el misterioso y sibilino teatro cartesiano aquel escenario donde Betty y Rita lloraban porque no había banda- para mudarse a un vecindario -el del cerebro y sus ciudades dormitorio, esto es, el cuerpo- del que Damasio nos da un adjetivo y un sintagma adjetival exactos: digno y menos sublime. Es crucial considerar como menos sublime esta nueva morada. Porque en lo sublime se encuentra la razón de ser del cogitum no físico representado por el ciberespacio, por sus estéticas -retóricas, excesivas $y$, sin embargo, vacuas y melifluas- $y$ por sus comportamientos: la pasividad disfrazada de interactividad y la resignación. ¿Cómo establecer y exigir parámetros sociales asentados en la dignidad cuando quisimos despojar al cuerpo de la misma? Responder a esta pregunta nos devolvería algunas de las catástrofes sociales del siglo XXI que, sin ser nuevas, han alcanzado cotas de visibilidad nunca experimentadas: terrorismo, asesinatos, violencia de género y torturas. ${ }^{156}$

Así, hay que tener presente que el estudio de la mente y de sus productos se ha convertido, ante todo, en un estudio y en un problema del cuerpo. La literatura científica sobre la cognición corporeizada, encarnada, materializada o personificada-embodied cognition-, lejos de la asepsia que se le presuponía ha desatado una tormenta de dilemas conductuales que las humanidades habían abandonado o menospreciado. El uso de herramientas, la modificación del entorno en un doble sentido - del hombre hacia este y viceversa-, los mecanismos de supervivencia, la implementación cultural de habilidades preexistentes, la conservación, la adaptación y la eventual represión del instinto, la producción y el consumo de arte, las emociones estéticas, la plasticidad cerebral y cultural, la epigenética, la cooperación y el individuo, la sedimentación y el afloramiento de los universales formales y narrativos, etc.

\footnotetext{
${ }^{156}$ Aludo a la visibilidad de la violencia y la enfrento a su ausencia de originalidad, por la compulsión a la que nos hemos entregado a la hora de registrar hechos reprobables y delictivos. Es esta otra de las supervivencias mediante la cual la naturaleza humana se infiltra en la cultura contemporánea. Cuando Pinker nos ha relatado con su habitual capacidad divulgativa el declive de la violencia, cabe preguntar por qué su iconografía -por repulsiva que sea- ha emprendido el camino opuesto. La explicación más sencilla es la asociada al posibilismo tecnológico: abundancia, ubicuidad y facilidad de las herramientas. Pero no nos engañemos, la violencia gráfica ha crecido con la multiplicación de los medios, pero también por nuestra demanda, sin la cual no habría reporte alguno de beneficios. Nuestra elaboración cultural la ve execrable al tiempo que la explota materialmente. Nuestra base biológica la percibe como experiencia vicaria del dolor. En la intersección, asistimos y fabricamos un acto liberado -con las excepciones que todos conocemos- de algunas -que no todas- de las responsabilidades morales y penales que los hechos retratados sí acarrean.

Cuando cito a Pinker me refiero a: PINKER, Steven, The better angels of our nature. Why violence has declined, Nueva York: Penguin, 2011.
} 
Fenómenos que requieren de algo más que una mente deambulando por el espacio virtual. Fenómenos que requieren de un cuerpo histórico que las ha sufrido y que está legitimado para explicarlos. La explicación final -actual- de la mente descansa en un intrincado tejido biológico, cultural y social de más de tres millones de años. A ese tejido hay que seguir administrándole materialidad. Exhalar la mente hacia el vapor del ciberespacio es una irresponsabilidad. Explicarla en términos de estrictos acontecimientos cerebrales que soslayen el resto de órganos y el ambiente, un reduccionismo.

Una condición necesaria para la cognición es la corporeización (...) La noción básica de la corporeización está ampliamente aceptada como la única vía por la que un organismo dotado con capacidades sensomotoras es capaz de interactuar satisfactoriamente con su medio ambiente. ${ }^{157}$

Sin materia no hay cuerpo. Sin cuerpo no hay mente. Sin mente no hay imágenes. Sin imágenes no hay conciencia. Sin conciencia no hay relato. Sin relato no hay yo. Es esta una simplificación gruesa, pero creo que responde bien a los diferentes reactivos que intento precisar. Utilizo el término reactivos de manera literal, como elemento químico, no como metáfora. Cada eslabón ayuda a explicar y a valorar las propiedades del anterior y del siguiente. El cuerpo no es mero soporte, contenedor o mera extensión, también es contenido. El cuerpo es materia y, por lo tanto, es forma y es relato. La conclusión de la neurobiología contemporánea es la siguiente: la mente no es concebible sin algún grado de corporeización. ${ }^{158}$ Recordando a Vivian Sobchak en uno de sus rotundos e irónicos -afirma ser

157 COWART, Monica, "Embodied cognition" en Internet Encyclopedia of Philosophy, 27 de febrero de 2012. <http://www.iep.utm.edu/embodcog/> [consulta: 11-08-2015] [La traducción es mía]

158 DAMASIO, Antonio, El error de Descartes. La razón de las emociones, Santiago de Chile: Andrés Bello, 1999 [Primera edición de 1994].

Damasio cita (p. 260) una serie de nombres que, en aquel entonces, mientras refutaban la descorporeización sentaban las bases de lo que, apenas unos años después -pongamos diez-, se convertiría en el estudio de la cognición corporeizada. No solo de biólogos (Francisco Varela, Gerald Edelman) se nutre la lista, también de filósofos (Mark Johnson) lingüistas (George Lakoff) y psicólogas (Eleanor Rosch). Cabría añadir otros muchos que ya ejercían y que, por suerte, lo han seguido haciendo: Patricia Churchland, Vivian Sobchak, Daniel Dennett o el mismo Damasio.

Lakoff y Johnson corporeizaron la filosofía de manera brillante y en época poco propicia -el challenge del título es un buen aviso- para la causa en: Philosophy in the flesh. The embodied mind and its challenge to western thought, Nueva York: Basic Books, 1999.

Lakoff y Johnson concluyen que los conceptos y los pensamientos no son ni reflexiones puras e ideales, ni reflejos perfectos de la realidad exterior, son procesos modelados de manera crucial por nuestros cerebros y cuerpos.

En la lista de Damasio se aprecia el peso de esta publicación: ROSCH, Eleanor; THOMPSON, Evan; VARELA, Francisco, The embodied mind. Cognitive science and human experience, Cambridge: The MIT Press, 1991. La importancia de esta publicación es triple. Sin ser pionera, es temprana; aporta una 
una posthumana real después de perder una pierna a causa de un cáncer y sustituirla por una prótesis- pensamientos carnales: la naturaleza de la existencia humana es una cuestión drásticamente material y corporeizada. Solo aceptando la vulnerabilidad y la imperfección del cuerpo, solo asumiendo la mortalidad, podremos salir vivos de este siglo. ${ }^{159}$

Quiero concluir con una fábula posmoderna. Lyotard se preguntaba en el primer capítulo de Lo inhumano ${ }^{160}$, si podríamos pensar sin cuerpo. Con la muerte del sol como último e ineluctable suceso, Lyotard lanzaba esta pregunta a la filosofía y a las tecnociencias. ¿Cómo convertir el pensamiento no en un superviviente, sino en una supervivencia? Es decir, siendo el pensamiento un fenómeno irreductible del cuerpo ("de la organización pensante". De la forma que tiene la mente de "seguir ganándose la vida"), ¿podría el pensamiento escapar al diluvio de la materia de una explosión solar? ¿Cabría una supervivencia del pensamiento sin cuerpo? Lyotard lo tenía claro, pensar sin cuerpo era la condición para poder pensar la muerte de los cuerpos y la de los pensamientos ligados a él de manera entrañable.

El cuerpo debía perecer para facilitar la supervivencia del pensamiento. El cuerpo humano, esto es, el "organismo vivo terrestre y complejo", debía renunciar a su condición para poder perpetuar su base inmaterial. El nuevo habitáculo sería soporte, pero no sería cuerpo: el hardware. A partir de ahí, lejos de solucionarse el problema, surgirían otros tantos dentro del orden de la complejidad: empezando por la diferencia sexual y por el choque entre intuición, ambigüedad e indeterminación del pensar humano, frente a la axiomática computación binaria. Pero el más importante era devolver al nuevo cuerpo -que no era cuerpo, que era hardware- su antigua naturaleza. Esto es crucial: para que el pensamiento se transformara en una supervivencia, el nuevo cuerpo debía volver a ser (como) el viejo:

Lo que hace inseparables el pensamiento y el cuerpo no es simplemente que este sea el indispensable hardware de aquel, su condición material de existencia, sino que cada uno de ellos es análogo al otro en su relación con su ambiente respectivo (sensible, simbólico). ${ }^{161}$

perspectiva histórica y fenomenológica del concepto, esto es, a partir de la experiencia humana del mismo; y, sobre todo, lo integra sin renunciar a la legítima funcionalidad de la computación.

${ }^{159}$ SOBCHAK, Vivian, Carnal thoughts. Embodiment and moving image culture, Los Angeles: University of California Press, 2004, p. i y 178.

${ }^{160}$ LYOTARD, Jean François, "Si se puede pensar sin cuerpo" en Lo inhumano, op. cit., pp. 17-31.

${ }^{161}$ Ibid., pp. 24-25. 
Lo que hizo Lyotard fue reciclar la enseñanza de Bergson en Materia y memoria. ${ }^{162}$ Como en toda operación de apropiación y reciclaje, se introdujo cierto cierto cambio semántico que, sin embargo, no alteró la raíz del original: la supervivencia de la mente sobre un cuerpo descompuesto. Así, la moraleja de la fábula cósmica ilustra cómo la posmodernidad, en su hiperbólica lucha contra la materia, termina recurriendo a la analogía como método de supervivencia en un paisaje postapocalíptico regido por la entropía. En el fondo y en la forma esta enseñanza revela tres constantes básicas del pensamiento posmoderno: pastiche, arcaísmo y fundamento reaccionario.

El ser humano es signo -cuerpo- y símbolo -mente- desde sus inicios. El cuerpo fue uno de los primeros, si no el primer receptáculo de nuestra actividad iconográfica. Las pantallas corporales de Fabio Mauri, de Malcolm Le Grice o de Sally Golding resultan históricamente apropiadas si nos recordamos a nosotros mismos, embadurnados de ocre, emprendiendo nuestra aventura social. Con el cuerpo por delante, comunicando. El cuerpo sigue siendo aquel artefacto simbólico que hoy puede expresarse a través de bits, pero que no puede descomponerse o transmutarse en ellos. Es su imagen, la imagen del cuerpo, la única que puede lograrlo. El gran problema es que el cuerpo no puede ser visto en una estricta y vulgar materialidad, aislado de su producción simbólica, de su mente. Ni cerebro en la tina, ni pedazo de carne zombi. Como diría Lacan ${ }^{163}$, la escandalosa y perturbadora descomposición de la unidad viviente. Aun siendo posible, aun obrando el dualismo, el cuerpo no podría reemplazar al significado, de la misma manera que la imagen no podría reemplazar al cuerpo. Tanto el cuerpo como la imagen producen y reorientan significados, no los suplantan.

El gran problema, en definitiva, es que Madeleine -transustanciada en óleo o en píxels, y por mucho que suspirara Roderick-, no vivía en el cuadro.

${ }^{162}$ Es necesario citar un párrafo completo de la obra. BERGSON, Henri, Materia y memoria, op. cit., p. 298.

"Si hubiera equivalencia entre lo cerebral y lo mental, la conciencia podría seguir los destinos del cerebro y la muerte ser el final de todo: por lo menos la experiencia no diría lo contrario y el filósofo que afirma la supervivencia estaría reducido a apoyar su tesis sobre alguna construcción metafísica (...) Pero si, como hemos intentado mostrar, la vida mental desborda la vida cerebral (...) entonces la supervivencia deviene tan verosímil que la carga de la prueba corresponderá a aquel que niega, más bien que a aquel que afirma; pues la única razón para creer en una extinción de la conciencia después de la muerte es que se ve al cuerpo desorganizarse, y esta razón ya no tiene valor si la independencia de la casi totalidad de la conciencia respecto del cuerpo es también un hecho que se constata".

${ }^{163}$ A lo largo de la clase 6 del Seminario 2 ("Homeostasis e insistencia", bis, 12 de enero de 1955. En la edición de Paidós viene rotulada como "Freud, Hegel y la máquina", pp. 103-122), Lacan ofrece su discutible punto de vista sobre el dualismo cartesiano, sobre el cuerpo como máquina, sobre su producción simbólica y sobre el conflicto entre biología y energía. 


\title{
8.4. La imagen-cuerpo
}

\author{
«Oye ahora con qué facilidad y \\ rapidez surgen estas imágenes, \\ cómo resbalan fuera de los cuerpos \\ desprendiéndose en un perpetuo fluir...» \\ De rerum natura (Lucrecio, s. I a. C.) ${ }^{164}$
}

«Los ojos carecen de aparato digestivo»

Abel Gance ${ }^{165}$

Durante un pasaje de Tokio ya no nos quiere, la compañera del protagonista le presenta a su madre. Una madre muerta. La presentación es cuerpo a cuerpo, pero ella está encerrada en un viejo monitor en blanco y negro. La madre muerta vive ahí, como imagen, gracias a un programa de reencarnación elaborado a partir de "registros de memoria y patrones de comportamiento, notas, diarios, pruebas grafológicas, exámenes neuronales, fotografías, análisis, recuerdos, vídeos caseros". La reencarnación respeta "las reacciones humanas naturales basadas en los instintos, los recuerdos, las bases genéticas". La paradoja está servida: la imagen es el imposible y nuevo cuerpo. La incomodidad propia de una presentación ante la suegra aumenta porque, en esos momentos tan delicados, solo puede haber algo peor que una suegra viva: una suegra muerta reencarnada como imagen. El chico, confuso, rompe el hielo: "Una imagen preciosa (...) una mujer preciosa, quiero decir" ${ }^{166}$

Este recurso ficcional ayuda a explicar un mundo distópico que ya no nos quiere, ni nos querrá. Un mundo donde la reencarnación ha perdido todo su sentido, empezando por el etimológico. De este breve pasaje se obtiene, además, un aspecto determinante: la frecuente disonancia cualitativa entre imagen y tecnología. La contradicción de una hipertecnología capaz de constituir una reencarnación creíble, pero expresada de manera bidimensional dentro de un hardware obsoleto y mediante un pulso iconográfico de baja calidad. Vestir de mendigo un fundamento científico avanzado, fue una de las características del ciberpunk que, apenas transformada en las formas y trocando los medios y los formatos, hemos vuelto a encontrar en pleno siglo XXI.

\footnotetext{
${ }^{164}$ LUCRECIO CARO, Tito, op. cit., p. 331.

165 GANCE, Abel, “iHa llegado el tiempo de la imagen!” en ROMAGUERA i RAMIÓ, Joaquim; ALSINA THEVENET, Homero (eds.), op. cit., p. 458.

${ }^{166}$ LORIGA, Ray, Tokio ya no nos quiere, Barcelona: Plaza y Janés, 1999, p. 69.
} 
Certifico que confundir el cuerpo con su imagen es el corolario al que se aviene este octavo apartado. El desajuste entre dos realidades materiales a menudo complementarias pero diferentes, ha contribuido al desarrollo de un idealismo naif y peligroso. También a la charlatanería académica y a la infantilización del pensamiento. Como decía más arriba, no es casualidad que se haya producido un regreso poderoso y localizado de las sociedades occidentales a la religión y al animismo. Pido disculpas si resulto insistente, pero gran parte de la culpa debe recaer sobre las humanidades. Justo cuando tuvieron que cumplir con todo el rigor su función pedagógica, abandonaron el presente por el futuro o se dedicaron a explicar el primero con un fárrago que la gente -sí, la gente, incluida la gente instruida- no comprendía.

Ortega decía que el cuerpo era, de por sí, auténtica puerilidad. Y que su culto era el síntoma de esa condición. Ortega trató de disimular cierto dualismo con aquello de que el ser humano no era solo alma, sino la "unión mágica de espíritu y cuerpo". En esta ocasión, la gente fue víctima de una disonancia cognitiva global: lo que vivían, no concordaba con lo que veían y leían. Los teóricos decían que los cuerpos iban a dejar de ser necesarios, pero la gente seguía sudando, seguía fracturándose los huesos, seguía oxidándose... seguía muriendo. Las humanidades abandonaron la necesaria estrategia dialógica, aquella que no pierde de vista y que tiene en cuenta la otredad, para entregarse a una retórica narcisista protegida en su ininteligibilidad. En paralelo y en muchos casos como ilustración directa de las teorías culturales dominantes, los cineastas filmaban cuerpos esculturales y omnipotentes que no conocían o que transgredían los límites. Y lo hacían más allá, pero también más acá de la ciencia ficción.

¿Cómo reaccionó la gente? ¿Qué hizo? Una mañana cualquiera, tras arrancarse las legañas, mirarse al espejo y aborrecer su imagen. No es posible que ese sea yo. A mí me han prometido otra cosa. Por desgracia, somos así de sugestionables y de cándidos. Como en toda disonancia cognitiva, esa mirada frente al espejo desató una lucha interna para reordenar los pensamientos. Había que hacer encajar lo que se decía con lo que se tenía. En el intento, acercamos la mano al espejo y este comenzó a licuarse y a licuarnos. Dimos un paso más y, como en un filme de Cocteau, nos engulló. En el espejo creímos haber visto la salida de emergencia, cuando solo era la entrada al laberinto. Al otro lado no estaba Alicia, sino el trauma y, agarrado de la mano, el modelado estético del cuerpo. El cuerpo disonante quiso recuperar "su unidad en la imagen del otro", porque ese otro aparecía como "su propia imagen anticipada". En una situación de idolatría psicótica y de narcisismo frustrado, la 
conciencia se descompone y el sujeto oscila hasta el punto de ser "aspirado por la imagen, a la vez engañosa y realizada del otro". ${ }^{167}$

Mientras llegaba la liberación absoluta del cuerpo, había que ir preparándola, modelándola. Mientras el cuerpo persistiera había que adecuarlo a la imagen y, si era posible, convertirlo en ella. Porque los comportamientos apocalípticos por excelencia son la espera y la preparación, no la histeria y la resignación. Y la preparación de un suceso terminal solo puede ser articulada en torno a la neurosis. En términos jungianos, la neurosis encubre pero, al mismo tiempo, expresa el trauma. La fantasía patológica, la repetición enfermiza de lo mismo para conjurar lo disonante. El modelado corporal devino neurosis desencadenada por una disonancia cognitiva entre cuerpo e imagen. Quiero decir, la imagen-cuerpo, la imagen que quiso ser cuerpo, se convirtió en "una empresa sustitutiva insatisfactoria". ${ }^{168} \mathrm{Y}$ tanto, la grasa que creímos perder en el trance -la grasa proscrita- fue reciclada en forma de jabón y vendida a precio de oro por un lunático anarquista adicto al dolor.

Utilizo el término modelado de manera extensiva, superando la inmediata alusión a la cirugía $^{169}$ y al entrenamiento físico para abarcar un muestrario de prácticas y de modos de percibir. En el modelado está el bisturí y el ejercicio, pero también su negativo: las anomalías morfológicas y el sedentarismo. La revalorización y la devaluación del cuerpo; pues a la cancelación de la carne se accede por exceso y por defecto. En el modelado también caben, por supuesto, los trastornos alimenticios, los deportes de riesgo, el dopaje, la decoración corporal, la sexualidad y sus parafilias, la violencia y las perversiones visuales. ${ }^{170}$

\footnotetext{
${ }^{167}$ LACAN, Jacques, “Homeostasis e insistencia” en Seminario 2, clase 5, 5 de diciembre de 1954, Buenos Aires: Paidós, 2008, p. 88.

168 JÜNG, Carl Gustav, op. cit., p. 14.

${ }^{169} \mathrm{El}$ modelado estético tiene respaldo estadístico. Antes que rancio tópico humanista para denunciar la frivolidad contemporánea, conviene utilizarlo como hecho estadístico irrebatible. En Estados Unidos, a partir de 1992, se disparó la cirugía mamaria hasta el 500\% respecto a los años precedentes. Pero si tomamos las estadísticas desde finales de siglo pasado (1997) hasta la actualidad, el incremento continuó siendo impresionante. Durante ese periodo, el total de actuaciones estéticas (sumando quirúrgicas y cosméticas) subió un 274\%. El gasto total en 2014 ascendió a más de doce mil millones de dólares. Además, se han diversificado los tipos de operación y se han incrementado los tratamientos no invasivos. Actuaciones antes residuales se han convertido en masivas. Lo mismo ha sucedido con los sexos, la raza y los grupos de edad. En principio limitadas a las mujeres adultas caucásicas de entre 35 y 50 años, las operaciones estéticas conquistaron el mercado masculino (un $43 \%$ más solo en los últimos cinco años) mientras extendían su campo de acción desde la pubertad hasta la vejez.

Datos obtenidos de The American Society for Aesthetic Plastic Surgery:

<http://www.surgery.org/media/statistics> [consulta: 18-08-2015]

${ }^{170}$ Un catálogo de perversiones y anomalías no orgánicas de la mirada en: GUBERN, Román, La mirada opulenta. Exploración de la iconosfera contemporánea, op. cit., pp. 36-42.
} 
Todas dirigiéndose hacia los extremos, fuera de la moderación o de una norma ya superada. Síntomas que expresan el trauma. Modos de desenvolverse dentro de lo que un día llegamos a conocer -gracias a Gilbert Cohen-Séat (1959)- como iconosfera pero que, rápidamente, en apenas tres décadas, se convirtió en iconofagia. ${ }^{171}$ En la primera, las imágenes se multiplicaban e invadían nuestro ecosistema, pero también nos envolvían y nos invitaban a interactuar. En la segunda, la imágenes terminaron por devorar y suplantar el cuerpo. En la iconosfera, la imagen era el simulacro del cuerpo; en la iconofagia, el cuerpo se convirtió en el simulacro de la imagen.

La imagen-cuerpo quiso reírse de la cita que Debord hizo de Feuerbach. ${ }^{172} \mathrm{Y}$, aun antes, el principio conceptual de la iconofagia como fenómeno que tiende a confundir imagen y cuerpo, arrancaba en Spinoza. ${ }^{173}$ El filósofo aludía a un cuerpo atribulado por su incapacidad para formar y procesar un número creciente y simultáneo de imágenes. Sobrepasado ese límite fisiológico y cognitivo, las imágenes -decía Spinoza- se confundían en el cuerpo hasta el punto de quedar todas catalogadas bajo un mismo atributo: el de ser o el de cosa.

En la actualidad, sin embargo, la imagen-cuerpo -igual que sucedió con la denuncia periódica de la estética del fragmento ${ }^{174}$ - no llegó a hacer de la escena, ni de la mirada sobre ésta, una realidad descorporeizada como afirmaba Casetti. ${ }^{175}$ Antes bien, terminó delatando lo decisivo de un cuerpo incluso fragmentado. De la misma manera que la inmersión del creador o del programador en el lenguaje informático no supuso su desaparición, solo una nueva manera de modelar enmascarada por la evolución amigable de la interfaz de usuario. A pesar de las tecnofábulas, la pantalla no es el mundo y el mundo -que no puede ser encuadrado- tampoco es una pantalla. Nos sentamos frente a la pantalla con la idea equivocada de que esta es "el escritorio del mundo". ${ }^{176}$ En Tombée de nuit sur Shanghai (2007), Chantal Akerman -que en

\footnotetext{
${ }^{171}$ BAITELLO JUNIOR, Norval, La era de la iconofagia, Sevilla: ArCiBel Editores, 2008.

Otro término propuesto para el fenómeno es iconorrea. BROWNE, Rodrigo, "Comunicación indisciplinada. Iconofagia e iconorrea en los medios de (in)comunicación" en Revista Austral de Ciencias Sociales, Universidad Austral de Chile, № 11, ISSN 0718-1795, pp. 101-114.

${ }^{172}$ Feuerbach y Debord supieron apreciar nuestra capacidad para desarrollar -que no para adquirir, pues viene de serie, está en nuestra naturaleza- el poder usurpador de la representación: "Y sin duda nuestro tiempo (...) prefiere la imagen a la cosa, la copia al original, la representación a la realidad, la apariencia al ser". DEBORD, Guy, La sociedad del espectáculo, Santiago de Chile: Ediciones Naufragio, 1995, p. 7.

${ }^{173}$ SPINOZA, Baruch, op. cit., p. 145.

${ }^{174}$ Un estudio de la estética del fragmento en: CALABRESE, Omar, op. cit., pp. 102-104.

${ }^{175}$ CASETTI, Francesco, El film y su espectador, Madrid: Cátedra, 1989, pp. 101-102.

${ }^{176}$ VILCHES, Lorenzo, op. cit., p. 217.
} 
gloria esté- reflexionaba sobre esa ilusión: "el estado del mundo (...) profusión de sonidos e imágenes (...) todo se muestra y desaparece a la vez".

Mientras la iconofagia -con la publicidad y el cine comercial al frente- enaltecía la cultura de la desaparición y los nuevos cuerpos, algunos sectores de la fotografía y del audiovisual insistían en los antiguos, en los reales. Esta escisión se consolidaría y se extendería hasta nuestros días. ¿Por qué? porque, siguiendo a Girard ${ }^{177}-\mathrm{y}$ a tantos otros-, la violencia esencial no cesa de regresar o, mejor dicho, de manar de nosotros. Lo hace como acto corporeizado tanto en el plano de la historia, como en el plano del saber. Y lo hace mediante una forma narrativa ya estudiada aquí: la espectacular. Violencia esencial manifestada a través de nuestros cuerpos de manera espectacular y, diría más, racional. La violencia instintiva es otro saldo evolutivo que admite a la razón, además de cómo represión, como mediadora y hasta como lenguaje. Porque la razón no es espectral, sino sensible; no es una impregnación, sino un producto. La presencia, la tensión y el estrés del cuerpo violento o violentado frente a esa razón mediadora, contribuye al afloramiento de todo un inventario temático de lo siniestro. Esto es, la interpretación canónica que hizo Freud -vía Schelling- del unheimlich: "todo lo que estando destinado a permanecer en el secreto, en lo oculto, (...) ha salido a la luz" ${ }^{178} \mathrm{El}$ retorno de lo mismo o la pasmosa aparición de lo fantástico en lo real.

También hubo y hay cuerpos dolientes en esta iconofagia de violencia esencial: los de Abu Ghraib ${ }^{179}$, los del genocidio de Ruanda ${ }^{180}$ y los del bombardeado del mercado central de Sarajevo. Los cuerpos extremos de Gunther von Hagens y los autorretratos de David Nebreda. Así, en plena iconofagia surgieron, casi como acto reflejo abrasador, el torture porn y el cine extremo francés y asiático. También se recuperaba de manera masiva el cine de zombis. El fracaso de la imagen-cuerpo quedó certificado con la presencia corporal en numerosas instalaciones ${ }^{181}$ y con la explotación de las relaciones espacio-tiempo-cuerpo que para algunos

\footnotetext{
177 GIRARD, René, op. cit., p. 334.

178 FREUD, Sigmund: "Lo ominoso" en Obras Completas, Buenos Aires: Amorrortu, vol. XVII, 1992, pp. 215-251. Véase la síntesis que realizó Trías de ese inventario en Lo bello y lo siniestro, op. cit., p. 42 y ss.

${ }^{179}$ Cuando el cineasta debe y sabe ejercer de historiador para poder, luego, ejercer de hermeneuta: Standard Operating Procedure (Erroll Morris, 2008).

${ }^{180}$ THOMPSON, Allan (ed.), The media and the Rwanda genocide, Ann Arbour: Pluto Press, Fountain Publishers, IDRC, 2007.

${ }^{181}$ Cfr. RIDGWAY, Nicole; STERN, Nathaniel, "The implicit body".

La presencia como hecho inevitable para que la obra se haga ante uno y con uno. Véanse las precursoras instalaciones de vídeo que realizaron Peter Campus, Dan Graham, Bruce Nauman y Laurie Anderson. Las instalaciones sonoras de ésta última, "no sólo requerían la presencia del espectador para ser activadas, sino que se centraban fundamentalmente en el registro de la presencia como medio para establecer el significado". WALLIS, Brian (ed.), op. cit., p. 177.
} 
habían sido fulminadas por los entornos digitales. ${ }^{182}$ El inesperado corolario de la iconofagia fue la reactualización del non finito de Miguel Ángel. La maleabilidad eterna y jactanciosa del non finito digital, se acercaba al non finito marmóreo. Imperfecto, basto, desafiante; materia depravada y rotundamente acabada. Superficie insurrecta que revela nuestras miserias más profundas. Nuestras miserias, en este caso, son esas que despuntan ante la "imposibilidad de materializar los ideales creados por el cerebro, a través de la experiencia sumativa de lo particular, en la vida real". ${ }^{183}$

A la exploración iconográfica ${ }^{184}$ del cuerpo, además de su valor histórico, debemos añadir el valor diagnóstico. La capacidad científica de la bioimagen no está reñida con la estética. La interioridad corporal, otrora tabú y objeto de imágenes desagradables -estas tampoco han desaparecido. Ahí tenemos todos esos lúgubres paisajes de las exploraciones endoscópicas-, nos entrega hoy una iconografía fascinante ${ }^{185}$ donde los motivos más recónditos aparecen como "imágenes del espacio exterior" ${ }^{186}$ y como sugerentes abstracciones. De los viejos rayos X de Röntgen, a los remozados microscopios electrónicos de barrido y a las novísimas tomografías computarizadas que hacen realidad el sueño de Epstein, Belson o Youngblood. Imágenes que durante su proceso de elaboración enclaustran o profanan el cuerpo para reafirmarlo, para expandirlo.

"Los cuerpos están ahí (...) algo que en muchas ocasiones olvidamos" ${ }^{187}$ Siempre estuvieron y nunca se han ido. Recordemos el macabro reino de las sombras de Hersey en lugar del de Gorki. Cuando los cuerpos desaparezcan o cuando se modifiquen de manera drástica -algo más que probable-, será el momento de explicar el evento. Hasta entonces hay que dar cuenta de cómo los cuerpos han regido y rigen la historia de las artes plásticas y de las imágenes. Lo hicieron con la escultura y con la pintura y no dejaron de hacerlo con la fotografía. Desde la

182 Prácticas ejemplares como Very nervous system de David Rokeby y Breath de Ulrike Gabriel. MUNSTER, Anna, op. cit., pp. 3-4. Los experimentos de Adam Rokhsar o la reflexión irónica sobre la presencia de los cuerpos dentro de los nuevos medios en parte de la obra de Oliver Laric.

${ }^{183}$ MORA, Francisco (coord.), Esplendores y miserias del cerebro, Madrid: Fundación Banco Santander, 2004, p. 410.

${ }^{184}$ De la opacidad a la transparencia del cuerpo, uno de los epígrafes de MALDONADO, Tomás, Crítica de la razón informática, Barcelona: Paidós, 1998, pp. 163-166, puede servir para constatar las diferencias entre la desaparición absoluta del cuerpo y los cambios o giros en la percepción del mismo.

${ }^{185}$ Véase el lustroso: DE FELIPE OROQUIETA, Javier, El jardín de la neurología. Sobre lo bello, el arte y el cerebro, Madrid: Consejo Superior de Investigaciones Científicas, 2014.

${ }^{186}$ KEMBER, Sarah, “¿La nueva visión de la medicina?” en LISTER, Martin (ed.), op. cit., p. 137.

187 PAREDES BADÍA, Israel, Imágenes del cuerpo, Cáceres: Asociación Re Bross, Filmoteca de Extremadura y Librería Ocho y Medio, 2007. 
catalogación y la identificación de los criminales de Alphonse Bertillon ${ }^{188}$ y las pioneras descomposiciones del movimiento de Muybridge (ejemplar al respecto el documental de Thom Andersen: Eadweard Muybridge, Zoopraxographer, 1975) y Marey, a los filmes médicos de Marinescu o a los combates de los hermanos Skladanowsky. Pasando por las danzas silentes heredadas de las variedades, por el slapstick y la pantomima, por las obras reflexivas de Martha Graham, Maya Deren y Norman McLaren, por los cuerpos sometidos de Pasolini o por los redactados de Kobayashi y Greenaway, hasta llegar al wire fu, al motion capture y a la pixilation. La comicidad y la tragedia son dos fluidos corporales más.

La relación del cuerpo con la imagen cinematográfica instituyó una nueva síntesis entre signo y símbolo. En junio de 1896, los hermanos Arnold y Zsigmond Szikaly ${ }^{189}$ dieron fe de ella de manera inintencionada. Tras adquirir una cámara Lumière, los hermanos se dispusieron a filmar la visita del emperador Francisco José I a Budapest. La figura del emperador paseando por el Városliget sería impactante. Sin embargo, la angustia y el rechazo que generó el resultado solo se puede explicar por la regencia del cuerpo. Poco o nada diestros en el manejo del invento, el emperador apareció decapitado por el encuadre. ¡Ultraje!, clamó el público eminentemente burgués que llenaba el improvisado cine. Fue aquella, quizá, la primera gran bronca recibida durante una proyección. Con los años, aquel cuerpo fragmentado se convertiría en metáfora primigenia de la desmembración del Imperio Austro-Húngaro tras la Primera Guerra Mundial.

\footnotetext{
${ }^{188}$ SEKULA, Allan, "El cuerpo y el archivo" en PICAZO, Gloria; RIBALTA, Jorge (eds.), Indiferencia y singularidad. La fotografía en el pensamiento artístico contemporáneo, Barcelona: Gustavo Gili, 2003, pp. 133-199.

${ }^{189}$ CUNNINGHAM, John, Hungarian cinema. From coffee house to multiplex, Londres: Wallflower Press, 2004, p. 6.
} 


\section{9. ¿CAMBIO DE PARADIGMA?}

Las imágenes cinematográficas, periodísticas, publicitarias, televisivas y cibernéticas; las imágenes estáticas y las imágenes en y del movimiento; en definitiva, las imágenes del audiovisual del siglo XXI acuñaron un axioma según el cual la introducción de los procesos digitales acarreaban de manera indefectible tres aspectos: desmaterialización, virtualidad y vaciado narrativo. Aceptar este planteamiento facilitaría el análisis de las imágenes. Sería sencillo hacer borrón y cuenta nueva tras declarar un cambio de paradigma. Sin embargo, esa hipotética ontología de la imagen -como estoy intentado demostrar- estaría muy lejos de ser nueva y, se quiera o no, de ser cierta.

¿Ha cambiado el paradigma de las imágenes? Sí y no. Lo ha hecho o está en vías de hacerlo en determinadas instancias, mientras que ha ejercido su capacidad para la supervivencia en otras tantas. Es más, las viejas imágenes, las imágenes materiales, han llegado a intensificar su presencia en plena era digital. ¿Por qué? La primera de las muchas razones la obtenemos porque, de la misma manera que sucedía con las imágenes mentales, las imágenes digitales también son imágenes materiales. Es, por lo tanto, una cuestión de principio, de axiomas enfrentados. Aceptar uno u otro implica la necesidad de pruebas. Las mías se encontrarán cuando constante los diferentes métodos y medios de supervivencia de las imágenes materiales en la iconografía digital. Pero antes debo ser más preciso en la quiebra o en la supervivencia del paradigma.

Quiero adoptar una postura clásica. Para saber si un paradigma ha cambiado o no, solicito el consejo de Thomas Kuhn. El problema de acudir a una fuente canónica, pero de otro campo del conocimiento y quizá superada en ciertos aspectos, es que no se puede aplicar como una plantilla para cartografiar la estética. Los paradigmas científicos de Kuhn eran una suerte de depósito comunitario, fiable, sólido y estático desde el cual y durante un tiempo determinado se suministraban los problemas y las soluciones. El terreno de las imágenes y del arte es diferente, el depósito no es tan comunitario y está diversificado, el tiempo es más flexible y los problemas y sus soluciones podrían equivaler a los medios de producción, no a un producto -a una imagen- susceptible de juicio estético.

En cualquier caso, para que exista un cambio de paradigma debe darse una condición indispensable: el nuevo modelo debe ser incompatible con el anterior. Es a partir de ese punto 
sin retorno de donde Kuhn obtiene su metáfora política de la revolución científica. También lo hace del periodo que precede al cambio. La comodidad que proporcionaba poseer el libro con las soluciones, se convierte en incertidumbre cuando se comprueba que estaban equivocadas. Ese malestar creciente ante el mal funcionamiento del sistema es otro de los síntomas que anuncia el cambio. Pero cuando un régimen se tambalea genera una fuerza de reacción y de resistencia que le conduce a clasificar la verdad como herejía o, en términos laicos, como deslealtad. En esa tesitura, la única salida es la deserción. De ahí que el cambio de paradigma no pueda darse por acumulación o por consenso, sino por disenso revolucionario. El cambio de paradigma no solo afecta a lo factual y a los modelos de trabajo, también al propio mundo. El mundo y, con el sus habitantes, dejó de ser el mismo cuando Copérnico, Darwin o Einstein expusieron sus teorías.

Es lugar común pervertir la noción de cambio de paradigma. Los discursos sobre la imagen del siglo XXI no han sido una excepción. Estos han utilizado la fórmula de Kuhn para ilustrar justo lo contrario, la supervivencia del paradigma. Aquí debo asentir a esta llamada de Mario Bunge: "todos hablamos de revoluciones conceptuales o cambios radicales de paradigma (...) se ha exagerado la ruptura o discontinuidad a expensas de la continuidad" ${ }^{190}$

En primer lugar, el presunto cambio de paradigma provocado por la imagen digital se aceptó sin rechistar y de manera instantánea. Las teorías de los medios digitales prosiguieron su carrera sumando adhesiones y patrocinios. En segundo lugar, en ningún caso la imagen digital convirtió en incompatibles las imágenes precedentes, ni sus materiales, ni sus relatos, ni sus iconografías. Solo algunos de sus medios de producción y exhibición. $Y$ no todos y no de manera completa. Hace quince años, poco después de masacrar el arranque de Sed de mal (Touch of evil, Orson Welles, 1958), Walter Murch decía que la industria del cine era un sándwich digital entre rebanadas de pan analógico. ${ }^{191} \mathrm{Hoy}$-aun habiéndose entremezclado el pan y el relleno- seguimos en esa transición, en ese side by side del documental de Christopher Kenneally (El impacto del cine digital, 2012). Digo aun porque el anuncio del mesías se lleva predicando por los púlpitos desde finales de los años noventa. Un paradigma en transición, por

\footnotetext{
${ }^{190}$ BUNGE, Mario, "Paradigmas y revoluciones en ciencia y técnica" en El Basilisco, № 15, marzo-agosto de 1983, p. 2. En este artículo, Bunge realiza una dura crítica conceptual y metodológica de las ideas de Kuhn y Feyerabend. En especial de la inconmensurabilidad entre paradigmas o, si se quiere, de la incompatibilidad entre el paradigma que desplaza y el desplazado.

${ }^{191} \mathrm{MURCH}$, Walter, In the blink of an eye. A perspective in film editing, Los Ángeles: Silman-James Press, 2a edición revisada, 2001.
} 
definición, invalida la ruptura. Aceptar o no el sintagma paradigma mixto podría servir, si acaso, como débil precaución epistemológica.

Otro motivo de perversión radica en la teleología -en el mejor de los casos púdica e implícitaque asume la teoría digital. La misma que ha seguido aquel plan conductor del romanticismo que asociaba imagen e inmortalidad, se limitó a matizarlo introduciendo los conceptos de calidad, de inmersión y de mejora biológica. Que hoy siga sin cuestionarse la equivalencia entre digital y calidad, habla tan bien de la propaganda como tan mal de nuestra capacidad crítica. Las imágenes, como la evolución, carecen de un propósito superior. Tienen multitud de proyectos intermedios y de cambios adaptativos, pero ninguno que pueda considerarse como la causa final. La imagen no encuentra colofón en agradar o en disgustar, en informar o en engañar. La imagen ganaría cualquier clasificación de las metas volantes, pero jamás una clasificación general.

Podrá argumentarse que las imágenes progresan, que mejoran en términos cuantitativos y cualitativos. Que ganan en tamaño y en definición, pero hay que apostillar que carecen de un objetivo máximo: la infinitud y la perfección. Esto es, la imagen camina hacia alguna parte que no tiene por qué ser ni la profundidad en la representación de la realidad hasta lograr su habitabilidad, ni el desdoblamiento vital del sujeto. La imagen ni siquiera tiene como último cometido servir de memoria visual y semántica de nuestra especie. En ausencia del hombre, la imagen sobrevivirá, estoica e indiferente, como una piedra. Así pues, la única teleología posible de la imagen es, simplemente, seguir siendo una imagen.

Escribo estas líneas en una tarde de agosto. Lo hago junto a una ventana orientada a poniente. Es por la tarde y es tarde, pero el sol mantiene la altura necesaria para seguir acogotando con impunidad. Mientras el cruel verano castellano sigue desahuciando pájaros de los nidos, me pregunto si alguna vez hemos producido y consumido imágenes más pequeñas y de peor calidad que en este siglo XXI. Pienso en la precariedad de esos pájaros abrasados, incapaces de encontrar respiro y consuelo en las alas de la madre, y solo puedo imaginarlos en una imagen difusa, dilatada por el calor, deformada por y en el sufrimiento. En el suyo y en el mío. Una imagen jadeante y de aire rarefacto cocinada por una Fata Morgana. Investigo y, lógicamente, no encuentro sustento estadístico que avale mi respuesta a la pregunta. Porque mi respuesta es un no. Sin paliativos y sin matices. Jamás hemos disfrutado de unas imágenes tan pobres. Digo más, nunca como ahora las imágenes indigentes han condicionado tanto a las burguesas. 
Ángel Quintana las denomina imágenes innobles. Es lo mismo, su idea parte de idéntico postulado:
Las imágenes innobles (...) pueden afectar al funcionamiento de los sistemas de representación profesionales (...) Lo amateur no hace más que contaminar y transformar la imagen profesional. ${ }^{192}$

En una época de cacareado cambio de paradigma, de tecnoeuforia y de lustre digital, quiero certificar que gran parte de las modas iconográficas de los últimos lustros han sido impuestas por los mendigos. A falta de un imposible inventario absoluto, borgiano, intentaré rebajar la consciente superficialidad de mi afirmación. Equiparar un cambio de canon estético con un cambio de paradigma ${ }^{193}$, tal ha sido el exceso. Primero, porque el cambio de paradigma abarca una serie de instancias que comprometen su íntegro cumplimiento. Segundo, porque el cambio de canon estético tampoco ha tenido lugar o, al menos, no ha tenido lugar con la intensidad y la difusión que se podía esperar. Es aquí donde algunos de los planteamientos de Kuhn sí encajan. Uno por encima del resto: la resistencia al cambio. Y añadiría el medio para lograrlo: la torsión del tiempo. En este punto, Kuhn confluye con el análisis del paradigma que hizo Agamben. En su sexta tesis, el filósofo italiano afirmaba que "la historicidad del paradigma no está en la diacronía ni en la sincronía, sino en un cruce entre ellas". ${ }^{194}$

En las imágenes del siglo XXI, la resistencia y la torsión no solo se han ejercido desde el centro y desde la élite, también desde la periferia y el vulgo. Es más, volcando los términos de la operación, fue el sistema quien quiso imponer la revolución adelantando las manijas del reloj. Mientras tanto, una parte del pueblo se opuso. Una parte nada desdeñable y siempre insubordinada que, en su cabezonería, corrió a armarse. No con azadas, piedras y hoces, sino con la nostalgia que siempre excita a la resistencia. O tal vez con nostalgia de la resistencia. El objetivo: demostrar que parte de la primera y de la quinta tesis de Agamben eran las buenas: “el paradigma es una forma de conocimiento (...) analógica” y “toda imagen es arcaica”. ${ }^{195}$

\footnotetext{
${ }^{192}$ QUINTANA, Ángel, op. cit., pp. 184-185. También pueden verse las pp. 179-187.

${ }^{193}$ El propio Quintana se muestra algo confuso y contradictorio al respecto. Tan pronto afirma que "el cine ha comenzado a cambiar de forma radical sus planteamientos estéticos" (Ibíd., p. 18) y que "La digitalización ha estado acompañada por una serie de fenómenos básicos que han cambiado todos los oficios del cine y la relación que la imagen establecía con la realidad referencial" (Ibíd., p. 37) -esto es, un cambio de paradigma en toda regla-, como matiza de manera tímida al señalar que "la gran paradoja de la tecnología digital (...) no se ha impuesto como la base (...) que anula enteramente la imagen fotográfica" (Ibíd., p. 108).

${ }^{194}$ AGAMBEN, Giorgio, Signatura rerum. Sobre el método, Barcelona: Anagrama, 2010, p. 41.

${ }^{195}$ Ibíd., pp. 40-41.
} 
Las nostalgias, quién lo iba a decir, convertidas en supervivencias. Las nostalgias como refugio desde el que asaltar el castillo del noble. Las nostalgias -sigo con el plural porque son varias-, siempre asociadas a la melancolía y al impulso autolítico, reconvertidas en contracción, en sístole vital. Las nostalgias como acopio a la espera de recobrar el paraíso. En este momento de la historia, puedo decir que esa resistencia ha tenido un éxito relativo. Y el término relativo alude a un valor cuantitativo nada despreciable. Ha tenido lugar un movimiento que, al margen de la contaminación y de la infección de las imágenes ya reseñada, ha implicado transformaciones en los medios de producción. Estos, exigidos por el sentimiento reactivo hacia una forma y una tecnología, han debido amoldarse. El noble state of the art digital ha hincado la rodilla ante el vasallo facilitando la continuación de lo "nuevo viejo". 196

\title{
9.1. El material con el que se fabrican las nostalgias
}

\author{
"Y entonces en esos días íbamos a los cineclubs a ver películas mudas (...) \\ y vos pobrecita no entendías absolutamente nada de \\ esa estridencia amarilla convulsa previa a tu nacimiento, \\ esa emulsión estriada donde corrían los muertos...» \\ Rayuela (Julio Cortázar) ${ }^{197}$ \\ "Sigue, pues, sigue cuchillo, \\ volando, hiriendo. Algún día \\ se pondrá el tiempo amarillo \\ sobre mi fotografía.» \\ El rayo que no cesa (Miguel Hernández) ${ }^{198}$
}

«Las fotografías, cuando se ajan, ensucian, manchan, resquebrajan y amarillean, conservan un buen aspecto; con frecuencia mejoran. La fotografía transforma la belleza de las ruinas (...) en un gusto genuinamente popular.» Sobre la fotografía (Susan Sontag) ${ }^{199}$

\footnotetext{
${ }^{196}$ HENNING, Michelle, op. cit., p. 289.

${ }^{197}$ CORTÁZAR, Julio, Rayuela, Madrid: Cátedra, 2005, p. 124.

198 HERNÁNDEZ, Miguel, “El rayo que no cesa” en FERRIS, José Luis (ed.) Miguel Hernández. Breve antología poética, Alicante: Fundación Cultural Miguel Hernández, 2000, p. 38.

199 SONTAG, Susan, Sobre la fotografía. Para esta cita he escogido la traducción de Carlos Gardiní que puede leerse en Editorial Sudamericana (Buenos Aires, 1980, p. 25) y Edhasa (Barcelona, 1992) en lugar de la revisada y más afortunada de Aurelio Major para Alfaguara (México D. F., 2006, p. 171). En esta última se traduce el "faded" original (On photography, Nueva York: Rosetta Books, 2005, p. 62) por "palidecen". La razón para esta fraudulenta elección puede apreciarse a simple vista: mantener la constante del amarillo.
} 
La nueva imagen digital se había mostrado en sintonía con la representación cinematográfica institucional. Aquella prendida en un punto de vista de ortogonal, pulcramente encuadrara y todo lo nítida que permitía apreciar la fisiología humana. La eterna pantalla albertiana invocando al mundo. Pared rota por una ilusión que la convertía en transitable. La era de la iconofagia tuvo su apogeo con el despegue y la consolidación del digital. Imágenes cristalinas en su doble valor semántico e icónico: limpias y comprensibles en primera instancia. Imágenes panópticas, siluetas pluscuamperfectas, campos visuales abigarrados, proyecciones desmesuradas que parecían buscar la succión. La imagen cinematográfica quería desbordar pero, en su intento, solo satisfacía ad náuseam la nostalgia por el control del territorio. El exceso reduce nuestra capacidad predictiva. Y, en épocas de cómoda saturación y de aparente perfección, surgen los mitos reaccionarios, las restauraciones políticas, las teorías de la conspiración, los nacionalismos y las utopías sentimentales. Del buen salvaje a los Iluminados pasando por el Locus amoenus.

Como una variante de esas nostalgias, el siglo XXI ha conocido creadores y espectadores que añoran la sábana virginal. Su condición desnuda y su planitud. Pero también la distancia, la imperfección y la ruina. Los trazos sueltos, insinuantes o desagradables, pero siempre dispuestos a satisfacer nuestro ansia por zurcir. En el fondo de las imágenes del nuevo milenio, seguían latiendo la pureza y el peligro de un filme lírico. Esto es, la aventura de un filme blanco y de un filme deforme, de un anti-filme sobre el que filmar o imaginar nuestra propia historia. La iconofagia tampoco nos había vacunado contra la nostalgia primigenia. La nostalgia del horizonte y de la roca por pintar. La nostalgia de un paisaje ${ }^{200}$ simple y hostil que fue todo lo contrario de la Arcadia. Nostalgia no trazable desde el mito clásico, sino desde nuestra configuración cerebral. La misma que fue evolucionando a lo largo del Pleistoceno. Siempre intentando adivinar qué peligros y qué virtudes se escondían tras aquel horizonte. Siempre intentando adivinar qué animal se escondía tras aquel recodo.

\footnotetext{
Fiebre amarilla, lánguido sol del membrillo; pátina desvaída, ictericia iconográfica.

${ }^{200}$ La importancia del paisaje en nuestra sensibilidad solo se puede apreciar en toda su dimensión desde postulados de la psicología evolucionista. La historia de los paisajes artísticos nos habla de otros factores, muchos de ellos coyunturales, pero no de la raíz biológica: nuestro habitar prehistórico. En ocasiones, experimentos tan discutibles como los de Komar y Melamid pueden iluminar nuestra pulsión paisajística innata: <http://awp.diaart.org/km/index.php/> [consulta: 25-08-2015].

Denis Dutton, entre otros, siempre ha mostrado especial preocupación por este aspecto.

DUTTON, Denis, "America's Most Wanted, and why no one wants it" en Philosophy and Literature, no 22, 1998, pp. 530.543. DUTTON, Denis, "Paisaje y anhelo" en El instinto del arte, op. cit., pp. 29-48. DISSANAYAKE, Ellen, "Komar and Melamid discover Pleistocene taste" en Philosophy and Literature, no 22, 1998, pp. 486-496.
} 
Solo pretendo argumentar que el regreso al pasado es posible, pero no desde el indigenismo cinematográfico. El pasado no regresa porque ya lo llevamos incorporado en nuestro cuerpo. En cierto modo, nuestro cuerpo no es más que un paisaje del pasado. De ahí que las nostalgias relacionadas con las imágenes posean una doble vertiente: la individual y la histórica. No se añora simplemente un estado del yo anterior, se añora el tiempo histórico donde estaba la inscripción de aquel yo. La nostalgia deviene, así, sentimiento unificador del dualismo cuerpohistoria. Convertida en uno de los sentimientos que con mayor fuerza han punteado las estéticas contemporáneas, podría asegurarse que la nostalgia devino eje sobre el que se anudó un auténtico metarrelato: el de una modernidad melancólica ${ }^{201}$ donde la constitución y la expresión del ser presentaban desperfectos.

La nostalgia opera, así, desde un presente que desea restituir un pasado para validarlo de cara a un futuro. Pero, cuidado, también desde un presente que desea imaginar un futuro que incorpore reminiscencias del pasado. Además, la nostalgia puede despertar el anhelo de promesas incumplidas pero arraigadas en el afecto y en el acervo. La nostalgia puede desear el regreso a aquello que nunca existió -la descorporeización-, y puede desear volver donde nunca se estuvo -el Pleistoceno, el espacio exterior-. Es menos complejo de lo que parece si nos acordamos de la fuga histórica como metodología positiva o contrafactual, y de la querencia de la ciencia ficción por el retrofuturismo.

Como decía Boym ${ }^{202}$, la nostalgia es la rebelión contra la irreversibilidad de un tiempo histórico ligado al progreso. Porque el progreso es compatible con la ausencia de razón y porque la ruina como entidad aberrante ilustra como ningún otro objeto la ausencia o la fragmentación de dicha razón. En un tiempo donde se cruzan en la escalera la cultura y el consumismo -¿cuál sube y cuál baja?-, la ironía y la nostalgia son las dos herramientas que hemos encontrado para aliviar las tensiones derivadas del uso - para algunos fraudulento- que hizo del pasado y del futuro la posmodernidad. ${ }^{203}$ El tiempo y el orbe globalizado no curan la nostalgia, la agudizan. Christine Ross, tras analizar una serie de exposiciones e instalaciones contemporáneas protagonizadas por medios audiovisuales, llegaba a la conclusión de que todas escondían la

\footnotetext{
${ }^{201}$ MOLINUEVO, José Luis, Retorno a la imagen. Estética del cine en la modernidad melancólica, op. cit., p. 211.

202 BOYM, Svetlana, The future of nostalgia, Nueva York: Basic Books, 2001, pp xv y 22.

${ }^{203}$ TRIGG, Dylan, The aesthetics of decay. Nothingness, nostalgia, and the absence of reason, Nueva York: Peter Lang, 2006, pp. xvii y 76.
} 
misma pregunta: ¿Qué tipo de futuro se puede construir una vez que la idea de progreso se ha evaporado de su contenido? ? $^{204}$

Para ir concluyendo. Es por esta capacidad para convertir -si bien de manera imaginaria- un tiempo en un espacio, que la nostalgia se convierte en una herramienta ética y creativa. La nostalgia ha pasado de ser un tabú y una intimidad, a una reivindicación pública. Entre otros motivos, porque ejecuta el tránsito que va de la emoción biológica bruta a la representación artística refinada pasando por el filtro moral. Por lo tanto, es un instrumento valioso para las imágenes y para el cine. La nostalgia ayuda a materializar el tiempo y la conciencia con y en la imagen. El utilitarismo de la nostalgia crece porque, además, acepta las reconstrucciones y las predicciones fragmentarias y fetichistas. Basta con recuperar un encuadre, un objeto, una frase o un olor para que nuestra memoria ejecute el relato. La nostalgia nos convierte en lo que de verdad somos: alumnos de un Actor's Studio colectivo, pero a la vez íntimo. La nostalgia nos ayuda a recordar que somos un actor interpretándose a sí mismo. Somos los constructores de nuestra propia Matrix.

La nostalgia no sirve para oponer número y luz, circuito integrado y cruz de malta, píxel y grano, capa y emulsión, moviola y computadora, bobina y disco duro... idea e imagen, flujo y materia. La nostalgia, bien utilizada y como excelente emoción impura, puede servir para darnos cuenta de que muchos de los pares no son antagónicos, sino variaciones de una melodía. En conclusión, la imagen deviene nostos etimológico. Lugar de recogimiento y de consuelo frente a la punzante -algia. La imagen melancólica es aquella que quiere fijar un paisaje puro de la manera más impura posible. ${ }^{205}$ Es decir, la ilustración de lo recobrado puede conllevar una suerte de culpabilidad y de mortificación enunciadas mediante la excitación de la materia. La imagen nostálgica es, en fondo y forma, una imagen epicúrea: material, matérica y lenitiva.

\footnotetext{
${ }^{204}$ ROSS, Christine, The past is the present; It's the future too. The temporal turn in contemporary art, Londres: Bloomsbury Publishing, 2012.

${ }^{205}$ Pienso en la cantidad de filmes con aire ensayístico y experimental construidos a partir de películas caseras. Pip Chodorov iniciaba su documental Free radicals. A history of Experimental Film (DVD disponible en los sellos Re:Voir y Kino Lorber, 2012) poniendo en práctica esta idea del paisaje puro excitado por una materia impura. El director recuperaba unas películas caseras descompuestas no solo por el tiempo, también por el orín de un perro. En términos más neorrománticos, pero compartiendo sentido, existe un filme -quizá el único- que ha conseguido adaptar fielmente las ideas de Barthes sin saberlo -o eso creo- Mort à Vignole (1998) del genial Oliver Smolders.
} 


\subsection{La educación sentimental}

«Se lo contaron muchas veces, Completando cada uno los recuerdos del otro.

Y cuando acabaron:

-Esa fue nuestra mejor aventura-dijo Frédéric. -Sí, quizá sea nuestra mejor aventura-repuso Deslauriers. La educación sentimental (Gustav Flaubert, 1869) ${ }^{206}$

Una de las características más llamativas de la nostalgia contemporánea es su enorme influencia sobre la población joven o recién entrada en la madurez.

Este tipo de nostalgia no es tanto la expresión de una vejez prematura, como la de un descontento real y no sé hasta qué punto justificado. Es, también, una nostalgia azuzada por un modelo vigente que ha encontrado en los individuos de la primera madurez el target publicitario oportuno. Siempre he sentido curiosidad por este fenómeno. Por entender cómo y porqué la generación a la que yo pertenezco -así como las adyacentes- ha querido regresar a lo que nunca conoció o a lo que nunca utilizó. Por ejemplo, a los formatos fotográficos subestándar. Por no hablar de todo lo que engloba el fenómeno vintage. Encuentro sentido a una nostalgia por ciertas imágenes low-res típicas del vídeo doméstico, de los primeros videojuegos y de las videocámaras primitivas, pero sigo en ascuas respecto a esa sensibilidad que podría desplegarse bajo el título de Memorias del Cinexin. Sobre todo porque todos estos sentimientos han adquirido carácter global, en absoluto restringidos a los simpatizantes y conocedores del cine experimental. Es como si Miroslav Tichý se hubiera dedicado a inseminar compulsivamente a nuestras madres allá por los setenta y los ochenta.

A veces he pensado cómo puede irritar tanto nuestro depósito de imágenes ideales, el acto por fortuna cada vez más frecuente- de redescubrir recién restaurada ${ }^{207}$ aquella película muda

\footnotetext{
${ }^{206}$ FLAUBERT, Gustav, La educación sentimental, Barcelona: Mondadori, 2005, p. 518.

207 Esta idea de la restauración nos devuelve a las disputas arquitectónicas del siglo XIX entre Ruskin y Viollet le Duc. Parecía que el cine no podía caer en un conflicto de ese tipo, pero lo hizo. Y no hablo de los típicos remontajes historicistas que han sufrido ciertas películas, sino de respetar o de mejorar los elementos originales de un filme deteriorado. La polémica parece superada, pero en su momento estuvo vigente hasta el punto de considerar blasfemo mejorar un sonido craquelado porque suponía violentar la peripecia y el contexto de una filmación precaria. Véase: BORDE, Raymond, "La restauración de los films: problemas éticos" en Los archivos cinematográficos, Valencia: Filmoteca de la Generalitat Valenciana, 1991, pp. 195-213.

La postura de Borde quería ser histórica, pero era puramente romántica: “una especie de alegría artesanal y un placer táctil que son irremplazables: es un oficio artístico (...) el manejo amoroso del
} 
que convertimos en tótem cinéfilo. Sus imágenes no podían ser tan limpias. Los cuerpos no podían moverse con tanta naturalidad. La original era la otra, la de los cuerpos espasmódicos que se habían acantonado en una decrépita cinta VHS cuyo árbol genealógico echaba raíces en la noche de los tiempos. Pátina d'antico, hija del tiempo y de la historia, espectadora del sentimiento. El terrible poder de la pátina fotoquímica sumada a la distorsión electrónica. El Expresionismo era eso. Algún día veremos Del alba a la medianoche (Von morgens bis mitternacht, Karl Heinz Martin, 1920) restaurada en sus elementos originales y nos daremos con el codo durante su visionado. Sin apenas contener la risa, murmurando que falta un cartel prendido en los decorados con un "Recién pintado". Ruskin ${ }^{208}$ se habría inflamado cual nitrato de celulosa caminando entre las ruinas de cualquier paisaje con roña posindustrial. Peripatético, perseguido y respondiendo las preguntas de un pelotón de jóvenes aprendices.

A partir de un cuestionario ${ }^{209}$ y de las conversaciones que he mantenido con una serie de creadores, investigadores, docentes, profesionales de la imagen y de simples aficionados a lo que yo he llamado la obsolescencia creativa y contemplativa, he extraído cinco conclusiones básicas. Primera, la horquilla de edad abarca de los treinta a los cuarenta años. Rara vez más o menos. Segunda, a mi pregunta sobre las motivaciones que le condujeron a buscar esas imágenes del pasado, dos ideas -camuflada en diferentes expresiones- eran recurrentes: la obtención de cierto placer estético y una actitud disidente o reivindicativa frente a lo establecido. Tercera, preguntados por otras razones suplementarias, una me llamó la atención por común y por -nunca mejor dicho- reveladora: la atracción por la visibilidad y la temporalidad de los procesos. Cuarta, preguntados si las imágenes digitales de baja calidad o con desperfectos les producían un interés o placer parecidos, predominó el no. Lo más curioso de todo es que a la pregunta de si se consideraban nostálgicos, muy pocos dieron el sí. Quinta, dados a elegir entre una serie de cualidades diferenciales entre la imagen analógica y la digital, destacó sobremanera la de materialidad.

objeto. Defiendo el cuadro, el libro y el film contra el desierto gris de las señales invisibles." (Ibíd., p. 191) Este romanticismo-fetichista respecto al celuloide y a otros materiales hoy sigue presente.

${ }^{208}$ RUSKIN, John, The poetry of architecture, en gutenberg.org, <http://www.gutenberg.org/files/17774/17774-h/17774-h.htm> [consulta: 04-09-2015] RUSKIN, John, Las siete lámparas de la arquitectura, Barcelona: Alta Fulla, 1997.

${ }^{209}$ El ejercicio fue, ante todo, un acto de responsabilidad y pudor. No podía hablar de sentimientos ajenos y globales sin, bibliografía al margen, intentar escuchar una muestra significativa. El problema: para obtener dicha muestra eran necesarios unos medios, un tiempo y unos conocimientos demoscópicos de los que carezco. No puedo otorgarle ese valor demoscópico por dos razones básicas: el universo y las propias preguntas. El primero, insuficiente (medio centenar de entrevistas orales y escritas); las segundas, sesgadas. Era la única manera de obtener cierta orientación. En todo caso, agradezco la atención, la amabilidad y la sabiduría de todos aquellos que participaron. 
La edad corresponde a una generación no sobreprotegida, pero sí instalada en cierto bienestar familiar, lo cual no es equivalente a un estatus social acomodado. Generación muy bien educada y formada, con alta estima por el respeto y hasta por las jerarquías, pero algo pusilánime. El placer que muchos dicen o decimos obtener, interpreto que responde a una sensibilidad no tan cercana a la de un atribulado esteta romántico. Esto es, existe un placer hiriente, pero está más encaminado al placer como destete de la conciencia o como segunda iniciación. La sensualidad y el arrebatamiento ausentes en la molicie social donde se han criado. Algo que, por otra parte, es una cuestión inherente a toda la historia del arte. El exceso y la deformación como instrumentos para la erotización de lo real. Ahí cabe recuperar nuestra pasión ancestral por las narrativas religiosas, míticas y paranormales. ${ }^{210}$

En cuanto a la disidencia, tiene tanto que ver con lo que declaraban ${ }^{211}$ los cineastas de las vanguardias de la segunda mitad del XX, como con la labor crítica de las ruinas contemporáneas analizadas por Dylan Trigg. ${ }^{212}$ La destrucción como primer símbolo de un capitalismo fermentado. La imagen-ruina como visión de un progreso mezquino. Buscar en esa desilusión personal y colectiva hasta hallar una magnífica miseria ${ }^{213}$, un esplendor recóndito. Revertir -volver sensible- la celebración y la espectacularización inseparable de toda ceremonia de la destrucción. Esto es, hay cierta -quizá tenue- relación entre la orientación estética y la ideológica. Es este un aspecto importante porque, en un principio, podría suponerse de antemano -tal era mi idea preconcebida- que una vez superadas décadas de mayor agitación política, iba a predominar el esteticismo sobre cualquier otra consideración. Merecería la pena profundizar en esta línea de la investigación.

Por último, el acceso mecánico y sentimental a los procesos de creación y disfrute es otro síntoma de esta melancolía de la modernidad. Diría más, es un falso síntoma porque se formula por oposición sobre la invisibilidad de gran parte de los procesos relativos a las imágenes comerciales digitales y de síntesis. Se quiere ver y buscar en ellos una suerte

\footnotetext{
${ }^{210}$ Existe una correlación evidente entre la imagen indigente, hipoformalizada o de baja resolución y el suceso paranormal. Del célebre y degradado $16 \mathrm{~mm}$. de Patterson-Gimlin (1967) o las múltiples grabaciones de Nessie y demás criptofauna, pasando por las pareidolias marcianas y los sucesos ovni, hasta llegar a la estética de la Bruja de Blair y a los vídeos digitales de la era fake y viral. No sabría establecer qué tanto por ciento de las películas de terror contemporáneo incorporan la imagen indigente como artilugio pasajero o vehicular, pero siempre pertinente. El porcentaje debe ser realmente elevado.

${ }^{211}$ Véase el imprescindible catálogo: KILCHESTY, Albert (ed.), Big as life. An american history of $8 \mathrm{~mm}$ films, San Francisco: Cinematograph y San Francisco Cinematheque, 1998.

${ }^{212}$ TRIGG, Dylan, op. cit., 2006.

${ }^{213}$ MOLINUEVO, José Luis, Magnífica miseria. Dialéctica del Romanticismo, Murcia: Cendeac, 2009.
} 
rematerialización, obviando que en los otros modos de producción también siguen existiendo. El sentimiento prevalece sobre la razón. Esto es, la modernidad melancólica transita y se hibrida con una melancolía neorromántica. Personalmente -y así se lo hice saber a algunos de mis conversadores- creo que un "libro" como Recipes for disaster ${ }^{214}$, que por idea y por formato se ha convertido muy a su pesar en canónico, no difiere en lo sustancial de un manual de programación informática o, si se quiere, de uno de los múltiples no-manuales o antimanuales hacker. No saber apreciar el código, ignorar toda su periferia y su logística, no implica ni su desaparición, ni su invisibilidad.

Creo que cuando James Benning filmó Stemple Pass (2012), convirtió esta metáfora en realidad. De hecho existe otro nexo evidente entre la ruina analógica y la perfección digital: en sus dos diferentes versiones de lo inacabado, ambas quedan irónicamente completadas.

\subsection{Kit de supervivencia}

Finalmente, quiero definir la desmaterialización como una opacidad. Como el burka que las sociedades posindustriales han colocado sobre el rostro de la logística y de la mediación tecnológica. Como la falacia que quería salvar el abismo conceptual entre espacio metafórico y espacio real. Cuando Toscano y Kinkle se decidieron a cartografiar el capitalismo, es decir, a cartografiar lo absoluto, se encontraron con este problema: cómo cartografiar lo invisible. ${ }^{215} \mathrm{El}$ primer paso fue convertir lo invisible en algo inteligible: lo invisible es solo aquello que se quiere ocultar, no aquello que es, materialmente, imposible de ver.

Privarnos de la visión de la tramoya responde a dos razones básicas: carece de erótica -es poco o nada penetrante-, y constituye un indicio revelador de los medios de producción. Los autores parten del mapa cognitivo ${ }^{216}$ de Jameson. Una fórmula que asumía y validaba -de manera crítica y hasta invertida- la funcionalidad de la teoría de la conspiración para desentrañar el escenario. ¿Cómo ver el capitalismo? El mapa cognitivo se encargaba de

\footnotetext{
${ }^{214}$ HILL, Helen (ed.), Recipes for disaster. A handcrafted film cookbooklet, Nueva Orleans, 2005. El libro toma el nombre y el formato del célebre opúsculo anarquista elaborado por un colectivo anónimo: Recipes for disaster. An anarchist cookbook, Olympia: CrimethInc, 2004.

Existen libros más convencionales sobre el asunto, por citar el último conocido: WOLOSHEN, Steven, Scratch, crackle \& pop. A whole grains approach to making films without a camera, Montreal: Scratchatopia Books, 2015. Woloshen, autor, a su vez, de una antisecuela del libro de Hill: Recipes for reconstruction, Montreal: Scratchatopia Books, 2010.

${ }^{215}$ KINKLE, Jeff; TOSCANO, Alberto, Cartographies of the absolute, Alresford: Zero Books, 2015.

${ }^{216}$ JAMESON, Fredric, La estética geopolítica. Cine y espacio en el sistema mundial, Barcelona: Paidós, 1995, p. 29.
} 
discernir, para luego representar el espacio público y las relaciones sociales durante una época -posmoderna- de ocultamiento y disfraz sistémico.

Toscano y Kinkle utilizan de manera brillante -con Allan Sekula en el recuerdo- la poética del container. Barcos descomunales surcando el océano repletos de contenedores tan simples y funcionales como horrorosos. Solitarios, ajenos a un mundo que solo pueden transitar de acuerdo a un rumbo prefijado. Naves mecidas por la rizada. Mastodontes que más tarde se desguazan -se desmaterializan- en la intimidad de los astilleros o en las remotas costas del tercer mundo donde solo llega la cámara de Peter Hutton. Para los autores -y para mí-, esa es la verdadera conectividad y la inmaterialidad de una nueva economía que prefiere mostrar la tersura de su rostro virtual en lugar del rictus ceñudo de de los paisajes donde acontece la materia. En todos esos paisajes manufacturados de Jennifer Baichwal (2006). Es a través de esta perversa dialéctica hide and seek, por donde se ha intentado despojar a la narración y a la materia de sus funciones y compromisos esenciales para con la imagen.

En cierta manera, cuando el capitalismo nos escamoteaba la trastienda, solo estaba reinventado la grazia vasariana. Un nexo nada forzado porque, a través de Vasari, podemos ligar el ansia desmaterializadora contemporánea con el neoplatonismo de donde él cosechó la idea. La necesidad de una imagen ideal que cubriera la imagen material. La grazia guiaba el giudizio -la intuición visual- del espectador. En una de sus acepciones ${ }^{217}$, la grazia de Vasari era aquella refinada, delicada y etérea cualidad que, al hacer presencia, permitía que la superficie de la obra ocultara cualquier atisbo del trabajo anterior, de la vulgar y sucia rutina de los procesos. Arnheim siempre decía que la buena forma lo era porque pasaba desapercibida. El sudor, mucho antes de que Nixon transpirara en el primer debate televisado de la historia (1960), siempre ha estado proscrito por la estética y por la política. Que suden los otros.

Es imposible negar que muchas imágenes contemporáneas han seguido el camino de la grazia. Ocultar el dispositivo o, en su defecto, embellecerlo. Hasta un subgénero documental-debería haber puesto publicitario- como el making of ha tenido que ser fuertemente erotizado para proceder a su empaquetado. El cine comercial ha sido paradigmático, pero ni mucho menos monolítico. Hoy seguimos recordando la insuperable perfección de Lubitsch y, en el mejor de los casos, recuperamos la anécdota del piano como esforzada instancia precedente. Aun nos

\footnotetext{
${ }^{217}$ La grazia es un término versátil, huidizo y mudable. Cuenta con una larga historia y con numerosos conceptos hermanados. BARASCH, Moshe, Teorías del arte. De Platón a Winckelmann, Madrid: Alianza, 1996, pp. 180-187.
} 
resistimos a aceptar que Lubitsch solo volvía con la perfección aprendida después de tirar de la cadena.

Trasladando estas ideas a la práctica, la supervivencia de la materia, en tanto elemento decisivo en la formación y en la mediación de las imágenes, atiende a criterios de magnitud y de género. Aumont, como un turista plano en mano, preguntaba por el lugar de la imagen donde circunscribir la materia... “¿en la película?, ¿en la luz?, ¿en la pantalla?, ¿nada de esto?". ${ }^{218}$ La dificultad para encontrarla radica en el maquillaje y en nuestra predisposición natural para obviarla. Muchos de los rastros de la materia en la imagen, sean trazos en bruto o ya in-formados, son fácilmente eludidos por nuestra percepción. Eliminamos la materia de la ecuación con idéntica facilidad a como rellenamos la ausencias en los patrones visuales y en las palabras. O quizá sería más acertado decir que, una vez percibida, la materia de la imagen es rápidamente enviada al mismo pozo donde viven nuestros monstruos. La materia es el sustrato donde germina el trauma. Tal es el destino donde la facturamos: a la mazmorra del inconsciente.

Materia maquillada y/o escondida por el modelo socioeconómico. Materia reprimida por nuestro sistema cognitivo y emocional. $\mathrm{Y}$ en una instancia intermedia: materia olvidada $\mathrm{e}$ ignorada por "la voz dominante de la crítica". ${ }^{219}$ Olvidada porque, como sucedía con el cuerpo y con el hardware, le incomodaba. Pocas veces la materia en sí misma, despojada de todo sentimentalismo -incluido el marxista- ha servido a los propósitos de las tres grandes corrientes históricas de la crítica cinematográfica: la tardomarxista, la neorromántica y la neocristiana. Las tres profundamente trasnochadas. La cinefilia, simplemente, nunca llegó a discernir lo suficiente como para dudar entre utilizarla o ignorarla. Porque el asunto de la materia de la imagen y de la materia en la imagen, ha quedado reducida a un discurso insignificante y ridículo sobre las texturas. Críticos y teóricos de cine que creyeron ponerse al día por describir una superficie utilizando jerga de cocineros.

Bellour rescataba la materia de la imagen del ostracismo o, en el mejor de los casos de una supervivencia angustiosa, hasta restituir sus valores. La siguiente cita viene a confirmar que en términos de imagen- narración y materia no solo comparten genoma, también están interconectadas por las activaciones epigenéticas que generan la Historia y de la Estética.

\footnotetext{
${ }^{218}$ AUMONT, Jacques, Materia de imágenes, redux, op. cit., p. 17.

${ }^{219}$ Ibíd., p. 11
} 
Lo difícil de concebir, pero es algo crucial, es que en cuanto se ha iniciado una mínima narratividad (...) lo que se convierte en relato es la realidad material de la propia imagen, antes que cualquier prescripción del orden del lenguaje. ${ }^{220}$

Matizaría a Bellour en algo, también, crucial: existe la serie posibilidad de que haya sido la propia disposición de la materia la que ha dado pie -puede que de manera subrepticia- a la narratividad. Los afectos y las emociones se convierten en elementos banales de la imagen si no somos conscientes de que anidan en una materia narrativa o, si se prefiere, en una narración material.

En lo que a mi postura concierne debo realizar nuevos apuntes. Por un lado, conviene ir desechando la idea que atribuye en exclusiva al cine convencional o comercial el enmascaramiento y el camuflaje de lo matérico. Es quien más lo ha practicado, pero no de manera tan tiránica como el modelo socioeconómico que lo alberga. La pulcritud y la alta iconicidad de ese tipo de imágenes han sido una extensión simbólica del clima neoconservador que ha dominado las sociedades del nuevo milenio. Borrado de huellas y prurito de infalibilidad para atenuar la psicosis desatadas por el terrorismo y por pandemias que nunca acontecen. $\mathrm{O}$ que solo acontecen en el tercer mundo. Por el otro lado, conviene ampliar el rango de supervivencia de la materia allende las fronteras de la creación marginal, experimental e independiente.

Como no he vetado la aparición de la materia en todos los medios audiovisuales digitales entre los que se incluye el denominado cine mainstream- y como, además, defiendo su imposible grado cero de y en las imágenes, debo realizar otra pregunta. ¿Cómo y dónde apreciar la materia en esos medios? El gran problema de identificar la materia parte de su integración en una trastienda no ya política o social, sino cosmológica. Como hemos podido comprobar desde el desarrollo de la física moderna, todo eso que parece constituir nuestro universo no se aviene al sentido común. Al contrario, es poderosamente antiintuitivo. $Y$ lo es hasta límites exasperantes. Para intentar responder a la pregunta anterior apelo a la voluntad taxonómica.

- La emulación textural. Las estéticas del filtro. Bien en plena creación, bien en postproducción o mediante la fusión de ambas. Ya sea emular un filme del periodo

\footnotetext{
${ }^{220}$ BELLOUR, Raymond, op. cit., p. 191.
} 
silente, del Hollywood dorado, un Grindhouse, un filme familiar o de aficionado o cualquiera de los diferentes tipos de deterioros del celuloide. ${ }^{221}$ Hoy sigue resultando enternecedor cómo ciertos subgéneros del audiovisual -publicidad, videoclip, reportaje, noticias, transiciones, autopromociones, etc.-, instalados en una digitalización menos boyante de lo que nos quieren mostrar, recurren al efecto y al filtro de ruido cuando quieren subrayar que están mostrando imágenes cinematográficas. El deterioro, quién lo iba a decir, como signo de distinción de la imagen. Esa imagen histórica y hasta aristocrática solo es concebible si muestra las páginas arañadas y el blasón estriado.

- Hipertrofia o desproporción en alguno de los componentes escalares. El caso de los grandes formatos panorámicos, de las tecnologías envolventes, del IMAX y de las 3D. Toda una historia del cine a través del formato gigante. Lo que para algunos siempre fue grandeur, para otros solo era pompier. Como en aquella contestación de Jacques Dutronc, el mejor Van Gogh cinematográfico (Van Gogh, Maurice Pialat, 1991), a la interpelación de un colega: - El formato grande, siempre la grandilocuencia. - Será maricón.

- Formas internas o trucos ópticos que desvelan o que proponen un juego geométrico con el encuadre. Recursos plásticos que de manera mordaz, crítica o metanarrativa matizan la pantalla como fiel o falso reflejo del formato. Deformaciones y anamorfosis.

- Degradación e insuficiencias tecnológicas que pueden responder a criterios intencionales, azarosos o, simplemente, al mayor o menor grado de desarrollo en el que se encuentra la tecnología aplicada. El caso de la incompatibilidad entre tecnologías, datos y formatos. El caso de la codificación de la información icónica. La

\footnotetext{
${ }^{221}$ Véase la exhaustiva e ilustrada catalogación realizada por Alfonso del Amo García en: Inspección técnica de materiales en el archivo de una filmoteca, Madrid: Cuadernos de la Filmoteca no 3 , segunda edición electrónica de noviembre del 2007, pp. 64-85.

Para un conocimiento serio de las causas del deterioro y de las diferencias existentes entre los procesos químicos (humedad, microorganismos, síndrome del vinagre, viscosidad, inflamación, etc.) y mecánicos (espesor, contracción, elasticidad, tracciones, empalme, adherencia, etc.), así como entre los procesos de envejecimiento artificial y natural de los materiales fotoquímicos: Del AMO GARCÍA, Alfonso; CATALINA, Fernando, Los soportes de la cinematografía 2, Madrid: Cuadernos de la Filmoteca, no 6, 1999. También puede consultarse el catálogo de la exposición La imagen rescatada, Valencia: Filmoteca de la Generalitat Valenciana, 1995.
} 
pérdida de datos entre sucesivas generaciones por transcodificación y reescalado. ${ }^{222}$ Toda imagen digital comercial es una imagen de pérdida algorítmicamente comprimida. El raw, lo más cercano en fotografía a un hipotético negativo lossless, no tiene cabida en el mercado, solo en el laboratorio.

- Las estéticas del desperfecto. Todos los fenómenos que pueden encontrar cobijo en el supraconjunto del digital artifact y del digital noise. En términos informáticos, la backdoor por la que se ha introducido el transmedia y el arte postdigital. El databending, el glitch art $^{223}$, el bug, las aberraciones cromáticas (saturaciones, posterización y solarización, efecto negativo, descomposiciones del RGB y del histograma de color), activismo hacker, la distorsión: el vortex, el entrelazado, el efecto warped, liquify, aliasing, etc., la performance ludita.

- Incorporaciones y fusiones con la obsolescencia tecnológica -no solo analógica- creativa: el pixel art, de los 2 a los 16 bits, la lomografía, efectos estenopéicos, el scratch video, el VHS y el digital8, el subestándar fotoquímico, ampliaciones entre diferentes pasos de películas, la retroelectrónica, bucles, redundancias y retroalimentación.

${ }^{222}$ Surgieron y siguen haciéndolo numerosos creadores que ven en la compresión digital una herramienta estética. No me resisto a señalar uno especialmente brillante. Fernando Franco realizó un ejercicio que conciliaba en términos estéticos e históricos la hipoformalización analógica con el desperfecto y la compresión digital. Me refiero a la inocente cabecera para la edición del Festival Punto de Vista del año 2011. En la descripción del vídeo que procedo a enlazar se explica con corrección el contexto y la metodología:

$<$ https://www.youtube.com/watch?v=Y-ynYdEoqMw> [consulta: 29-10-2015]

${ }^{223} \mathrm{El}$ glitch art se ha convertido en la práctica más reconocida. Una de las pocas que ha despertado interés teórico serio. Sin ser capaz de advertir cómo será su desarrollo en términos temporales y estéticos -muchos de estos fenómenos son efímeros-, cabe reseñar algunos de los estudios que se han preocupado de él. El más completo, a mi juicio: KRAPP, Peter, Noise Channels. Glitch and error in digital culture, Minneapolis: University of Minnesota Press, 2011. Algo más parciales y jugando con el formato y las imágenes como parte del contenido: MORANDI, Iman (ed.), Glitch. Designing imperfection, Nueva York: Mark Batty Publisher, 2009 y MENKMAN, Rosa, The glitch moment(um), Amsterdam: Institute of Network Cultures, 2011. Menkman es autora de una suerte de manifiesto ("Glitch Studies Manifesto") en ocho puntos: LOVINK, Geert; SOMERS MILES, Rachel (eds.), Video vortex II. Moving images beyond Youtube, Amsterdam: Institute of Network Cultures, 2011, pp. 336-347.

La publicación Virose le dedicó un temprano monográfico en el verano del 2008: "Errors and glitches" <http://virose.pt/vector/> [consulta: 31-08-2015]. El opúsculo de Pedro Ajo: La estética del error en la era digital, información de publicación desconocida.

A raíz del triunfo masivo en la Red gracias a plataformas como Tumblr, los textos sobre el glitch art y sus derivados han florecido -menos de lo que yo personalmente esperaba- en blogs y revistas online. 
- Incorporaciones y fusiones con las estéticas lo-fi y low-res de la Red: videovigilancia, Youtube, Live Leak, Vine, webcams, videochats, Instagram. El GIF y el anaglifo, el mahsup, la animutation, el poop video, el viral, etc.

- Bioimagen y utilería científica: radiografía y tomografía, microscopías, visión térmica y nocturna, figuras de Lichtenberg, visión subjetiva, osciloscopios y despliegues del interfaz. Residuos materiales (polvo) y lumínicos (glare).

- $\quad$ Las estéticas del número: el big data y el data art, el software art y el arte generativo. $^{224}$

En el otro bando, lo matérico siempre ha estado presente de manera menos oblicua. La representación epidérmica apenas puede renegar de su dermis material. Lejos de dormir el sueño de justos en los museos o de quedar reducidas a prácticas endogámicas y residuales, hoy siguen estando vigentes. Una larga tradición experimental, a menudo sindicada con las diferentes vanguardias cinematográficas, ha rescatado prácticas históricas justo en ese instante crítico donde las creaciones, antes de convertirse en clásicas o en ancianas respetables, son solamente viejas. Además, como anuncié, estos ejercicios poseen todavía una capacidad sobresaliente para contaminar al resto de modelos.

- $\quad$ El cine estructural y el videoarte. Los formatos subestándar. El cine amateur, la música visual y la animación abstracta.

- El trabajo con materiales de archivo, independientemente de su paso o formato. El reciclaje y la apropiación, el documental de archivo y compilación, el collage, el desmontaje ${ }^{225}$, el found footage. ${ }^{226}$

- La degradación material deliberada o azarosa. El banal trajín en las diferentes instancias del dispositivo, la refotografía estética y la destrucción instantánea o progresiva.

\footnotetext{
${ }^{224}$ En España, creadores individuales al margen, hay un espacio colectivo de creación y reflexión sobre estos y otros fenómenos citados en apartados anteriores: <http://www.arteklab.org/> [consulta: 29-102015]

${ }^{225}$ BONET, Eugeni (coord.), Desmontaje: Film, vídeo/apropiación, reciclaje, Valencia: IVAM et. al., 1993.

${ }^{226}$ WEINRICHTER, Antonio, Metraje encontrado. La apropiación en el cine documental y experimental, Pamplona: Fondo de Publicaciones del Gobierno de Navarra, Colección Punto de Vista, no4, 2009.
} 
- $\quad$ Las acciones directas -obviando las de la luz- sobre el soporte fotoquímico. Rayado, dibujo, pintura, adhesión de materiales orgánicos e inorgánicos.

- Uso de materiales inadecuados o defectuosos. Jonas Mekas ironizaba sobre aquellos que alababan su pericia para conseguir matices y efectos inauditos con el blanco y negro. Salían así porque compraba la película virgen que podía, la más barata. Por regla general caducada. Lo mismo que sucedía con aquellos tonos crudos y macilentos en Roma ciudad abierta (Roma città aperta, 1945). ${ }^{227}$

Rodowick $^{228}$ quería ver en el paso de las herramientas que modelan la materia de la imagen analógica a las que hacen lo propio con la digital, una transición del modelo geométrico euclidiano al cartesiano o analítico. Es discutible, lo que no admite discusión es que en ambos paradigmas las herramientas siguen modelando algo. Porque las artes digitales, en contra de lo que afirma Rodowick, no carecen de materia (el autor utiliza, de manera artera, el término substance). El problema, como asume en seguida el autor, es poder identificarlas como objetos inscritos en un medio específico dotado o susceptible de una ontología. Rodowick, en román paladino, quería ir a mesa puesta. En todo caso, con estas divisiones a vuelapluma no quiero establecer un enfrentamiento maniqueo entre buenos y malos, entre instituciones represoras y espíritus libres, entre sistemas egoístas y gremios generosos, entre cultura y negocio.

Mi intención, al margen de señalarlos como indicadores de la supervivencia de la materia, se dirige hacia una inquietud filológica. No podemos seguir analizando imágenes, no podemos seguir otorgando significados si despreciamos su filología. Es necesario superar, o al menos ampliar y matizar, la idea de una imagen-documento. Nos hemos dedicado a observar su contenido y a comprobar la veracidad de su relato, sin cuestionarnos una investigación ulterior: la de la materia que acoge y que en ocasiones puede condicionar y modificar dicho relato. Con la tecnología digital parece haber calado un peligroso y quién sabe si definitivo conformismo filológico respecto a la imagen.

\footnotetext{
${ }^{227}$ Es una anécdota común que se puede encontrar reconstruida en Celuloide, la novela de Ugo Pirro (1983) más tarde llevada al cine por Carlo Lizzani (1996).

${ }^{228}$ RODOWICK, D. N., op. cit., p. 9.
} 
No solo eso. Sacralizada la tesis del áurea benjaminiana ${ }^{229}$, se ha dejado de poner en duda cualquier interferencia sobrevenida durante los procesos de formación, reproducción, distribución y exhibición de la imagen. Los errores metodológicos se suceden si partimos de una base que no tiene presente esta posibilidad. Pensamos que los tiempos de las carnicerías derivadas del shoot and protect, del pan\&scan, de las ultrajantes emisiones televisivas, de las máscaras de proyección equivocadas y de las indecentes adaptaciones al vídeo doméstico, eran masacres del pasado. Inocencia consentida, error imperdonable. Un investigador de la imagen contemporánea no necesita emular a Buster Keaton despiezando y remontando una cámara de cine. ${ }^{230}$ Tampoco está obligado a saber operar un digital intermediate, como tampoco estaban obligados sus antecesores a manejar una truca. No tiene por qué saber configurar los RAID, etalonar, elegir la mejor matriz de cuantificación o ejecutar el script algorítmico para comprimir una secuencia. Simplemente debe conocer su existencia y su capacidad para -en términos judiciales- ejercer la maquinación y la alteración del precio de las cosas. Hoy, quizá más que nunca, conviene recordar y repensar el díptico Print generation Cable vision generations (1974) de J.J. Murphy. Y hacerlo mediante un careo con la fascinante idea de supervivencia evolutiva de las Genetic images de Karl Sims. ${ }^{231}$ Filología y filogenia de las imágenes.

El found footage, el collage, la apropiación, el desmontaje, la compilación y el trabajo con materiales de archivo han visto remozada su vigencia durante el boom digital contra todo pronóstico. La razón, nostalgias al margen, se encuentra indisolublemente arraigada en el fundamento filológico y filogenético que todas comparten. Ya sea para reforzarlo o para

${ }^{229}$ BENJAMIN, Walter, "La obra de arte en la época de su reproductibilidad técnica" en Discursos interrumpidos I. Filosofía del arte y de la historia, Buenos Aires: Taurus, 1989, pp. 15-59.

${ }^{230}$ Keaton, recién llegado del mundo de las variedades, no tenía ningún conocimiento cinematográfico. Es más, su padre despreciaba el cine, lo consideraba profundamente vulgar. Lo primero que hizo para curar su ignorancia fue pedir una cámara prestada y proceder a su desmontaje y remontaje durante un fin de semana. Concluido su peculiar periodo de iniciación, acudió dispuesto a sumarse a la compañía de Fatty Arbuckle.

${ }^{231}$ La instalación interactiva de las Genetic images tuvo lugar en 1993. Pudo verse en el Centro Georges Pompidou de París, en el Ars Electronica de Linz y en el Interactive Media Festvial de Los Angeles. Una maravillosa mezcla entre el juicio estético humano y la capacidad algorítmica de la máquina. Las imágenes generadas por ordenador se desplegaban en un arco formado por 16 monitores. El espectador determinaba qué imágenes sobrevivían al permanecer un tiempo determinado frente a ellas. Lo hacía atendiendo a su criterio estético. Las imágenes no elegidas eran eliminadas y reemplazadas por la descendencia de las imágenes seleccionadas. Una descendencia generada matemáticamente por un computador. Descendencia que presentaba rasgos heredados, pero también variaciones fenotípicas y mutaciones genéticas azarosas. La supervivencia del más bello. La doble belleza del fruto de la evolución y de sus propios mecanismos de selección y reproducción. El ciclo se prolongaba y, con él, se multiplicaban los efectos, las constantes, las retenciones y las variaciones.

Véase: <http://www.karlsims.com/genetic-images.html> [consulta: 01-09-2015] 
subvertirlo, cuando una de esas prácticas hurga en el material genético y filológico de la imagen, lo hace también en el de la historia. Así, esa supervivencia diría que maravillosamente epistemológica de la materia, nos ayuda a detectar el instante donde el principio de incertidumbre que rige todo método, se convierte en principio de negligencia. El error, el ruido y el desperfecto digital también son legítimas expresiones de la materia que nos hablan de los medios y de cierta tendencia creativa, incluida la del azar.

No se trata de esperar o de descifrar el error. De convertir su huella -sí, isu huella y su fantasma! como en lo analógico- en la imagen en un acto detectivesco, sino de aceptarlo e incorporarlo como factor estético y metodológico de pleno derecho. Redibujar un mapa cognitivo donde localizar la taberna pirata regentada por Louis Delluc. Entrar y pedirle una botella de ron:

En el cine todos los planos son claros. ¡Oh qué lógico! Porque es en nombre de la lógica que todos los errores de fotografía e iluminación rodean nuestros filmes de absurdidad. ¿No es la lógica de esos dictadores (...) la que repudia la deformación (...) En efecto, solo está permitido producir juguetes [imágenes] bien recortados. ${ }^{232}$

\subsection{Donde viven los monstruos. Donde viven las imágenes}

« Tienes que ver las cosas con claridad: ¡La idea existe! Después está la materia y luego la forma.

$Y$ no hay nada que hacer, nadie le puede dar la vuelta.» Jean-Marie Straub ${ }^{233}$

Godard decía que "siempre habrá un soporte". ${ }^{234}$ Con JLG me ha sucedido algo extraño. A lo largo de los años mi confianza ha sido decreciente hacia sus palabras y -con alguna excepción o, por qué no decirlo, con algún susto- creciente hacia sus películas. Por eso me gusta recuperar esa frase, porque reconduce mi sesgo. La sentencia de Godard me devuelve la

${ }^{232}$ DELLUC, Louis, "Fotogenia", en ROMAGUERA i RAMIÓ, Joaquim; ALSINA THEVENET, Homero (eds.), op. cit., pp. 331-332.

${ }^{233}$ ¿Dónde yace tu sonrisa escondida? (Où gît votre sourire enfoui?, Pedro Costa, 2001). Edición DVD en: Cofre Pedro Costa, Intermedio, DVD 2, 2009, minuto 13 aprox.

${ }^{234}$ BURDEAU, Emmanuel; TESSON, Charles, "Futuro(s) del cine. Entrevista con Jean-Luc Godard" en De BAECQUE, Antoine (comp.), Teoría y crítica del cine. Avatares de una cinefilia, Barcelona: Paidós, 2005, p. 196. 
confianza no en sus boutades, sino en un estudio racional y por lo tanto emocional de la imagen. Siempre habrá un soporte. Es más, siempre lo ha habido, lo hay y, acompañando a Godard en el tiempo verbal, lo habrá. En contra de lo que decía -tal vez ni siquiera lo pensabaBaudrillard, las cosas tienen lugar. Aunque no nos sean mostradas o aunque nos sean mostradas bajo formas vaporosas.

El único problema ha sido la nefasta identificación de ese soporte. Fruto, en buena medida, de una terminología nada rigurosa. Si esto ya sucedió con la película fotoquímica, cuando las imágenes se mudaron al barrio alto del digital la confusión se volvió insoportable. En su momento, nunca se quiso -utilizo el impersonal, pero podría ser primera del plural- distinguir entre soporte, paso y formato. El uso intercambiable nos relajó de cara a la digitalización. Es tarde y puede que hasta parezca ridículo e innecesario, pero no me resigno a dejar las palabras retozando en el lodo de la indiferencia.

El concepto "paso" hace referencia, simultáneamente, al ancho de la película y a la distancia entre los bordes de ataque de dos perforaciones sucesivas. En general, para determinar el paso de un soporte cinematográfico, se indica únicamente la medida del ancho del soporte expresado en milímetros; así, diremos: película de $35 \mathrm{~mm}, 9^{\prime} 5 \mathrm{~mm}$, de $16 \mathrm{~mm}$, etc.

Aunque frecuentemente los conceptos de área de imagen y de formato de proyección tienden a confundirse -y la costumbre (...) lleva a utilizar el término "formato" para referirse indistintamente a uno u otro- se trata de dos conceptos diferentes, el primero de los cuales da nombre al área de superficie emulsionada que se utiliza para la filmación de la imagen y el segundo a las dimensiones de la imagen en pantalla. ${ }^{235}$

No es tarde, aun ha lugar. Porque las imágenes que vemos pueden no responder al paso, al soporte o al formato donde fueron concebidas. La paradoja de un depende constante y en ocasiones determinante. Hay dos terribles pragmatismos en la supervivencia de los soportes físicos. El primero es biológico: las ideas y las imágenes mentales siempre han necesitado mediación material para constituirse en símbolos. Una necesidad natural que surgió con nuestra especie para conservar y comunicar una cultura -religión incluida- en ciernes. En

${ }^{235}$ Del AMO GARCÍA, Alfonso, op. cit., p. 35 y 36 respectivamente. 
ausencia de un lenguaje desarrollado, sujeto a estructuras gramaticales y a formas de relato avanzadas, la cultura material -o la materialidad de la cultura- evitaba la disipación informativa. Sobre la tradición oral y sobre los soportes físicos comenzamos a construir nuestro acervo. A la manera de una evolución, la materia fue primero seleccionada y más tarde adaptada como el mejor medio que encontró la estética para su supervivencia. En esta histórica migración de la mente al soporte es imposible apreciar un proceso de desmaterialización. Ni siquiera, como decía Straub entre carraspeo y carraspeo, un viaje de la idea a la forma. Esa diáspora de las imágenes ideales es un acto de rematerialización o, si se prefiere, de cambio de sustancia expresiva.

El segundo pragmatismo es menos elegante, pero no por ello carece de importancia: la materia tasa, mide, mercantiliza, fetichiza. Se dirá que la materia como arancel es una idea del siglo XIX, tan obsoleta como los propios soportes físicos; y será otro error. Volver a considerar los flujos de datos de los recientes modos de distribución, exhibición y consumo como formas desmaterializadas, ni siquiera ha servido para solucionar el peliagudo sintagma de la propiedad intelectual. Digo más, esos flujos son tan deficientes que, en sus carencias, no hacen más que revelar la base material de un ciberespacio que, siendo precario, creyó ser omnipotente. Disculpen la vulgarización, pero la euforia del virtualismo omnímodo se asemeja a la figura del siervo que, alzando la vista desde su miseria, no deja de honrar la cuerda que acaricia su cuello.

Cuando los soportes de la película fotográfica tradicional evolucionaron atendiendo a criterios de seguridad ${ }^{236}$, redujeron de manera progresiva el grosor del material estructural -aquel indistinguible emparedado compuesto por el soporte de (tri)acetato, el sustrato adhesivo y el antihalo-, que no de la emulsión. Entonces nadie se atrevió a considerar el proceso como un indicio de la desmaterialización de las imágenes. Como tampoco se sacó a colación cuando las películas mudas dejaron de positivarse por contacto para hacerlo de manera óptica. En cambio, hoy asistimos a la luminosa estilización -por no decir anorexia- de los diferentes terminales audiovisuales y de inmediato los incorporamos al discurso de la desmaterialización. Llegará el grafeno como ya han llegado los soportes bendable y la serenata impostará aun más su voz. Aunque esos nuevos materiales se redujeran hasta resultarnos fisiológicamente

\footnotetext{
${ }^{236}$ Del inicial (1884-1889) e inflamable nitrato de celulosa se pasaría (a finales de los años cuarenta y durante la década de los cincuenta) a materiales de seguridad formados por acetato de celulosa y otros derivados más perfeccionados como el triacetato. Finalmente, desde finales del siglo XX, el poliéster fue sustituyendo al resto.
} 
inapreciables, seguiría existiendo un soporte. Entre otros motivos porque el soporte de las imágenes digitales no son los propios terminales, ni ninguno de sus componentes.

La imagen digital sólo alcanza estatus icónico significante una vez que la información binaria que la compone se ha ordenado, transmitido y emitido en sus coordenadas correctas. Se forman así una serie de píxeles que, en su contigüidad, generan una superficie de apariencia homogénea. Tal apariencia se adquiere dentro de un entramado informático que, a su vez, sirve como plataforma para lanzarla a otros soportes (papel y película fotográfica incluidos) o para visualizarlas en otro periféricos de la cadena: las pantallas. Considerar estas últimas como los soportes de la imagen digital es un error alarmante por normalizado. Sabiendo del triunfo de esta equivocación, se comprenden mejor las deficiencias metodológicas y la despreocupación filológica por la imagen contemporánea. Fascinados por el espectáculo interminable que nos brindaba, hemos sido incapaces de mirar tras ella, de coger un destornillador y, como Keaton, desmontarla.

Dilatando la semántica del término soporte, podría pensarse que es el lugar físico donde reside la información. No en vano reciben ese nombre: soportes rígidos. Los SSD (Solid State Drive. Unidad de Estado Sólido) y los vetustos HDD (Hard Disk Drive. Unidad de Disco Duro). Igual que los soportes portátiles en forma de discos o de tarjetas. Pero en todos ellos no hay ni una sola imagen en el sentido estricto de la palabra. Solo hay información codificada, una suerte de imagen-feto. Son, por lo tanto, no-lugares de la imagen, espacios de almacén y de tránsito. Espacios donde las imágenes no viven porque, sencillamente, carecen de identidad. La información ahí almacenada necesita ser procesada y transmitida según códigos establecidos por el software hacia otras terminales del hardware. Es una cuestión, como no podía ser de otra manera, de mediación. Considerar la imagen digital como un ente puro e ideal, esto es, numérico, es un neoplatonismo sonrojante. Solo podría serlo si fuéramos capaces de inventar o de descubrir un nuevo tipo de sinestesia que nos haga experimentar de manera automática y fiable los protocolos numéricos como un conjunto con valor icónico. Por desgracia esto no es así y el código, a nuestros ojos, es pura criptografía. Número y píxel son unidades de información, no unidades significantes.

En conclusión, el soporte de la imagen digital de la que hoy -año 2015- disfrutamos es una combinación entre software alfanumérico y hardware matérico. Mente y cuerpo. La imagen digital rehabilita la cuestión filológica a través de la materialidad de los procesos. Exactamente igual que sucedía con la imagen analógica. Alcanzo aquí el punto de no retorno de esta 
investigación: la imagen digital es la última muestra tecnoestética de la derogación del dualismo cartesiano. A su vez, la imagen digital en su vertiente prístina y comercial ha favorecido la prolongación y el resurgimiento de cierto pensamiento de corte neoplatónico.

¿Y cuando las espumas del ciberespacio alcancen la pleamar? ¿Y cuando la nanotecnología se infiltre en nuestro cuerpo no solo para curarnos y comunicarnos, sino para modificar la realidad a discreción? ¿Y cuando nuestra evolución natural y/o volitiva nos permita experimentar las imágenes de manera telepática? ¿Y cuando podamos reconstruir nuestras vivencias para rebobinarlas y disfrutarlas como una película? Supongo que hay muchas tesis doctorales implícitas en estas y en otras preguntas similares. Es más, estoy seguro de que ya se han realizado unas cuantas. Como libros se han escrito y conferencias impartido sobre las utopías de la imagen. Ninguna objeción, suelen ser apasiones. Ninguna objeción siempre y cuando incorporen un aviso legal en su inicio advirtiendo de que no están basadas en hechos reales.

Cuando todo o algo de eso acontezca, habrá que seguir aludiendo y estudiando la relación indeleble de la imagen con nuestro sistema nervioso, con nuestro cuerpo y con nuestro cerebro. Esto es, con nuestra mente. 

ANÁLISIS 


\section{PIXAR. NARRACIÓN Y MATERIA EN EL CINE DE ATRACCIONES}

\subsection{Justificación del corpus}

¿Por qué elegir Pixar para este colofón? No es sencillo adoptar un corpus analítico adecuado en una investigación como la aquí presentada. Al manejar hechos históricos y conceptos estéticos tan extensos y en ocasiones difusos, se pierde el recurso de lo biográfico y de lo genérico. Suerte que mi deseo no es realizar solo una ilustración fiel y, por lo tanto, repetitiva de lo ya tratado. Habrá repetición, lógicamente, pero espero que bajo la forma de una variación musical. Grosso modo, existen dos posibilidades para introducir una filmografía práctica en la tesis en curso. Primera, seleccionar una retahíla de películas y puede que hasta de escenas huérfanas. Segunda, encontrar una suerte de sustituto -que no de sucedáneo- del ecosistema proporcionado por una biografía o por un género. Llegado este punto, tengo la obligación de reconocer que mi elección final ha debido sobreponerse a mi propio sesgo. Mi preferencia inicial, arraigada y cultivada durante años en el análisis textual, me empujaba a la primera opción. Reflexionar sobre el contenido y las necesidades de la investigación, recondujo mi postura.

Dada la estructura y los razonamientos precedentes, era absolutamente necesario encontrar no tanto un repertorio como una síntesis. Si en algunos momentos la investigación puede haber caído en una teoría abstracta, este déficit no se iba a solucionar acudiendo a un muestrario que, en su exhaustividad, solo iba a revelar su insuficiencia. Es más, he corrido el riesgo de resultar impreciso en algunos juicios, debido a la huida consciente del ejemplo inmediato. En determinadas ocasiones era inevitable, pero, en lo posible, he buscado eludirlo por un doble motivo.

Uno, la inclusión de ejemplos sucesivos convierte al concepto en esclavo. Al mismo tiempo, excluye al resto de los no mencionados. Resolver esto último con etcéteras y con parches dignos de estudios basados en buscadores de Internet, me parece deshonesto. El limbo donde moran los ejemplos no materializados, siempre corre el riesgo de convertirse en un purgatorio de imágenes desconsoladas. Dos, el ejemplo es la mejor forma de acelerar el envejecimiento de una idea. A menudo, durante la labor de documentación, me he sorprendido ante la feroz obsolescencia de muchos textos solo por la deficiente o coyuntural elección de los ejemplos. Ideas que podían seguir siendo fértiles, quedaban convertidas en reliquias gracias a la 
carabina. Se nos olvida que el ejemplo no es una parte del sintagma adjetival. El ejemplo debe fundar un sintagma nominal propio, nuevo y pertinente.

He optado por acudir a la filmografía de un estudio de animación por las siguientes razones. Ninguna de ellas se entenderá si antes no menciono el puro pragmatismo metodológico. Es obligatorio declararlo. Como también conviene especificar que pragmatismo no implica ventajismo. Pixar ofrece un conjunto coherente, condensa el análisis y evita la dispersión. Su línea temporal sobrepasa las tres décadas hasta solaparse con el triunfo de la imagen y de la teoría digital. En ambos casos, en la teoría y en la práctica, su presencia es inexcusable. Su zona de influencia geográfica, partiendo de Estados Unidos, no conoce restricción. Su método de trabajo basado en la colectividad, en el reparto y en una suave -que no totaldescentralización, pone en cuestión la trasnochada noción de autor cinematográfico. Pixar, también, es un tótem contemporáneo que, a priori, afianza todos y cada uno de los conceptos aquí discutidos.

No solo sus películas, también sus modos de producción se han constituido en modelos para aquellas ideas que he intentado aquilatar. Pixar es uno de los emblemas del cine de atracciones por motivos de los que daré cuenta. Entre sus protagonistas no existe un solo cuerpo humano real. Con Pixar, la habitual querencia de la animación por el animismo ha adquirido una nueva intensidad. La imagen fotográfica analógica -igual que el cuerpo- es residual aunque, en ocasiones, no pueda calificarse de anecdótica. Pixar es un generador de mundos tridimensionales rotundamente virtuales. Algún crítico pedante puede decir -seguro que ya lo ha dicho- que no hay un solo plano en la filmografía de Dreyer -o de Tarkovski, Bergman, Angelopoulos, Antonioni...- que, en su hermética composición no remita a los misterios del alma. Bien, si adaptamos esa fórmula de cineclub años sesenta a la retórica academicista del cine de atracciones, podría decirse que no hay un solo plano en toda la filmografía de Pixar que, en su excelencia técnica, no represente un acto de exhibición del dispositivo.

Pixar es, en definitiva, una de las encarnaciones de eso que podemos llamar el sistema o la industria del espectáculo. En principio, una derivada del reino mágico, virginal e impoluto de Disney.

De este modo, durante la planificación de una nueva película, no pensamos ni en los adultos, ni en los niños, sino en ese lugar amable, limpio e inmaculado que 
yace en el fondo de cada uno de nosotros y que el mundo nos ha hecho olvidar y que, tal vez, nuestras imágenes puedan ayudar a recobrar. ${ }^{1}$

Esta cita es una buena antítesis a parte de mis argumentos. Volviendo a Pinker, es una negación explícita y no sé hasta qué punto moderna de la naturaleza humana. Bandera sobre la que se ha dibujado un escudo con forma y mensaje de tabla rasa. Espíritu de buen salvaje ensuciado por una sociedad vil que le arrebató su condición primigenia de ser de luz. Así, permitir que Pixar asuma el corpus es un nuevo elemento autocrítico. Es seguir poniendo en crisis la tesis y el método. El objetivo: solo puede salir legitimado aquello que no deja de cuestionarse.

Antes incluso que en sus personas, en sus imágenes y en las herramientas con las que son fabricadas, Pixar añade un interés único como compañía. Ha adquirido estatus de atracción después de veinte años realizando largometrajes. Para comprender su escalafón actual, es necesario retroceder a sus orígenes. Pixar nació, creció y se desarrolló gracias a tres enfoques y a tres ambientes diferentes unidos por el espinazo de la atracción. En primer lugar, la compañía se engendró y dio sus primeros pasos desde finales de los años setenta como una subdivisión de Lucasfilm. Imposible encontrar anfitrión más adecuado que el del director de $L a$ guerra de las galaxias (Star Wars, George Lucas, 1977), filme fundacional del cine de atracciones contemporáneo. Fue allí donde comenzaron a desarrollar su propia tecnología.

En segundo lugar, Pixar creció como compañía independiente a partir de la segunda mitad de los ochenta. Escindida del emporio Lucasfilm, seguirá invirtiendo en talento humano, en tecnología autóctona y, ahora sí, en producción de cortometrajes y luego de películas. De George Lucas a Steve Jobs. Del cine de atracciones, al tecnofetichismo. Dos conceptos íntimamente ligados y de enorme influencia sobre la presunta disolución del relato y la desmaterialización. Nadie hizo tanto por la fetichismo tecnológico y por la tecnoeuforia como el CEO de Apple. En tercer lugar, Pixar concluye su travesía integrándose en la corporación Disney. Obviaré mencionar el volumen obsceno de dinero movido desde sus orígenes, las sucesivas ventas e inversiones, hasta su boyante condición actual.

\footnotetext{
${ }^{1}$ Esta célebre cita de Walt Disney ha sido descontextualizada con frecuencia hasta convertirla en una declaración de intenciones atemporal. Todo fue más circunstancial: se produjo durante una charla radiofónica (CBS) con Cecil B. DeMille el 26 de diciembre de 1938. Allí, a propósito de Blancanieves, también aludía a la imposible trazabilidad histórica de los cuentos populares: "nadie sabe cuándo o dónde se contó por primera vez". MERLOCK JACKSON, Kathy, Walt Disney. Conversations, Jackson: University of Mississippi, 2006, pp. 13-14. [La traducción es mía]
} 
Si Pixar como productora posee este enlace histórico con el concepto de atracción, una de sus semillas creativas amplía el nexo de lo estrictamente empresarial a los emocional. John Lasseter, un admirador de Disney, se licenció en CalArts. ${ }^{2}$ Lasseter llegó a trabajar en Disneyland como barrendero y como conductor del barco safari. Cuando Disney y Pixar renegociaron un multimillonario acuerdo en 2006, una de las principales razones fue la de impulsar y renovar unos parques temáticos habitados por personajes cada vez más envejecidos y desprovistos de herederos. Pixar proporcionaría una nueva camada de sueños y disfraces.

La última línea genealógica en la fundación del estudio se desliga de esta relación, pero establece otra decisiva para la investigación: la permeabilidad entre arte y ciencia, entre estética y epistemología. Los nombres de Edwin Catmul y Alvy Ray Smith, ambos salidos del Instituto Tecnológico de Nueva York y presentes desde los orígenes como cofundadores, aportaron la dimensión científica del proyecto. La computación gráfica, las ciencias puras y el desarrollo de la tecnología asociada fueron elementos indispensables para lograr el refinamiento estético que todos hemos conocido. Una tecnología que en su momento compatibilizó las funciones artísticas con las científicas. El diseño gráfico solo era una de las capacidades a las que aquel computador, bautizado como la compañía, podía atender. Pixar podía triangular la imagen en busca del movimiento y de la profundidad espacial mientras guardaba, más o menos en secreto, sus competencias en geodesia, telecomunicaciones e imagen diagnóstica. Aunque en aquel momento la percepción era a la inversa, parecía un derroche utilizar toda aquella potencia solo para la fruslería de los dibujitos.

Repasar de manera cronológica los cortometrajes realizados por la compañía, restituye una impresión fiel y por momentos sorprendente de la evolución tecnológica. Si trazamos una panorámica desde aquellas rudimentarias aventuras de André y Wally B. (1982) hasta el delicioso Partly cloudy (2009), obtendremos enseñanzas sobre cómo la disposición tecnológica no conlleva su aplicación indiscriminada. Con indiscriminada quiero referirme a a la pérdida inevitable $o$ al enmascaramiento de las estéticas y de las técnicas precedentes por obsoletas que hayan quedado. Esto es, la tecnología -o, si se quiere, el imperativo tecnológico- no acarrea obligatoriamente un cambio de paradigma.

\footnotetext{
2 Instituto de las Artes de California. Centro de estudios para diseñadores gráficos fundado por Walt Disney en 1961. De aquí también salió otro de los creativos destacados de Pixar: Brad Bird.
} 
Pixar es mucho más que un relato evolutivo de las texturas. Convertir en habitable un campo y dotar de flexibilidad a los materiales rígidos, siempre ha sido un tour de force más emocional que técnico. Empezando por su emblema en Luxo Jr. (John Lasseter, 1986) y por el melancólico monociclo de Red's dream (John Lasseter, 1987).

\subsection{Imágenes por accidente}

En un documental del año 2007 -ya algo desfasado- con claro corte oficialista, encuentro tres imágenes que me sirven como entradilla para el análisis. Leslie Iwerks comienza The Pixar story enfocando el interior de un zoótropo para, a partir de su giro, enlazar cronológicamente diferentes hitos de la animación hasta concluir en Buzz Lightyear. Esto es, hasta llegar al infinito y más allá. Un montaje teleológico donde Pixar aparece como la culminación de la arqueología del cine. Un discurso en sintonía con la teoría de atracciones y la teoría del aparato. Me corresponde apostillar que Pixar no es una culminación de la imagen en movimiento o del dibujo animado, de la misma manera que Usain Bolt tampoco lo es de un australopitecino.

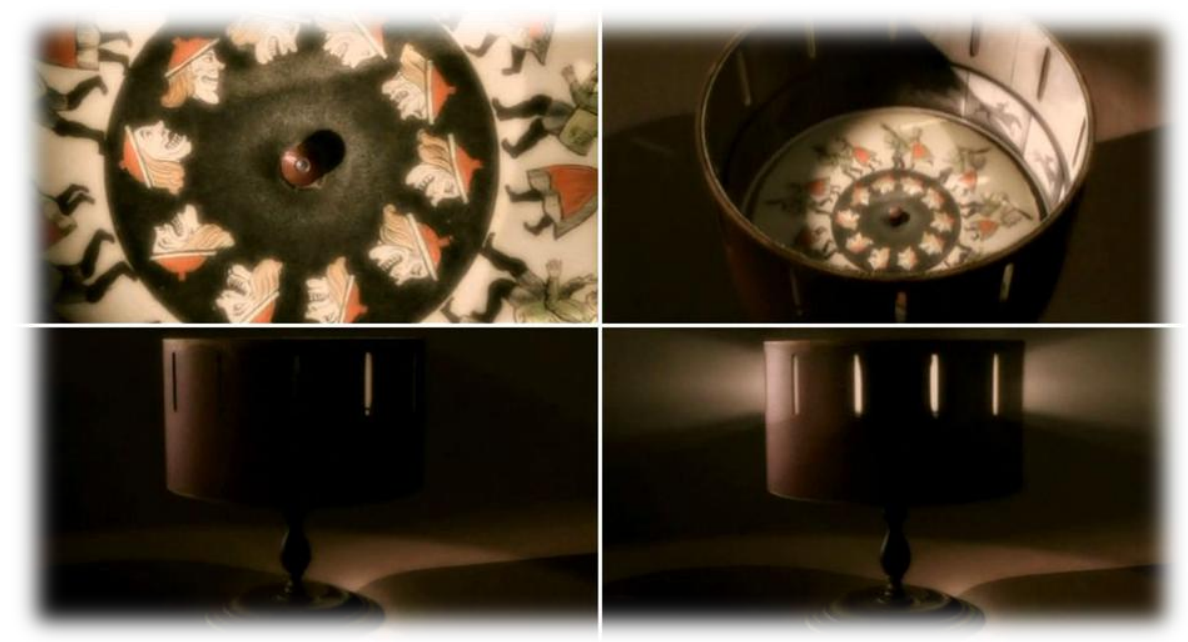

Con las otras dos imágenes estoy más de acuerdo. Es más, son imágenes tan perfectas que corren el riesgo de caer en la obviedad. Procedo a describir la segunda. Iwerks concluye su prólogo con un fundido a negro del que resucita con una leve panorámica ascendente. Desplaza la cámara en torno a una mesa repleta de crayones usados sobre la que irrumpe una mano. Dedos sucios, tiznados por la materia, que ahora recogen otra de las barras para colorear un boceto. La imagen se encadena por sobreimpresión con otro movimiento donde los crayones y los dedos se convierten en lápices y pinceles. Iwerks cierra la secuencia con un nuevo encadenado donde vemos otras manos modelando un pequeño y narigudo busto de arcilla. Los planos son muy cerrados, primeros planos que convierten la actividad en acto 
anónimo. Manos sin nombre. Táctil abstracción que respeta el ser mientras extingue el ego. Idea universal no sujeta a coyuntura.

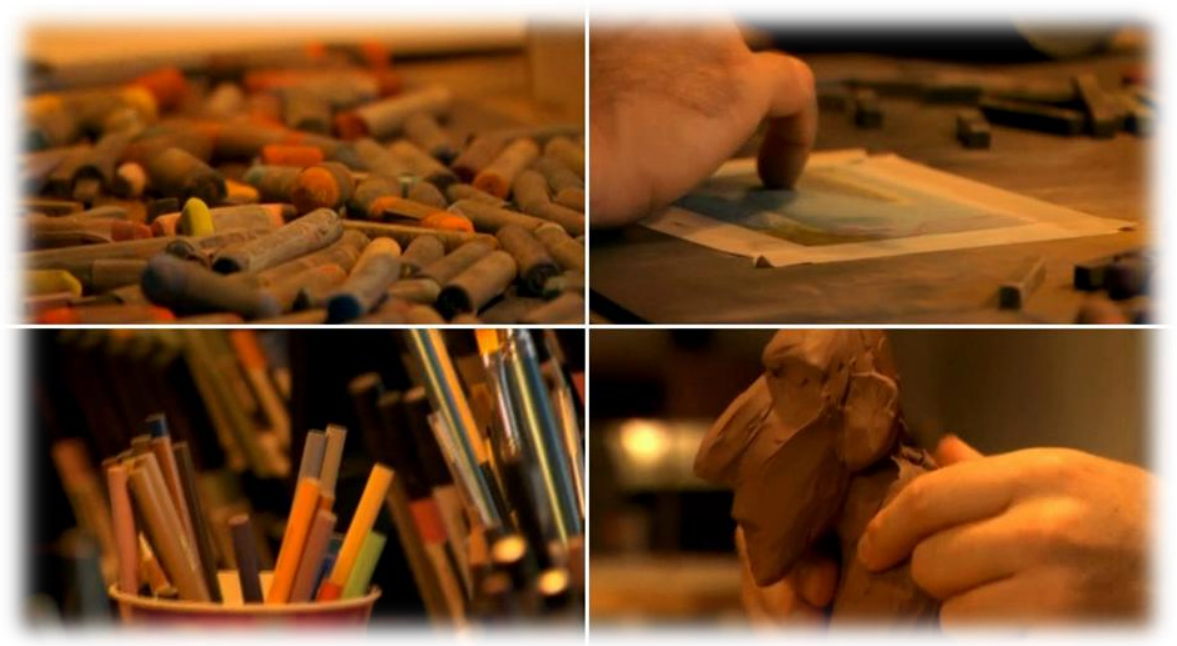

Madera, papel, cerdas, tizas y dedos. Dedos - digiti- que toman, que indican, que cuentan. En el reino de la imago digitalis y de los espacios virtuales, Iwerks filma una escena que podía acontecer en un taller de Pixar o en una gruta del Paleolítico. Las extremidades de un sapiens domesticando la materia para elaborar una narración. Una pintura parietal o el boceto de un fondo marino, un busto narigudo o una venus prehistórica. Tras contemplar estas imágenes, huelga regresar a la supervivencia de la materia y de la narración en los productos obtenidos de la unión entre hardware y software. Las imágenes de Pixar no están realizadas en una campana de vacío ni en un laboratorio esterilizado. Las imágenes de Pixar no están dibujadas por ectoplasmas o posthumanos. Las imágenes de Pixar solo pueden considerarse la culminación de un mundo dominado por la carne y por la suciedad. La imagen se consuma porque los dibujantes y los ingenieros se encargan de regular la entropía. Esto es, su cometido es conseguir que la materia deje de estar fuera de sitio. No tardaremos en comprobar que la materia en peligro y la trasformación son dos de los vectores de la compañía.

La tercera y última imagen son varias y proceden de materiales de archivo. Iwerks recicla viejos vídeos que la compañía utilizó durante la preparación de Bichos, una aventura en miniatura ( $A$ bug's life, John Lasseter, Andrew Stanton, 1998). En ellos observamos imágenes de flora rastrera grabadas con una minúscula videocámara de baja resolución. La máquina recibió el nombre de bug camera. Su función era intentar captar la sensación espacial de un insecto habitante del suelo para ayudar en los diseños preliminares. De nuevo una visión de la tramoya donde se urden las imágenes. Mi interés en este metraje intrascendente y de apariencia deslavazada, reside en la referida baja resolución. Debo concluir que esas imágenes, encuadradas desde el punto de vista de una hormiga imaginaria, carentes de cualquier prurito 
autoral y de ambición estética pero repletas de funcionalidad, son fascinantes. Asumo que lo que estoy a punto de escribir me puede costar alguna amistad. Son imágenes que recuerdan al experimental realizado en formatos subestándar por cineastas incomparables como Rose Lowder, Nathaniel Dorsky, Claudio Caldini o Chris Welsby.

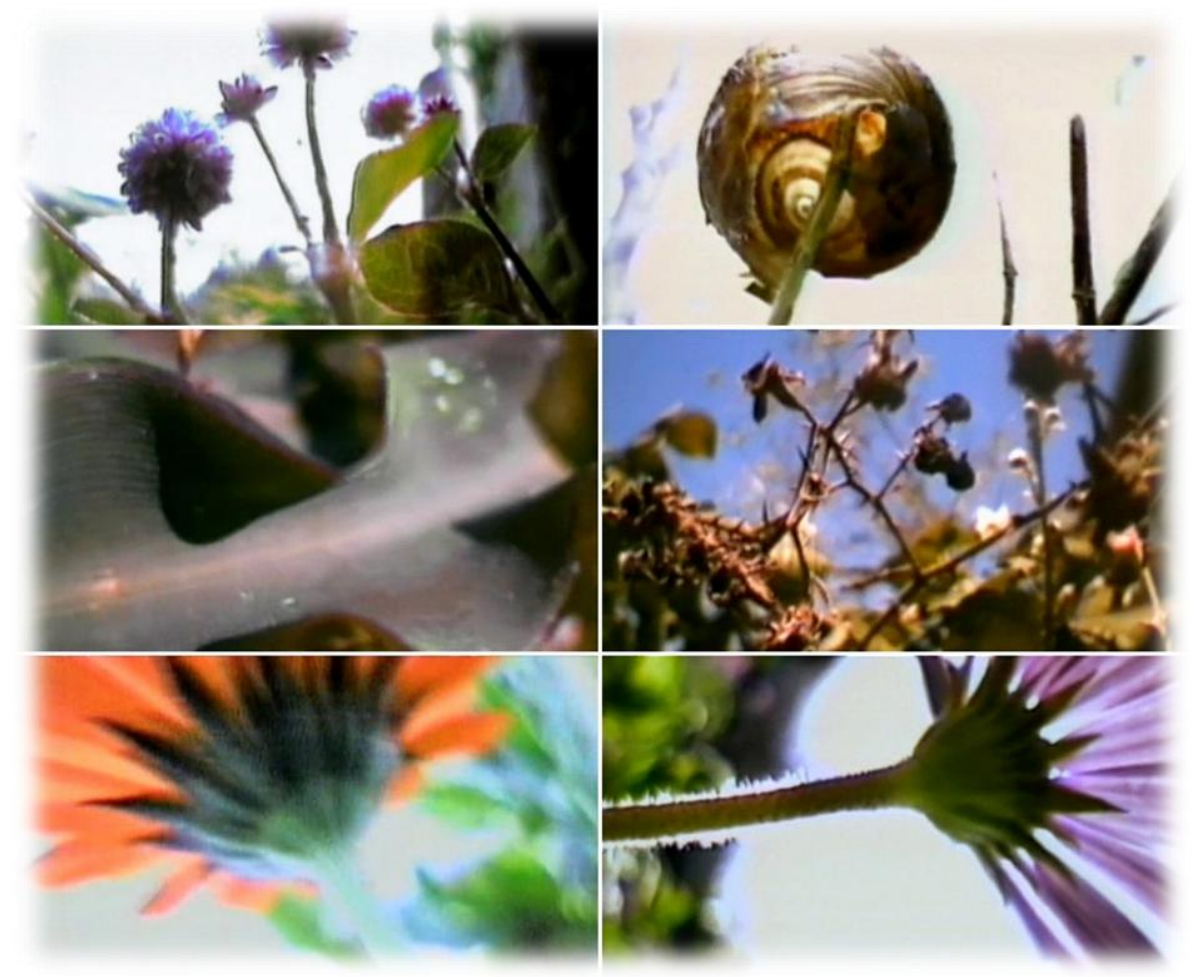

Habrá ocasión de ver cómo Pixar incorpora a sus películas ciertas estéticas low-res y un discurso sin dobleces sobre el desperfecto y la nostalgia.

\subsection{Ellos cambiaron el paradigma}

Ellos no lo cambiaron. Pero se dijo, se chismorreó. Es más, les acusaron de haberlo hecho y de haber destrozado la perspectiva laboral de todo un gremio de animadores no adiestrados en la nueva tecnología. Cierto que el triunfo y la consolidación de la animación tridimensional por ordenador condujo a una reestructuración del sector. Pero, al decir que fueron ellos quienes quebraron el paradigma, lo único que de verdad quebrantamos es el octavo mandamiento.

Viajemos al lugar donde empezó todo: la habitación de un niño. Quiero introducirme en ella, ocuparla y utilizarla como texto de mi planteamiento. Iba a escribir como metáfora, pero espero que el resultado legitime la literalidad textual. De momento, elimino al niño de la ecuación, le arrebato la escritura de propiedad solo para devolvérsela intacta más adelante. Toy story (John Lasseter, 1995), primer largometraje de Pixar y primer largometraje de ficción elaborado íntegramente por ordenador, queda sito en un espacio habitado por juguetes. Un 
ecosistema estable y semicerrado que se renueva cada año coincidiendo con el cumpleaños del niño ausente. En la habitación reina un clima cordial y democrático. El talante del sheriff Woody ha facilitado la integración de los inmigrados. Pero los tiempos están cambiando y la última efeméride aporta una novedad que hace que el sistema establecido se tambalee. En un lugar donde las nubes pintan las paredes, pero donde todos están atados al poder gravitatorio del parqué, aparece un astronauta volador.

No cuesta imaginar a Woody como un trasunto del cine clásico. Fiel representante de la reescritura histórica realizada por un país sin raíces o con unas raíces aniquiladas y enclaustradas en reservas. Woody es -hasta se parece- Ransom Stoddard. Junto al sheriff, un atribulado Mr. Potato que cambia, pierde y recupera su anatomía. Este collage peripatético realiza un alarde picassiano y es ahí donde le adjudico su papel como representante del cine experimental y de vanguardia. Por la habitación también pulula una hucha con forma de cerdito algo cínico, falto de empatía y siempre dispuesto a interpretar el papel de villano. Si no es por accidente, le cuesta aflojar el tapón que custodia las monedas. El cerdo es el indispensable componente industrial, el orondo productor. Un dinosaurio pusilánime que tiene por condena haber perdido la capacidad para generar miedo, podría ser ese cine mudo que hoy algunos ven como algo enternecedor y propio de las cavernas. Una delicada pastorcita, con rebaño incluido, aporta la dosis kitsch y camp inherente a los subgéneros televisivos y publicitarios. El solícito perro salchicha, en su capacidad para resultar intensivo y extensivo, alberga la modernidad y el videoarte. Los soldados lechuguinos conforman el ejército de la cinefilia. El huerfanito extravagante de pelo rosa, en su afasia y aire autista es el cine de autor. El forzudo sin discurso es un teórico de la posmodernidad.

Con estos personajes conviven los gadgets. El audiovisual se alimenta de la tecnología y la incorpora a sus modelos. Ahí tenemos dos ojos como dos prismáticos, una pantalla de dibujo electrónico, un par de intercomunicadores, un micrófono con grabadora y hasta una máquina para deletrear que alfabetiza a los residentes.

¿Y el astronauta? Buzz es el forastero. Personaje predilecto y vertebrador de la leyenda americana. El astronauta ha tenido la desfachatez de llegar en una nave distinta al Mayflower. Buzz Lightyear es la imagen digital, ies Pixar! irrumpiendo en el audiovisual contemporáneo. Buzz agita la comunidad. Aparece con su escafandra transparente y su uniforme cromado asegurando poder volar. La vestimenta sugiere un saco de músculos rematados por una mandíbula de macho alfa. Atlético e impetuoso, llega cargado de botones que activan 
numerosos dispositivos. Además, se comunica con una jerigonza a medio camino entre la pseudociencia y la marcialidad. Buzz es, en definitiva, la omnipotencia del digital desplegando su fascinante rayo láser ante un público ensimismado. Woody, en cambio, aun tiene que recurrir a un ridículo cordel atado a su espalda para poder recitar frases de repertorio. El pobre vaquero analógico ha quedado, de facto, convertido en una antigualla.

Puede decirse, con razón, que esto sucede en innumerables películas. El eterno cuento de lo viejo y lo nuevo. Pero también sucede en esta. Un aquí y un ahora específicos y especiales. Si aceptamos el planteamiento de la habitación como supraconjunto y al ranger espacial como la novedad estética, teórica y tecnológica que pone en peligro el paradigma vigente, es necesario saber cómo se soluciona el conflicto. Esa aceptación acarrea otro dato que no conviene pasar por alto: la carga metanarrativa del guión. Esto es, Pixar está contando parte de su propia historia. Y lo está haciendo en tiempo real, antes de conocer el recibimiento. Para conocer cómo resuelven la situación me voy a detener en los dos aspectos que considero esenciales.

El primero, por estricto orden cronológico, ataña a la estructura y a la temática de la narración. Los guionistas de Pixar encauzan el cambio de paradigma en ciernes a través de un método y de un afecto que gobernará su modo de producción y el resto de su filmografía: el trabajo en equipo y la amistad. La historia de los juguetes puede acontecer más allá de la habitación porque tanto la resistencia al cambio, como el cambio en sí mismo establecen una alianza. Y lo hacen durante una experiencia que deviene supervivencia. De esta forma, Toy story queda convertido en un survival de triple nivel. A saber, el de los dos personajes principales, el de su ecosistema y el del paradigma (histórico, narrativo, estético y tecnológico) donde se inscribe la compañía que les ha dado vida. Así, Woody no quedará convertido en un sujeto incompatible o desprovisto de sus funciones. Él y el resto de un grupo que ya había aceptado sin reservas el cambio, reabsorben la tensión y vuelven a convivir en armónica tirantez.

El segundo momento tiene que ver con Buzz y contribuye de manera irreversible a la prolongación del paradigma. Me refiero a su toma de conciencia. Aquella mediante la cual asume que el fulgor con el que aterrizó no era una extensión natural de su omnipotencia, sino de una prepotencia mal disfrazada. Buzz, trasunto de la imagen digital y de la misma compañía, se deprime al comprobar que no puede volar. Y, lo más trágico, ni siquiera es un guardián del espacio. Buzz debe conformarse con ser un simple juguete. De la misma manera que la imagen digital debería darse por satisfecha con ser solo una imagen y no un ungüento mágico. Igual de importante que esta conclusión, es la forma con la que se fabrica. 
Buzz asiste a su desplome identitario en un anuncio de televisión. Un televisor de aire retro que emite imágenes plagadas de interferencias y parpadeo analógico. Buzz, frente al espejo lacaniano del mass media, no alcanza a reconocerse en el otro. En los otros, porque una perspectiva infinita de Buzzs quiere materializar el tubo abisal desde donde se proyectan los malignos rayos catódicos. Angustioso punto de fuga. Buzz carecía de conciencia; tenía un relato interno, sí, tenía un software preinstalado que bloqueaba el verdadero yo narrativo. La identidad de Buzz no era más que uno de los subterfugios de la serialidad. Una estrategia de mercado. "Soy un juguete perdido", "Soy un fraude". Lamentos a consecuencia de un idealismo hormonado por una teoría falaz. Portador de una identidad menos glamurosa que la de fábrica, Buzz solo deberá temerle a todas esas réplicas de carácter fáustico, a esos dobles mecánicos, areneros (Toy story 2, John Lasseter, Ash Brannon, Lee Unkrich, 1999) y a un hipotético reseteado (Toy story 3, Lee Unkrich, 2010).

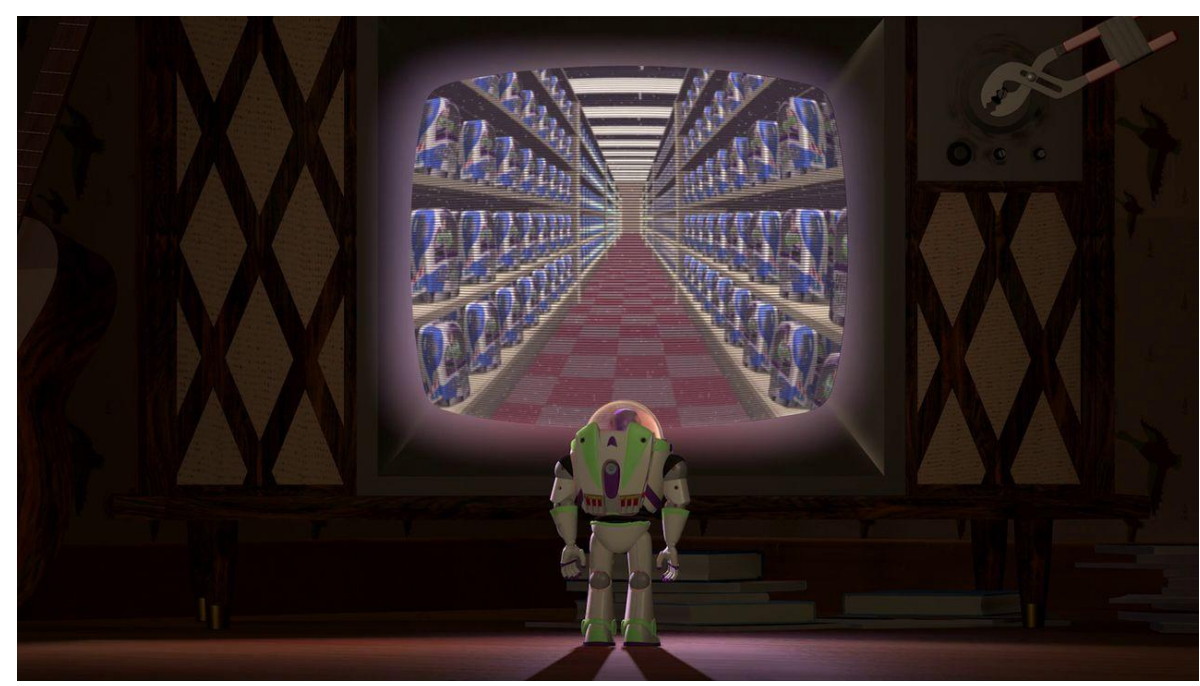

No debe menospreciarse esto que acabo de contar. El reflejo del yo en el otro y en los objetos opera en nuestra realidad y opera desde el principio en esta película. Cualquier interesado en redefinir el concepto de atracción debería empezar por aludir al persistente uso que se hace de los reflejos en el parqué. Es un detalle mínimo pero capital para construir la vivencia de los juguetes. Es, además, un motivo ineludible para una puesta en escena condicionada por la escala y los tamaños. El virtuoso animismo de Pixar no puede permitirse el lujo de eliminar o de dar por sobreentendidos aspectos que en una película convencional son asimilados con facilidad. No nos importa que los personajes no expulsen vaho durante una helada. En cambio, suprimir aquí este plus de materialidad habría sido catastrófico.

Regresando a la supervivencia del paradigma. Esta no consiste únicamente en asumir e integrar la novedad. Para que el paradigma continúe activo es indispensable que el proceso de 
conciliación no conlleve pérdida o fosilización de actores y funciones. Estas pueden mutar y hasta intercambiarse, pero ninguna ha de quedar reducida a pieza de exposición. Es justo aquí donde la primera parte de Toy story enlaza con su secuela de 1999. Salvado el paradigma en 1995, casi un lustro después se enfrenta al riesgo de ser musealizado. El museo es la muerte en vida. Lugar tétrico como la galería-morgue donde Charles Muntz custodia sus esqueletos en Up (Pete Docter, Bob Peterson, 2009). Restaurado y reubicado en una aséptica vitrina, el vaquero analógico se prepara para una placentera eternidad de only for display. De la misma manera que Buzz tuvo que hurgar en su conciencia, Woody debe ahora rechazar la tentación. Regresar al campo de batalla, volver a la habitación para seguir sirviendo al oficio aun a costa de sufrir nuevas heridas. Enseñanza que los guionistas remarcan con la coda del dinosaurio y del videojuego: forma vicaria e insatisfactoria de la vivencia real. "No necesito jugar, yo lo vivi", replica un feliz tiranosaurio por haber superado la frustración de un game over permanente.

Con Woody en un museo de Japón, el paradigma habría muerto. De ahí que sus compañeros organizaran esa nueva expedición con dos objetivos indisolubles: el rescate individual que asegure la supervivencia colectiva.

En conclusión, Pixar se presenta en sociedad leyendo un discurso cuyo mensaje es diáfano: venimos en son de paz. La propuesta se lanza en su primer largometraje y, bajo nuevas formas, se extiende a lo largo de su filmografía. El discurso sobre el rescate y la supervivencia del paradigma atraviesa Cars (John Lasseter, Joe Ranft, 2006). La despiadada autopista interestatal que convierte en páramo del espanto la otrora floreciente Ruta 66. Recta contra curva. El contravolante como brillante metáfora de los vericuetos en la linealidad temporal y espacial. También, en un tono diferente, está presente en Cars 2 (John Lasseter, Brad Lewis, 2011), donde la resistencia al cambio la ejerce la mafia de la obsolescencia.

Ratatouille (Brad Bird, Jan Pinkava, 2007) sirve como ejercicio de integración avanzada. Frente a un categórico "No puedes cambiar la naturaleza", la rata humanizada responde con la sabiduría -darwinista- propia de su género: "El cambio es la naturaleza". Así que no todo es rescate o supervivencia. Wall-E (Andrew Stanton, 2008) se encarga de desafiar el paradigma en curso. Cuando éste es nocivo o está equivocado hay que impugnar el axioma. El paradigma errado de Monstruos S.A. (Monsters Inc., Pete Docter, David Silverman, Lee Unkrich, 2001) era el energético, hasta que Sulley y Mike lo cambiaron. Desafiar la norma, aunque solo sea para hacerla permeable a cambios sentimentales, era el propósito de la rubicundísima Merida en Indomable (Brave, Mark Andrews, Brenda Chapman, Steve Purcell, 2012). El paradigma de una 
niña que se convierte en adolescente siempre es el hormonal: la tristeza tiñendo de azul el alegre amarillo en Del revés (Inside out, Pete Docter, Ronaldo Del Carmen, 2015).

\subsection{Montañas rusas}

Cuando se ha querido aludir al cine de atracciones como algo más que un ente abstracto o como un supergénero donde cabe cualquier película con componentes espectaculares, se ha utilizado la figura de la montaña rusa. En rigor, rara vez se ha llegado a utilizar en su traducción española. Es mucho más sencillo encontrar el original inglés: roller coaster. El roller coaster viene a ser, en líneas generales, aquella escena o secuencia donde el componente tecnológico se exhibe mediante un alarde de pirotecnia audiovisual. Es decir, el roller coaster es la parte práctica y sensible del concepto atracción en su vertiente y uso desnaturalizados.

Lo cierto es que el término cinematográfico roller coaster tiene más de sesenta años de vida. Se empezó a utilizar después de que el primer filme rodado en Cinerama se subiera a la montaña rusa del Rockaways Playland. De hecho, This is Cinerama! (Merian C. Cooper, Gunther von Fritsch, Michael Todd, 1952) arrancaba con la triple imagen recompuesta de la atracción en marcha. A partir de entonces, la expresión fue de uso común para designar el tipo de escenas mencionado. Su empleo siempre ha llevado implícito otro factor: el gran formato. De los formatos panorámicos clásicos a las 3D, pasando por el IMAX hasta concluir -fuera gran formato o no en cuanto a dimensión y escala- en el Digital, con mayúscula y como aglutinador.

Todas las películas de Pixar contienen momentos que pueden ser designados como muestras de roller coaster. Además de las escenas como elementos independientes, Pixar ha incorporado la hipertrofia del factor formato. Solo seis de las quince han sido filmadas en proporciones iguales o superiores a 2.35:1. Sin embargo, todas -incluidas estas últimas- han sido estrenadas o, en su defecto, reestrenadas en 3D o en IMAX y derivados. Por si no fuera suficiente y como ya avisaba en la introducción, su asombrosa pericia técnica ha llegado al punto de que casi cualquier detalle pueda ser considerado como una atracción. Mencionaba de pasada el reflejo en el parqué, pero la lista es amplia. La recreación de las emociones, de las texturas y de los movimientos más complejos y más temidos para los animadores. El cabello de una princesa, el pelo de una colonia de ratas y de una población de monstruos, la masa sincronizada de un hormiguero, el coral marino y la escama del pez, el brillo ocular y la invisible musculatura facial, la tela agitada por el viento y empapada por el agua, las nubes. 
Pero lo que más me interesa es transmitir que estos datos, en lugar de constituirse bajo la forma de un vulgar cine de atracciones, crean elegantes narrativas. Es más, muchos de esos alardes anteponen la razón diegética a otra espectacular donde la forma haya oscurecido el contenido. Me enrosco de nuevo en los tirabuzones de la melena de Merida, signo y símbolo de rebeldía. Sucede lo mismo en las construcciones más complejas, en las secuencias. No son pocas las que juegan con la etiqueta de roller coaster. Pero no nos podemos quedar ahí. Es necesario pensar en su ubicación y en su función dentro del conjunto. Siempre he sido el primero en legitimar la metodología de la placa de Petri. La extracción quirúrgica no ya de una escena o de unos cuantos planos, sino de un fotograma exacto para someterlo a cultivo. En esta ocasión no ha lugar. El roller coaster de Pixar es un recurso transversal en todos los sentidos. No se entiende sin el antes, sin el después y sin el envoltorio. Con frecuencia permítaseme la vaguedad, he de admitir que no siempre y no en cada segundo de duraciónestá saturado de significados y de trascendencias narrativas.

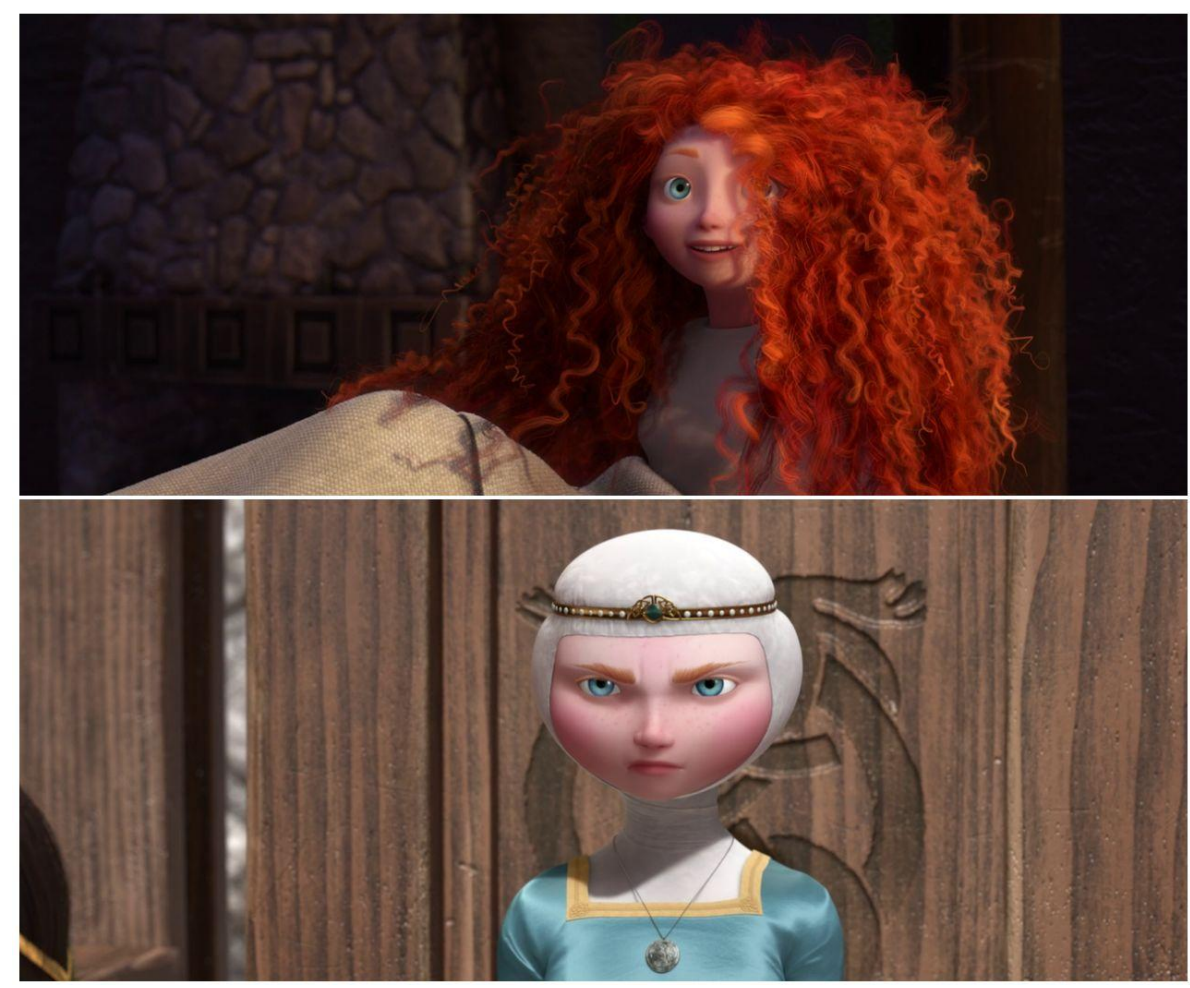

Toy story inaugura la locomotora de la particular montaña rusa de Pixar con la emblemática secuencia de la persecución. Huida o persecución son los subproductos narrativos habituales del roller coaster. También es importante identificar los ingredientes que componen esa atracción a nivel plástico y conceptual: explosión y velocidad, ingravidez y vértigo, obstáculo y trayecto, tecnología interna y externa. Igual de sustancial es comprender cómo se traslada el fundamento conceptual de la atracción al lenguaje y a la técnica cinematográfica. Está la eterna y esta vez cierta correspondencia entre frenesí dramático y el aumento de los 
emplazamientos, de los cortes y de la reducción sensible en la duración del plano respecto a bloques precedentes. La capacidad técnica debe estar lo suficientemente desarrollada para soportar y acompañar la ubicuidad del punto de vista. Dentro de esta variabilidad, se introduce de manera llamativa la visión subjetiva. Como es el caso, la deformación de los materiales no solo debe estar presente, también debe adecuarse a la intensidad de las fuerzas ejercidas. Lo normal -más aun en el cine animación- es que, en estas circunstancias, fuerza y deformación recurran a la hipérbole.

Son secuencias donde el contraste escalar también ejerce un papel determinante. El gran plano general y el plano detalle pueden ser vecinos bien avenidos. En Pixar no se puede aludir a la cámara como tal. No hay una cámara que se mueva, no hay un artefacto logístico donde cargarla y desplazarla por tierra y aire a toda pastilla. Esa histórica gambeta de la cámara es aquí la suma de una arquitectura y de una ingeniería computacional capaz de recrear mundos tridimensionales y, lo que es más importante, de explorarlos en toda su profundidad.

En cualquier caso, considero que todos estos aspectos son bastante obvios para cualquier lector-espectador apenas iniciado. Me interesa bastante más otra característica que hace de este roller coaster de Pixar algo especial. Y ahora me refiero a toda su filmografía, no solo a Toy story. Un análisis sosegado de la estructura narrativa de sus películas, devuelve un resultado concluyente: el roller coaster tiende a ser utilizado como prólogo (Toy story 2 y Toy story 3; Cars y Cars 2) o como antesala del desenlace. En Toy story ejerce de clímax, pero el esquema que encontramos a partir de entonces responde a una aparición que busca incrustarse entre el segundo y el tercer acto. Aludir a la simple ubicación temporal de este tipo de escenas, no es accesorio. Es básico si hablamos de una construcción a la que se le ha querido robar su influencia diegética. En Pixar, el roller coaster no es una digresión sobre la tecnología empleada en su fabricación. El alarde existe, pero no obsta para que el componente dramático permanezca intacto. Como refutación de la atracción diré que, aquí, el acto exhibicionista queda enmascarado por el acto narrativo.

La yincana de Buzz y Woody es canónica desde un punto de vista técnico y plástico. Pero hay que incorporarle las consideraciones que acabo de mencionar. Quizá sean más difíciles de identificar, pero ahí están, funcionando sin descanso. Luego vendrán nuevos y variados ejemplos. Sin ánimo de exhaustividad: la secuencia de las maletas en Toy story 2 y la del basurero en Toy story 3. La corriente oceánica de Buscando a Nemo (Finding Nemo, Andrew Stanton, Lee Unkrich, 2003) y la magistral del almacén de puertas en Monstruos S.A. La lucha 
en familia durante el pasaje insular de Los increíbles (The incredibles, Brad Bird, 2004) y las carreras o las persecuciones de Cars y Cars 2. La fugaz singladura por la alcantarilla de Ratatouille, la huida de la jauría a través de los barrancos en Up y los colapsos cerebrales en Del revés.

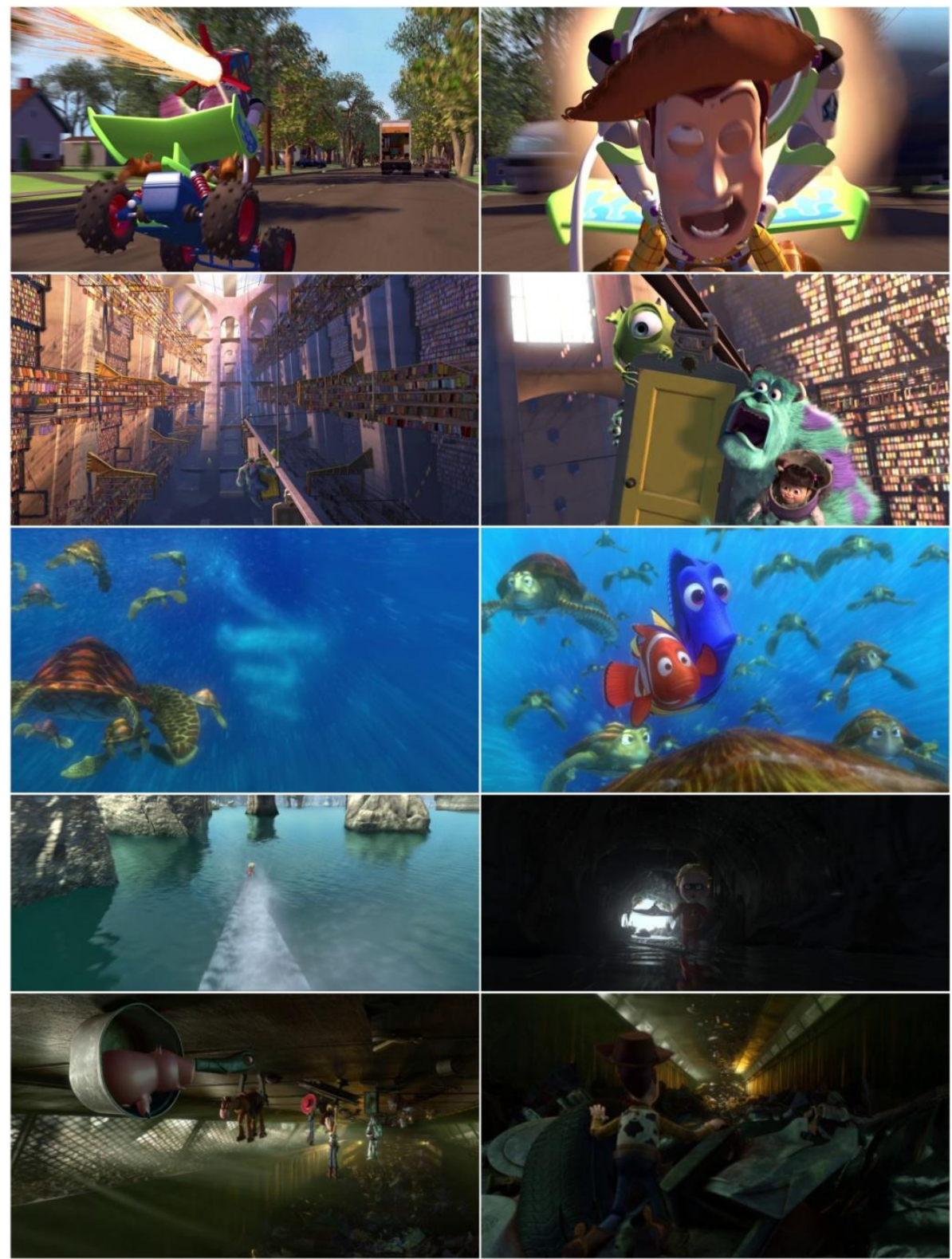




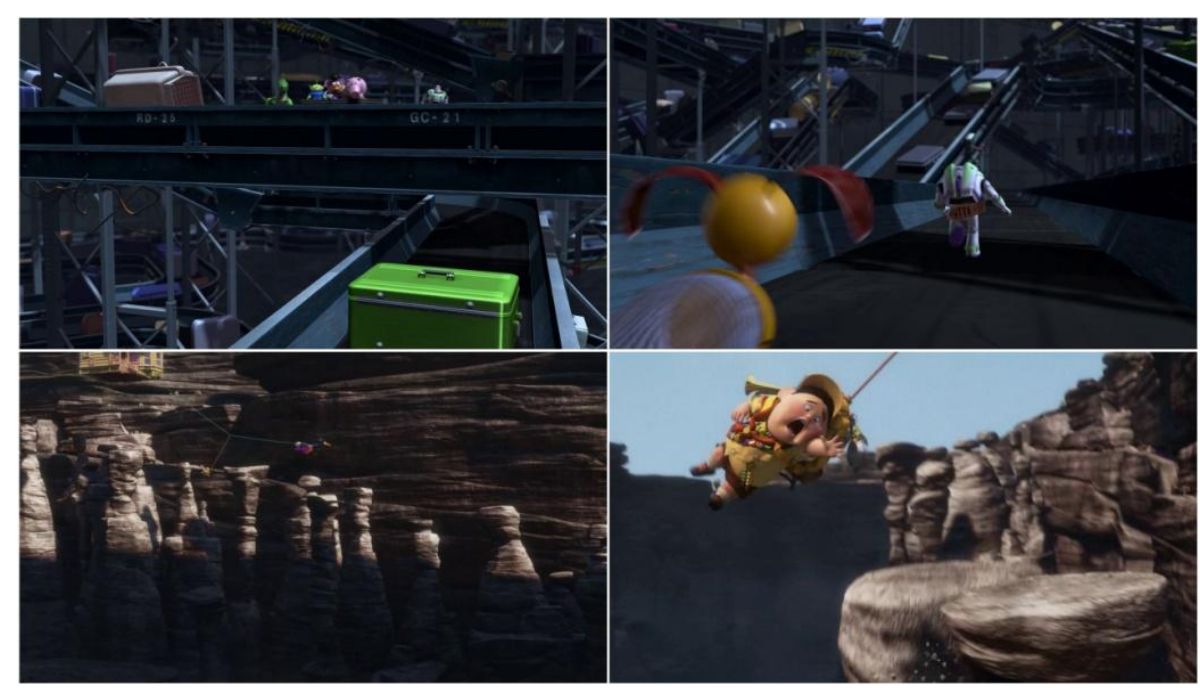

Solo he querido citar aquellas que presentan uno de los mandatos del roller coaster: el cauce o el trayecto que somete y que, a menudo, hay que transgredir. La tensión entre cauce y movimiento genera de por sí un relato de disputa y liberación. En este sentido, Pixar mantiene la ortodoxia sobre la que avanzó el Cinerama: raíles, cauces acuáticos y desplazamientos aéreos. El raíl, si algún defensor del exhibicionismo tecnológico hubiera estado ojo avizor, se podría haber convertido en la exteriorización de la circuitería ${ }^{3}$ del dispositivo electrónico. Afortunadamente no ha llegado el caso y cabe limitar su función a la potencia narrativa y simbólica que acabo de destacar. El discurso de Tron (Steven Lisberger, 1982) y Tron: Legacy (Joseph Kosinski, 2010) tomaba esta idea sin reparos. Por cierto, Tron ejerció una influencia decisiva sobre Lasseter y su equipo creativo.

Sin embargo, la muestra más conseguida no presenta ninguna de estas guías. Me refiero a la de la danza espacial entre Wall-E y Eve. No hay un itinerario prefijado porque los robots vagan por el espacio. Allí no hay un abajo y un arriba, aunque la pantalla y la puesta en escena los reconstruyan para nosotros. Esa dimensión abstracta que debería contribuir a despojar al evento de toda condición narrativa, sirve para reconcentrar los afectos. Wall-E y Eve surcan el espacio mientras generan estelas de felicidad. Ballet ingrávido que, en tono opuesto, recuerda al terrorífico flashback que martiriza a la protagonista de Alas (Krylya, Larisa Shepitko, 1966). La pareja de robots han materializado aquello que anuncié muchas páginas atrás: la atracción se ha desplegado en y por el espacio. Un espacio doble: el narrativo y el astronómico.

\footnotetext{
${ }^{3}$ Esta idea, ligeramente modificada, la supo apreciar y plasmar Godfrey Reggio en apenas una docena de planos de Koyaanisqatsi (1982). Los gigantescos planos aéreos de una urbe contemporánea, encadenados con primerísimos planos de circuitería y microprocesadores. La imagen del mundo o la imagen-mundo, deja de corresponderse únicamente con el gran panóptico cenital. Ahora, como explicaré en el apartado 10.8, se intenta tomar conciencia de la infinitud a nanoescala.
} 


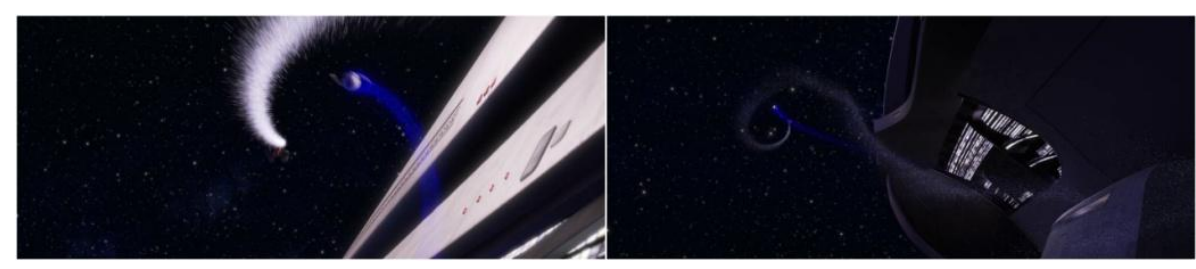

En conclusión, hay que prestar la debida atención a la montaña rusa de Pixar porque es un artefacto narrativo de primer orden. Sus vagones forman parte del convoy dramático. En su interior puede acontecer algo que condicione el futuro o que ayude a reconsiderar el presente. Como sucedía durante aquella noche de tormenta en Soledad (Lonesome, Paul Fëjos, 1928), una montaña rusa puede ser la causa de un amor extraviado.

\subsection{La historia de este reino es poderosa}

Con esta frase que ahora utilizo a modo de epígrafe, Merida reconciliaba a los pintorescos clanes de su reino. La princesa apelaba a la grandeza de un relato que había sobrevivido a enfrentamientos civiles y a sortilegios delirantes. Merida, de nuevo, hablaba de Pixar. Porque su breve historia tampoco es ajena a los conflictos o a los episodios de riesgo, incluidos los de la quiebra y la desaparición. Lasseter siempre dice que la historia es lo más importante. Algo que, por otro lado, lo han repetido mil cineastas a lo largo de la historia del cine. Esta muletilla solo puede presentarse como recurso en una entrevista rutinaria con un periodista, nunca como prueba de cargo en una investigación. Los filmes producidos por Pixar no adquiere una narratividad incontestable porque uno de sus creadores diga esa pavada. La sentencia de Lasseter, si acaso, puede ser tomada como un conclusión, no como un argumento. Y las conclusiones deben sostenerse en el discurso precedente. En un ejercicio de ingeniería inversa, ya he empezado a detallar por qué la historia sí es importante en Pixar. He señalado el componente narrativo de la atracción cinematográfica, tanto a nivel celular como del organismo. Ahora quiero exponer otra serie de factores, pura y objetivamente narrativos, relacionados con esta investigación.

Mencioné con anterioridad que Toy story se convertía en una survival movie. Añado ahora que otros largometrajes de Pixar no se limitan a validar la supervivencia de la historia o de la narración, sino que buscan modelos donde la construcción y la transmisión de las narraciones se convierta en el método y en la vía para la supervivencia. ¿Cómo intenta contrarrestar el hormiguero de Bichos el hostigamiento de los saltamontes? Fabricando una ficción. Un pájaro a escala que intimide a los invasores. ¿Cómo consigue establecerse un vínculo verosímil entre padre e hijo durante la narración de Buscando a Nemo? Mediante la transmisión oral de la 
historia del primero. Esta llega a oídos del pequeño gracias a una cadena que permite preparar un plan de fuga y de reencuentro.

¿Cómo consiguen Mike y Sulley regresar del mundo de los humanos sin perecer a manos de la policía y de los niños? Planificando una secuencia -diría que hasta un guión- de terror que genere la suficiente energía para desbloquear la puerta que comunica ambas dimensiones. Esta secuencia de Monsters University es, además de un brillante ejemplo de construcción narrativa para la supervivencia, otro de refutación práctica de la atracción: el refinado susto narrativo superando en valor e intensidad al susto visceral y mecánico. ¿Cómo realizan la transición de superhéroes a gente corriente los protagonistas de Los increíbles? Mediante otra ficción, una coartada que les permita sobrevivir al cambio social. En este caso malvivir, de ahí que la abandonen y rehabiliten el paradigma perdido.

Y la más importante. ¿Cómo se garantiza el futuro del grupo de juguetes al final de la trilogía de Toy story? Entregando el testigo a una nueva dueña que, al margen de poseer edad y carácter amigable, sea capaz de seguir inventando historias para que los juguetes preserven su función narrativa. El cierre de Toy story 3 es el magnífico corolario a la tesis biológica del sapiens como síntesis de homo fictus y homo ludens. Los perseverantes muñecos no representan la serialidad y el devenir cíclico del relato, sino la imposibilidad de su desaparición.

Algunas de las historias de Pixar adoptan la supervivencia, literal o simbólica, porque existe un oponente que ejerce la retórica del miedo, el fraude o la tiranía. El niño sádico de Toy story, el apestoso minero Pete de Toy story 2 y el vengativo osito Lotso en Toy story 3. Los saltamontes en Bichos, el director de la factoría en Monstruos S.A. y el renegado Charles Muntz en Up. El superhéroe artificial Síndrome en Los increíbles, el todoterreno Miles Axelroad y la mafia en Cars 2. Y dos más a los que considero importantes por cuestiones de fondo. Primero, que el depuesto chef de Ratatouille se llame Skinner, no parece causalidad. Es un recurso de guión frecuente (el director del colegio de Los Simpson) y poco o nada disimulado recurrir al apellido del icono del conductismo para bautizar al villano. Segundo, el remedo de Hall 9000 en Wall-E. Su omnisciencia apelmazada en un punto de luz, así como su perfección circular, avisan de la dictadura de la tecnología. También los hay que son némesis accidentales: el hechizado oso Mor'du en Indomable y el dentista y su sobrina en Buscando a Nemo.

En este sentido, la filmografía de Pixar está bastante acomodada en lo que en Estados Unidos se conoce como ideología liberal y que en Europa, con toda nuestra buena voluntad, seguimos 
pensando que equivale a la socialdemocracia y hasta a la izquierda decimonónica. La suerte y la inteligencia de Pixar es que han sabido reconducir lo que podrían ser historias panfletarias sobre guerras de liberación, en emocionantes historias de supervivencia.

Quiero concluir este apartado con dos apuntes de carácter técnico. Los guiones de Pixar están tan condicionados por la coherencia narrativa que, cuando esta se pone en peligro, no tienen reparo en volver a la Antigüedad, con mayúscula. Pocas veces hemos visto un ejemplo de deus ex máchina tan fiel como el empleado para resolver la secuencia del incinerador en Toy story 3. En una recuperación e inversión de guión respecto a la máquina expendedora de la primera parte, los encantadores alienígenas despliegan a su dios -ila Gaaarra!- para salvar a sus compañeros. Años atrás, en Buscando a Nemo, la garra fue un pelícano. Aquí, la descomunal pinza de la grúa desciende de los cielos sobre el montículo de basura, empoderada por las tres dimensiones.



Conviene reconsiderar la aparición explícita de algo tan arcaico como un deus ex máchina en el cine contemporáneo. Digo esto porque puede ser un recurso mal considerado entre profesionales. En la época del guionista gurú (Robert Mckee) y de los mil talleres de escritura, puedes levantar carcajadas si resucitas a Eurípides. Invocar el deus ex máchina es reconocer tu incapacidad; una claudicación ante el relato. Falso. Griffith nunca tuvo miedo al ridículo y por eso no dejo de usarlo. Mucho antes de sus last minute rescues, otra garra mecánica ya resolvió el conflicto generado por la desmesurada pamela de una espectadora en Those awful hats (1909).

Traigo a colación la simplicidad del deus ex máchina no para constatar su vigencia, sino para ver cómo se integra sin problemas en un momento donde ha triunfado el guión alambicado y en ocasiones indescifrable. Los guiones de Pixar también son densos y poseen fragmentos 
altamente comprimidos. Siempre se menciona el prólogo de Up. Esa historia condensada del matrimonio se enriquece en términos históricos si la reconocemos como una variante de su precedente: la balada de Jessie en Toy story 2.

La supervivencia como relato y metarrelato no implica que los guiones de Pixar sean sencillos. Aunque todas las historias de supervivencia tienden a la simplicidad y al encadenamiento, la crisis, la sorpresa, la tensión y la apertura son inseparables de la supervivencia. Para vencerlas, la supervivencia siempre despliega una de sus estrategias naturales: la búsqueda de patrones. Patrones simples y humanos, porque la naturaleza también posee patrones de complejidad desbordante que somos incapaces de detectar. Las películas de Pixar son capaces de integrar esta dualidad incluso en películas aparentemente más deslavazadas o episódicas como Cars 2. Tomemos el comienzo de Toy story 3 y veamos cómo se incorpora la complejidad sin perder la coherencia.

La película se abre con un prólogo frenético, roller coaster incluido. Una escena en el Oeste que añade motivos extraños y alucinados. Es un western posmoderno, con coches, hongos atómicos y naves espaciales. Que Cowboys \& Aliens (John Favreau, 2011) se estrenara un año después induce a la sospecha. En el apogeo, la historia se rompe. Se desviste la enunciación y se desvela el enunciador. Dejamos de asistir a la representación embellecida para verla desnuda en sus mecanismos. El niño, demiurgo carnal y eterno fabricante de historias, reconduce a los protagonistas hacia la salvación. Justo en ese instante acontece otra quiebra. Cambia el enunciador y cambia el modo de la enunciación. La madre entra en escena bajo la visión subjetiva de un videocámara.

En estos primeros seis minutos de película encontramos tres enunciaciones diferentes y una de ellas, además, en doble versión. Está la metanarración, esto es, Toy story 3 que, no por contingencia, se abre quemando la pantalla. ${ }^{4}$ Dentro de ella tenemos un western iconoclasta que responde a las imágenes mentales del niño y una fugaz resolución no extradiegética pero sí extracerebral. Finalmente, está la grabación del suceso por parte de la madre.

\footnotetext{
${ }^{4}$ Al mismo tiempo que realizaba esta investigación, fui recopilando y enmarcando aquellos momentos del cine convencional -hacerlo con los del cine adscrito a las diferentes vanguardias y al experimental sería una tarea infinita- donde la película sufría una agresión física-narrativa intencionada. No es el lugar para discutir y resolver esas intenciones. Quede, pues, como divertida y agradable ilustración que, en determinado momento, llegué a seleccionar y remontar con la ayuda de los ritmos de la naturaleza y de la letra de Novalis. Véase: <http://tearingcinema.tumblr.com/> [consulta: 07-10-2015]
} 
Todo concluye al tiempo que el vídeo casero. Poderosa elipsis escondida bajo un fundido a negro. Una nueva capa temporal de este complejo artefacto narrativo. Diez años en la vida de los personajes que buscan corresponderse con una década en la vida real. Los muñecos, al contrario que el niño -o que Celine y Jesse-, no han envejecido. El presente imaginario con el que arrancó la película, pronto devino pasado. Una historia y un dispositivo de apariencia unitaria y perfectamente suturado que resultaron ser tres.

\subsection{Cine sin cuerpos}

Hacia el final de los títulos de crédito de Ratatouille, justo encima de los logotipos correspondientes al gremio, al color, al material y al sonido, aparece un intruso. Un hombrecillo entusiasmado que guiña el ojo y eleva el pulgar en señal de aprobación. Al dibujito le acompaña esta exclamación: "100\% Genuine animation! No motion capture or any other performance shortcuts were used in the production of this film". Pixar exhibe su garantía de calidad disimulándola e integrándola con trazo simpático. Haríamos bien en preguntarnos el porqué de este aviso. En un primer momento se piensa en una forma jocosa de autobombo. Pero, si lo pensamos un segundo, nos daremos cuenta de que no estamos solo ante un acto de mínima y justificada propaganda, también ante un aviso epistemológico y filológico. Pixar notifica que en su película no se han utilizado técnicas de captura de movimiento para poner en valor su trabajo pero, sobre todo, para evitar confusiones.



¿Por qué? Ya en el año 2007, Pixar había alcanzado el desarrollo tecnológico adecuado para dotar a sus creaciones de una sorprendente capacidad para la forma y el movimiento corporal. Cuando utilizo adecuado me refiero a que eran capaces de representar forma y movimiento con verosimilitud, con validez y con correspondencias científicas. A pesar de esta facultad y aun teniendo posibilidades ciertas de lograrlo, Pixar renunció a la animación anatómica. Nunca ha llegado a profundizar en la vieja aspiración de hacer converger a la animación con la imagen fotográfica. Fiel a la otra tradición histórica, a la de la hipérbole y la caricatura, ha optado por 
mantener la técnica al servicio de un modelo crítico con el naturalismo y la convencionalidad de las formas.

No exagero al afirmar que el triunfo del modelo defendido por Pixar, destrozó en términos artísticos a la otra corriente con la que compitió en paralelo. ¿Cuál? La de esa tecnología de captura del movimiento encabezada por Polar Express (2004), Beowulf (2007) -del mismo año que Ratatouille- o Cuento de Navidad (A Christmas carol, 2009). Los tres dirigidos por Robert Zemeckis. Ni siquiera el último intento de Spielberg por retomar y matizar esa vía con Las aventuras de Tintín. El secreto del unicornio (The adventures of Tintin, Steven Spielberg, 2011), relanzó el proyecto.

En Pixar escasean los cuerpos. El cuerpo humano, de hecho, puede ser considerado como especie en peligro de extinción. Pixar es, ante todo, un cine de los objetos y de los animales. Pixar es el animismo y la prosopopeya digital en todo su esplendor. Y, sin embargo, es una de las compañías que mejor ha entendido el valor del cuerpo en un tiempo que lo mistificaba. En Pixar hay juguetes, insectos, peces, monstruos, coches, ratas, osos y robots. Sus diferentes morfologías arrinconan y condicionan la forma y la aparición del cuerpo humano. No así la norma. Es esta la que Pixar incorpora en sus guiones para entregársela a los nuevos inquilinos, por extravagantes que sean. Pixar puede permitirse el lujo de prescindir del cuerpo humano, pero no del humanismo. Del humanismo real, el que tiene la delicadeza de hacer pasar a la cultura por el tamiz de la razón naturalista.

Pixar no agota los cuerpos en la causa morfológica de la emoción. Está presente, pero no es más que un nivel de la citada animación anatómica. Son maestros en ello, casan músculo y facción, tic y sentimiento. Dilatan las pupilas de un robot o de un oso y nos abismamos en su negritud amnésica. Modulan el iris y nos emocionamos al mismo son con el que reverdea su conciencia. Existe un discurso a lo largo de su filmografía -a ratos explícito, a ratos subyacenteque nos informa de la supervivencia del cuerpo. El cuerpo como superstes. En Pixar, el cuerpo organiza y defiende la troncalidad que, para nuestra lengua, le otorga su jerarquía latina. 


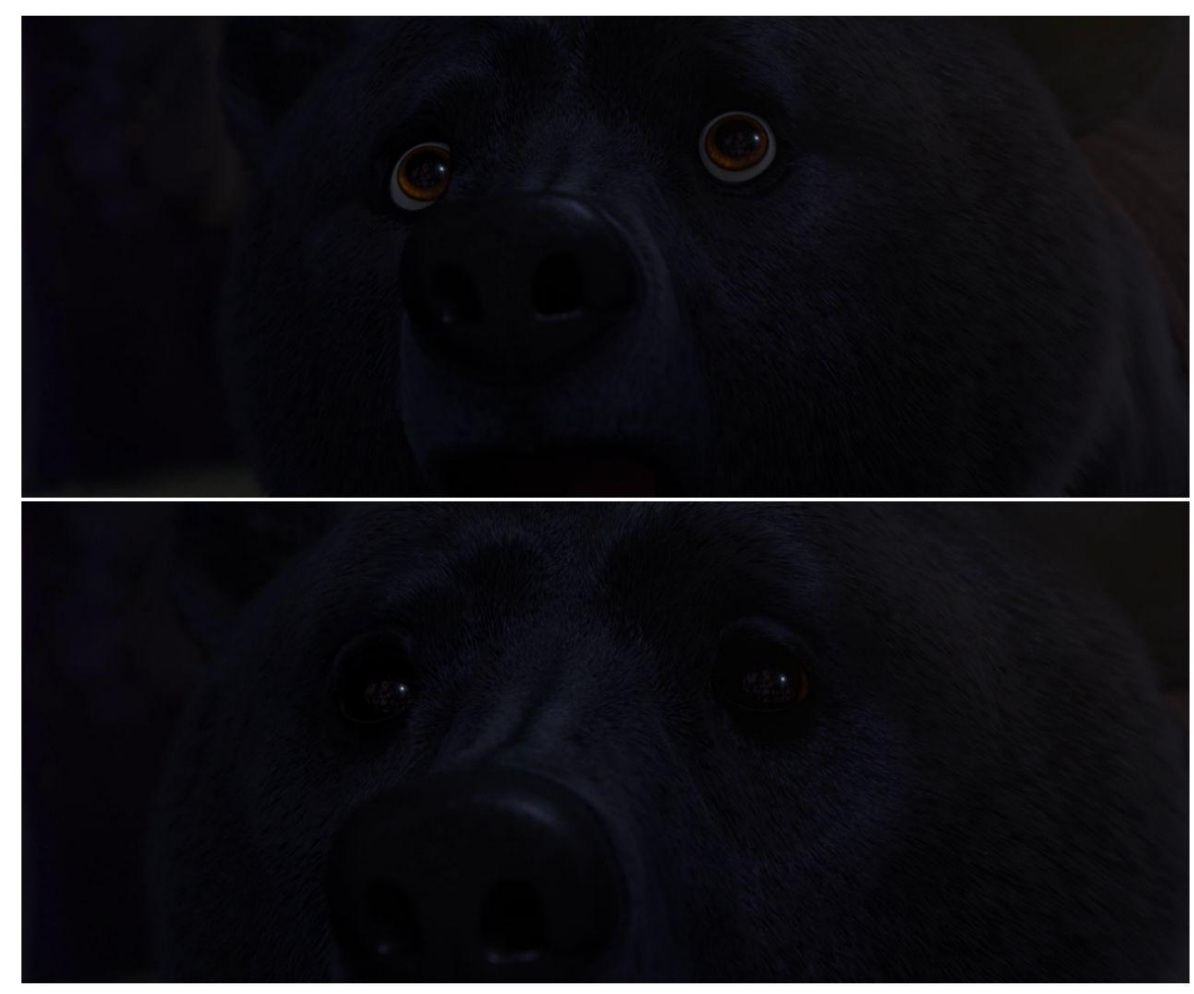

En Toy story, durante su cautiverio en la habitación del prepúber sádico, Woody es torturado. Es una escena magnífica que encaja con parte de lo comentado. La puesta en escena termina correspondiéndose con la dislocación y el sufrimiento corporal. Se intercambian los picados y los contrapicados entre Woody y el chico de acuerdo a sus puntos de vista. Víctima y verdugo en desigualdad de condiciones. Las imágenes alternan sadismo y estoicidad. Al arrebatamiento angular y al contrapunto, se suma la distorsión introducida por la lupa. El plano se desfigura por una razón científica que, a su vez, convierte una prótesis médica -la ortodoncia- en ingenio dramático. La luz se reconcentra sobre la frente de Woody, el humo de la quemadura comienza a surgir y el indefenso juguete termina con el entrecejo de Dancin' Kid en Johnny Guitar (Nicholas Ray, 1954) o con el de Stockburn en El jinete pálido (Pale rider, Clint Eastwood, 1985). El cuerpo torturado como representación de una conciencia conquistada a través del dolor, como sabemos, es uno de los ejes de la imagen cinematográfica del siglo XXI. La secuencia concluye con una estimación de daños realizada sobre otra superficie deformante: el lado convexo de una cuchara. 




Que todo suceda gracias a un sujeto no humano, contribuye a la funcionalidad del discurso. Porque la tortura sobre un cuerpo real, suspensión de incredulidad mediante, siempre corre el riesgo de resbalar hacia los extremos: al puro goce o a la moralina.

La habitación donde acontece la tortura deja otro detalle interesante. La legión de juguetes es bien diferente a la de la habitación protagonista. Si aquella era el audiovisual, esta otra es su fase subterránea. Cuerpos mutilados e hibridados en un mestizaje tétrico e irracional. Una cabeza humana sobre un rodillo, la de un bebé sobre un mecano de tintes arácnidos, unas esbeltas piernas femeninas rematas por una caña de pescar, una cabeza de pato y otra de mosca sobre torsos musculados, una mano monstruosa emergiendo de una caja, brazos a modo de ruedas en un descapotable. Fragmentación y resucitación contra natura que, con Frankenstein y la pintura flamenca del XVI en el recuerdo, no han logrado extinguir el instinto primigenio. En este caso, el de la bondad del juguete. A Frans de Waal ${ }^{5}$ le encantarán estos muñecos -más que con alma de bonobos- de moral congénita.

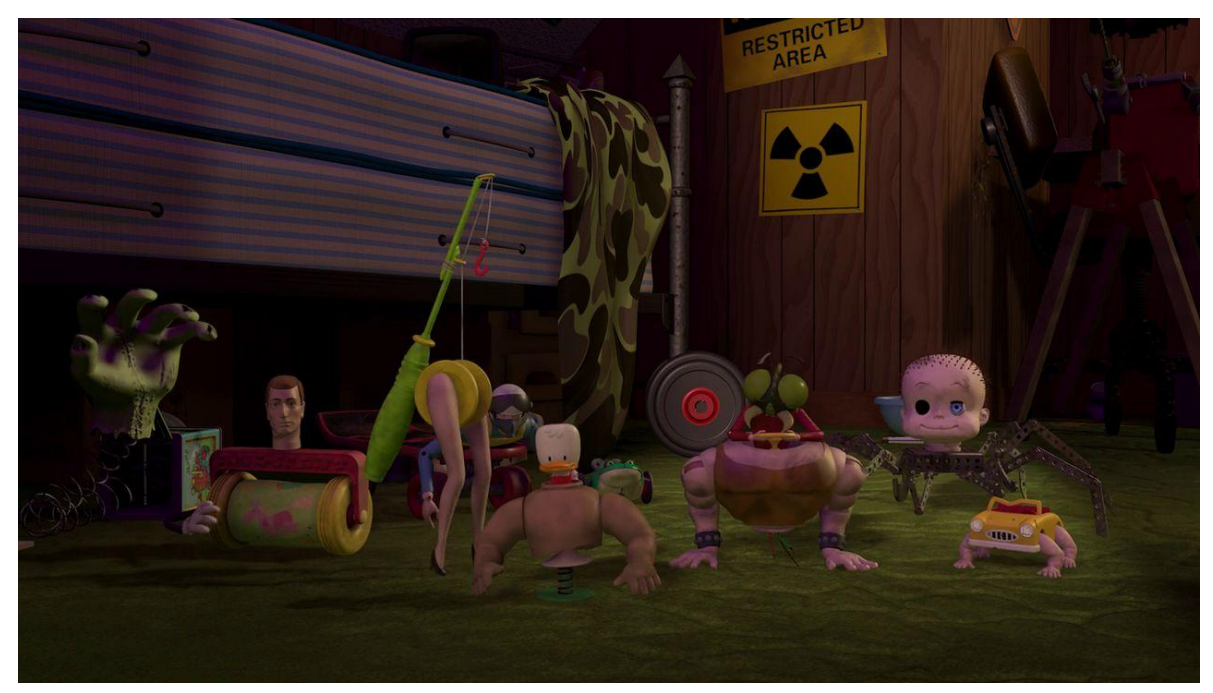

\footnotetext{
${ }^{5}$ Entre otros: de WAAL, Frans, El mono que llevamos dentro, Barcelona: Tusquets, 2007.
} 
Que el conflicto con el torturador se resuelva con un remedo del cine de zombis, abunda en este relato del resurgir corporal y del cuerpo imperfecto. Algo que no se queda ahí. Sirve de premisa para la secuela y para buena parte de la tercera entrega. El drama de Toy story 2 solo será posible gracias al desgarro narrativo que sufre el brazo de Woody. El padecer de la troupe en Toy story 3 estará ligado a nuevas y múltiples formas de tortura -más o menos involuntarias- en una guardería. Cuerpos también castigados y vigilados al más puro estilo foucaltiano por un chimpancé acusica. Por no hablar del milagroso ojo de la Señora Potato que, aun desgajado del cuerpo, es capaz de entregar información visual a través del espacio y del tiempo.

He querido detenerme en el cuerpo de Woody porque encarna el problema de la descorporeización con un enfoque original. Woody fue concebido, en origen, como marioneta. Era la estrella de un teatrillo televisivo donde los hilos lo manipulaban de manera heroica. Sin esa acción teledirigida o sin las manos de su dueño, como simple muñeco de mercadotécnica, Woody está literalmente descuajaringado. Perdida su condición de neurospasta, su cuerpo cae sobre la cama como lo que es: una flácida masa de algodón carente de esqueleto. Al revivir, los ecos de ese organismo inarticulado y blandengue seguirán subrayando sus movimientos. Años después, Pixar renovará la idea con la rata Remy y el chef Linguini. La torpeza, la descoordinación y hasta los desmanes característicos de un cuerpo adolescente reconducido y recableado a través del pelo.

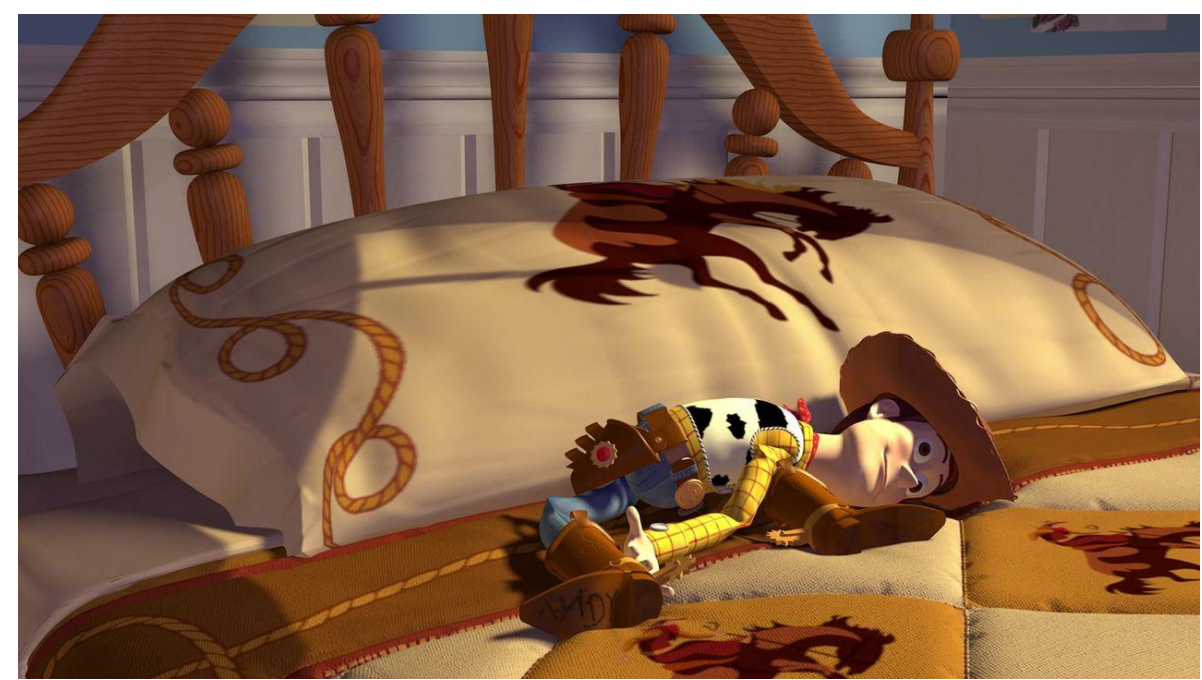

Los increíbles también introduce nuevos matices al discurso. Allí nos encontramos con una dialéctica provocadora: imposibles supercuerpos reales frente a un lógico supercuerpo biónico. Los protagonistas ven cómo sus organismos privilegiados claudican ante la realidad. Sufren los achaques de la anatomía y de la vida de a pie, igual que le sucede a la crujiente espalda del Sr. Fredricksen en Up. Ese abuelo también es un verdadero cíborg, ha conseguido 
acumular una dentadura postiza, unas gafas, un bastón y hasta un audífono. Por su parte, el hercúleo Sr. Increíble debe luchar contra sus lorzas, mientras la maleable Elastigirl debe dedicar todas sus extensiones a la pacificación de la prole. En el bando opuesto, un cuerpo ajeno al estrés y a las grasas saturadas, el de Síndrome. La tecnología adherida le permite prescindir de cualquier romanticismo. La tecnología busca ejecutar su mandato para borrar o sepultar la naturaleza: "Cuando todos sean superhéroes, nadie lo será". La sutil frontera entre la democratización y la dictadura tecnológica.

Es interesante que Pixar se valga de los supercuerpos de seres excepcionales para realzar la diversidad de lo real. Todos sus atributos -hiperfuerza, hiperelasticidad, hipervelocidad, invisibilidad, autocombustión y autogeneración de campos de fuerza- resultan compatibles con un discurso sobre la normalidad del cuerpo humano. En ausencia de glorificación virtualista, la visión queda en sintonía con la desmitificación del superhéroe en el cine contemporáneo. ${ }^{6} \mathrm{Ni}$ siquiera los supercuerpos han sido inmunes a la verdadera pandemia del nuevo siglo: la neurosis.

La distopía corporal es tratada con acierto y llaneza en Wall-E. La liberación del cuerpo a través de la tecnología y de la virtualidad deviene biosedentarismo. Obesidad ingrávida, contemplación adiposa y tautismo esterilizado. Observamos a los sucesivos capitanes del Axioma, y la galería de retratos se convierte en lámina forense de la involución humana. La revolución a bordo comienza con dos actos de corporalidad: un involuntario roce de manos y, pocos minutos después, un inocente pero rítmico movimiento de pie. Dejo el primero para más adelante porque merece compañía. Esa revolución solo podía concluir con una logro mayor: la reconquista del bipedismo. ${ }^{7}$ El capitán, homo sapiens envalentonado por el intertexto de Stanley Kubrick y Richard Strauss, se reincorpora como si fuera Rocky Balboa contemplando el fantasma de Adrian. La multitud -una masa informe de gordura- clama, Hall9000/Apollo está a punto de ser derrotado. El mórbido capitán acciona el control manual, nivela la nave y pone rumbo a un estercolero llamado Tierra. De vuelta en el basurero, el ejercicio y la gravedad se encargarán de recomponer el tejido óseo y muscular.

\footnotetext{
${ }^{6}$ Mi súper exnovia (My super exgirlfriend, Ivan Reitman) es dos años posterior; Hancock (Peter Berg), cuatro; Watchmen (Zack Snyder), cinco.

${ }^{7}$ El único plano inteligente que había en Gravity (Alfonso Cuarón, 2013) era el que recogía a Sandra Bullock, en la orilla de la historia, reincorporándose sobre dos piernas atrofiadas.
} 


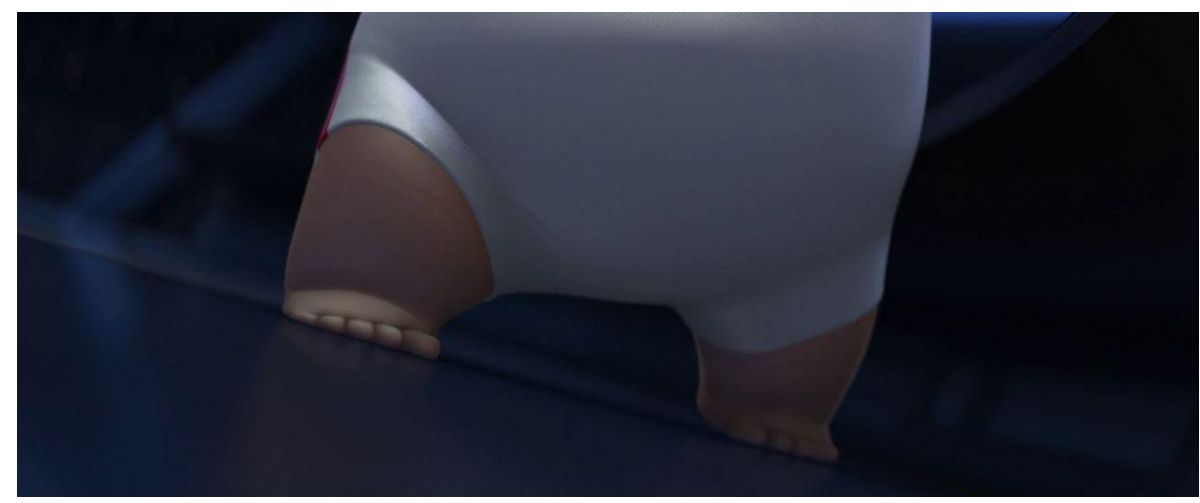

Cuando en Indomable Pixar suma al discurso otro de los latiguillos posmodernos en torno al cuerpo, cabe lamentar que no le otorgara mayor profundidad. Me refiero a la transformación o, por volver a Ovidio, la metamorfosis. Con todo, Indomable aun contiene trazas de lo que supone la metamorfosis como relato simbólico elaborado por el hombre para intentar comprender a su especie, sus orígenes y sus dioses. La reina Elinor, transformada en descomunal osa, mantiene ademanes repletos de feminidad al tiempo que debe combatir un destino biológico que empuja desde el interior de una anatomía ocupada. Igual que sucedía a Calisto $^{8}$, mantiene sus pensamientos y se horroriza con las bestias durante su disonancia mente-cuerpo. Es una lástima que este cuento gaélico termine enfocando todos los problemas derivados de la metamorfosis, hacia una apología naif del libre albedrío. Suerte que luego llegará Riley en Del revés para reconducir el voluntarismo de Merida en la toma de decisiones. A un divertimento como Del revés no podemos pedirle mayor rigor científico, basta con que aporte esa dosis determinista y hasta mecanicista ausente tres años atrás.

Puestos en antecedentes, no puede extrañar que Pixar casi haya convertido una parte del cuerpo en emblema tácito. La mano. Aunque sería más preciso decir las manos. Y todavía más certero sería decir las manos en contacto. Una mano que puede ser la aleta del pez y hasta la rueda del coche. Los juguetes entrelazan sus manos ante el incinerador de Toy story 3. El pequeño Nemo tiene una aleta disminuida que muestra y choca con orgullo. Los coches de Cars inventan complejos saludos o pasean rozando sus cauchos. Pero es aquí donde regreso a Wall-E. El primer plano de unas manos al encuentro filmado por Gene Kelly en Hello Dolly! (1969) es utilizado como Leitmotiv. Luego, la danza cósmica de los dos robots facilita el encuentro de las manos de dos pasajeros. Finalmente, Wall-E y Eve entrelazan sus dedos como muestra definitiva de recuperación y de reconocimiento.

\footnotetext{
${ }^{8}$ OVIDIO, Metamorfosis, Madrid: Cátedra, 1995, p. 257.
} 
Antes que en Bresson, es como si Pixar hubiera pensado en el Godard del episodio 4A -a mi juicio el más brillante- de las Historie(s) du cinéma (1998).

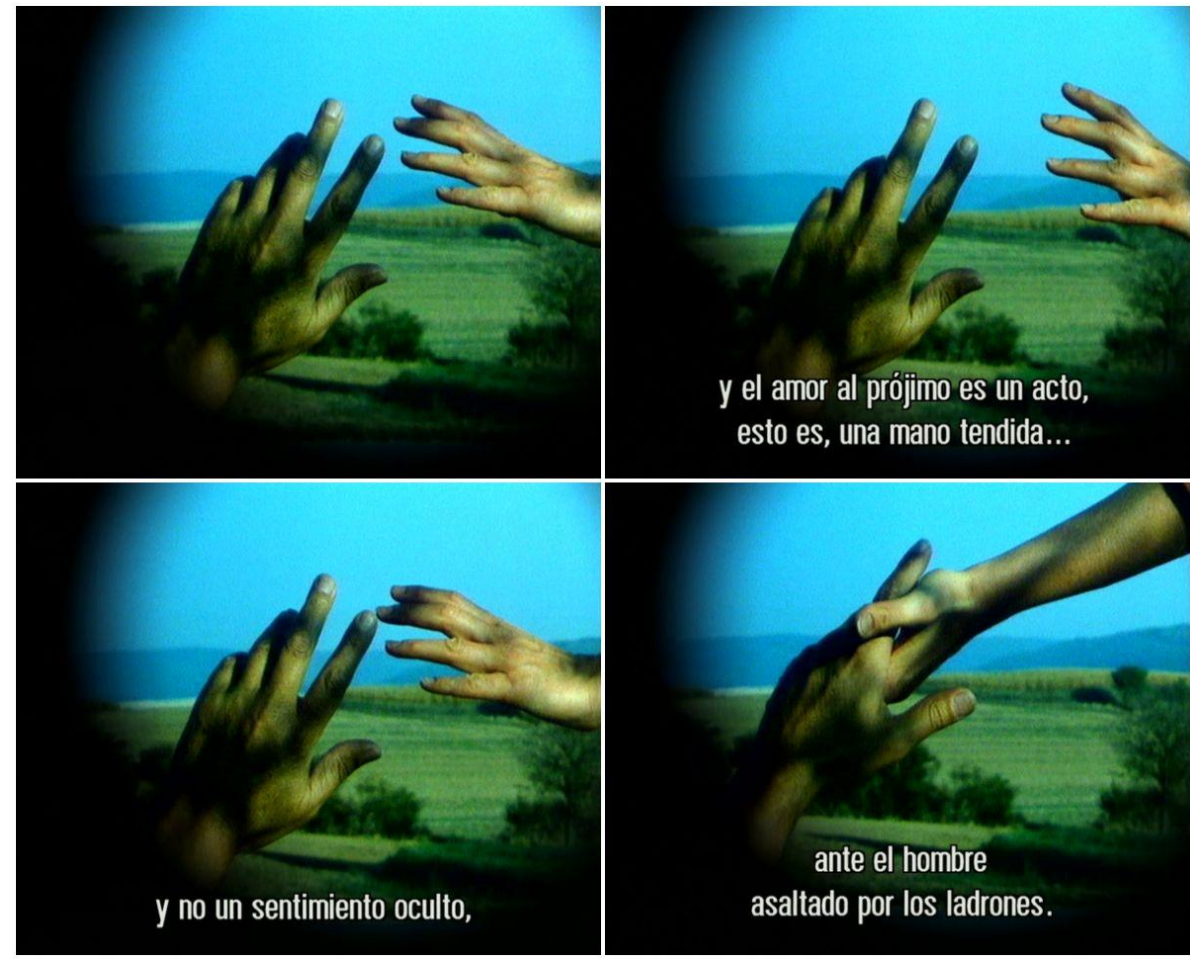

Cuando el Comité Invisible cierra su última publicación apelando a las manos, uno tiene la satírica intención de reconciliar a Disneyland con el anarquismo; sea cual sea su facción.

Renunciar a construir mundos con nuestras manos es condenarse a una existencia de espectro. ${ }^{9}$

\subsection{Materialismo ecológico}

Continúo ahora con Wall-E, pero me sitúo en su apertura. Estamos en el siglo XXIX y la Tierra ha dejado de ser habitable. Los planos aéreos y las vistas generales agigantan una distopía que, como las pesadillas, representa un presente aplazado. En ocasiones, el futuro se coloca detrás de ti para hostigarte hasta cumplimentar el título español de la conocida película de Richard Fleischer (Soylent green, Cuando el destino nos alcance, 1973). El futuro es la jauría parlante de Up. Este posapocalipsis de la inmundicia, del aire viciado y de la severidad climática, podría ser considerado como una crítica convencional al modo de vida que lo ha propiciado. Lo es, no cabe duda. Pero después de esta primera página vienen otras muchas y hasta una última. Pixar, agarrado a un escuálido brote verde, hace regresar la nave Axioma a la Tierra. Los siglos de feliz diáspora galáctica no han servido para que la especie olvide el sentido de pertenencia.

\footnotetext{
${ }^{9}$ COMITÉ INVISIBLE, A nuestros amigos, México D.F.: Ediciones Anarquía es una sinfonía, 2014, p. 139.
} 
Nunca han conocido aquel páramo remoto, pero algo les dice que aquel es su lugar. ¿iCómo no regresar donde uno puede plantar y cultivar pizzas!?

Cuando Pixar, haciendo caso a Dorothy (There's no place like home) e ignorando a Nicholas Ray (We can't go home again), regresa a casa, está escribiendo un manifiesto claro y concreto: el del materialismo ecológico. Solo el culpable de destruir el hogar puede ser capaz de restaurarlo. La distopía no resultó ser la de un planeta desértico, sino el de un ciberespacio despótico, fofo y aburrido. Un ciberespacio sometido a raíles donde escasea el movimiento y sobra asepsia, azúcar... e imágenes. El Axioma queda constituido como una gran iconosfera repetitiva que induce a una iconofagia saciante. Dispositivos de reproducción desmaterializados que entregan las imágenes de forma etérea. Las pantallas han dejado de estar, ahora simplemente surgen allí donde son requeridas. La ubicuidad de una imagen que no puede ver pero que controla.



Mientras tanto, la Tierra, en su devastación, ha ido recuperando la virginidad iconográfica. Todas las imágenes se han vuelto invisibles. Yacen sepultadas por el polvo o comprimidas en perfectos cubos de chatarra. Pixar también vuelve a la Tierra porque desea recuperar el placer de habitar un mundo desprovisto de imágenes. Más que de imágenes, de una serie de retóricas exhaustas. Se trata de adecentar el paraíso perdido.

Wall-E sobrevive con la compañía de un viejo artefacto que logra proyectar y redimensionar gracias a una curiosa cadena de obsolescencia audiovisual. El estuche de la cinta es una tostadora. Una cinta que ni siquiera es un VHS, ies Beta! El ingenioso robot se las ha apañado para que ese voluminoso reproductor envíe la imagen magnética a un pequeño iPod nano de generación desconocida. Pero como la minúscula pantalla del iPod es del todo insatisfactoria, añade otro apéndice: otra pantalla más grande. Nada de cristal líquido o LED, las esquinas redondeadas y la visibilidad de líneas verticales apuntan a la escoria de una televisión de tubo. Contrastes tecnológicos como los que podemos ver en la reciente entrega de Misión imposible 
(Mission: impossible. Rogue nation, Christopher McQuarrie, 2015), donde Ethan Hunt asiste al típico mensaje de misión gracias a la cohabitación de un tocadiscos y de un holograma con estética de retrocomputadora de fósforo verde.

Wall-E no es solo un precavido catalogador y un infatigable compactador del desecho, es un sibarita del residuo y un esteta de la chatarra.

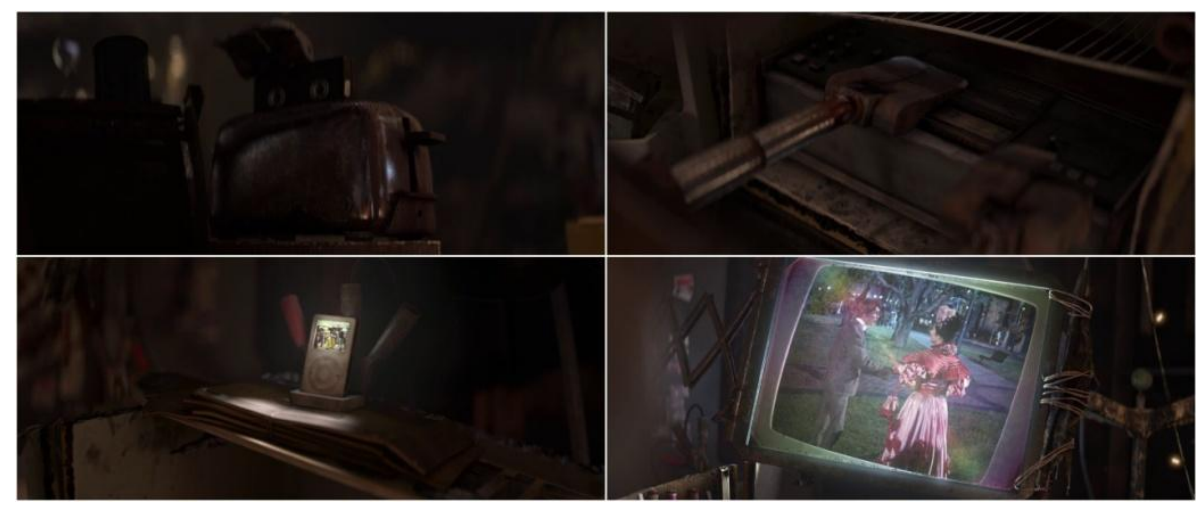

Fueron los robots renegados los primeros en ayudar durante la revuelta del Axioma. Robots desquiciados, con la tuerca sin apretar o perdida, con el software obsoleto o violentado. La diferencia y la locura surgiendo como nuevo brote verde, en este ocasión de libertad. Prosiguió el capitán al recurrir a un manual de instrucciones escrito nada más y nada menos que en papel. Así, el materialismo ecológico abarca -de hecho es uno de sus fundamentos- a la tecnología. No supone tanto un regreso a la pureza como una reconsideración de las metodologías. El objetivo: la supervivencia de la comunidad. Contribuir a la salud y al bienestar ciudadano.

Pixar quiere asumir la impureza y el contacto. Esto es, el peligro. Redescubrir la vigencia de lo que en su día fue clasificado como obsoleto. Reciclar tanto las obras como los medios con los que eran elaboradas. Aunque sea a través del simulacro. Esto surge porque el control y la profilaxis son dos de nuestras neurosis preferidas. Los monstruos de Pixar descubrieron que no había nada de tóxico en su contacto con los humanos, más bien todo lo contrario. De la misma manera que los humanos de Ratatouille descubrieron que las ratas podían aceptar protocolos de higiene sensatos. El basurero ya enmarcaba el deus ex máchina de Toy story 3 y también aparecía en su derivada acuática de la bahía de Sídney durante el desenlace de Buscando a Nemo. Este último, claro ejemplo de los peligros de la sobreprotección.

Pixar toma una fotografía de la basura, observa el negativo y lo manda a positivar. Este optimismo escatológico no queda restringido a Wall-E. Pixar subvierte su condición fiduciaria 
del reino mágico de Disney, así como la regulación de una imagen contemporánea perfecta e impoluta: ideal. En Pixar se puede apreciar la escatología en su doble acepción: la ultratumba y lo excrementicio. La ultratumba es el limbo donde se amontona la chatarra y la obsolescencia tecnológica. Todos sabemos que el limbo es el no-lugar por excelencia. Es ese espacio que no existe pero donde, por algún motivo arcano, las almas esperan la llamada y la aceptación del altísimo. La dinamo de Toy story 3 es el temor, al principio subliminal y luego explícito, a la obsolescencia. La pandilla teme visitar ese limbo hábilmente representado por un trastero jamás mostrado, solo insinuado por una escalera y un rectángulo tan oscuro como las leyendas sobre sus inquilinos. El peligro es idéntico al de Carl Fredricksen en Up. Asediado por una modernidad que viste de negro, anciano y casa se atrincheran en una obsolescencia por duplicado.

Lo excrementicio reside en la basura, pero también en el desperfecto. Materia degenerada y decadente. También materia en perfecto estado de revista pero fuera de su sitio. Pixar siente predilección por ese tipo de materia descastada. En cualquier caso, las pestilencias no siempre se toman en su vertiente positiva. Ahí tenemos al minero hediondo en su labor de villano encubierto de Toy story 2. Lo que Pixar también incorpora sin descanso es la estética retro y la reproducción de una imagen desvaída. No importa el formato y la tecnología. Puede ser una pantalla futurista o una viejo álbum de fotos. Pixar empotra una imagen caducada en un tiempo que glorifica a su némesis. Esta imagen declinante o esa declinación de la imagen, no aparece en una práctica marginal, surge en plena corriente dominante.

La imagen rasgada, renegar del linaje sajando un tapiz, es el drástico medio que tiene Merida para transmitir su insurrección. Al Sr. Fredricksen también se le pone el tiempo amarillo sobre el álbum fotográfico que guarda y revé con nostalgia. Estética extendida a los créditos finales de la película. Las grabaciones de un alto representante -el único cuerpo humano real de toda la filmografía de Pixar- de la corporación que se hizo con el gobierno en la Tierra, incorporan la interferencia y la pixelización. 


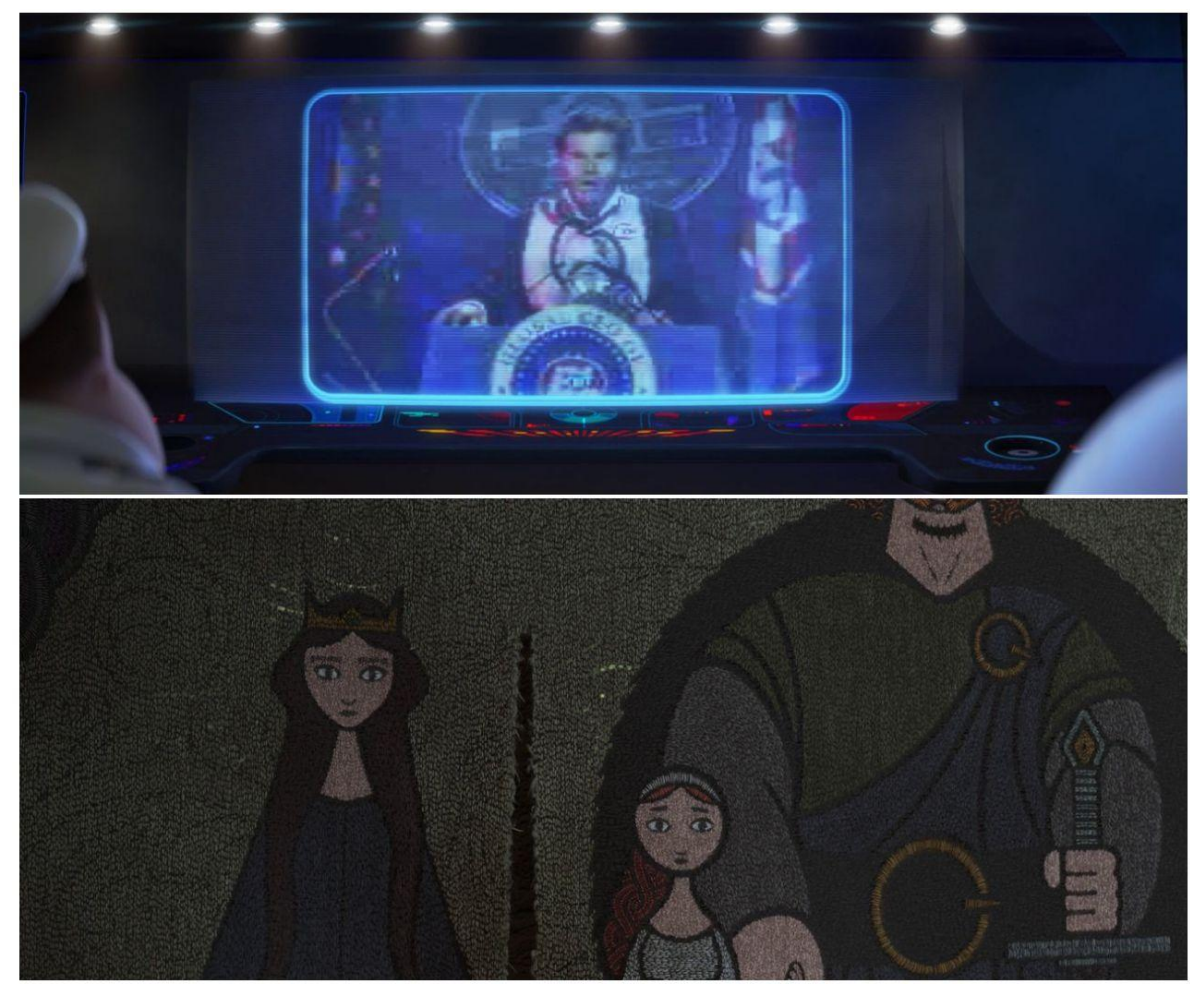

Ya he mentado las recurrentes televisiones y el artilugio de Wall-E. No es redundante recordar la videocámara casera de Toy story 3 con su grabación mordida por los cabezales magnéticos y, seguramente, por un visionado o regrabado recurrente. Sendos arranques en Los increíbles y Up acuden a la estética del noticiario cinematográfico años 1930-1950 para ponernos en situación. Con su formato cuadrangular embutido en el rectángulo, con su grano simulado, con sus barras de arrastre, con su eventual desenfoque y hasta con su sonido craquelado. Que al final de los mencionados créditos de Up suene un vinilo The spirit of adventure no es un adorno, es parte del discurso. En Ratatouille llegamos a encontrar un remedo de música visual sinestésica durante el episodio en el que Remy intenta instruir a su hermano en el mundo de la degustación.

Pero Pixar no se limita a recuperar esa obsolescencia digamos ajena. Recupera la propia, la relativa a la animación. Un magnífico pasaje bidimensional en Del revés y un sugerente despliegue de pixel art en los créditos de Wall-E. En estos últimos, creados por Jim Capobianco, junto a una historia condensada de las imágenes donde no se olvidan de las pinturas parietales, desfilan versiones low-res de algunos de los robots protagonistas. En Your friend the rat (2007), maravilloso cortometraje hermano de Ratatouille, también hay ocasión para observar una recuperación de la clásica imagen de los primitivos juegos arcade. Además, Pixar está plagada de múltiples y diversas -en tiempo y forma- visiones de interfaz. 
Materializar el interfaz nos enseña, en clave subjetiva y simbólica pero también en clave impersonal y objetiva, parte de la vulgar y confusa tramoya tecnológica.

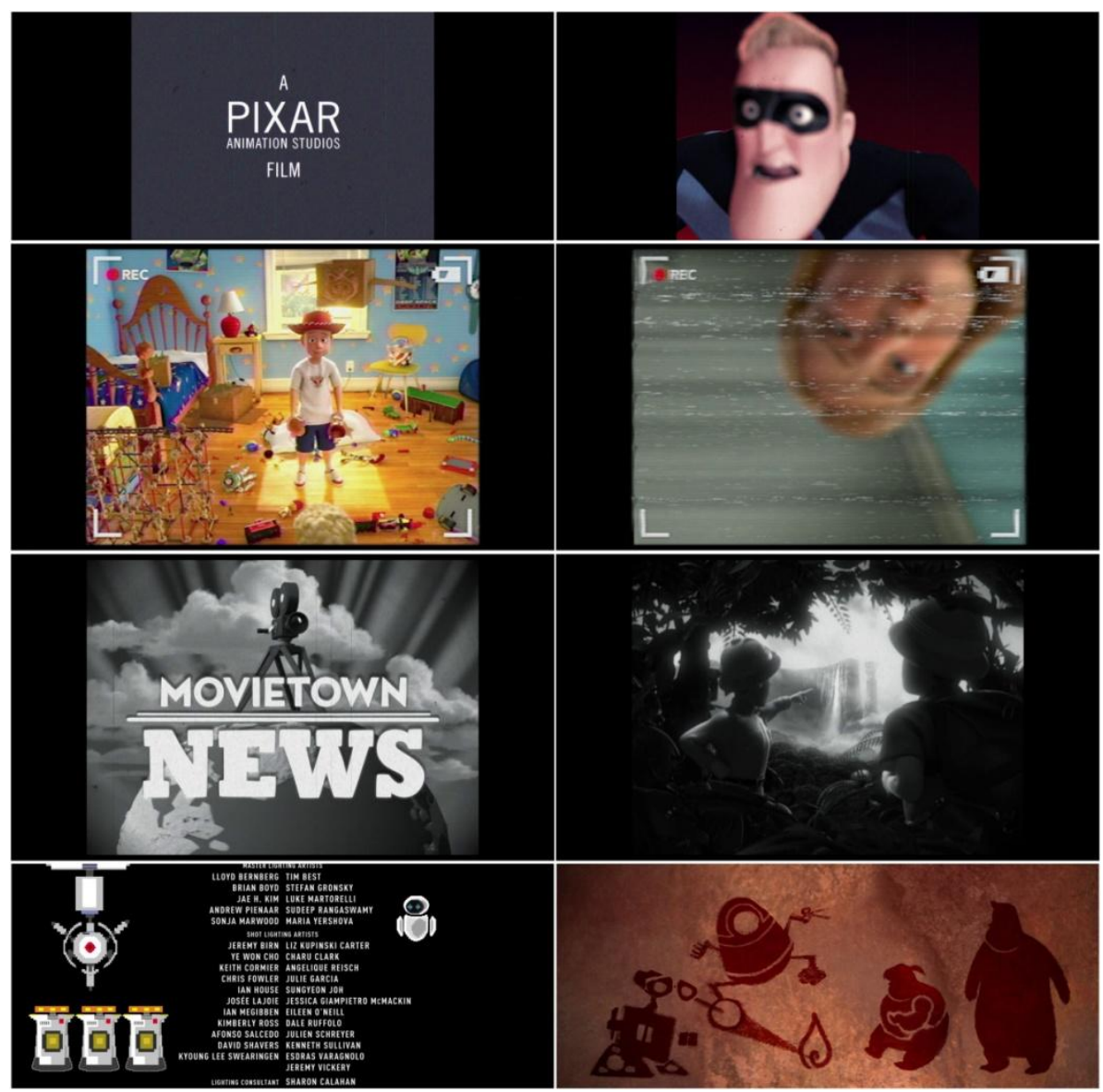

Por último, es pertinente indicar el frecuente uso de la dialéctica entre texturas. Está insinuada en la pareja Woody-Buzz y hasta en la maligna rugosidad de los saltamontes de Bichos. Pero encuentra su gran expresión en las dos partes de Cars. Rayo McQueen y Mater, pasado y presente que quiere ser futuro de las carrocerías. Pixar los convierte en amigos íntimos. En Cars 2, durante el proceso de camuflaje, Mater se niega a perder todas sus cicatrices. Esas abolladuras, esa pátina sentimental es el obsequio del tiempo y la amistad. El óxido es el proceso vital por excelencia. Solo vivimos porque logramos convertir el oxigeno en alimento. Que el primer anunciante del flamígero McQueen sea una compañía personificada por tartanas llamada Rust-eze $e^{10}$, tampoco se puede achacar al azar. Solo después de esta pareja vendrá y se entenderá la dialéctica terso-áspero de Eve y Wall-E.

En conclusión, el materialismo ecológico solo puede articularse gracias a la ciencia y a una ética gravitatoria. A un reencuentro entre la técnica evolucionada, impregnada de intelecto, y un conocimiento desacralizado, extraído de su esfera ideal. A pesar de ese deseo de paraíso

\footnotetext{
${ }^{10}$ Rust, como nombre: óxido, herrumbre, orín; como verbo: oxidarse, corroerse.
} 
recobrado del que tanto nos cuesta despegarnos, el materialismo ecológico no se corresponde con un ecologismo ideológico y sentimentaloide, sino con una cognición cierta y rigurosa de la ecología. Es, por lo tanto, un método, una recomendación y, sobre todo, una emoción.

\subsection{Old but cool}

He defendido la necesidad de un corpus analítico cerrado y coherente. Ahora me veo en la necesidad de incumplirlo. Creo que de manera mínima y justificada. Quiero señalar algunos elementos adicionales y complementarios a los ya expuestos en el último apartado y, para ello, recurro a iRompe Ralph! (Wreck it Ralph!, Rich Moore, 2012). Digo que la desobediencia en pequeña y razonada porque la película también es de animación tridimensional, porque pertenece a la matriz Disney y porque su productor ejecutivo es John Lasseter. Aun desconociendo estos datos, cualquier espectador que se acerque a ella con un conocimiento medio de la filmografía de Pixar, no tardará en identificar algunos de los estilemas de la compañía de Emeryville.

A continuación procedo a unir el principio y el final del relato en su estricta materialidad. Esto es, desde una cabecera y un pie que, en teoría, flotan ajenos al devenir narrativo. Todos conocemos el logotipo que abre las películas de Disney. Travelling aéreo que arranca enfocando una estrella titilante, baja hasta el horizonte para recorrer el paisaje y termina reencuadrando el castillo de Cenicienta entre fuegos artificiales y purpurina. Ese paisaje dice muchas cosas de Disney. Algunas ya las he mencionado: apetito primigenio, virginidad natural. Otras son auténticos correlatos de esa ambición: encontrar una forma universal que la represente. El paisaje de Disney no es un Patinir, es -en rigor- una variante de los Most wanted paintings de Komar y Melamid. Esa consolación que el instinto de la especie y el kitsch cultural suele ofrecer a los legos en evolución y en historia del arte.

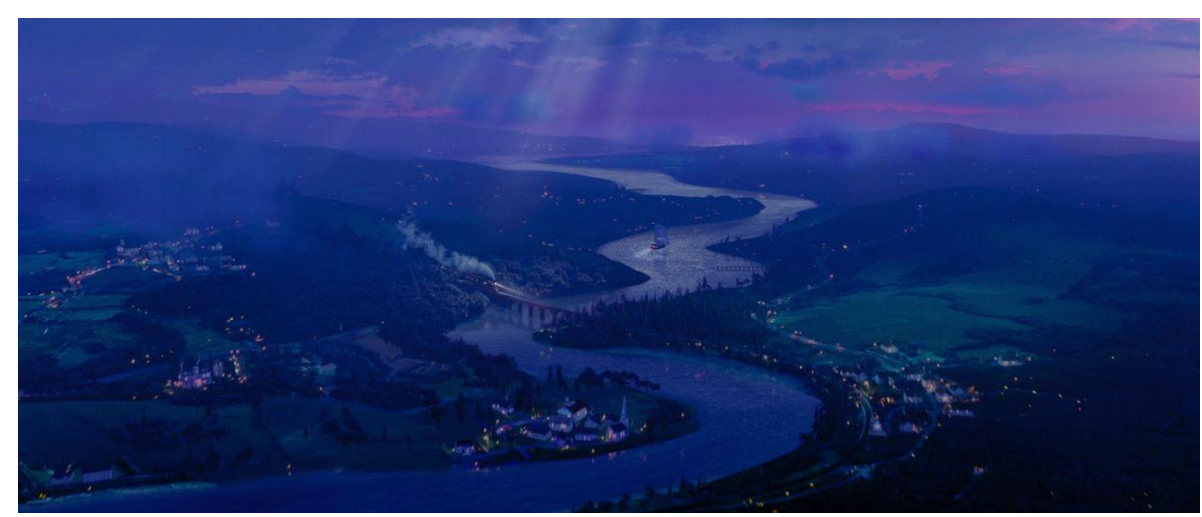

Gran parte de los paisaje del cine contemporáneo no se comprenden sin este factor. Mucho se ha hablado de las postales desmesuradas del cine digital, de sus abigarradas recomposiciones, 
del hiperrealismo y de la devastación como amenaza. De igual modo, mucho se ha escrito sobre el paisaje neorromántico o de las líneas de abstracción pictórica ligadas al cine de autor contemplativo. Sin embargo, poco se menta la normalidad. El paisaje de Disney es la normalidad biológica apenas alterada por luces y transportes. La defensa y la nostalgia arcádica nace de nuestro simple instinto de reproducción. Igual que le pasaba al solterón protagonista de Tierra prometida (Promised land, Gus Van Sant, 2012), por elegir un ejemplo que de cine ecologista que pertenece al mismo año que iRompe Ralph! Camino de los 40, el protagonista -que también era guionista- apreciaba un apacible recodo como el lugar perfecto para procrear con la núbil Rosemarie DeWitt. Al fin y al cabo, no es tanto una cuestión del mito de la Arcadia como de la configuración cerebral. Frente a unas ciudades cada vez menos amables para la cría, un paisaje con agua, vegetación, veredas y animales es el lugar adecuado para asentarse y tener descendencia. Nuestra relación con el paisaje retratado siempre ha pretendido rememorar, reencontrar y habitar ese jardín en la máquina. ${ }^{11}$

Concluyo con esos planos para pasar al siguiente. Disney duplica su logo pero con una nueva estética. Al logotipo canónico le sucede otro diseñado para la ocasión. Un cartel en negro panorámico en cuyo centro aparece el primer dibujo animado con sonido sincronizado de su emblema el ratón Mickey: Steamboat Willie (1928). No es una novedad, lo han utilizado con anterioridad. Lo realmente importante es cómo están dibujados tanto el viejo cartoon como las letras corporativas: en pixel art a baja resolución. Con la misma estética arcade y con la misma tecnología obsoleta que protagonizará la película.

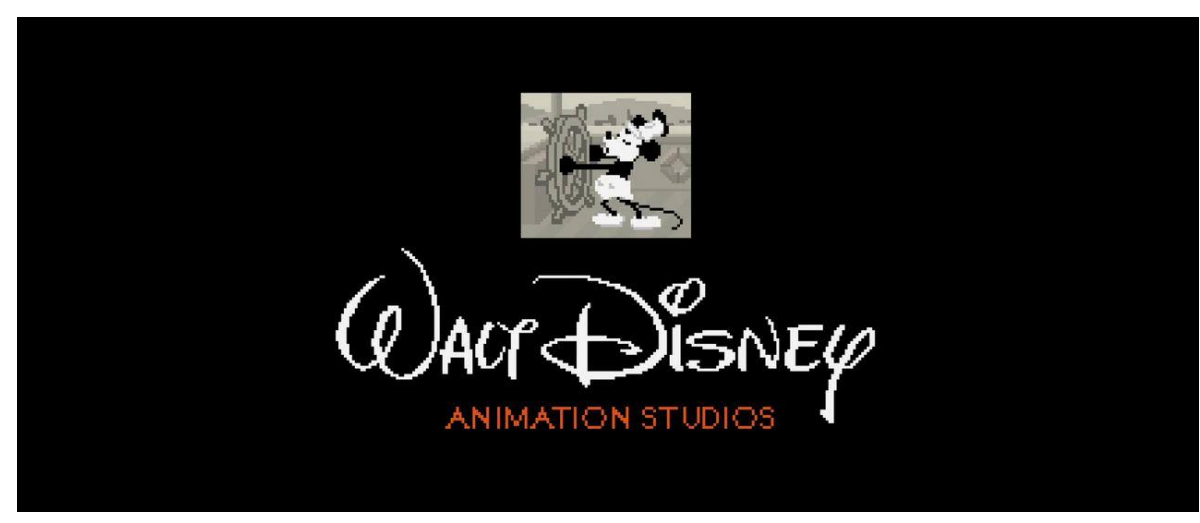

Salta la aguja desde este preludio para coserlo con el final. Después del largo desfile de los créditos, el logo con Mickey se duplica, solo que ahora en su forma convencional. Tras él, la clausura con el logo del castillo. Pero ahora falla, se aturulla y queda invadido por números,

\footnotetext{
${ }^{11}$ The garden in the machine fue el sugerente título -por la crítica cartesiana implícita- empleado por Scott MacDonald en su estudio -con especial atención a la vanguardia americana de la segunda mitad del siglo XX- sobre la representación cinematográfica del paisaje: MacDONALD, Scott, The garden in the machine. A field guide to independent films about place, Berkeley: University of California Press, 2001.
} 
figuras de videojuego, macrobloques y glitch. El logo se va a negro imitando el apagado de un viejo dispositivo CRT. La materia de la película y del relato se condensan en una terminal e inútil forma de supervivencia: un punto de luz que son tres. Último aliento RGB de unos rayos que se apagan, de una materia que se desvanece entregando una postrera satisfacción a la educación sentimental del espectador.

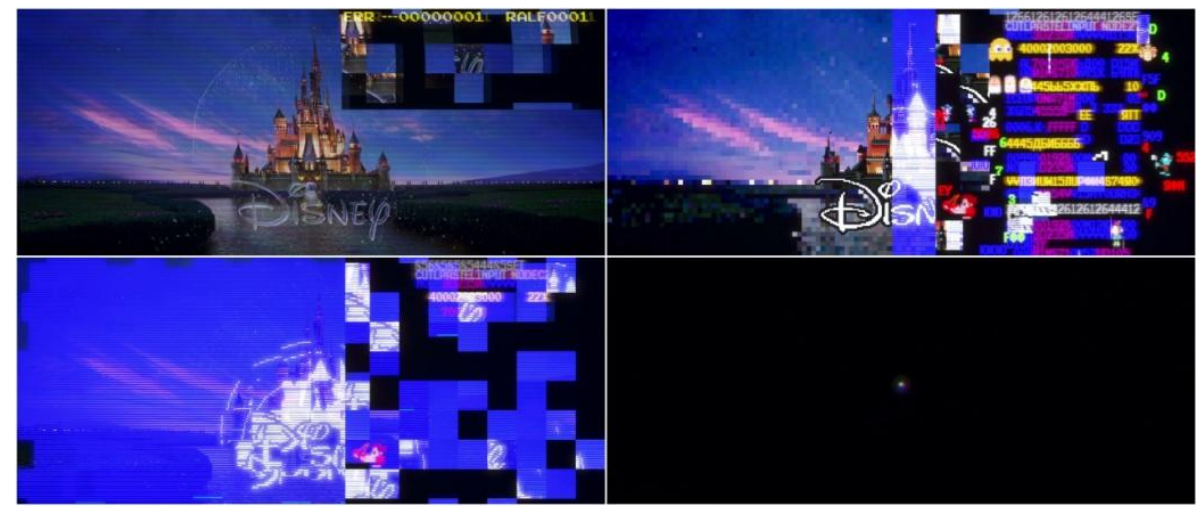

Se podrá argumentar que es algo normal, una adecuación simpática al tema; y de nuevo se estará en lo cierto. En determinados casos, sea cual sea el estudio, se realiza un nuevo diseño que case con la estética del filme. Pero cabe seguir preguntando. ¿Se puede sacar alguna conclusión más a partir de la distorsión del propio logotipo? Creo que sí y sin forzar la interpretación. Para ello hay que tener presente la relación entre instinto y paisaje ya mencionada y, además, una nueva idea. Renunciar a la Arcadia profanando tu marca implica una tendencia y una concesión de mercado y, sobre ella, un discurso implícito sobre la imperfección humana y tecnológica. Esto que en otra compañía podría ser anecdótico, en Disney es relevante. ${ }^{12}$ Ensuciar tu Verónica, aunque sea de manera artificial y pasajera, no es un acto libre de consecuencias.

Lo ha hecho Disney y lo ha hecho la Universal acomodándose a la estética chat de alta compresión y de conectividad deficiente en Eliminado (Unfriended, Levan Gabriadze, 2014). Y quién le iba a decir a la casa donde había más estrellas que en el cielo, que terminaría marchitando la melena de su león a base de glitch. Véase el comienzo del remake de Poltergeist (Gil Kenan, 2015). Que productoras pequeñas diseñen sus logos atendiendo desde el inicio a esas estéticas en lugar de incorporarlas de manera coyuntural, es lógico. No he realizado un estudio de campo sobre ello, pero la memoria me alcanza para recordar al menos dos: Annapurna y Blumhouse. Que algunas de las grandes majors de la antigüedad se vean en

\footnotetext{
${ }^{12}$ Disney reutilizará tímidamente esta idea y, a su vez, intentará rehabilitar el futuro como Arcadia, en Tomorrowland (Brad Bird, 2015). Allí, el primer plano es otro punto de luz seguido de una cadena de glitch. El futuro amenazado por distopías que nadie quiere remediar. Nadie excepto una niña obstinada, una robot desterrada del paraíso.
} 
el apuro de jugar al desperfecto, es una ironía histórica y, también, el último síntoma de su voraz metabolismo a la hora de digerir la vanguardia.



Lo que sucede entre las divisas de Disney también tiene interés. Al fin y al cabo, en una película, aunque esté compuesta por un cuadro monocromo en bucle, siempre ocurre algo. ¡Rompe Ralph! no suma elementos retro por separado como podía suceder en algunos trabajos de Pixar. Es, de principio a fin -de castillo a castillo-, un filme que nos habla del pasado con el lenguaje del presente. Es, ante todo, un filme en 3D y en gran formato panorámico compuesto por imágenes y movimientos concordantes con la última tecnología del momento. Teniendo esto en cuenta, es necesario preguntarse cuánto y cómo de nostálgico puede llegar a ser.

Quiso serlo y así fue vendido y reseñado. Como la recuperación sentimental del pasado para una generación criada a caballo entre las calles, las primeras consolas y los salones recreativos. Es mi caso, a medias. A mí me gustaba más la calle que los juegos. Siempre me dieron algo de miedo aquellos salones histéricos frecuentados por los peores quinquis de la ciudad. Los nuevos adultos del siglo XXI dejaron de identificarse con las nuevas estéticas para añorar las viejas. Adultos que pueden seguir practicando con videojuegos de última generación, pero que 
también pueden dedicarse a emular juegos arcaicos y a restaurar máquinas arcade mientras pasan la gamuza por encima de un vinilo.

La realidad es bien distinta. ¡Rompe Ralph!, una vez analizadas sus imágenes, carece de un discurso nostálgico inmediato. Espera despertarlo en espectador, pero no lo ofrece en bandeja. Sus imágenes y su lenguaje están demasiado alejados de sus referentes (circa 1982) como para que la conexión funcione. Por eso es una gran película, porque falla la intención y la expresión del componente nostálgico. Si prestamos atención, casi todo es un gran simulacro. En seguida se abandona el look de baja resolución para entregarse a la erógena suavidad del digital. Quiere disimular falseando los contornos, creando angulaciones llamativas donde debería prevalecer la curva y arrebatando la fluidez a los movimientos.

Este simulacro de baja resolución es inteligente y está realmente conseguido en el interior del edificio que intenta desbaratar Ralph y que arregla Felix, pero es insuficiente. No conviene pasar por alto esa situación. La abolición del grano y de las imperfecciones fue el debate cumbre de la primera década de Internet. Cualquiera que conociera y viviera la época dorada de las discusiones en los foros relacionados con el audiovisual, recordará auténticas reyertas provocadas por este asunto. Una lástima que tanto el debate en sí, como el formato en el que se desarrollaba, cayeran en el olvido ante el empuje y la banalidad del social media de la segunda década del siglo. También dice muy poco de la agudeza de la academia y de cierta crítica $^{13}$ que se mantuvieran al margen de aquello, ya fuera por gusto aristocrático o por simple ignorancia.

¡Rompe Ralph! es un nuevo ejemplo de lo que algunos podrán llamar cine de atracciones, con su sensualidad iconográfica y textural, con sus pletóricos roller coaster y sus múltiples intertextos. Sin olvidar que presenta una estructura narrativa similar a las de Pixar en cuanto a la dosificación y al emplazamiento de los mismos. También una voz off que, como en sus parientes, puntúa principio y final. O motivos recurrentes como el animismo -aquí los muñecos prosiguen y organizan sus vidas cuando los humanos dejan de accionarlos-, la basura y el desperfecto. Ralph vive en un vertedero y su oficio consiste en destrozar. Aunque es evidente el contraste entre lo informe del vertedero y la geometría del edificio, las dialécticas de Cars y Wall-E viven aquí reformuladas más en términos de texturas sentimentales que de texturas materiales.

\footnotetext{
${ }^{13}$ Una notable excepción: PRINCE, Stephen, "The emergence of filmic artifacts" en Film Quarterly, no 3, vol. 57, pp. 24-33.
} 
En este sentido, el detalle más sutil es un piropo que Felix le hace a Calhoun. El pánfilo muñeco, recién llegado de un mundo olvidado por el tiempo, se topa con la voluptuosa viuda negra y solo puede exclamar: “¡Mira esa alta definición! ¡Su cara! ¡Es increíble!”. He ahí la sensualidad a la que me refería, la digitalofilia textural que se extiende desde Felix hasta el espectador sin menospreciar al teórico de los nuevos medios.

Si he elegido iRompe Ralph! no es por el discurso fracasado de la nostalgia o por su relación con Pixar. Recurro a ella porque me permite hablar de manera recta de la materialidad de las imágenes. En este caso con una excitante combinación entre dispositivos electrónicos digitales y analógicos. Ya he empezado a hacerlo con su prólogo y con su clausura, ahora quiero hacerlo con su nudo. La materialidad del filme está presente en numerosos detalles que ya conocemos: la hipertrofia del formato y en este caso de las propias máquinas arcade si las comparamos con las desmaterializadas consolas actuales, la baja resolución de algunos de sus pasajes y paisajes, los reflejos de lo real afeando lo virtual, la obsolescencia y la materia fuera de sitio, el puntual metraje granulado-cinematográfico de emulación, interfaces, los bugs y los virus. La que ahora más me preocupa es una materia con mayor densidad, de fondo. Materia mostrada por dos líneas que no corren en paralelo, ni siquiera en convergencia o en divergencia. Dos vías dispuestas hacia un encuentro ortogonal. Accedemos a la materialidad electrónica gracias a una inmersión literal y horizontal -pantalla y cables- que se prolonga hacia sus tripas gracias a una inmersión simbólica y vertical -la cripta del código y el glitch.

La inmersión será casi inmediata, en apenas dos minutos. Antes, el punto de vista de presentación queda vinculado a la exploración del espacio exterior: la galería de juegos. Espacio público de fruición que, como en el caso del cine, irá virando hacia el privado. Un travelling de retroceso acompañado de un time lapse simulado, nos termina desvelando una elipsis de treinta años. Todo con la máquina de Fix-it Felix Jr. en el eje axial del encuadre. Ya situados en la actualidad (2012), no tardamos en comprobar que la máquina protagonista sigue en su sitio. El salón de juegos tiene nuevos y seductores inquilinos, pero la máquina donde habitan Felix y Ralph ha aguantado erguida las tres décadas. Es una superviviente. Nos sumergimos en ella de manera lúdica. ${ }^{14}$

\footnotetext{
${ }^{14}$ Existe otra vertiente cinematográfica de este tipo de inmersión condicionada por la pesadilla y el terror. Es Ilamativo que los originales de Tron y Poltergeist (Tobe Hooper, 1982) compartieran año y que casi volvieran a hacerlo con sus respectivas extensiones (2010) o remakes (2015). El remake de Poltergeist se abre, con toda la intencionalidad posible, invirtiendo el mecanismo de inmersión. La
} 
La primera maniobra de inmersión es sencilla y se asemeja al despegue de un avión. V1: visión subjetiva pero a la vez impersonal, neutra, es una y somos todos -tripulación y pasaje- en movimiento de avance controlado. VR: durante el acercamiento a la pantalla se alcanza la velocidad de rotación pero, en lugar de un leve ángulo ascendente se cambia por otro en ligero picado. V2: velocidad necesaria para el despegue, en este caso para la inmersión; punto de no retorno que conduce a la succión del punto de vista. En ese momento crítico llegamos a observar la materia electrónica de la pantalla. Textura analógica característica de la tecnología CRT. La solución visual para hacer creíble la inmersión es el resplandor generado por los haces de luz. Un par de coloridos fogonazos y nos hallamos al otro lado del espejo. En ese mismo instante, abandonado el mundo real para ingresar en el virtual, se produce un cambio evidente de las texturas. Dejamos atrás los rectángulos analógicos y la superficie de la imagen adquiere el pulimento característico del digital contemporáneo. A partir de ahora, lo analógico y el digital de baja resolución serán emulaciones realizadas por el state of the art del siglo veintiuno.

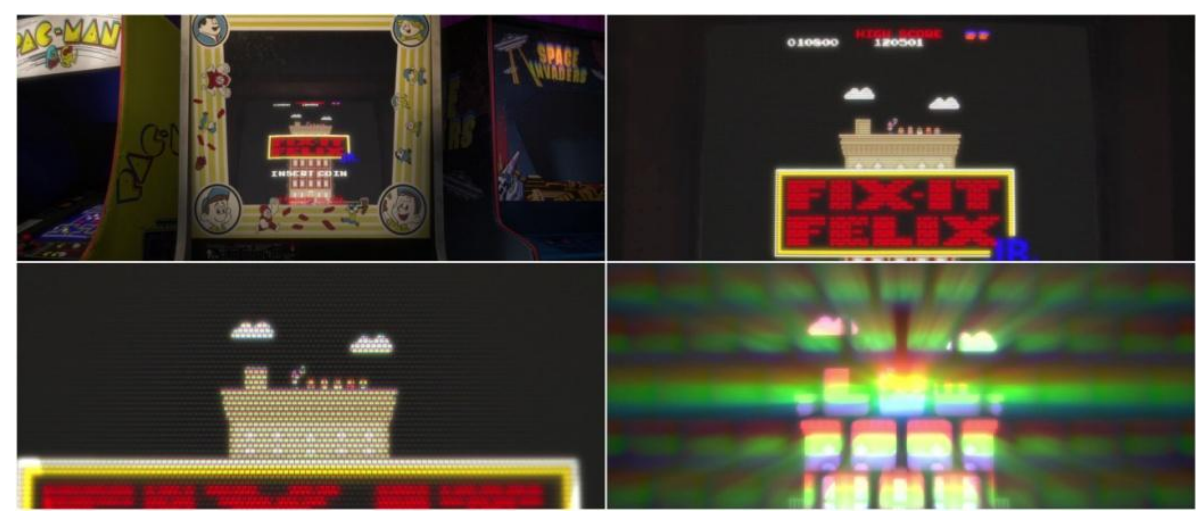

La inmersión se prolonga sin cambiar o cortar el plano. Movimiento de 360 grados en torno al edificio protagonista. La eterna superficie bidimensional de una pantalla reforzada por la fachada del edificio, queda convertida en espacio transitable. La operación cinematográfica es brillante: describe y, al tiempo, posibilita. Invade un lugar, nos ofrece toda la información necesaria sobre el mismo y lo convierte en habitable. Vemos que su firmamento particular también posee estrellas. La tierra ha dejado de ser plana, la imagen tridimensional está dispuesta a construir un discurso científico sobre su circularidad. La tierra ha dejado de ser un lienzo empeñado en ocultar su trastienda. Nuestro mundo, el mundo real, se ha convertido en el más allá de una imagen tridimensional con relato propio.

cámara parte de la superficie pixelada de un iPad para desvelarnos la figuración negada por la cercanía $y$, solo después, el espacio que rodea al dispositivo. 
Sabiendo que la máquina de Ralph es habitable, debemos conocer si está incomunicada o si hay relación con sus vecinos. La primera inmersión evoluciona, se profundiza. Las máquinas no están comunicadas de manera directa pero pueden intercambiar vivencias y espacios pasando por un nudo de comunicaciones. La regleta de donde absorben la energía queda convertida en una gran estación central de aire neoyorquino. A ella se accede a través de los respectivos cableados. También vemos su interior, nos subimos a los vagones y avanzamos según el pulso eléctrico que los conduce. Esta inmersión y esta materialización de los componentes camuflados y del fluir energético es un recurso inofensivo, pero se ha convertido en uno de los planos recurrentes de cierto cine contemporáneo. Todos nos volvemos a acordar de Tron (Steven Lisberger, 1982) y de su secuela ${ }^{15}$, ambas de Disney, pero aquello era distinto por estilo y por estar protagonizadas por cuerpos humanos reales.

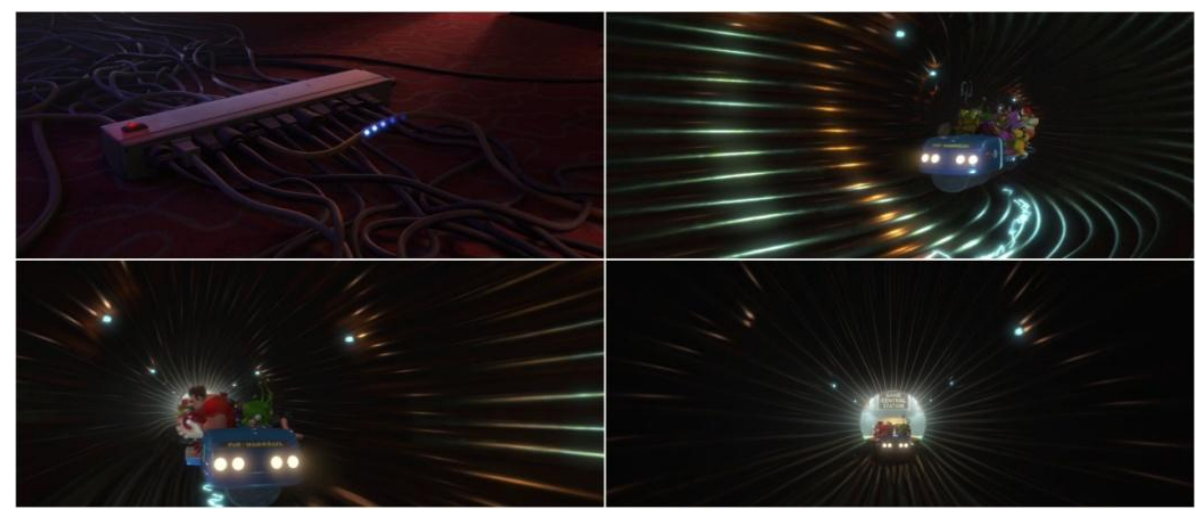

Este ansia por sumergir el punto de vista en la materia recóndita habla de la capacidad tecnológica reinante. Es un alarde, pero también una latencia, una verdad, una supervivencia. La exploración de la materia a nanoescala ha reemplazado a la vieja fantasía de la exploración corporal cinematográfica. De Viaje alucinante (Fantastic voyage, Richard Fleischer, 1966) a EI chip prodigioso (Innerspace, Joe Dante, 1987) pasando por Érase una vez la vida (Il était une fois... la vie, Albert Barillé, 1986) y por innumerables documentales hasta llegar al roller coaster neural de los créditos iniciales de El club de la lucha (Fight club, David Fincher, 1999). Hoy queremos desvelar la materia vulgar a nivel infinitesimal y para ello interpretamos trayectos y texturas imposibles. Vemos cómo las partículas del colisionador de hadrones dibujan líneas y geometrías sobre pantallas de ordenador y no sabemos muy bien qué significa aquello. No lo sabemos o no nos atrevemos a saber porque podría significarlo todo. Podría ser el origen del universo disfrazado de música visual o de arte generativo.

\footnotetext{
${ }^{15}$ Es anecdótico pero no me resisto a señalarlo. En Tron: Legacy la inmersión está material y físicamente reforzada por la necesidad de descender a la mazmorra. Una vez succionado, el joven sabrá a lo que se enfrenta: - ¿Qué se supone que debo hacer?, le pregunta a una paisana; -Sobrevivir.
} 
Durante la secuencia de apertura de Blackhat (Michael Mann, 2014) asistimos al, por el momento, último tour de force de este punto de vista de la superconductividad. La imagen se adentra y explora los tejidos computacionales a la velocidad de la luz. Luz convenientemente reconducida en tiempo, forma y espacio por la estética digital. La metáfora de la autopista y del ciberespacio de la información ha quedado desfasada. La imagen que recreaba un globo terrestre surcado por vectores, ha sido sustituida por otra con capacidad para excavar en el suelo. La imagen grácil reemplazada por la imagen tuneladora.

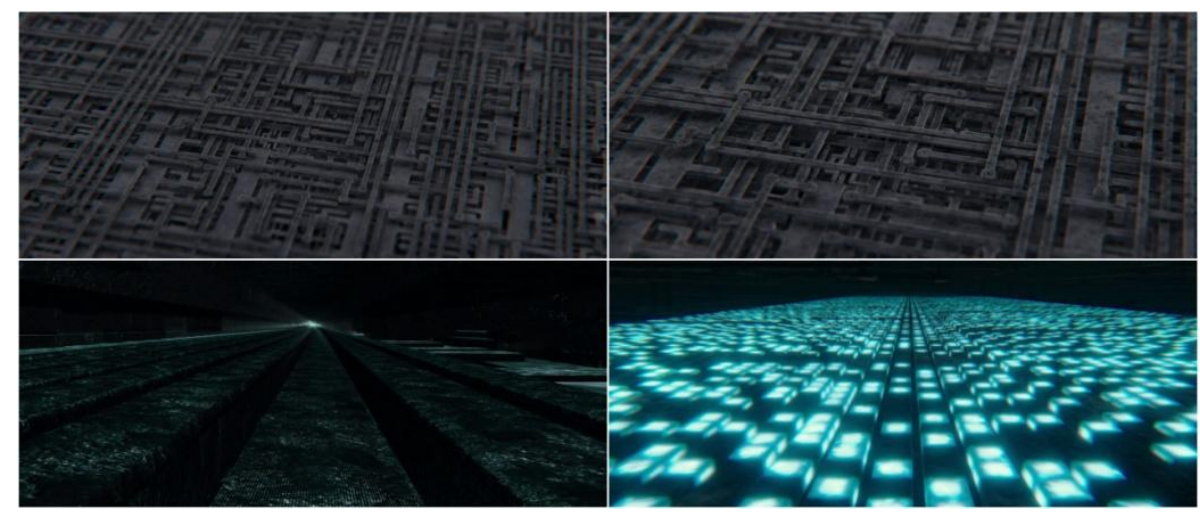

Vuelvo a la última fase de la inmersión en iRompe Ralph! porque es la más conseguida desde un punto de vista estético y discursivo. King Candy, el rey que gobierna el juego con sospechosa cordialidad, resulta ser un repudiado que no soportó la obsolescencia del salón arcade. Su mecanismo de supervivencia fue, primero, la rebelión violenta frente al cambio de paradigma y, segundo, la invasión silenciosa y modosa del vecino. El rey fraudulento usurpó el código que hacía posible el mundo y lo adaptó a sus necesidades. Imposible que lo virtual ilustre mejor lo real que esa acción. En la puesta en imágenes de ese fraude monárquico del digital reina la abstracción. El rey se desliza por la ingravidez oscura de la cripta donde se custodia el secreto de la vida. La cripta del código toma forma de espacio exterior donde el sol deviene procesador, pero también de cerebro repleto de conexiones inescrutables.

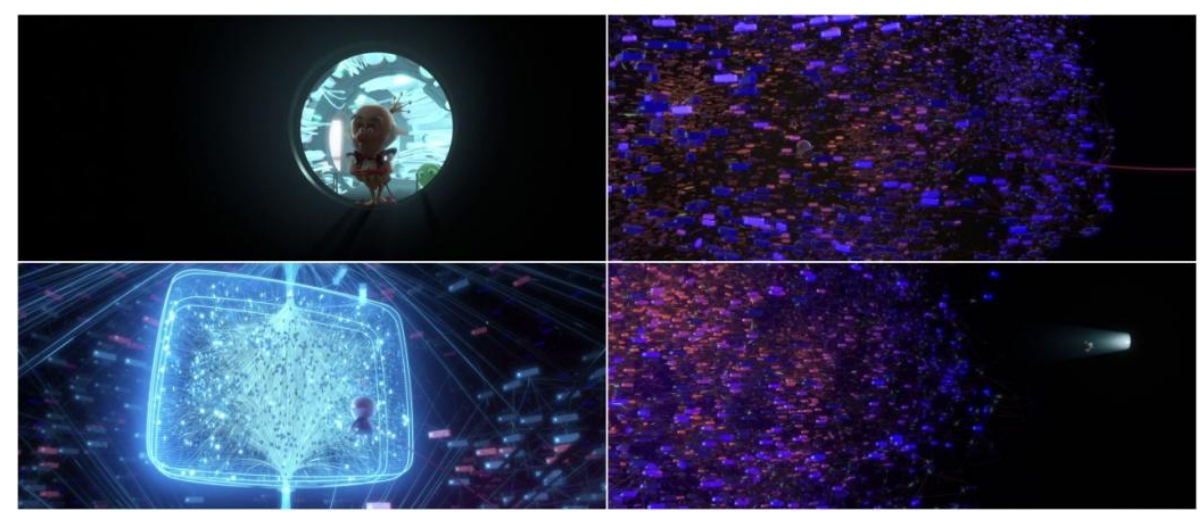

El código es la sangre vital, dice el rey. Cierto, es el manual de instrucciones o el de la supervivencia, según se mire. Es la estructura material básica para in-formar y para replicar. El código es el genoma. La víctima de la alteración en la secuencia de los cóntigos es la pizpireta 
Vanellope. Ella posee el instinto, pero la mutación adquirida por malignas causas epigenéticas le niega su esencia. "Soy una corredora, lo siento en mi código". En la vida real estaría perdida porque la mutación es irreversible, solo se puede retener o desechar a lo largo de las generaciones. Suerte que el código, en rigor, no es el genoma; sólo es otra metáfora. Los efectos de manipulación ejercida por King Candy le afectan a nivel corporal y social. Vanellope se ha convertido en una apestada, en una paria. Ella dice que solo sufre pixlexia, mientas las demás la ven como una leprosa, como un error: un glitch.

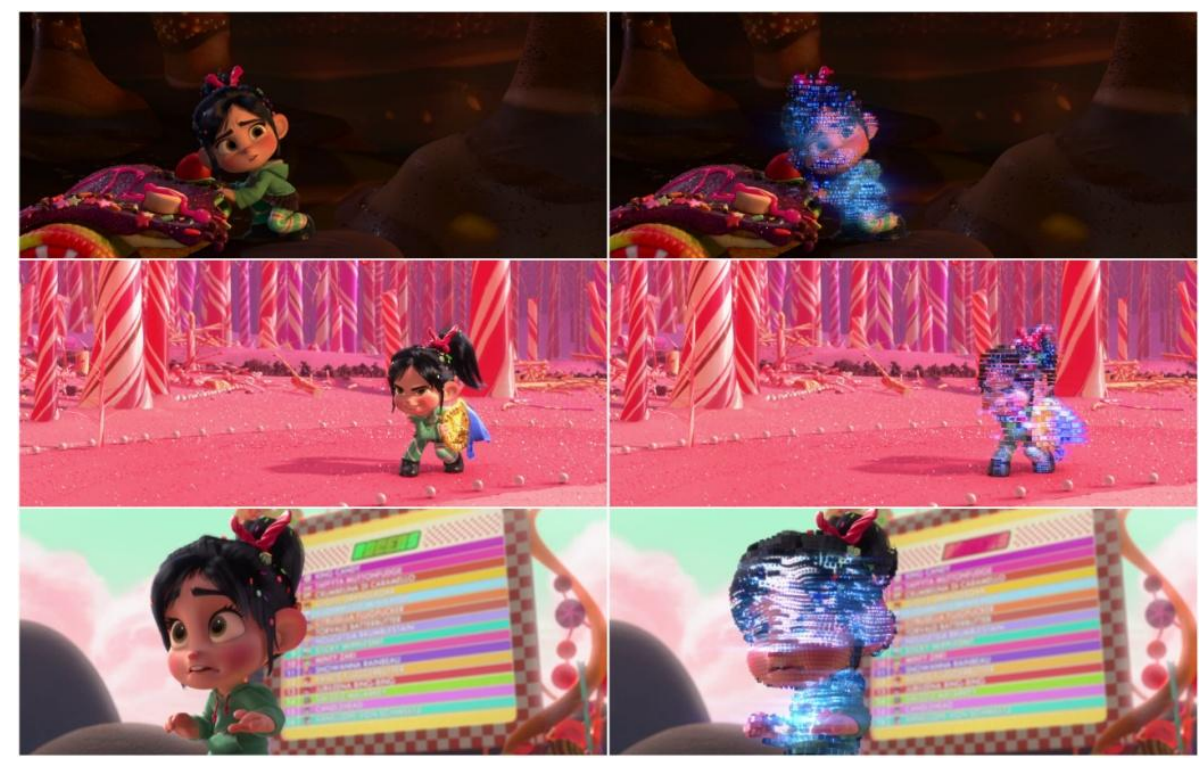

Vanellope es un error, pero no en su sentido debordiano. Aquel error orquestado y pagado de sí mismo que se desplegaba por la sociedad del espectáculo: "la ignorancia natural ha dado paso al espectáculo organizado del error" ${ }^{16}$ Vanellope, en tanto glitch, es el error inherente a nuestro statu quo humano y tecnológico. Es un error azul y por lo tanto bondadoso, frente al error rojo del maligno Turbo/King Candy. No busquen simbología política o psicológica en lo que es simple lenguaje coloquial. Lenguaje y convención que, por otra parte, ha terminado malinterpretando la añeja teoría del color de Goethe. ${ }^{17}$ El error imposibilita la dictadura. Tal era el combate y la enseñanza de Tron: Legacy. La libertad seguirá existiendo mientras lo haga el glitch y mientras los robots o la IA puedan ejecutar su autolisis como sucedía en Daft Punk: Electroma (Thomas Bangalter, Guy-Manuel De Homem-Christo, 2006).

\footnotetext{
${ }^{16}$ DEBORD, Guy, op. cit., p. 107.

17 Para el poeta, el azul era dual y contradictorio; una negación estimulante, un encuentro entre la excitación y el reposo, lo lejano y lo cercano. Esta última pareja sigue prendida a la perspectiva aérea (da VINCl, Leonardo, Tratado de pintura, Madrid: Akal, 1995, pp. 263-270). Mientras, el rojo era gravedad y dignidad, elegancia y atractivo: von GOETHE, Johann Wolfgang, Theory of colours, Londres: John Murray, 1840, pp. 310-316.
} 
Marc Olivier ${ }^{18}$ afirma, pletórico de gnosis y razón, que el glitch no tiene nada de inmaterial o de espiritual. El glitch es contenido, es materia y, como decía, es estructura. Es uno de los mecanismos capaces de resquebrajar la opacidad digital. No solo es el ladrillo visto -como en la máquina arcade de esta película- de sus arquitecturas, también es el método para derruirlas y la forma en la que colapsan. En esta película, además, es atributo dramático. El glitch de Vanellope es el atractivo fenotipo de los disturbios genéticos. La expresión de una emoción y hasta una estrategia infalible para el adelantamiento, para la supervivencia durante la carrera final. Vanellope, con toda la redondez de sus facciones, se transmuta, siquiera por unos segundos, en una serie de cuadraditos que recuerdan a la ígnea figura del Salto (The jump, 1978) de Jack Goldstein.

Olivier, aun compartiendo el fondo, recusa la utilización que hace Gunning ${ }^{19}$ del glitch como fantasma, como transparencia del filme y, en última instancia, como revelación y exhibición del aparato. El problema de Gunning es que sigue utilizando la metáfora del filme como material. La metáfora es un error conceptual. El glitch nunca puede acontecer en el celuloide aunque, vía reproducción, podamos verlo sobre él. Durante los procesos de degradación de los soportes de triacetato de celulosa se puede generar un reacción de hidrólisis, que tiene como consecuencia el desprendimiento de ácido acético. Esa disociación que coloquialmente conocemos como síndrome del vinagre, sería una suerte de glitch. De hecho, si atendemos al dibujo de sus estructura molecular disociada ${ }^{20}$, comprobaremos que la maraña de enlaces y valencias podría generar un eco sentimental, pero nada más. ${ }^{21}$

El glitching de Vanellope agrede de manera didáctica su figura. Sus deliciosos y numerosos glitchs son el agujero de gusano que utiliza el espectador para consumir materia. De pronto, toda la tersura de su piel y de su carne digital se resquebraja como la tierra seca y nos muestra, más que sus entrañas, el lenguaje del universo digital. Porque el glitch es error y es ruido, pero no todo el ruido es glitch. El glitch es la matriz del ruido, su dimensión estructural.

\footnotetext{
${ }^{18}$ OLIVER, Marc, "Glitch gothic" en LEEDER, Murray (ed.), Cinematic ghosts. Haunting and spectrality from silent cinema to the digital era, Nueva York y Londres: Bloomsbury, 2015, p. 260 y ss.

${ }^{19}$ GUNNING, Tom, "Phantom images and modern manifestations. Spirit photography, magic theater, trick films, and photography's uncanny" en LEEDER, Murray (ed.), op. cit., pp. 17-38.

${ }^{20}$ Del AMO GARCíA, Alfonso; CATALINA, Fernando, op. cit., p. 95.

${ }^{21}$ Utilizo como símil el síndrome del vinagre y no cualquier acción directa sobre la emulsión, por una cuestión de niveles. Esto es, el síndrome del vinagre, como el glitch, es una afección estructural del soporte que puede trasladarse hasta la emulsión. Mientras que las acciones directas sobre la emulsión son eminentemente superficiales. Esto debería ser válido aun para quienes consideren a los píxeles y a las sales de plata como entidades equivalentes.
} 
Su poder es suprasensible, igual que el de los disparos de Thomas Bachler sobre una fotografía. El agujero queda ordenado como símbolo.

La supervivencia de Vanellope no será la de una moralina de cuento de hadas. La enseñanza subyacente pero robusta es la del triunfo del instinto y de la naturaleza sobre las diferentes capas y represiones que hemos ido construyendo hasta conseguir negarlos. Vanellope es la paciencia y la cautela frente al tecnofuturismo. Vanellope es la doncella que aun se resiste a ser mancillada por la Singularidad. 
CONCLUSIONES 
«¿Y qué es el error, y su sucedáneo, la mentira, sino una especie de Caput Mortuum, una materia inerte sin la cual la verdad, harto volátil, no podría triturarse en los morteros humanos...?» Opus nigrum (Margerite Yourcenar) ${ }^{1}$

«-¿Hay algo más aburrido que la historia del pasado? -Quizá un futuro sin historia» Carol (Patricia Highsmith) ${ }^{2}$

Esta investigación comenzaba con la profesora Gabi Teichert enfrentándose a un caput mortuum. Su oficio, después de infinitas alquimias metodológicas, se había convertido en una escombrera hacia la que todos volvían la cabeza para escupir. Decadencia y desolación en lo que fue el edén de la Historia. Clío siempre había sufrido la angustia del método. Unas veces con indolencia, otras con rebeldía, casi siempre con parálisis. Incapaz de cerrar la herida por la que se desangraba un conocimiento empeñado en segregar ciencia y arte, Clío era la musa de la indecisión. A lo largo de estas páginas, mi esfuerzo se ha centrado en sacarla del letargo. Para ello, he encuadernado su libro y he afinado su trompeta. Empeñado en satisfacerla, puse a su disposición nuevos instrumentos. En lugar de vestidos y perfume, le regalé tiempo y metáforas. Llegados a destino, justo cuando quería presentarla en sociedad como la distinguida dama que es, Clío se había convertido en Vanellope von Schweetz.

Los designios de la evolución son escrutables. Clío era musa; Vanellope, qué duda cabe, es Cenicienta. Pero es una Cenicienta punk. Sabiendo lo banal de codiciar un vergel donde soplar suavemente la trompeta, Vanellope se dedicó a rasgar las cuerdas de su guitarra de caramelo entre las ruinas y el sarro del capitalismo posindustrial. Solo Vanellope podría aparecer entre los intersticios de una película de Derek Jarman vendiendo algodón de azúcar. Vanellope es la patita fea naturalista que debería conducir a las humanidades del siglo XXI hasta la tierra prometida. Pero ella no quiere ejercer de reina y mucho menos de mesías. Abjuró del miriñaque y de la monarquía mientras se ajustaba la faldita y los leotardos asimétricos. Sin más corona que una coleta, sin más cetro que un regaliz, Vanellope proclamó la república del conocimiento, amnistió a los pecadores y legalizó la práctica del insulto cariñoso.

\footnotetext{
${ }^{1}$ YOURCENAR, Marguerite, Opus nigrum, Madrid: Alfaguara, 1994, p. 119.

${ }^{2}$ HIGHSMITH, Patricia, Carol, Barcelona: Anagrama, 1991, pp. 41-42.
} 
Vanellope, pixléxica perdida, convirtió el rancio y caligráfico volumen de la Historia en un código open source. Ante la imposibilidad y la injusticia de prohibir y castigar el error -ella misma lo es-, lo incorporó a los manuales de estética.

Lo mejor de todas estas mutaciones es que Vanellope no terminó convertida en algo sobre lo que añadir el prefijo neo- o pos-. Vanellope es neo en sí misma, en su código abierto y modificado, en sus lógicos saltos espaciotemporales, en su numérico sentimiento. Vanellope no habla del futuro, pero nos conduce hacia él. Lo hace mientras tararea a los Sex Pistols: $\mathrm{J}$ No future, no future for you, no future for me $\mathrm{J}$

\section{Debord estaba equivocado}

Como todos lo hemos estado en algún momento. Como lo estuvo Descartes en su apreciación del alma y como lo estuvo Rousseau en su candoroso análisis de la naturaleza humana. Este epígrafe, en todo caso, es sensacionalista y, además, induce a pensar que Debord siempre estuvo equivocado. Lo he utilizado solo para recuperar una de sus ideas. Si aceptamos que aquella sociedad del espectáculo se ha extendido -con todos los matices y transformaciones que se quieran- hasta nuestros días, esta investigación jamás se podría haber llevado a cabo. Solo podría haberse realizado levantando mentira sobre mentira o conjetura sobre conjetura.

Cuando Debord dijo ${ }^{3}$ que los conocimientos que conformaban el pensamiento del espectáculo -cierta ciencia general- estaban sometidos y condicionados desde el mismo momento en que no podían ni querían pensar su propia base material, se equivocaba. También lo hizo cuando extendió ese criterio -sin citarlo, pero en clara referencia al arte conceptual- a la disolución del arte moderno. Para Debord, el sistema espectacular era demasiado taimado como para permitirlo. Revertir esta imposibilidad, querer pensar esa base material. Tal ha sido mi intención en este trabajo.

Vuelvo al metafórico caput mortuum de Gabi Teichert y lo amplío con ayuda de Michel Leiris. No solo es posible pensar la base material dentro de un sistema espectacular, sino que puede hacerse partiendo del último, peor y más críptico de los despojos.

Por definición, el investigador va tras algo que no tiene a mano, una cosa que se le escapa, que desea. ¿Cuál es esa cosa? Una especie de cosa en sí oscura, tentadora

\footnotetext{
${ }^{3}$ DEBORD, Guy, La sociedad del espectáculo, op. cit., p. 117.
} 
y misteriosa, residuo supremo que se puede embellecer con el valor más ideal o con el más sórdidamente material (...) Cosa que, por supuesto, el investigador nunca conseguirá capturar ni dominar. ${ }^{4}$

Leiris veía en la escoria alquímica un punto de partida del que salían dos caminos: el ideal y el material. El camino del ideal embellecido es la opción que no presenta trabas, sale disparado como una flecha alérgica al cimbreo y atraviesa la sociedad espectáculo. Corte quirúrgico, golpe de regla, línea deslizante con el asfalto recién apisonado. En sus márgenes y en sus cunetas florecen las fondas y los anuncios. Ese camino es la interestatal 40 de Cars. El camino más sórdidamente material atraviesa el mismo territorio, pero es en sí mismo un détour quebrado y bacheado. En lugar de someter al paisaje, se ha acostado en sus pliegues como un paño de Fidias. Las cunetas están sin barrer y las estaciones de servicio se han convertido en ludotecas para grajos. Los anuncios ya no se riegan, ni siquiera con los esputos de un viejo que masca tabaco. Ese camino es la Ruta 66 de Cars.

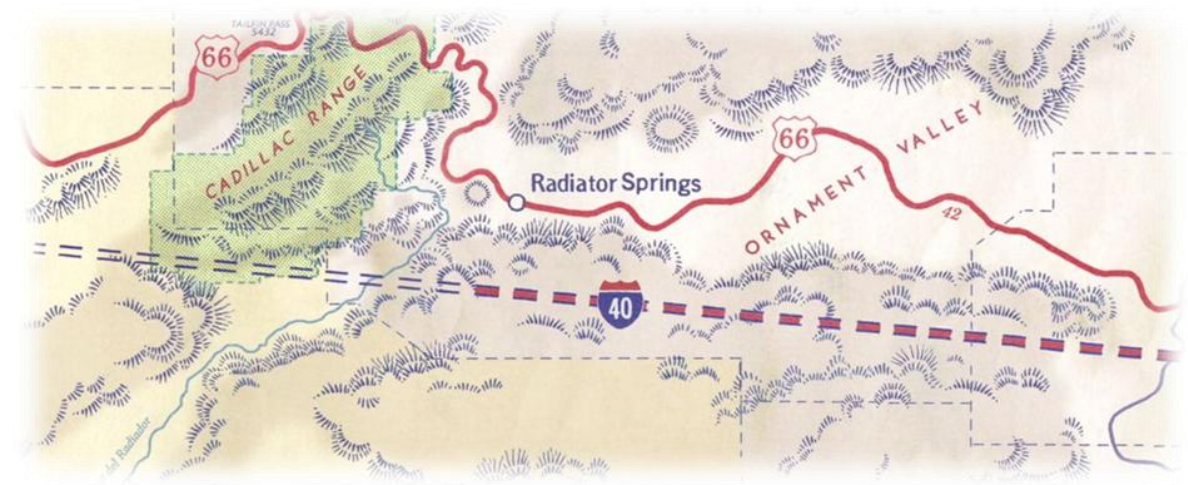

\section{Dualismo}

Esta investigación es una crítica explícita al dualismo biológico y epistemológico. Ahora no quiero revocarla con la imagen de dos carreteras antagónicas que, al fin y al cabo, conducen al mismo sitio. Mi planteamiento partía de la consiliencia y esto puede llevar a un acomodo. Quiero decir, la consiliencia no debe confundirse con consenso y armonía, con un darse la mano para contemplar una puesta de sol. Seguro que en algún momento he podido transmitir esa impresión. Pero para eso están las conclusiones. La consiliencia que demandan las humanidades es menos amable. Requiere de renuncias, de replanteamientos y de una sincera asunción de errores. Reconocer que hemos abusado del esoterismo retórico y metodológico.

\footnotetext{
${ }^{4}$ LEIRIS, Michel, "Le caput mortuum ou la femme de l'alchimiste" en Documents, № 8, 1930, pp. 461466, citado y traducido en DIDI-HUBERMAN, Georges, Fasmas. Ensayos sobre la aparición 1, Santander: Shangrila Textos Aparte, 2015, p. 11.
} 
Lo que de ninguna manera requiere es que todos los del gremio nos convirtamos en hombres del Renacimiento o en científicos ilustrados.

Digo esto porque mi creencia en las humanidades sigue intacta. Escuchad a alguien menospreciar las humanidades y estaréis escuchando a un terrorista del conocimiento. Quizá solo a un envidioso o a un necio. Su valor y su condición de imprescindibles aumentan cuando los gobiernos de turno, sea del país que sea, amenazan con mutilarlas. Así pues, que uno de los propósitos y de las metodologías de esta investigación sea la autocrítica de las humanidades, no implica que mi punto de vista sea el de un renegado o el de un converso resentido. Todo lo contrario.

Es el momento de ser consilientes pero, al mismo tiempo, no conformarse con este concepto. Tal vez sea necesario volver a los orígenes $y$, sin revisionismos o impugnaciones, jugar con ellos. Tomar el libro primero de la Metafísica y el libro segundo de la Física de Aristóteles y, como si fueran rollos de celuloide recién hallados en un cubo de basura, llamar a Craig Baldwin para que los remonte. Una solución extrema y alienígena. Puede que convenga ser más conservadores $y$, simplemente, dedicarnos a repensar la techné. ${ }^{5}$ Esto es, ampliar el reduccionismo de la técnica -de un empirismo básico de la materia y de la forma- haciéndola permeable -universal- a la moral y al intelecto. Desenvolverse en el qué y en el cómo, pero preguntándonos por el porqué. Reinyectar episteme en la techné, tal es la conclusión metodológica de este escrito.

Para lograrlo he intentado construir un relato histórico que partiera de un fundamento o Big Bang semiótico. Un relato consciente del pasado y tutelado por el presente. Todo inscrito en un gran marco biológico enfocado con una lente cuya distancia focal no estaba graduada en milímetros, sino en cierto humanismo naturalista. El análisis de los elementos particulares ha querido poner en práctica ese principio de fusión aristotélica. Lo que ha conllevado un despliegue considerable de importación y de metáfora científica. Dentro del relato también ha habido tiempo para el recreo y para la sonrisa, para el psicoanálisis.

Utilicé dos bloques maximalistas etiquetados como narración y materia para comprobar que era imposible tratarlos por separado. Esta formulación dual de la hipótesis contiene su propia crítica. De todos modos, quise suturarlos con un interludio vanguardista que resultó ser, en el

\footnotetext{
${ }^{5}$ ARISTÓTELES, Metafísica, Madrid: Gredos, 1994, pp. 69-84. ARISTÓTELES, Física, Madrid: Gredos, 1995, pp. 135-146.
} 
mejor de los casos, una membrana osmótica. El interludio nació y ejerció como tal sin perder de vista su función literaria y estilística dentro del relato global. Narración y materia no son lo mismo, pero comparten fluidos. Narración y materia nunca han dejado de filtrarse. La narración como materia y vehículo de la episteme, la materia como narración y vehículo de la techné. La narración es materia y material cuando se escribe, cuando se piensa, cuando se recita, cuando se filma, cuando se vive. La materia es narración y narrativa cuando está en orden y cuando está en desorden, cuando abunda y cuando escasea, cuando perfuma y cuando hiede. Mi padre es fontanero jubilado y no guarda la herramienta, dejemos que la gotera fluya.

¿Y cuando dicen que la pareja narración-materia desaparece y, ciertamente, puede llegar a parecerlo? Es ahí donde el historiador debe actuar de oficio. ¿Para qué? para zurcir ese aparente silencio. Igual que hacían nuestros mecanismos biológicos de ilusión e inferencia frente a la abstracción. Debemos acudir para enhebrar los restos y las pistas, por escasos y deformes, por ambiguas e inconexas que sean.

\section{Hipocondrías}

Aun a riesgo de resultar cargante, he puesto énfasis en la idea de tramoya. Considero el énfasis necesario, tanto como ahora puntualizarlo. En ocasiones, desvelar la tramoya puede ser inservible. Es más, puede que en otras tantas ni siquiera exista. La estética en general y la del cine en particular, quiso superar el academicismo descriptivo adentrándose en la conspiración. Todos nos hemos entregado alguna vez al delirio, a la paranoia y a una hermenéutica hipocondríaca. Igual que Nexus-6, hemos querido ver cosas que ni nosotros mismos creeríamos. Vimos códigos brillar en la oscuridad cerca de la puerta de la Iconología. Bipolares, también quisimos ver las imágenes como una proyección maléfica del sistema espectacular. Como sedantes que prolongaran nuestro placer modorro. Es una de sus funciones y de sus dimensiones, no se puede negar. Pero la imagen no siempre coincide ni con el discurso de un replicante que parece haber leído a Novalis, ni con el apéndice edulcorado de una matrix ulcerada.

Páginas atrás escribía "la opacidad digital" y me quedaba tan tranquilo. Era una exageración, una rebeldía con causa. La causa de una praxis deficiente que ha dejado de ver y de trabajar las imágenes como documentos, hasta convertirlas en reflejos idealizados de un mundo insatisfactorio. Es más, aludía a la opacidad de la imagen con una proyección optimista, como 
contrapunto necesario a lo que Català definía con como "la miseria de la vida occidental, fundamentada en el mito de la transparencia". ${ }^{6}$

La última deducción de todo buen hipocondríaco es si se debe medicar la hipocondría. Una vez que el diagnóstico te asegura que no padeces enfermedad alguna, proceder a aceptarlo no sin antes pedir algún remedio para ese no padecer. Como decía unas líneas más arriba, el encuentro y la conciliación no deben confundirse con lo políticamente correcto y con una metodología meliflua y miedosa. Prefiero cometer un error por hipocondría, que por sedación. Descifrar, predecir y hasta inventar códigos forma parte de nuestra naturaleza más preciada. Fue y sigue siendo uno de nuestros mejores mecanismos para la supervivencia. Además, el código implica una actividad fisiológica indisociable de un posterior análisis cultural.

Frente a una imagen, sin abandonar su naturaleza de cosa en sí, de signo, de materia y de documento, existen posibilidades reales para la síntesis. La imagen puede no ser, en absoluto, la muleta que nos coloca frente al hocico el sistema espectacular. Pero la imagen también puede ser algo más que la sensualidad -o la sexualidad- fetichista de una superficie. Siguiendo a Didi-Huberman, la imagen puede pensarse según la dualidad de una corteza: como piel, como lámina orgánica y vital; o como manto, como ornamento y velo.

Hay superficies que transforman el fondo de las cosas (...) Los filósofos de la idea pura (...) solo piensan en la superficie como un maquillaje, una mentira: lo que esconde la verdadera esencia de las cosas. Apariencia contra esencia o semejanza contra sustancia (...) Se puede pensar, al contrario, que la sustancia decretada más allá de las superficies es solo un señuelo metafísico. Se puede pensar que la superficie es lo que cae de las cosas: lo que viene directamente de ellas. ${ }^{7}$

Traigo esta idea a las conclusiones porque representa de manera poética la tramoya a la que ha apelado este trabajo: el triple cognitivismo biológico, social y estético. La importancia de los procesos corporales, políticos y técnicos, por recónditos que sean. Es nuestra labor saber cuándo y cómo decorticar para evaluar el tronco. También es nuestra labor saber cuándo y cómo se establecen correspondencias entre la triple dermis y los tejidos subyacentes. DidiHuberman no es equidistante, no puede serlo porque está hablando de cortezas de birke, de

\footnotetext{
${ }^{6}$ CATALÀ DOMENECH, Josep María, op. cit., p. 70.

7 DIDI-HUBERMAN, Georges, Cortezas, Santander: Shangrila Textos Aparte, 2014, p. 66. Véase también la p. 68.
} 
abedul, que aun pueden contener sedimentos de cuerpos cremados. El historiador francés termina aceptando y afirmando que es a través de la corteza como el árbol se manifiesta. Tiene razón, pero la relación entre árbol y corteza siempre es la misma: albura suavizada, corteza estriada.

La relación entre dispositivo e imagen cinematográfica tiende a invertir esta relación. En determinados casos, puede convertir la relación en un compuesto inestable; hace años diríamos que inflamable. De ahí que esta imagen de la corteza sirva para dejar en precario, de manera definitiva, la habitual y esencialista teoría del autorreferente o del exhibicionismo cinematográfico.

\section{Evidencias}

¿Han sobrevivido la narración y la materia al nuevo siglo? No cabe duda. Lo han hecho parafraseando el título del filme de Claude Lanzmann- como alguien vivo que pasa. La supervivencia siempre implica cierta resistencia, pero también mutación. Entre ambas, la adaptación. Narración y materia nunca fueron Carlota Valdés y Madeleine Elster. No tuvieron la necesidad de regresar de entre los muertos porque jamás se lanzaron al vacío desde una torre. Cuando Judy Barton apareció vaciada de toda aquella delicadeza, sin una pose de cuadro, sin un bouquet entre las manos, sin un moño en espiral que lubricara nuestra mirada, con el cabello platino venido a cobre, maquillada con vulgaridad y expresándose de manera procaz, el pobre Scottie dudó. Todos hemos sido Scottie en algún momento. Sin embargo, Scottie supo apreciar que todo era una farsa. Que lo que cayó de la torre era un cadáver, pero también un señuelo.

Narración y materia nunca debieron aparecer en las esquelas que nos apresuramos a escribir. Muchos las redactaron por morbo, otros por ignorancia, los más llevados por la corriente. Algunos tuvieron la decencia y la precaución de colocarlas entre interrogaciones o de cambiarlas por un cartel de se busca. Por fortuna para el ser humano y para el conocimiento científico, la pareja siguió operando ajena al desprestigio y a los recurrentes intentos de asesinato.

Narración y materia han logrado sobrevivir a lo largo del tiempo en numerosos espacios. Yo me he encargado de apuntar a las imágenes. Aunque no solo a las imágenes. La principal supervivencia que ha ejercido sin descanso y que ha posibilitado las demás, ha sido la puramente fisiológica. Una supervivencia biológica donde materia y narración han seguido 
modulando nuestra conciencia, nuestro yo narrativo. Por eso fue necesaria una reconsideración de las imágenes mentales. Aceptada su narratividad, era obligatorio reivindicar su fisicidad. Encarnar la idea, arrebatársela al alma y a la ideología para devolvérsela al cuerpo y a la ciencia. Introducir las diferentes supervivencias del instinto para combatir el idealismo. Sin ese punto de partida donde fue abolido el dualismo cartesiano para dar paso a las ciencias de la mente, el resto de las supervivencias habrían sido más difíciles de argumentar.

También era fundamental anteponer los procesos de formación y de mediación de la imagen para poder esquivar el bucle en el cayó la Teoría de atracciones. Se ha podido comprobar que la difusión de esta última contribuyó sobremanera al discurso de la muerte de los relatos. En este sentido, creo que fue acertado focalizar la discusión -asumiendo una redundancia peligrosa- en un concepto como el de atracción, en lugar de colocar el debate en un plano más abstracto. El ejemplo de la atracción quedaba validado por su expansión temporal -no es coyuntural- y por su enorme influencia en el mundo teórico -no es residual. Primero tracé sus orígenes técnicos e históricos para transmitir que no era un concepto novedoso. Pero como esta investigación no podía quedar en una simple enumeración de sus debilidades y mistificaciones, elaboré un discurso paralelo que identificara las formas y los lugares donde se libraba la supervivencia.

Constaté la supervivencia de la narración, a mayores, en los metarrelatos. Luego la extendí a criterios de calado social como el fetichismo tecnológico y a las industrias de los contenidos audiovisuales. Dentro de estas, hice especial hincapié en cómo se veía afectada la continuidad narrativa de las imágenes cinematográficas con la llegada de la atracción, del impacto y de la serialidad. Las dos primeros conceptos desafiaban el canon tradicional de la sutura narrativa, mientras que el segundo hacía lo propio con el canon de la clausura del relato. Ambos salieron airosos. De manera transversal, las teorías digitales de corte futurista y virtualista mostraron sus deficiencias al enfrentarlas con un presente donde nuestra naturaleza biológica aun se mostraba obstinada. Cabía y cabe defender la existencia de una rotunda naturaleza humana antes que la de una caprichosa naturaleza cinematográfica.

En cuanto al interludio vanguardista, se tomaron una serie de temas, de técnicas y de iconografías tradicionalmente asociadas a una confusa dimensión espiritual, para evaluarlas y devolverles una materialidad sin la que resultan imposibles de comprender. Esto ayudó a recapacitar sobre el mito de un cine y de unas representaciones consideradas, sin más matices, 
como antinarrativas y desmaterializadas. De nuevo, la condición narrativa de las vanguardias estaba ligada de manera íntima a la materia de los medios -incluido el propio cuerpo- y a los propios metarrelatos históricos.

Tomé la desmaterialización con la misma intención que me guió en la atracción. Tracé una genealogía contemporánea que partía de la modernidad decimonónica y del arte conceptual, para denunciar su ulterior e indiscriminado uso. Este apartado estuvo condicionado por un conflicto temporal entre pasado, presente y futuro. De de la mano de la desmaterialización se han elaborado discursos futuristas que triunfaron por la mera imposibilidad fáctica de ser refutados. Cuando el tiempo los ha ido alcanzando, han demostrado sus carencias y su corte totalitario. Se apreció cómo esos discursos futuristas también quedaban enraizados en una metodología nacida de la cibernética. El mito de la desmaterialización, además, fomentó el desarrollo de la retórica del miedo y de la virtualidad bélica. Para refutar esta alianza fue necesario acudir a una iconografía nada noble como la atómica. Además, la creciente confusión corporal a la que nos hemos enfrentado ha sido revocada mediante la cruda confrontación entre la imagen y el cuerpo. Sin opciones para ejecutar la suplantación definitiva, el segundo -explicado con la ayuda de las ciencias- ha prevalecido.

Por último, como fin de trayecto, defendí la supervivencia de un paradigma de las imágenes cinematográficas aun condicionado por la materia y enfocado a la narración. Los cambios radicales y apresurados de paradigma fueron matizados con la aparición de ciertos sentimientos como la nostalgia - del pasado o del futuro-, con la resiliencia, la resistencia y las residencias de una materia diversificada y sometida a criterio taxonómico.

\section{Vías abiertas}

Una investigación abierta no tiene por qué ser una investigación defectuosa. De la misma manera que esa apertura no puede tomarse como aval de la imprecisión y de la falta de rigor. Así mismo, la falta de respuestas a determinadas preguntas no implica necesariamente una actitud evasiva o una incapacidad. Una investigación cerrada quizá tenga más posibilidades de resultar fallida o, cuando menos, de ser ensimismada. Esto es válido para las ciencias y para las artes. La investigación científica no se termina con la detección, descripción y catalogación de, pongamos, una proteína. De ese ejercicio se derivan multitud de consecuencias y aplicaciones que los investigadores pueden o no estar en condiciones de abordar. En las humanidades, lógicamente, sucede lo mismo. 
Las principales vías abiertas que deja esta investigación son de orden metodológico, de orden analítico y de nuevas tendencias creativas. El cognitivismo cinematográfico, con matices, es una de ellas. Aquí he utilizado el cognitivismo más como herramienta del discurso general que del análisis específico. Esto último es lo más habitual en la teoría anglosajona. En cualquier caso, espero que pueda contribuir a su mejor conocimiento y aplicación en el ámbito académico español. La vía que definitivamente queda abierta es la de la estética evolucionista. No debe causar ningún reparo epistemológico acudir a la fuente primigenia: nuestra especie. Por desgracia y aunque estén íntimamente relacionadas, me temo que antes triunfará -lo está haciendo- todo aquello relativo a la etiqueta neuro-. Como avisé en páginas precedentes, la charlatanería en torno a ella es imparable y ya podemos verla compartiendo espacios con el reiki, con la autoayuda o con el masaje tailandés.

Es necesario ampliar el campo de acción del cognitivismo, emparentarlo con la estética mencionada y no especializarlo en el análisis de la percepción ligado a las técnicas de filmación y montaje. Como siempre nos ha gustado cambiar el apellido a nuestro nombre científico, siempre será mejor explorar la evolución de unos risueños y repletos de realidad homo fictus y homo ludens, que el de unos tediosos y pesimistas homo videns y homo pantalicus. ${ }^{8}$ Urge revalorizar nuestras habilidades cognitivas -la ética incluida- para analizar con corrección el hacer y la fruición. Escupir sobre las pantallas, como escupir sobre la Historia, es escupir sobre nosotros mismos.

Una de las investigaciones más interesantes que todavía duermen en estas líneas, es el estudio comparativo entre los filmes de emulación contemporáneos y sus referentes. A todos los niveles pero, sobre todo, a nivel narrativo y material. Quiero decir, analizar las distancias que se abren entre modelo y actualización, entre referente y reproducción. Cómo se puede reelaborar el pasado con un lenguaje y una materia del presente. Hasta dónde llega la emulación, en qué punto se rompe o se abandona, dónde se refuerza. Gombrich ${ }^{9}$ realizó algo parecido en muchos de sus textos. Por ejemplo, con la pintura romántica inglesa de paisaje reintrepretada por los ojos chinos de Chiang Yee. Su análisis era tímido y quizá no del todo certero, pero provocaba multitud de preguntas. Ya no se trataba de la formación, del estilo y del contexto histórico, sino de la propia fisiología del pintor, de sus sesgos cognitivos y de un

\footnotetext{
${ }^{8}$ SARTORI, Giovanni, Homo videns. La sociedad teledirigida, Madrid: Taurus 1998. LIPOVETSKY, Gilles; SERROY, Jean, La pantalla global. Cultura mediática y cine en la era hipermoderna, Barcelona: Anagrama, 2009.

9 GOMBRICH, Ernst, "Truth and the stereotype" en Art and illusion. A study in the psychology of pictorical representation, op. cit., pp. 52-73 [para Chiang Yee p. 68 y ss.]
} 
depósito de formas universales a las que Gombrich no aludía pero que estaban presentes en los sintagmas signos naturales e imágenes conceptuales.

Trasladado al cine podríamos ver, por ejemplo, las divergencias entre un filme silente real y remedos contemporáneos como los que han podido realizar Guy Maddin, Veit Helmer, Franka Potente, Milford Thomas, Raúl Perrone, Rolf de Heer, Esteban Sapir o David Lee Fisher. Esto mismo es aplicable a filmes de otros periodos y géneros. ${ }^{10} \mathrm{O}$ en cómo han reelaborado las estéticas del horror tradicional de los años veinte y treinta, los filmes producidos por la HP Lovecraft Historical Society. Un trabajo que tuviera presente esas ideas, podría acabar en una necesaria discusión sobre cómo se ha confundido de manera irremediable el manierismo material y narrativo con el (neo)clasicismo: Paul Thomas Anderson, Wes Anderson, los hermanos Coen, Sam Mendes, Curtis Hanson, Frank Darabont, James Gray, Michael Mann. Toda emulación implica o es maniera.

Otra vía abierta que intuyo especialmente fértil, es la relativa a las transacciones narrativas entre soporte e imagen. Ya sea mediante recuperaciones fotoquímicas o con tecnologías digitales. Hay que atender a una serie de factores (soportes, formatos, escala, procesos y herramientas creativas, medios de reproducción y de registro, iconografía) que poseen, además de su inmediato valor físico, un fuerte componente in-formador. Esto es, expresivo y significante. La idea que asocia esos elementos a la función exclusiva de conformadores marcos, portadores- es a todas luces incompleta. Una vez incorporados, discutir la imagen conformada como soporte para la comunicación en una doble vertiente: por el contenido semántico de la representación que acoge, y por la emergencia de esos factores inferiores o informadores. Estos últimos pueden llegar a constituirse en un nivel "típicamente diferenciador de los textos estéticos" ${ }^{11}$

Dentro de esta misma corriente, profundizar en el análisis sobre las diferentes metodologías de visionado previo y simultáneo al análisis fílmico. Si este se ve afectado o es deudor del tipo

\footnotetext{
${ }^{10}$ Esta línea histórica seguiría abierta hacia, por ejemplo, el encaje de filmes como El buen alemán (The good german, Steven Soderbergh, 2006) o Buenas noches y buena suerte (Good night, and good luck, Georges Clooney, 2005) con sus referentes clásicos de posguerra años cuarenta y cincuenta, respectivamente. Otros como Sin city (Robert Rodríguez, 2005) y La dalia negra (The black dahlia, Brian De Palma, 2006) con el imaginario noir; Todd Haynes y el melodrama de los cincuenta, etc. Existe un estudio interesante y relativamente reciente, pero que no tiene ni la amplitud ni la concreción que podría alcanzar un análisis comparativo. Me refiero a: SPRENGLER, Christine, Screening nostalgia. Populuxe props and Technicolor aesthetics in contemporary american film, Nueva York y Oxford: Berghahn Books, 2009.

${ }^{11}$ ZUNZUNEGUI, Santos, Pensar la imagen, Madrid: Cátedra, 2003, p. 79.
} 
de acercamiento a la obra. Detallar aspectos concretos que vulneran la obra como referente universal, sin quedarse en el cansino recurso al aura y a la reproductibilidad. He de reconocer que tengo realizado un estudio de este corte, pero también debo reconocer que está, en parte, obsoleto.

En relación con lo anterior, es necesaria una reactualización de los criterios compositivos y narrativos de los filmes rodados en grandes formatos. Bordwell se encargó de poner al día y de ampliar las viejas e insuficientes ideas de teóricos ya citados como John Belton y Barry Salt. También las de otros pioneros como Kenneth MacGowan ${ }^{12}$ y James Limbacher ${ }^{13}$, que entrelazaron a duras penas técnica y estética. Hasta llegar a estudios más completos y modernos como los de Carr y Hayes. ${ }^{14}$ Hoy se ha asimilado gran parte de la herencia de Bordwell sin cuestionarla. Hay motivos para ello. Sobre todo porque el gran formato panorámico se ha convertido, sin casi, en el estándar contemporáneo. ${ }^{15}$

Rehabilitado el relato cinematográfico, urgen nuevas cartografías narrativas. Ampliar el tradicional trasvase al cine de los estudios narratológicos, de manera que se identifiquen y se detallen posibles patrones asociados a la complejidad. Además de estudiarlas en sus elementos desglosados, acudir a la ubicación y a la función de las escenas de impacto y de las atracciones. Rehabilitada la materia, abundar en su presencia dentro del magma digital. Tan

${ }^{12}$ MACGOWAN, Kenneth, Behind the screen. The history and techniques of the motion picture, Nueva York: Delta Book, 1965.

${ }^{13}$ LIMBACHER, James, Four aspects of the film, Nueva York: Brussel and Brussel, 1968.

${ }^{14}$ CARR, Robert; HAYES, R.M., Wide screen movies. A history and filmography of wide gauge filmmaking, Jefferson: McFarland \& Company, 1988.

${ }^{15}$ Dentro de una investigación paralela a esta, he secuenciado el número de películas filmadas en grandes formatos panorámicos, en tres dimensiones o en IMAX y derivados, a lo largo de las últimas tres décadas y media. Le he hecho tomando las cincuenta películas más taquilleras de cada curso en el mercado americano y en el mercado global. Los números y las gráficas obtenidas no dejan lugar a dudas. El estudio es amplio, minucioso y está inacabado. Grosso modo: durante los años ochenta, el porcentaje de filmes rodados con alguno de esos suplementos se movía entre el $14 \%$ y $25 \%$. No es hasta la segunda mitad de los noventa cuando el porcentaje se instala en torno al $50 \%$. El incremento se mantiene en los primeros años del nuevo siglo con parámetros del 56\%-64\%. A lo largo de los últimos siete años -los de la crisis- el porcentaje se ha disparado. Primero al $72 \%$, hasta alcanzar consecutivamente el $82 \%$, el $84 \%$, el $86 \%$, el $88 \%$ y el $92 \%$ en el año 2013.

El estudio es valioso porque no existe -al menos que yo conozca- uno similar. Solo pude localizar uno antiguo pero muy reducido, en tanto sólo tomaba los filmes estrenados durante el periodo 1953-1960. Su estructura atendía al mercado interno estadounidense y no presentaba un desglose año por año. La fuente de consulta que utilizó dicho estudio fue la revista Variety en su edición de enero de 1960. Véase: PRATT, David, "Widescreen Box Office performance to 1959", en The Velvet Light Trap, no 21, verano de 1985, pp. 65-66.

El estudio también posee muchos condicionantes y notables implicaciones industriales, estéticas y tecnológicas que no estoy en disposición de comentar en esta nota al pie. Es probable que los próximos años veamos una disminución, no sé si progresiva o drástica, de estos números. Todo dependerá de cómo se gestione la nueva muerte de las 3D y de los posibles sustitutos. 
confusa e inabarcable como sugerente, toda la creatividad en torno al arte derivado de la generación y del procesado de datos puros. La información y el número, en un paradójico aislamiento masivo, al servicio de imágenes y sonidos improbables. Las nuevas expansiones del Vjing y de la geodesia, de la música o del ruido visual y de las reintrepetaciones -conscientes o no- de Fluxus en la era posdigital. ${ }^{16}$

Ampliar el estudio de las estéticas del desperfecto, de la baja resolución, de las calidades deficientes y de las imágenes hipoformalizadas, del collage, del reciclaje, de la apropiación y del pastiche digital. ${ }^{17}$ Su relación con la narratividad, con el contexto y con unas técnicas y unos conceptos que siempre estuvieron asociados a los materiales fotoquímicos. Dejar de confinarlas al cine experimental para observar su presencia y su influencia en el cine comercial. Sin perder de vista su profunda relación biológica con las narraciones paranormales y la fisiología de las creencias. En todos los casos, realizar un seguimiento para comprobar si arraigan o si se desvanecen entre modas.

Por simple curiosidad personal, desearía ver un estudio médico-fisiológico del desperfecto iconográfico. Esto es, ver si existen diferencias cognitivas reseñables entre la visión de una imagen en su estado óptimo y en diferentes estados de degradación. Con qué intensidad y a qué zonas cerebrales afecta. Probar con diferentes artes y materiales, no solo con imágenes fotoquímicas y digitales, también con esculturas y arquitecturas. Al caballero que abría esta tesis doctoral con una cita de 1933, le habría encantado.

\footnotetext{
${ }^{16}$ Algunos nombres a seguir: Nicolas Maigret, Paul Prudence, Memo Akten, Lucy Benson, Ryoji Ikeda, Alexander Dupuis, Mattia Giovanetti, Derek Holzer, David Szauder, Kasi Justka, Frank Bretschneider, Benjamin Jantzen, Timo Bingmann, Sabrina Ratté, Jerobeam Fenderson, Alva Noto, Nicolas Bernier, etc.

17 Merecen la pena los delirantes trabajos de compilación y fusión audiovisual de Clint Enns <https://vimeo.com/clintenns> [consulta: 30-10-2015]. En los juegos con la hipoformalización, Jim Campbell:

<http://www.jimcampbell.tv/portfolio/low_resolution_works/> [consulta: 30-10-2015]

En la pintura y en la fusión de técnicas (reprografía, escultura, vídeo, textil, bosquejo, óleo, etc.), las inquietantes obras de Andy Denzler <http://www.andydenzler.com/home/> [consulta: 30-10-2015]

En fotografía, las de un gran conocedor del cine experimental como Fred Camper <http://www.fredcamper.com> [consulta: 14-10-2015]. Cómo logra evocar en las series Likenesses y Quarries -con las vanguardias históricas en el recuerdo- las nuevas estéticas del glitch y del píxel mediante simples técnicas de descomposición, de collage y de damero. Técnicas que se siguen utilizando en formato subestándar fotoquímico, véanse las magníficas Tokyo - Ebisu, Shibuya - Tokyo (2010), de Tomonari Nishikawa.
} 


\section{BIBLIOGRAFÍA}


Presento la bibliografía dividida en cuatro grandes bloques atendiendo a un criterio de funcionalidad. Tras colocar según qué libro en un apartado o en otro, surgen dudas y hasta errores. Hay libros que podrían caber en tres de los cuatro bloques establecidos. No solo eso, en una investigación que ha defendido lo interdisciplinar, esta división puede resultar contradictoria. En todo caso, he decidido que las ventajas de este formato prevalecían sobre los inconvenientes. Así pues, tómese la división como convención y como herramienta de lectura, no como corte conceptual. Por último, el orden dentro de cada bloque es alfabético.

\section{Humanidades, tecnología y epistemología}

AGAMBEN, Giorgio, Signatura rerum. Sobre el método, Barcelona: Anagrama, 2010.

ALBERRO, Alexander; STIMSON, Blake (eds.), Conceptual art. A critical anthology, Cambridge: The MIT Press, 1999.

ALLOWAY, Lawrence, "Junk culture as a tradition" en New Media-New Forms, Nueva York: Catálogo de la exposición en la Galería Martha Jackson, del 6 al 24 de junio de 1960.

ALONSO, Rodrigo; MERCADO, Leonardo, “Arte y diseño editorial: de la revolución tipográfica al libro del futuro" en Encuentro Nacional de Investigación en Arte y Diseño ENIAD 2001, Facultad de Bellas Artes de la Universidad de La Plata, 2001.

<http://www.roalonso.net/es/arte_y_tec/revolucion_tipografica.php> [consulta: 22-10-2015]

ALTHUSSER, Louis, Escritos, Barcelona: Laia, 1974.

ARISTÓTELES, Acerca del alma, Madrid: Gredos, 1983.

ARISTÓTELES, Metafísica, Madrid: Gredos, 1994.

ARISTÓTELES, Física, Madrid: Gredos, 1995.

ARNHEIM, Rudolf, Ensayos para rescatar el arte, Madrid: Cátedra, 1992.

ARNHEIM, Rudolf, To the rescue of art. Twenty-six essays, Berkeley: University of California Press, 1992.

ARNHEIM, Rudolf, El poder del centro, Madrid: Alianza, 1998.

BARASCH, Moshe, Teorías del arte. De Platón a Winckelmann, Madrid: Alianza, 1996.

BARTHES, Roland, El placer del texto y lección inaugural de la Cátedra de Semiología Lingüística del Collège de France, México D.F.: Siglo XXI, 1991.

BARTHES, Roland, El grado cero de la escritura, seguido de nuevos ensayos críticos, México D.F.: Siglo XXI, 2006.

BATESON, Gregory, Steps to an ecology of mind. Collected essays in anthropology, psychiatry, evolution, and epistemology, Northvale: Jason Aronson, 1987.

BATTCOCK, Gregory (ed.), La idea como arte. Documentos sobre el arte conceptual, Barcelona: Gustavo Gili, 1977. 
BAUDRILLARD, Jean, El crimen perfecto, Barcelona: Anagrama, 1997.

BAUMAN, Zygmunt, Modernidad líquida, Buenos Aires: Fondo de Cultura Económica, 2003.

BAUMAN, Zygmunt, Miedo líquido. La sociedad contemporánea y sus temores, Buenos Aires: Paidós, 2007.

BENJAMIN, Walter, Discursos interrumpidos I. Filosofía del arte y de la historia, Buenos Aires: Taurus, 1989.

BENJAMIN, Walter, Libro de los pasajes, Madrid: Akal, 2004.

BERGSON, Henri, “La evolución creadora” en Obras escogidas, Madrid: Aguilar, 1963, pp. 433-755.

BERGSON, Henri, Ensayo sobre los datos inmediatos de la conciencia, Salamanca: Sígueme, 1999.

BERKELEY, George, Tratado sobre los principios del conocimiento humano, Barcelona: Folio, 1985.

BERMAN, Marshall, Todo lo sólido se desvanece en el aire. La experiencia de la modernidad, Madrid: Siglo XXI, 1988.

BORGMANN, Albert, "La tecnología y la búsqueda de la felicidad" en Revista Iberoamericana de Ciencia, Tecnología y Sociedad, vol. 2, no 5, junio 2005, pp. 81- 93.

BOYM, Svetlana, The future of nostalgia, Nueva York: Basic Books, 2001.

BOYNTON, Robert, "A conversation with Jonathan Schell. People's power vs. nuclear power" en Daedalus, vol. 136, no 1, invierno del 2007, pp. 22-9.

BRICMONT, Jean; SOKAL, Alan, "Transgressing the boundaries. Towards a transformative hermeneutics of quantum gravity" en Social Text, Durham: Duke University Press, no 46-47, primavera-verano de 1996, pp. 217-252.

BRICMONT, Jean; SOKAL, Alan, Imposturas Intelectuales, Barcelona: Paidós, 1999.

BUNGE, Mario, Causalidad. El principio de causalidad en la ciencia moderna, Buenos Aires: Eudeba, 1961.

BUNGE, Mario, Teoría y realidad, Barcelona: Ariel, 1981.

BUNGE, Mario, "Paradigmas y revoluciones en ciencia y técnica” en El Basilisco, no 15, marzo-agosto de 1983, pp. 2-9.

BUNGE, Mario, Tres mitos de nuestro tiempo: virtualidad, globalización, igualamiento, Santa Fe: Universidad Nacional del Litoral, 2001.

BÜRGER, Peter, Teoría de la vanguardia, Barcelona: Península, 1997.

CASSIRER, Ernst, Antropología filosófica. Introducción a una filosofía de la cultura, México D. F.: Fondo de Cultura Económica, 1968.

CHANDLER, John; LIPPARD, Lucy, "The dematerialization of art" en Art International, vol. XII, no 2, Lugano, febrero de 1968, pp. 31-36.

CHOMSKY, Noam; HERMAN, Edward, The Washington connection and third world fascism. The political economy of human rights, Boston: South End Press, 1979. 
CLOTTES, Jean; LEWIS-WILLIAMS, David, Los chamanes de la Prehistoria, Barcelona: Ariel, 2001.

COMITÉ INVISIBLE, A nuestros amigos, México D.F.: Ediciones Anarquía es una sinfonía, 2014.

COPLESTON, Frederik, Historia de la filosofía vol. V. De Hobbes a Hume, Barcelona: Ariel, 1993.

CUESTA ABAD, José Manuel; JIMÉNEZ HEFFERNAN, Julián (eds.), Teorías literarias del siglo XX, Madrid: Akal, 2005.

DA VINCl, Leonardo, Tratado de pintura, Madrid: Akal, 1995.

DANTO, Arthur, Después del fin del arte. El arte contemporáneo y el linde de la historia, Barcelona: Paidós, 1999.

DAVIDSON, Arnold, Foucault and his interlocutors, Chicago: University of Chicago Press, 1997.

DE MICHELI, Mario, Las vanguardias artísticas del siglo XX, Madrid: Alianza, 1998.

DEBORD, Guy, Comentarios sobre la sociedad del espectáculo, Barcelona: Anagrama, 1990.

DEBORD, Guy, La sociedad del espectáculo, Santiago de Chile: Ediciones Naufragio, 1995.

DEBRAY, Regis, El arcaísmo posmoderno. Lo religioso en la aldea global, Buenos Aires: Manantial, 1996.

DELEUZE, Gilles, Conversaciones. 1972-1990, Valencia: Pre-Textos, 1996.

DELEUZE, Gilles; GUATTARI, Félix, Mil mesetas. Capitalismo y esquizofrenia, Valencia: Pre-textos, 2002.

DESCARTES, René, Las pasiones del alma, Madrid: Tecnos, 1997.

DIDEROT, Denis, Carta sobre los ciegos, seguido de Carta sobre los sordomudos, Aldaia: Pre-Textos, 2002.

DIDI-HUBERMAN, Georges, La imagen superviviente. Historia del arte y tiempo de los fantasmas según Aby Warburg, Madrid: Abada, 2009.

DIDI-HUBERMAN, Georges, Supervivencia de las luciérnagas, Madrid: Abada, 2012.

DIDI-HUBERMAN, Georges, Cortezas, Santander: Shangrila Textos Aparte, 2014.

DIDI-HUBERMAN, Georges, En la cuerda floja, Santander: Shangrila Textos Aparte, 2015.

DIDI-HUBERMAN, Georges, Fasmas. Ensayos sobre la aparición 1, Santander: Shangrila Textos Aparte, 2015.

DOSSE, François, La historia en migajas, Valencia: Edicions Alfons el Magnánim, 1988.

DOUGLAS, Mary, Pureza y peligro. Un análisis de los conceptos de contaminación y tabú, Madrid: Siglo XXI, 1973.

EAGLETON, Terry, Las ilusiones del posmodernismo, Buenos Aires: Paidós, 1997.

ECHEVERRI, Santiago, La existencia del mundo exterior, Medellín: Universidad de Antioquía, 2008.

ECO, Umberto, The open work, Cambridge: Harvard University Press, 1989.

ECO, Umberto, La estructura ausente. Introducción a la semiótica, Barcelona: Lumen, 1989. 
ENGELS, Friedrich; MARX, Karl, Manifiesto comunista, Ediciones elaleph.com, 2000.

EPICURO, Obras completas, Madrid: Cátedra, 2012.

FARRELL KRELL, David (ed.), Martin Heidegger. Basic writings, San Francisco: Harper \& Row, 1993.

FERRER, Esther, “La exposición 'Los inmateriales' muestra en París la decrepitud de la modernidad” en El País, 17 de mayo de 1985.

<http://elpais.com/diario/1985/05/17/cultura/485128816_850215.html> [consulta: 07-08-2015]

FOUCAULT, Michel, “Qu'est-ce qu'un auteur?” en Bulletin de la Société Française de philosophie, vol. 63, no 3, julio-septiembre de 1969.

FOUCAULT, Michel, La arqueología del saber, México: Siglo XXI, 1970.

FOCAULT, Michel; GORDON, Colin, Power/knowledge. Selected interviews and other writings 1972-1977, Nueva York: Pantheon Books, 1977.

FOUCAULT, Michel, Entre filosofía y literatura, Barcelona: Paidós, 1999.

FUKUYAMA, Francis, El fin de la Historia y el último hombre, Barcelona: Planeta, 2002.

GENETTE, Gérard, “Fronteras del relato” en AA.VV., Análisis estructural del relato, Buenos Aires: Tiempo Contemporáneo, 1970.

GIRARD, René, La violencia y lo sagrado, Barcelona: Anagrama, 2012.

GIVONE, Sergio, Historia de la estética, Madrid: Tecnos, 1990.

GOMBRICH, Ernst, La historia del arte, Madrid: Debate, 1997.

GOMBRICH, Ernst, La preferencia por lo primitivo. Episodios de la historia del gusto y el arte de Occidente, Barcelona: Debate, 2003.

GOODMAN, Nelson, Fact, fiction and forecast, Cambridge y Londres: Harvard University Press, 1983.

GUTIÉRREZ ORDÓÑEZ, Salvador, Introducción a la semántica funcional, Madrid: Síntesis, 1989.

HAMBURGER, Kate, La lógica de la literatura, Madrid: Visor, 1995.

HARDISON, O. B., Disappearing through the skylight. Culture and technology in the twentieth century, Nueva York: Viking, 1989.

HEIDEGGER, Martin, "La pregunta por la técnica” en Conferencias y artículos, Barcelona: Ediciones del Serbal, 1994, pp. 9-37.

HEIDEGGER, Martin, Filosofía, ciencia y técnica, Santiago de Chile: Editorial Universitaria, 1997.

HEIDEGGER, Martin, Caminos de bosque, Madrid: Alianza, 2010.

HJELMSLEV, Louis, Prolegómenos a una teoría del lenguaje, Madrid: Gredos, 1980.

HIGGS, E.; STRONG, D.; LIGHT, A., (eds.), Technology and the good life, Chicago: University of Chicago Press, 2000. 
HILBERG, Raul, Perpetrators victims bystanders. The jewish catastrophe, 1933-1945, Nueva York: Harper Collins, 1992.

HODGKIN, Katharine; RADSTONE, Susannah (eds.), Contested past. The politics of memory, Nueva York: Routledge, 2003.

HUME, David, Tratado de la naturaleza humana, Albacete: Diputación de Albacete, 2001.

HUYSSEN, Andreas, "The hidden dialectic. Avantgarde, technology, mass culture" en After the great divide. Modernism, mass culture, postmodernis, Londres: MacMillan Press, 1988, pp. 3-15.

HUYSSEN, Andreas, "In the Shadow of McLuhan: Jean Baudrillard's Theory of Simulation" en Assemblage, no 10, Cambridge: The MIT Press, Diciembre de 1989.

JACOBY, Roberto, “Después de todo, nosotros desmaterializamos. La teórica del conceptualismo olvidó citar unos cuantos antecedentes argentinos" en Ramona. Revista de Artes Visuales, Buenos Aires: Fundación Start, no 9-10, diciembre del 2000 - marzo del 2001, pp. 34-35.

JAMES, Henry, El futuro de la novela, Madrid: Escuela de Letras, 1994.

JAMESON, Fredric, The ancients and the postmoderns. On the historicity of forms, Londres y Nueva York: Verso Books, 2015.

JONAS, Hans, El principio de responsabilidad. Ensayo de una ética para la civilización tecnológica, Barcelona: Herder, 1995.

JONES, Jonathan, "Apocalypse no! Why artists should not go into the Fukushima exclusion zone" en The Guardian, 20 de julio de 2015.

<http://www.theguardian.com/artanddesign/jonathanjonesblog/2015/jul/20/fukushima-exclusionzone-art-politics> [consulta: 07-09-2015]

KANDINSKY, Vasili, De lo espiritual en el arte, México D.F.: Premia Editora, 1989.

KANT, Immanuel, Prolegómenos a toda metafísica del porvenir. Observaciones sobre el sentimiento de lo bello y lo sublime. Crítica del juicio, México D.F.: Editorial Porrúa, 1991.

KAPROW, Allan, Essays on the blurring of art and life, Berkeley: University of California Press, 2003.

KINKLE, Jeff; TOSCANO, Alberto, Cartographies of the absolute, Alresford: Zero Books, 2015.

KLEIN, Naomi, La doctrina del "shock". El auge del capitalismo del desastre, Barcelona: Paidós, 2007.

KLOESEL, Christian (ed.), Writings of Charles S. Peirce. Volume 5: 1884-1886, Bloomington: Indiana University Press, 1993.

KLÜSER, Bernd (ed.), Joseph Beuys. Ensayos y entrevistas, Madrid: Síntesis, 2006.

KOSUTH, Joseph, "Art after philosophy” en Studio International, vol. 178, no 915, 916 y 917, octubre, noviembre y diciembre de 1969, pp. 134-137, 160-161, 212-213; respectivamente.

KOSUTH, Joseph, Art after philosophy and after. Collected writings, 1966-1990, Cambridge: The MIT Press, 1991. 
LANGER, Susanne, Philosophy in a new key. A study in the symbolism of reason, rite and art, Nueva York: Mentor Books, 1954.

LÉVI-STRAUSS, Claude, Introduction to the work of Marcel Mauss, Londres: Routledge \& Kegan Paul, 1987.

LÉVI-STRAUSS, Claude, Antropología estructural, Barcelona: Paidós, 1995.

LÉVI-STRAUSSS, Claude, Mitológicas I. Lo crudo y lo cocido, México D.F.: Fondo de Cultura Económica, 2002.

LeWITT, Sol, "Paragraphs on conceptual art" en Artforum, vol 5, no 10, verano de 1967, pp 79-83.

LIPPARD, Lucy, Changing. Essays in art criticism, Nueva York: E. P. Dutton, 1971.

LIPPARD, Lucy, Six years. The dematerialization of the art object from 1966 to 1972, Berkeley: University of California Press, 1997.

LIPPARD, Lucy, Seis años, Madrid: Akal, 2004.

LISITSKI, EI, “The future of the book” en New Left Review, enero-febrero de 1967, pp. 39-44.

LONGONI, Ana, "Óscar Masotta: vanguardia y revolución en los años sesenta" en Séptimas jornadas de artes y medios digitales, Córdoba (Argentina), jueves 18 de agosto de 2005.

<http://www.liminar.com.ar/pdf05/longoni.pdf> [consulta: 23-10-2015]

LUCRECIO CARO, Tito, De rerum natura, Barcelona: Acantilado, 2012.

LYOTARD, Jean-François, La condición posmoderna, Madrid: Cátedra, 1989.

LYOTARD, Jean-François, Lo inhumano. Charlas sobre el tiempo, Buenos Aires: Ediciones Manantial, 1998.

LYOTARD, Jean-François, La posmodernidad explicada a los niños, Barcelona: Gedisa, 2003.

MALDONADO, Tomás, Crítica de la razón informática, Barcelona: Paidós, 1998.

MARCHÁN FIZ, Simón, Del arte objetual al arte de concepto, Madrid: Akal, 2012.

MARINETTI, Filippo Tomaso, Critical writings, Nueva York: Farrar, Straus \& Giroux, 2006.

MARX, Karl, Obras escogidas. Tomo I, Moscú: Progreso, 1980.

MASSOTA, Óscar, et al., Happenings, Buenos Aires: Jorge Álvarez, 1967.

MASSOTA, Óscar, Conciencia y estructura, Buenos Aires: Jorge Álvarez, 1968.

MASSOTA, Óscar, "Después del Pop, nosotros desmaterializamos" en Ramona. Revista de Artes Visuales, Buenos Aires: Fundación Start, no 9-10, diciembre del 2000 - marzo del 2001.

MEYER, Ursula, "De-objectification of the object" en Arts Magazine, vol 43, no 8, verano de 1969, pp. 2021.

MEYER, Ursula, Conceptual art, Nueva York: Dutton, 1972. 
MOLINUEVO, José Luis (ed.), ¿Deshumanización del arte?, Salamanca: Ediciones Universidad, 1996.

MOLINUEVO, José Luis, La vida en tiempo real. La crisis de las utopias digitales, Madrid: Biblioteca Nueva, 2006.

MOLINUEVO, José Luis, Magnífica miseria. Dialéctica del Romanticismo, Murcia: Cendeac, 2009.

ORTEGA y GASSET, José, La rebelión de las masas, Madrid: Espasa Calpe, 1972.

ORTEGA Y GASSET, José, La deshumanización del arte y otros ensayos de estética, Madrid: Austral, 2004.

PEIRCE, Charles Sanders, "On the algebra of logic. A contribution to the philosophy of notation" en American Journal of Mathematics, nㅇ 2, vol. 7, enero de 1885, pp. 180-202.

PEREDA, Carlos, Vértigos argumentales. Una ética de la disputa, Barcelona: Anthropos, 1994.

PINKER, Steven, The sense of style. The thinking person's guide to writing in the 21st century, Nueva York: Penguin, 2014.

PLANT, Sadie, El gesto más radical. La Internacional Situacionista en una época postmoderna, Madrid: Errata naturae, 2008.

PLATÓN, Diálogos I, Madrid: Gredos, 1981.

PLATÓN, Diálogos III. Fedón. Banquete. Fedro, Madrid: Gredos, 1988.

PLATÓN, República, Madrid: Gredos, 1988.

POLLITT, J. J., Arte y experiencia en la Grecia clásica, Bilbao: Xarait Ediciones, 1987.

POPPER, Karl Raimund, La responsabilidad de vivir. Escritos sobre política, historia y conocimiento, Barcelona: Paidós, 2006.

QUINTANILLA, Miguel Ángel, Tecnología. Un enfoque filosófico, Madrid: Fundesco, 1989.

RAMONET, Ignacio, "La pensée unique" en Le Monde Diplomatique, enero de 1995, <http://www.monde-diplomatique.fr/1995/01/RAMONET/6069> [consulta: 20-10-2015].

RICOEUR, Paul, Historia y verdad, Madrid: Ediciones Encuentro, 1990.

RIZZO, Patricia, Instituto Di Tella. Experiencias '68, Buenos Aires: Fundación Proa, 1998.

ROSS, Christine, The past is the present; It's the future too. The temporal turn in contemporary art, Londres: Bloomsbury Publishing, 2012.

RUIZ DOMÈNEC, José Enrique, El reto del historiador, Barcelona: Península, 2006.

RUSSELL, Bertrand, El conocimiento humano, Barcelona: Folio, 2002.

SCHAEFFER, Jean-Marie, ¿¿Por qué la ficción?, Madrid: Lengua de Trapo, 2002.

SCHELL, Jonathan, El destino de la Tierra, Barcelona: Argos Vergara, 1982.

SCHLEGEL, Friedrich, Conversación sobre la poesía, Buenos Aires: Biblios, 2005. 
SEBASTIÁN, Santiago, Contrarreforma y barroco. Lecturas iconográficas e iconológicas, Madrid: Alianza, 1989.

SFEZ, Lucien, Técnica e ideología. Un juego de poder, México: Siglo XXI, 2005.

SHARP, Willoughby, "An interview with Joseph Beuys" en Artforum, vol. 8, no 4, diciembre de 1969, pp. 40-47.

SHKLOVSKI, Viktor, Theory of prose, Londres: Dalkey Archive Press, 1991.

SLOTERDIJK, Peter, Temblores de aire. En las fuentes del terror, Valencia: Pre-Textos, 2003.

SLOTERDIJK, Peter, Esferas I, Madrid: Siruela, 2003.

SPINOZA, Baruch, Ética demostrada según el orden geométrico, Madrid: Orbis, 1990.

STOOPEN GALÁN, María (coord.), Sujeto y relato. Antología de textos teóricos, México D.F.: Universidad Nacional Autónoma de México, 2009.

STRANO, Carmelo, /l segno della devianza, Milán: Mursia, 1984.

STRONG, Roy, Arte y poder. Fiestas del Renacimiento 1450-1650, Madrid: Alianza, 1988.

TORRES SANTOMÉ, Jurjo, Globalización e interdisciplinariedad: el currículum integrado, Madrid: Ediciones Morata, 2006.

TOULMIN, Stephen, Regreso a la razón, Barcelona: Península, 2003.

TRÍAS, Eugenio, Lo bello y lo siniestro, Barcelona: Ariel, 2001.

TRIGG, Dylan, The aesthetics of decay. Nothingness, nostalgia, and the absence of reason, Nueva York: Peter Lang, 2006.

VATTIMO, Gianni: Filosofía, política, religión. Más allá del pensamiento débil, Oviedo: Nobel, 1996.

VATTIMO, Gianni, Nihilismo y emancipación, Barcelona: Paidós, 2004.

VAUCHEZ, André, La espiritualidad del Occidente medieval, Madrid: Cátedra, 2001.

VERDÚ, Vicente, El estilo del mundo. La vida en el capitalismo de ficción, Barcelona: Anagrama, 2006.

VERDÚ, Vicente, Yo y tú. Objetos de lujo, Barcelona: Debolsillo, 2007.

VEYNE, Paul, Cómo se escribe la historia. Foucault revoluciona la historia, Madrid: Alianza, 1984.

VIGNALE, Silvana, "Experiencia y narratividad en Walter Benjamin" en Revista Páginas de Filosofía, Departamento de Filosofía de la Facultad de humanidades de la Universidad Nacional del Comahue, vol. 12 , n‥ 15, pp. 5- 16.

WALLIS, Brian (ed.), Arte después de la modernidad. Nuevos planteamientos en torno a la representación, Madrid: Akal, 2001.

WEIGHTMAN, John, “On not understanding Michel Foucault” en The American Scholar, no 58, verano de 1989, pp. 383-406.

WITTGENSTEIN, Ludwig, Tractatus logico-philosophicus, Madrid: Alianza, 2010. 
WOLLEN, Peter, "The two avant-gardes" en Studio International, noviembre de 1975, pp. 171-175.

WOLLEN, Peter, "The avant-gardes: Europe and America" en Framework, primavera de 1981.

WOLLHEIM, Richard, El arte y sus objetos. Introducción a la estética, Barcelona : Seix Barral, 1972.

WOODFIELD, Richard (ed.), Gombrich esencial, Madrid: Debate, 1997.

\section{Teoría y práctica del audiovisual. Cine, comunicación, fotografía}

ABRIL, Gonzalo, "El séptimo día. Notas sobre la comunicación en la era digital”, conferencia dictada en el I Congreso Ibérico “La Sociedad de la Comunicación”, Málaga, mayo de 2001.

<https://icjournal.files.wordpress.com/2013/01/1265039240-1abril1.pdf> [consulta: 10-08-2015]

AJO, Pedro, La estetica del error en la era digital, información de publicación desconocida.

AMABA, Roberto, “Jean Epstein" en BELMONTE NAVARRO, Antonio (coord.), Ojos sin rostro. Semblanza de trece directores europeos, Madrid: Ártica, 2015, pp. 111-139.

ANDREW, Dudley, “Cognitivism: quests and questionings" en Iris, no 9, Cinema and cognitive psychology, 1989, pp. 1-10.

ANTONIONI, Michelangelo, Para mí hacer una película es vivir, Barcelona: Paidós, 2002.

ARTAUD, Antonin, El cine, Madrid: Alianza, 1982.

ARTHUR, Paul, "Structural Film: Revisions, new versions, and the artifact" en Millennium Film Journal, no 2, primavera-verano de 1978.

ARTHUR, Paul, "Structural Film: Revisions, new versions, and the artifact. Part two" en Millennium Film Journal, no 4-5, verano-otoño de 1979.

AUMONT, Jacques; BERGALA, Alain; MARIE, Michel; VERNET, Marc, Estética del cine. Espacio filmico, montaje, narración, lenguaje, Barcelona: Paidós, 1985.

AUMONT, Jacques; GAUDREAULT, André; MARIE, Michel (eds.), Histoire du cinéma. Nouvelles approches, París: Publications de la Sorbonne, 1989.

AUMONT, Jacques, La imagen, Barcelona: Paidós, 1992.

AUMONT, Jacques, El ojo interminable. Cine y pintura, Barcelona: Paidós, 1997.

AUMONT, Jacques, El rostro en el cine, Barcelona: Paidós, 1997.

AUMONT, Jacques, Las teorías de los cineastas. La concepción del cine de los grandes directores, Barcelona: Paidós, 2004.

AUMONT, Jacques, Materia de imágenes, redux, Santander: Shangrila Textos Aparte, 2014.

BAER, Alejandro, El testimonio audiovisual. Imagen y memoria del Holocausto, Madrid: Centro de Investigaciones Sociológicas, 2005.

BAITELLO JUNIOR, Norval, La era de la iconofagia, Sevilla: ArCiBel Editores, 2008. 
BARTHES, Roland, La cámara lúcida. Nota sobre la fotografía, Barcelona: Paidós, 1995.

BARTHES, Roland, La Torre Eiffel. Textos sobre la imagen, Barcelona: Paidós, 2001.

BAUDRILLARD, Jean, The evil demon of images, Sídney: Power Institute of Fine Arts, 1987.

BAUDRILLARD, Jean, The ecstasy of communication, Nueva York: Semiotext(e), 1988.

BAUDRILLARD, Jean, "La Guerre du Golfe n'aura pas eu lieu" en Libération, 4 de enero, 1991, p. 5.

BAUDRILLARD, Jean, "La Guerre du Golfe a-t-elle vraiment lieu?" en Libération, 6 de febrero, 1991, p. 10.

BAUDRILLARD, Jean "La Guerre du Golfe n'a pas eu lieu" en Libération, 29 de marzo, 1991, p. 6.

BAUDRILLARD, Jean, La Guerre du Golfe n'a pas eu lieu, París: Galilée, 1991.

BAUDRILLARD, Jean, "The implosion of meaning in the Media" en Simulacra and simulation, Ann Arbor: University of Michigan Press, 1994, pp. 79-86.

BAUDRILLARD, Jean, The Gulf War did not take place, Bloomington: Indiana University Press, 1995.

BAUDRY, Jean-Louis, "Ideological effects of the basic cinematographic apparatus" en Film Quarterly, vol. 28, no 2, invierno 1974-1975, pp. 39-47.

BAZIN, André, ¿Qué es el cine?, Madrid: Rialp, 1990.

BAZIN, André, Jean Renoir. Periodos, filmes y documentos, Barcelona: Paidós, 1999.

BELLOUR, Raymond, "The double helix" en DRUCKERY, Timothy (ed.), Electronic culture. Technology \& visual representation, Nueva York: Aperture, 1997, pp. 173-199.

BELLOUR, Raymond, El cuerpo del cine. Hipnosis, emociones, animalidades, Santander: Shangrila Textos Aparte, 2013.

BELTON, John, Widescreen cinema, Londres: Harvard University Press, 1992.

BENET, José Vicente, “Montaje y narratividad en el cine primitivo" en Archivos de la Filmoteca, Valencia: Filmoteca de la Generalitat Valenciana, no 2, junio-agosto de 1989, pp. 94-99.

BERNERS-LEE, Tim, Tejiendo la red. El inventor del World Wide Web nos descubre su origen, Madrid: Siglo XXI, 2000.

BOGDANOVICH, Peter, Who the devil made it. Conversations with legendary film directors, Nueva York: Ballantine Books, 1998.

BOLTER, Jay David; GRUSIN, Richard, Remediation. Understanding New Media, Cambridge: The MIT Press, 1999.

BONET, Eugeni (coord.), Desmontaje: Film, vídeo/apropiación, reciclaje, Valencia: IVAM et. al., 1993.

BONITZER, Pascal, "Voici. La notion de plan et le sujet du cinéma" en Cahiers du Cinéma, no 273, enerofebrero de 1977, pp. 5-18.

BONITZER, Pascal, “Décadrages” en Cahiers du Cinéma, no 284, enero de 1978, pp. 7-15. 
BORDE, Raymond, Los archivos cinematográficos, Valencia: Filmoteca de la Generalitat Valenciana, 1991.

BORDWELL, David; THOMPSON, Kristin, Film Art. An introduction, Nueva York: McGraw-Hill, 1979. [En español: El Arte cinematográfico, Barcelona: Paidós, 2002].

BORDWELL, David; CARROLL, Noël (eds.), Post-Theory. Reconstructing film studies, Madison: University of Wisconsin Press, 1996.

BORDWELL, David; STAIGER, Janet; THOMPSON, Kristin, El cine clásico de Hollywood. Estilo cinematográfico y modo de producción hasta 1960, Barcelona: Paidós, 1997.

BORDWELL, David, On the history of film style, Cambridge: Harvard University Press, 1997.

BORDWELL, David, "Intensified continuity. Visual style in contemporary american film" en Film Quarterly, Berkeley: University of California Press, vol. 55, no 3, 2002.

BORDWELL, David, The way Hollywood tells it. Story and style in modern movies, Berkeley: University of California Press, 2006.

BORDWELL, David, "Intensified continuity revisited" en Observations on film art, 27 de mayo del 2007, <http://www.davidbordwell.net/blog/2007/05/27/intensified-continuity-revisited/> [consulta: 20-102015].

BRAKHAGE, Stan, Metaphors on vision, Nueva York: Film Culture, 1963.

BRAKHAGE, Stan, Brakhage Scrapbook. Collected writings 1964 - 1980, Kingston: McPherson \& Company, edición y compilación de Robert Haller, 1982.

BRESSON, Robert, Notas sobre el cinematógrafo, Madrid: Árdora, 2002.

BOWSER, Eileen (ed.), The slapstick symposium, Bruselas: FIAF, 1988.

BROUGHTON, James, "Film as a way of seeing" en Film Culture, no 29, verano de 1963, pp. 19-20.

BROWNE, Rodrigo, "Comunicación indisciplinada. Iconofagia e iconorrea en los medios de (in)comunicación" en Revista Austral de Ciencias Sociales, Universidad Austral de Chile, no 11, ISSN 0718-1795, pp. 101-114.

BULLOT, Érik, El cine es una invención post mortem, Santander: Shangrila Textos Aparte, 2015.

BURCH, Noël, Praxis del cine, Madrid: Fundamentos, 1979.

BURCH, Noël, El tragaluz del infinito. Contribución a la genealogía del lenguaje cinematográfico, Madrid: Cátedra, 1999.

BUSTAMANTE, Enrique, La televisión económica, Barcelona: Gedisa, 1999.

CALABRESE, Omar, La era neobarroca, Madrid: Cátedra, 1989.

CARDONA ARNAU, Rosa; Del AMO, Alfonso; FERNÁNDEZ COLORADO, Luis; GALLEGO CHRISTENSEN, Jennifer; RUS AGUILAR, Encarnación, Los soportes de la cinematografía 1, Madrid: Cuadernos de la Filmoteca Española, 1999. 
CARR, Robert; HAYES, R.M., Wide screen movies. A history and filmography of wide gauge filmmaking, Jefferson: McFarland \& Company, 1988.

CARROLL, Noël, Mystifying movies. Fads \& fallacies in contemporary film theory, Nueva York: Columbia University Press, 1988.

CARROLL, Noël, "Cognitivism, Contemporary Film Theory and Method. A Response to Warren Buckland" en Journal of Dramatic Theory and Criticism, Lawrence: Departamento de Teatro de la Universidad de Kansas, vol. VI, no 2, primavera de 1992, pp. 165-231.

<https://journals.ku.edu/index.php/jdtc/issue/view/138> [consulta: 23-06-2015]

CARROLL, Noël, Theorizing the moving image, Nueva York: Cambridge University Press, 1996.

CARROLL, Noël; CHOI, Jinhee (eds.), Philosophy of film and motion pictures. An anthology, Malden: Blackwell Publishing, 2006.

CARRUTHERS, Susan, "New media, new war" en International Affairs, vol. 77, no 3, julio del 2001, pp. 673-681.

CARRUTHERS, Susan, The media at war. Communication and conflict in the twentieth century, Nueva York: Palgrave Macmillan, 2002.

CARTWRIGHT, Lisa, Screening the body. Tracing medicine's visual culture, Minneapolis y Londres: University of Minnesota Press, 1995.

CASETTI, Francesco, El film y su espectador, Madrid: Cátedra, 1989.

CASETTI, Francesco, Teorías del cine, Madrid: Cátedra, 1994.

CHERCHI USAI, Paolo, Silent cinema. An introduction, Londres: British Film Institute, 2000.

$\mathrm{CHERCHI}$ USAI, Paolo, The death of cinema. History, cultural memory and the digital dark age, Londres: $\mathrm{BFI}, 2001$.

COCCIA, Emanuele, El bien en las cosas. La publicidad como discurso moral, Santander: Shangrila Textos Aparte, 2015.

COLLADO, Esperanza, Paracinema. La desmaterialización del cine en las prácticas artísticas, Madrid: Trama Editorial, 2012.

COLLINS, Douglas, The history of Kodak, Nueva York: Abrams Books, 1990.

COMOLLI, Jean-Louis, "Technique et Idéologie" en Cahiers du Cinéma, no 229 (5-21), 230 (52-57), 231 (43-49), 233 (39-45), 234 (95-100), 241 (20-24), de la primavera de 1971 al otoño de 1972.

COMPANY, Juan Miguel; MARZAL, José Javier, La mirada cautiva. Formas de ver en el cine contemporáneo, Valencia: Generalitat Valenciana, 1999.

CONRAD, Tony, "Lyssophobia. On Four Violins" en COX, Christoph; WARNER, Daniel (eds.), Audio Culture: readings in modern music, Londres: Continuum Books, 2004, pp. 313-318.

COUSINS, Mark, Historia del cine, Barcelona: Blume, 2005.

CUETO, Juan, Exterior noche, Madrid: Ediciones Júcar, 1985. 
CUNNINGHAM, John, Hungarian cinema. From coffee house to multiplex, Londres: Wallflower Press, 2004.

DANEY, Serge, L'exercice a été profitable, Monsieur, París: P.O.L., 1993.

DARLEY, Andrew, Cultura visual digital, Barcelona: Paidós, 2000.

DE BAECQUE, Antoine (comp.), Teoría y crítica del cine. Avatares de una cinefilia, Barcelona: Paidós, 2005.

DE LAURETIS, Teresa; HEATH, Stephen (eds.), The cinematic apparatus, Nueva York: St. Martin's Press, 1980.

DEL AMO, Alfonso; ORTIZ, Aurea; PIQUERAS, María Jesús, La imagen rescatada, Valencia: Filmoteca de la Generalitat Valenciana, 1995.

DEL AMO GARCÍA, Alfonso; CATALINA, Fernando, Los soportes de la cinematografía 2, Madrid: Cuadernos de la Filmoteca, no 6, 1999.

DEL AMO GARCÍA, Alfonso, Inspección técnica de materiales en el archivo de una filmoteca, Madrid: Cuadernos de la Filmoteca no 3, noviembre del 2007.

DEBRAY, Régis, Vida y muerte de la imagen. Historia de la mirada en Occidente, Barcelona: Paidós, 1994.

DELEUZE, Gilles, La imagen movimiento. Estudios sobre cine I, Barcelona: Paidós, 1984.

DELEUZE, Gilles, La imagen tiempo. Estudios sobre cine 2, Barcelona: Paidós, 1987.

DELEYTO, Celestino, Ángeles y demonios. Representación e ideología en el cine contemporáneo de Hollywood. Barcelona: Paidós, 2003.

DOBERMAN, Gary, “New York cut the crap” en Cinemanews, vol. 79, no 5-6, primavera de 1980.

DUBOIS, Philippe, El acto fotográfico. De la representación a la recepción, Barcelona: Paidós, 1994.

EISENSTEIN, Sergei, Nonindifferent nature. Film and the structure of things, Cambridge: Cambridge University Press, 1987.

ELCOTT, Noam M., “Darkened Rooms. A genealogy of Avant-Garde filmstrips from Man Ray to the London Film-Makers Co-op and back again” en Grey Room, no 30, invierno de 2008, pp. 6-37.

ELSAESSER, Thomas, Early cinema. Space, frame, narrative, Londres: BFI, 2006.

ENGELHARDT, Tom, The end of victory culture. Cold War America and the disillusioning of a generation, Amherst: University of Massachusetts Press, 2007.

FAIRFAX, Daniel (ed.), Jean-Louis Comolli. Cinema against spectacle. Technique and ideology revisited, Amsterdam: Amsterdam University Press, 2015.

FLAXMAN, Gregory (ed.), The brain is the screen. Deleuze and the philosophy of cinema, Minneapolis: University of Minnesota Press, 2000.

FRAMPTON, Hollis, Circles of confusion: film, photography, video. Texts 1968 - 1980, Rochester: Visual Studies Workshop, 1983.

FRIEDBERG, Anne, The Virtual Window. From Alberti to Microsoft, Cambridge: The MIT Press, 2006. 
FRODON, Jean-Michel, “Voyager le cinéma” en Trafic, no 37, marzo de 2001.

GARCÍA LÓPEZ, Sonia; GÓMEZ VAQUERO, Laura (eds.), Piedra, papel y tijera. El collage en el cine documental, Madrid: Ocho y Medio, 2009.

GAUDREAULT, André; GUNNING, Tom, "Le Style non continu du cinéma des premiers temps" en Les Cahiers de la Cinémathêque, no 29, Perpiñán, invierno de 1979, pp. 24-34

GAUDREAULT, André; GUNNING, Tom, "Les Détours du récit filmique. Sur la naissance du montage paralléle" en Les Cahiers de la Cinémathêque, no 29, Perpiñán, invierno de 1979, pp. 88-107.

GAUDREAULT, André, “Film, récit, narration; le cinéma des frères Lumière,” en Iris, 1984, pp. 61-70.

GAUDREAULT, André, "Narration et monstration au cinéma” en Hors Cadre, nํ2, abril de 1984, pp. 8798.

GAUDREAULT, André; GUNNING, Tom, “Le cinéma des premiers temps: un défi à l'histoire du cinéma?" en Gendai Shiso. Revue de la pensée d'aujourd'hui, vol.14, n²12, noviembre 1986, pp. 164-186.

GAUDREAULT, André; JOST, François, El relato cinematográfico. Cine y narratología, Barcelona: Paidós, 2001.

GAUDREAULT, André, Cine y literatura. Narración y mostración en el relato cinematográfico, México D.F.: Unarte, 2011.

GEUENS, Jean-Pierre, "The grand style" en Film Quarterly, vol 58, no 4, Berkeley: University of California Press, 2005, pp. 27-38.

GIDAL, Peter (ed.), Structural film anthology, Londres: BFI, 1978.

GIMFERRER, Pere, Cine y literatura, Barcelona: Seix Barral, 1999.

GÓMEZ TARÍN, Francisco Javier, "Ficcionalización y naturalización: caminos equívocos en la supuesta representación de la realidad" en POYATO SÁNCHEZ, Pedro (coord.), Documental, carcoma de la ficción, Córdoba: Filmoteca de Andalucia y AEHC, 2004, Tomo I.

GÓMEZ TARÍN, Francisco Javier, "Tensiones en la constitución del modelo de representación institucional (M.R.I.): David Wark Griffith como paradigma" en VV. AA., Imatge $i$ viatge. De les vistes òptiques al cinema: la configuració de l'imaginari turístic, Girona: Fundació Museu del Cinema Col.lecció Tomàs Mallol - Ajuntament de Girona, 2004, pp. 251-258.

<http://www.bocc.ubi.pt/pag/tarin-francisco-tensiones-mri.pdf> [consulta: 17-10-2015]

GONZÁLEZ GARCÍA Fernando (ed.), Mohsen Makhmalbaf: del discurso al diálogo, Granada: Consejería de Cultura de la Junta de Andalucía, Filmoteca de Andalucía y Festival de Granada cines del Sur, 2008.

GONZÁLEZ REQUENA, Jesús, El discurso televisivo: espectáculo de la posmodernidad, Madrid: Cátedra, 1995.

GRAF, Alexander; SCHEUNEMANN, Dietrich (eds.), Avant-garde film, Amsterdam: Rodopi, 2007.

GUARNER, José Luis, Roberto Rossellini, Madrid: Fundamentos, 1985.

GUBERN, Román, La mirada opulenta. Exploración de la iconosfera contemporánea, Barcelona: Gustavo Gili, 1992. 
GUBERN, Román, Historia general del cine, Madrid: Cátedra, 1995.

GUBERN, Román, Del bisonte a la realidad virtual. La escena y el laberinto, Barcelona: Anagrama, 1996.

GUBERN, Román, El eros electrónico, Madrid: Taurus, 2000.

GUNNING, Tom, "The cinema of attraction. Early film, its spectator and the avant-garde" en Wide Angle, vol. 8, no 3-4, otoño, 1986, pp. 63-70.

HANOUN, Marcel, Cine, cineasta. Notas sobre la imagen escrita, Santander: Shangrila Textos Aparte, 2014.

HANSEN, Mark (ed.), New philosophy for new media, Cambridge: The MIT Press, 2004.

HARRIES, Dan, (ed.), The new media book, Londres: BFI, 2002.

HATFIELD, Jackie, "Expanded Cinema and Narrative. Some reasons for a review of the Avant-Garde debates around narrativity" en Millennium Film Journal, no 39-40, invierno del 2003, pp. 50-65.

HATFIELD, Jackie, “Expanded cinema and 'cinema of attractions'” en Art in-sight, no 14, 2005, pp. 5-9.

HILL, Helen (ed.), Recipes for disaster. A handcrafted film cookbooklet, Nueva Orleans, 2005.

HOPKINS, David (ed.), Neo-Avant-Garde, Amsterdam y Nueva York: Rodopi, 2006.

IIMURA, Takahiko, The collected writings of Takahiko limura, Maryland: Wildside Press, 2007.

JAMESON, Fredric, La estética geopolítica. Cine y espacio en el sistema mundial, Barcelona: Paidós, 1995.

JASON, Paul; KELLER, Sarah (eds.), Jean Epstein. Critical essays and new translations, Amsterdam: Amsterdam University Press, 2012.

JENKINS, Bruce, “A case against 'Structural Film"” en Journal of the University Film Association, vol. 33, no 2, primavera de 1981, pp. 9-14.

JOST, François, "Le film comme œuvre" en Protée, vol. 19, $n^{\circ} 3$, Le cinéma et les autres arts, Chicoutimi: Universidad de Quebec, 1991.

JOUBERT-LAURENCIN, Hervé, “Le joujou du riche” en Trafic, París: P.O.L, no 2, primavera de 1992.

KAPLAN, Ann, Women \& film. Both sides of the camera, Londres: Routledge, 2000.

KILCHESTY, Albert (ed.), Big as life. An american history of $8 \mathrm{~mm}$ films, San Francisco: Cinematograph y San Francisco Cinematheque, 1998.

KRACAUER, Sigfried, Teoría del cine. La redención de la realidad física, Barcelona: Paidós, 1996.

KRAPP, Peter, Noise Channels. Glitch and error in digital culture, Minneapolis: University of Minnesota Press, 2011.

LAGNY, Michele, Cine e Historia. Problemas y métodos en la investigación cinematográfica, Barcelona: Bosch, 1997.

LEEDER, Murray (ed.), Cinematic ghosts. Haunting and spectrality from silent cinema to the digital era, Nueva York y Londres: Bloomsbury, 2015. 
LE GRICE, Malcolm, Abstract film and beyond, Londres: Studio Vista, 1977.

LE GRICE, Malcolm, Experimental cinema in the digital age, Londres: BFI, 2001.

LIANDRAT-GUIGUES, Suzanne; LEUTRAT, Jean-Louis, Cómo pensar el cine, Madrid: Cátedra, 2003.

LIMBACHER, James, Four aspects of the film, Nueva York: Brussel and Brussel, 1968.

LIPOVETSKY, Gilles; SERROY, Jean, La pantalla global. Cultura mediática y cine en la era hipermoderna, Barcelona: Anagrama, 2009.

LISTER, Martin (ed.), La imagen fotográfica en la cultura digital, Barcelona: Paidós, 1997.

LIVINGSTONE, Paisley; PLANTINGA, Carla (eds.), The Routledge Companion to Philosophy and film, Londres y Nueva York: Routledge, 2009.

LÓPEZ SILVESTRE, Federico, El paisaje virtual. El cine de Hollywood y el neobarroco digital, Madrid: Biblioteca Nueva, 2004.

LOVINK, Geert; SOMERS MILES, Rachel (eds.), Video vortex II. Moving images beyond Youtube, Amsterdam: Institute of Network Cultures, 2011.

LUNENFELD, Peter (ed.), The digital dialectic. New essays on new media, Cambridge: The MIT Press, 1999.

LUTZE, Peter C., Alexander Kluge. The last modernist, Detroit: Wayne State University Press, 1998.

MacDONALD, Scott, The garden in the machine. A field guide to independent films about place, Berkeley: University of California Press, 2001.

MacDONALD, Scott, A critical cinema 5. Interviews with independent filmmakers, Berkeley: University of California Press, 2006.

MacDONALD, Scott, Canyon Cinema. The life and times of an independent film distributor, Berkeley: University of California Press, 2008.

MACGOWAN, Kenneth, Behind the screen. The history and techniques of the motion picture, Nueva York: Delta Book, 1965.

MADDIN, Guy, From the atelier Tovar. Selected writings, Toronto: Coach House Books, 2005.

MANOVICH, Lev, "La Vangurdia como software" en Artnodes, Revista de Arte, ciencia y tecnología, Barcelona: Universitat Oberta de Catalunya, no 2, ISSN 1695-5951, 2003.

MANOVICH, Lev, "What is new media?" en HASSAN, Robert; THOMAS, Julian, (eds.), The new media theory reader, Maidenhead: Open University Press, 2006.

MARGULIES, Ivone (ed.), Rites of realism. Essays on corporeal cinema, Durham y Londres: Duke University Press, 2003.

MARKOPOULOS, Gregory, "The intuition space” en Millenium Film Journal, no 32-33, otoño de 1998.

McCARTHY, Todd, Howard Hawks. The grey fox of Hollywood, Nueva York: Grove Press, 1997.

MacARTHUR, John, El segundo frente. Censura y propaganda en la Guerra del Golfo, Madrid: Cuadernos de Langre, 2003. 
McLUHAN, Marshall, Compender los medios de comunicación. Las extensiones del ser humano, Barcelona: Paidós, 1996.

McLUHAN, Marshall, Understanding Media. The extensions of man, Londres: Routledge, 2001.

MARKOPOULOS, Gregory, "Towards a new narrative film form" en Film Culture, no 31, invierno 19631964, pp. 11-12.

MARTIN, Adrian; ROSENBAUM, Jonathan (coords.), Mutaciones del cine contemporáneo, Madrid: Errata Naturae, 2010.

MEKAS, Jonas, “Movie Journals” en Film Culture, no 43, invierno de 1966, p. 11.

MEKAS, Jonas, “An interview with Peter Kubelka” en Film Culture, no 44, 1967.

MEKAS, Jonas, “The experimental film in America” en Film Culture, nº3, mayo-junio de 1955, pp. 15-20.

MENKMAN, Rosa, The glitch moment(um), Amsterdam: Institute of Network Cultures, 2011.

MERLOCK JACKSON, Kathy, Walt Disney. Conversations, Jackson: University of Mississippi, 2006.

METZ, Christian, Ensayos sobre la significación en el cine [1964-1968], Barcelona: Paidós, 2002.

MILLER, Toby, El nuevo Hollywood. Del imperialismo cultural a las leyes del marketing, Barcelona: Paidós, 2005.

MITRY, Jean, Estética y psicología del cine 1. Las estructuras, Madrid: Siglo XXI, 1986.

MITRY, Jean, Estética y psicología del cine 2. Las formas, Madrid: Siglo XXI, 1986.

MOLINUEVO, José Luis, Retorno a la imagen. Estética del cine en la modernidad melancólica, Salamanca: Archipiélagos, 2010.

MONTERDE, José Enrique, La representación cinematográfica de la Historia, Madrid: Akal, 2001.

MORANDI, Iman (ed.), Glitch. Designing imperfection, Nueva York: Mark Batty Publisher, 2009.

MORIN, Edgar, El cine o el hombre imaginario, Barcelona: Paidós, 2001.

MULVEY, Laura, "Visual pleasure and narrative cinema" en Screen, vol. 16, no 3, otoño de 1975, pp. 618.

MULVEY, Laura, “Placer visual y cine narrativo” en Eutopías, 2a época, vol. 1, Valencia: Episteme, 1988.

MULVEY, Laura, Death 24x second. Stillness and the moving image, Londres: Reaktion Books, 2006.

MUNSTER, Anna, Materializing New Media. Embodiment in information aesthetics, Lebanon: University Press of New England, 2006.

MURCH, Walter, In the blink of an eye. A perspective in film editing, Los Ángeles: Silman-James Press, 2a edición revisada, 2001.

MURRAY SMITH, Greg, Film structure and the emotion system, Nueva York y Londres: Cambridge University Press, 2003.

NALDINI, Nico, Pier Paolo Pasolini. Una vida, Barcelona: Circe, 2001. 
NANCY, Jean-Luc, La evidencia del filme. El cine de Abbas Kiarostami, Madrid: Errata Naturae, 2008.

NEALE, Steve; MURRAY, Smith (eds.), Contemporary Hollywood cinema, Londres: Routledge, 1998.

NEGROPONTE, Nicholas, Being digital, Nueva York: Vintage Books, 1995.

NEGROPONTE, Nicholas, El mundo digital, Barcelona: Ediciones B., 1995.

NÖTH, Winfried; SANTAELLA, Lucía, Imagen. Comunicación, semiótica y medios, Kassel: Reichenberger, 2003.

O'GRADY, Gerald; POSNER, Bruce (eds.), The articulated light. The emergence of abstract film in America, Boston: Harvard Film Archives, 1996.

OUBIÑA, David (comp.), Jean-Luc Godard: el pensamiento del cine. Cuatro miradas sobre Historie(s) du cinéma, Buenos Aires: Paidós, 2003.

PALACIO, Manuel; ZUNZUNEGUI, Santos (eds.), Historia general del cine. vol. XII. El cine en la era del audiovisual, Madrid: Cátedra, 1995.

PALAO, José Antonio, La profecía de la imagen-mundo. Para una genealogía del paradigma informativo, Valencia: Ediciones de la Filmoteca, 2004.

PAREDES BADÍA, Israel, Imágenes del cuerpo, Cáceres: Asociación Re Bross, Filmoteca de Extremadura y Librería Ocho y Medio, 2007.

PARENTE, André, Cinéma et narrativité, París: L'Harmattan, 2005.

PEARSON, Matt, Generative art. A practical guide ussing processing, Nueva York: Manning Publications, 2011.

PÉREZ BOWIE, José Antonio, "La adaptación cinematográfica a la luz de algunas aportaciones teóricas recientes" en Signa: Revista de la Asociación Española de Semiótica, ISSN 1133-3634, no 13, 2004.

PERKINS, Victor, El lenguaje del cine, Madrid: Fundamentos, 1997.

PETIT, Chris: "You'll never eat dog-meat in this town again" en The Guardian, 20 de noviembre de 2004, p. 14.

<http://www.theguardian.com/books/2004/nov/20/highereducation.film> [consulta: 17-10-2015]

PIÑERA TARQUE, Ismael, Mundos literarios. Relato literario y relato fílmico, Kassel: Reichenberger, 2009.

POSTER, Mark, The mode of information. Poststructuralism and social context, Chicago: University of Chicago Press, 1990.

PRAGA, Jorge, Biografías del tiempo, Valladolid: Caja España, 1999.

PRATT, David, “Widescreen” en The Velvet Light Trap, no 21, verano de 1985.

PRINCE, Stephen, "The emergence of filmic artifacts" en Film Quarterly, no 3, vol. 57, pp. 24-33.

QUINTANA, Ángel, Después del cine. Imagen y realidad en la era digital, Barcelona: Acantilado, 2011.

QUINTERO, Alejandro, Nuevas guerras, vieja propaganda. De Vietnam a Irak, Valencia: Universitat de València, 2005. 
RAGONA, Melissa, "Hidden noise: strategies of sound montage in the films of Hollis Frampton" en October Magazine, no 109, verano del 2004, pp. 97-118.

RAMONET, Ignacio, La tiranía de la comunicación, Madrid: Debate, 1998.

RANCIÈRE, Jacques, La fábula cinematográfica. Reflexiones sobre la ficción en el cine, Barcelona: Paidós, 2005.

RANCIÈRE, Jacques, El espectador emancipado, Castellón: Ellago Ediciones, 2010.

RANCIÈRE, Jacques, The intervals of cinema, Londres y Nueva York: Verso Books, 2014.

REVAULT D’ALLONNES, Fabrice, La luz en el cine, Madrid: Cátedra, 2003.

RIAMBAU, Esteve, Hollywood en la era digital. De Jurassic Park a Avatar, Madrid: Cátedra, 2011.

RICHTER, Hans, “The film as an original art form" en Film Culture, no 1, enero de 1955.

ROBINS, Kevin, "Post-photography, the highest state of photography" en TRIGGS, Teal (ed.), Communication design, Londres: Batsford, 1995.

RODOWICK, D. N., The virtual life of film, Cambridge y Londres: Harvard University Press, 2007.

ROHMER, Éric, El gusto por la belleza, Barcelona: Paidós, 2000.

ROHMER, Éric, L'organisation de l'espace dans le Faust de Murnau, París: Petite Bibliothèque des Cahiers du Cinéma, 2000.

ROMAGUERA i RAMIÓ, Joaquim; ALSINA THEVENET, Homero (eds.), Textos y manifiestos del cine, Madrid: Cátedra, 1998.

ROSSELL, Deac, "The Biograph large format technology" en TURCONI, Davide (ed.), Griffithiana, no 6670, 1999-2000, pp. 79-117.

ROSSELLINI, Roberto, Un espíritu libre no debe aprender como esclavo, Barcelona: Paidós, 2001.

RUBIO ALCOVER, Agustín, La postproducción cinematográfica en la era digital: efectos expresivos y narrativos, Castellón: Universitat Jaume I. Departamento de Filosofía, Sociología, Comunicación Audiovisual y Publicidad, Tesis doctoral inédita, 2006.

RUIZ JIMÉNEZ, Antonio Gabriel, El cine. Muerte o transfiguración, Sevilla: Comunicación Social, 2005.

SALT, Barry, Film style \& technology: History \& analysis, Londres: Starword, 1983.

SÁNCHEZ-BIOSCA, Vicente, Cine y vanguardias artísticas. Conflictos, encuentros, fronteras, Barcelona: Paidós, 2004.

SÁNCHEZ-BIOSCA, Vicente, Cine de historia, cine de memoria, Madrid: Cátedra, 2006.

SANDUSKY, Sharon, "Toward archival film. The archaeology of redemption" en Millenium Film Journal, no 26, Archaeologies, otoño de 1992, pp. 2-25.

SARTORI, Giovanni, Homo videns. La sociedad teledirigida, Madrid: Taurus 1998.

SASSEN, Saskia, "Sited materialities with global span" en HOWARD, Philip; JONES, Steve (eds.), Society online. The Internet in context, Londres: Sage, 2003. 
SCHRADER, Paul, El estilo trascendental en el cine, Ozu, Bresson, Dreyer, Madrid: Ediciones J. C., 1999.

SEIB, Philip, Media and conflict in the twenty-first century, Nueva York: Palgrave Macmillan, 2005.

SEKULA, Allan, "El cuerpo y el archivo" en PICAZO, Gloria; RIBALTA, Jorge (eds.), Indiferencia y singularidad. La fotografía en el pensamiento artístico contemporáneo, Barcelona: Gustavo Gili, 2003, pp. 133-199.

SFEZ, Lucien, Crítica de la comunicación, Buenos Aires: Amorrortu, 1995.

SITNEY, Paul Adams, "Structural film" en Film Culture, no 47, verano de 1969, pp. 1-10.

SITNEY, Paul Adams, Visionary Film. The american avant-garde 1943-1978 (Second edition), Nueva York: Oxford University Press, 1979.

SITNEY, Paul Adams (ed.), Film Culture reader, Nueva York: Cooper Square Press, 2000.

SITNEY, Paul Adams, Visionary Film. The american avant-garde 1943-2000, Nueva York: Oxford University Press, 2002.

SNOW, Michael, The collected writings of Michael Snow, Waterloo: Wilfrid Laurier University Press, 1994.

SONTAG, Susan, Sobre la fotografía, Buenos Aires: Editorial Sudamericana, 1980. [Barcelona: Edhasa, 1992] [México D. F.: Alfaguara, 2006]

SONTAG, Susan, Ante el dolor de los demás, Barcelona: Círculo de Lectores, 2003.

SONTAG, Susan, On photography, Nueva York: RosettaBooks, 2005.

SORLIN, Pierre, Sociología del cine. La apertura para la historia de mañana, México D.F.: Fondo de Cultura Económica, 1985.

SPRENGLER, Christine, Screening nostalgia. Populuxe props and Technicolor aesthetics in contemporary american film, Nueva York y Oxford: Berghahn Books, 2009.

STRAUVEN, Wanda (ed.), The cinema of attractions, reloaded, Amsterdam: Amsterdam University Press, 2006.

TALENS, Jenaro; ZUNZUNEGUI, Santos (eds.), Contracampo. Ensayos sobre teoría e historía del cine, Madrid: Cátedra, 2007.

TARKOVSKY, Andrei, Esculpir en el tiempo, Madrid: Rialp, 2005.

TEJEDA, Carlos, Arte en fotogramas. Cine realizado por artistas, Madrid: Cátedra, 2008.

THOMPSON, Allan (ed.), The media and the Rwanda genocide, Ann Arbour: Pluto Press, Fountain Publishers, IDRC, 2007.

THOMPSON, Kristin, Storytelling in the New Hollywood, Cambridge: Harvard University Press, 1999.

TURVEY, Malcom, Doubting vision. Film and the revelationist tradition, Nueva York: Oxford University Press, 2008. 
URRUTIA, Juan, "Redes de personas, Internet y la lógica de la abundancia. Un paseo por la Nueva Economía" en Ekonomiaz. Revista Vasca de Economía, San Sebastián: Departamento de Hacienda y Finanzas, no 46, Panorama de las industrias de red, ISSN 0213-3865, 2001, pp. 182-201.

USTARROZ, César, Realización y representación a tiempo real. Apropiación de retórica y estética de las vanguardias artísticas del s. XX, Madrid: Libertarias, 2010.

VERTOV, Dziga, El cine ojo. Textos y manifiestos, Barcelona: Fundamentos, 1974.

VILCHES, Lorenzo, La migración digital, Barcelona: Gedisa, 2001.

VILLAFAÑE, Justo, Introducción a la teoría de la imagen, Madrid: Pirámide, 1985.

VILLAIN, Dominique, El encuadre cinematográfico, Barcelona: Paidós, 1997.

VIRILIO, Paul, La máquina de visión, Madrid: Cátedra, 1989.

VIRILIO, Paul, “Alerte dans le cyberspace” en Le Monde Diplomatique, 28 de agosto de 1995. Traducción al español en: <http://aleph-arts.org/pens/speed.html> [consulta: 08-08-2015]

VIRILIO, Paul, Ciudad pánico, Buenos Aires: Libros del Zorzal, 2006.

VV. AA., "Errors and glitches" en Virose <http://virose.pt/vector/> [consulta: 31-08-2015].

VV. AA., "Alexander Kluge. Historia, cine y resistencia crítica” en Shangrila. Derivas y ficciones aparte, no 12, 2010.

WALKER, Janet, "The Traumatic Paradox: Documentary films, historical fictions, and cataclysmic past events", en Signs, no 4, verano 1997, pp. 803-825.

WALKER, Janet, Trauma cinema. Documenting incest and the Holocaust, Berkeley: University of California Press, 2005.

WEBBER, Mark, Film as Film. The collected writings of Gregory J. Markopoulos, Nueva York: The Visible Press, 2014.

WEES, William C., Light moving in Time. Studies in the visual aesthetics of avant-garde film, Berkeley: University of California Press, 1992.

WEES, William C., Recycled images, Nueva York: Antology Film Archives, 1993.

WEINRICHTER, Antonio (coord.), La forma que piensa. Tentativas en torno al cine-ensayo, Pamplona: Fondo de Publicaciones del Gobierno de Navarra, Colección Punto de Vista, 2007.

WEINRICHTER, Antonio, Metraje encontrado. La apropiación en el cine documental y experimental, Pamplona: Fondo de Publicaciones del Gobierno de Navarra, Colección Punto de Vista, no4, 2009.

WEINRICHTER, Antonio (ed.), "El cine en el espacio del arte" en Secuencias. Revista de Historia del Cine, no 32, 20 semestre del 2010.

WENDERS, Wim, El acto de ver, Barcelona: Paidós, 1992.

WILLIAM MITCHELL, John, The reconfigured eye. Visual truth in the post-photographic era, Cambridge: The MIT Press, 1992. 
WOLOSHEN, Steven, Scratch, crackle \& pop. A whole grains approach to making films without a camera, Montreal: Scratchatopia Books, 2015.

WOLOSHEN, Steven, Recipes for reconstruction, Montreal: Scratchatopia Books, 2010.

WOOD, Robin, Hollywood from Vietnam to Reagan... and beyond, Nueva York: Columbia University Press, 2003.

WYATT, Justin, High Concept. Movies and marketing in Hollywood, Austin: University of Texas Press, 2000.

YOUNGBLOOD, Gene, Expanded cinema, Nueva York: Dutton \& Co., 1970.

ZAMORA ÁGUILA, Fernando, Filosofía de la imagen. Lenguaje, imagen, representación, México D. F.: UNAM, 2007.

ZRYD, Michael, “History and ambivalence in Hollis Frampton's Magellan” en October Magazine, no 109, verano del 2004, pp. 119-142.

ZUNZUNEGUI, Santos, La mirada cercana. Microanálisis fílmico, Barcelona: Paidós, 1996.

ZUNZUNEGUI, Santos, Pensar la imagen, Madrid: Cátedra, 2003.

\section{Naturaleza humana. Estética evolucionista, consiliencia y ciencias del cuerpo}

ATRAN, Scott, In gods we trust. The evolutionary landscape of religion, Nueva York: Oxford University Press, 2002.

ATRAN, Scott, "What neuroscience and machine models of the mind should be looking for" en Edge.org, <http://edge.org/response-detail/26079> [consulta: 15-10-2015]

AUGÉ, M.; DAVID-MÉNARD, M.; GRANOFF, W.; LANG, J.L.; MANNONI, O., El objeto en psicoanálisis. El fetiche, el cuerpo, el niño, la ciencia, Buenos Aires y Barcelona: Gedisa, 1987.

AYALA, Francisco J., Darwin y el diseño inteligente. Creacionismo, cristianismo y evolución, Madrid: Alianza, 2007.

AYALA, Francisco J.; CELA CONDE, Camilo J., evolución humana. El camino hacia nuestra especie, Madrid: Alianza, 2013.

BAARS, Bernard J.; GAGE, Nicole, M., Cognition, brain and consciousness. Introduction to cognitive neuroscience, Oxford: Elsevier-Academic Press, 2010.

BARGH, John; HASSIN, Ran; ULEMAN, James (eds.), The new unconscious, Nueva York: Oxford University Press, 2005.

BARRETT, Louise; DUNBAR, Robin; LYCETT, John, Evolutionary psychology. A Beginner's Guide. Human behaviour, evolution and the mind, Oxford: Oneworld Book, 2007.

BAUMEISTER, Roy, The cultural animal. Human nature, meaning, and social life, Nueva York: Oxford University Press, 2005. 
BAUMEISTER, Roy; MELE, Alfred; VOHS, Kathleen (eds.), Free will and consciusness. How might they work?, Nueva York: Oxford University Press, 2010.

BERGSON, Henri, Materia y memoria. Ensayo sobre la relación del cuerpo con el espíritu, Buenos Aires: Cactus, 2010.

BIGELOW, Julian; ROSENBLUETH, Arturo; WIENER, Norbert, "Behavior, purpose and teleology" en Philosophy of Science, vol. 10, no 1, 1943, pp. 18-24.

BOOKER, Christopher, The seven basics plots. Why we tell stories, Nueva York: Continuum, 2004.

BOYD, Bryan, On the origin of stories. Evolution, cognition and fiction, Londres: Harvard University Press, 2009.

BOYER, Pascal, The naturalness of religious ideas. A cognitive theory of religion, San Francisco: University of California Press, 1994.

BRESSLOFF, Paul, et. al., "Geometric visual hallucinations, Euclidean symmetry and the functional architecture of striate cortex" en Philosophical Transactions of the Royal Society B: Biological Sciences, vol. 356, no 1407, 2000, pp. 299-330.

BRESSLOFF, Paul., et. al., "What geometric visual hallucinations tell us about the visual cortex" en Neural Computation, vol. 14, no 3, marzo de 2002, pp. 473-491.

BROCKMAN, John, The third culture. Beyond the scientific revolution, Londres y Nueva York: Simon \& Schuster, 1995.

BROCKMAN, John (ed.), El nuevo humanismo y las fronteras de la ciencia, Barcelona: Kairós, 2007.

BROCKMAN, John (ed.), This explains everything. Deep, beautiful and elegant theories of how the world works, Nueva York: Harper Collins, 2012.

BROWN, Donald, Human universals, Nueva York: McGraw-Hill, 1991.

BRUGGER, Peter, "From haunted brain to haunted science: A cognitive neuroscience view of paranormal and pseudoscientific thought" en HOURAN, James; LANGE, Rense (eds.), Hauntings and Poltergeists. Multidisciplinary perspectives, 2001, pp. 195-213.

BUNGE, Mario, El problema mente-cerebro. Un enfoque psicobiológico, Madrid: Tecnos, 2002.

BUNGE, Mario, Emergencia y convergencia. Novedad cualitativa y unidad del conocimiento, Barcelona: Gedisa, 2004.

BUNGE, Mario, Materia y mente. Una investigación filosófica, Pamplona: Editorial Laetoli, 2015.

CALVO ROY, Antonio, “Entrevista con Francisco José Ayala” en El País, 22 de julio de 2015. <http://elpais.com/elpais/2015/07/21/eps/1437498561_652239.html> [consulta: 15-10-2015].

CAMPBELL, Joseph, El héroe de las mil caras. Psicoanálisis del mito, México D.F.: Fondo de Cultura Económica, 2006.

CARROLL, Joseph, Literary darwinism. Evolution, human nature, and literature, Nueva York: Routledge, 2004. 
CHALLIS, Sam; LEWIS-WILLIAMS, David, Deciphering ancient minds: the mystery of San bushmen rock art, Londres: Thames \& Hudson, 2011.

CHURCHLAND, Patricia; LLINÁS, Rodolfo (eds.), El continuum mente-cerebro. Procesos sensoriales, Bogotá: Universidad Nacional de Colombia, 2006.

CONRAD, Klaus, "La Esquizofrenia incipiente. Intento de un análisis de la forma del delirio" en Revista de la Asociación Española de Neuropsiquiatría, vol 14, no 49, 1994, pp. 319-328.

<http://www.revistaaen.es/index.php/aen/article/viewFile/15377/15238> [consulta: 15-05-2015]

COWART, Monica, "Embodied cognition" en Internet Encyclopedia of Philosophy, 27 de febrero de 2012. <http://www.iep.utm.edu/embodcog/> [consulta: 11-08-2015]

CRAWFORD, Cassandra, Ghost in the machine. A genealogy of phantom-prosthetic relations, San Francisco: University of California, 2007.

D'ARC, Mirela, et. al., "Origin of the HIV-1 group O epidemic in western lowland gorillas" en PNAS, vol. 112 no 11, 2 de marzo del 2015.

<http://www.pnas.org/content/112/11/E1343.full.pdf> [consulta: 23-10-2015]

DAMASIO, Antonio, El error de Descartes. La razón de las emociones, Santiago de Chile: Andrés Bello, 1999.

DAMASIO, Antonio, The feeling of what happens. Body and emotion in the making of consciousness, San Diego: Harcourt Incorporated, 1999.

DAMASIO, Antonio, Y el cerebró creó al hombre. ¿Cómo pudo el cerebro generar emociones, sentimientos, ideas y el yo?, Barcelona: Destino, 2010.

DARWIN, Charles, El origen de las especies, Barcelona: RBA, 2002.

DAWKINS, Richard, El gen egoísta. Las bases biológicas de nuestra conducta, Barcelona: Salvat, 1993.

DAWKINS, Richard, El espejismo de Dios, Madrid: Espasa Calpe, 2007.

DAWKINS, Richard, Evolución: el mayor espectáculo sobre la tierra, Madrid: Espasa Calpe, 2009.

DE FELIPE OROQUIETA, Javier, El jardín de la neurología. Sobre lo bello, el arte y el cerebro, Madrid: Consejo Superior de Investigaciones Científicas, 2014.

DEHAENE, Stanislas, "The neural basis of the Weber-Fechner law. A logarithmic mental number line" en Trends in Cognitive Sciences, vol. 7, no 4, abril del 2003, pp. 145-147.

<http://homepages.uni-tuebingen.de/andreas.nieder/Dehaene(2003)TICS.pdf> [consulta: 21-10-2015]

DE WAAL, Frans, El mono que llevamos dentro, Barcelona: Tusquets, 2007.

DENNETT, Daniel, La conciencia explicada, Barcelona: Paidós, 1995.

DISSANAYAKE, Ellen, “Komar and Melamid discover Pleistocene taste" en Philosophy and Literature, no 22, 1998, pp. 486-496.

DUTTON, Denis, El instinto del arte. Belleza, placer y evolución, Barcelona: Paidós, 2010. 
EPSTEIN, Jean, La Lyrosophie, París: Éditions de la Sirène, 1922.

FALZEDER, Ernst (ed.), The complete correspondence of Sigmund Freud and Karl Abraham, Londres: Karnac Books, 2002.

FFYTCHE, Dominic, H.; CATANI, Marco, "Beyond localization: from hodology to function" en Philosophical Transactions of The Royal Society of London B: Biological Sciencies, vol. 360, no 1456, pp. 767-779.

FFYTCHE, Dominic H., "Visual hallucinatory syndromes: past, present, and future" en Dialogues in Clinical Neuroscience, no 9, junio de 2007, pp. 173-189.

FRAISSE, Paul; PIAGET, Jean, La percepción. Tratado de psicología experimental, Buenos Aires: Paidós, 1973.

FREUD, Sigmund: “Lo ominoso” en Obras Completas. Volumen XVII, Buenos Aires: Amorrortu, 1992.

FREUD, Sigmund, Obras completas. El porvenir de una ilusión, El malestar en la cultura, y otras obras (1927-1931) Volumen XXI, Buenos Aires: Amorrortu, 1992.

GARDNER, Howard, The mind's new science. A history of the cognitive revolution, Nueva York: Basic Books, 1985.

GARDNER, Howard, Arte, mente y cerebro. Una aproximación cognitiva a la creatividad, Barcelona: Paidós, 1997.

GLYNN, Ian, An anatomy of thought. The origin and machinery of the mind, Nueva York: Oxford University Press, 2003.

GOMBRICH, Ernst, Art and illusion. A study in the psychology of pictorical representation, Londres: Phaidon Press, 1984.

GOMBRICH, Ernst, El sentido del orden, Madrid: Debate, 1999.

GOTTSCHALL, Jonathan, The storytelling animal. How stories make us human, Nueva York: Houghton Mifflin Harcourt, 2012.

GRANDIN, Temple, Thinking in pictures. My life with autism, Nueva York: Vintage Books, 2006.

GRAYLING, A. C., Against all gods. Six polemics on religion and an essay on kindness, Londres: Oberon Books, 2010.

GRAYLING, A. C., El poder de las ideas. Claves para entender el siglo XXI, Barcelona: Ariel, 2013.

HAMEROFF, Stuart; PENROSE, Roger, "Consciousness in the universe. A review of the 'Orch OR' theory" en Physics of Life Reviews, vol. 11, no 1, marzo de 2014, pp. 39-78.

HASSON, Uri et al., "Neurocinematics. The neuroscience of film" en Projections, vol. 2, no 1, verano del 2008, pp. 1-26.

HAYLES, Katherine, How we became posthuman. Virtual bodies in cybernetics, literature, and informatics, Chicago: University of Chicago Press, 1999.

HOBSON, Allan; McCARLEY, R., "The brain as a dream-state generator. An activation-synthesis hypothesis of the dream process" en American Journal of Psychiatry, no 134, 1997, pp. 1335-1348. 
HOBSON, Allan, Psychodynamic neurology. Dreams, consciousness, and virtual reality, Boca Ratón: CRC Press, 2014.

HUIZINGA, Johan, Homo ludens, Madrid: Alianza, 2007.

JOHNSON, Mark; LAKOFF, George, Philosophy in the flesh. The embodied mind and its challenge to western thought, Nueva York: Basic Books, 1999.

JÜNG, Carl Gustav, Formaciones de lo inconsciente, Barcelona: Paidós, 1990.

KANIZSA, Gaetano, Gramática de la visión. Percepción y pensamiento, Barcelona: Paidós, 1986.

KAPPELER, Peter; SILK, Joan (eds.), Mind the gap. Tracing the origins of human universals, Heidelberg: Springer, 2010.

KLÜVER, Heinrich, Mescal and mechanisms of hallucinations, Chicago: University of Chicago Press, 1966.

KOSSLYN, Stephen; OSHERSON, Daniel (eds.), An Invitation to Cognitive Science. Visual cognition, Volume 2, Cambridge: The MIT Press, 1995.

KOSSLYN, Stephen; THOMPSON, William; GANIS, Giorgio, The case for mental imagery, Nueva York: Oxford University Press, 2006.

KROKER, Arthur; KROKER, Marilouise, Body invaders. Panic sex in America, Nueva York: St. Martin's Press, 1987.

KUHN, Thomas, La estructura de las revoluciones científicas, México: Fondo de Cultura Económica, 2004. KURZWEIL, Ray, Singularity is near. When humans transcend biology, Nueva York: Penguin, 2005.

KURZWEIL, Ray, La singularidad está cerca. Cuando los humanos transcendemos la biología, Berlin: Lola Books, 2012.

LACAN, Jacques, Seminario 2. El Yo en la teoría de Freud y en la técnica psicoanalítica, Buenos Aires: 2008.

LACAN, Jacques, Seminario 4. La relación de objeto, Buenos Aires: Paidós, 2008.

LACAN, Jacques, Seminario 10. La angustia, Buenos Aires: Escuela Freudiana de Buenos Aires.

LeDOUX, Joseph, "The amygdala is NOT the brain's fear center. Separating findings from conclusions" en Psychology Today, 10 de agosto de 2015.

<https://www.psychologytoday.com/blog/i-got-mind-tell-you/201508/the-amygdala-is-not-the-brainsfear-center> [consulta: 20-08-2015]

LEVY, Neil, "Evolutionary psychology, human universals and the standard social science model" en Biology and Philosophy, $\mathrm{n}$ o 19, 2004, pp. 459-472.

LEWIS-WILLIAMS, David, et. al., "The signs of all times: entoptic phenomena in upper paleolithic art" en Current Anthropology, vol. 29, no 2, abril de 1988, pp. 201-245.

LEWIS-WILLIAMS, David, La mente en la caverna. La conciencia y los orígenes del arte, Madrid: Akal, 2005. 
LEWIS-WILLIAMS, David, Conceiving God. The cognitive origin and evolution of religion, Nueva York: Thames \& Hudson, 2010.

LYNCH, David, Catching the big fish. Meditation, consciousness, and creativity, Nueva York: Penguin, 2006.

MCCULLOCH, Warren, Embodiments of mind, Cambridge: The MIT Press, 1988.

MATURANA, Humberto; VARELA, Francisco, De máquinas y seres vivos. Una teoría sobre la organización biológica, Santiago de Chile: Editorial Universitaria, 1994.

MERLEAU-PONTY, Maurice, El ojo y el espíritu, Barcelona: Paidós, 1985.

MERLEAU-PONTY, Maurice, Fenomenología de la percepción, Barcelona: Planeta De Agostini, 1993.

MISNKY, Marvin, La sociedad de la mente. La inteligencia humana a la luz de la inteligencia artificial, Buenos Aires: Galápago, 1986.

MITHEN, Steven (ed.), Creativity in human evolution and Prehistory, Londres y Nueva York: Routledge, 1998.

MITHEN, Steven, Arqueología de la mente. Orígenes del arte, de la religión y de la ciencia, Barcelona: Mondadori, 1998.

MOLES, Abraham, La información y percepción estética, Madrid y Gijón: Ediciones Júcar, 1975.

MORA, Francisco (coord.), Esplendores y miserias del cerebro, Madrid: Fundación Banco Santander, 2004.

MORA, Francisco, Neurocultura. Una cultura basada en el cerebro, Madrid: Alianza, 2007.

MORAVEC, Hans, Mind children. The future of robot and human intelligence, Cambridge: Harvard University Press, 1998.

MORAVEC, Hans, Robot. Mere machine to transcendt mind, Nueva York: Oxford University Press, 1999.

MORIN, Edgar, El paradigma perdido. Ensayo de bioantropología, Barcelona: Kairós, 1974.

MORIN, Edgar, La identidad humana. El método V. La humanidad de la humanidad, Barcelona: Círculo de Lectores, 2004.

NIGEL, Thomas, "Mental Imagery" en ZALTA, Edward (ed.), The Stanford encyclopedia of philosophy, Edición de otoño del 2014

<http://plato.stanford.edu/archives/fall2014/entries/mental-imagery/> [consulta:15-10-2015].

NISHIMOTO, Shinji; VU, An T.; NASELARIS, Thomas; BENJAMINI, Yuval; YU, Bin; GALLANT, Jack L., "Reconstructing visual experiences from brain activity evoked by natural movies" en Current Biology, vol. 21, no 19, octubre de 2011, pp. 1641-1646.

<http://www.stat.berkeley.edu/ binyu/ps/papers2011/NishimotoVNBYG11.pdf> [consulta: 21-10-2015]

NOBLE, William; DAVIDSON, lain, "The evolutionary emergence of modern human behaviour. Language and its archaeology" en Man. Journal of the Royal Anthropological Institute, vol. 26, no 2, junio de 1991, pp. 223-253. 
PANESSE, Alessia, "La mente y la imagen" en Vértebra. Revista de arte y literatura, no 11, 2009. <http://revistavertebra.files.wordpress.com/2009/10/051.pdf> [consulta: 16-10-2015].

PERREAULT, A.; GURNSEY, R.; DAWSON, M.; MOTTRON, L.; BERTONE, A., "Increased sensitivity to mirror symmetry in autism"

en PLoS One, 29-04-2011. <http://journals.plos.org/plosone/article?id=10.1371/journal.pone.0019519> [consulta: 20-05-2015]

PINKER, Steven, La tabla rasa. La negación moderna de la naturaleza humana, Barcelona: Paidós, 2003.

PINKER, Steven, El instinto del lenguaje. Cómo crea el lenguaje la mente, Madrid: Alianza, 1995.

PINKER, Steven, How the mind works, Nueva York: Penguin Books, 1997.

PINKER, Steven, The better angels of our nature. Why violence has declined, Nueva York: Penguin, 2011.

PINKER, Steven, "Science is not your enemy" en The New Republic, 6 de agosto de 2013. <http://www.newrepublic.com/article/114127/science-not-enemy-humanities> [consulta: 28-01-2015].

PRIGOGINE, Ilya, Las leyes del caos, Barcelona: Crítica, 1997.

RAMACHANDRAN, Vilayanur S., The tell-tale brain. A neuroscientist's quest for what makes us human, Londres: W.W. Norton \& Company, 2012.

RESNICK, MitcheL, Turtles, termites, and traffic jams. Explorations in massively parallel microworlds, Cambridge: The MIT Press, 1994.

RIDGWAY, Nicole; STERN, Nathaniel, "The implicit body” en RICARDO, Francisco (ed.), Cyberculture and New Media, Amstedram y Atlanta: Rodopi, 2008, pp. 117-155.

ROSCH, Eleanor; THOMPSON, Evan; VARELA, Francisco, The embodied mind. Cognitive science and human experience, Cambridge: The MIT Press, 1991.

ROSE, Hilay; ROSE, Steven, Genes, cells and brains. The promethean promises of the New Biology, Londres y Nueva York: Verso Books, 2012.

ROSS ASHBEY, William, Introducción a la Cibernética, Londres: Chapman \& Hall, 1956.

RYLE, Gilbert, El concepto de lo mental, Barcelona: Paidós, 2005.

SABATANO, Claudia; SANTOIANNI, Flavia (eds.), Brain development in learning environments. Embodied and perceptual advancements, Newcastle: Cambridge Scholars Publishing, 2007.

SACKS, Oliver, Alucinaciones, Barcelona: Anagrama, 2013.

SARTRE, Jean-Paul, Lo imaginario. Psicología fenomenológica de la imaginación, Buenos Aires: Losada, 1976.

SHERMER, Michael, Why people believe weird things. Pseudoscience, superstition, and other confusions of our time, Nueva York: First Owl Books, 2002.

SHERMER, Michael, The believing brain. From ghosts and Gods to politics and conspiracies. How we construct beliefs and reinforce them as truths, Nueva York: Times, 2011.

SNOW, Charles Percy, Las dos culturas, México D.F.: UNAM, 2006. 
SOBCHAK, Vivian, Carnal thoughts. Embodiment and moving image culture, Los Ángeles: University of California Press, 2004.

TONONI, Giulio, "An information integration theory of consciousness" en BMC Neuroscience, vol. 5, no 42, 2004. <http://www.biomedcentral.com/1471-2202/5/42> [consulta: 17-07-2015].

URTUBIA VICARIO, César, Neurobiología de la visión, Barcelona: Ediciones UPC, 1997.

VALDIZÁN, J.R.; ZARAZAGA ANDÍA, I.; ABRIL VILLALABA, B.; SANS CAPDEVILA, O.; MÉNDEZ GARCÍA, M.; "Reconocimiento de caras en el autismo" en Revista de Neurología, vol. 36, no 12, 16-06-2003, pp. 11861189.

VARELA, Francisco, La habilidad ética, Barcelona: Debate, 1992.

VARELA, Francisco, Ética y acción, Santiago de Chile: Dolmen Ediciones, 1996.

VON NEWMANN, John, The computer and the brain, New Haven: Yale University Press, 2012.

WIENER, Norbert, Cybernetics: or control and communication in the animal and the machine, Cambridge: The MIT Press, 1948. [Español: Cibernética: o el control y comunicación en animales y máquinas, Barcelona: Tusquets, 1998]

WIENER, Norbert, The human use of human beings. Cybernetics and society, Boston: De Capo Press, 1988.

WIENER, Norbert, Cibernética y sociedad, Buenos Aires: Editorial Sudamericana, 1988.

WILSON, Edward Osborne, Consilience. La unidad del conocimiento, Barcelona: Galaxia Guntenberg, 1999.

WILSON, Edward Osborne, The social conquest of Earth, Nueva York y Londres: Liverlight Publishing Corporation, 2012.

WOLPERT, Lewis, Six impossible things before breakfast. The evolutionary origins of belief, Londres: Faber \& Faber, 2010.

ZEKI, Semir, "El cerebro: en la búsqueda de lo esencial" en Elementos. Ciencia y Cultura, Puebla de Zaragoza: Universidad Autónoma de Puebla, vol. 7, no 40, diciembre-febrero 2000-2001.

ZEKI, Semir, Visión interior. Una investigación sobre el arte y el cerebro, Madrid: Antonio Machado Libros, 2005.

ZEMAN, Adam; DELLA SALA, Sergio; et al., "Loss of imagery phenomenology with intact visuo-spatial task performance. A case of "blind imagination'” en Neuropsychologia, no 1, vol. 48, enero de 2010, pp. 145-155.

ZEMAN, Adam; DEWAR, Michaela; DELLA SALLA, Sergio, "Lives without imagery. Congenital aphantasia" en Cortex, 3 de junio de 2015.

<http://medicine.exeter.ac.uk/media/universityofexeter/medicalschool/research/neuroscience/docs/th eeyesmind/Lives_without_imagery.pdf> [consulta: 15-10-2015] 


\section{Miscelánea. Narrativa y otras artes}

ALIGHIERI, Dante, Divina comedia, Madrid: Unidad Editorial, Edición de Ángel Chiclana, 1999.

ALLAN POE, Edgar, Cuentos, Barcelona: Círculo de Lectores, Traducción, prólogo y notas de Julio Cortázar, 1999.

ANÓNIMO, Recipes for disaster. An anarchist cookbook, Olympia: Crimethlnc, 2004.

BERNHARD, Thomas, La calera, Madrid: Alianza, 2003

BORGES, Jorge Luis, El hacedor, Madrid: Alianza, 2005

BRASSAÏ, Conversations with Picasso, Chicago: The University of Chicago Press, 1999.

BRECHT, Bertolt, La ópera de cuatro cuartos, Madrid: Alianza Editorial, 2000.

CIRLOT, Victoria; GARÍ, Blanca, La mirada interior. Escritoras místicas y visionarias en la Edad Media, Madrid: Siruela, 2008.

CORTÁZAR, Julio, Rayuela, Madrid: Cátedra, 2005.

CULIANU, Ioan, Eros y magia en el Renacimiento, Madrid: Siruela, 2007.

DE BINGEN, Hildegarda, "Libro de las obras divinas", en hildegardiana.es, febrero de 2013, traducción y notas de Rafael Renedo [consulta: 02-07-2015].

DE HIPONA, San Agustín, De vera religione.

UNAMUNO, Miguel, Amor y pedagogía, Madrid: Espasa Calpe, 1968.

DELEUZE, Gilles, Francis Bacon. The logic of sensation, Londres y Nueva York: Continuum, 2003.

EZECHIEL, “La profecía de Ezechiel” en Sagrada Biblia, Zaragoza: UNALI, p. 748.

FERNÁNDEZ-GALIANO, Luis (coord.), Voces de vidrio. Foster, Fuksas, Norten, Perrault, Piano, Zwimpfer, no 82 de la revista Arquitectura Viva, Madrid, 2002.

FIRBANK, Roland, The flower beneath the foot, Londres: Grant Richards, 1923.

FLAUBERT, Gustav, La educación sentimental, Madrid: Cátedra, 1990.

GIBSON, William, Neuromante, Barcelona: Minotauro, 2006.

HERNÁNDEZ, Miguel, “El rayo que no cesa” en FERRIS, José Luis (ed.) Miguel Hernández. Breve antología poética, Alicante: Fundación Cultural Miguel Hernández, 2000.

HERSEY, John, Hiroshima, Barcelona: Mondadori, 2009.

HIGHSMITH, Patricia, Carol, Barcelona: Anagrama, 1991.

HÖLDERLIN, Friedrich, Hölderlin. Poesía completa, Barcelona: Ediciones 29, 1977.

HUGO, Víctor, Les miserables. Vol. 2, Ware: Wordsworth Editions, 1994.

IOANNES PAULUS II, Veritatis splendor, Ciudad del Vaticano: Santa Sede, Carta Encíclica 06-08-1993. 
<http://w2.vatican.va/content/john-paul-ii/es/encyclicals/documents/hf_jp-ii_enc_06081993_veritatissplendor.html> [consulta: 01-04-2015]

KARDEC, Allan, El libro de los espíritus, Brasilia: Consejo Espírita Internacional, 2008.

LEIRIS, Michel, “Le caput mortuum ou la femme de l'alchimiste” en Documents, no 8, 1930, pp. 461-466.

LORIGA, Ray, Tokio ya no nos quiere, Barcelona: Plaza y Janés, 1999.

OVIDIO, Metamorfosis, Madrid: Cátedra, 1995.

PASOLINI, Pier Paolo, Poesía en forma de rosa, Madrid: Visor, 2002.

PIRRO, Ugo, Celluloide, Turín: Einaudi, 1995.

ROAS, David, El castillo del espectro. Antología de relatos fantásticos españoles del siglo XIX, Barcelona: Círculo de Lectores, 2002.

RUSKIN, John, The poetry of architecture, en gutenberg.org,

<http://www.gutenberg.org/files/17774/17774-h/17774-h.htm> [consulta: 04-09-2015]

RUSKIN, John, Las siete lámparas de la arquitectura, Barcelona: Alta Fulla, 1997.

SAN JUAN, "El Santo Evangelio de Nuestro Señor Jesucristo según San Juan" en Sagrada Biblia, Zaragoza: UNALI, 1974, p. 972.

SERRANO SÁSETA, Rafael, "Los orígenes comerciales del fenómeno de la desmaterialización de la fachada en la arquitectura moderna. Transparencia y luz eléctrica" en Revista Europea de Investigación en Arquitectura (REIA), Madrid: Universidad Europea, no 2, 2014, pp. 163-180.

SHIELDS, David, Reality hunger. A manifesto, Nueva York: Knopf, 2010.

VON GOETHE, Johann Wolfgang, Theory of colours, Londres: John Murray, 1840.

WHITMAN, Walt, Hojas de hierba, Buenos Aires: Losada, 2009.

WOLFE, Tom, ¿Quién teme al Bauhaus feroz? El arquitecto como mandarín, Barcelona: Anagrama. Barcelona, 1988.

YOURCENAR, Marguerite, Opus nigrum, Madrid: Alfaguara, 1994.

ZWEIG, Stefan, Momentos estelares de la humanidad. Catorce miniaturas históricas, Barcelona: Círculo de Lectores, 2004. 
